\title{
The thermo-tectonic evolution of the Suckling-Dayman metamorphic core complex, southeastern Papua New Guinea
}

By

Jürgen Erwin Österle

\author{
A thesis \\ submitted to Victoria University of Wellington \\ in fulfilment of the requirements for the degree of \\ Doctor of Philosophy in Geology
}

Victoria University of Wellington

2019 


\section{Abstract}

The Suckling-Dayman metamorphic core complex (SDMCC) in the Woodlark Rift of southeastern Papua New Guinea is being exhumed along the Mai'iu Fault, an active low-angle normal fault dipping $\sim 20-22^{\circ}$ northwards at the surface. The spectacularly smooth topography of the Mai'iu Fault footwall clearly is expressive of geologically recent uplift. The precise timing and rates of the exhumation of this continental metamorphic core complex (MCC) have, however, never been studied in detail. This thesis provides the first systematic set of U-Pb, fission track (FT), (U-Th[-Sm])/He and ${ }^{26} \mathrm{Al} /{ }^{10} \mathrm{Be}$ ages from metaigneous and metasedimentary rocks of the footwall of the SDMCC, clasts and a tephra deposit contained within syn-tectonic conglomerates (the Gwoira Conglomerate) in a rider block, and modern stream sediments in the footwall and hanging wall of the Mai'iu Fault. The ages are complemented by whole-rock compositional and thermobarometric data (Al-in-amphibole, Al-in-biotite, Raman spectroscopy of carbonaceous material). Based on these data, the timing of the onset of extension along the Mai'iu Fault, its long-term dip-slip rate and its initial dip were constrained. These data are presented in the context of the evolution of the SDMCC from the Cretaceous to the present.

The dominant lithology of the SDMCC, the Goropu Metabasalt, formed in a marginal basin to the northeast of the Australian continent. Two zircon U-Pb ages of $103.0 \pm 5.7$ and 71.6 $\pm 3.3 \mathrm{Ma}$, indicative of maximum depositional ages, from metasedimentary intercalations (the Bonenau Schist) in the Goropu Metabasalt, suggest formation of the oceanic protolith in the Late Cretaceous. Between $60.4 \pm 2.5$ and $56.6 \pm 2.3 \mathrm{Ma}$ (zircon U-Pb), tholeiitic to mildly calc-alkaline gabbroic to tonalitic rocks of the Yau Igneous Complex intruded the Goropu Metabasalt. The age of the Yau Igneous Complex overlaps with the known timing of north-directed subduction of the oceanic lithosphere along the Owen Stanley Fault (OSF) beneath the Cape Vogel Arc and provides a minimum age for the oceanic protolith.

A second phase of magmatism, consisting of peraluminous-metaluminous calc-alkaline (Suckling Granite) and high-K (Mai'iu Monzonite, Bonua Porphyry) granitoids and basaltic andesite dikes that were cut by the Mai'iu Fault, was associated with the tectonic inversion of the OSF. Zircons from these syn-extensional intrusions suggest crystallization between $3.8 \pm$ 0.2 and $2.0 \pm 0.1 \mathrm{Ma}$. The oldest age of this range is inferred to mark the time by which the OSF had been re-activated as an extensional structure, the Mai' iu Fault. Al-in-amphibole and -biotite thermobarometry suggests crystallization of the Suckling Granite and Mai'iu Mon- 
zonite in a relatively shallow crust $(\sim 2-8 \mathrm{~km}$ depth) at pressures of $\sim 0.4-2.3 \mathrm{kbar}$. Inherited zircons in the Plio-Pleistocene granitoids indicate that the Goropu Metabasalt carapace of the SDMCC is underlain by Australian-derived Cretaceous crustal material that is inferred to be the continuation of the Kagi Metamorphics in the central Papuan Peninsula.

Further constraints of the timing of unroofing of the SDMCC were determined from three quartz clasts in the Gwoira Conglomerate. ${ }^{26} \mathrm{Al} /{ }^{10} \mathrm{Be}$ burial ages of these samples indicate deposition in the Pliocene between $4.6 \pm 2.9$ and $3.4 \pm 2.1 \mathrm{Ma}$. A tephra in the upper section of the exposed conglomerates was dated employing $\mathrm{U}-\mathrm{Pb}$ methods on zircon, combined with apatite, zircon and magnetite (U-Th[-Sm])/He chronometers, yielding a complex age spectrum. An eruption age of $0.6 \pm 0.4 \mathrm{Ma}$ was extrapolated for this tephra. FT and (U-Th[$\mathrm{Sm}]$ )/He low-temperature thermochronometry details a young ( $\leq 3 \mathrm{Ma})$ and rapid exhumation history. Based on the crystallization ages of the syn-extensional granitoids, the depositional age of the Gwoira Conglomerate, the extensional cooling recorded by low-temperature thermochronometry, and the backwards projection of the published Holocene dip-slip rate of the Mai' iu Fault, the timing of the onset of extension is estimated at $\sim 4$ Ma.

A minimum dip-slip rate of $8.1 \pm 1.3 \mathrm{~km} / \mathrm{myr}$ has been calculated from the inverse slope of zircon $(\mathrm{U}-\mathrm{Th}) / \mathrm{He}(\mathrm{ZHe})$ ages with slip-parallel distance from Mai' iu Fault trace. This is slightly lower than the $>12 \mathrm{~km} /$ myr required to restore the intrusion depths $(2-8 \mathrm{~km})$ of the syn-extensional granitoids, now exposed $20-25 \mathrm{~km}$ south of the Mai'iu Fault trace at elevations up to $3.4 \mathrm{~km}$. Collectively, these constraints suggest that the Mai'iu Fault has moved at cm-per-year rates since $\sim 3 \mathrm{Ma}$.

Evidence for both a fossil zircon FT (ZFT) partial annealing zone (PAZ) and a ZHe partial retention zone (PRZ) on the footwall of the SDMCC is presented. Combining paleotemperature estimates from the inferred bases of the zircon PAZ and PRZ, peak-metamorphic temperatures inferred from Raman spectroscopy of carbonaceous material (RSCM), and published peak-metamorphic temperature constraints on the extensional shear zone mylonites near the Mai'iu Fault trace, a minimum slip-parallel, down-dip paleo-temperature gradient of $9.7 \pm 2.2^{\circ} \mathrm{C} / \mathrm{km}$ has been estimated for the exhumed Mai'iu Fault plane. Assuming that the modern regional geothermal gradient in the Woodlark Rift is a maximum estimate of that which existed prior to extensional exhumation of the SDMCC, the paleo-temperature gradient was used to estimate an average initial dip of the Mai'iu Fault of $\sim 44^{\circ}$ for preextensional geothermal gradients ranging between 10 to $20^{\circ} \mathrm{C} / \mathrm{km}$. Presently dipping 20-22 ${ }^{\circ}$ at the surface, the constraints on the initial dip suggest that the Mai'iu Fault may have been back-rotated by $>20^{\circ}$ since the onset of extension, consistent with a rolling hinge-style evolution of this continental MCC. 


\section{Acknowledgements}

First and foremost I would like to thank my supervisors Diane Seward and Tim Little for giving me the opportunity to be part of an incredible project and to work with many wonderful people. I have learned so much during the last four years thanks to you. Diane, thank you for your incredible patience with me and for teaching me the ,art“ of fission-track counting as you would call it. Tim, thanks for everything I learned from you about scientific writing and structural geology. A huge thanks goes to Daniel Stockli for inviting me to come over to Austin and work in your lab, and having given me the jester's licence on your instruments. This project could not have happened were it not for the financial support of the Marsden Fund, NSF grant and scholarships from Victoria University of Wellington. I also acknowledge funding from the Faculty Strategic Research Grant that allowed me to attend the 15th and 16th International Conference on Thermochronology in Maresias, Brazil, and Quedlinburg, Germany, respectively.

I owe a debt of gratitude to the many people at Victoria University of Wellington for their help throughout the years. The technical staff at SGEES: Jane Chewings, Luisa Ashworth, Steward Bush and Fiona Tuckett, thanks for all you have done for me. I am also indebted to Ian Schipper who inducted me into the microprobe facilities. Thank you to Ross Whitmore, Jamey Stutz and Gavin Holdon for helping me in the Cosmo lab at various stages. Gratitude is also expressed to the Victoria University of Wellington Library staff for their immense help with the many interloan requests I made. A big thanks goes to Matt Sagar for the many conversations on zircons and your help in obtaining my first zircon U-Pb results. I am also thankful for thoughtful conversations with Julie Vry and Bruce Charlier on zircon matters.

I am grateful for the support I received during my time at the University of Texas at Austin. Special thanks go to Lisa Stockli for teaching me how to run the LA-ICP-MS system, Rudra Chatterjee for teaching me all the practical skills I needed for the (U-Th[-Sm])/He analyses, and Emily Cooperdock for teaching me everything there is to know about preparing, imaging and analysing magnetite. Thank you Des Patterson, Douglas Barber, Patrick Boyd, Steffi Wafforn, Federico Galster and Margo Odlum for assitance with (U-Th[-Sm])/He analyses, ICP-MS tuning, data reduction in Iolite, and thoughtful discussions on $\mathrm{U}-\mathrm{Pb}$ dating.

Many thanks to Ian Smith, Hugh Davies and Nathan Daczko for providing me with rock samples, field notes and documents that were helpful in many regards. 
I am much indebted to the many people that I met in Papua New Guinea. Thank you Colin, Sam and Caroline for accommodating us in Biniguni, and Paul and Ethyl for hosting us in Rakau. My sincere gratitude goes to our carriers without whose help our work would not have been possible: Andrew, Jerome, Harold, Gabriel, Mark, Judah, Steven, Danziel, Tennyson, Phineas, Amos, Derek, James, Vera, Livingston, Jamie, McLaren, Gabriel, Vincent, Luke, Ernest, Mark, and the other carriers whose names I do not recall (sorry!). They journeyed with us for several weeks leaving behind their families and helping us carrying our gear and rocks as well as their own belongings. They assisted us in the rugged and often slippery terrain, stood by us in times of insecurity and told us about their lives in this remote part of the world. I will never forget this.

Special thanks goes to my current and past office mates Marcel Mizera, Ben Hines, Tom Womack and Nick Hitt. Sharing this office space with you has been a blast. Thank you to all the other postgraduate students and staff at Vic I had the pleasure to study and share my time with. In no particular order, Leo Pure, Elliot Swallow, Celine Mandon, Valerie van den Bos, Jenni Hopkins, Kate Mauriohooho, Willy Henrique Gonzalez, Loretta Corcoran, Chris Conway, Matt Ryan, Ross Whitmore, Jamey Stutz, Dominic Evanzia, Konrad Weaver, Hubert Zal, Konstantinos Michailos, Chet Hopp, Kenny Graham, Sam Webber, Cam Watson, Chris Kraus, Annika Greve, Elisa Piispa, Dez Tesler, Andrew Rees, Monika Hanson, Miranda Voke, Emma Fisher, Kosta Tashkoff, Cassandra A Trinh-Le, Aleksandr Beliaev, Emily Brook and Steff Marinus.

I also want to say thank you to my Austin flatmates Evan Ramos, Thomas Etzel and Nick Ettinger for your hospitality and introducing me to Austin life. Thank you James Biemiller, Doug Barber, Patrick Boyd, JJ Munoz, Simon Scarpetta, Federico Galster, Rudra Chatterjee, Tomas Capalid, Margo Odlum, Alissa Kotowski, Sarah George, Eirini Poulaki and Megan Flansburg for having made my little spare time memorable.

Thank you Julie and Peter Vose for all you have done for me and your generosity. You made me feel like at home here in New Zealand. Elizabeth, thank you for your endless support and your patience, you have lived this $\mathrm{PhD}$ as much as I did. Thanks for putting a smile on my face over and over again.

Last but certainly not least, I am eternally grateful to the support of my family. They supported my decision to come to New Zealand and to do a $\mathrm{PhD}$ even though it meant the world was between us. Thank you for the countless Skype sessions and the thousands of photographs and videos capturing the moments I missed while I was overseas. Thanks also to my friends at home and across the globe for keeping in touch with me, it meant a lot to me. 


\section{Contents}

$\begin{array}{ll}\text { Abstract } & \text { iii }\end{array}$

$\begin{array}{ll}\text { Acknowledgements } & \text { v }\end{array}$

$\begin{array}{lc}\text { List of Figures } & \text { xiv }\end{array}$

\begin{tabular}{ll} 
List of Tables & XV \\
\hline
\end{tabular}

1 Introduction 1

1.1 Motivation . . . . . . . . . . . . . . . . . . . . 1

1.2 Research objectives . . . . . . . . . . . . . . . . . 2

1.3 Thesis structure . . . . . . . . . . . . . . . 6

1.4 Statement of contributions . . . . . . . . . . . . . . 7

1.5 Nomenclature of Cenozoic subseries and subepochs . . . . . . . . . . . . 9

2 Tectono-magmatic evolution of the SDMCC 11

2.1 Abstract . . . . . . . . . . . . . . . . . 11

2.2 Introduction . . . . . . . . . . . . . . . . . . 12

2.2.1 Geological framework . . . . . . . . . . . . . . . . . 14

2.2.2 Magmatism in southeastern Papua New Guinea . . . . . . . . . . . 17

2.2.3 The Suckling-Dayman metamorphic core complex . . . . . . . . . 20

2.2.4 Igneous rocks of the SDMCC . . . . . . . . . . . . 22

2.3 Analytical techniques . . . . . . . . . . . . . . . . 23

2.3.1 Whole rock major oxide and trace element analysis . . . . . . . . 23

2.3.2 Zircon $\mathrm{U}-\mathrm{Pb}$ analysis . . . . . . . . . . . . . . . 23

2.3.3 Electron probe micro-analysis . . . . . . . . . . . . . . 24

2.4 Results . . . . . . . . . . . . . . . . . . . . . . . 24

2.4 .1 Petrography .......................... 24

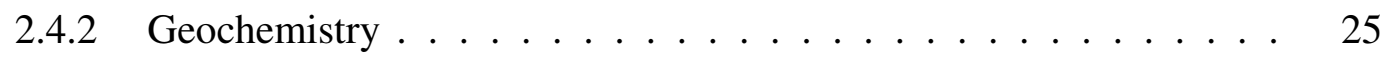

2.4.3 Zircon U-Pb geochronology . . . . . . . . . . . . 38

2.4.4 Al-in-amphibole and -biotite thermobarometry . . . . . . . . . 43

2.5 Discussion . . . . . . . . . . . . . . . . . . . . 47

2.5.1 The Goropu Metabasalt . . . . . . . . . . . . . . . . . . 47

2.5.2 The Yau Igneous Complex . . . . . . . . . . . . . . . . 48 
2.5.3 The Plio-Pleistocene calc-alkaline and high-K rocks . . . . . . 49

2.6 Conclusions . . . . . . . . . . . . . . . . . . . . . 55

3 Age of a tephra in the Gwoira Conglomerate 57

3.1 Abstract ............................. 57

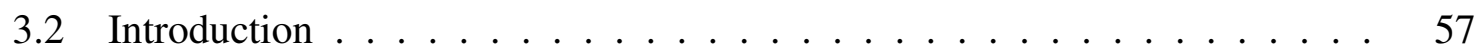

3.3 Geological setting . . . . . . . . . . . . . . . . . . . 59

3.4 Methods . . . . . . . . . . . . . . . . . . . . . . 59

3.5 Results . . . . . . . . . . . . . . . . . 62

3.6 Discussion . . . . . . . . . . . . . . . . . . 67

3.6.1 The nature of the zircon, apatite and magnetite grains . . . . . . 67

3.6.2 Spread in the $(\mathrm{U}-\mathrm{Th}[-\mathrm{Sm}]) / \mathrm{He}$ ages $\ldots \ldots \ldots$. . . . . . . . 67

3.6.3 The age of eruption and the source of the tephra . . . . . . . . . 69

3.7 Conclusions . . . . . . . . . . . . . . . . . . . . . . 69

4 Thermo-tectonic evolution of the SDMCC 71

4.1 Abstract . . . . . . . . . . . . . . . . 71

4.2 Introduction . . . . . . . . . . . . . . . . . . 72

4.3 Tectonic setting . . . . . . . . . . . . . . . . . . . 74

4.3.1 The Woodlark Rift . . . . . . . . . . . . . . . . . . . . 74

4.3.2 The Suckling-Dayman metamorphic core complex . . . . . . . 78

4.4 Methods . . . . . . . . . . . . . . . . . . . . . . . . 82

4.4 .1 Sampling strategy . . . . . . . . . . . . . . . 82

4.4.2 Raman spectroscopy of carbonaceous material . . . . . . . . 83

4.4.3 Zircon $\mathrm{U}-\mathrm{Pb}$ geochronology and trace element analysis . . . . . . . 83

4.4.4 Low-temperature thermochronometry . . . . . . . . . . . . . . 84

4.4.5 ${ }^{26} \mathrm{Al} /{ }^{10} \mathrm{Be}$ cosmogenic nuclide dating . . . . . . . . . . . . 84

4.5 Results and interpretation . . . . . . . . . . . . . . . 85

4.5.1 Paleo-temperature estimates from graphite crystallinity . . . . . . . 85

4.5.2 Zircon $\mathrm{U}-\mathrm{Pb}$ dating and trace elements . . . . . . . . . . . . 86

4.5.3 Fission-track thermochronometry . . . . . . . . . . . . . . 99

4.5.4 (U-Th[-Sm] $) /$ He thermochronometry . . . . . . . . . . . 100

4.5.5 ${ }^{26} \mathrm{Al} /{ }^{10} \mathrm{Be}$ burial ages . . . . . . . . . . . . . . 103

4.6 Discussion . . . . . . . . . . . . . . . . . . . . . 103

4.6.1 Euhedral Plio-Pleistocene zircons in the Goropu Metabasalt . . . . 103

4.6.2 Expanding the spatial coverage of the U-Pb age record . . . . . . 106

4.6.3 Evidence for a preserved zircon PRZ and PAZ . . . . . . . . . 107

4.6.4 Evidence for pre-extensional cooling of the Yau Igneous Complex . 108

4.6.5 Timing of the onset of extension . . . . . . . . . . . . . . . . 109

4.6.6 Apparent dip-slip rate of the Mai' iu Fault . . . . . . . . . . . . . 110 
4.6.7 The initial dip of the Mai'iu Fault . . . . . . . . . . . . . . 113

4.7 Conclusions . . . . . . . . . . . . . . . . . . . . . . . . 119

5 Synthesis $\quad 123$

$\begin{array}{lr}\text { Appendix } & 129\end{array}$

$\begin{array}{lll}\text { A Analytical techniques } & 131\end{array}$

A.1 Whole rock major oxide and trace element analysis . . . . . . . . . . 131

A.2 U-Pb and trace element LA-ICP-MS analysis . . . . . . . . . . . . 131

A.3 Electron probe micro-analysis . . . . . . . . . . . . . . . 133

A.4 Raman spectroscopy of carbonaceous material . . . . . . . . . . . . . . . 133

A.5 Fission track analysis . . . . . . . . . . . . . . . . . . . . 134

A.6 (U-Th-[Sm])/He analysis . . . . . . . . . . . . . . . . . . 134

A.7 ${ }^{26} \mathrm{Al} /{ }^{10} \mathrm{Be}$ cosmogenic nuclide analysis . . . . . . . . . . . . . 136

$\begin{array}{llr}\text { B Supplementary material } & 139\end{array}$

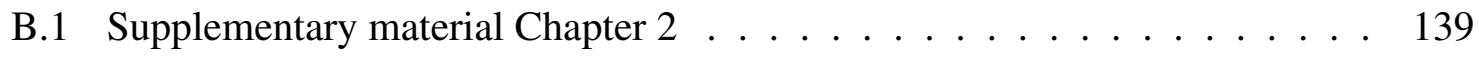

B.2 Supplementary material Chapter $3 \ldots \ldots$. . . . . . . . . . . 157

B.3 Supplementary material Chapter $4 \ldots \ldots$. . . . . . . . . . . . . . 161

$\begin{array}{lll}\text { C Electronic appendices } & 191\end{array}$

$\begin{array}{ll}\text { Bibliography } & 193\end{array}$ 


\section{List of Figures}

1.1 Geological map of the Suckling-Dayman metamorphic core complex . . . . 2

1.2 Topography of the SDMCC . . . . . . . . . . . . . . . . . . . 4

2.1 Geological map of southeastern Papua New Guinea . . . . . . . . . . . . . 14

2.2 Time-composition chart of igneous rocks . . . . . . . . . . . . . . 16

2.3 Geological map of the SDMCC . . . . . . . . . . . . . . . 21

2.4 Photomicrographs of the igneous rocks . . . . . . . . . . . . . . 29

2.5 Igneous rock classification . . . . . . . . . . . . . . . . 32

2.6 Harker diagrams . . . . . . . . . . . . . . . . . . . . . . 33

2.7 Multi-element diagram of the Yau Igneous Complex . . . . . . . . . . . . . 34

2.8 Rare earth element diagram of the Yau Igneous Complex . . . . . . . . . . 35

2.9 Geotectonic setting of the Yau Igneous Complex . . . . . . . . . . . . . . . 35

2.10 Multi-element diagram of the calc-alkaline and high-K rocks . . . . . . . 36

2.11 Rare earth element diagram of the calc-alkaline and high-K rocks . . . . . . 37

2.12 Granite classification . . . . . . . . . . . . . . . . . . . 37

2.13 Depositional age of the Bonenau Schist . . . . . . . . . . . . . . 43

2.14 Crystallization ages of the igneous rocks . . . . . . . . . . . . . 45

2.15 CL images of zircons from the Suckling Granite and Mai'iu Monzonite . . 45

2.16 Zircon inheritance . . . . . . . . . . . . . . . . . . . . . 47

3.1 Geological map of the SDMCC . . . . . . . . . . . . . . . 60

3.2 Setting of the tephra . . . . . . . . . . . . . 61

3.3 Photo-micrographs of zircon, magnetite and apatite . . . . . . . . . 63

3.4 Zircon $\mathrm{U}-\mathrm{Pb}$ results . . . . . . . . . . . . . . . . . . . . 64

3.5 Age of the tephra . . . . . . . . . . . . . . . 64

3.6 Zircon $(\mathrm{U}-\mathrm{Th}) /(\mathrm{Pb}-\mathrm{He})$ double-dating results . . . . . . . . . . . . . 66

3.7 Secondary electron images of apatite and magnetite . . . . . . . . . . 66

4.1 Geological map of the Woodlark Rift . . . . . . . . . . . . . . . . 76

4.2 Geological map of the SDMCC . . . . . . . . . . . . . . . . 80

4.3 Map of the SDMCC with age and paleo-temperature results . . . . . . . . 88

4.4 Graphite crystallinity vs. distance from the fault trace . . . . . . . . . . . 88

4.5 CL images of zircons from the Goropu Metabasalt and Bonenau Schist . . . 93

4.6 Zircon U-Pb results of the Goropu Metabasalt and Bonenau Schist . . . . . 94 
4.7 Tectono-magmatic zircon provenance . . . . . . . . . . . . . . . . 96

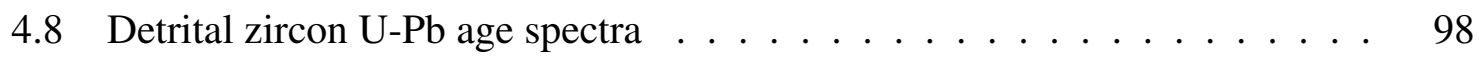

4.9 Age vs. distance from the fault trace . . . . . . . . . . . . . . . . . 102

4.10 Zircon $(\mathrm{U}-\mathrm{Th}) /(\mathrm{Pb}-\mathrm{He})$ double-dating results $\ldots \ldots \ldots$. . . . . . . . . . 104

4.11 Apparent time-averaged dip-slip rate of the Mai'iu Fault ～. . . . . . . . 113

4.12 Paleo-temperature gradient of the exhumed Mai'iu Fault . . . . . . . . . 116

4.13 The initial dip of the Mai'iu Fault f . . . . . . . . . . . . . . . . . . . 118

B.1 QAP classification diagram . . . . . . . . . . . . . . . . 147

B.2 ASI - AI classification diagram . . . . . . . . . . . . . . . . . . . 147

B.3 BSE images of zircon . . . . . . . . . . . . . . . . . 151

B.4 Tera-Wasserburg diagrams of the igneous rocks . . . . . . . . . . . . 152

B.5 Micro-photographs of a deformed Suckling Granite sample . . . . . . . . . 153

B.6 BSE images of amphibole . . . . . . . . . . . . . . . . . . . 154

B.7 Amphibole compositions . . . . . . . . . . . . . . . 155

B.8 Amphibole substitution analysis . . . . . . . . . . . . . . 156

B.9 Magnetite mounts . . . . . . . . . . . . . . . . . . . . . 159

B.10 Apatite rare earth element diagram . . . . . . . . . . . . . . . . 159

B.11 $\mathrm{SiO}_{2}$ whole rock from $\mathrm{Sr}$ in apatite . . . . . . . . . . . . . . . 160

B.12 Raman spectra of the Bonenau Schist . . . . . . . . . . . . . . . . 177

B.13 Sample distance from the Mai'iu Fault trace . . . . . . . . . . . . . . . 178

B.14 Rank-order plot of $\mathrm{Pb}_{c}$-corrected ${ }^{206} \mathrm{~Pb} /{ }^{238} \mathrm{U}$ dates . . . . . . . . . . . . . 179

B.15 Tera-Wasserburg diagrams of zircon in the Goropu Metabasalt . . . . . . . 180

B.16 Radial plots of the fission track data . . . . . . . . . . . . . . 186

B.17 Age-altitude plots . . . . . . . . . . . . . . . . . . 187

B.18 Setting of burial age samples . . . . . . . . . . . . . . . . 188

B.19 Biman Sandstone . . . . . . . . . . . . . . . . . . . . . . . 189

B.20 Cross-sections through the Gwoira Conglomerate . . . . . . . . . . . . . 190 


\section{List of Tables}

2.1 Petrography of the igneous rocks . . . . . . . . . . . . . . 27

2.2 Whole-rock geochemistry . . . . . . . . . . . . . 30

2.3 Zircon $\mathrm{U}-\mathrm{Pb}$ age summary . . . . . . . . . . . . . . . 42

2.4 Al-in-amphibole and -biotite results . . . . . . . . . . . . 50

2.5 Affinity of the Yau Igneous Complex . . . . . . . . . . . . . . . . . . . 51

3.1 Tephra $(\mathrm{U}-\mathrm{Th}[-\mathrm{Sm}]) / \mathrm{He}$ results $\ldots \ldots \ldots \ldots \ldots \ldots$

$4.1 \mathrm{U}-\mathrm{Pb}$, fission-track and $(\mathrm{U}-\mathrm{Th}[-\mathrm{Sm}]) / \mathrm{He}$ age summary $\ldots \ldots . . . . . . \quad 89$

B.1 Feldspar ${ }^{207} \mathrm{~Pb} /{ }^{206} \mathrm{~Pb}$ data . . . . . . . . . . . . . . . . . 146

B.2 Correction for secular disequilibrium . . . . . . . . . . . . . 158

B.3 Raman spectroscopy data . . . . . . . . . . . . . . . . . . 164

B.4 Fission track data . . . . . . . . . . . . . . . . . . . 165

B.5 Zeta calibration factors . . . . . . . . . . . . . . 166

B.6 Zircon $(\mathrm{U}-\mathrm{Th}) / \mathrm{He}$ age data $\ldots \ldots \ldots$. . . . . . . . . . . 167

B.7 Apatite $(\mathrm{U}-\mathrm{Th}-\mathrm{Sm}) / \mathrm{He}$ age data . . . . . . . . . . . . . . . . . 170

B.8 Magnetite $(\mathrm{U}-\mathrm{Th}-\mathrm{Sm}) / \mathrm{He}$ age data $\ldots \ldots \ldots \ldots$. . . . . . . . . 172

B.9 Zircon $(\mathrm{U}-\mathrm{Th}) /(\mathrm{Pb}-\mathrm{He})$ age data $\ldots \ldots \ldots \ldots$. . . . . . . . . 173

B.10 ${ }^{26} \mathrm{Al} /{ }^{10} \mathrm{Be}$ burial age data $\ldots \ldots \ldots \ldots \ldots \ldots$ 


\section{Introduction}

\subsection{Motivation}

Rock mechanical theory predicts that normal faults should form at dips of $\sim 60^{\circ}$ and frictionally lock up at angles $<30^{\circ}$ (Anderson, 1951). This prediction is supported by the rarity of earthquakes that occur on faults with dips of $<30^{\circ}$ (Collettini and Sibson, 2001; Jackson and White, 1989). Yet, low-angle normal faults (LANFs) or detachment faults are globally recognized features in the rock record (Collettini, 2011). Detachment faults often separate weakly or unmetamorphosed rocks in the hanging wall from metamorphosed rocks in the footwall. This tectonic assemblage is called a metamorphic core complex (MCC) (Coney, 1980; Platt et al., 2015). Various models have been proposed to explain the existence of LANFs (for examples see Platt et al., 2015). An elegant model that accounts for the observed geometry of LANFs at the surface, the rarity of earthquakes of the shallow part of the detachment fault, and initiation angles consistent with rock mechanical experiments is the rolling hinge model (Buck, 1988; Wernicke and Axen, 1988). In this model, unloading of the lower plate through sustained slip on the fault causes it to back-rotate and adopt an arched, convex-up topography (Spencer, 2010). Despite its elegance, the rolling hinge model has not yet been unequivocally verified in continental settings. At mid-ocean ridges, the rolling hinge model has been confirmed by paleomagnetic studies (Garcés and Gee, 2007; MacLeod et al., 2011; Morris et al., 2009) that documented footwall rotations on the order of 40-80 about near-ridge-parallel axes.

Testing the rolling hinge model in continental settings is complicated by the fact that many LANFs are ancient and have been eroded or have been deformed by tectonic events that post-date their formation, masking the inception geometry. The Mai'iu Fault in the Woodlark Rift of southeastern Papua New Guinea is an active LANF that is presently slipping at cm-per-year rates (Little et al., 2019; Wallace et al., 2014; Webber et al., 2018). This fault has re-activated a Paleogene subduction thrust, the Owen Stanley Fault (Davies and Jaques, 1984) and has exhumed in its footwall a remarkable structural dome, the Suckling-Dayman metamorphic core complex (SDMCC). Its outstanding preservation, present-day constraints of the thermal structure of the Woodlark Rift, and the well-constrained larger geodynamical context of this region make the Mai'iu Fault an excellent natural laboratory to study the mechanics of LANFs. This thesis provides the first systematic attempt to date and characterize the events associated with the formation of this MCC and test the rolling hinge model on 


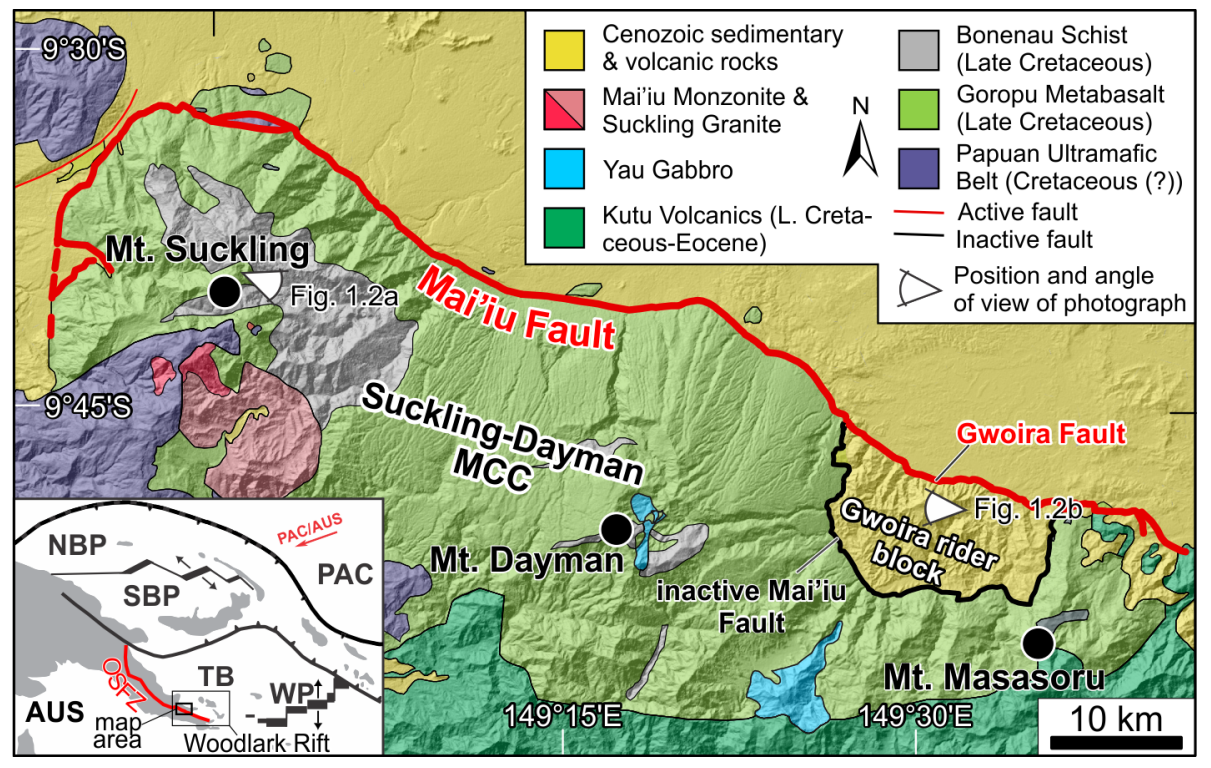

Figure 1.1: Geological setting of the Suckling-Dayman metamorphic core complex (modified from Davies and Smith, 1974). The map is underlain by a hillshade model (Shuttle Radar Topography Mission, $30 \mathrm{~m}$ ). Inset: Contemporaneous tectonic map of Papua New Guinea modified from Wallace et al. (2004). Abbreviations: AUS - Australian Plate, NBP - North Bismarck Plate, OSFZ - Owen Stanley Fault Zone, PAC - Pacific Plate, SBP South Bismarck Plate, TB - Trobriand Block, WP - Woodlark Plate. Red arrow (PAC/AUS) refers to the contemporary velocity of the Pacific Plate relative to the Australian Plate (10-11 $\mathrm{cm} / \mathrm{yr}$ ).

the active Mai' iu Fault. It is part of a multi-disciplinary, Marsden-funded project (13-VUW010) - "Using the world's most rapidly slipping normal fault to understand the mechanics of low-angle normal faults and the dynamics of continental extension".

\subsection{Research objectives}

\section{Constrain the onset of extensional slip on the Mai'iu Fault}

Estimates for the onset of extension in the Woodlark Rift (Figure 1.1, inset) range from $\sim 8.4$ to $4 \mathrm{Ma}$ (Petersen and Buck, 2015; Taylor and Huchon, 2002). These are based on a dated regional unconformity in the rift (Taylor and Huchon, 2002) and a plate tectonic restoration of the rifted margins of this continental rift utilizing the pole and angular opening rates implied from magnetic anomalies in the Woodlark Basin (Petersen and Buck, 2015; Taylor et al., 1999), respectively. But when did extensional slip on the Mai'iu Fault in the western Woodlark Rift commence, and how does the timing of the onset of extension compare to these regional estimates? Several lines of evidence suggest that extensional slip on the Mai'iu Fault commenced within the last few million years: 
a) The spectacularly smooth topography of the footwall of the Mai'iu Fault (Figure 1.2) prompted previous researchers to suggest that the footwall of the SDMCC was exhumed in the Quaternary (Davies, 1980).

b) Tilted and folded conglomerates (the Gwoira Conglomerate) resting in a depression between Mts. Dayman and Masasoru on the footwall of the SDMCC (Figure 1.1) have been associated with Quaternary unroofing tectonics (Davies, 1980). The depositional age of these syn-tectonic conglomerates (Webber, 2017) provides a minimum age for the onset of motion (exhumation) on the Mai'iu Fault. The age of deposition is, however, not tightly constrained and currently relies on correlations with older, and more distal units of Pliocene age in this region (Smith and Davies, 1976).

c) The footwall of the SDMCC is intruded by undeformed granitoids (Suckling Granite, Mai'iu Monzonite) in the vicinity and south of Mt. Suckling (Figure 1.1). Boulders of these granitoids, collected from the headwaters of streams draining Mt. Suckling, were dated by hornblende ( 10.8-4.4 Ma) and biotite ( 3.3 Ma) K-Ar methodologies (Davies and Smith, 1974). These K-Ar ages were interpreted to indicate initial cooling at $\sim 10 \mathrm{Ma}$ and uplift and cooling at $\sim 3 \mathrm{Ma}$ (Davies, 1980). Daczko et al. (2011) reported a zircon U-Pb age of $3.3 \pm$ 0.1 Ma from a boulder collected at the range front of the SDMCC and argued that the extensional mylonitic fabric of the metabasaltic Mai'iu Fault footwall was cut by the intrusion of granites at 3.3 Ma, thus providing a minimum estimate for the onset of extension.

d) Using ${ }^{10} \mathrm{Be}$ cosmogenic nuclide surface exposure dating of quartz veins in the Goropu Metabasalt, the chief lithology of the footwall of the SDMCC, Webber et al. (2018) established that the lowermost $\sim 130$ m of the Mai'iu Fault scarp due north of Mt. Dayman (Figure 1.1) has been exposed by slip on the Mai'iu Fault over the past 5500 years at a dip-slip rate of $11.7 \pm 3.5 \mathrm{~mm} / \mathrm{yr}$. Based on their dip-slip rate and inferred $\sim 30 \mathrm{~km}$ of total slip-parallel displacement along the Mai'iu Fault, Webber et al. (2018) estimated that the fault initiated at $2.8 \pm 0.8 \mathrm{Ma}$. This approximation assumes, however, that the Holocene dip-slip rate of the Mai' iu Fault was constant over time and depends on the slip magnitude, which is not precisely known, but estimated to be about 30-45 km (Little et al., 2019).

These studies suggest that the Mai'iu Fault was active since the Pliocene (or perhaps the Miocene), but the exact timing of initiation of the Mai'iu Fault has not yet been tightly constrained. Based on an integration of data from low-temperature thermochronometry of rocks collected in the footwall of the Mai'iu Fault, absolute dating of syn-kinematic footwall intrusions, and the depositional age of the Gwoira Conglomerate, I place new constraints on the time of extensional activity of the Mai'iu Fault. Re-dating of stream boulders previously 

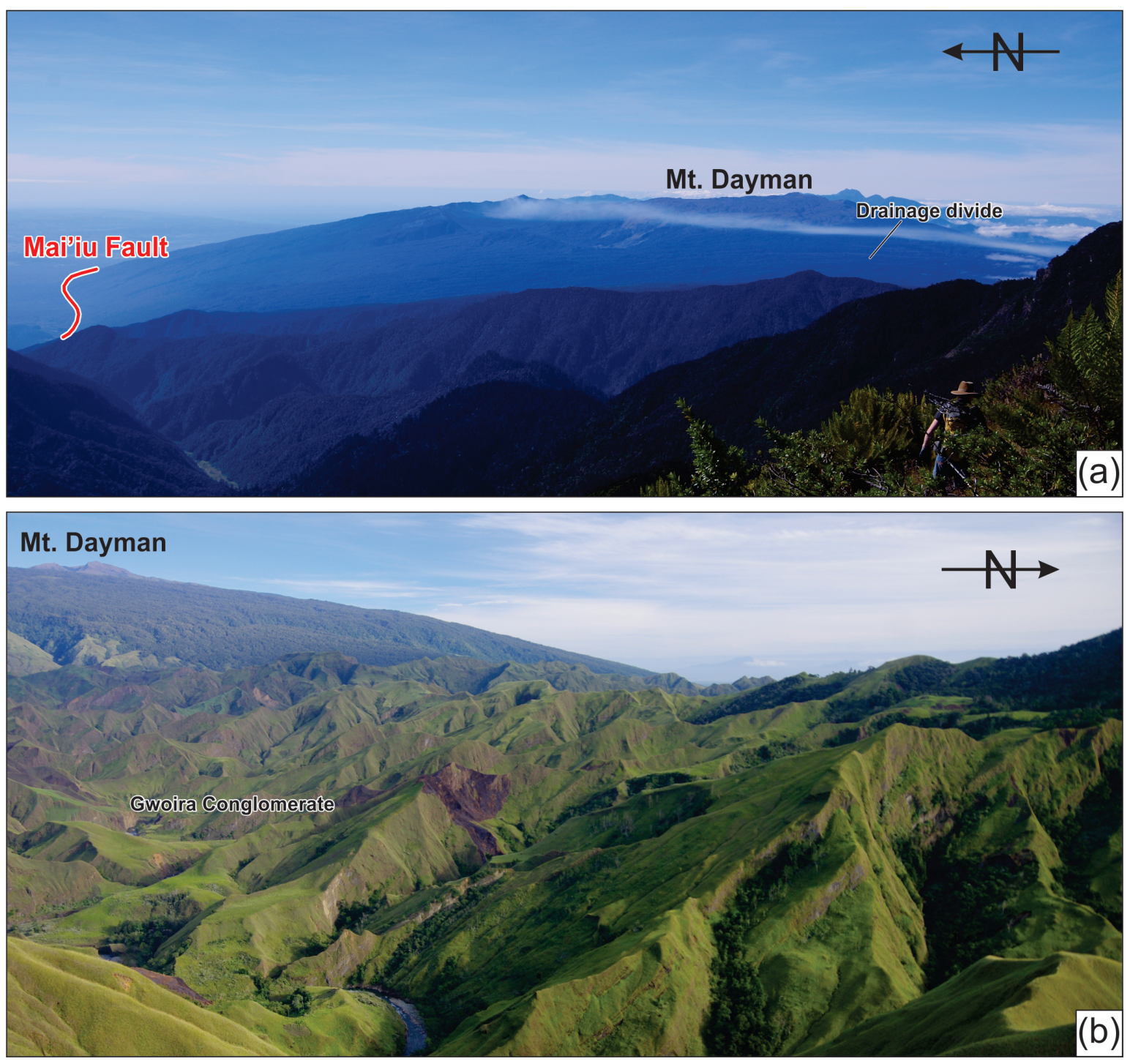

Figure 1.2: Photographs showing the remarkable topography of the Suckling-Dayman metamorphic core complex. (a) Photograph taken near the summit of Mt. Suckling facing east. Note the pristine convex-up shape of Mt. Dayman. South of the topographic main divide, rocks are tilted to the south and streams are draining southward. (b) Photograph taken near the summit of Mt. Gwoira facing west. Note the pristine convex-up shape of Mt. Dayman. Barren, south-tilted beds of the Gwoira Conglomerate are in the foreground. Photo credits: Daniel Stockli and Kevin Norton. 
dated by the K-Ar method by Davies and Smith (1974) allow me to assess the accuracy of their age constraints for granite emplacement.

\section{Assess the dip-slip rate of the Mai'iu Fault on a million-year timescale}

Present-day geodetic constraints from a regional network in southeastern Papua New Guinea (Wallace et al., 2014) suggest 7-9 mm/yr of approximately $\mathrm{N}-\mathrm{S}$ horizontal extension across the Mai'iu Fault (or 7.5-9.6 mm/yr if the horizontal slip rate is recast to a dip-slip rate using a dip of $21^{\circ}$ ). This slip rate, however, rests on the assumption that all of the extension across the Papuan Peninsula is accommodated by the Mai'iu Fault. Although slightly higher, the geodetically constrained slip rate is comparable to that $(11.7 \pm 3.5 \mathrm{~mm} / \mathrm{yr})$ obtained by Webber et al. (2018) from cosmogenic nuclide exposure dating of the lowermost fault scarp.

The dip-slip rates from GPS data (Wallace et al., 2014) and cosmogenic nuclide exposure dating (Webber et al., 2018) were determined on annual-millennial time scales. It has been shown, however, that slip-rates may change over time scales of $10^{4}-10^{5} \mathrm{yr}$ (Bergen et al., 2017). Extending the existing dataset from the Mai'iu Fault back in time, I employ lowtemperature thermochronometry to determine dip-slip rates over a million-year time scale.

\section{Determine the original dip of the Mai'iu Fault}

Whether LANFs are able to slip at low angles or whether they require initially steep angles is at the heart of the debate of the LANF paradox. Low-temperature thermochronometry may be used to map the spacing of paleo-isotherms on the exhumed footwall (Foster and John, 1999; Stockli, 2005) from which the original dip of the fault can be inferred. A key prerequisite for the reconstruction of the original fault configuration from thermochronometric data is the knowledge of the pre-extensional geothermal gradient. This key ingredient is, however, often associated with considerable uncertainties in studies on ancient MCCs.

Present-day observations from exploration wells and heat-flow measurements in the Woodlark Rift provide important information about the modern regional thermal structure of this young and active rift and suggest an overall low regional geothermal gradient of $\sim 20$ $23^{\circ} \mathrm{C} / \mathrm{km}$ (Garside and Stoen, 1973; Martinez et al., 2001; Stoen and Garside, 1973). Using the modern geothermal gradient as a maximum estimate of that which existed prior to extensional exhumation of the SDMCC, the spacing of paleo-isotherms on the exhumed fault plane can be used to constrain the initial dip of the Mai'iu Fault.

Little et al. (2019) and Watson (2019) independently determined the original dip of the Mai'iu Fault from restoration of bedding-fault cut-off angles between the inactive Mai'iu Fault and overlying beds in the Gwoira rider block (Figure 1.1), and a paleomagnetic study 
of the Goropu Metabasalt from the northern flank of Mt. Dayman, respectively. In both studies, the initial dip of the Mai' iu Fault was estimated to be $>40^{\circ}$. However, the reconstruction of the initial dip of Little et al. (2019) depends on the modelled geometry of the Mai' iu Fault surface (Webber, 2017) below the Gwoira Conglomerate and assumes rigid-body rotation, and that of Watson (2019) assumes that the rotation axis is horizontal and parallel to the strike of the Mai'iu Fault and that the paleomagnetic vector did not record any other deformation.

In this thesis, I constrain the initial dip of the Mai' iu Fault using results from low-temperature thermochronometry, peak-metamorphic temperatures estimated from Raman spectroscopy of carbonaceous material of metasedimentary pelitic rocks (the Bonenau Schist, Figure 1.1) intercalated with the metabasalt, and published constraints of the pressure-temperature (P-T) conditions during the formation of the extensional mylonitic fabric of the Goropu Metabasalt near the modern fault trace. This allows for a further test of the rolling hinge model in a continental MCC setting.

\section{Place constraints on the pre-extensional history of the SDMCC}

Slip on the Mai'iu Fault has exhumed the SDMCC in the last few million years and has exposed in its footwall igneous rocks of contrasting age and composition. Investigation of these igneous rocks holds important constraints on the pre-extensional history of the SDMCC. Absolute dating of the metasedimentary Bonenau Schist, which has been suggested to have formed in the Late Cretaceous (based on planktonic foraminifera of Maastrichtian age) in a MORB setting (Smith and Davies, 1976), allows a derivation of an age for the formation of the oceanic crust (the Goropu Metabasalt). Whole-rock geochemistry and absolute dating of pre- and syn-extensional intrusions (Yau Gabbro, Suckling Granite, Mai'iu Monzonite; Figure 1.1) leads to an understanding of their petrogenesis and their related tectono-magmatic context in this extensional setting.

\subsection{Thesis structure}

The body of this thesis is three self-contained studies (Chapters 2, 3 and 4) that I prepared for publication in academic journals. Thus they contain separate abstracts, introductions, methods, results, discussions, and conclusions. Because of this, there is some repetition between chapters. The publication-style chapters are followed by concluding remarks and directions for future studies (Chapter 5). References of all chapters are provided at the end of the thesis. 


\section{Chapter 2:}

The foci of this chapter are the igneous rocks in the footwall of the Mai'iu Fault. They record its evolution from oceanic spreading to subduction, to collision, to subduction-inversion and finally extensional exhumation. In this study, the first set of zircon U-Pb LA-ICP-MS ages from outcrop samples of metasedimentary intercalations in the metabasaltic footwall, lowgrade meta-gabbroic and -tonalitic rocks, and calc-alkaline to high-K granitoids (sensu lato) are presented. In addition, new whole-rock major oxide and trace element data, and thermobarometric (Al-in-amphibole, Al-in-biotite) constraints on the granitoids from the SDMCC are presented.

\section{Chapter 3:}

Discovered in a fresh road cut, a thin tephra deposit records the depositional age of the upper part of the Gwoira Conglomerate. U-Pb dating of zircon, and (U-Th[-Sm])/He analyses of zircon, apatite and magnetite yielded a complex age spectrum. The complex spectrum and possible sources of the large spread in the zircon, apatite and magnetite $(\mathrm{U}-\mathrm{Th}[-\mathrm{Sm}]) / \mathrm{He}$ systems are assessed and an age for the airborne deposit is derived.

\section{Chapter 4:}

This chapter is concentrated on the exhumation history of the actively exhuming SDMCC. Applying fission-track and (U-Th[-Sm])/He low-temperature thermochronometry, Raman spectroscopy of carbonaceous material (RSCM) and ${ }^{26} \mathrm{Al} /{ }^{10} \mathrm{Be}$ burial age dating of the Gwoira Conglomerate, and integrating the results provided in Chapters 2 and 3, as well as published data on the P-T constraints of the shear zone mylonites, estimates for the onset of extension, the dip-slip rate of the Mai'iu Fault on a million-year timescale, the paleo-temperature gradient, and the initial geometry of the Mai'iu Fault are presented.

\section{Chapter 5:}

In the final chapter, the key findings are examined with respect to the objectives outlined in Section 1.2. This last chapter also provides directions and recommendations for future work.

\subsection{Statement of contributions}

Although the results of this work are largely my personal contributions, I will use the first person plural "we" throughout Chapters 2 to 4 in favour of "I" to acknowledge the contributions of my co-authors on these publication-style chapters. All work has been conducted by myself unless stated otherwise. I am the primary author of all chapters in this thesis and the sole author of Chapters 1 and 5, and all Appendices. My contributions include field work and sample collection in Papua New Guinea in June-July 2015 and 2016; sample 
preparation (crushing, grinding, sieving, washing, magnetic and density separations, handpicking, leaching of quartz) for $\mathrm{U}-\mathrm{Pb}$, fission-track, (U-Th[-Sm])/He and ${ }^{26} \mathrm{Al} /{ }^{10} \mathrm{Be}$ analyses; fission-track analyses at Victoria University of Wellington and relevant preparatory tasks for external detector method dating (i.e., mounting, etching, and counting); U-Pb LA-ICP-MS depth profiling and (U-Th-[Sm)]/He analyses at the University of Texas at Austin and relevant preparatory tasks (selection of suitable grains, morphometrical measurement of grain dimensions, packing and unpacking of platinum tubes, digestion and spiking procedures); cutting of billets for thin section preparations for Raman spectroscopy of carbonaceous material, cathodoluminescence (CL) and back-scatter electron (BSE) imaging; and electron-probe micro-analyser (EPMA) analyses and CL imaging at Victoria University of Wellington.

My supervisors Prof. Diane Seward and Prof. Tim Little provided general guidance throughout the project. Prof. Daniel Stockli from the University of Texas at Austin mentored me during my research in Austin in 2017 and provided financial support (NSF grant EAR-1524729) for the U-Pb and (U-Th[-Sm])/He analyses. All chapters were reviewed and edited by Diane Seward, and Tim Little and Daniel Stockli provided feedback for the publication-style chapters. Other contributions to this thesis include $\mathrm{CL}$ imaging and U-Pb and trace element LAMC-ICP-MS analyses of polished zircons from the Goropu Metabasalt and Bonenau Schist (Stacia Gordon, University of Nevada), statistical treatment and calculation of maximum likelihood fission-track ages (Euan Smith, Victoria University of Wellington), additional (U$\mathrm{Th}[-\mathrm{Sm}]$ )/He analyses of various samples of zircon and apatite (Rudra Chatterjee, University of Texas at Austin), Raman spectroscopic analyses of carbonaceous material (Jeremy Rooney, University of Otago), provision of sample material (Ian Smith, University of Auckland; Nathan Daczko, Macquarie University), guidance in preparatory tasks for cosmogenic nuclide dating (Kevin Norton, Victoria University of Wellington) and column chemistry for ${ }^{26} \mathrm{Al} /{ }^{10} \mathrm{Be}$ burial age dating (Gavin Holden, Victoria University of Wellington).

At the time of writing, three publications are anticipated. The provisional titles, author lists and status of publication are listed below:

Chapter 2: The petrology, geochronology and tectono-magmatic setting of the igneous rocks in the Suckling-Dayman metamorphic core complex, Papua New Guinea

Österle, J. E., Little, T. A., Seward, D., Stockli D. F. and Gamble, J.

Intended for submission to Gondwana Research.

Chapter 3: Different chronometers, different ages. Using U-Pb and (U-Th[-Sm])/He chronometers to unravel the eruption age of an air-fall tephra

Österle, J. E., Seward, D., Stockli D. F. and Little, T. A.

Intended for submission to Terra Nova. 
Chapter 4: The thermo-tectonic evolution of an actively exhuming metamorphic core complex, the Suckling-Dayman metamorphic core complex in southeastern Papua New Guinea Österle, J. E., Seward, D., Stockli D. F., Little, T. A., Rooney, J. S. and Gordon, S. M. Intended for submission to Tectonics.

\subsection{Nomenclature of Cenozoic subseries and subepochs}

Despite not being formally recognised by the International Commission of Stratigraphy (Pearson et al., 2017), the notation of subseries/subepochs of the Cenozoic era adhere to the recommendations of Head et al. (2017) to capitalize the modifiers Lower/Early, Middle/Middle and Upper/Late. In this way, a set-in-stone chronological framework is provided that eliminates any ambiguities surrounding the ages of geologic units referred to in this thesis. The International Chronostratigraphic Chart v2018/08 (Cohen et al., 2013), the latest available at the time this thesis was written, was employed. 


\section{Petrology, geochronology and tectono-magmatic setting of the igneous rocks in the Suckling- Dayman metamorphic core complex, Papua New Guinea}

\subsection{Abstract}

The Papuan Peninsula in Papua New Guinea has been a site of magmatism throughout the Cenozoic, with the latest phase being concurrent with active extension in the Woodlark Rift. In the southeast of the Papuan Peninsula, the Suckling-Dayman metamorphic core complex (SDMCC) has exhumed middle-crustal rocks and raised them above the coastal plains in the past few million years along a still-active low-angle normal fault, the Mai'iu Fault. Uplift of the SDMCC has exposed metasedimentary and metaigneous rocks of Late Cretaceous-Pleistocene age that record the evolution from oceanic spreading to subduction, to collision, to subduction-inversion and final extensional exhumation. We present new petrographic, whole-rock geochemical, geochronologic (zircon U-Pb), and thermobarometric (Al-in-amphibole and -biotite) data for the igneous rocks of the SDMCC to reconstruct the long-term evolution of these rocks. The dominant lithology of the footwall of the SDMCC, the Goropu Metabasalt, is characterized by a mid-ocean ridge basalt (MORB) composition. Detrital zircons from metasedimentary rocks intercalated with the Goropu Metabasalt yielded U-Pb maximum depositional ages (MDA) of $103 \pm 5.7 \mathrm{Ma}$ and $71.6 \pm 3.3 \mathrm{Ma}$, suggesting a Late Cretaceous age of the oceanic protolith. Petrography and bulk compositions $\left(\mathrm{SiO}_{2} \sim 46-63 \mathrm{wt} \%\right)$ of low-grade meta-gabbroic and -tonalitic rocks (Yau Igneous Complex) suggest internal differentiation of this unit with trace-element geochemistry revealing both enriched and depleted chondrite-normalized light rare earth element patterns. Zircon $\mathrm{U}-\mathrm{Pb}$ ages from these rocks suggest that the Goropu Metabasalt was intruded by the Yau Igneous Complex between $\sim 60.4$ to $\sim 56.6 \mathrm{Ma}$, post-dating the zircon U-Pb MDA of the Goropu Metabasalt and providing a minimum age for the oceanic protolith. Syn-extensional granitoids with calc-alkaline to high-K compositions intruded the exhuming footwall between $\sim 3.8$-2.0 Ma (zircon $\mathrm{U}-\mathrm{Pb}$ ) at $\sim 2-15 \mathrm{~km}$ depth as evidenced by Al-in-amphibole and -biotite thermobarometry and the reported presence of andalusite in the contact aureole of these igneous rocks. Presently exposed at elevations of up to $3.4 \mathrm{~km}$ and at slip-parallel 
distances of 20-25 km south of the Mai'iu Fault trace, the intrusion depths of stocks of the syn-extensional Mai'iu Monzonite imply a long-term dip-slip rate of $>12 \mathrm{~km} / \mathrm{myr}$. We infer that the Mai'iu Fault re-activated a Paleogene thrust (the Owen Stanley Fault) as an extensional detachment fault by $3.8 \pm 0.2 \mathrm{Ma}$. Inherited xenocrystic zircons in the syn-extensional granitoids imply that the crust underlying the metabasaltic carapace of the SDMCC consists of Australian-derived metasedimentary rocks related to the Cretaceous Kagi Metamorphics that are exposed in the central Papuan Peninsula.

\subsection{Introduction}

The Cretaceous-Recent evolution of southeastern Papua New Guinea (i.e., the Papuan Peninsula and the islands offshore, Figure 2.1) was characterized by the complex tectonic interplay between seafloor spreading (Emo back-arc basin, Coral Sea, Solomon Sea, Woodlark Basin, and perhaps the Pocklington Sea or Uyaknji Basin) and subduction and associated arc magmatism (Cape Vogel Arc, Melanesian Arc, Maramuni Arc) (Davies et al., 1997; Dow, 1977; Gaina et al., 1999; Holm et al., 2013, 2015, 2016, 2019; Jaques and Chappell, 1980; Rogerson et al., 1991; Walker and McDougall, 1982; Worthing and Crawford, 1996). Episodes of large-scale Cenozoic tectonic reorganization were driven by convergent and collisional events such as the collision of the Ontong Java Plateau (OJP) of the Pacific Plate with the Melanesian Arc (Figure 2.1, inset) (Holm et al., 2013; Knesel et al., 2008) and the collision of the Australian continent with New Guinea (Hill and Hall, 2003; Holm et al., 2019; Schellart et al., 2006). This tectonic evolution was accompanied by igneous activity archived in the rock record of southeastern Papua New Guinea. The nature, tectonic affinities, and timing of this magmatism remain poorly resolved. For example, most previous age determinations of the igneous rocks of the Papuan Peninsula were performed using K-Ar methodology which may not always be accurate (e.g., incorporation of excess Ar; McDougall and Harrison, 1999), and indirect biostratigraphical dating, which is not always precise (Davies and Smith, 1974; Dow et al., 1974; Pieters, 1978; Rogerson and Hilyard, 1989; Rogerson et al., 1991; Smith and Davies, 1976). Furthermore, many published and unpublished geochemical datasets report no or only limited analyses of trace elements (Ruxton, 1966; Smith, 1972; Smith and Davies, 1976). 


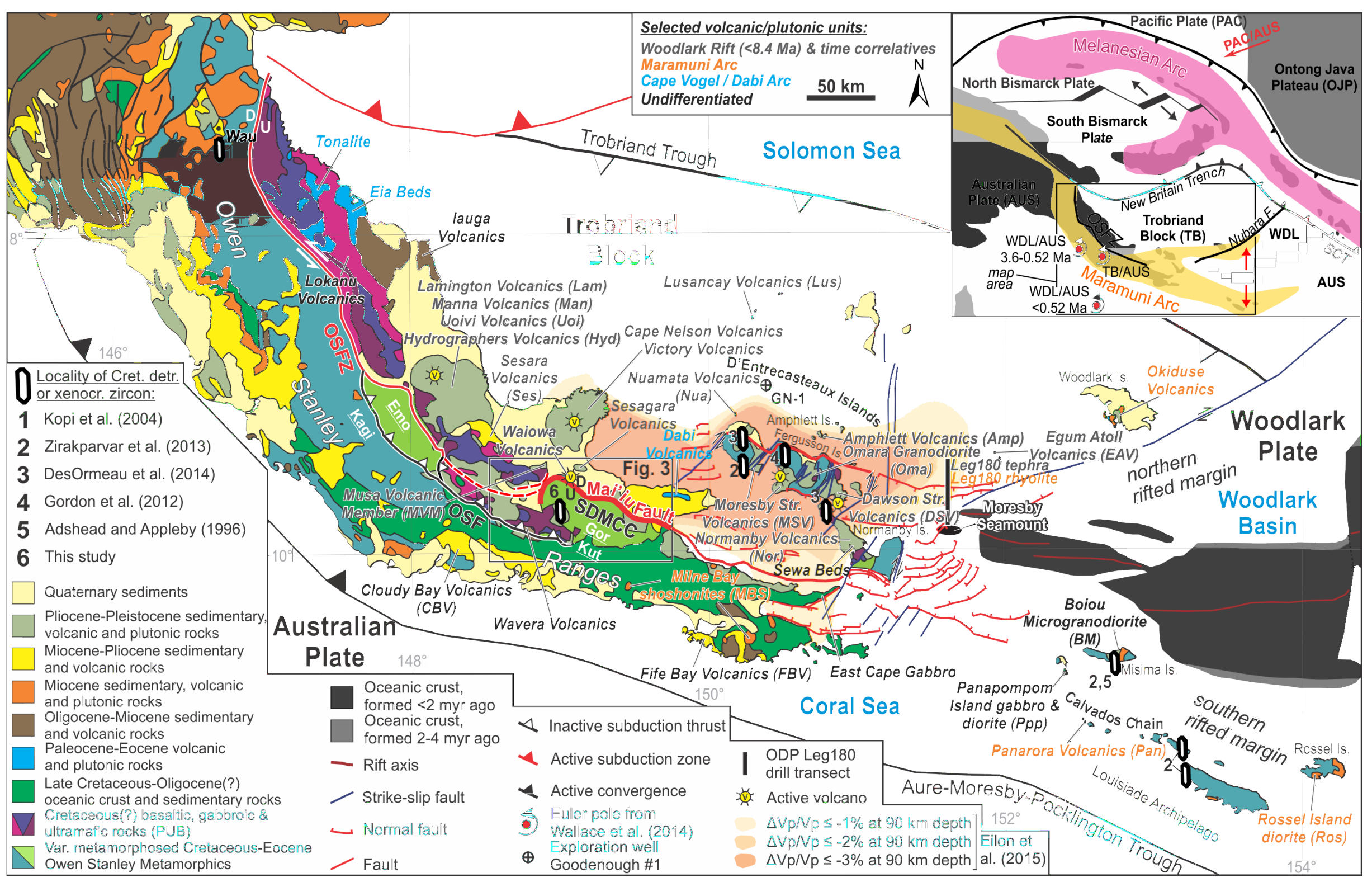


Figure 2.1: Simplified geological map of southeastern Papua New Guinea modified from D'Addario et al. (1976) after Baldwin et al. (2004), Cameron (2014), Ott and Mann (2015), Abers et al. (2016), and Little et al. (2019). Abbreviations: Emo - Emo Metamorphics, Gor - Goropu Metabasalt, Kagi - Kagi Metamorphics, Kut - Kutu Volcanics, OSF - Owen Stanley Fault, OSFZ - Owen Stanley Fault Zone. Extent of mantle $\mathrm{V}_{p}$ anomaly at $90 \mathrm{~km}$ depth is from Eilon et al. (2015). Locations of active volcanoes from Catalano (2012). Location of Goodenough No.1 (GN-1) exploration well from Tjhin (1976). Location of ODP Leg 180 drill hole transect from Taylor and Huchon (2002). Inset: Contemporary plate tectonic map Papua New Guinea modified from Wallace et al. (2004, 2014) after Holm et al. (2019). Abbreviations: OSFZ - Owen Stanley Fault Zone, SCT - San Cristobal Trench, WDK Woodlark Plate. Red arrow (PAC/AUS) is contemporary velocity of the Pacific Plate relative to the Australian Plate $(10-11 \mathrm{~cm} / \mathrm{yr})$. Small red arrows represent Woodlark-Australia spreading in the Woodlark Basin.

This study focuses on the plutonic rocks exposed in the Suckling-Dayman metamorphic core complex (SDMCC). The bounding Mai'iu Fault has exhumed in its footwall a mid-crustal section containing some of the youngest known granitoids (for reference see Ito et al., 2017b; Sano et al., 2002). We present the first outcrop zircon U-Pb ages for the Suckling Granite, Mai'iu Monzonite, Bonua Porphyry and the Yau Igneous Complex, integrated with wholerock major and trace element geochemistry, and Al-in-amphibole and -biotite thermobarometry. Moreover, we provide detrital zircon $\mathrm{U}-\mathrm{Pb}$ ages from metasedimentary intercalations in the Goropu Metabasalt that provide maximum age constraints for the metabasalts. The overall aim of this study is to refine previous age constraints for these plutonic bodies and to add critical new data in an effort to contribute to a better understanding of the magmatic and tectonic evolution of the SDMCC and the southeastern Papua New Guinea region.

\subsubsection{Geological framework}

The SDMCC is the westernmost of a series of metamorphic core complexes (MCCs) and gneiss domes on Misima, Normanby, Fergusson and Goodenough Islands in the active Woodlark Rift (Figure 2.1) (Abers et al., 2016; Baldwin et al., 2008; Daczko et al., 2009, 2011; Little et al., 2007, 2019; Peters, 2007; Webb et al., 2008). The footwall of the SDMCC is currently being exhumed and uplifted along the Mai'iu Fault - an inverted subduction thrust segment of the Owen Stanley Fault (Figure 2.1) (Davies, 1980; Little et al., 2019). Today, the Mai'iu Fault forms the plate boundary between the Australian Plate in the south and the Trobriand Block in the north (Figure 2.1) (Wallace et al., 2004, 2014). Counter-clockwise rotation of the Trobriand Block and the Woodlark Plate relative to the Australian Plate about nearby Euler poles since the Late Miocene led to extension in the continental Woodlark Rift and seafloor spreading in the oceanic Woodlark Basin (Figure 2.1, inset) - processes that are continuing today (Taylor et al., 1999; Wallace et al., 2014). 


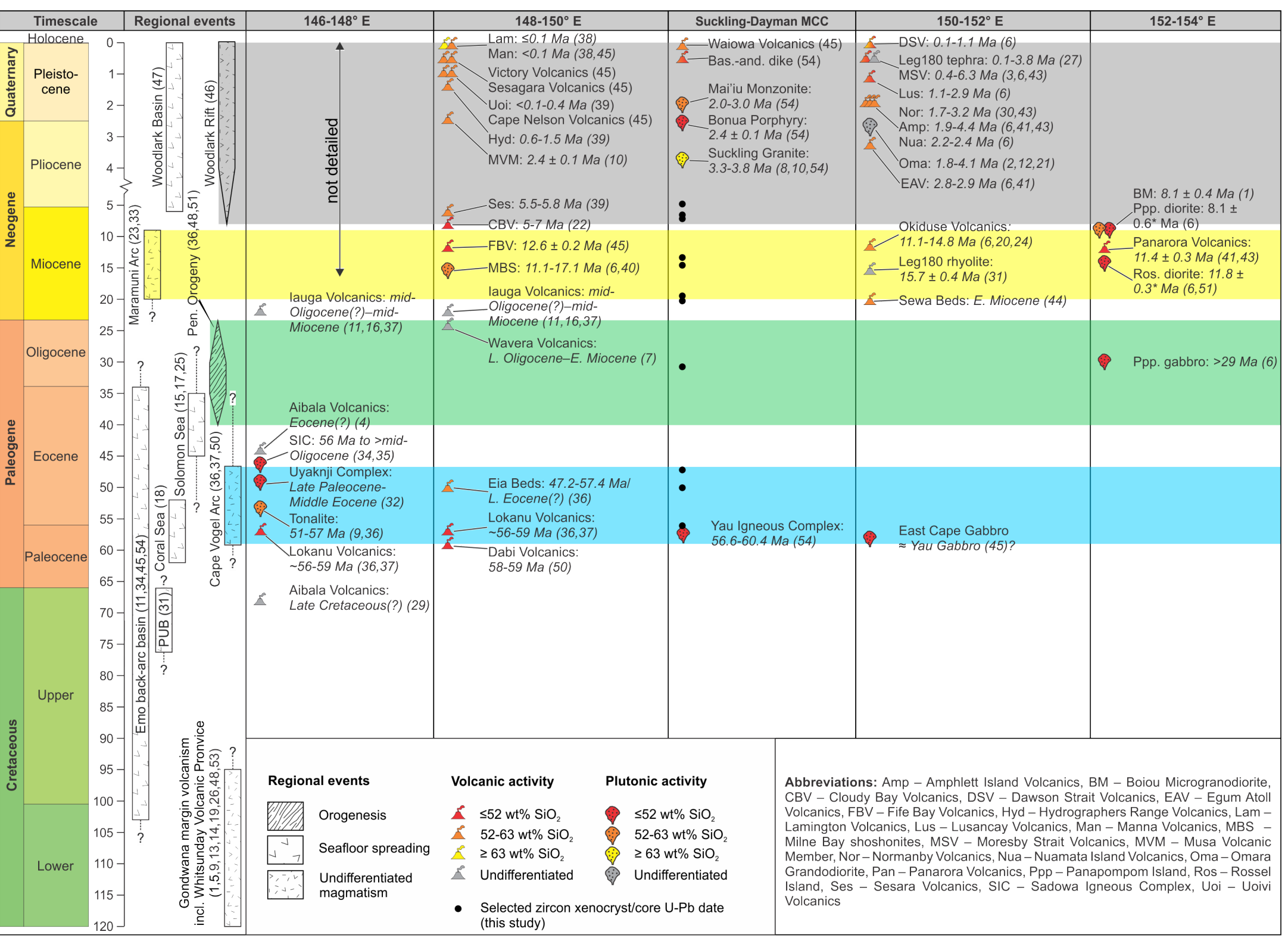


Figure 2.2: Time-composition chart of igneous rocks of southeastern Papua New Guinea and regional events from $120 \mathrm{Ma}$ to present. Compositional groupings (red, orange, yellow) reflect the average $\mathrm{SiO}_{2}$ contents of the individual igneous units. Where bimodal (DSV) or high-variance $\mathrm{SiO}_{2}$ contents (Bas.-and. dike, MSV, Lus) of any one suite have been reported, the colour of the symbols has been adapted to reflect a bi-modality (yellow-red) or transition (red-orange, orange-yellow). Age uncertainties are generally given at the $2 \sigma$ level. Where uncertainties have been reported at the $1 \sigma$ level (Catalano, 2012; Lus et al., 2004) they were recast to $2 \sigma$ (marked by an asterisk). Where the methodology was not detailed (Smith, 1972, 1973; Davies and Smith, 1974; Smith and Davies, 1976; Smith and Compston, 1982; Adshead and Appleby, 1996) the reported age uncertainties were quoted. See Figure 2.1 for location of the units in this figure. Time and compositional constraints from: (1) Adshead and Appleby (1996); (2) Baldwin and Ireland (1995); (3) Baldwin et al. (1993); (4) Brown (1977); (5) Bryan et al. (1997); (6) Catalano (2012); (7) Chaproniere (2009); (8) Daczko et al. (2011); (9) Davies and Smith (1971); (10) Davies and Smith (1974); (11) Davies and Williamson (1998); (12) DesOrmeau et al. (2014); (13) Dow et al. (1974); (14) Ewart et al. (1992); (15) Falvey and Pritchard (1982); (16) Francis et al. (1987); (17) Gaina and Müller (2007); (18) Gaina et al. (1999); (19) Glaessner (1949); (20) Graham (2009) in Burkett (2017); (21) Gordon et al. (2012); (22) Holm and Poke (2018); (23) Holm et al. (2015); (24) Joseph and Finlayson (1991); (25) Joshima et al. (1986); (26) Kopi et al. (2004); (27) Lackschewitz et al. (2001); (28) Lus et al. (2004); (29) Macnab (1969); (30) Monteleone (2007); (31) Monteleone et al. (2001); (32) Nion et al. (1987); (33) Page (1976); (34) Pieters (1978); (35) Rogerson and Hilyard (1989); (36) Rogerson et al. (1991); (37) Rogerson et al. (1993); (38) Ruxton (1999); (39) Ruxton and McDougall (1967); (40) Smith (1972); (41) Smith (1973); (42) Smith (1981); (43) Smith and Compston (1982); (44) Smith and Davies (1973b); (45) Smith and Davies (1976); (46) Taylor and Huchon (2002); (47) Taylor et al. (1999); (48) Tulloch et al. (2010); (49) van Ufford and Cloos (2005); (50) Walker and McDougall (1982); (51) Webb et al. (2014); (52) Worthing and Crawford (1996); (53) Zirakparvar et al. (2013); (54) this study.

Beyond the obvious imprint of Woodlark rifting, the role and configuration of earlier tectonic elements in this region are still under debate (Holm et al., 2016, 2019; Smith, 2013; Whattam, 2009). One of the most contentious tectonic elements is the Trobriand Trough (Figure 2.1) (Abers and Roecker, 1991; Cooper and Taylor, 1987; Davies et al., 1984). In modern plate tectonic reconstructions on the basis of multiple geological and geophysical datasets, the Trobriand Trough is viewed as a relatively short-lived subduction zone that initiated at $\sim 6 \mathrm{Ma}$ and started slowing at $\sim 2 \mathrm{Ma}$ (Holm et al., 2016). The lack of evidence for ongoing subduction, however, suggests that the Trobriand Trough is no longer an active convergence zone (Abers and Roecker, 1991; Drummond et al., 1979; Finlayson et al., 1976; Gill et al., 1993).

Debate also concerns the identity of the subduction zone that carried Late Cretaceous, Australian margin-derived mafic and felsic rocks, now exposed on the D'Entrecasteaux Islands, to eclogite-facies conditions (Davies and Warren, 1988; Little et al., 2019; Petersen and Buck, 2015; Webb et al., 2014; Zirakparvar et al., 2013). According to the model of Pe- 
tersen and Buck (2015), this was achieved by subduction of an unmapped subduction zone to the north of the current D'Entrecasteaux Islands in the Miocene. Miocene slip on a northdipping subduction zone at the Aure-Moresby-Pocklington Trough (Figure 2.1) has been suggested by Webb et al. (2014) and has also been proposed in studies of central Papua New Guinea (Cloos et al., 2005; Holm et al., 2015). Little et al. (2019) suggested, after Davies and Jaques (1984), that the north-dipping subduction zone that carried the Australian rifted margin (Kagi Metamorphics) to mantle depths lies structurally beneath the Goropu Metabasalt of the SDMCC. The suture of this Miocene north-dipping thrust is exposed in the central Papuan Peninsula where the Kagi Metamorphics are juxtaposed against the Emo Metamorphics (Figure 2.1). The latter have been interpreted to be laterally equivalent to the Goropu Metabasalt based on their similar structural position, rock type and metamorphic grade (Davies and Jaques, 1984; Pieters, 1978; Worthing and Crawford, 1996). The model of Little et al. (2019) is also consistent with studies that show no seismicity associated with the Aure-Moresby-Pocklington Trough and that instead map it as a passive margin (Drummond et al., 1979; Ott and Mann, 2015).

\subsubsection{Magmatism in southeastern Papua New Guinea}

The record of magmatism in southeastern Papua New Guinea is summarized in Figure 2.2. The evolution of the Papuan Peninsula likely commenced in the Early Cretaceous along the northeastern-eastern margin of Australia, situated at the eastern edge of Gondwana at that time (Hill and Hall, 2003). Erosion of the Australian continent and widespread AptianCenomanian volcanism (e.g., Dow et al., 1972; Dow, 1977; Hill and Gleadow, 1990; Hill and Hall, 2003) led to the accumulation of a $\geq 10 \mathrm{~km}$ thick (Pieters, 1978) volcano-sedimentary sequence (the Kagi Metamorphics, Figure 2.1) on rifted continental crust of the Australia continent (Bulois et al., 2017). Cropping out in present-day Queensland, the Whitsunday Volcanic Province (WVP) (Bryan et al., 1997; Ewart et al., 1992) was part of the same Aptian-Cenomanian volcanism.

The significance of the WVP as a source of volcanoclastic sediments for the protolith of the Kagi Metamorphics before the opening of the Coral Sea (see below) in the Paleocene is evinced by Cretaceous ( $120-80 \mathrm{Ma}$ ) detrital zircon U-Pb signatures in metasedimentary rocks of the Wau area (Kopi et al., 2004), basement gneisses on the D'Entrecasteaux Islands and the Calvados Schist on the Louisiade Archipelago (Zirakparvar et al., 2013), and inherited xenocrystic zircon in 8.1-1.8 Ma-old granitoids on the D'Entrecasteaux Islands (DesOrmeau et al., 2014; Gordon et al., 2012) and Misima Island (Adshead and Appleby, 1996) (Figure 2.1). A petrogenetic link between the WVP and the granitoids of the greater D'Entrecasteaux Islands region is also suggested by their overlapping ${ }^{87} \mathrm{Sr}^{86} \mathrm{Sr}_{i}$ isotopic values of 0.70312-0.70440 (Ewart et al., 1992) and 0.70380-0.70442 (Korchinski et al., 2014), respectively. 
Southwest-directed subduction of the Pacific Plate beneath the early Melanesian Arc in the Cretaceous (Tapster et al., 2014) was characterized by back-arc spreading between the Melanesian Arc and Australia (Seton et al., 2016). Relics of this back-arc basin, the Emo back-arc basin (EBAB) (Whattam, 2009; Worthing and Crawford, 1996) or the Emo Basin (Seton et al., 2016), are now preserved on the Papuan Peninsula and possibly on Normanby Island (Figure 2.1). It is, however, still debated which of these units (i.e., Emo Metamorphics, Goropu Metabasalt, Kutu Volcanics) are related and genetically linked to this episode of back-arc seafloor spreading (Rogerson et al., 1986; Smith, 2013; Worthing and Crawford, 1996). The age of the EBAB crust has primarily been constrained on the basis of Maastrichtian planktonic foraminifera from intercalated metasedimentary rocks (Smith and Davies, 1976). Similarly, it remains unclear how other Late Cretaceous-Oligocene(?) allochthonous units with MOR compositions (Brown, 1977; Macnab, 1969; Nion et al., 1987; Wai et al., 1994), cropping out in a semi-continuous fashion southwest of the Kagi Metamorphics relate to the EBAB (Figure 2.1).

In the Late Cretaceous-Paleocene, rifting and seafloor spreading led to the opening of the Coral Sea between the Australian continent in the south and the EBAB in the north (Symonds et al., 1984). Preserved chrons 27-24 suggest an age of 62-52 Ma for the Coral Sea crust (Gaina et al., 1999). At about the same time in the early Paleogene, the Owen Stanley Fault (OSF) developed during north-eastward subduction of EBAB lithosphere beneath a nascent island arc (Davies and Jaques, 1984). This island arc terrane is known as the Cape Vogel Arc (CVA; Glen and Meffre, 2009) or Dabi Arc (Little et al., 2019) and was active in the Paleocene-Eocene. Relics of it are preserved on the Papuan Peninsula including the 59-Ma Dabi Volcanics, the Eocene Eia Beds, and 57-51-Ma diorite and tonalite intrusions (Jaques and Chappell, 1980; Rogerson et al., 1991; Walker and McDougall, 1982). Subduction of the EBAB beneath the CVA transitioned to collision when the rifted continental Australian margin, including the Kagi Metamorphics, jammed the subduction channel (Davies and Jaques, 1984). During this collision, the CVA and its fore-arc basement, the Papuan Ultramafic Belt (PUB), were thrust south-westward over the distal Australia continental margin (Davies and Jaques, 1984). ${ }^{40} \mathrm{Ar} /{ }^{39} \mathrm{Ar}$ plateau ages of metamorphic hornblende from the sole of the PUB indicate that obduction of the fore-arc basement had begun by $58.3 \pm 0.4 \mathrm{Ma}$ (Lus et al., 2004).

A major change in the motion of the Pacific Plate occurred at $\sim 50 \mathrm{Ma}$ (Sharp and Clague, 2006). This resulted in the southward subduction of Pacific oceanic crust beneath the embryonic Melanesian Arc from 43-26 Ma, accompanied by spreading of the Solomon Sea (Figure 2.1) (Holm et al., 2013; Seton et al., 2016). The timing of opening of the Solomon Sea is still debated (Davies et al., 1984; Falvey and Pritchard, 1982; Joshima et al., 1986; Joshima 
and Honza, 1986), although preserved chrons 19-15 suggest a Middle to Late Eocene (45-35 Ma) age (Gaina and Müller, 2007).

A shift from dominantly basaltic MOR-like to dominantly intermediate arc-like magmatism occurred on the proto-Papuan Peninsula contemporaneous with the Peninsular Orogeny in the Oligocene (van Ufford and Cloos, 2005) (Figure 2.2). This change in igneous affinity coincides with a change in the tectonics at the Melanesian Arc (Figure 2.1, inset) where the arrival of the OJP at the trench jammed the subduction zone at $~ 26 \mathrm{Ma}$ (Holm et al., 2013; Knesel et al., 2008). On the proto-Papuan Peninsula, the transition to arc magmatism is manifested by basaltic-andesitic volcanic deposits of the Iauga Volcanics (Francis, 1985; Garside and Stoen, 1973), possibly the Wavera Volcanics south of the SDMCC (Lindley, 2014), and the andesitic Sewa Beds on Normanby Island (Smith and Davies, 1973b) (Figures 2.1 and 2.2).

The Miocene Maramuni Arc (Dow, 1977; Holm et al., 2015, 2019) is composed of calcalkaline to shoshonitic igneous rocks that crop out on the Papuan Peninsula, in the Woodlark Rift (rhyolites encountered in drill holes of ODP Leg 180) and the northern and southern rifted margins of the Woodlark Basin (Figures 2.1 and 2.2) (Baldwin et al., 2012). The main pulse of Maramuni Arc magmatism likely occurred between 18-12 Ma (Page, 1976), but younger igneous rocks ( 11-8 Ma) with arc affinities (Catalano, 2012) occur on Woodlark Island and the Louisiade Archipelago (Figures 2.1 and 2.2). The cause for this volcanism is still debated (Baldwin et al., 2012), but the two most cited models invoke southward underthrusting of Solomon Sea crust at the Trobriand Trough (Cooper and Taylor, 1987; Davies et al., 1984; Francis et al., 1987) or north-directed subduction at the Aure-MoresbyPocklington Trough to the south of the Papuan Peninsula (Figure 2.1) (Cloos et al., 2005; Holm et al., 2015; Webb et al., 2014).

In southeastern Papua New Guinea, seafloor spreading likely initiated at $\sim 6 \mathrm{Ma}$ (Taylor et al., 1999). The timing of the onset of rifting in the continental Woodlark Rift is still under debate. Estimates range from 9.3-8.3 Ma based on the stratigraphic record (Taylor and Huchon, 2002) and 4 Ma based on finite extension arguments (Petersen and Buck, 2015). An extensive record of latest Miocene-Recent volcanic and plutonic rocks that fall within the temporal and spatial reaches of the Woodlark Rift are preserved on the southeastern Papuan Peninsula (as far east as $148^{\circ} \mathrm{E}$ ), the D'Entrecasteaux Islands, the Lusancay Islands and the Egum Atoll (Figures 2.1 and 2.2). Despite the extensional tectonic regime, most of these igneous rocks are characterised by arc-like chemical signatures. Only in the Dawson Strait between Fergusson and Normanby Islands do peralkaline rhyolites of the Quaternary Dawson Strait Volcanics (Smith, 1976) herald a change from convergent to divergent tectonics caused by the impinging Woodlark Basin (Smith et al., 1977). The tectonic affinity of Late 
Miocene-Pliocene volcanic rocks (Cloudy Bay Volcanics, Fife Bay Volcanics) on the southwestern coast of the Papuan Peninsula (Figure 2.1) has not yet been established (Holm and Poke, 2018).

\subsubsection{The Suckling-Dayman metamorphic core complex}

In the western Woodlark Rift, extension on the active and rapidly slipping Mai'iu Fault has exhumed an up to $\sim 3.7-\mathrm{km}$-high, $\sim 60$-km-long, continuous, east-west-elongate, corrugate mountain mass in its footwall over the past few million years - the SDMCC (Figure 2.3) (Davies, 1980; Little et al., 2019). Three summits (Mt. Suckling, 3676 m; Mt. Dayman, 2980 m; Mt. Masasoru, $2300 \mathrm{~m}$ ) are built on 20-40-km-spaced major antiformal culminations (Little et al., 2019) with decreasing elevations towards the east (Figure 2.3). The footwall of the Mai'iu Fault consists chiefly of a 3-4-km-thick carapace (inferred from correlation with the Kutu Volcanics south of the SDMCC) of low-grade metabasalt (Goropu Metabasalt) of MORB affinity with subordinate hyaloclastite, pelagic limestone, tuffaceous marl and calcareous-siliceous phyllite (Davies, 1980; Davies and Smith, 1974). Locally, pillow structures are preserved in the metabasalt (Smith and Davies, 1976). The metamorphic grade decreases from greenschist facies at the modern-day fault scarp in the north, to pumpellyiteactinolite facies on the upper northern flank of the dome, to prehnite-pumpellyite south of the Onuam Fault before it grades into unmetamorphosed basalts (Kutu Volcanics) of similar composition still farther south (Daczko et al., 2009; Davies, 1980; Smith, 2013).

The ages of the Goropu Metabasalt and the Kutu Volcanics are constrained by Late Cretaceous (Maastrichtian)-Eocene planktonic foraminifera occurring in intercalated metasedimentary rocks (the Bonenau Schist) and stream boulders (Smith and Davies, 1976). Subordinate Oligocene-Miocene and Eocene fossils have been identified in stream boulders and in outcrop (Figure 2.3) on the mapped area of the Goropu Metabasalt. In contrast, the Kutu Volcanics are dominated by Eocene planktonic (and rare benthonic) foraminifera (Smith and Davies, 1976). No Kutu Volcanics of Paleocene age are known (Davies et al., 1984). In the vicinity of Mt. Suckling and Mt. Masasoru, the Goropu Metabasalt is structurally overlain by deformed ultramafic rocks of the PUB (Davies, 1980). The contact between the Goropu Metabasalt and the overlying rocks of the PUB is a fossilized remnant of the OSF (Davies, 1980; Little et al., 2019). Although the surface geology of the footwall of the SDMCC and its surroundings is dominantly mafic-ultramafic in composition (Davies and Smith, 1974; Smith and Davies, 1973a,b), it was speculated, based on the presence of granitoids on Mt. Suckling, that the SDMCC is underlain by continental crustal material (Davies and Smith, 1971). This is consistent with seismic studies (Abers et al., 2016; Ferris et al., 2006; Jin et al., 2015) that indicate that the crust beneath the Papuan Peninsula and the SDMCC is $30-40 \mathrm{~km}$ thick and of bulk intermediate-felsic composition $\left(\mathrm{V}_{p}=5.6-6.9 \mathrm{~km} / \mathrm{s}\right.$ at $10-25 \mathrm{~km}$ depth$)$. It is also supported by the proximity to the exposed Kagi Metamorphics to the southwest 


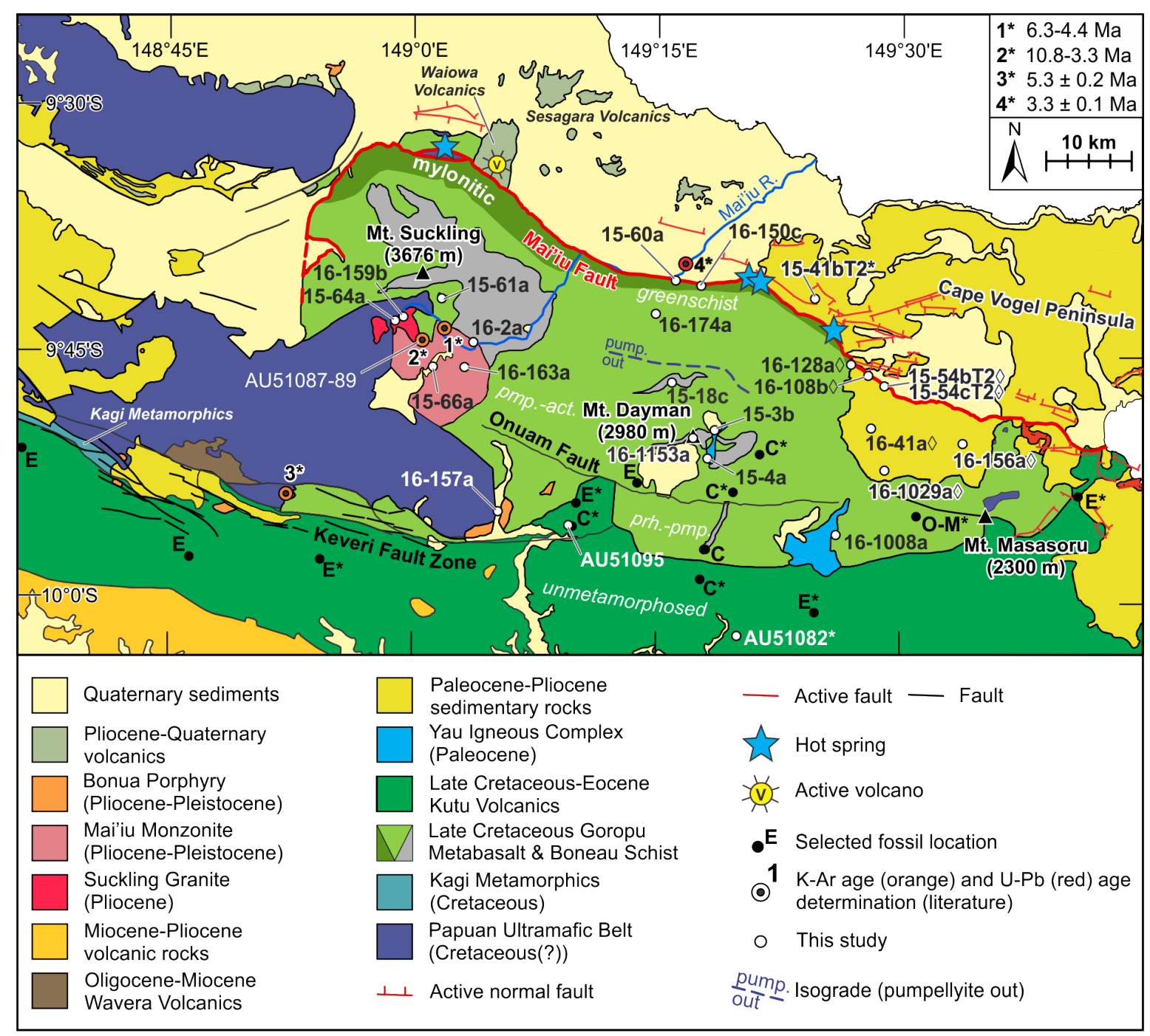

Figure 2.3: Geological map of the Suckling-Dayman metamorphic core complex. Modified from Davies and Smith (1974) and Lindley (2014). Location of hot springs from Davies and Smith (1974) and Little et al. (2019). Pumpellyite-out isograde from Little et al. (2019). Selected fossil and K-Ar dating sample locations from Davies and Smith (1974). Location of zircon U-Pb age sample from Caffi (2008). Asterisks denote stream boulders and diamonds refer to clasts collected in the Gwoira Conglomerate. Abbreviations: C - Late Cretaceous, E - Eocene, M - Miocene, O - Oligocene. 
of Mt. Suckling (Figure 2.3) and a Bouguer gravity low (Geological Survey of Papua New Guinea and British Geological Survey, 2004; Milsom, 1973) that is continuous with the Kagi Metamorphics further west in the central Papuan Peninsula.

\subsubsection{Igneous rocks of the SDMCC}

The footwall of the SDMCC has been intruded by two disparate plutonic suites. The first and older, the Yau Gabbro (but in this thesis called the Yau Igneous Complex), consists of metamorphosed tholeiitic gabbroic-tonalitic rocks that intruded in the eastern part of the core complex (Figure 2.3) (Smith and Davies, 1976). A contact aureole is present locally where the gabbros intruded limestone beds in the Goropu Metabasalt (Smith and Davies, 1976). There, the limestones have been hornfelsed and recrystallized to calc-silicate assemblages that include diopside, prehnite and grossular garnet (Latter, 1964; Smith and Davies, 1976). The gabbroic-tonalitic rocks have previously been interpreted as subvolcanic stocks, co-magmatic with the Late Cretaceous Goropu Metabasalt and Kutu Volcanics (Smith and Davies, 1976).

Chronologically, the second plutonic suite consists of granitoids (sensu lato) with calcalkaline to shoshonitic affinities (Suckling Granite, Mai'iu Monzonite, Bonua Porphyry; Smith and Davies, 1976). Geochemically, the Suckling Granite may be distinguished from Mai'iu Monzonite and Bonua Porphyry (Smith and Davies, 1976, and see below). The granitoids were emplaced in the western part of the core complex (Figure 2.3). Stream boulders of these granitoids in the headwaters of the Mai'iu River on Mt. Suckling have been dated by the K-Ar method (Davies and Smith, 1974), yielding apparent ages of $10.8 \pm 0.8$ and $9.4 \pm$ $0.8 \mathrm{Ma}$ for hornblende, and 3.3 $\pm 0.1 \mathrm{Ma}$ for biotite from two samples of Suckling Granite (6552-2577, 6552-2578). Daczko et al. (2011) reported a zircon U-Pb LA-ICP-MS age of $3.3 \pm 0.1 \mathrm{Ma}$ from a granite boulder collected in the Mai' iu River near the range front in the hanging wall of the Mai'iu Fault due north of Mt. Dayman (Figure 2.3). The larger stock of Mai'iu Monzonite comprises coarse grained granodiorite, adamellite, monzonite and hornblendite (Smith and Davies, 1976). Hornblende from two Mai'iu Monzonite stream boulders in the headwaters of the Mai'iu River yielded K-Ar ages of $6.3 \pm 0.4$ and $4.4 \pm 0.4 \mathrm{Ma}$, respectively (Davies and Smith, 1974). Lastly, smaller stocks of the Bonua Porphyry consist of hornblende, biotite and/or pyroxene-bearing porphyritic microdiorite and micromonzonite where they intrude mafic and ultramafic rocks of the Goropu Metabasalt and PUB, respectively (Smith and Davies, 1976). K-Ar dating of biotite from a single stream boulder of Bonua Porphyry south of Mt. Suckling yielded an apparent age of $5.3 \pm 0.2 \mathrm{Ma}$ (Davies and Smith, 1974).

Rare undeformed mafic dikes and sills of probable Quaternary age are locally present in the most recently exposed mylonitic parts of the footwall (Little et al., 2019). Daczko et al. 
(2011) inferred that the dikes intruded the mylonites shortly after cessation of ductile movement but under a similar stress regime that created the extensional fabric of the mylonitic rocks between <3.6 and 0.52 Ma. Little et al. (2019) disagree, however, that the intrusion of the dikes closely post-date mylonitization. The youngest phase of igneous activity in the vicinity of the SDMCC includes the pyroclastic absarokites and shoshonites of the Sesagara Volcanics in the hanging wall of the Mai'iu Fault, possibly last active in the Holocene (Smith and Davies, 1976), and the pyroclastic shoshonites of the Waiowa Volcanics that erupted from Goropu Crater in 1943 and 1944 (Baker, 1946) (Figure 2.3). Hydrothermal springs occur along the Mai'iu Fault trace but are presumably driven by heating of groundwater due to rapid exhumation of footwall rocks at depth (Latter, 1964; Little et al., 2019).

\subsection{Analytical techniques}

The analytical techniques used in this study are briefly described in the following section. For a detailed description of the instrumental and operational conditions, calibration and data reduction of the whole-rock, zircon $\mathrm{U}-\mathrm{Pb}$ and microprobe analyses, the reader is referred to Appendices A.1, A.2 and A.3.

\subsubsection{Whole rock major oxide and trace element analysis}

Rocks were powdered in an agate mill. Elemental concentrations were determined using a $1 \mathrm{KW}$ Bruker S8 Tiger wavelength dispersive X-ray fluorescence (WDS-XRF) analyser at the University of Waikato, New Zealand. For trace element analysis, representative samples were dissolved in $\mathrm{NH}_{4} \mathrm{~F}$ for 60 hours at $210^{\circ} \mathrm{C}$ (Hu et al., 2013). Trace element concentrations were measured on a Thermo-Scientific Element 2 sector-field ICP-MS housed at Victoria University of Wellington, New Zealand. The results can be found in Table 2.2.

\subsubsection{Zircon $\mathrm{U}-\mathrm{Pb}$ analysis}

Depth profiling was chosen over conventional in-situ dating on polished zircon grains because of (1) the possibility to recover and resolve thin late-stage rims and (2) the convenience for subsequent double-dating with (U-Th[-Sm])/He (see Chapter 4). Two samples of the Suckling Granite (PNG-15-61a, PNG-15-64a) were dated by in-situ LA-ICP-MS techniques to check for consistency and gain confidence in the interpretations made from depth profiling (see Electronic appendix 1). Zircon grains were picked onto double-sided adhesive tape on 1" acrylic disks for LA-ICP-MS U-Pb and trace element analyses performed at the UTChron Laboratories of the University of Texas at Austin. Single-grain U-Pb analyses were corrected for common $\mathrm{Pb}\left(\mathrm{Pb}_{c}\right)$ applying the Andersen (2002) routine following Paton et al. (2011). Following the $\mathrm{Pb}_{c}$ correction, single-grain ${ }^{206} \mathrm{~Pb} /{ }^{238} \mathrm{U}$ dates were corrected for 
the effects of initial ${ }^{230} \mathrm{Th}$ disequilibrium based on the measured whole-rock $\mathrm{Th} / \mathrm{U}$ (where available). The $T h / U_{m a g m a}$ of typical igneous rocks is $4 \pm 2$ (Schoene, 2014), but the average bulk $\mathrm{Th} / \mathrm{U}$ of the igneous rocks from the SDMCC is closer to 3. Thus, for samples where no whole-rock compositional data is available, Th/ $\mathrm{U}_{\text {magma }}$ was assumed to be 3 . All singlegrain dates are reported at the 2SE (standard error) confidence level (Electronic appendix 1). We report single-grain ${ }^{206} \mathrm{~Pb} /{ }^{238} \mathrm{U}$ dates for ages $<1 \mathrm{Ga}$ and ${ }^{207} \mathrm{~Pb} /{ }^{206} \mathrm{~Pb}$ dates for ages $>1$ Ga. Weighted mean ages have been calculated in Isoplot v.4 (Ludwig, 2009) from the $\mathrm{Pb}_{c^{-}}$ and ${ }^{230} \mathrm{Th}$-corrected single-grain ${ }^{206} \mathrm{~Pb} /{ }^{238} \mathrm{U}$ dates and are reported at the $2 \sigma$ confidence level (Table 2.3), excluding and including systematic errors (separated by a dash). We also plotted ${ }^{230} \mathrm{Th}$-corrected $\mathrm{U}-\mathrm{Pb}$ analyses (but uncorrected for $\mathrm{Pb}_{c}$ ) in Tera-Wasserburg diagrams and calculated lower-intercept ages by anchoring the upper intercept at ${ }^{207} \mathrm{~Pb} /{ }^{206} \mathrm{~Pb}=0.83$ \pm 0.02 . This value is based on ${ }^{207} \mathrm{~Pb} /{ }^{206} \mathrm{~Pb}$ analyses of co-genetic feldspars from samples of the Suckling Granite (PNG-15-61a, PNG-15-64a) and Mai'iu Monzonite (PNG-15-66a) (Table B.1).

\subsubsection{Electron probe micro-analysis}

Elemental analyses of amphibole and plagioclase were performed on a JEOL JXA 8230 electron probe micro-analyser (EPMA) at Victoria University of Wellington, using wavelength dispersive spectrometry (WDS) techniques. A ZAF correction (where $\mathrm{Z}$ is atomic number, $\mathrm{A}$ is absorption and $\mathrm{F}$ is fluorescence) was used to calculate all elemental concentrations. The results can be found in Electronic appendices 2 and 3.

\subsection{Results}

\subsubsection{Petrography}

Metamorphosed, prehnite-pumpellyite facies gabbroic/doleritic and tonalitic rocks (Table 2.1) cropping out between Mts. Dayman and Masasoru (Figure 2.3) were collectively referred to as the Yau Gabbro (Smith and Davies, 1976). Based on the occurrence of both gabbroic and tonalitic rocks, we suggest a more inclusive name: the Yau Igneous Complex. A plagioclase-rich cumulate (PNG-16-41a, Tables 2.1 and 2.2) is also grouped with the Yau Igneous Complex due to its tholeiitic composition. Cataclastic deformation and dynamic recrystallization of quartz are only evident in the doleritic samples (Figure 2.4a), while the coarser-grained gabbroic (Figure 2.4b) and tonalitic (Figure 2.4c) rocks appear to be undeformed. The difference in deformation between the finer-grained dolerites and the coarser-grained quartz-gabbros and tonalites is likely a reflection of the vertical proximity to the exhumed paleo-fault plane as approximated by the youthful topography of Mt. Dayman; 
that is, the deformed dolerites come from a structural level closer to the abandoned fault plane than the undeformed gabbros and tonalites.

Rocks collected from the Suckling Granite (Figure 2.4d), Mai'iu Monzonite (Figure 2.4f), Bonua Porphyry (Figure 2.4g), as well as rare basaltic andesite dikes (Figure 2.4h) exposed in the mylonitic parts of the footwall, are mostly undeformed. They generally have normal igneous textures but include cumulate-like rocks (e.g., hornblendite, PNG-16-163a; Table 2.1). Only one sample from the Suckling Granite revealed evidence for a progression from magmatic to ductile solid-state deformation indicated by the alignment of feldspar phenocrysts and recrystallized folia of white mica (Figure 2.4e), respectively. All samples show some degree of low-grade alteration, as evidenced by the replacement of biotite by chlorite. Petrographically, the Suckling Granite exhibits facies with different or variable abundances of mafic phases. Some contain biotite and hornblende, while others have only biotite, or neither biotite nor hornblende but white mica (Table 2.1). The Mai'iu Monzonite contains less quartz and K-feldspar, but higher relative abundance of mafic phases (biotite, hornblende, rare clinopyroxene) and accessory minerals compared to the Suckling Granite. In contrast, the Bonua Porphyry is characterized by clinopyroxene and biotite as the dominant mafic phases and K-feldspar instead of plagioclase as the prevailing feldspar. Two basaltic andesite dikes contain porphyritic hornblende and clinopyroxene and have chilled margins against the mylonitic fabric of the Goropu Metabasalt (Figures 2.3 and 2.4h).

Sample locations, rock descriptions and petrography of these units are summarized in Table 2.1. For a detailed description of the petrography of the Yau Igneous Complex, Suckling Granite, Mai'iu Monzonite, Bonua Porphyry and the basaltic andesite dikes see Supplementary material B.1.

\subsubsection{Geochemistry}

\section{Rock classification}

Major oxide and trace element compositions of igneous rocks from the various suites are presented in Table 2.2. The rocks have variable loss on ignition (LOI), ranging from 0.4$4.9 \%$, consistent with the rocks having experienced low-grade metamorphism. In a diagram of Co vs. Th after Hastie et al. (2007), topologically similar to the $\mathrm{K}_{2} \mathrm{O}$ vs. $\mathrm{SiO}_{2}$ diagram of Peccerillo and Taylor (1976) but less susceptible to alteration, samples of the Goropu Metabasalt and the Yau Igneous Complex plot in the basalt, basaltic andesite/andesite and dacite/rhyolite fields (corresponding to gabbro, gabbro/diorite and granodiorite/granite in plutonic terms), straddling the boundary between tholeiitic and calc-alkaline compositions (Figure 2.5a). Three quartz-gabbro and tonalite samples of the Yau Igneous Complex that plot exclusively in the calc-alkaline field (blue in Figure 2.5a), correspond to higher $\mathrm{SiO}_{2}$ 
concentrations ( $\sim 55-63 \mathrm{wt} \%)$ (Table 2.2$)$ and are referred to in the following as the 'highsilica suite'. Four samples (two dolerites, a quartz-gabbro and a tonalite) that lie in the basaltic field and straddle the boundary between tholeiitic and calc-alkaline compositions (purple in Figure 2.5a) are referred to as the 'low-silica suite'. Samples of the Suckling Granite lie in the dacite/rhyolite field in the upper portion of the calc-alkaline field (Figure 2.5a). The Mai'iu Monzonite, Bonua Porphyry and basaltic andesite dikes plot predominantly in the high-K calc-alkaline to shoshonite field with overall basaltic compositions (Figure 2.5a).

A similar relative geochemical attribution of the units is evident from a total alkali silica diagram (TAS; Le Maitre et al., 2002) (Figure 2.5b). It reveals that the Goropu Metabasalt, the Yau Igneous Complex, the Suckling Granite and the basaltic andesite dikes plot in the subalkaline field, whereas the Mai'iu Monzonite and the Bonua Porphyry lie largely in the alkaline field (Figure 2.5b). Virtually all samples from the various units exhibit metaluminous compositions (Figure B.2) after the classification of Shand (1947). Only PNG-15-61a and PNG-15-64a of the Suckling Granite are peraluminous with aluminium saturation indices $(\mathrm{ASI})>1.1$, classifying them as S-type granitoids (Chappell and White, 1974).

Whole-rock major oxide compositions (normalized to volatile-free compositions) of the various units reveal positive correlations of $\mathrm{SiO}_{2}$ with $\mathrm{Na}_{2} \mathrm{O}$ and $\mathrm{Al}_{2} \mathrm{O}_{3}$ and negative correlations with $\mathrm{Fe}_{t o t}, \mathrm{CaO}, \mathrm{MgO}, \mathrm{TiO}_{2}$ and $\mathrm{P}_{2} \mathrm{O}_{5}$ (Figure 2.6). No systematic correlation of $\mathrm{K}_{2} \mathrm{O}$ with $\mathrm{SiO}_{2}$ is evident (Figure 2.6b). Samples of the Goropu Metabasalt and the Yau Igneous Complex are systematically displaced to lower $\mathrm{K}_{2} \mathrm{O}$ contents compared to those of the Suckling Granite, Mai'iu Monzonite and Bonua Porphyry and one basaltic andesite dike (Figure 2.6b). The other basaltic andesite dike (PNG-15-60a), although plotting in the high-K calc-alkaline field in Figure 2.5a, shows $\mathrm{K}_{2} \mathrm{O}$ contents similar to those of the tholeiitic Goropu Metabasalt and Yau Igneous Complex. Because of the similar trace element abundances (see below) and inferred age (Quaternary) to the other basaltic andesite dike, the Mai' iu Monzonite and Bonua Porphyry (see below), PNG-15-60a is grouped with these high-K rocks rather than with the tholeiitic ones. The low $\mathrm{K}_{2} \mathrm{O}$ content of PNG-15-60a is likely explained by the nearcomplete alteration of biotite (the main carrier of $\mathrm{K}_{2} \mathrm{O}$ in this sample) to chlorite. Samples of the Goropu Metabasalt and the low-silica suite of the Yau Igneous Complex deviate from the trends defined by the Suckling Granite, Mai' iu Monzonite, Bonua Porphyry and the basaltic andesite dikes in $\mathrm{P}_{2} \mathrm{O}_{5}$ and $\mathrm{Fe}_{\text {tot }}$ vs. $\mathrm{SiO}_{2}$ (Figures 2.6c and h). Too few samples of any one unit are available to fully appreciate any intra-sample/suite variability and systematics at this stage. However, rocks of the Yau Igneous Complex range in $\mathrm{SiO}_{2}$ content from 46 to 63 wt\% (Table 2.2), indicating that the unit is internally differentiated. Similarly, rocks of the Mai'iu Monzonite with $\mathrm{SiO}_{2}$ contents ranging from 48 to $61 \mathrm{wt} \%$ also suggest possible internal differentiation, although in this case cumulate-like rocks such as hornblendite PNG-16-163a may partly explain the low $\mathrm{SiO}_{2}$ values. 
Table 2.1: Sample description, location and petrography of the igneous rocks of the SDMCC.

\begin{tabular}{|c|c|c|c|c|c|c|c|}
\hline Map unit & Sample ID & Sample type & Longitude $[\mathrm{E}]^{\dagger}$ & Latitude $[\mathrm{S}]^{\dagger}$ & Elevation $[\mathrm{m}]$ & Rock type & Mineral assemblage \\
\hline $\begin{array}{l}\text { Suckling } \\
\text { Granite }\end{array}$ & $\begin{array}{l}\text { PNG-15-61a } \\
\text { PNG-15-64a } \\
\text { AU51087* } \\
\text { AU51088* } \\
\text { AU51089* }\end{array}$ & $\begin{array}{l}\text { outcrop } \\
\text { outcrop } \\
\text { float } \\
\text { float } \\
\text { float }\end{array}$ & $\begin{array}{l}149^{\circ} 11^{\prime} 39.1^{\prime \prime} \\
148^{\circ} 58^{\prime} 51.3^{\prime \prime} \\
149^{\circ} 00^{\prime} 5^{\prime \prime} \\
149^{\circ} 0^{\prime} 5^{\prime \prime} \\
149^{\circ} 0^{\prime} 5^{\prime \prime}\end{array}$ & $\begin{array}{l}9^{\circ} 41^{\prime}, 45.6^{\prime \prime} \\
9^{\circ} 43^{\prime}, 12.1^{\prime \prime} \\
9^{\circ} 44^{\prime} 10.2^{\prime \prime} \\
9^{\circ} 44^{\prime} 10.2^{\prime \prime} \\
9^{\circ} 44^{\prime} 10.2^{\prime \prime}\end{array}$ & $\begin{array}{l}3410 \\
3450 \\
2470 \\
2470 \\
2470\end{array}$ & $\begin{array}{l}\text { Granodiorite }^{1} \\
\text { Qtz-monzodiorite }^{1} \\
\text { Qtz-monzodiorite }^{1} \\
\text { Qtz-monzodiorite }^{2} \\
\text { Qtz-monzodiorite }^{2}\end{array}$ & $\begin{array}{l}\mathrm{pl}(\mathrm{ab})+\mathrm{qtz}+\mathrm{wmca}+\mathrm{Fe}-\text { oxides }+\mathrm{ttn}+\mathrm{ap}+\mathrm{zrn} \\
\mathrm{pl}+\mathrm{qtz}+\mathrm{kfs}+\mathrm{bt}+\mathrm{Fe}-\text { oxides }+ \text { py }+\mathrm{ttn}+\mathrm{ap}+\mathrm{zrn}+\mathrm{aln}-(\mathrm{Ce}) \\
\mathrm{pl}+\mathrm{qtz}+\mathrm{kfs}+\mathrm{bt}+\mathrm{am}+\mathrm{Fe}-\text { Ti-oxides }+\mathrm{ttn}+\mathrm{ap}+\mathrm{zrn} \\
\mathrm{pl}+\mathrm{qtz}+\mathrm{kfs}+\mathrm{bt}+\mathrm{am}+\mathrm{Fe}-\text { Ti-oxides }+\mathrm{ttn}+\mathrm{ap}+\mathrm{zrn} \\
\mathrm{pl}+\mathrm{qtz}+\mathrm{kfs}+\mathrm{bt}+\mathrm{am}+\text { Fe-Ti-oxides }+\mathrm{ttn}+\mathrm{ap}+\mathrm{zrn}\end{array}$ \\
\hline $\begin{array}{l}\text { Mai'iu } \\
\text { Monzonite }\end{array}$ & $\begin{array}{l}\text { PNG-15-66a } \\
\text { PNG-16-2a } \\
\text { PNG-16-159b } \\
\text { PNG-16-163a } \\
\text { PNG-16-174a }\end{array}$ & $\begin{array}{l}\text { outcrop } \\
\text { outcrop } \\
\text { outcrop } \\
\text { outcrop } \\
\text { float }\end{array}$ & $\begin{array}{l}149^{\circ} 1^{\prime}, 14.3^{\prime \prime} \\
149^{\circ} 3^{\prime} 43.1^{\prime \prime} \\
148^{\circ} 59^{\prime} 23.9^{\prime \prime} \\
149^{\circ} 3,10.7^{\prime \prime} \\
149^{\circ} 15^{\prime} 3.7^{\prime \prime}\end{array}$ & $\begin{array}{l}9^{\circ} 45^{\prime}, 58.2^{\prime \prime} \\
9^{\circ} 44^{\prime} 28.7^{\prime \prime} \\
9^{\circ} 42^{\prime} 56.1^{\prime \prime} \\
9^{\circ} 45^{\prime} 58.8^{\prime \prime} \\
9^{\circ} 42^{\prime} 9.7^{\prime \prime}\end{array}$ & $\begin{array}{l}2045 \\
1675 \\
3380 \\
1835 \\
1070\end{array}$ & $\begin{array}{l}\text { Qtz-monzodiorite }^{1} \\
\text { Qtz-monzodiorite }^{1} \\
\text { Monzodiorite }^{1} \\
\text { Hornblendite }^{2} \\
\text { Monzonite }^{1}\end{array}$ & $\begin{array}{l}\mathrm{pl}+\mathrm{qtz}+\mathrm{kfs}+\mathrm{bt}+\mathrm{am}+\mathrm{cpx}+\mathrm{Fe}-\mathrm{Ti} \text { oxides }+\mathrm{ttn}+\mathrm{ap}+\mathrm{zrn} \\
\mathrm{pl}+\mathrm{qtz}+\mathrm{kfs}+\mathrm{bt}+\mathrm{am}+\mathrm{Fe}-\mathrm{Ti} \text { oxides }+\mathrm{ttn}+\mathrm{ap}+\mathrm{zrn}+\mathrm{Fe} \text {-sulfides } \\
\mathrm{pl}+\mathrm{qtz}+\mathrm{kfs}+\mathrm{bt}+\mathrm{am}+\mathrm{Fe}-\mathrm{Ti} \text { oxides }+\mathrm{ttn}+\mathrm{ap}+\mathrm{zrn} \\
\mathrm{pl}+\mathrm{kfs}+\mathrm{bt}+\mathrm{am}+\mathrm{Fe}-\mathrm{Ti} \text { oxides }+\mathrm{ttn}+\mathrm{ap}+\mathrm{zrn} \\
\mathrm{pl}(\mathrm{ab})+\mathrm{qtz}+\mathrm{kfs}+\mathrm{am}+\mathrm{chl}+\mathrm{Fe}-\mathrm{Ti} \text { oxides }\end{array}$ \\
\hline $\begin{array}{l}\text { Bonua } \\
\text { Porphyry }\end{array}$ & $\begin{array}{l}\text { PNG-16-157a } \\
\text { AU51095* }\end{array}$ & $\begin{array}{l}\text { outcrop } \\
\text { outcrop }\end{array}$ & $\begin{array}{l}149^{\circ} 5^{\prime} 17.4^{\prime \prime} \\
149^{\circ} 9^{\prime} 38^{\prime \prime}\end{array}$ & $\begin{array}{l}9^{\circ} 54^{\prime}, 45.8^{\prime \prime} \\
9^{\circ} 55^{\prime} 39.4^{\prime \prime}\end{array}$ & $\begin{array}{l}270 \\
220\end{array}$ & $\begin{array}{l}\text { Monzonite } \\
\text { Latite }^{1}\end{array}$ & $\begin{array}{l}\mathrm{kfs}+\mathrm{bt}+\mathrm{cpx}(\mathrm{di})+\mathrm{cal}+\mathrm{chl}+\mathrm{Fe}-\mathrm{Ti} \text { oxides }+\mathrm{ttn}+\mathrm{ap}+\mathrm{zrn}+\mathrm{py} \\
\mathrm{bt}+\mathrm{cpx}+\mathrm{opx}+\operatorname{srp}+\text { opaques }\end{array}$ \\
\hline $\begin{array}{l}\text { Yau Igneous } \\
\text { Complex }\end{array}$ & $\begin{array}{l}\text { PNG-15-3b } \\
\text { PNG-15-4a } \\
\text { PNG-15-41b T2 } \\
\text { PNG-15-54b T2 } \\
\text { PNG-15-54c T2 } \\
\text { PNG-16-41a } \\
\text { PNG-16-108b } \\
\text { PNG-16-128a } \\
\text { PNG-16-156a } \\
\text { PNG-16-1008a } \\
\text { PNG-16-1029a } \\
\text { AU51082* }\end{array}$ & $\begin{array}{l}\text { outcrop } \\
\text { outcrop } \\
\text { float } \\
\text { clast } \\
\text { clast } \\
\text { clast } \\
\text { clast } \\
\text { clast } \\
\text { clast } \\
\text { outcrop } \\
\text { clast } \\
\text { float }\end{array}$ & $\begin{array}{l}149^{\circ} 18^{\prime}, 34.1^{\prime \prime} \\
149^{\circ} 18^{\prime} 8.1^{\prime \prime} \\
149^{\circ} 24,37.9^{\prime \prime} \\
149^{\circ} 29^{\prime}, 0.2^{\prime \prime} \\
149^{\circ} 29^{\prime} 0.2^{\prime \prime} \\
149^{\circ} 28^{\prime} 11.0^{\prime \prime} \\
149^{\circ} 27^{\prime} 58.1^{\prime \prime} \\
149^{\circ} 26^{\prime} 54.6^{\prime \prime} \\
149^{\circ} 33^{\prime} 48.9^{\prime \prime} \\
149^{\circ} 26^{\prime} 2.1^{\prime \prime} \\
149^{\circ} 29^{\prime} 1.6^{\prime \prime} \\
149^{\circ} 19^{\prime} 59^{\prime \prime}\end{array}$ & $\begin{array}{l}9^{\circ} 49^{\prime}, 45.1^{\prime \prime} \\
9^{\circ} 51^{\prime}, 28.2^{\prime \prime} \\
9^{\circ} 41^{\prime} 49.4^{\prime \prime} \\
9^{\circ} 46^{\prime} 59.5^{\prime \prime} \\
9^{\circ} 46^{\prime} 59.5^{\prime \prime} \\
9^{\circ} 49^{\prime} 34.3^{\prime \prime} \\
9^{\circ} 46^{\prime} 22.8^{\prime \prime} \\
9^{\circ} 45^{\prime}, 41.5^{\prime \prime} \\
9^{\circ} 50^{\prime} 29.0^{\prime \prime} \\
9^{\circ} 56^{\prime} 5.3^{\prime \prime} \\
9^{\circ} 52^{\prime}, 8.6^{\prime \prime} \\
10^{\circ} 2^{\prime} 12.1^{\prime \prime}\end{array}$ & $\begin{array}{c}2290 \\
2500 \\
140 \\
220 \\
220 \\
410 \\
155 \\
275 \\
200 \\
1160 \\
440 \\
190\end{array}$ & $\begin{array}{l}\text { Gabbro/Dolerite } \\
\text { Gabbro/Dolerite }^{1} \\
\text { Qtz-gabbro }^{2} \\
\text { Qtz-gabbro }^{2} \\
\text { Qtz-gabbro }^{2} \\
\text { Pl-px cumulate } \\
\text { Qtz-gabbro }^{1} \\
\text { Qtz-gabbro }^{2} \\
\text { Qtz-gabbro }^{1} \\
\text { Tonalite }^{1} \\
\text { Tonalite }^{1} \\
\text { Tonalite }^{1}\end{array}$ & 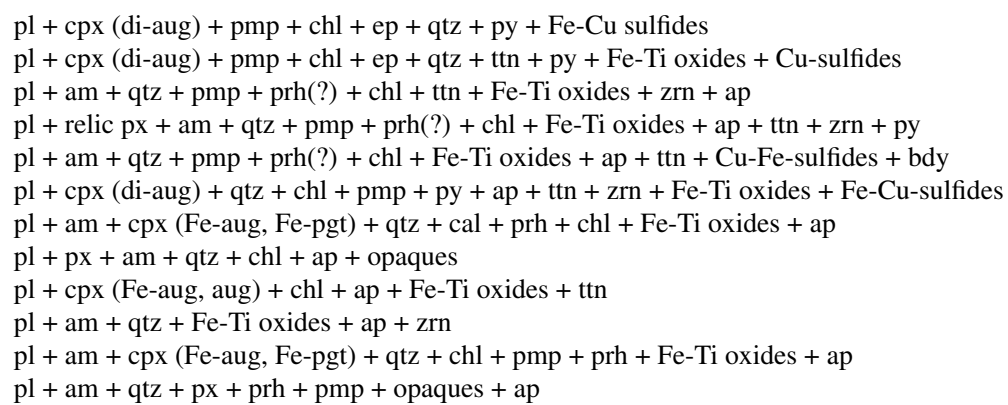 \\
\hline Dikes & $\begin{array}{l}\text { PNG-15-60a } \\
\text { PNG-16-150c }\end{array}$ & $\begin{array}{l}\text { outcrop } \\
\text { outcrop }\end{array}$ & $\begin{array}{l}149^{\circ} 16^{\prime} 7.1^{\prime \prime} \\
149^{\circ} 17^{\prime} 38.8^{\prime \prime}\end{array}$ & $\begin{array}{l}9^{\circ} 40^{\prime} 38.9^{\prime \prime} \\
9^{\circ} 40^{\prime} 52.1^{\prime \prime}\end{array}$ & $\begin{array}{l}230 \\
270\end{array}$ & $\begin{array}{l}\text { Basaltic andesite }{ }^{1} \\
\text { Basaltic andesite }^{1}\end{array}$ & $\begin{array}{l}\mathrm{pl}(\mathrm{ab})+\mathrm{cpx}(\mathrm{di})+\mathrm{bt}+\mathrm{ttn}+\mathrm{chl}+\mathrm{pmp}+\mathrm{py} \\
\mathrm{pl}+\mathrm{am}+\mathrm{relic} \mathrm{px}+\mathrm{qtz}+\mathrm{chl}+\mathrm{kfs}+\mathrm{ttn}+\mathrm{cal}+\mathrm{py}\end{array}$ \\
\hline
\end{tabular}

$\dagger$ : Reference datum AGD1966, AMG Zone 55.

Sample type: 'Clast' refers to gabbroic-tonalitic rock clast in the Gwoira Conglomerate. 'Float' refers to stream or landslip boulder.

*: Samples provided by Ian Smith. Sample locations approximated from labelled aerial photographs.

1 : Rock type based on bulk composition (see Figure B.1)

2: Rock type based on petrography.

Abbreviations after Siivola and Schmid (2007): ab - albite, act - actinolite, aln-(Ce) - allanite-(Ce), am - amphibole, ap - apatite, aug - augite, bt - biotite, cal - calcite, chl - chlorite,

cpx - clinopyroxene, di - diopside, ep - epidote, kfs - K-feldspar, opx - orthopyroxene, pgt - pigeonite, pl - plagioclase, pmp - pumpellyite, prh - prehnite, px - pyroxene, py - pyrite,

qtz - quartz, srp - serpentine, ttn - titanite, wmca - white mica, zrn - zircon; bdy - baddeleyite (Whitney and Evans, 2010).

Note, the order of minerals in column "Mineral assemblage" does not reflect relative abundances. 

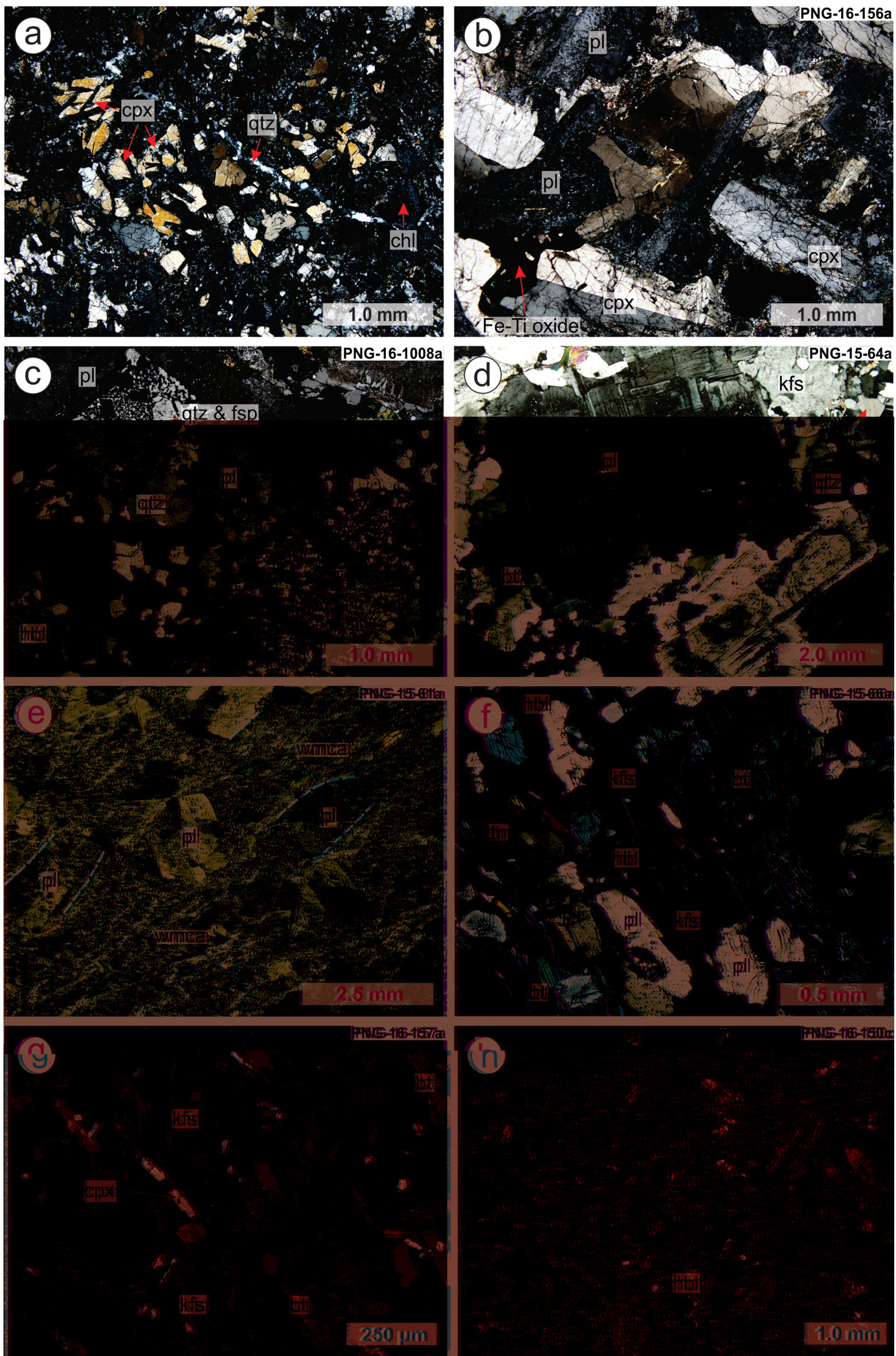
Figure 2.4: Photomicrographs of igneous rock units from the Suckling-Dayman metamorphic core complex. (a) Dolerite consisting of clinopyroxene in a fine-grained matrix of plagioclase showing cataclastic deformation (e.g., disrupted clinopyroxenes) and dynamically recrystallized quartz vein. (b) Quartz-gabbro consisting principally of clinopyroxene (locally twinned), altered plagioclase (albite \pm relics of anorthite) and Fe-Ti oxides. (c) Tonalite with granophyric-like texture (consisting of quartz and feldspar) and altered, cloudy plagioclase and hornblende. (d) Relatively undeformed Suckling Granite with phenocryst of plagioclase (zoned), K-feldspar, quartz and biotite. (e) Deformed Suckling Granite showing plagioclase (albite-rich) phenocrysts in a fine-grained groundmass of quartz, plagioclase and foliae of white mica. (f) Mai'iu Monzonite showing poikilitic textures with chadacrysts of hornblende, titanite, plagioclase and biotite enclosed in oikocrysts of K-feldspar. (g) Bonua Porphyry consisting principally of clinopyroxene, biotite and (felty) K-feldspar. (h) Amphibolephyric basaltic andesite dike with a fine-grained quartzo-feldspathic groundmass. Mineral abbreviations after Siivola and Schmid (2007).

\section{Trace element characteristics}

Trace element data for the Yau Igneous Complex are depicted as fertile mantle-normalized (Pearce and Parkinson, 1993) multi-element (Figure 2.7) and chondrite-normalized (Arevalo and McDonough, 2010, and references therein) rare earth element (REE) (Figure 2.8) diagrams. Rocks of the low-silica suite reveal similar patterns where very highly incompatible (VHI) $\geq$ highly incompatible (HI) $\geq$ moderately incompatible (MI) $>$ slightly incompatible/slightly compatible (SI/SC) > moderately compatible $(\mathrm{MC})>$ highly compatible $(\mathrm{HC})$ elements (Figure 2.7a). Notable differences between the dolerites (PNG-15-3b, PNG-15$4 \mathrm{a}$ ) and the coarse-grained quartz-gabbro and tonalite of the low-silica suite (PNG-16-156a, PNG-16-1029a) include more pronounced positive $\mathrm{V}$ anomalies and negative $\mathrm{Cr}$ anomalies of the latter. The trace element patterns of the low-silica suite are markedly different from those of the high-silica suite (AU51082, PNG-16-108b, PNG-16-1008; Figure 2.7b). The latter reveal more step-like patterns ( VHI $>\mathrm{HI}>\mathrm{MI}>\mathrm{SI} / \mathrm{SC}>\mathrm{MC}>\mathrm{HC}$ ) with pronounced negative $\mathrm{V}$ and $\mathrm{Ti}$ anomalies. Furthermore, $\mathrm{Cr}$ and $\mathrm{Ni}$ values are close to zero. Also, Sc (MI) is similarly abundant as the SI/SC elements Mn and Fe. The trace element patterns of the high-silica suite differ from those of the Goropu Metabasalt (grey band, Figure 2.7), whereas those from the low-silica suite, and in particular those from the dolerites, resemble those of the metabasalt well.

The dolerites of the low-silica suite and the quartz-gabbros and tonalites of the high-silica suite have relatively flat chondrite-normalized REE patterns (Figure 2.8) with slightly positive slopes $\left((\mathrm{Ce} / \mathrm{Yb})_{N}>1\right)$. In particular the REE patterns of the dolerites resemble those from the Goropu Metabasalt that also show slightly enriched LEE patterns $\left((\mathrm{Ce} / \mathrm{Yb})_{N}>1\right)$. Conversely, the quartz-gabbro and tonalite samples of the low-silica show slightly negative slopes $\left((\mathrm{Ce} / \mathrm{Yb})_{N}<1\right.$; Figure 2.8). Samples of the high-silica suite have higher abundances of REE compared to those of the low-silica suite and show negative Eu anomalies. 
Table 2.2: Whole-rock major oxide and trace element data.

\begin{tabular}{|c|c|c|c|c|c|c|c|c|c|c|c|}
\hline \multirow[b]{2}{*}{ Sample } & \multicolumn{8}{|c|}{ Yau Igneous Complex } & \multicolumn{3}{|c|}{ Suckling Granite } \\
\hline & $\begin{array}{c}\mathrm{AU} \\
51082\end{array}$ & $\begin{array}{l}\text { PNG- } \\
15-3 b\end{array}$ & $\begin{array}{l}\text { PNG- } \\
15-4 a\end{array}$ & $\begin{array}{l}\text { PNG- } \\
16-41 \mathrm{a}\end{array}$ & $\begin{array}{l}\text { PNG- } \\
16-108 \mathrm{~b}\end{array}$ & $\begin{array}{l}\text { PNG- } \\
16-156 a\end{array}$ & $\begin{array}{c}\text { PNG- } \\
16-1008 \mathrm{a}\end{array}$ & $\begin{array}{c}\text { PNG- } \\
16-1029 a\end{array}$ & $\begin{array}{c}\mathrm{AU} \\
51087\end{array}$ & $\begin{array}{l}\text { PNG- } \\
15-61 \mathrm{a}\end{array}$ & $\begin{array}{l}\text { PNG- } \\
15-64 a\end{array}$ \\
\hline $\mathrm{SiO}_{2}$ & 56.34 & 46.65 & 46.92 & 45.08 & 55.52 & 49.23 & 63.23 & 53.41 & 68.70 & 68.92 & 66.91 \\
\hline $\mathrm{Al}_{2} \mathrm{O}_{3}$ & 12.90 & 14.13 & 13.71 & 19.73 & 12.90 & 12.31 & 13.09 & 13.77 & 15.73 & 16.74 & 17.63 \\
\hline $\mathrm{TiO}_{2}$ & 1.54 & 1.60 & 1.48 & 1.58 & 1.54 & 2.60 & 0.77 & 1.27 & 0.32 & 0.38 & 0.32 \\
\hline $\mathrm{MnO}$ & 0.25 & 0.18 & 0.21 & 0.13 & 0.23 & 0.25 & 0.15 & 0.19 & 0.04 & 0.03 & 0.03 \\
\hline $\mathrm{Fe}_{t o t}$ & 14.67 & 12.08 & 13.50 & 10.99 & 14.38 & 14.04 & 10.96 & 14.10 & 2.22 & 2.74 & 2.14 \\
\hline $\mathrm{MgO}$ & 1.47 & 7.83 & 6.74 & 4.84 & 1.62 & 4.02 & 0.91 & 3.30 & 1.12 & 0.84 & 0.98 \\
\hline $\mathrm{CaO}$ & 5.72 & 9.92 & 9.92 & 12.38 & 5.87 & 9.56 & 4.29 & 7.70 & 2.22 & 0.45 & 1.61 \\
\hline $\mathrm{Na}_{2} \mathrm{O}$ & 3.73 & 2.71 & 3.17 & 2.24 & 4.79 & 3.23 & 4.51 & 2.87 & 5.15 & 4.37 & 5.34 \\
\hline $\mathrm{K}_{2} \mathrm{O}$ & 0.62 & 0.30 & 0.08 & 0.06 & 0.33 & 0.08 & 0.20 & 0.10 & 3.50 & 2.93 & 3.36 \\
\hline $\mathrm{P}_{2} \mathrm{O}_{5}$ & 0.52 & 0.17 & 0.15 & 0.05 & 0.63 & 0.23 & 0.27 & 0.13 & 0.15 & 0.18 & 0.17 \\
\hline $\mathrm{SO}_{3}$ & 0.04 & 0.32 & 0.06 & 0.31 & 0.02 & 0.01 & 0.03 & 0.11 & 0.02 & 0.01 & 0.02 \\
\hline $\mathrm{SrO}$ & 0.01 & 0.01 & 0.02 & 0.01 & 0.01 & 0.01 & 0.01 & 0.01 & 0.16 & 0.03 & 0.21 \\
\hline $\mathrm{BaO}$ & 0.02 & 0.01 & 0.02 & 0.01 & 0.01 & 0.02 & 0.01 & 0.01 & 0.09 & 0.09 & 0.10 \\
\hline LOI & 1.57 & 3.35 & 3.24 & 1.29 & 1.67 & 3.62 & 1.54 & 2.33 & 0.44 & 2.79 & 2.10 \\
\hline Total & 99.39 & 99.28 & 99.21 & 98.71 & 99.53 & 99.21 & 99.95 & 99.30 & 99.90 & 100.50 & 100.96 \\
\hline $\mathrm{Li}$ & 4.78 & 10.73 & 12.84 & 1.66 & 2.65 & 3.08 & 2.81 & 5.73 & 11.41 & 7.62 & 7.14 \\
\hline $\mathrm{Rb}$ & 14.2 & 4.9 & 2.7 & 0.7 & 4.1 & 1.5 & 1.9 & 1.4 & 71.0 & 76.0 & 67.6 \\
\hline $\mathrm{Sr}$ & 206 & 189 & 231 & 180 & 140 & 138 & 128 & 119 & 1561 & 335 & 1750 \\
\hline Y & 115.30 & 25.70 & 27.45 & 7.23 & 92.16 & 55.32 & 99.23 & 28.50 & 7.33 & 7.09 & 4.97 \\
\hline $\operatorname{Zr}(90)^{*}$ & 453.51 & 97.12 & 88.45 & 11.79 & 368.60 & 182.25 & 422.22 & 67.72 & 45.97 & 163.87 & 118.19 \\
\hline $\mathrm{Nb}$ & 22.86 & 6.28 & 5.00 & 0.66 & 18.03 & 10.67 & 21.55 & 1.73 & 6.90 & 9.21 & 7.58 \\
\hline Cs & 0.12 & 0.19 & 0.27 & 0.12 & 0.03 & 0.04 & 0.14 & 0.13 & 2.08 & 2.10 & 1.83 \\
\hline $\mathrm{Ba}$ & 104 & 32 & 104 & 10 & 55 & 23 & 58 & 23 & 941 & 857 & 931 \\
\hline $\mathrm{La}$ & 26.83 & 5.56 & 5.25 & 0.82 & 19.75 & 7.30 & 22.50 & 3.30 & 23.12 & 20.71 & 19.70 \\
\hline $\mathrm{Ce}$ & 69.07 & 14.18 & 13.04 & 2.12 & 51.07 & 20.78 & 58.21 & 8.79 & 44.62 & 36.08 & 37.24 \\
\hline $\operatorname{Pr}$ & 10.04 & 2.11 & 1.98 & 0.34 & 7.54 & 3.35 & 8.33 & 1.38 & 4.92 & 4.35 & 4.17 \\
\hline $\mathrm{Nd}$ & 50.17 & 10.87 & 10.46 & 1.98 & 38.78 & 18.41 & 41.64 & 7.56 & 18.05 & 16.21 & 15.74 \\
\hline $\mathrm{Sm}$ & 14.97 & 3.47 & 3.39 & 0.76 & 11.83 & 6.15 & 12.25 & 2.65 & 3.11 & 2.88 & 2.78 \\
\hline $\mathrm{Eu}(151)^{*}$ & 4.39 & 1.27 & 1.28 & 0.57 & 3.64 & 2.29 & 3.35 & 0.99 & 1.02 & 0.96 & 1.01 \\
\hline $\mathrm{Gd}$ & 17.68 & 4.13 & 4.21 & 1.01 & 14.14 & 7.70 & 14.35 & 3.55 & 2.86 & 2.73 & 2.43 \\
\hline $\mathrm{Tb}$ & 3.30 & 0.79 & 0.82 & 0.21 & 2.66 & 1.52 & 2.74 & 0.73 & 0.33 & 0.34 & 0.28 \\
\hline Dy & 21.53 & 5.10 & 5.26 & 1.45 & 17.31 & 10.08 & 17.79 & 5.15 & 1.53 & 1.52 & 1.19 \\
\hline Ho & 4.61 & 1.09 & 1.13 & 0.31 & 3.67 & 2.19 & 3.84 & 1.15 & 0.28 & 0.27 & 0.20 \\
\hline $\mathrm{Er}$ & 13.88 & 3.12 & 3.33 & 0.91 & 10.97 & 6.53 & 11.71 & 3.54 & 0.85 & 0.79 & 0.61 \\
\hline $\mathrm{Tm}$ & 1.99 & 0.45 & 0.48 & 0.13 & 1.58 & 0.96 & 1.73 & 0.53 & 0.11 & 0.10 & 0.08 \\
\hline $\mathrm{Yb}$ & 12.70 & 2.76 & 2.99 & 0.82 & 10.10 & 6.10 & 10.87 & 3.52 & 0.68 & 0.64 & 0.50 \\
\hline $\mathrm{Lu}$ & 1.98 & 0.42 & 0.47 & 0.13 & 1.57 & 0.96 & 1.69 & 0.55 & 0.10 & 0.10 & 0.08 \\
\hline $\mathrm{Hf}$ & 12.32 & 2.56 & 2.57 & 0.40 & 9.29 & 4.76 & 10.68 & 1.94 & 1.62 & 5.11 & 3.45 \\
\hline $\mathrm{Ta}$ & 2.28 & 0.53 & 0.68 & 0.15 & 1.50 & 0.91 & 1.73 & 0.17 & 0.88 & 0.73 & 0.57 \\
\hline $\mathrm{Pb}$ & 0.31 & 0.43 & 0.20 & 0.07 & 0.18 & 0.17 & 0.64 & 0.23 & 48.26 & 34.89 & 142.97 \\
\hline Th & 2.36 & 0.29 & 0.34 & bdl & 1.74 & 0.67 & 2.14 & 0.22 & 5.88 & 8.27 & 7.70 \\
\hline $\mathrm{U}$ & 0.66 & 0.13 & 0.11 & 0.01 & 0.52 & 0.23 & 0.64 & 0.11 & 1.55 & 4.35 & 3.49 \\
\hline $\mathrm{Sc}$ & 29.01 & 44.07 & 51.98 & 34.27 & 25.95 & 50.26 & 15.13 & 37.98 & 4.02 & 3.34 & 3.31 \\
\hline V & 12 & 324 & 412 & 741 & 12 & 817 & 2 & 543 & 41 & 43 & 39 \\
\hline $\mathrm{Cr}$ & 2 & 301 & 191 & 1 & 1 & 2 & 5 & 9 & 167 & 59 & 64 \\
\hline Co & 20.43 & 45.96 & 55.24 & 45.07 & 16.78 & 45.95 & 8.84 & 42.21 & 6.18 & 5.43 & 3.96 \\
\hline $\mathrm{Ni}$ & bdl & 67 & 79 & 37 & bdl & 28 & bdl & 16 & 742 & 49 & 9 \\
\hline $\mathrm{Cu}$ & 1.71 & 102.71 & 196.07 & 63.89 & 1.43 & 5.68 & 1.62 & 81.50 & 2.90 & 6.19 & 19.01 \\
\hline $\mathrm{Zn}$ & 128.77 & 95.59 & 82.71 & 64.28 & 208.69 & 81.46 & 74.26 & 117.12 & 40.39 & 57.92 & 38.25 \\
\hline $\mathrm{Ga}$ & 33.32 & 17.82 & 19.95 & 21.84 & 26.50 & 23.54 & 24.81 & 20.71 & 22.90 & 24.83 & 22.41 \\
\hline
\end{tabular}


Table 2.2 - continued from previous page

\begin{tabular}{|c|c|c|c|c|c|c|c|c|c|c|c|}
\hline \multirow[b]{2}{*}{ Sample } & \multicolumn{5}{|c|}{ Mai'iu Monzonite } & \multicolumn{2}{|c|}{ Bonua Porphyry } & \multicolumn{2}{|c|}{ Bas. andesite dikes } & \multicolumn{2}{|c|}{ Goropu Metabasal } \\
\hline & $\begin{array}{l}\text { PNG- } \\
15-66 a\end{array}$ & $\begin{array}{c}\text { PNG- } \\
16-159 b\end{array}$ & $\begin{array}{c}\text { PNG- } \\
16-163 a\end{array}$ & $\begin{array}{c}\text { PNG- } \\
16-174 a\end{array}$ & $\begin{array}{l}\text { PNG- } \\
16-2 a\end{array}$ & $\begin{array}{c}\text { PNG- } \\
16-157 a\end{array}$ & $\begin{array}{c}\text { AU } \\
51095\end{array}$ & $\begin{array}{l}\text { PNG- } \\
15-60 a\end{array}$ & $\begin{array}{c}\text { PNG- } \\
16-150 \mathrm{c}\end{array}$ & $\begin{array}{l}\text { PNG- } \\
16-17 \mathrm{z}\end{array}$ & $\begin{array}{c}\text { PNG- } \\
16-17.2 \mathrm{~d}\end{array}$ \\
\hline $\mathrm{SiO}_{2}$ & 55.10 & 49.88 & 48.51 & 51.29 & 61.14 & 51.58 & 46.19 & 54.19 & 56.07 & 48.84 & 45.56 \\
\hline $\mathrm{Al}_{2} \mathrm{O}_{3}$ & 14.07 & 16.24 & 14.17 & 15.84 & 16.68 & 14.09 & 12.60 & 12.40 & 14.73 & 12.32 & 14.74 \\
\hline $\mathrm{TiO}_{2}$ & 1.26 & 1.38 & 1.74 & 1.32 & 0.84 & 1.51 & 1.59 & 1.06 & 0.99 & 1.63 & 1.33 \\
\hline $\mathrm{MnO}$ & 0.11 & 0.13 & 0.13 & 0.11 & 0.07 & 0.12 & 0.12 & 0.11 & 0.12 & 0.22 & 0.19 \\
\hline $\mathrm{Fe}_{t o t}$ & 7.07 & 8.99 & 9.18 & 7.41 & 4.82 & 7.53 & 8.26 & 6.65 & 6.72 & 11.95 & 11.45 \\
\hline $\mathrm{MgO}$ & 7.55 & 5.72 & 7.80 & 6.77 & 4.01 & 5.84 & 8.97 & 10.06 & 7.18 & 6.75 & 7.60 \\
\hline $\mathrm{CaO}$ & 6.49 & 6.14 & 7.19 & 5.22 & 4.44 & 5.47 & 7.67 & 6.00 & 4.16 & 9.37 & 11.49 \\
\hline $\mathrm{Na}_{2} \mathrm{O}$ & 3.55 & 3.55 & 3.22 & 3.96 & 4.37 & 3.50 & 2.01 & 4.35 & 3.52 & 2.96 & 2.08 \\
\hline $\mathrm{K}_{2} \mathrm{O}$ & 2.19 & 3.24 & 2.16 & 3.47 & 2.90 & 4.92 & 5.05 & 0.34 & 2.64 & 0.04 & 0.14 \\
\hline $\mathrm{P}_{2} \mathrm{O}_{5}$ & 0.60 & 0.87 & 0.92 & 0.64 & 0.26 & 0.65 & 1.04 & 0.52 & 0.33 & 0.19 & 0.14 \\
\hline $\mathrm{SO}_{3}$ & 0.02 & 0.03 & 0.02 & 0.03 & 0.03 & 1.45 & 0.34 & 0.26 & 0.07 & 0.17 & 0.07 \\
\hline $\mathrm{SrO}$ & 0.14 & 0.23 & 0.17 & 0.09 & 0.13 & 0.10 & 0.16 & 0.05 & 0.02 & 271.00 & 82.00 \\
\hline $\mathrm{BaO}$ & 0.07 & 0.10 & 0.09 & 0.09 & 0.08 & 0.14 & 0.18 & 0.01 & 0.04 & 81.00 & 94.00 \\
\hline LOI & 2.60 & 2.72 & 3.92 & 3.18 & 1.32 & 3.52 & 4.70 & 3.87 & 3.20 & 4.91 & 4.24 \\
\hline Total & 100.84 & 99.28 & 99.26 & 99.44 & 101.13 & 100.45 & 98.93 & 99.87 & 99.78 & 99.38 & 99.04 \\
\hline $\mathrm{Li}$ & 10.88 & 11.97 & 10.33 & 9.25 & 15.40 & 6.72 & 12.41 & 26.21 & 17.91 & nd & 11.39 \\
\hline $\mathrm{Rb}$ & 64.7 & 94.0 & 70.3 & 75.1 & 65.0 & 173.1 & 120.4 & 7.2 & 68.4 & 0.3 & 2.9 \\
\hline $\mathrm{Sr}$ & 1262 & 2189 & 1645 & 970 & 1156 & 952 & 1443 & 493 & 195 & 280 & 141 \\
\hline $\mathrm{Y}$ & 17.14 & 16.25 & 22.93 & 20.68 & 9.47 & 16.24 & 19.00 & 20.54 & 17.96 & 23.65 & 22.08 \\
\hline $\operatorname{Zr}(90)^{*}$ & 53.08 & 117.93 & 65.44 & 383.34 & 169.58 & 298.41 & 424.86 & 464.81 & 266.18 & 104.55 & 80.88 \\
\hline $\mathrm{Nb}$ & 11.68 & 9.80 & 13.74 & 15.22 & 5.77 & 18.26 & 17.10 & 8.12 & 8.50 & 6.65 & 4.80 \\
\hline Cs & 2.62 & 3.61 & 2.58 & 0.17 & 1.75 & 2.42 & 6.08 & 0.29 & 1.30 & 0.03 & 0.05 \\
\hline $\mathrm{Ba}$ & 656 & 955 & 855 & 848 & 759 & 1224 & 1535 & 114 & 373 & 22 & 17 \\
\hline $\mathrm{La}$ & 42.03 & 34.23 & 52.26 & 54.29 & 19.15 & 59.23 & 59.20 & 58.87 & 29.92 & 6.19 & 4.67 \\
\hline $\mathrm{Ce}$ & 90.01 & 71.89 & 115.73 & 108.37 & 38.75 & 125.10 & 125.51 & 130.68 & 62.74 & 15.77 & 11.89 \\
\hline $\operatorname{Pr}$ & 11.00 & 8.76 & 14.04 & 12.60 & 4.40 & 14.02 & 14.53 & 15.69 & 7.41 & 2.34 & 1.79 \\
\hline $\mathrm{Nd}$ & 45.12 & 36.10 & 56.86 & 49.25 & 17.44 & 52.93 & 57.17 & 64.20 & 29.88 & 11.42 & 9.34 \\
\hline $\mathrm{Sm}$ & 8.00 & 6.88 & 10.02 & 8.27 & 3.33 & 8.05 & 9.55 & 12.09 & 5.83 & 3.36 & 3.04 \\
\hline $\operatorname{Eu}(151)^{*}$ & 2.27 & 2.17 & 2.81 & 2.37 & 1.18 & 2.39 & 2.76 & 3.01 & 1.61 & 1.26 & 1.15 \\
\hline $\mathrm{Gd}$ & 7.33 & 6.46 & 9.50 & 8.07 & 3.28 & 8.01 & 8.68 & 10.32 & 5.57 & 4.03 & 3.66 \\
\hline $\mathrm{Tb}$ & 0.88 & 0.80 & 1.17 & 0.96 & 0.42 & 0.90 & 1.02 & 1.19 & 0.76 & 0.79 & 0.68 \\
\hline Dy & 3.98 & 3.72 & 5.37 & 4.45 & 2.07 & 3.83 & 4.38 & 4.87 & 3.88 & 4.89 & 4.41 \\
\hline Ho & 0.71 & 0.67 & 0.95 & 0.80 & 0.39 & 0.67 & 0.77 & 0.81 & 0.73 & 1.02 & 0.91 \\
\hline $\mathrm{Er}$ & 1.99 & 1.90 & 2.76 & 2.36 & 1.14 & 1.94 & 2.31 & 2.31 & 2.12 & 2.98 & 2.67 \\
\hline $\mathrm{Tm}$ & 0.23 & 0.23 & 0.32 & 0.28 & 0.14 & 0.23 & 0.26 & 0.26 & 0.28 & 0.42 & 0.38 \\
\hline $\mathrm{Yb}$ & 1.40 & 1.36 & 1.93 & 1.77 & 0.90 & 1.38 & 1.63 & 1.62 & 1.76 & 2.67 & 2.34 \\
\hline $\mathrm{Lu}$ & 0.20 & 0.20 & 0.28 & 0.27 & 0.13 & 0.20 & 0.24 & 0.24 & 0.27 & 0.41 & 0.37 \\
\hline $\mathrm{Hf}$ & 2.44 & 3.32 & 3.00 & 8.55 & 4.03 & 7.14 & 9.92 & 11.51 & 6.65 & 2.81 & 2.16 \\
\hline $\mathrm{Ta}$ & 1.08 & 0.70 & 1.03 & 1.22 & 0.51 & 1.26 & 1.36 & 0.76 & 0.79 & 0.63 & 0.45 \\
\hline $\mathrm{Pb}$ & 16.35 & 18.89 & 11.55 & 16.40 & 19.64 & 50.41 & 19.54 & 47.15 & 15.02 & 1.01 & 0.28 \\
\hline Th & 14.32 & 3.91 & 5.25 & 11.39 & 7.66 & 8.16 & 10.65 & 20.44 & 8.93 & 0.56 & 0.21 \\
\hline $\mathrm{U}$ & 3.23 & 1.22 & 1.33 & 2.83 & 2.48 & 2.65 & 2.85 & 4.67 & 2.60 & 0.18 & 0.10 \\
\hline $\mathrm{Sc}$ & 20.71 & 23.59 & 29.17 & 21.38 & 12.00 & 18.62 & 22.83 & 18.51 & 19.07 & 33.89 & 41.95 \\
\hline V & 162 & 216 & 237 & 190 & 106 & 214 & 207 & 161 & 142 & 290 & 309 \\
\hline $\mathrm{Cr}$ & 375 & 134 & 371 & 395 & 129 & 273 & 484 & 843 & 479 & 201 & 309 \\
\hline $\mathrm{Co}$ & 35.69 & 29.47 & 45.19 & 35.63 & 21.63 & 29.40 & 33.97 & 43.79 & 32.94 & 36.24 & 51.98 \\
\hline $\mathrm{Ni}$ & 207 & 77 & 191 & 200 & 94 & 86 & 177 & 459 & 279 & 51 & 67 \\
\hline $\mathrm{Cu}$ & 18.53 & 21.96 & 46.45 & 44.74 & 45.52 & 61.99 & 65.21 & 57.05 & 37.89 & 99.43 & 107.17 \\
\hline $\mathrm{Zn}$ & 75.93 & 110.87 & 87.18 & 89.85 & 51.57 & 91.34 & 78.27 & 94.40 & 84.30 & 172.19 & 92.07 \\
\hline $\mathrm{Ga}$ & 20.00 & 24.68 & 21.28 & 22.54 & 20.85 & 22.24 & 17.68 & 19.99 & 21.63 & 16.57 & 19.17 \\
\hline
\end{tabular}

nd: not determined; bdl: below level of quantification; *: numbers in brackets denote the measured atomic mass.

Major oxides in wt\% determined by XRF. Trace elements in ppm determined by ICP-MS. See Appendix A.1 for details. 

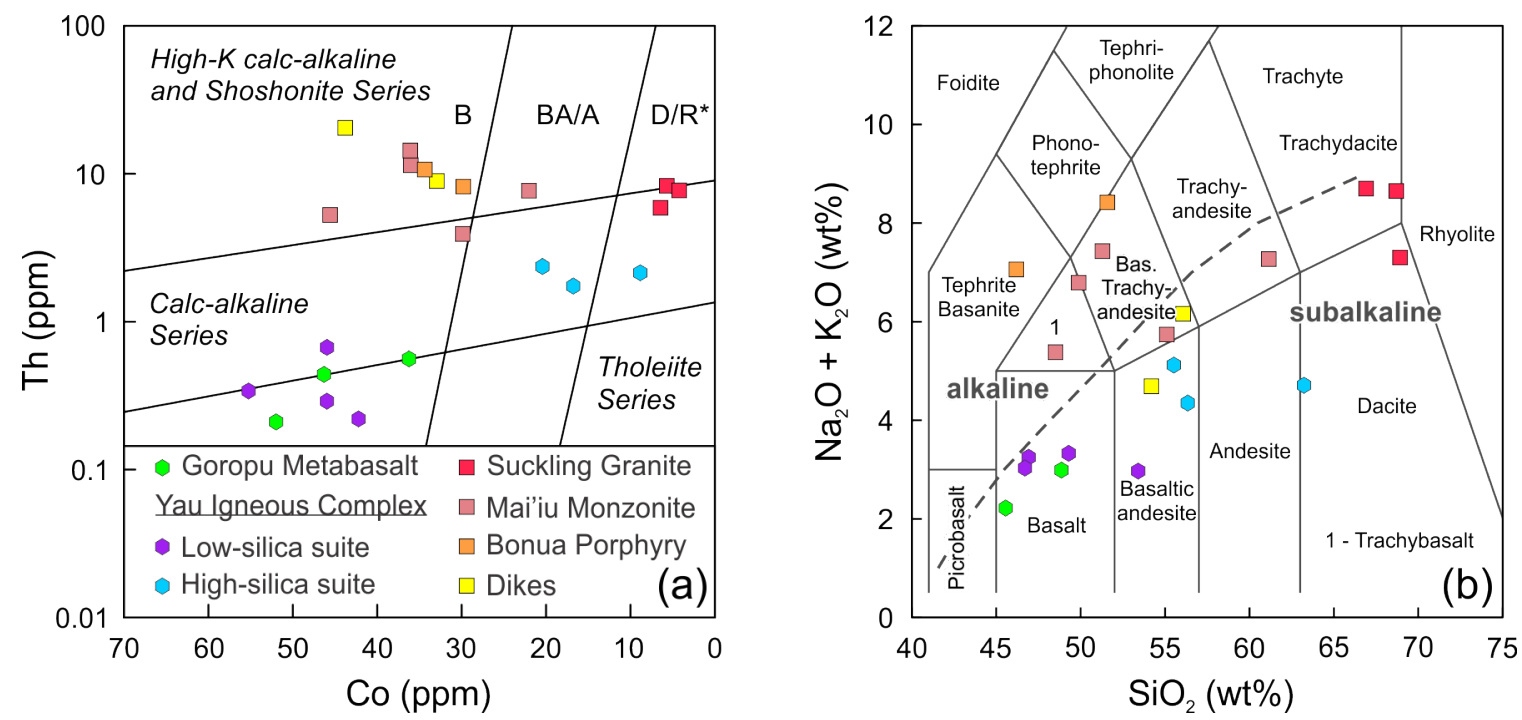

Figure 2.5: Rock classification diagrams of the igneous rocks from the Suckling-Dayman metamorphic core complex after (a) Hastie et al. (2007) and (b) Le Maitre et al. (2002). Note, for convenience, extrusive and intrusive rocks have been plotted on the same diagrams. Abbreviations: B - basalt, BA/A - basaltic andesite/andesite, D/R* - dacite/rhyolite.

$\mathrm{Nb} / \mathrm{Yb}$ vs. $\mathrm{Th} / \mathrm{Yb}$ (Figure $2.9 \mathrm{a}$ ) and $\mathrm{Nb} / \mathrm{Yb}$ vs. $\mathrm{TiO}_{2} / \mathrm{Yb}$ (Figure $2.9 \mathrm{~b}$ ) diagrams after Pearce (2008) for the Yau Igneous Complex and the Goropu Metabasalt suggest geo-tectonic settings and compositions transitional between E- and N-MORB on the MORB-OIB array (Figure 2.9a). Only one tonalite (PNG-16-1029a) of the low-silica suite plots above the MORB-OIB array close to the N-MORB composition (Figure 2.9a). Similarly, rocks of the low-silica suite of the Yau Igneous Complex and the Goropu Metabasalt lie on the MORB array in the $\mathrm{Nb} / \mathrm{Yb}$ vs. $\mathrm{TiO}_{2} / \mathrm{Yb}$ diagram (Figure $2.9 \mathrm{~b}$ ). Those from the high-silica suite of the Yau Igneous Complex fall below the MORB array. For reference, published data from Smith (2013) of the Goropu Metabasalt and the average composition of the Kutu Volcanics are shown (Figure 2.9).

Trace element variations of the Suckling Granite are illustrated in chondrite-normalized (Arevalo and McDonough, 2010, and references therein) multi-element (Figure 2.10) and REE (Figure 2.11) diagrams. The calc-alkaline rocks of the Suckling Granite are characterized by high $\mathrm{Rb}, \mathrm{Ba}, \mathrm{Ta}, \mathrm{Nb}, \mathrm{Zr}$ and $\mathrm{Hf}$ (Figure $2.10 \mathrm{a})$, enriched LREE patterns $\left((\mathrm{Ce} / \mathrm{Yb})_{N}\right.$ $\sim 15-20$ ) and positive Eu anomalies (Figure 2.11a). In the tectonic classification diagrams after Pearce et al. (1984), the Suckling Granite plots in the 'volcanic arc \& syn-collision granite' (Figure 2.12a) and in the 'volcanic arc granite' (Figure 2.12b) fields. 


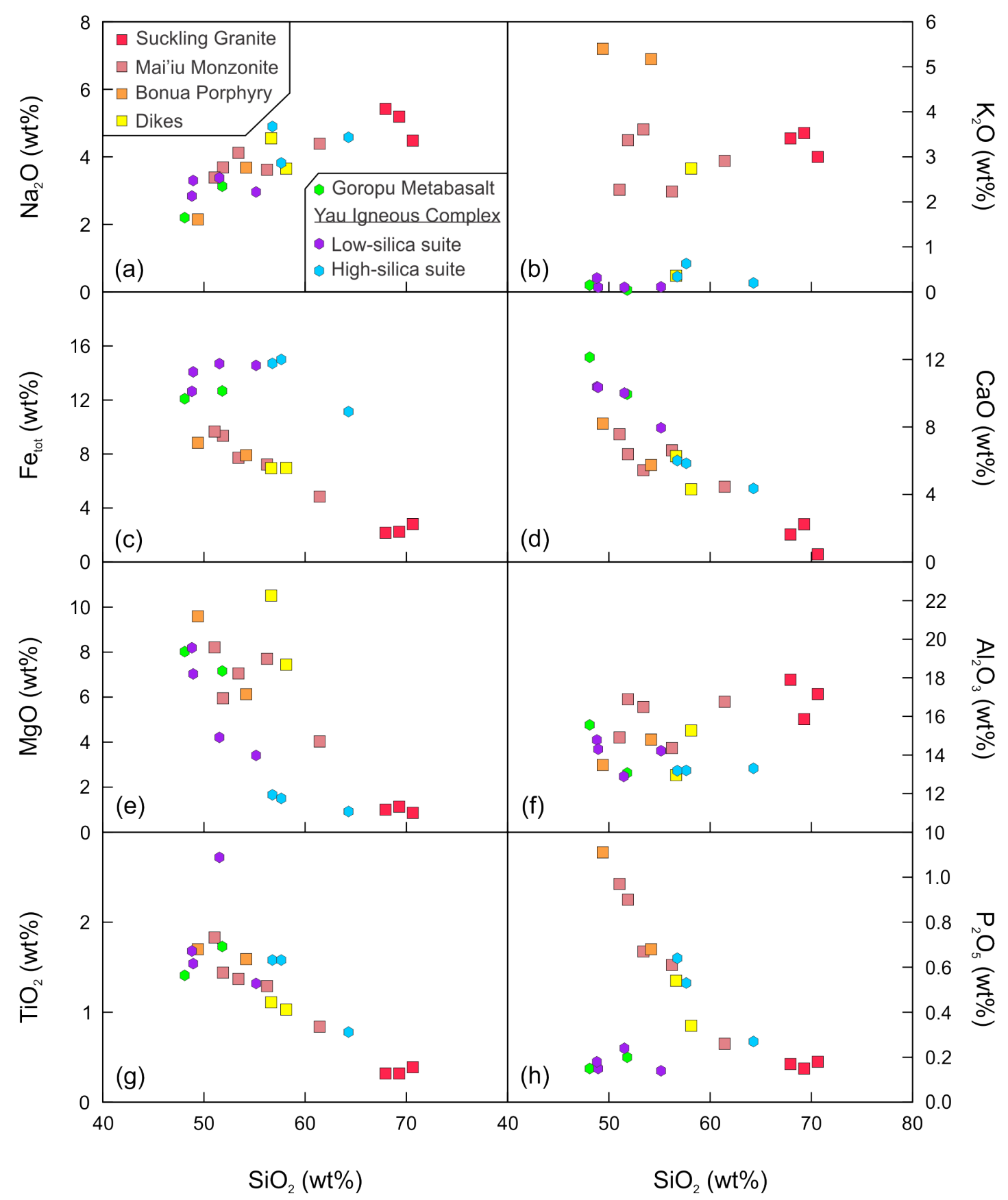

Figure 2.6: Harker diagrams for igneous rocks of the Suckling-Dayman metamorphic core complex normalized to volatile-free compositions. 


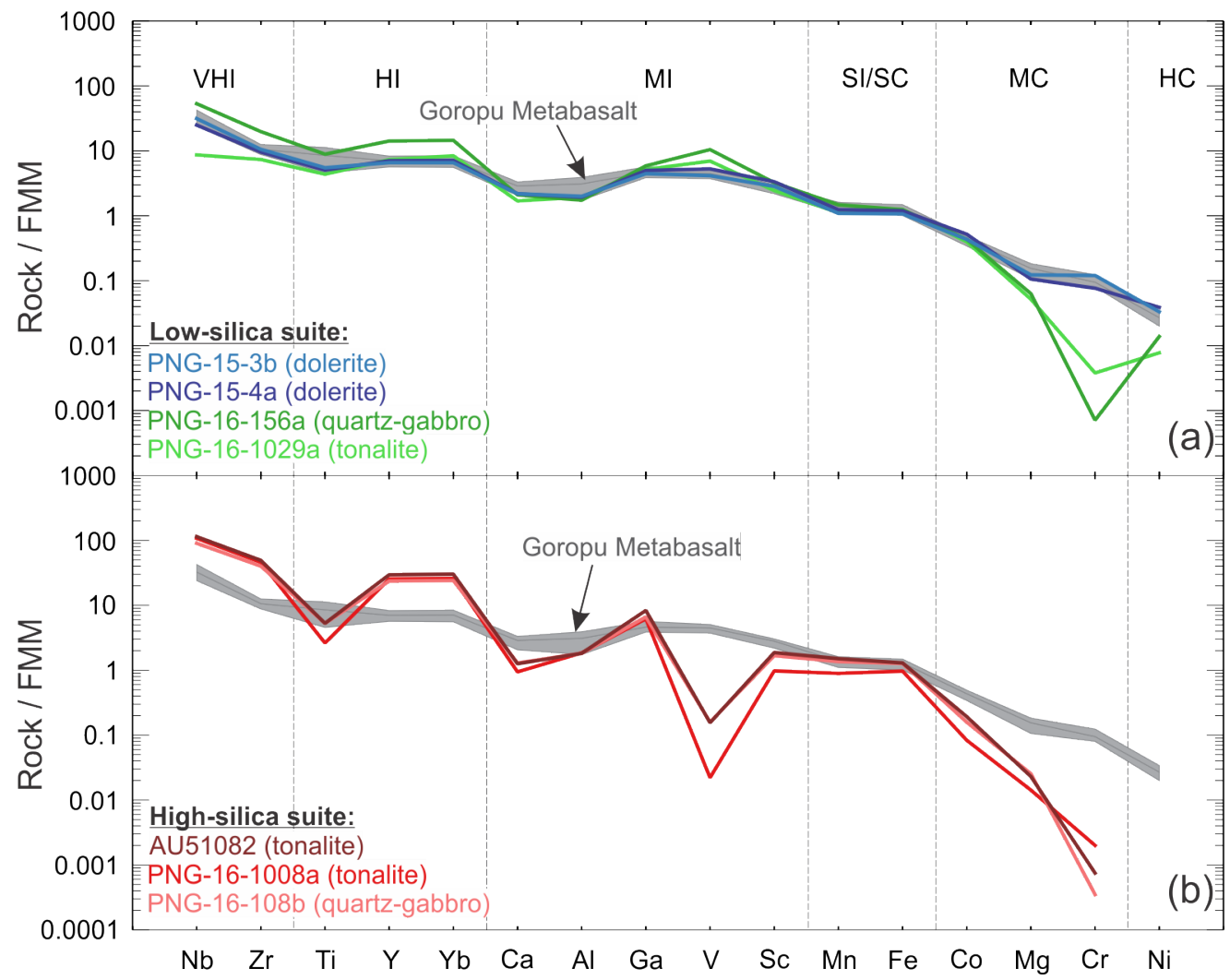

Figure 2.7: Fertile mantle-normalized multi-element diagrams (after Pearce and Parkinson, 1993) of (a) the low-silica suite and (b) the high-silica suites of the Yau Igneous Complex. Abbreviations: VHI - very highly incompatible, HI - highly incompatible, MI - moderately incompatible, SI/SC - slightly incompatible/slightly compatible, MC - moderately compatible, HC - highly compatible. For comparison, the compositional range of trace element abundances of the Goropu Metabasalt is shown (data from this study and Smith, 2013). 


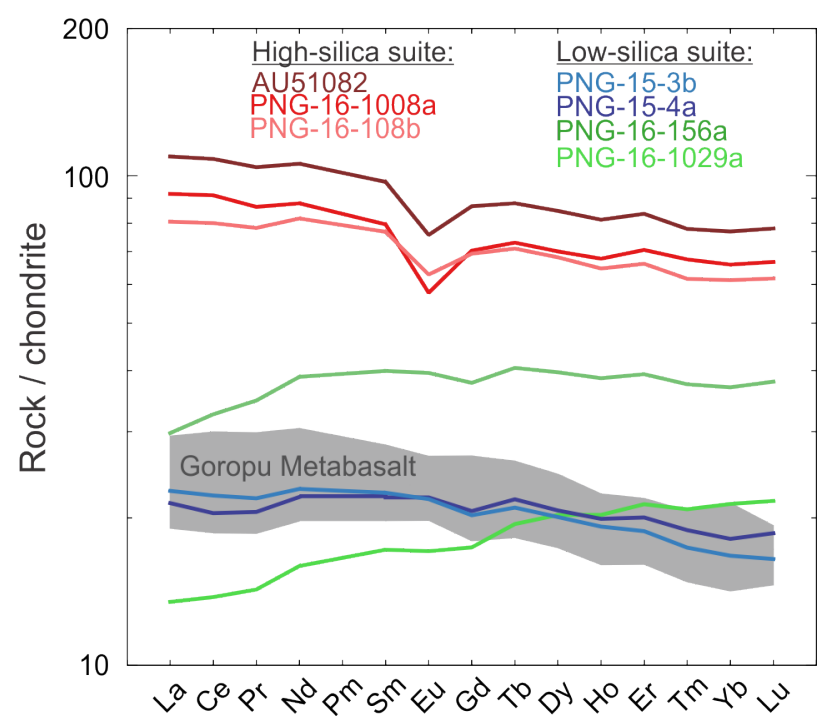

Figure 2.8: Chondrite-normalized rare earth element (REE) diagram of the Yau Igneous Complex. Values of Pm were obtained from linear interpolation between Nd and Sm. Normalization values from Arevalo and McDonough (2010) and references therein. For reference, the compositional range of REE values of the Goropu Metabasalt (data from this study and Smith, 2013) is shown.
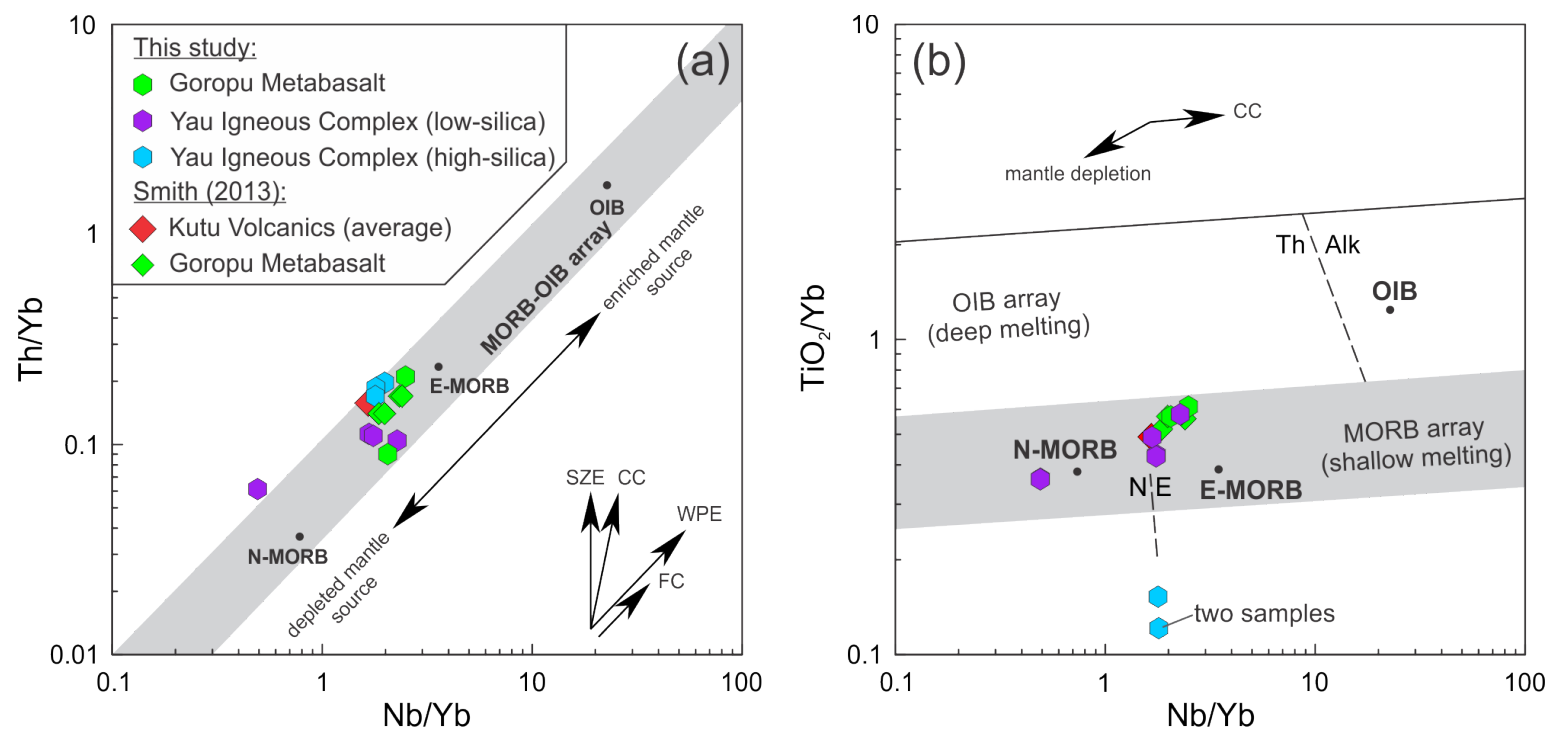

Figure 2.9: Geotectonic discrimination diagrams after Pearce (2008). (a) $\mathrm{Nb} / \mathrm{Yb} \mathrm{vs}$. $\mathrm{Th} / \mathrm{Yb}$ diagram. (b) $\mathrm{Nb} / \mathrm{Yb}$ vs. $\mathrm{TiO}_{2} / \mathrm{Yb}$ diagram. Reference compositions of the Goropu Metabasalt (green diamonds) and the average of the Kutu Volcanics (red diamond) from Smith (2013). 


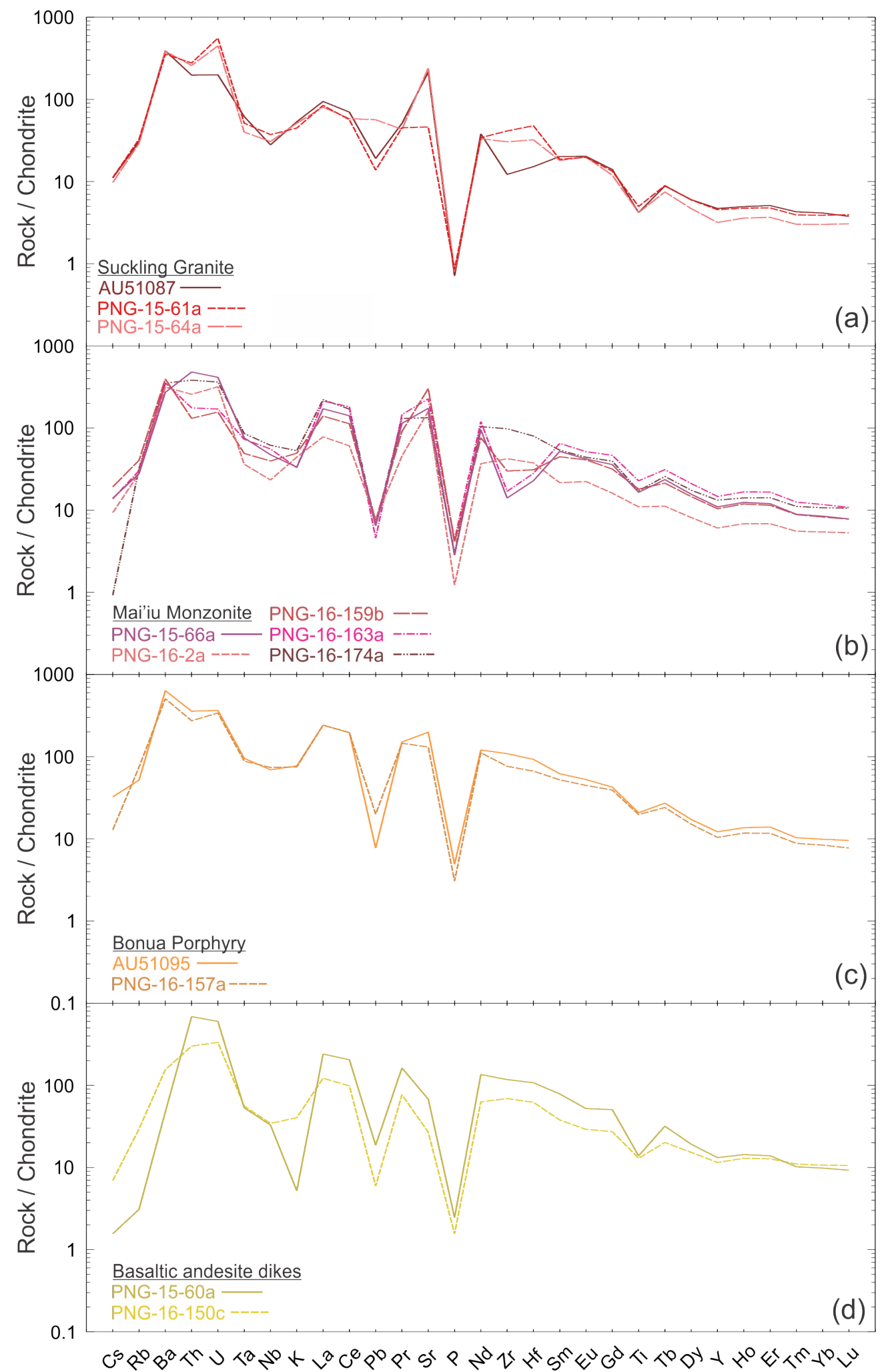

Figure 2.10: Chondrite-normalized multi-element diagram of the calc-alkaline and highK rock suites. Normalization values from Arevalo and McDonough (2010) and references therein. 


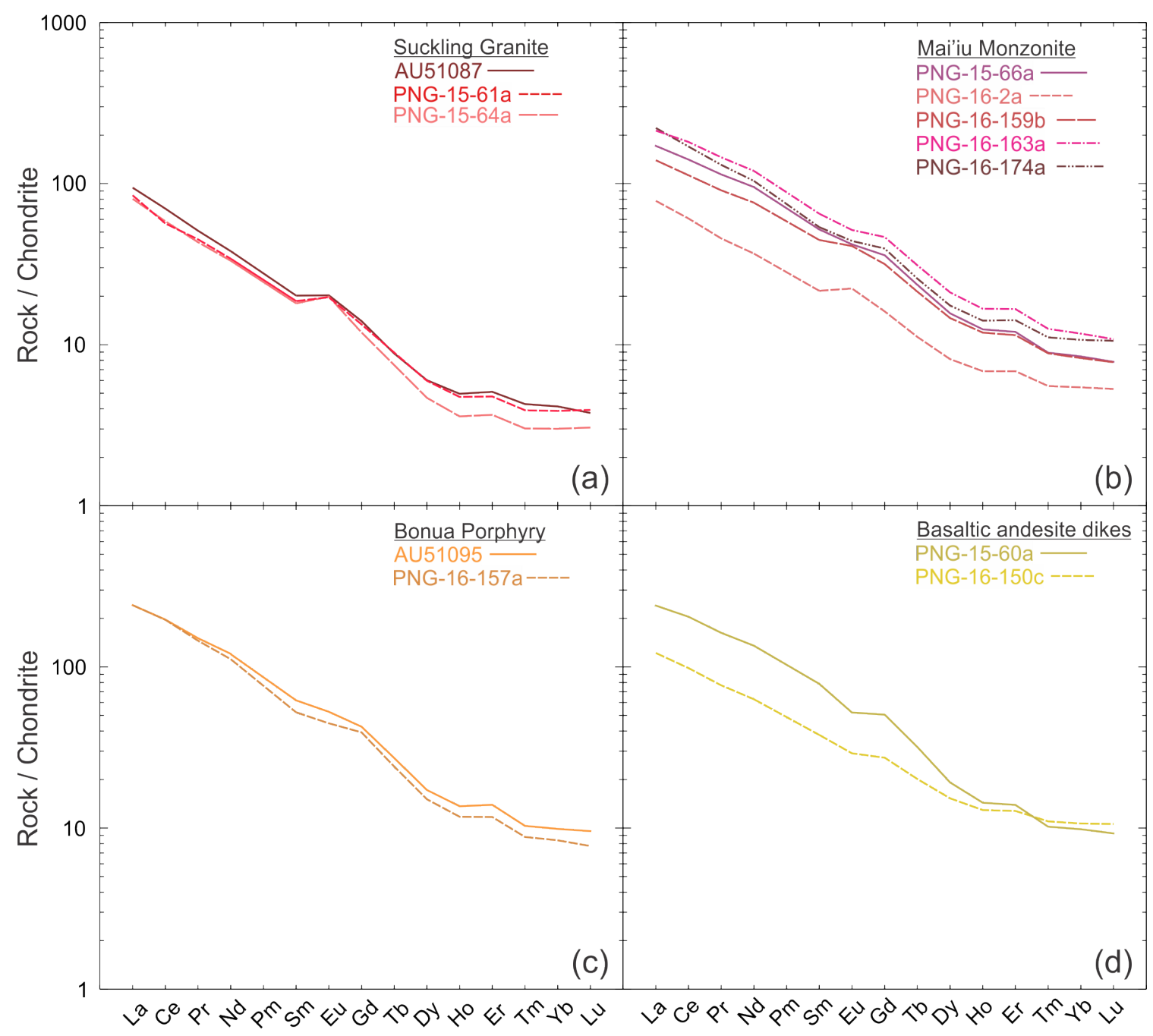

Figure 2.11: Chondrite-normalized rare earth element diagrams of the calc-alkaline and high-K rock suites. Values of Pm were obtained from linear interpolation between $\mathrm{Nd}$ and Sm. Normalization values from Arevalo and McDonough (2010) and references therein.
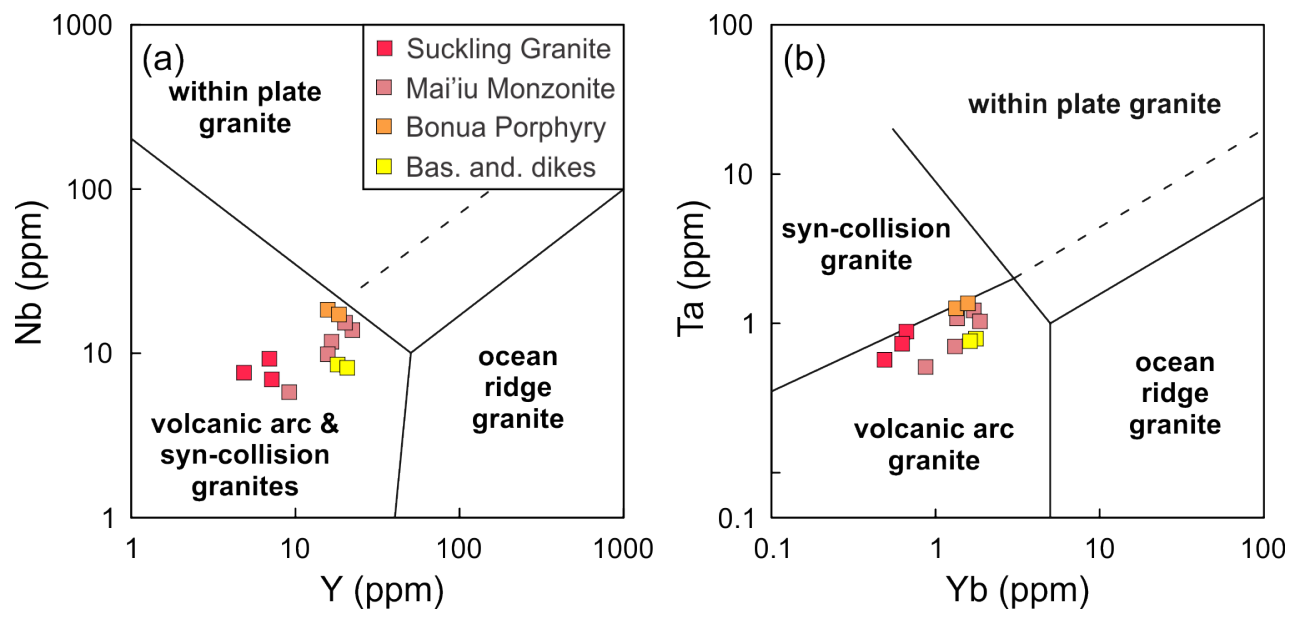

Figure 2.12: Trace element classification diagrams for granites after Pearce et al. (1984). 
The high-K Mai'iu Monzonite, Bonua Porphyry and the basaltic andesite dikes exhibit similar chondrite-normalized trace element patterns with high $\mathrm{K}_{2} \mathrm{O}, \mathrm{Rb}, \mathrm{Ba}, \mathrm{Ta}, \mathrm{Nb}, \mathrm{Zr}$ and $\mathrm{Hf}$ (Figures 2.10b-d). These units also display an enrichment in LREE $\left((\mathrm{Ce} / \mathrm{Yb})_{N} \sim 10-25\right)$. Overall, the trace element patterns resemble those of the Suckling Granite, but most samples lack positive Eu anomalies (Figures 2.11b-d). Overall trace element abundances are generally higher in the high-K rocks. In the tectonic classification diagrams after Pearce et al. (1984), the Mai'iu Monzonite, Bonua Porphyry and the basaltic andesite dikes plot in the 'volcanic arc \& syn-collision granite' (Figure 2.12a) and in the 'volcanic arc granite' (Figure $2.12 b)$ fields.

\subsubsection{Zircon U-Pb geochronology}

\section{Bonenau Schist}

Zircons, extracted from metasedimentary rocks (PNG-15-18c, PNG-16-1153a) intercalated with the Goropu Metabasalt, the Bonenau Schist (Figure 2.3), are generally small detrital grains with their long dimension typically $<150 \mu \mathrm{m}$. Although five zircons in sample PNG16-1153a yielded $\mathrm{Pb}_{c}$-corrected ${ }^{206} \mathrm{~Pb} /{ }^{238} \mathrm{U}$ dates of 3.4-0.3 Ma, and one yielded an age of 18.9 Ma (highly discordant U-Pb analyses with a ${ }^{206} \mathrm{~Pb} /{ }^{238} \mathrm{U}$ date of $95.9 \mathrm{Ma}$ before $\mathrm{Pb}_{c}$ correction), the majority $(\mathrm{n}=22$ ) of detrital zircons yielded dates between 115.2-69.6 Ma (Figure 2.13, Electronic appendix 1). Five $\mathrm{Pb}_{c}$-corrected ${ }^{206} \mathrm{~Pb} /{ }^{238} \mathrm{U}$ dates cluster between 72.8-69.5 Ma and are statistically distinct from an older group (115.2-93.2 Ma). Additionally, one older $\mathrm{Pb}_{c}$-corrected ${ }^{206} \mathrm{~Pb} /{ }^{238} \mathrm{U}$ date is $234.5 \pm 4.0 \mathrm{Ma}$ and one ${ }^{207} \mathrm{~Pb} /{ }^{206} \mathrm{~Pb}$ date is $1615 \pm 32 \mathrm{Ma}$ (Electronic appendix 1). Zircons from PNG-15-18c yielded exclusively Cretaceous (144.0-93.1 Ma) $\mathrm{Pb}_{c}$-corrected ${ }^{206} \mathrm{~Pb} /{ }^{238} \mathrm{U}$ dates (Figure 2.13). The youngest Cretaceous ${ }^{206} \mathrm{~Pb} /{ }^{238} \mathrm{U}$ subpopulations of each sample (PNG-16-1153a and PNG-15-18c) yielded weighted mean ages of 71.6 $\pm 1.7 / 3.3$ and 103.0 \pm 3.9/5.7 Ma, respectively (Table 2.3, Figure 2.13).

\section{Yau Igneous Complex}

Zircons were extracted from five Yau Igneous Complex samples: one from mapped outcrop of the Yau Gabbro (PNG-16-1008a), three from clasts contained within the Gwoira Conglomerate (PNG-15-54bT2, PNG-15-54cT2, PNG-16-156a), and a boulder from a modern stream incising into the hanging wall north of the Mai'iu Fault (PNG-15-41bT2) (Figure 2.3). Petrographically, zircons were observed at grain boundaries (plagioclase/amphibole and quartz/plagioclase), at the tip of a sealed fracture(?) in quartz, in altered amphibole and plagioclase, and in a mesostasis consisting principally of pumpellyite and amphibole (Figures B.3a-n). These zircons are generally prismatic, often present as broken fragments, and

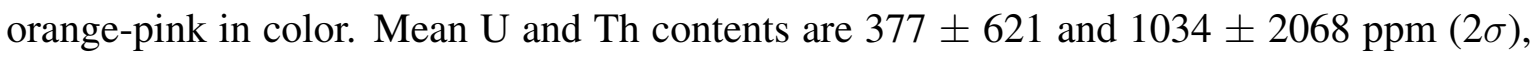
respectively (Electronic appendix 1). Mean Th/U values range from $0.95 \pm 0.29$ to $3.62 \pm$ 


\section{$2.50(2 \sigma)$ (Table 2.3).}

A Tera-Wasserburg diagram reveals that the majority of $\mathrm{Pb}_{c}$-uncorrected but ${ }^{230} \mathrm{Th}$-corrected zircon U-Pb analyses are concordant (Figures B.4a-e). $\mathrm{Pb}_{c^{-}}$and ${ }^{230} \mathrm{Th}$-corrected zircon U-Pb analyses of the five samples show a broad range of ${ }^{206} \mathrm{~Pb} /{ }^{238} \mathrm{U}$ dates between $\sim 66.3-53.2 \mathrm{Ma}$ (Figures 2.14a and b, Electronic appendix 1). A single concordant ${ }^{206} \mathrm{~Pb} /{ }^{238} \mathrm{U}$ date was found to be as young as $10.0 \pm 1.5 \mathrm{Ma}$ (Electronic appendix 1). In each sample, the difference in age between oldest and youngest $\mathrm{Pb}_{c^{-}}$and ${ }^{230} \mathrm{Th}$-corrected single-grain ${ }^{206} \mathrm{~Pb} /{ }^{238} \mathrm{U}$ date is at least $\sim 5$ myr (PNG-15-41bT2, PNG-15-54bT2, PNG-16-156a) and in other cases up to $\sim 11$ myr (PNG-15-54cT2, PNG-16-1008a) (Figures 2.14a and b). Kernel density estimation (KDE) diagrams (Figure 2.14a) exhibit broad peaks (PNG-15-54cT2, PNG-16-1008a) and shoulders on either side of the main peak (PNG-15-41bT2, PNG-15-54bT2) or to the younger tail (PNG-16-156a). Although statistically possible, we refrained from a deconvolution of the KDE age spectra due to the rather continuous topology of the rank-order plots of all samples of the Yau Igneous Complex (Figure 2.14b). Weighted mean ages of the $\mathrm{Pb}_{c^{-}}$and ${ }^{230} \mathrm{Th}$-corrected ${ }^{206} \mathrm{~Pb} /{ }^{238} \mathrm{U}$ dates of the five samples of the Yau Igneous Complex range from $60.4 \pm 0.5 / 2.5$ to $56.6 \pm 0.4 / 2.3 \mathrm{Ma}$ (Figure 2.14b, Table 2.3).

\section{Suckling Granite}

Zircons were separated from five Suckling Granite samples. They occur within plagioclase, K-feldspar, quartz and biotite crystals and at the grain boundaries between amphibole and plagioclase (Figures B.3o-s). These are typically prismatic, euhedral, pink, translucent, have an average size of 100-200 $\mu \mathrm{m}$ and aspect ratios of 2:1 to 3:1. Cathodoluminescence (CL) images of two samples (PNG-15-61a, PNG-15-64a) reveal numerous zircons with bright xenocrystic cores mainly enclosed by rims with oscillatory zoning, but sector, stripy, diffuse, patchy, complex and faintly-unzoned grains have also been observed (Figure 2.15a). Some cores reveal obvious cracking possibly due to volumetric expansion in response to metamictization. Mean U and Th contents are $828 \pm 2087$ and $725 \pm 1450 \mathrm{ppm}(2 \sigma)$, respectively (Electronic appendix 1). Mean Th/U values in zircon of all samples range from $0.42 \pm 0.30$ to $1.17 \pm 1.71(2 \sigma)$ (Table 2.3).

Plotting the $\mathrm{Pb}_{c}$-uncorrected but ${ }^{230} \mathrm{Th}$-corrected zircon U-Pb analyses in a Tera-Wasserburg diagram shows that most analyses are slightly discordant (Figures B.4f-j). Most zircons in the Suckling Granite yielded $\mathrm{Pb}_{c^{-}}$and ${ }^{230} \mathrm{Th}$-corrected single-grain ${ }^{206} \mathrm{~Pb} /{ }^{238} \mathrm{U}$ dates that range from $\sim 4.6-2.9$ Ma (Figures 2.14c and d), but older dates have been measured in all but one sample (Electronic appendix 1). Excluding $\mathrm{Pb}_{c^{-}}$and ${ }^{230} \mathrm{Th}$-corrected ${ }^{206} \mathrm{~Pb} /{ }^{238} \mathrm{U}$ dates $\geq 5 \mathrm{Ma}$ (outside the $3 \sigma$ limit of the mean values of each sample), the difference in age between oldest and youngest single-grain dates is on the order of $\sim 0.5-1.0$ myr (Figure 2.14d). Although KDE diagrams show shoulders (AU51088, PNG-15-61a) and secondary 
peaks (AU51088) on the older tail (Figure 2.14c), a clear-cut statistical deconvolution of the spectra was not possible.

Weighted mean ages of the $\mathrm{Pb}_{c^{-}}$and ${ }^{230} \mathrm{Th}$-corrected ${ }^{206} \mathrm{~Pb} /{ }^{238} \mathrm{U}$ dates of the five Suckling Granite samples range from $3.81 \pm 0.05 / 0.16$ to $3.27 \pm 0.05 / 0.14$ Ma (Table 2.3, Figure 2.14d). Among these five samples are two (AU51088, AU51089) that were previously dated by Davies and Smith (1974) using K-Ar methodology (their samples 6552-2577 and 65522578). Of these, $\mathrm{Pb}_{c^{-}}$and ${ }^{230} \mathrm{Th}$-corrected zircon ${ }^{206} \mathrm{~Pb} /{ }^{238} \mathrm{U}$ dates yielded indistinguishable weighted mean ages of $3.32 \pm 0.04 / 0.14$ and $3.27 \pm 0.05 / 0.14$ Ma (Table 2.3), significantly younger than their hornblende K-Ar dates $(9.4 \pm 0.8 \mathrm{Ma}, 10.8 \pm 0.8 \mathrm{Ma})$, but identical to their biotite $\mathrm{K}-\mathrm{Ar}$ date $(3.3 \pm 0.1 \mathrm{Ma})$. Twenty-two concordant $\mathrm{Pb}_{c^{-}}$and ${ }^{230} \mathrm{Th}$-corrected ${ }^{206} \mathrm{~Pb} /{ }^{238} \mathrm{U}$ dates range from Precambrian to Miocene (Electronic appendix 1).

\section{Mai'iu Monzonite}

The plutonic Mai' iu Monzonite samples (PNG-15-66a, PNG-16-159b, PNG-16-163a) yielded large volumes of zircon (>1-3 grams for rock samples of $\sim 5-10 \mathrm{~kg}$ each) despite the significantly more mafic mineral assemblages of these rocks compared to those of the Suckling Granite. Conversely, the zircon yield of the Mai'iu Monzonite dike (PNG-16-2a) was significantly less ( $<100$ crystals). Zircon was identified as inclusions in hornblende, plagioclase, biotite, K-feldspar and quartz, as well as at grain boundaries (Figures B.3t-x).

Zircons are typically euhedral, pink and translucent. Two Mai' iu Monzonite samples (PNG15-66a, PNG-16-163a) exhibit a variety of morphologies (stubby, long-prismatic, platy, equant), sizes $(50-500 \mu \mathrm{m})$ and aspect ratios (1:1 to 5:1), while those of PNG-16-159b are predominantly prismatic and typically have higher aspect ratios (generally $>1: 2$ to $1: 6$ ). CL images of zircons from two samples (Figure 2.15b; PNG-15-66a, PNG-16-159b) reveal that most grains show faint stripy, sector or diffuse zoning, but some are virtually unzoned and a few have rare faint oscillatory zoning (Figure 2.15b). Rare xenocrystic cores were observed. A common feature is the occurrence of (CL) dark mineral inclusions of unknown composition. Mean U and Th contents are $422 \pm 1529$ and $650 \pm 3934$ ppm $(2 \sigma)$, respectively (Electronic appendix 1). Mean $\mathrm{Th} / \mathrm{U}$ values range from $0.97 \pm 0.72$ to $1.62 \pm 1.80(2 \sigma)$ (Table 2.3).

As is the case with zircons from the Suckling Granite, most $\mathrm{Pb}_{c}$-uncorrected but ${ }^{230}{ }^{20}$ corrected zircon $\mathrm{U}-\mathrm{Pb}$ analyses appear to be slightly discordant (Figures B.4k-n). The difference in age between oldest and youngest single-grain $\mathrm{Pb}_{c^{-}}$and ${ }^{230} \mathrm{Th}$-corrected ${ }^{206} \mathrm{~Pb} /{ }^{238} \mathrm{U}$ dates in three samples (PNG-16-2a, PNG-16-159b, PNG-16-163a) is 1.9-2.6 myr (Figure 2.14f). Only $\mathrm{Pb}_{c^{-}}$and ${ }^{230} \mathrm{Th}$-corrected ${ }^{206} \mathrm{~Pb} /{ }^{238} \mathrm{U}$ dates of zircons from one sample (PNG15-66a) fall within a relatively narrow range of $\sim 0.6 \mathrm{myr}$ (Figure $2.14 \mathrm{f}$ ). KDE plots (Fig- 
ure 2.14e) show secondary peaks (PNG-16-2a, PNG-16-159b) and shoulders or long tails (PNG-16-163a) towards older $\mathrm{Pb}_{c}$ - and ${ }^{230} \mathrm{Th}$-corrected ${ }^{206} \mathrm{~Pb} /{ }^{238} \mathrm{U}$ dates. In all three cases, mixture modelling (auto mode; Vermeesch, 2012) suggested two populations. Based on a visual assessment of the topology of the KDE and rank-order plots of the Mai'iu Monzonite samples, we rejected $\mathrm{Pb}_{c^{-}}$and ${ }^{230} \mathrm{Th}$-corrected ${ }^{206} \mathrm{~Pb} /{ }^{238} \mathrm{U}$ dates that tail off to higher ages (grey symbols in Figure 2.14f) from the weighted mean age calculation. Excluding these dates, $\mathrm{Pb}_{c^{-}}$and ${ }^{230} \mathrm{Th}$-corrected ${ }^{206} \mathrm{~Pb} /{ }^{238} \mathrm{U}$ dates of the remainder yielded weighted mean ages ranging from $2.96 \pm 0.07 / 0.14$ to $1.99 \pm 0.05 / 0.09 \mathrm{Ma}$ (Figure 2.14f, Table 2.3). Two analyses yielded concordant Cambrian $\mathrm{Pb}_{c}$ - and ${ }^{230} \mathrm{Th}$-corrected ${ }^{206} \mathrm{~Pb} /{ }^{238} \mathrm{U}$ dates (Electronic appendix 1).

\section{Bonua Porphyry}

Zircon in one sample of the Bonua Porphyry (PNG-16-157a) has been identified at the interface of biotite/K-feldspar and prehnite(?)/K-feldspar in thin section. Zircons from this sample are generally pink, translucent and range in size from $\sim 80-380 \mu \mathrm{m}$. They are typically prismatic but many are smoothly rounded. Zircon is less abundant compared to those in samples of the Suckling Granite and Mai'iu Monzonite. Mean U and Th contents are 663 \pm 1385 and $971 \pm 4678 \mathrm{ppm}(2 \sigma)$, respectively (Electronic appendix 1). An average $\mathrm{Th} / \mathrm{U}$ of $1.01 \pm 1.33(2 \sigma)$ (Table 2.3) was calculated.

Plotting the $\mathrm{Pb}_{c}$-uncorrected but ${ }^{230} \mathrm{Th}$-corrected $\mathrm{U}-\mathrm{Pb}$ analyses in a Tera-Wasserburg diagram reveals that most analyses are slightly discordant (Figure B.4o). Most $\mathrm{Pb}_{c^{-}}$and ${ }^{230} \mathrm{Th}-$ corrected zircon ${ }^{206} \mathrm{~Pb} /{ }^{238} \mathrm{U}$ dates fall within the broad range of $\sim 4.2-1.7 \mathrm{Ma}$ (Electronic appendix 1). Of these, a KDE plot exhibits a bimodal age spectrum (Figure 2.14e) with a major $(\sim 80 \%)$ and a minor $(\sim 20 \%)$ peak at $3.5 \pm 0.1 \mathrm{Ma}$ and $2.5 \pm 0.1 \mathrm{Ma}$ (cf. Sambridge and Compston, 1994), respectively. The weighted mean age of the younger population of the $\mathrm{Pb}_{c^{-}}$and ${ }^{230} \mathrm{Th}$-corrected zircon ${ }^{206} \mathrm{~Pb} /{ }^{238} \mathrm{U}$ dates is $2.44 \pm 0.13 / 0.16 \mathrm{Ma}$ (Figure 2.14f, Table 2.3). Two $\mathrm{Pb}_{c^{-}}$and ${ }^{230} \mathrm{Th}$-corrected ${ }^{206} \mathrm{~Pb} /{ }^{238} \mathrm{U}$ dates are Cretaceous (Electronic appendix 1).

\section{Basaltic andesite dike}

Only two zircon crystals were separated from sample PNG-15-60a (Figure 2.3). Morphologically, one grain was euhedral $(\mathrm{U}=246 \mathrm{ppm}, \mathrm{Th}=274 \mathrm{ppm})$ and the other was rounded $(\mathrm{U}$ $=241 \mathrm{ppm}$, Th $=215 \mathrm{ppm}) . \mathrm{Pb}_{c^{-}}$and ${ }^{230} \mathrm{Th}$-corrected ${ }^{206} \mathrm{~Pb} /{ }^{238} \mathrm{U}$ dates of the euhedral and rounded grains are $0.2 \pm 0.1$ and $89.7 \pm 2.3 \mathrm{Ma}$, respectively (Electronic appendix 1). 
Table 2.3: Resolved ages from U-Pb dating of zircon.

\begin{tabular}{|c|c|c|c|c|c|c|c|c|c|c|c|c|}
\hline Map unit & Sample & $\begin{array}{l}\text { Sample } \\
\text { type }\end{array}$ & $\mathrm{Th} / \mathrm{U}$ & $\begin{array}{l}\text { Concordia } \\
\text { age }[\mathrm{Ma}]^{a}\end{array}$ & $\begin{array}{c}2 \sigma \\
{[\mathrm{Ma}]}\end{array}$ & MSWD & $\mathbf{n}_{a} / \mathbf{n} / \mathbf{n}_{z r n}$ & $\begin{array}{c}\text { Weighted mean } \\
\text { age }[\mathrm{Ma}]^{b}\end{array}$ & $\begin{array}{c}\mathbf{2} \sigma \\
{[\mathbf{M a}]^{c}}\end{array}$ & $\begin{array}{c}\mathbf{2} \sigma \\
{[\mathbf{M a}]^{d}}\end{array}$ & MSWD & $\mathbf{n}_{a} / \mathbf{n} / \mathbf{n}_{z r n}$ \\
\hline Bonenau & PNG-15-18c & outcrop & & & & & & $103.0 \dagger$ & 3.9 & 5.7 & 16.0 & $12 / 12 / 11$ \\
\hline Schist & PNG-16-1153a & outcrop & & & & & & $71.6 \dagger$ & 1.7 & 3.3 & 1.5 & $5 / 32 / 22$ \\
\hline Yau Igneous & PNG-15-41bT2 & float & 3.62 & $58.1^{*}$ & 0.3 & 3.7 & $50 / 50 / 50$ & $57.9 *$ & 0.4 & 2.3 & 3.5 & $50 / 50 / 50$ \\
\hline \multirow[t]{4}{*}{ Complex } & PNG-15-54bT2 & clast & 0.95 & $56.6^{*}$ & 0.3 & 2.1 & $47 / 50 / 50$ & $56.6 *$ & 0.4 & 2.3 & 3.0 & $50 / 50 / 50$ \\
\hline & PNG-15-54cT2 & clast & 1.16 & $60.0^{*}$ & 0.5 & 5.2 & $41 / 51 / 50$ & $60.4 *$ & 0.5 & 2.5 & 8.3 & $51 / 51 / 50$ \\
\hline & PNG-16-156a & clast & 3.35 & $58.0^{*}$ & 0.5 & 9.6 & $40 / 40 / 40$ & $57.8^{*}$ & 0.5 & 2.4 & 9.3 & $40 / 40 / 40$ \\
\hline & PNG-16-1008a & outcrop & 1.76 & $58.9^{* *}$ & 0.8 & 15 & $55 / 55 / 50$ & $58.6 * *$ & 0.6 & 2.4 & 8.0 & $55 / 55 / 50$ \\
\hline Suckling & AU51087 & float & 0.82 & $3.35^{* * *}$ & 0.03 & 2.5 & $51 / 51 / 50$ & 3.33** & 0.03 & 0.14 & 2.2 & $51 / 51 / 50$ \\
\hline \multirow{4}{*}{ Granite } & AU51088 & float & 1.17 & $3.34 *$ & 0.04 & 3.9 & $50 / 50 / 49$ & 3.32* & 0.04 & 0.14 & 3.0 & $50 / 50 / 49$ \\
\hline & AU51089 & float & 1.06 & $3.33^{*}$ & 0.06 & 5.4 & $44 / 44 / 43$ & $3.27 *$ & 0.05 & 0.14 & 4.6 & $44 / 44 / 43$ \\
\hline & PNG-15-61a & outcrop & 0.42 & $3.83 * *$ & 0.05 & 2.5 & $43 / 43 / 43$ & $3.81 * *$ & 0.05 & 0.16 & 2.2 & $43 / 43 / 43$ \\
\hline & PNG-15-64a & outcrop & 0.75 & $3.69 * *$ & 0.08 & 9.7 & $45 / 46 / 46$ & $3.67 * *$ & 0.05 & 0.16 & 4.2 & $46 / 46 / 46$ \\
\hline Mai'iu & PNG-15-66a & outcrop & 1.13 & $2.05^{* *}$ & 0.05 & 5.8 & $44 / 44 / 43$ & $2.02 * *$ & 0.04 & 0.09 & 4.8 & $44 / 44 / 43$ \\
\hline \multirow[t]{3}{*}{ Monzonite } & PNG-16-2a & outcrop & 1.62 & $2.02 * *$ & 0.05 & 8.4 & $36 / 50 / 50$ & $1.99 * *$ & 0.05 & 0.09 & 6.7 & $36 / 50 / 50$ \\
\hline & PNG-16-159b & outcrop & 0.99 & $2.93 * *$ & 0.10 & 3.7 & $36 / 50 / 50$ & $2.96 * *$ & 0.07 & 0.14 & 1.8 & $36 / 50 / 50$ \\
\hline & PNG-16-163a & outcrop & 0.97 & $2.05^{* *}$ & 0.09 & 5.7 & $41 / 50 / 50$ & $2.02 * *$ & 0.07 & 0.11 & 4.9 & $41 / 50 / 50$ \\
\hline $\begin{array}{l}\text { Bonua } \\
\text { Porphyry }\end{array}$ & PNG-16-157a & outcrop & 1.01 & $2.47 * *$ & 0.14 & 5.6 & $9 / 49 / 49$ & $2.44 * *$ & 0.13 & 0.16 & 4.3 & $9 / 49 / 49$ \\
\hline
\end{tabular}

Sample type: 'Clast' refers to gabbroic-tonalitic clast in the Gwoira Conglomerate. 'Float' refers to stream boulder

${ }^{a}$ : Lower-intercept ages calculated from ${ }^{230} \mathrm{Th}$-corrected U-Pb analyses. For the calculation, the ${ }^{238} \mathrm{U} /{ }^{235} \mathrm{U}$ value of GJ-1 (137.824, after Hiess et al., 2012) was used. ${ }^{207} \mathrm{~Pb} /{ }^{206} \mathrm{~Pb}$ was anchored at $0.83 \pm 0.02$.

$b$ : Weighted mean ages calculated from $\mathrm{Pb}_{c}$ - and ${ }^{230} \mathrm{Th}$-corrected ${ }^{206} \mathrm{~Pb} /{ }^{238} \mathrm{U}$ dates. Corrections after Andersen (2002) and Schärer (1984). $\dagger$ not corrected for ${ }^{230} \mathrm{Th}$ disequilibrium.

${ }^{c}$ : Uncertainty excluding systematic uncertainties.

$d$ : Uncertainty including systematic uncertainties from decay constants $\left(\lambda_{238}, \lambda_{235}\right.$; Jaffey et al., 1971), ${ }^{238} \mathrm{U} /{ }^{235} \mathrm{U}$ (Hiess et al., 2012) and $4 \%$ long-term reproducibility of Plešovice standard zircon.

*: $\mathrm{Th} / \mathrm{U}_{\text {magma }}=3$ inferred for ${ }^{230} \mathrm{Th}$ correction.

**: Th/U $\mathrm{U}_{\text {magma }}$ from whole-rock composition (see Table 2.2)

Bold font: Preferred radiometric age. 

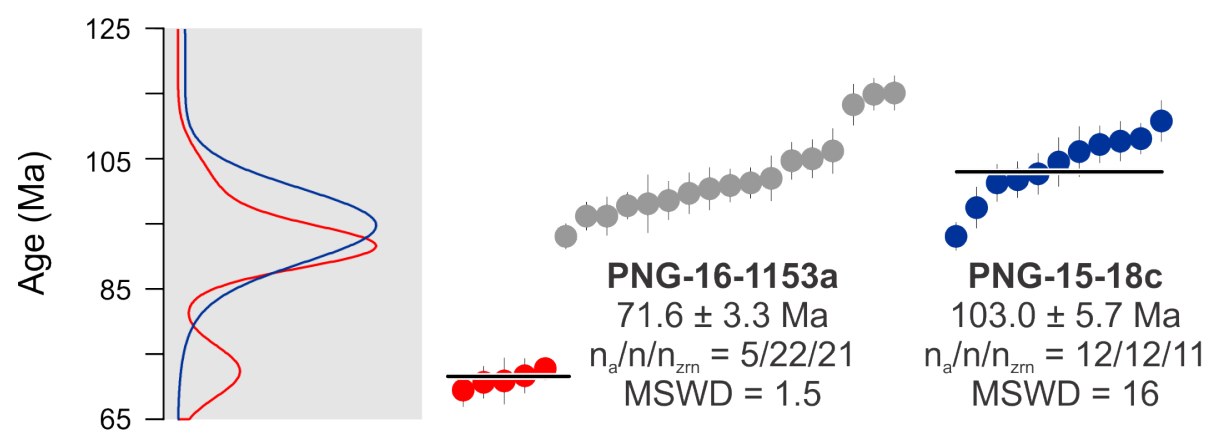

Figure 2.13: Adaptive kernel density estimation and rank-order plots of $\mathrm{Pb}_{c}$-corrected ${ }^{206} \mathrm{~Pb} /{ }^{238} \mathrm{U}$ dates for zircons from the Bonenau Schist. Error bars correspond to the 2SE confidence interval (analytical uncertainties only). The black bars represent the weighted mean ages. Where individual analyses have been excluded from the calculation of the weighted mean they are coloured grey. The uncertainties of the weighted mean ages include systematic uncertainties (see Table 2.3). Details of the weighted mean age calculation are given below the corresponding rank-order plot for each sample. Abbreviations: $\mathrm{n}_{a}-$ number of analyses used to calculate the age; $\mathrm{n}$ - number of analyses; $\mathrm{n}_{z r n}-$ number of zircons analysed.

\subsubsection{Al-in-amphibole and -biotite thermobarometry}

For a detailed description of amphibole textures and chemistry, the calculation of pressures, temperatures and oxygen fugacity from Al-in-amphibole and Al-in-biotite thermobarometry, the reader is referred to Supplementary material B.1. The results from the thermobarometric calculations are summarized in Table 2.4. Using the calibration of Mutch et al. (2016), calculated pressures from three samples of the Mai'iu Monzonite (PNG-15-66a, PNG-16-159b, PNG-16-163a) range from $1.3 \pm 0.3$ to $2.3 \pm 0.7 \mathrm{kbar}(2 \sigma)$ (Table 2.4). Amphibole from two float samples of the Suckling Granite (AU51087, AU51088) yielded pressures of $2.3 \pm 0.4$ and $1.2 \pm 0.4 \mathrm{kbar}(2 \sigma)$ (Table 2.4), respectively, very comparable with those of the Mai'iu Monzonite. When the topographic relief over which the outcrop samples were collected is considered, the pressure estimates of the Mai'iu Monzonite samples change to $0.8 \pm 0.3$ to $2.3 \pm 0.7$ kbar $(2 \sigma)$ (Table 2.4).

Pressure estimates derived from Al-in-amphibole barometry are similar to those from Alin-biotite barometry (after Uchida et al., 2007). Biotite in Mai'iu Monzonite samples PNG15-66a and PNG-16-159b yielded pressures (corrected for topographic relief) of $0.4 \pm 0.8$ and $1.9 \pm 0.5 \mathrm{kbar}(2 \sigma)$, respectively (Table 2.4). Collectively, these results are consistent with the reported presence of andalusite in the contact aureole of the Suckling Granite and Mai'iu Monzonite (Smith and Davies, 1976), that indicates pressures of $\leq 4 \mathrm{kbar}$ (Clarke et al., 2005). Higher pressures (4.3 $\pm 0.9 \mathrm{kbar}$, corrected for topographic relief) are recorded in amphiboles from the Mai'iu Monzonite dike (PNG-16-2a, Table 2.4). 


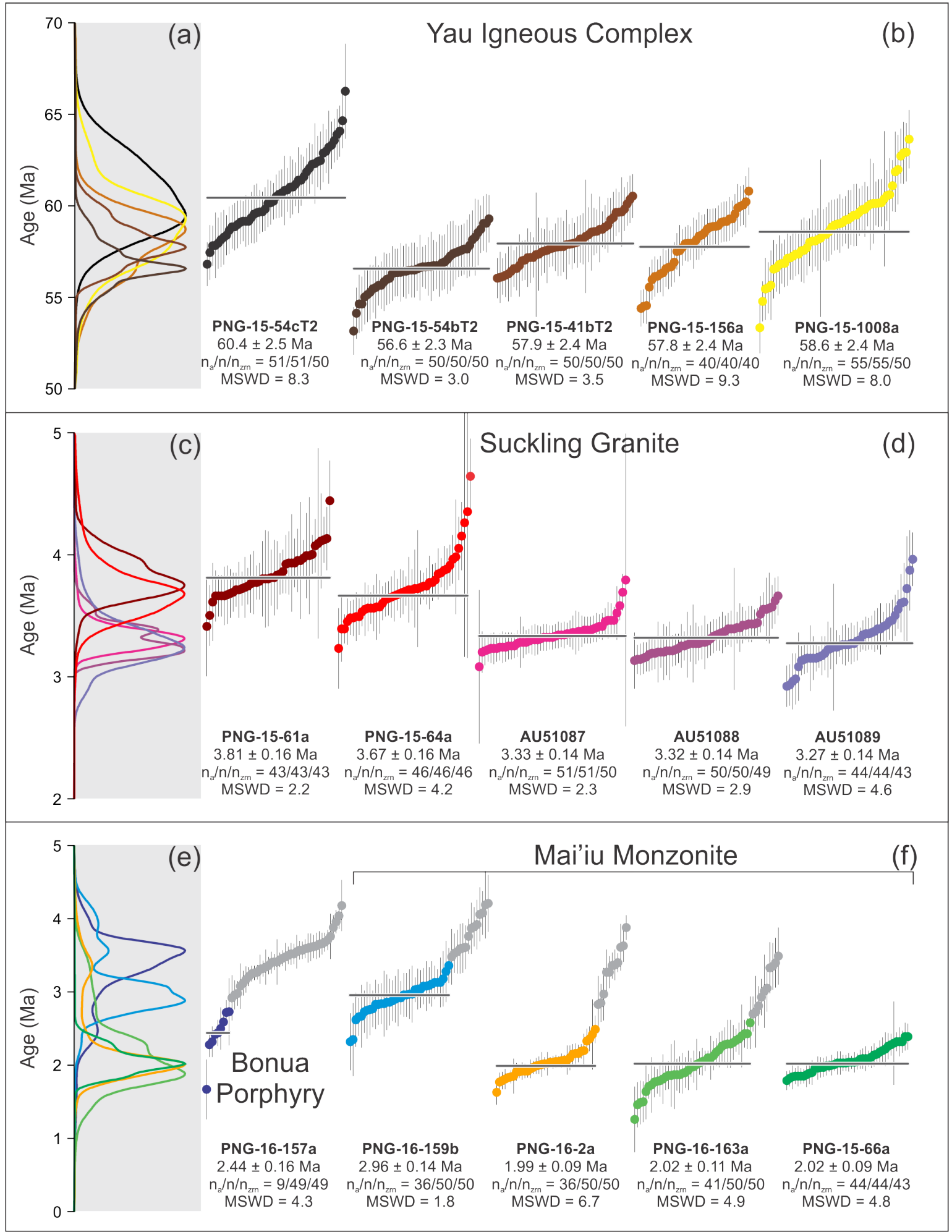


Figure 2.14: Adaptive kernel density estimation and rank-order plots of $\mathrm{Pb}_{c^{-}}$and ${ }^{230} \mathrm{Th}-$ corrected ${ }^{206} \mathrm{~Pb} /{ }^{238} \mathrm{U}$ dates for zircons from rocks of the (a-b) Yau Igneous Complex, (c-d) Suckling Granite, and (e-f) Bonua Porphyry and Mai'iu Monzonite. Error bars correspond to the 2SE confidence interval (analytical uncertainties only). The dark grey bars represent the weighted mean ages. The uncertainties of the weighted mean ages include systematic uncertainties (see Table 2.3). Where individual analyses have been excluded from the calculation of the weighted mean they are coloured grey. The identification of 'outliers' was aided by the kernel density estimation (KDE) plots and linearized probability density (not shown) plots. Details of the weighted mean age calculation are given below the corresponding rank-order plot for each sample. Abbreviations: $\mathrm{n}_{a}$ - number of analyses used to calculate the age; $\mathrm{n}-$ number of analyses; $\mathrm{n}_{z r n}$ - number of zircons analysed.

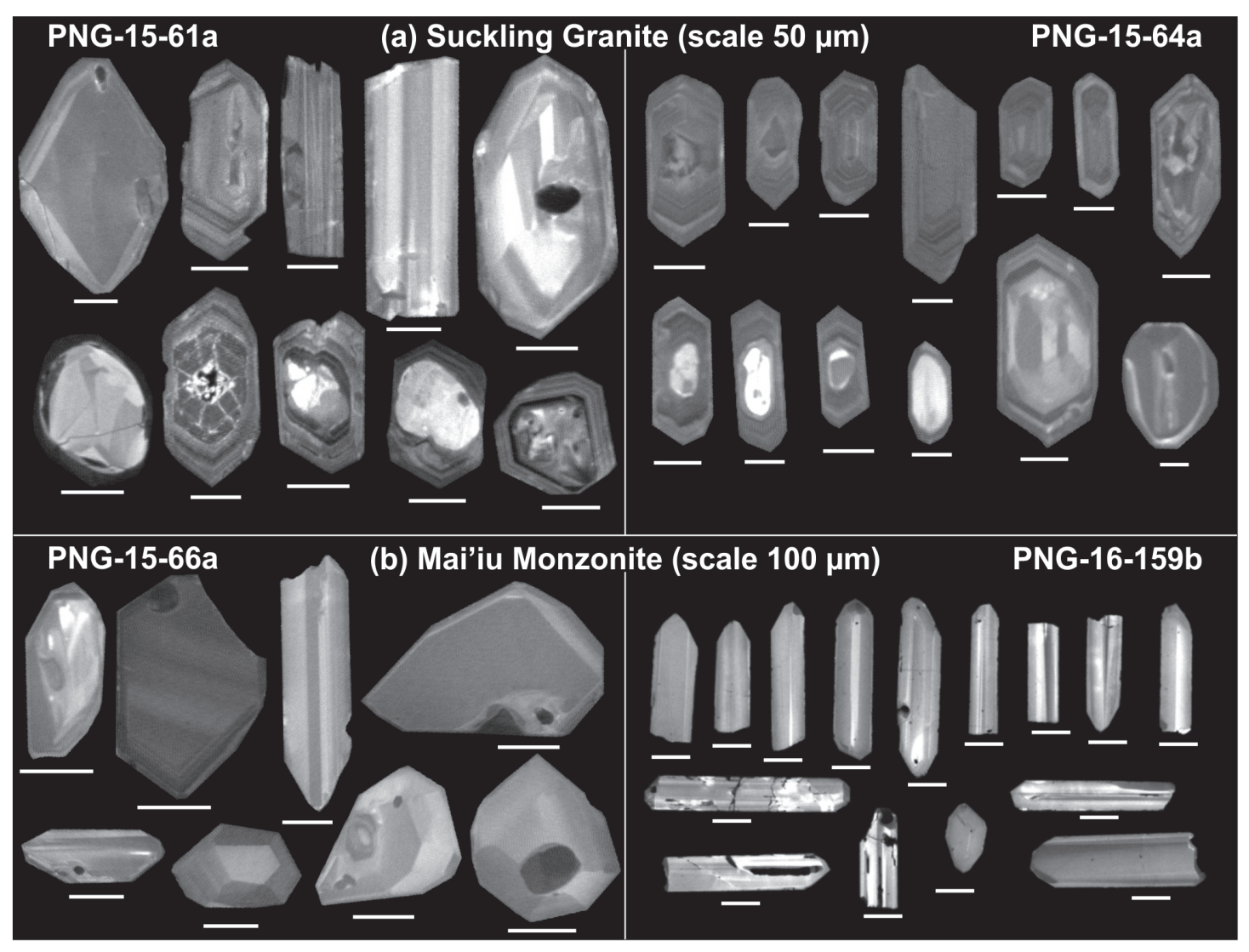

Figure 2.15: Cathodoluminescence (CL) images of zircon from (a) the Suckling Granite (PNG-15-61a, PNG-15-64a) and (b) the Mai'iu Monzonite (PNG-15-66a, PNG-16-159b) samples. See figure for scale. 

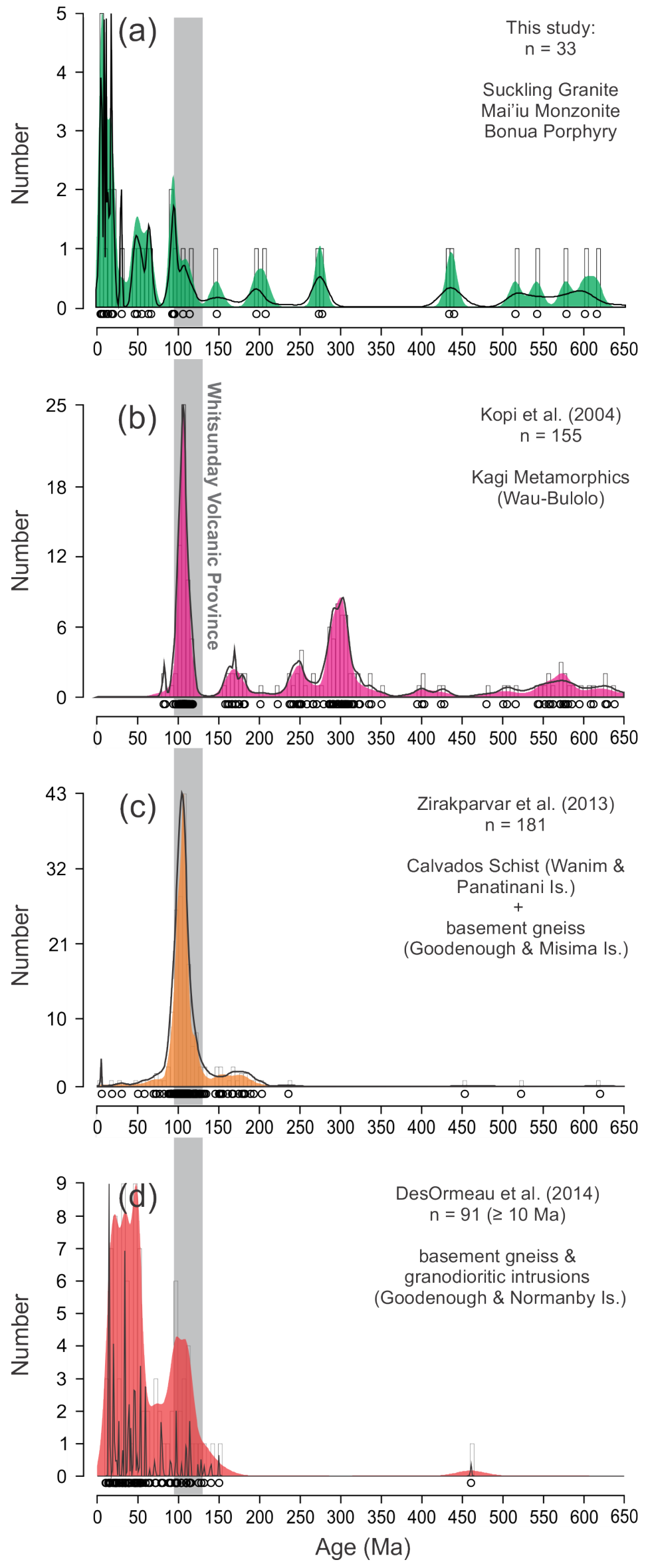
Figure 2.16: Kernel density estimation plots of $\mathrm{Pb}_{c^{-}}$and ${ }^{230} \mathrm{Th}$-corrected ${ }^{206} \mathrm{~Pb} /{ }^{238} \mathrm{U}$ dates showing age distributions of (a) inherited (i.e., xenocrystic) zircons from igneous rocks of the Suckling-Dayman metamorphic core complex (Suckling Granite, Mai'iu Monzonite, Bonua Porphyry), (b) detrital zircons from the Kagi Metamorphics in the Wau area (Kopi et al., 2004), (c) detrital zircons from basement gneisses on Goodenough Island and the Louisiade Archipelago (Zirakparvar et al., 2013) and (d) inherited zircons in granitoids from Goodenough and Normanby Islands (DesOrmeau et al., 2014). The grey bar marks the duration of igneous activity associated with the Whitsunday Volcanic Province (Bryan et al., 1997; Ewart et al., 1992; Tulloch et al., 2010). The bin and band widths were set to 5 myr, respectively. The coloured area represents the results from the kernel density estimation function while the black solid lines represent the probability density function. Black circles represent the number of analyses and the empty boxes the bins of the histogram.

Temperature estimates from amphibole-plagioclase thermometry (after Holland and Blundy, 1994) of the Mai'iu Monzonite (PNG-15-66a, PNG-16-159b, PNG-16-163a) range from $\sim 690-630^{\circ} \mathrm{C}(2 \sigma)$ (Table 2.4). Relative $\Delta \mathrm{NNO}$ values (after Ridolfi et al., 2010) from all samples range between $2.40 \pm 0.38$ and $1.05 \pm 0.22(2 \sigma)$ (Table 2.4).

\subsection{Discussion}

\subsubsection{The Goropu Metabasalt}

The Goropu Metabasalt reveals geochemical affinities transitional between N-MORB and EMORB, but closer to the latter (i.e., $\left.(\mathrm{Ce} / \mathrm{Yb})_{N}>1\right)$. The compositional similarity to the Kutu Volcanics supports the view (e.g., Davies, 1980; Smith, 1982) that both units have a common origin. The age of the Bonenau Schist, and hence the Goropu Metabasalt, is constrained by detrital zircon $\mathrm{U}-\mathrm{Pb}$ ages that we interpret as maximum depositional ages (MDAs). The MDAs (Figure 2.13) may suggest that the Goropu Metabasalt was formed over a period between $\sim 103-72 \mathrm{Ma}$. The younger MDA at 71.6 $\pm 3.3 \mathrm{Ma}$ is consistent with the Maastrichtian age of the planktonic foraminifera in the Bonenau Schist (Smith and Davies, 1976). The sample with the older MDA (103.0 $\pm 5.7 \mathrm{Ma}$, PNG-15-18c) was collected north of the sample with the younger MDA (71.6 \pm 3.3 Ma, PNG-16-1153a) (Figure 2.3). Although tentative, an overall younging of the Goropu Metabasalt to the south is consistent with the Late Cretaceous-Eocene age of the Kutu Volcanics south of the SDMCC (Figure 2.3).

The age of the Goropu Metabasalt has important implications for paleogeographic reconstructions of the southwestern Pacific region (e.g., Crawford et al., 2003; Glen and Meffre, 2009; Schellart et al., 2006; Seton et al., 2016; Whattam, 2009). The Goropu Metabasalt and the Emo Metamorphics have been considered as parts of a back-arc basin (the EBAB, Worthing and Crawford, 1996) that, in some models (e.g., Seton et al., 2016), is portrayed 
as an extension of the South Loyalty Basin of Cluzel et al. (2001). A recent study from the Solomon Islands reported xenocrystic zircon $\mathrm{U}-\mathrm{Pb}$ age populations that indicate derivation from the eastern Gondwana margin (e.g., Tapster et al., 2014), thus suggesting that the Solomon Island Arc (part of the Melanesian Arc system) is not purely intra-oceanic in nature. Hence, the age of the Goropu Metabasalt constrains the age of the EBAB and the timing of rifting events that separated hyper-extended continental crust (e.g., Solomon Island Arc) from the eastern margin of Gondwana.

\subsubsection{The Yau Igneous Complex}

\section{Petrogenesis}

The broad range of $\mathrm{SiO}_{2}$ contents of the dolerites, quartz-gabbros and tonalites of the Yau Igneous Complex ( $\sim 7-63 \mathrm{wt} \%$ ) suggest that this unit is internally differentiated, a conclusion already drawn by Smith and Davies (1976) on petrographic grounds. Compositionally, the virtual absence of Fe-Ti oxides in the dolerites, their comparatively higher $\mathrm{MgO}, \mathrm{Cr}, \mathrm{Ni}$ and Th contents (Table 2.2), slightly enriched chondrite-normalized LREE patterns (Figure 2.8), and the resemblance and (in some cases) overlap with "canonical" values of $\mathrm{Ti} / \mathrm{Eu}, \mathrm{Y} / \mathrm{Ho}$ and $\mathrm{Ce} / \mathrm{Pb}$ from the literature (Table 2.5) suggest that these rocks formed in a MORB environment, transitional between E- and N-MORB (Figure 2.9). The close match of the trace element patterns of the dolerites and the Goropu Metabasalt (Figures 2.7 and 2.8) further supports this notion.

The quartz-gabbros and tonalites of the high-silica suite of the Yau Igneous Complex are more fractionated. The low $\mathrm{MgO}(0.91-1.62 \mathrm{wt} \%$, Table 2.2), the marked difference from VHI to HC elements, the negative Eu, Ti and V anomalies (Figures 2.7b and 2.8), as well as the very low $\mathrm{Cr}(1-5 \mathrm{ppm}$ ) and $\mathrm{Ni}$ (below the detection limit) contents (Table 2.5), are those expected from more evolved melts. The coupled negative Ti and V anomalies suggest fractionation by $\mathrm{Fe}$-Ti oxides and the negative Eu anomalies may indicate plagioclase fractionation. The fact that the REE patterns of the dolerites of the low-silica suite and the quartz-gabbros and tonalites of the high-silica suite are almost parallel may indicate that they are linked by crystal fractionation. In contrast, the chondrite-normalized REE patterns of the quartz-gabbros and tonalites of the low-silica suite are depleted and cannot be directly linked to the slightly enriched patterns of the Goropu Metabasalt.

\section{Intrusion age}

Zircon $\mathrm{U}-\mathrm{Pb}$ analyses of five samples of quartz-gabbros and tonalites of the Yau Igneous Complex each reveal a large range of $\mathrm{Pb}_{c^{-}}$and ${ }^{230} \mathrm{Th}$-corrected ${ }^{206} \mathrm{~Pb} /{ }^{238} \mathrm{U}$ dates of at least $\sim 5$ myr (Figure 2.14b). Such apparent crystallization periods are not compatible with the idea that zircon in mafic/tholeiitic rocks forms in late, fractionated melt pockets (Schaltegger 
and Davies, 2017). Both in fast- and slow-spreading MOR settings, time scales of zircon crystallization in oceanic gabbroic plutons were found to be on the order of $\sim 0.1-0.2 \mathrm{myr}$ (Lissenberg et al., 2009; Rioux et al., 2012), significantly shorter than that which we observe in the quartz-gabbros and tonalites of the Yau Igneous Complex. The reason for these apparently protracted time scales of zircon growth in the samples of the Yau Igneous Complex remains obscure but may be due to inheritance or post-crystallization processes. CL imaging and dating of zircons in thin sections will further elucidate the cause of this broad range of single-grain ${ }^{206} \mathrm{~Pb} /{ }^{238} \mathrm{U}$ dates in these rocks.

The Yau Gabbro (but here called the Yau Igneous Complex) was previously described as a subvolcanic pluton related to the Goropu Metabasalt (Smith and Davies, 1976). Weighted mean ages ranging between $60.4 \pm 2.5$ and $56.6 \pm 2.3 \mathrm{Ma}$ (Figure 2.14b) of all five samples of the Yau Igneous Complex post-date the Late Cretaceous protolith of the Goropu Metabasalt by at least $\sim 5-10$ myr. The protolith age of the Goropu Metabasalt is, however, only constrained by a few samples and it is possible that it extends to younger ages. Regardless, the Paleocene age of the Yau Igneous Complex provides a minimum age for the oceanic protolith of the Goropu Metabasalt. Interestingly, the range of the weighted mean ages of the Yau Igneous Complex ( 60.4-56.6 Ma) overlaps with the onset of southwest-directed obduction of the PUB over the rifted Australian margin at $58.3 \pm 0.4 \mathrm{Ma}$ and the magmatic activity ( 59-47 Ma) in the CVA in the upper plate (Figure 2.2) (Lus et al., 2004; Rogerson et al., 1991; Walker and McDougall, 1982). A common origin of the Yau Igneous Complex and the igneous rocks of the CVA is, however, unlikely given the MORB-like character of the former and the arc-like affinities of the latter.

\subsubsection{The Plio-Pleistocene calc-alkaline and high-K igneous rocks}

\section{Petrogenesis}

Based on mineralogical differences and major oxide compositions, a calc-alkaline (Suckling Granite) and a high-K (Mai'iu Monzonite, Bonua Porphyry, basaltic andesite dikes) suite may be distinguished. The transition from felsic/peraluminous ( $\sim 3.8-3.7 \mathrm{Ma})$ to intermediatemafic/metaluminous ( 3.3-2.0 Ma) bulk compositions (Figure B.2) and an accompanying change in mineralogy (white mica $\rightarrow$ biotite-only $\rightarrow$ biotite-hornblende) may suggest an increase in more primitive mantle-derived (I-type) material over time, temporarily/spatially restricted partial melting of crustal (S-type) material, or both. This observation is consistent with those made by Chappell and White (1974) where S-type granites tend to be early in the intrusive sequence. 


\begin{tabular}{|c|c|c|c|c|c|c|c|c|c|c|}
\hline Sample & Setting & Amp-pl $\left[{ }^{\circ} \mathrm{C}\right]^{a}$ & $\mathrm{n}$ & $\mathrm{Al}_{t o t}(\mathrm{amp})$ & Al-in-amp [kbar ${ }^{b}$ & $\mathrm{n}$ & $\mathrm{Al}_{\text {tot }}(\mathrm{bt})$ & Al-in-bt $[\mathrm{kbar}]^{c}$ & $\mathrm{n}$ & $\Delta \mathrm{NNO}^{d}$ \\
\hline AU51087 & float & & & $1.19 \pm 0.13$ & $2.3 \pm 0.4$ & 16 & & & & $1.05 \pm 0.22$ \\
\hline AU51088 & float & & & $0.69 \pm 0.22$ & $1.2 \pm 0.4$ & 21 & & & & $2.37 \pm 0.36$ \\
\hline PNG-15-66a & outcrop & $630 \pm 51$ & 20 & $0.76 \pm 0.18$ & $1.3 / \mathbf{0 . 8} \pm 0.3$ & 20 & $2.44 \pm 0.27$ & $0.9 / \mathbf{0 . 4} \pm 0.8$ & 15 & $2.40 \pm 0.38$ \\
\hline PNG-16-2a & outcrop & & & $1.93 \pm 0.22$ & $4.9 / 4.3 \pm 0.9$ & 26 & & & & $1.36 \pm 0.37$ \\
\hline PNG-16-159b & outcrop & $689 \pm 54$ & 16 & $1.18 \pm 0.26$ & $2.3 / \mathbf{2 . 3} \pm 0.7$ & 18 & $2.77 \pm 0.17$ & $1.9 / \mathbf{1 . 9} \pm 0.5$ & 14 & $1.30 \pm 0.36$ \\
\hline PNG-16-163a & outcrop & $663 \pm 53$ & 15 & $0.98 \pm 0.26$ & $1.8 / \mathbf{1 . 3} \pm 0.6$ & 15 & & & & $2.15 \pm 0.45$ \\
\hline
\end{tabular}

Uncertainties are given at the $2 \sigma$ confidence interval.

${ }^{a}$ : Edenite-richterite thermometer (B) after Holland and Blundy (1994)

b: Al-in-amphibole barometer after Eq. 5 of Mutch et al. (2016)

c: Al-in-biotite barometer after Eq. 2 of Uchida et al. (2007)

$d$ : Relative oxygen fugacity after Eq. 2 of Ridolfi et al. (2010)

Bold font: pressure estimates corrected for topographic relief (normalized to 3400 m.a.s.l.) and assuming a lithostatic gradient of $0.29 \mathrm{kbar} / \mathrm{km}$. 
Table 2.5: Trace element characteristics of the Yau Igneous Complex

\begin{tabular}{|c|c|c|c|c|c|c|}
\hline Sample & $\mathbf{T i} / \mathbf{E u}$ & Y/Ho & $\mathrm{Ce} / \mathrm{Pb}$ & $\mathrm{Cr}[\mathbf{p p m}]$ & $\mathrm{Ni}[\mathrm{ppm}]$ & Th $[p p m]$ \\
\hline \multicolumn{7}{|l|}{ Low-silica suite: } \\
\hline PNG-15-3b & 7580 & 23.6 & 32.9 & 301 & 67 & 0.29 \\
\hline PNG-15-4a & 6923 & 24.3 & 65.3 & 191 & 79 & 0.34 \\
\hline PNG-16-156a & 6782 & 25.3 & 124.4 & 2 & 28 & 0.67 \\
\hline PNG-16-1029a & 7697 & 24.8 & 38.8 & 9 & 16 & 0.22 \\
\hline \multicolumn{7}{|l|}{ High-silica suite: } \\
\hline AU51082 & 2102 & 25.0 & 219.5 & 2 & bdl & 2.36 \\
\hline PNG-16-108b & 2536 & 25.1 & 278.0 & 1 & bdl & 1.74 \\
\hline PNG-16-1008a & 1372 & 25.9 & 90.7 & 5 & bdl & 2.14 \\
\hline N-MORB ${ }^{a}$ & $7060 \pm 1270^{*}$ & $28.4 \pm 3.6^{*}$ & $22.2 \pm 9.7 *$ & & & \\
\hline Island Arc Tholeiitic Series ${ }^{b}$ & & & & $0-50$ & $0-30$ & 0.50 \\
\hline Abyssal Tholeiitic Series ${ }^{b}$ & & & & $200-400$ & $30-200$ & 0.15 \\
\hline
\end{tabular}

We infer that the calc-alkaline rocks of the Suckling Granite have been derived by partial melting of underlying continental crust. This inference is supported by the positive Eu anomalies of the samples of the Suckling Granite and the occurrence of abundant xenocrystic zircon in the granites. Little et al. (2019) inferred that the Kagi Metamorphics were subducted along a Miocene thrust below the Goropu Metabasalt. In this model, the subducted continental crust partially melted at mantle depths after the onset of extension in the Woodlark Rift. These partial melts rose into the extending lithosphere of the overlying rift, locally emerging to form the gneiss domes of the D'Entrecasteaux Islands. In their model, small amounts of melts migrated up the Mai'iu Fault zone where the Suckling Granite was intruded.

The mechanisms involved in the petrogenesis of the high-K rocks of the SDMCC is uncertain. Principally associated with subduction zones (e.g., Morrison, 1980), the high-K rocks ( 3.0-2.0 Ma) post-date north-directed Miocene subduction beneath the Goropu Metabasalt and Papua New Guinea-wide igneous activity of the Maramuni Arc in the Miocene (Figure 2.2) (Holm et al., 2015). It has been argued (cf. Johnson et al., 1978) that the chemical signatures of many Late Cenozoic volcanic rocks in Papua New Guinea (including rocks that were also associated with the Maramuni Arc) are inherited from a previous phase of subduction. This is consistent with the interpretation of Ruprecht et al. (2013) who inferred, based on trace element and volatile abundances (4,500 ppm S; enriched $\mathrm{Th} / \mathrm{Nb}$; up to $3.3 \mathrm{wt} \% \mathrm{H}_{2} \mathrm{O}$ ) in olivine-hosted melt inclusions from the Waiowa Volcanics (Figure 2.3), that previous subduction had overprinted the mantle but that low $\mathrm{H}_{2} \mathrm{O} / \mathrm{Ce}$ values of $\sim 350-800$ are unlike those from active volcanic arcs. 
In the Woodlark Rift, a $250-\mathrm{km}$-long by $<100-\mathrm{km}$-wide corridor of asthenospheric mantle $\left(\Delta \mathrm{V}_{p} / \mathrm{V}_{p}\right.$ up to $-4 \%$; Figure 2.1$)$ has been imaged by teleseismic P- and S-waves (Eilon et al., 2015). The presence of this slow region has been attributed to thermal and chemical erosion of the lithospheric mantle from adiabatic upwelling of asthenospheric mantle ahead of the west-propagating seafloor spreading tip (Abers et al., 2016; Eilon et al., 2015). Daczko et al. (2011) suggested that the mafic dikes at the range front (the basaltic andesite dikes of this study) may have been produced by partial melting of the rising asthenosphere. We argue that the importance of the rising asthenosphere in producing more primitive melts (Mai'iu Monzonite, Bonua Porphyry and the basaltic andesite dikes) compared to the earlier more crustal-like melts of the slightly older Suckling Granite has increased since the onset of extension along the Mai'iu Fault (see discussion below). Supporting this notion, thermobarometry of olivine (forsterite content $>89 \%$ ) from basaltic andesite lava of the Waiowa Volcanics suggests that these magmas equilibrated prior to their extraction from the mantle at temperatures and pressures of $\sim 1150-1200^{\circ} \mathrm{C}$ and 5.5-7.5 kbar, respectively (Ruprecht et al., 2013).

\section{The age of the syn-extensional granitoids}

Zircons from rocks of the Suckling Granite, Mai'iu Monzonite and Bonua Porphyry show characteristics of magmatic growth. That is, they (1) have $\mathrm{Th} / \mathrm{U}>0.1,(2)$ are mostly prismatic with pyramidal terminations and (3) show (where CL images are available) oscillatory, sector and stripy zoning (Corfu et al., 2003; Lancaster et al., 2017; Rubatto et al., 1998; Williams and Claesson, 1987). The weighted mean ages of $\sim 3.8-2.0$ Ma reported in Table 2.3 are interpreted as the crystallization ages of the various units (Suckling Granite, Mai'iu Monzonite and Bonua Porphyry). The topology of the KDE spectra and rank-order plots of the $\mathrm{Pb}_{c^{-}}$and ${ }^{230} \mathrm{Th}$-corrected ${ }^{206} \mathrm{~Pb} /{ }^{238} \mathrm{U}$ dates in samples of the Mai' iu Monzonite and the Bonua Porphyry (Figures 2.14e and f) suggests that a considerable number of zircons are antecrystic (cf. Miller et al., 2007). It is, however, possible that the bimodality of the KDE spectrum of the Bonua Porphyry sample (Figure 2.14e) is an analytical artefact (low signal to noise ratio of the youngest $\mathrm{U}-\mathrm{Pb}$ analyses). Thus, the crystallization age of the Bonua Porphyry may be closer to the older KDE peak at $3.5 \pm 0.1 \mathrm{Ma}$ (Figure 2.14e).

The weighted mean ages of the three Suckling Granite stream boulders ( $\sim 3.3 \mathrm{Ma}$, Figure $2.14 \mathrm{~d}$ ) are in excellent agreement with a ${ }^{206} \mathrm{~Pb} /{ }^{238} \mathrm{U}$ age of $3.3 \pm 0.1 \mathrm{Ma}$ (Daczko et al., 2011; Caffi, 2008) from a suspect Suckling Granite boulder collected in the Mai'iu River near the range front (Figure 2.3). Conversely, we could not confirm the hornblende K-Ar dates of 10.8-4.4 Ma reported by Davies and Smith (1974) for the Suckling Granite. We suspect their K-Ar dates were affected by excess Ar (McDougall and Harrison, 1999). The $\mathrm{Pb}_{c^{-}}$and ${ }^{230} \mathrm{Th}$-corrected ${ }^{206} \mathrm{~Pb} /{ }^{238} \mathrm{U}$ date of a single euhedral zircon from a basaltic andesite dike (PNG-15-60a) may suggest crystallization at $0.2 \pm 0.1 \mathrm{Ma}$. This is, however, only a first 
attempt to date the undeformed basaltic andesite dikes exposed in the most recently uplifted parts of the mylonitic Goropu Metabasalt (Figure 2.3).

The tectonic significance of the crystallization ages of the granitoids (sensu lato) directly relates to the timing of activity of the Mai'iu Fault. Field relationships demonstrate that the granitoids were cut by the Mai'iu Fault. One sample of Suckling Granite (PNG-1561a) exhibits a progression from magmatic to ductile solid-state deformation (Figures $2.4 \mathrm{e}$ and B.5) suggesting syn-extensional intrusion of this sample at or below the brittle-ductile transition. Because this is the oldest known granitoid, this implies that the younger granitoids are syn-extensional too. The undeformed condition of the other samples is likely a result of their intrusion into an even shallower brittle part of the crust. Based on these arguments, we infer that the Mai'iu Fault was initiated as an extensional structure by $3.8 \pm 0.2 \mathrm{Ma}$.

\section{Intrusion depths of the Suckling Granite and Mai'iu Monzonite}

Intrusion of the syn-extensional Suckling Granite and Mai'iu Monzonite into the shallow brittle crust is consistent with the results from Al-in-amphibole and -biotite thermobarometry (Table 2.4) as well as the reported occurrence of andalusite in the contact aureole of these units (Smith and Davies, 1976). Collectively, these data suggest that the Suckling Granite and the Mai'iu Monzonite may have crystallized in a relatively shallow ( $\sim 2-15 \mathrm{~km}$, assuming a lithostatic gradient of $0.29 \mathrm{kbar} / \mathrm{km}$ ) and oxidized ( $\Delta \mathrm{NNO} \sim 2.4-1.0$ ) environment (cf. Collins et al., 2016; Ridolfi et al., 2010), at temperatures of $\sim 630-690^{\circ} \mathrm{C}$. The relatively low temperatures may be explained by the volatile-rich ( $\sim 2-3 \%$, Table 2.2$)$ compositions of these rocks. The higher pressure estimate of the Mai'iu Monzonite sample PNG-16-2a (4.3 $\pm 0.9 \mathrm{kbar}$ ), on the other hand, indicates that crystallization of amphibole started at slightly greater depth of $\sim 16 \mathrm{~km}$, possibly prior to final emplacement of this dike.

Collected at a similar distance of about $20-25 \mathrm{~km}$ from the modern Mai'iu Fault trace, the lower calculated pressures of the younger Mai'iu Monzonite samples $(\sim 0.4-1.2 \mathrm{kbar}, \sim 2$ Ma; PNG-15-66a, PNG-16-163a) compared to the slightly higher pressures of the older Mai'iu Monzonite sample ( 1.9-2.3 kbar, $3 \mathrm{Ma}$; PNG-16-159b) are an expected outcome of progressive exhumation and sequential intrusion of the syn-extensional granitoids into the footwall of fault. Knowing the age of intrusion (see above) and assuming a dip-slip rate of $11.7 \pm 3.5 \mathrm{~mm} / \mathrm{yr}$ (Webber et al., 2018) and a fault dip of $30^{\circ}$ (present-day dip of the Mai'iu Fault at depth; Little et al., 2019), we can estimate the expected intrusion depths of these samples. This simplistic calculation indicates pressures of -0.3-1.9 kbar or intrusion depths of -1.1-7.4 km for samples PNG-15-66a, PNG-16-159b and PNG-16-163a. Despite the negative sign (implies intrusion above the surface), this calculation yielded pressures that agree broadly with the range of values calculated from Al-in-amphibole and -biotite barometry ( $\sim 0.4-2.3 \mathrm{kbar}$ ) for these samples and that equate to intrusion depths of $\sim 2-8$ 
$\mathrm{km}$. The fact that the calculation of the expected intrusion depths slightly underestimates the barometrically-derived intrusion depths of the Mai'iu Monzonite suggests that either the syn-extensional dip of the Mai'iu Fault was $>30^{\circ}$ and/or that the dip-slip rate was $>11.7$ $\mathrm{km} / \mathrm{myr}$. Applying the same simplistic calculation (see above) to the two outcrop samples of the Suckling Granite (PNG-15-61a, PNG-15-64a) that do not contain amphibole, yielded crystallization pressures of 2.9-3.5 kbar and intrusion depths of $\sim 11-13 \mathrm{~km}$. These pressures are also consistent with the reported occurrence of andalusite in the contact aureole of the Suckling Granite (Smith and Davies, 1976).

\section{Zircon inheritance}

A number of zircon U-Pb analyses in samples of the Suckling Granite, Mai'iu Monzonite and Bonua Porphyry yielded $\mathrm{Pb}_{c^{-}}$and ${ }^{230}$ Th-corrected zircon ${ }^{206} \mathrm{~Pb} /{ }^{238} \mathrm{U}$ dates that greatly pre-date the youngest age subpopulations of the respective samples. These inherited zircons (Figure 2.16a) provide critical information about the subcrustal structure of the SDMCC. Xenocrystic zircon from the syn-extensional intrusions yielded $\mathrm{Pb}_{c^{-}}$and ${ }^{230} \mathrm{Th}$-corrected zircon ${ }^{206} \mathrm{~Pb} /{ }^{238} \mathrm{U}$ dates $(\sim 120-90 \mathrm{Ma})$ that are similar to those from inherited zircons in a 8.1 \pm 0.4 Ma-old microgranodiorite on Misima Island ( 120-100 Ma, Adshead and Appleby, $1996)$ and a $1.98 \pm 0.01$ Ma-old andesitic dike on Normanby Island ( 114-72 Ma, DesOrmeau et al., 2014). Furthermore, the Cretaceous age component recorded in these inherited zircons is comparable to that exhibited by published and unpublished zircon ${ }^{206} \mathrm{~Pb} /{ }^{238} \mathrm{U}$ dates from the Kagi Metamorphics on the Papuan Peninsula near Wau (Kopi et al., 2004), the basement gneisses on the D'Entrecasteaux Islands and the Calvados Schist on the Louisiade Archipelago (DesOrmeau et al., 2014; Zirakparvar et al., 2013) (Figure 2.1). The Cretaceous KDE peaks of each dataset are virtually in phase (Figure 2.16), implying a similar source. The zircon ${ }^{206} \mathrm{~Pb} /{ }^{238} \mathrm{U}$ dates also agree well with the Aptian-Cenomanian fossil record of the Kagi Metamorphics (Davies, 2012; Dow et al., 1974; Glaessner, 1949). Collectively, these constraints indicate a Cretaceous protolith age of the Kagi Metamorphics.

We therefore infer that the xenocrystic zircons in the syn-extensional intrusions of the SDMCC are derived from the Kagi Metamorphics. Although the (mapped) surface exposure of the Kagi Metamorphics narrows significantly east of $148^{\circ} 15^{\prime} \mathrm{E}$ and dies out east of $148^{\circ} 45^{\prime} \mathrm{E}$, the occurrence of Cretaceous zircon xenocrysts in the granitoids of the SDMCC may imply that the Kagi Metamorphics underlie the basaltic carapace of this MCC. This is consistent with studies that mapped a low Bouguer gravity anomaly over Mt. Suckling (Geological Survey of Papua New Guinea and British Geological Survey, 2004; Milsom, 1973). If indeed so, this may link the Kagi Metamorphics of the eastern-central Papuan Peninsula with the basement gneisses on the D'Entrecasteaux Islands and the Calvados Schist on the Louisiade Archipelago (Figure 2.1). This supports the inference made by Davies and Smith (1971) that these Mesozoic sialic schists and gneisses form a single discontinuous belt, the continental 
core of southeastern Papua New Guinea, between approximately $146-154^{\circ}$ E (Figure 2.1).

After Kopi et al. (2004) and Zirakparvar et al. (2013) we infer that the source region of the detrital zircons in the metasedimentary units and the inherited zircon in the syn-extensional intrusions of the SDMCC likely lay on the eastern coast of Australia. The Cretaceous KDE peaks of our dataset and those from the literature (Adshead and Appleby, 1996; DesOrmeau et al., 2014; Kopi et al., 2004; Zirakparvar et al., 2013) are all entirely within the range of the Rb-Sr, K-Ar and zircon U-Pb ages (134-95 Ma, Figure 2.16) reported from the WVP in Queensland, Australia (Bryan et al., 1997, 2012; Ewart et al., 1992; Tulloch et al., 2010). On the D'Entrecasteaux Islands, 4.1-1.8 Ma intrusions of granodioritic composition yielded essentially the same crystallization ages as the syn-extensional granitoids of the SDMCC (Baldwin and Ireland, 1995; DesOrmeau et al., 2014; Gordon et al., 2012). Recent work on the isotopic composition of deformed granodiorites from Fergusson and Normanby Islands (Korchinski et al., 2014) yielded ${ }^{87} \mathrm{Sr}^{86} \mathrm{Sr}_{i}$ signatures that are virtually indistinguishable from those of rocks of the WVP (Ewart et al., 1992), further supporting a petrogenetic link between the rocks of the WVP and southeastern Papua New Guinea.

Although a recent SHRIMP U-Pb study (Bodorkos et al., 2013) concluded that the maximum depositional age of a sample from the Kagi Metamorphics in the Wau area was PermoTriassic, this is not supported by the evidence presented above. The Permo-Triassic zircon $\mathrm{U}-\mathrm{Pb}$ ages resemble those from other basement rocks in the eastern Highlands (Van Wyck and Williams, 2002). These authors concluded that the most likely source for their PermoTriassic zircons is the Coen Inlier in northern Queensland (Blewett et al., 1998). Archean zircons such as those recovered from igneous and metamorphic clasts in Pliocene and younger conglomerates in the Goodenough No.1 well (Figure 2.1) (Baldwin and Ireland, 1995) probably indicate second-order (or higher) recycling.

Inherited zircons or zircon domains (e.g., cores, mantles) of Eocene-Miocene age in the Suckling Granite may suggest that the continental crust underlying the SDMCC has been modified by events that shaped the proto-Papuan Peninsula at these times. Although tentative only, the Eocene-Miocene zircon ages overlap with the established timeframe of activity of the Paleocene-Eocene Cape Vogel Arc, the Peninsular Orogeny and the Maramuni Arc (Figure 2.2). Older inherited zircons ( $197-1752 \mathrm{Ma}$ ) may indicate recycling of JurassicPaleoproterozoic material.

\subsection{Conclusions}

Two weighted mean zircon $\mathrm{U}-\mathrm{Pb}$ ages of $103 \pm 5.7 \mathrm{Ma}$ and $71.6 \pm 3.3 \mathrm{Ma}$ support the previously suggested Late Cretaceous age of the metasedimentary intercalations in the Goropu 
Metabasalt. Collectively, the zircon U-Pb ages and the biostratigraphic constraints indicate that the slightly enriched MORB protolith of the Goropu Metabasalt may have formed between approximately 103 to $66 \mathrm{Ma}$.

Chondrite-normalized REE patterns and discriminant diagrams $(\mathrm{Nb} / \mathrm{Yb}$ vs. $\mathrm{Th} / \mathrm{Yb})$ of the Goropu Metabasalt and the gabbroic-tonalitic rocks of the Yau Igneous Complex may define a lineage between N-MORB and E-MORB. Weighted mean zircon U-Pb ages from quartzgabbros and tonalites of the Yau Igneous Complex suggest crystallization and intrusion of this unit between $\sim 60.4$ and $\sim 56.6 \mathrm{Ma}$. These zircon $\mathrm{U}-\mathrm{Pb}$ ages provide minimum ages for the oceanic protolith of the Goropu Metabasalt.

The calc-alkaline Suckling Granite likely formed by partial melting of continental crust underlying the Goropu Metabasalt carapace of the SDMCC. The petrogenesis of the high-K Mai'iu Monzonite, Bonua Porphyry and the basaltic andesite dikes is less certain but may involve melting of previously modified mantle, triggered by upwelling of asthenospheric mantle.

Zircon U-Pb dating suggests that the Suckling Granite, Mai'iu Monzonite and Bonua Porphyry intruded the footwall of the SDMCC syn-extensionally between $\sim 3.8-2.0 \mathrm{Ma}$. The age of the oldest syn-extensional granitoid implies that the Mai'iu Fault was re-activated as an extensional structure by $3.8 \pm 0.2 \mathrm{Ma}$.

Al-in-amphibole and -biotite thermobarometry suggest crystallization of the Suckling Granite and Mai'iu Monzonite at temperatures of $630-690^{\circ} \mathrm{C}$ in a shallow $(2-8 \mathrm{~km})$, relatively oxidized part of the crust. The barometry-derived intrusion depths are consistent with the reported occurrence of andalusite in the contact aureole, but slightly underestimate the intrusion depths inferred from the crystallization age and the known Holocene dip-slip rate of the Mai'iu Fault, thus suggesting a long-term dip-slip rate of $>12 \mathrm{~km} / \mathrm{myr}$.

${ }^{206} \mathrm{~Pb} /{ }^{238} \mathrm{U}$ dates of xenocrystic zircons in the syn-extensional granitoids have a Cretaceous age component ( $\sim 120-90 \mathrm{Ma})$ that is essentially indistinguishable from detrital zircon U$\mathrm{Pb}$ ages from the Kagi Metamorphics on the Papuan Peninsula, felsic basement gneisses on the D'Entrecasteaux Islands and the Calvados Schist on the Louisiade Archipelago. This supports the notion that the SDMCC is underlain by crustal material akin to that of the Cretaceous Kagi Metamorphics. Zircon U-Pb ages of these rocks are consistent with $\mathrm{Rb}-\mathrm{Sr}$, $\mathrm{K}-\mathrm{Ar}$ and U-Pb ages from the WVP in eastern Australia, suggesting that the latter may be the source of the detrital zircons recovered from the metasedimentary rocks in Papua New Guinea. 


\section{Different chronometers, different ages. Using $\mathrm{U}-\mathrm{Pb}$ and $(\mathrm{U}-\mathrm{Th}[-\mathrm{Sm}]) / \mathrm{He}$ chronometers to un- ravel the eruption age of an air-fall tephra}

\subsection{Abstract}

The dating of volcanic tephra layers forms a critical cornerstone for determining chronostratigraphy. It is paramount for the temporal understanding of the geological timescale, sedimentary basins, evolution of life, and tectonics. In deep-time studies, high-precision U-Pb and ${ }^{40} \mathrm{Ar} /{ }^{39} \mathrm{Ar}$ dating have been the tools of choice, however, there are serious limitations of these techniques in Quaternary geochronology. This study presents integrated apatite, magnetite and zircon (U-Th[-Sm])/He and zircon (U-Th)/(Pb-He) double-dating of a single tephra deposit in the Woodlark Rift of Papua New Guinea and explores the isotopic systematics related to isotopic inheritance and disequilibrium. Zircon ${ }^{206} \mathrm{~Pb} /{ }^{238} \mathrm{U}$ dates range from $\sim 107-1.0 \mathrm{Ma}$, but after statistically excluding the obvious inherited or contaminant detrital zircon grain ages $(\sim 107-4.4 \mathrm{Ma})$, only the four youngest ${ }^{206} \mathrm{~Pb} /{ }^{238} \mathrm{U}$ dates reflect the time of crystallization at $1.1 \pm 0.2 \mathrm{Ma}$. Zircon, apatite and magnetite $(\mathrm{U}-\mathrm{Th}[-\mathrm{Sm}]) / \mathrm{He}$ ages range from $\sim 10.2-0.4 \mathrm{Ma}$. We examined the reasons for the age spread, including inheritance and disequilibrium, highlighting the importance of using multiple chronometers to determine the most accurate eruption age of this Quaternary volcanic tephra layer. Based on disequilibrium-uncorrected $\mathrm{AHe}$ and $\mathrm{ZHe}$ ages that post-date the zircon $\mathrm{U}-\mathrm{Pb}$ crystallization age, the preferred eruption age for the Woodlark Rift tephra is $0.6 \pm 0.4 \mathrm{Ma}(2 \sigma)$.

\subsection{Introduction}

Tephras are important time markers in the geologic record that have been utilized to constrain changes in plate motions, the age of geomagnetic polarity reversals and calibration of the geological time scale, orbital tuning, hominid evolution, and basin stratigraphy (Hopkins and Seward, 2019; Jones et al., 2017; Morgan and Renne, 2008; Suganuma et al., 2015; Svensen et al., 2015). Dating of volcanic tuffs is routinely done using $\mathrm{U}-\mathrm{Pb}$ and ${ }^{40} \mathrm{Ar} /{ }^{39} \mathrm{Ar}$ methodologies (Lackschewitz et al., 2001; Matthews et al., 2015; Wotzlaw et al., 2014). In deep-time studies, $\mathrm{U}-\mathrm{Pb}$ and ${ }^{40} \mathrm{Ar} /{ }^{39} \mathrm{Ar}$ tephrochronology provides unparalleled precision 
(Min et al., 2001; Svensen et al., 2015). These techniques have, however, limitations in Quaternary geochronology. Major issues pertaining to the U-Pb system are inheritance of pre-existing mineral phases and protracted crystallization histories (Ito et al., 2017a; Sano et al., 2002). The ${ }^{40} \mathrm{Ar} /{ }^{39} \mathrm{Ar}$ system, on the other hand, is susceptible to alteration and/or excess $\operatorname{Ar}$ (McDougall and Harrison, 1999).

A method with increasing popularity in tephra studies is (U-Th[-Sm])/He (e.g., Coble et al., 2017). These studies typically target zircon for the dating of volcanic eruptions (Danišík et al., 2017; Mucek et al., 2017; Sisson et al., 2019) but apatite (Davidson et al., 2004; Farley et al., 2002) and more exotic (U-Th[-Sm])/He chronometers such as magnetite (Blackburn et al., 2007) have also been employed for this task. Due to the rapid accumulation of radiogenic ${ }^{4} \mathrm{He}$ mostly from actinide decay and low atmospheric He concentrations, the (U-Th[$\mathrm{Sm}]$ )/He method is ideally suited for dating of young volcanic rocks (Farley, 2002). This advantage of the (U-Th[-Sm])/He system has been exploited to date volcanic eruptions even on late prehistoric-historic timescales (Aciego et al., 2003; Schmitt et al., 2010).

There are, however, several potential geological and isotopic pitfalls in (U-Th[-Sm])/He dating that need to be considered. Although its temperature sensitivity $\left(\sim 40-250^{\circ} \mathrm{C}\right.$; Farley, 2002) to upper to mid-crustal processes has made (U-Th[-Sm])/He dating a prime tool in thermochronological studies (House et al., 1998; Stockli et al., 2000), this thermal sensitivity can also be a pitfall when the method is employed as a geochronometer. Thus, the determination of an eruption age of a tephra will only be successful if it can be demonstrated that the volcanic deposit of interest was not subject to post-eruptive burial and reheating to critical temperatures where $\mathrm{He}$ is no longer quantitatively retained in the host crystal (e.g., $>40-80^{\circ} \mathrm{C}$ in apatite; Wolf et al., 1998). Other factors that impact the determination of a tephra age are (1) the incorporation of extraneous material from the volcanic plumbing system or surficial material in which the $(\mathrm{U}-\mathrm{Th}[-\mathrm{Sm}]) / \mathrm{He}$ system was unreset at the time of eruption (Blondes et al., 2007), (2) post-eruptive dissolution and precipitation of the host mineral phase (e.g., apatite; Meier et al., 2018) and (3) reworking of the tephra deposit. In addition, there are several previously identified isotopic reasons that may affect the He budget of the (U-Th[-Sm])/He system such as parent nuclide zonation (Hourigan et al., 2005), U-Th-rich inclusions of refractory phases that do not dissolve during the laboratory digestion procedures of the host phase (Farley, 2002), radiation damage (Shuster et al., 2006), implantation from neighbouring mineral (the 'bad neighbour effect', Gautheron et al., 2012; Spiegel et al., 2009) and grain boundary (Murray et al., 2014) phases, or secular disequilibrium (Farley et al., 2002).

A recently discovered tephra deposit in a conglomeratic sequence in the Woodlark Rift of southeastern Papua New Guinea contains zircon, apatite and magnetite, all three of which can 
generally be dated by $(\mathrm{U}-\mathrm{Th}[-\mathrm{Sm}]) / \mathrm{He}$ methodologies. We analysed zircon by $(\mathrm{U}-\mathrm{Th}) /(\mathrm{Pb}-$ $\mathrm{He})$ double-dating and apatite and magnetite by (U-Th-Sm)/He dating. The results reveal an unexpectedly broad range of ages and highlight the importance of the double-dating approach in recognizing zircon inheritance, and air abrasion techniques to mitigate the effects of implantation of ${ }^{4} \mathrm{He}$ from neighbouring phases.

\subsection{Geological setting}

The Suckling-Dayman metamorphic core complex (Figure 3.1) is an actively exhuming metamorphic core complex (MCC) bounded by an active low-angle normal fault, the Mai'iu Fault, in the Woodlark Rift (Little et al., 2019). Subaerial exposure of this MCC resulted in erosion of the footwall and deposition of syn-tectonic conglomerates in the hanging wall (Smith and Davies, 1976). The Gwoira Conglomerate (Figures 3.1 and 3.2a) rests in a faultbounded slice (rider block) of the former hanging wall of this fault that was transferred to the uplifting footwall of the MCC when a previously active surface strand of the Mai'iu Fault was abandoned in favour of a forward-stepping, more steeply-dipping splay fault, the Gwoira Fault (Webber, 2017). The depositional age of the Gwoira Conglomerate has been inferred to be Pliocene based on lithological correlations with older and more distal units of that age in the region (Smith and Davies, 1976).

A tephra deposit recently identified at the top of the exposed stratigraphic section of the Gwoira Conglomerate (Figures 3.2b and c) provides a first opportunity to constrain the depositional age of these syn-tectonic conglomerates associated with the unroofing of the MCC. The tephra is strongly weathered, cream-colored, poorly consolidated and has a maximum thickness of $\sim 10 \mathrm{~cm}$ (Figure 3.2c). It consists of phenocrysts of quartz, relic plagioclase and $\mathrm{K}$-feldspar, Fe-Ti oxides and lithic fragments in a fine-grained matrix of clay minerals, suggesting an overall intermediate-felsic composition. Glass shards have not been identified but may have undergone complete devitrification.

\subsection{Methods}

Zircon U-Pb LA-ICP-MS depth-profile analyses (Electronic appendix 1) and zircon (ZHe), magnetite $(\mathrm{MgHe})$ and apatite $(\mathrm{AHe})(\mathrm{U}-\mathrm{Th}[-\mathrm{Sm}]) / \mathrm{He}$ analyses (Table 3.1) were performed at the UTChron Laboratories at the University of Texas at Austin following procedures outlined by Blackburn et al. (2007), Cooperdock and Stockli (2016), Hart et al. (2016), Prior et al. (2016) and Wolfe and Stockli (2010). For details of the U-Pb and (U-Th[-Sm])/He 


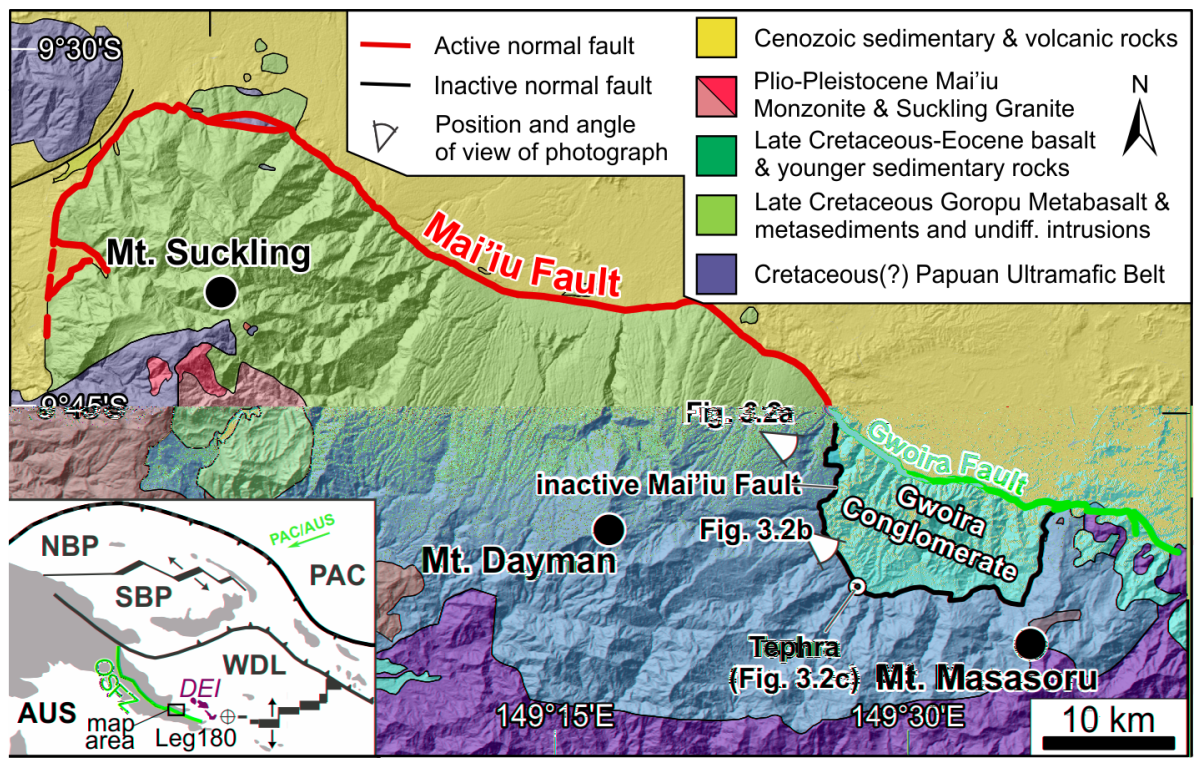

Figure 3.1: Geological setting of the Suckling-Dayman metamorphic core complex (modified from Davies and Smith, 1974). Inset: Contemporaneous tectonic map of Papua New Guinea modified from Wallace et al. (2004). Abbreviations: AUS - Australian Plate, DEI D'Entrecasteaux Islands, NBP - North Bismarck Plate, OSFZ - Owen Stanley Fault Zone, PAC - Pacific Plate, SBP - South Bismarck Plate, WDL - Woodlark Plate (including Trobriand Block). Red arrow (PAC/AUS) refers to contemporary velocity of the Pacific Plate relative to the Australian Plate $(10-11 \mathrm{~cm} / \mathrm{yr})$. Rhyolitic tephras were encountered in ODP Leg1 80 drill holes (Lackschewitz et al., 2003) and in outcrop on the D'Entrecasteaux Islands on either sides of the Moresby and Dawson Straits (Davies, 1973; Smith, 1973). See Figure 3.2 for field photographs. 


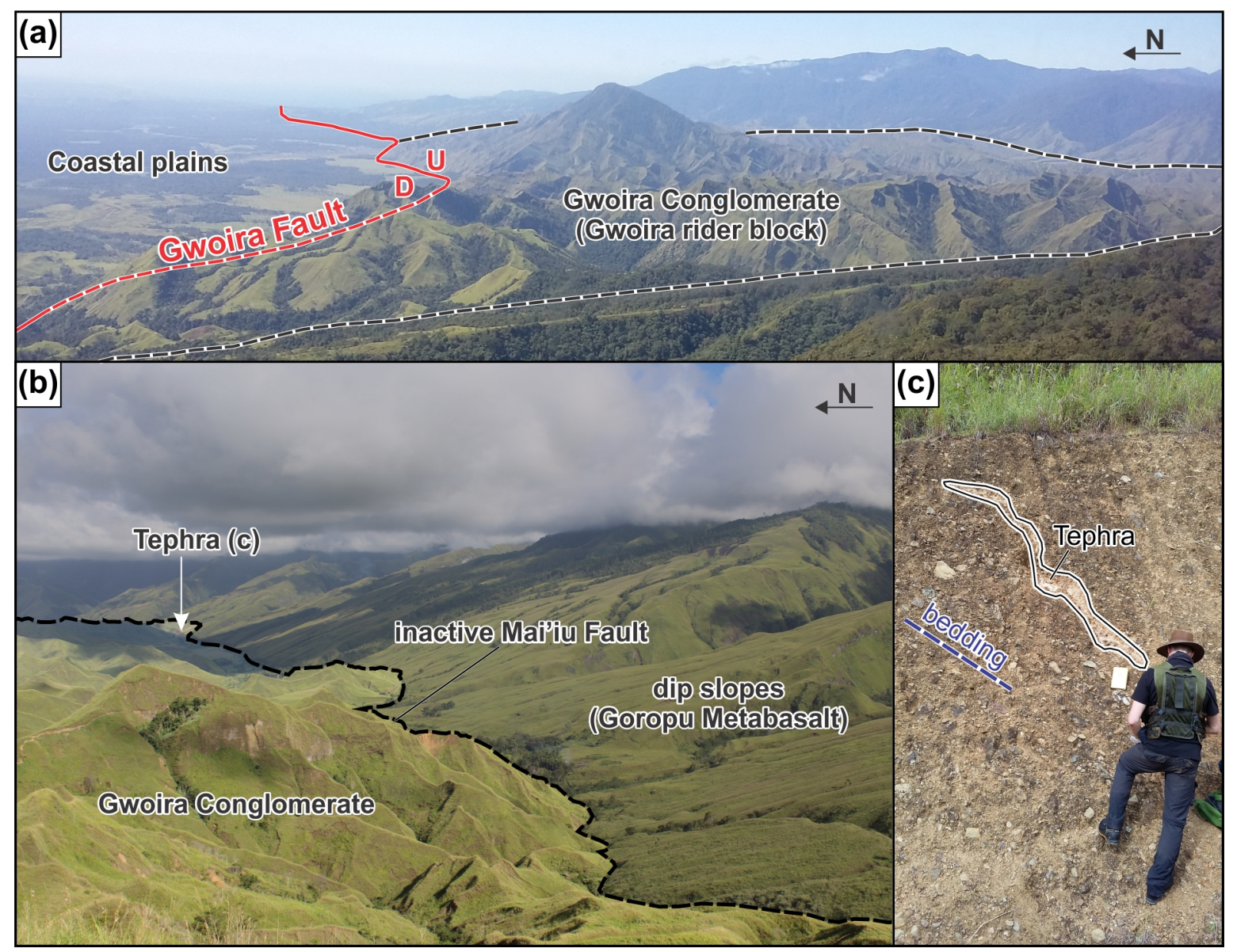

Figure 3.2: Photographs of the study area. (a) The Gwoira rider block. The break in slope at the range front marks the trace of the active Gwoira Fault that was initiated in response to the abandonment of a now inactive segment of the Mai'iu Fault (black stippled line), and raised the Gwoira Conglomerate above the coastal plains. (b) The tephra crops out high in the stratigraphic section of the Gwoira Conglomerate where the latter drapes over dip slopes of the underlying Goropu Metabasalt (shaded area). (c) The poorly consolidated tephra (cream-colored) varies laterally in thickness $(\leq 10 \mathrm{~cm})$ and appears to undulate subparallel to the poor bedding (stippled blue line). Photo credits: Marcel Mizera and Sam Webber. 
methodologies, the reader is referred to Appendices A.2 and A.6, respectively. Using conventional techniques of magnetic and density separation, apatite, zircon and magnetite were retrieved from the sample. Time-resolved analyses performed by depth profiling were divided into rims (youngest part of ${ }^{206} \mathrm{~Pb} /{ }^{238} \mathrm{U}$ signal) and cores (oldest part of ${ }^{206} \mathrm{~Pb} /{ }^{238} \mathrm{U}$ signal). Some crystals had intermediate ${ }^{206} \mathrm{~Pb} /{ }^{238} \mathrm{U}$ age domains that are here referred to as mantles. Cores determined by depth profiling may, however, not represent the oldest ${ }^{206} \mathrm{~Pb} /{ }^{238} \mathrm{U}$ age domain in a zircon grain due to the maximum penetration depth of the laser of $\sim 15$ $\mu \mathrm{m}$. Reported single-grain ${ }^{206} \mathrm{~Pb} /{ }^{238} \mathrm{U}$ dates $( \pm 2 \mathrm{SE})$ were corrected for ${ }^{230} \mathrm{Th}$ disequilibrium (Schärer, 1984) assuming Th/ $\mathrm{U}_{\text {magma }}=5$ (see Supplementary material B.2). Weighted mean ages were calculated using MS Excel add-in Isoplot (Ludwig, 2009). Selected zircon and apatite crystals were screened for inclusions, clarity, morphology and size. Each crystal was photographed and morphometrically measured for subsequent alpha-ejection $\left(\mathrm{F}_{T}\right)$ correction. Magnetite crystals were screened for inclusions and matrix material using $\mu$-CT. Selected magnetite crystals were then air-abraded to remove the outermost portion susceptible to He implantation. No $\mathrm{F}_{T}$ correction was applied to magnetite. Concentrations of ${ }^{4} \mathrm{He}$, $\mathrm{U}, \mathrm{Th}$, and $\mathrm{Sm}$ in apatite, zircon and magnetite were measured using a quadrupole mass spectrometer (for ${ }^{4} \mathrm{He}$ ) and inductively couple plasma mass spectrometer (for $\mathrm{U}$, Th, and $\mathrm{Sm}$ ). Multi-grain AHe and ZHe ages are presented as geometric mean ages $\pm 2 \sigma$. Because of the potential effects of ${ }^{230} \mathrm{Th}$ disequilibrium in young zircons ( $<\sim 1 \mathrm{Ma}$; Farley et al., 2002), the $\mathrm{ZHe}$ ages were corrected for this using McHeCalc software (Schmitt et al., 2010) (see Supplementary material B.2). Apatite tends to accommodate $U$ and Th with little fractionation (Farley et al., 2002), hence no disequilibrium correction was applied.

\subsection{Results}

Fourteen zircon crystals were retrieved from the tephra. Most show some degree of rounding (Figure 3.3a), and most have thin $(\sim 1-3 \mu \mathrm{m})$ rims enclosing older cores (Electronic appendix 1). Average $\mathrm{U}$ and Th contents are $\sim 360$ and $\sim 210 \mathrm{ppm}$, respectively, and $\mathrm{Th} / \mathrm{U}$ ranges from $<0.1$ to $\sim 1.7$ (Electronic appendix 1). In grains with multiple $\mathrm{U}-\mathrm{Pb}$ age domains (i.e., rims and cores), intra-grain $U$ and $\mathrm{Th}$ differences are less than an order of magnitude. ${ }^{230} \mathrm{Th}$ corrected ${ }^{206} \mathrm{~Pb} /{ }^{238} \mathrm{U}$ dates of these grains range from $1.0 \pm 0.1$ to $107 \pm 3 \mathrm{Ma}$ (Figure 3.4). Rim, mantle, and core ${ }^{206} \mathrm{~Pb} /{ }^{238} \mathrm{U}$ dates range from $\sim 1.6-11.6 \mathrm{Ma}, \sim 42-93 \mathrm{Ma}$, and $\sim 71-107$ $\mathrm{Ma}$, respectively (Figure 3.4). Single ${ }^{206} \mathrm{~Pb} /{ }^{238} \mathrm{U}$-age domain analyses range from $\sim 1.0-6.1$ Ma (Figure 3.4). The four youngest zircon ${ }^{206} \mathrm{~Pb} /{ }^{238} \mathrm{U}$ dates (three single-age domain and one rim $\mathrm{U}-\mathrm{Pb}$ analyses) range from $1.0 \pm 0.1$ to $1.6 \pm 0.8 \mathrm{Ma}$, yielding a weighted mean age of $1.1 \pm 0.2 \mathrm{Ma}$ (Figure 3.4; MSWD = 3.1). The older ${ }^{206} \mathrm{~Pb} /{ }^{238} \mathrm{U}$ dates $(\geq 4.4 \pm 0.7 \mathrm{Ma})$ lie beyond the $3 \sigma$ limit of the mean age of the youngest subpopulation (Figure 3.4) and were not considered for the weighted mean age calculation. 

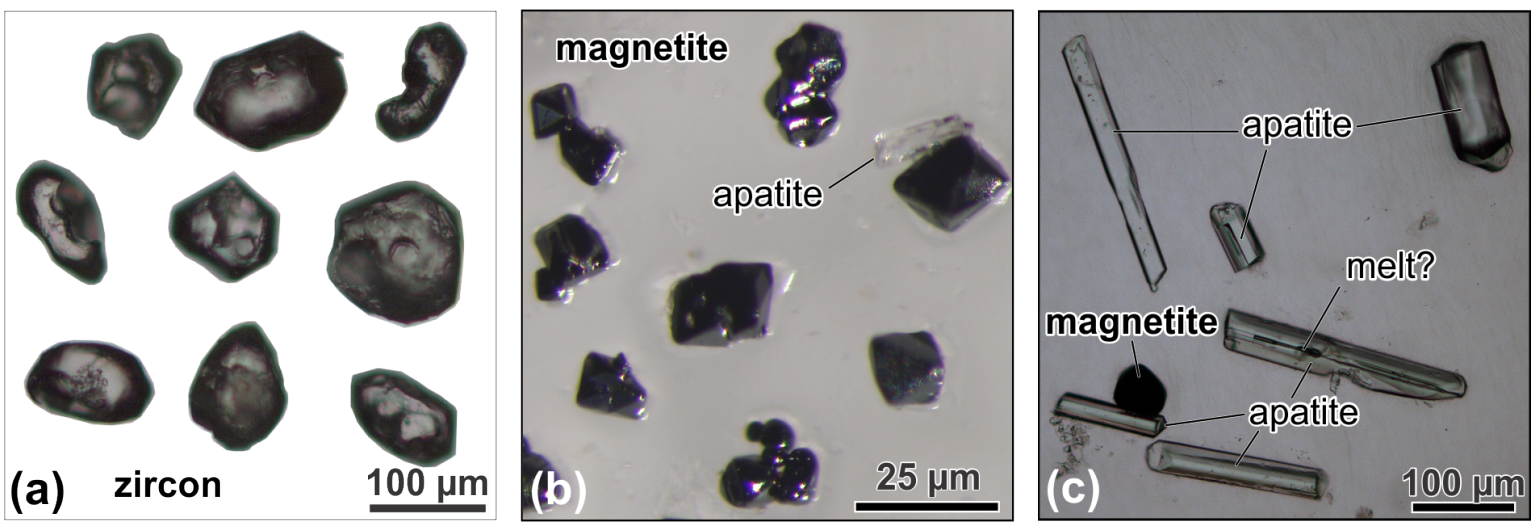

Figure 3.3: Photo-micrographs of zircon, magnetite and apatite crystals recovered from the tephra. (a) Most zircon grains are rounded or broken. Some grain surfaces seem to be etched. Note, holes in the zircon grains are ablation pits (30 $\mu \mathrm{m}$ across). (b) Pristine euhedral magnetite (often twinned or intergrown) crystals showing preserved metallic luster. (c) Euhedral and corroded apatite crystals. Some apatite crystals contain infilled (melt?) tube-like cavities parallel to the c-axis.

(U-Th)/He dating of seven zircon crystals that were also dated by U-Pb LA-ICP-MS yielded ZHe ages between $0.5 \pm 0.0$ and $1.0 \pm 0.1 \mathrm{Ma}$ (Table 3.1, Figure 3.5), identical to those corrected for ${ }^{230} \mathrm{Th}$ disequilibrium $(0.5 \pm 0.0$ to $1.0 \pm 0.1 \mathrm{Ma}$, Table B.2). Two older disequilibrium-uncorrected ZHe ages are 1.6 \pm 0.1 and $1.7 \pm 0.1$ (Table 3.1, Figure 3.5). $\mathrm{U}, \mathrm{Th}, \mathrm{Th} / \mathrm{U}$, effective $\mathrm{U}(\mathrm{eU})$ and effective spherical radius (ESR) range between 49-193 ppm, 13-83 ppm, 0.22-0.96, 56-212 ppm and 33-72 $\mu \mathrm{m}$, respectively (Table 3.1). No obvious correlations of $\mathrm{ZHe}$ age with eU, ESR and Th/U were observed (Table 3.1). However, a general trend is that older $\mathrm{ZHe}$ ages correspond to older zircon ${ }^{206} \mathrm{~Pb} /{ }^{238} \mathrm{U}$ dates (Figure 3.6). The two oldest ZHe ages $(\sim 1.6$ and $\sim 1.7 \mathrm{Ma})$ pre-date the zircon $\mathrm{U}-\mathrm{Pb}$ weighted mean age (Figure 3.5) and are rejected from the calculation of the mean $\mathrm{ZHe}$ age. The geometric mean of the seven remaining disequilibrium-uncorrected $\mathrm{ZHe}$ ages is $0.7 \pm 0.4 \mathrm{Ma}(2 \sigma)$ (Figure $3.5)$.

Euhedral magnetite is generally $<200 \mu \mathrm{m}$ in size, has a well-preserved metallic lustre and is commonly twinned (Figure 3.3b). In this tephra, the magnetite is often found clumped together with apatite (Figure 3.7). Three multi-grain aliquots of magnetite yielded disequilibriumuncorrected $\mathrm{MgHe}$ ages ranging from $2.0 \pm 0.8$ to 10.2 $\pm 0.9 \mathrm{Ma}$ (Table 3.1, Figure 3.5), all pre-dating the weighted mean zircon $\mathrm{U}-\mathrm{Pb}$ age. $\mathrm{U}, \mathrm{Th}, \mathrm{Th} / \mathrm{U}$, eU and average ESR range between 0.06-0.11 ppm, 0.24-0.48 ppm, 3.19-4.78, 0.13-0.25 ppm, and 55-91 $\mu \mathrm{m}$, respectively (Table 3.1). Generally, no correlation of MgHe with eU or ESR is apparent, but a positive correlation with $\mathrm{Th} / \mathrm{U}$ may exist. 


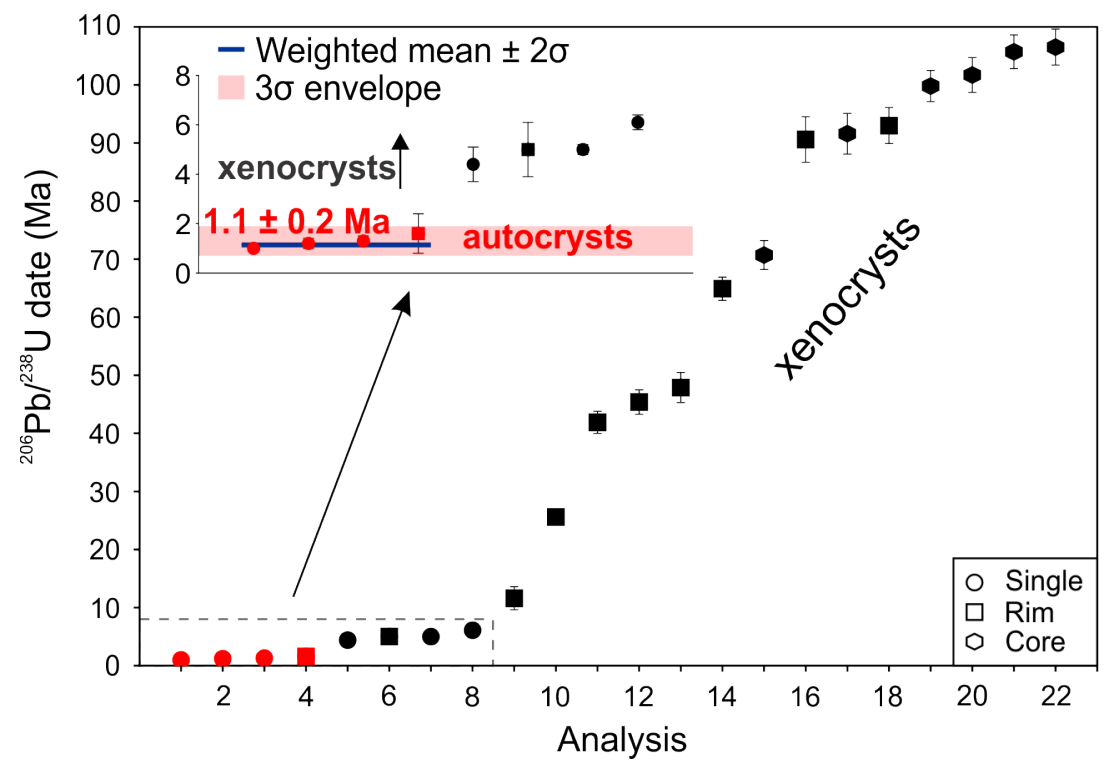

Figure 3.4: Rank-order plot of zircon ${ }^{206} \mathrm{~Pb} /{ }^{238} \mathrm{U}$ dates. Where the error bars are missing, they are concealed by the size of the symbols. The blue solid line and red semi-transparent box in the close-up (0-8 Ma) represent the weighted mean age and the $3 \sigma$ error envelope of the mean, respectively, of the four youngest ${ }^{230} \mathrm{Th}$-corrected ${ }^{206} \mathrm{~Pb} /{ }^{238} \mathrm{U}$ dates. The distinction between inferred auto- and xenocrystic zircon is based on the ${ }^{206} \mathrm{~Pb} /{ }^{238} \mathrm{U}$ dates. The youngest inferred xenocryst $(4.4 \pm 0.7 \mathrm{Ma})$ does not overlap with the inferred autocrystic age subpopulation at the $3 \sigma$ level. For this plot, the individual age domains (e.g., core and rim) of each crystal are shown (see Electronic appendix 1).

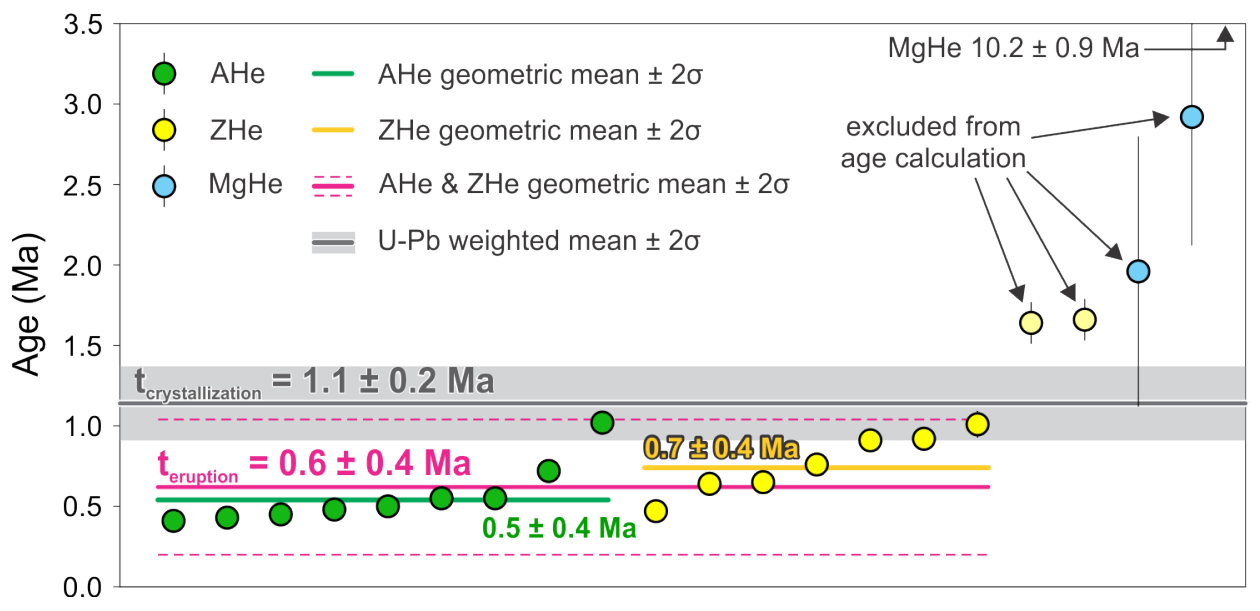

Figure 3.5: Compilation of $\mathrm{AHe}, \mathrm{ZHe}$ and $\mathrm{MgHe}$ ages of the tephra deposit. The grey solid line and grey rectangle refer to the weighted mean zircon U-Pb age (interpreted as crystallization age) and $2 \sigma$ error envelope, respectively. The green and orange bars refer to the geometric mean ages of the AHe and ZHe chronometers, respectively. The solid and dashed magenta lines represent the geometric mean age (inferred eruption age) of all 'plausible' (U-Th[-Sm])/He ages and the $2 \sigma$ error envelope, respectively. 
Table 3.1: (U-Th[-Sm])/He ages from apatite, zircon and magnetite.

\begin{tabular}{|c|c|c|c|c|c|c|c|c|c|c|c|c|}
\hline Aliquot & $\begin{array}{l}\text { Age } \\
{[\mathrm{Ma}]}\end{array}$ & $\begin{array}{l} \pm 2 \sigma \\
{[\mathrm{Ma}]}\end{array}$ & $\begin{array}{c}\mathrm{U} \\
{[\mathrm{ppm}]}\end{array}$ & $\begin{array}{c}\text { Th } \\
{[\mathrm{ppm}]}\end{array}$ & $\begin{array}{c}\mathrm{Sm} \\
{[\mathrm{ppm}]}\end{array}$ & $\begin{array}{c}\mathrm{eU} \\
{[\mathrm{ppm}]}\end{array}$ & $\mathrm{Th} / \mathrm{U}$ & $\begin{array}{c}\mathrm{He} \\
{[\mathrm{nmol} / \mathrm{g}]}\end{array}$ & $\begin{array}{l}\text { mass } \\
{[\mu \mathrm{g}]}\end{array}$ & $\mathrm{F}_{T}$ & ESR & \# of grains \\
\hline \multicolumn{13}{|l|}{ Apatite: } \\
\hline PNG-16-1030a-1 & 0.72 & 0.06 & 2.2 & 8.0 & 157.6 & 4.9 & 3.60 & 0.010 & 3.00 & 0.61 & 39 & \\
\hline PNG-16-1030a-2 & 0.48 & 0.04 & 2.3 & 7.0 & 193.1 & 4.8 & 3.08 & 0.010 & 5.40 & 0.72 & 57 & \\
\hline PNG-16-1030a-3 & 0.55 & 0.04 & 3.6 & 10.8 & 234.0 & 7.3 & 3.00 & 0.010 & 3.00 & 0.60 & 38 & \\
\hline PNG-16-1030a-4 & 0.41 & 0.03 & 2.4 & 6.0 & 171.3 & 4.7 & 2.49 & 0.010 & 3.80 & 0.66 & 45 & \\
\hline PNG-16-1030a-5 & 0.55 & 0.04 & 1.3 & 4.2 & 114.2 & 2.8 & 3.36 & 0.010 & 5.70 & 0.72 & 56 & \\
\hline PNG-16-1030a-7-DS & 0.45 & 0.03 & 1.2 & 4.2 & 117.0 & 2.8 & 3.47 & 0.006 & 15.86 & 0.78 & 75 & \\
\hline PNG-16-1030a-8-DS & 1.02 & 0.06 & 6.4 & 20.0 & 394.7 & 12.9 & 3.15 & 0.038 & 0.74 & 0.48 & 28 & \\
\hline PNG-16-1030a-9-DS & 0.43 & 0.03 & 1.1 & 4.0 & 112.5 & 2.6 & 3.53 & 0.005 & 8.09 & 0.73 & 58 & \\
\hline PNG-16-1030a-10-DS & 0.50 & 0.03 & 4.4 & 13.7 & 351.2 & 9.3 & 3.10 & 0.018 & 2.21 & 0.65 & 43 & \\
\hline \multicolumn{13}{|l|}{ Zircon: } \\
\hline zPNG-16-1030a-1 & 0.76 & 0.06 & 49 & 33 & 0.0 & 56 & 0.68 & 0.20 & 1.55 & 0.65 & 33 & \\
\hline zPNG-16-1030a-2 & 1.01 & 0.08 & 158 & 53 & 1.7 & 171 & 0.33 & 0.70 & 5.39 & 0.77 & 50 & \\
\hline zPNG-16-1030a-3-DS & 0.92 & 0.07 & 145 & 71 & 3.6 & 162 & 0.49 & 0.58 & 2.62 & 0.72 & 41 & \\
\hline zPNG-16-1030a-4-DS & 1.66 & 0.13 & 152 & 63 & 0.0 & 167 & 0.42 & 1.07 & 2.68 & 0.72 & 41 & \\
\hline zPNG-16-1030a-6 & 0.47 & 0.04 & 167 & 64 & 33.4 & 182 & 0.38 & 0.40 & 14.12 & 0.84 & 72 & \\
\hline zPNG-16-1030a-7 & 1.64 & 0.13 & 193 & 83 & 4.9 & 212 & 0.43 & 1.40 & 3.84 & 0.73 & 42 & \\
\hline zPNG-16-1030a-10-DS & 0.65 & 0.05 & 53 & 23 & 0.0 & 58 & 0.44 & 0.15 & 3.16 & 0.73 & 43 & \\
\hline zPNG-16-1030a-11-DS & 0.91 & 0.07 & 62 & 13 & 0.0 & 65 & 0.22 & 0.25 & 4.90 & 0.77 & 50 & \\
\hline zPNG-16-1030a-16 & 0.64 & 0.05 & 55 & 53 & 4.8 & 67 & 0.96 & 0.20 & 3.90 & 0.74 & 45 & \\
\hline \multicolumn{13}{|l|}{ Magnetite: } \\
\hline mgPNG-16-1030a-6 & $\begin{array}{l}10.20 \\
1.96\end{array}$ & 0.85 & 0.06 & $\begin{array}{l}0.40 \\
0.24\end{array}$ & $\begin{array}{l}0.34 \\
2.76\end{array}$ & 0.13 & $\begin{array}{l}4.10 \\
3.19\end{array}$ & $\begin{array}{l}0.02 \\
0.00\end{array}$ & $57^{1}$ & $\begin{array}{l}1.00 \\
1.00\end{array}$ & $66^{2}$ & $\begin{array}{l}15 \\
7\end{array}$ \\
\hline mgPNG-16-1030a-7 & 2.92 & 0.79 & 0.11 & 0.36 & 4.21 & 0.22 & 3.44 & 0.00 & $54^{1}$ & 1.00 & $55^{2}$ & 19 \\
\hline
\end{tabular}

Suffix -DS denotes aliquots analysed by Rudra Chatterjee/Daniel Stockli.

1: Refers to the mass of a multi-grain aliquot, not individual grains.

2: Refers to the average ESR (equivalent spherical radius) of individual grains combined into a single aliquot.

\# of grains: Refers to the number of grains combined into a single aliquot (only applicable to MgHe aliquots). See Figure B.9 for an example. 


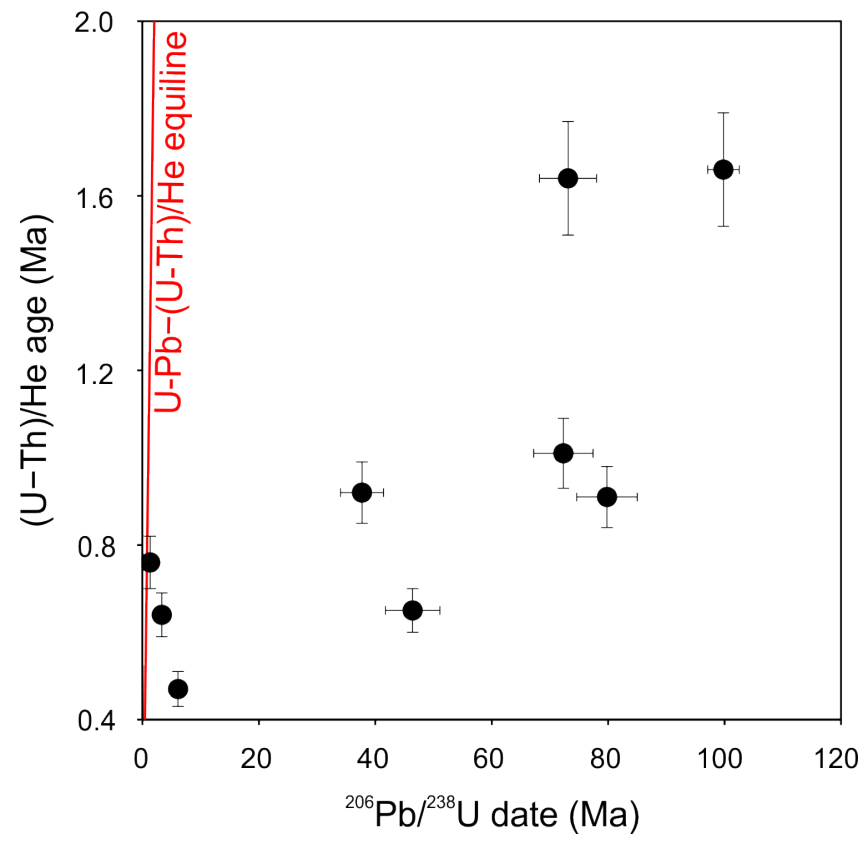

Figure 3.6: Results from zircon $(\mathrm{U}-\mathrm{Th}) /(\mathrm{Pb}-\mathrm{He})$ double-dating. The red line is the $\mathrm{U}-\mathrm{Pb}-(\mathrm{U}-$ $\mathrm{Th}) / \mathrm{He}$ equiline. All analyses lie on or to the right of this line. Where missing, error bars are smaller than the size of the symbol. Note, for this plot the entire signal of the U-Pb analysis (i.e., not separated into age domains of cores and rims) was used (see Electronic appendix $1)$.

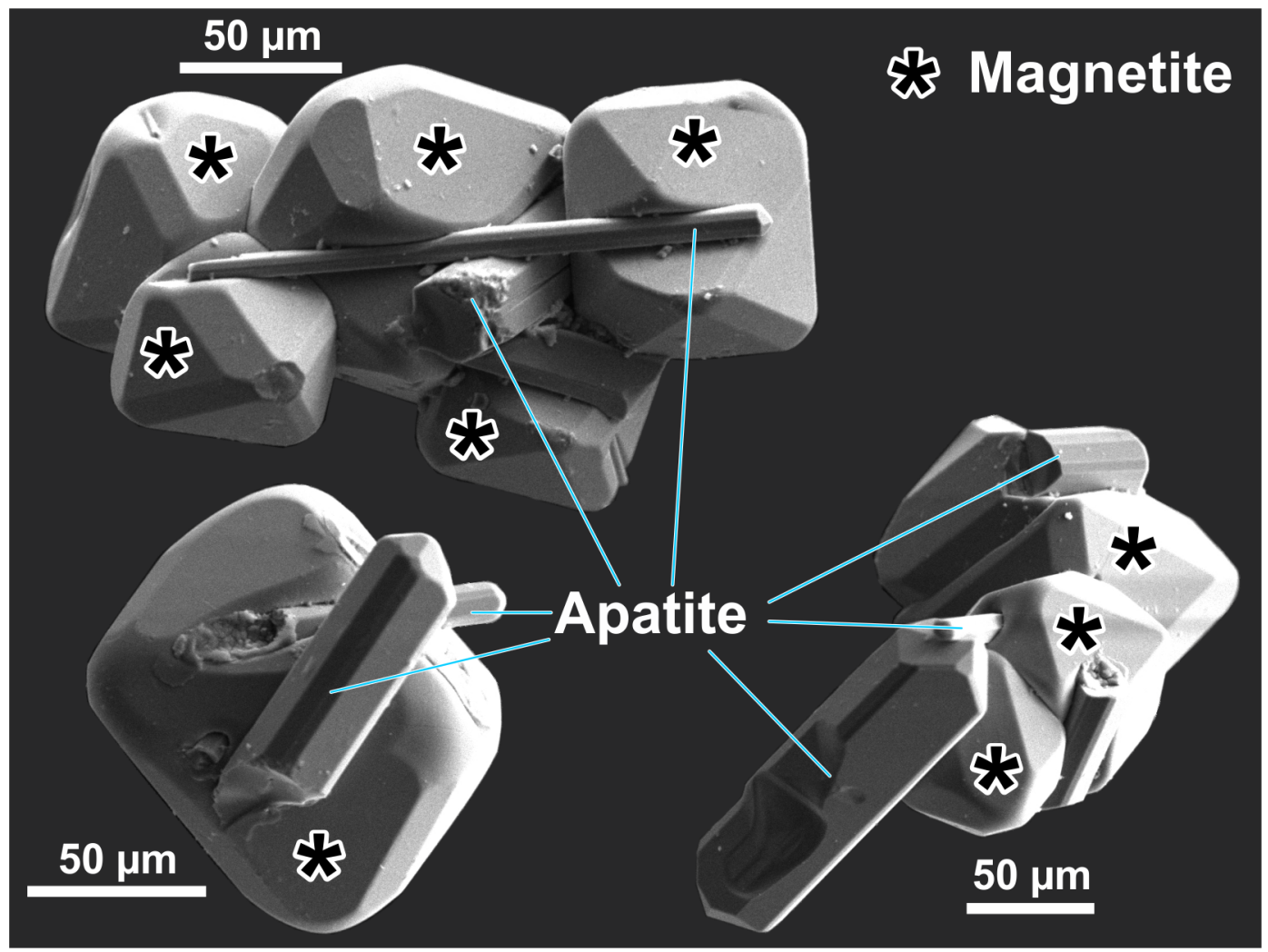

Figure 3.7: Secondary electron images of clustered apatite and magnetite crystals. A comagmatic growth is indicated by the intergrowth of apatite with magnetite and the indentations seen on the surface of magnetite. 
Apatite crystals are euhedral and have high aspect ratios of up to 11:1 (Figures 3.3c and 3.7). Five disequilibrium-uncorrected AHe ages range from $0.4 \pm 0.0$ to $1.0 \pm 0.1$ Ma with a mean of $0.5 \pm 0.4 \mathrm{Ma}$ (Table 3.1, Figure 3.5). U, Th, Th/U, eU and ESR range from 1.1-6.4 ppm, 4.0-20.0 ppm, 2.49-3.60, 2.6-12.9 ppm, and 28-75 $\mu \mathrm{m}$, respectively (Table 3.1). AHe ages do not correlate with eU, ESR or Th/U.

\subsection{Discussion}

\subsubsection{The nature of the zircon, apatite and magnetite grains}

Based on the broad range of ${ }^{230} \mathrm{Th}$-corrected single-grain zircon ${ }^{206} \mathrm{~Pb} /{ }^{238} \mathrm{U}$ dates $(\sim 1-107$ $\mathrm{Ma}$ ) and the mostly rounded morphology, most zircons in the tephra are clearly inherited and pre-date autocrystic zircon growth in the magma (cf. Miller et al., 2007). Only the four youngest zircon $\mathrm{U}-\mathrm{Pb}$ dates with a weighted mean age of $1.1 \pm 0.2 \mathrm{Ma}$ (Figure 3.4) are inferred to date zircon crystallization related to the magma that later erupted. In contrast, the euhedral morphology of apatites and magnetites and their common occurrence in clusters suggest that they grew together in the magma. Trace elements in the apatites (Figure B.10, Electronic appendix 4) show uniform abundances and chondrite-normalized rare earth element patterns, thus supporting the inference of a single, autocrystic apatite population. The high aspect ratios of the apatite crystals are indicative of rapid cooling (Gardner, 1972; Webster and Piccoli, 2015). The $\mathrm{Sr}$ content in apatite may be used to infer the $\mathrm{SiO}_{2}$ content of the whole rock (Bruand et al., 2016). This yielded a whole-rock $\mathrm{SiO}_{2}$ content of $\sim 70 \%$ (Figure B.11), implying a rhyolitic composition of this tephra. Post-depositional physical reworking is unlikely, not least because of the pristine, delicate nature of apatite crystals (Figure 3.7) and the preserved metallic lustre of magnetite. The tephra's position at the top of the exposed stratigraphic section of the Gwoira Conglomerate (Figure 3.2) makes subsequent burial to depths where temperatures are sufficiently high to partially or fully reset $(\mathrm{U}-\mathrm{Th}[-\mathrm{Sm}]) / \mathrm{He}$ ages and renewed uplift and erosion very unlikely.

\subsubsection{Spread in the $(\mathrm{U}-\mathrm{Th}[-\mathrm{Sm}]) / \mathrm{He}$ ages}

(U-Th[-Sm])/He dating of apatite, zircon and magnetite reveals a broad spread of AHe, ZHe and $\mathrm{MgHe}$ ages from $\sim 10.2$ to $\sim 0.4 \mathrm{Ma}$ (Figure 3.5). As a first step to resolve this spread, the zircon double-dating approach allows us to discriminate between geologically meaningful (U-Th[-Sm])/He ages and those that are not: because U-Pb dating of zircon determines the time of zircon growth (Möller et al., 2002), the crystallization age (1.1 $\pm 0.2 \mathrm{Ma})$ must pre-date the eruption age, although zircons may grow immediately prior to eruption. Therefore, any $(\mathrm{U}-\mathrm{Th}[-\mathrm{Sm}]) / \mathrm{He}$ ages that pre-date crystallization are disqualified as representing 
a possible eruption age. This applies to the two oldest $\mathrm{ZHe}$ and all $\mathrm{MgHe}$ ages (Figure 3.5).

So what are the reasons for the large spread in $(\mathrm{U}-\mathrm{Th}[-\mathrm{Sm}]) / \mathrm{He}$ ages? No correlation of age (AHe, $\mathrm{MgHe}, \mathrm{ZHe}$ ) with eU or grain size was observed. Due to its much higher $\mathrm{U}$ and Th contents (and therefore ${ }^{4} \mathrm{He}$ ), ${ }^{4} \mathrm{He}$ implantation from neighbouring phases (cf. Gautheron et al., 2012) is unlikely to severely affect the He budget in zircon. Similarly, parentless ${ }^{4} \mathrm{He}$ from high-U mineral inclusions (e.g., monazite) is improbable because such mineral inclusions would readily dissolve during the $\mathrm{HF}: \mathrm{HNO}_{3}$ digestion procedure augmenting $\mathrm{U}$ and Th to the zircon analysis, in part cancelling out the effect of additional ${ }^{4} \mathrm{He}$. Finally, inferring homogeneity in the U-Th distribution in zircon by using $\mathrm{F}_{T}$ (Farley et al., 1996) instead of $\mathrm{F}_{Z A C}$ (that accounts for U-Th zonation; Hourigan et al., 2005) certainly influences the $\mathrm{ZHe}$ ages, but the observed levels of $U$ and Th enrichment are likely insufficient to explain the magnitude of the observed spread in ZHe ages ( $>1$ myr). For reference, Hourigan et al. (2005) computed a maximum inaccuracy of $\sim 30 \%$ for a $\sim 4-\mu$ m-thick rim $20 x$ enriched in $\mathrm{U}$ and Th, compared to the $\sim 2-\mu$ m-thick rims in zircons of the Woodlark Rift tephra with a lower degree of enrichment (core vs. rim; $\mathrm{U} \leq 3 \mathrm{x}$, Th $\leq 10$ ). The overall positive correlation of $\mathrm{ZHe}$ with ${ }^{206} \mathrm{~Pb} /{ }^{238} \mathrm{U}$ dates and the xenocrystic nature of most zircons in this sample suggest incomplete resetting of the ZHe system may be a more appropriate explanation of the spread in $\mathrm{ZHe}$ ages, thus emphasizing the value of the (U-Th)/(Pb-He) double-dating approach. Incomplete resetting has been reported previously from zircon contained within middle-upper crustal xenoliths in basaltic eruptions from Oak Creek and Fish Springs volcanoes in the USA (Blondes et al., 2007). Based on modelling of He diffusion kinetics in zircon, Blondes et al. (2007) showed that zircons contained within a xenolith with a diameter of $5 \mathrm{~cm}$ would lose $<99.99 \% \mathrm{He}$ in $<10 \mathrm{~min}$. Based on their results, we infer that incomplete resetting of single zircon crystals is likely only if the zircons were entrained immediately prior to or during the eruption.

Both apatite and magnetite are inferred to have grown in the source magma and are unlikely to have retained He quantitatively at magmatic temperatures (Farley, 2002). Because of the common occurrence of apatite and magnetite in grain clusters (Figure 3.7) we attribute the scatter in $\mathrm{MgHe}$ ages to He implantation of the former into the latter. Although the magnetite was air-abraded, the removal of the outermost portion equivalent to the stopping distance of $\sim 16 \mu$ m (Blackburn et al., 2007) could generally not be confirmed. This result implies that only internal fragments or grains with fully removed rims are likely to yield correct $\mathrm{MgHe}$ ages and thus highlights the importance of careful air-abrasion treatment (Blackburn et al., 2007). Whether the 'bad neighbour-effect' (Gautheron et al., 2012) can explain all of the scatter observed in the $\mathrm{MgHe}$ ages is, however, not clear. It is possible that undetected highly radiogenic mineral inclusions $(<6 \mu \mathrm{m})$ that are beyond the resolution of the $\mu$-CT and that did not dissolve during the digestion procedure might have played a role. 
Although ${ }^{4} \mathrm{He}$ implantation works both ways, the U-Th concentrations of the apatites are about an order of magnitude higher than those from the magnetites (Table 3.1) rendering the effect of He implantation into apatite unlikely (compared to magnetite). AHe ages show the least (but still considerable) spread in our dataset ( $\sim 600 \mathrm{kyr})$. No mineral inclusions were observed, but the oldest AHe aliquot age has the highest He content and the smallest ESR (Table 3.1), possibly indicating an undetected inclusion.

\subsubsection{The age of eruption and the source of the tephra}

The geometric mean of all arguably-plausible disequilibrium-uncorrected $\mathrm{AHe}$ and $\mathrm{ZHe}$ ages is $0.6 \pm 0.4 \mathrm{Ma}(2 \sigma)$ and is taken to represent the age of eruption of the tephra. Because the disequilibrium-corrected $\mathrm{ZHe}$ ages are essentially identical to the uncorrected ones, and assumptions had to be made regarding this correction, the uncorrected values are preferred. This age provides the first radiometric evidence for the depositional timeframe of the upper exposed section of the Gwoira Conglomerate. Locating a source of the tephra is difficult, but calc-alkaline and transitional per-alkaline rhyolites of Quaternary age ( 1.29-0.03 Ma) are known from the D'Entrecasteaux Islands and from offshore drill cores in the Woodlark Rift (Figure 3.1; Lackschewitz et al., 2003; Catalano, 2012). It is suggested that the D’Entrecasteaux Islands are a likely source region.

\subsection{Conclusions}

Our study shows that (U-Th[-Sm])/He analyses of even young tephras can yield cooling ages that exhibit a large spread. Furthermore, we emphasize the (U-Th)/(Pb-He) double-dating approach and the importance of the air-abrasion techniques outlined in previous studies.

(1) The pristine euhedral nature of apatite, its uniform trace element characteristics and the close spatial association with euhedral magnetite in grain clusters suggest a magmatic origin, possibly with a rhyolitic source composition.

(2) We infer that the four youngest U-Pb analyses date the time of zircon crystallization (1.1 $\pm 0.2 \mathrm{Ma}$ ), and thus delimit a maximum possible eruption age for the tephra.

(3) Zircon, apatite and magnetite (U-Th[-Sm])/He geochronology of the Woodlark Rift tephra reveals a complex age spectrum. The complex spectrum is attributed to complexities through incomplete resetting of the $\mathrm{ZHe}$ system during entrainment of xenocrystic zircon prior to eruption, and possibly the 'bad neighbour effect' for the MgHe system following deposition 
of the tephra.

(4) Our preferred age of eruption is $0.6 \pm 0.4 \mathrm{Ma}$ taking the $\mathrm{AHe}$ and $\mathrm{ZHe}$ ages younger or within error of the crystallization age. This age dates the uppermost preserved part of the Gwoira Conglomerate and constrains the time of abandonment of the now inactive part of the Mai'iu Fault in favour of the Gwoira Fault.

(5) The tephra source region is inferred to be the D'Entrecasteaux Islands. 


\section{The thermo-tectonic evolution of an actively ex- huming metamorphic core complex, the Suckling- Dayman metamorphic core complex in south- eastern Papua New Guinea}

\subsection{Abstract}

The Mai'iu Fault in the Woodlark Rift of southeastern Papua New Guinea is an active, rapidly slipping low-angle normal fault that has exhumed in its footwall a remarkable structural dome: the Suckling-Dayman metamorphic core complex (SDMCC). Its youthful topography suggests recent uplift but the exhumation history of the remote SDMCC has never been studied in detail. Here we provide the first detailed thermochronometric study of this actively exhuming core complex applying zircon U-Pb geochronology, fission-track (FT) and (U-Th$[\mathrm{Sm}]) / \mathrm{He}$ thermochronometry, ${ }^{26} \mathrm{Al} /{ }^{10} \mathrm{Be}$ burial dating, and Raman spectroscopy of carbonaceous material (RSCM) to a selection of samples collected at different distances from the fault trace on transects parallel to the slip direction, and clasts in a syn-tectonic conglomerate and modern stream sediments. In this study we provide evidence that slip on the Mai'iu Fault had initiated by $\sim 4$ Ma based on the crystallization ages of syn-extensional granitoids, the depositional age of syn-tectonic conglomerates and extensional cooling recorded by lowtemperature thermochronometry. Evidence is also presented for a preserved zircon FT (ZFT) partial annealing zone (PAZ) and a zircon (U-Th)/He (ZHe) partial retention zone (PRZ) on the northern flank of Mt. Dayman. East of Mt. Dayman a pre-extensional cooling phase is indicated by $\sim 37-30$ Ma ZFT and ZHe ages of the Yau Igneous Complex. Based on ZHe ages from a transect parallel to the slip direction of the Mai'iu Fault, we calculated a minimum dip-slip rate for the fault of $8.1 \pm 1.3 \mathrm{~km} / \mathrm{myr}$, slightly lower than the $>12 \mathrm{~km} / \mathrm{myr}$ required to exhume syn-extensional granitoids from 2-8 $\mathrm{km}$ depths to their present position on the Mai'iu Fault scarp 20-25 km south of the fault trace. Overall, our constraints on the long-term dip-slip rate of the Mai'iu Fault are consistent with independent millennial constraints from cosmogenic nuclide dating of quartz veins from the lowermost Mai'iu Fault scarp and annual constraints from a regional campaign GPS network, thus providing evidence for cm-per-year slip on the Mai'iu Fault over three different timescales. Integrating paleo-temperature estimates from the bases of the zircon PAZ and PRZ, RSCM, and pub- 
lished metamorphic temperatures from the extensional shear zone mylonites near the fault trace, we constrained a minimum slip-parallel paleo-temperature gradient for the exhumed part of the Mai'iu Fault surface at $9.7 \pm 2.2^{\circ} \mathrm{C} / \mathrm{km}$. For a range of possible regional preextensional geothermal gradients in the Woodlark Rift $\left(10-20^{\circ} \mathrm{C} / \mathrm{km}\right)$, the down-dip paleotemperature gradient is used to estimate the average initial dip of the Mai' iu Fault of $\sim 44^{\circ}$. Presently dipping $20-22^{\circ}$ at the fault trace, this estimate suggests that the footwall of the Mai'iu Fault was back-tilted by $>20^{\circ}$ since it re-activated a former subduction thrust, thus supporting a rolling hinge-style evolution of this continental MCC.

\subsection{Introduction}

Metamorphic core complexes (MCCs) are globally recognized geologic structures that occur in regions of extension in collapsed orogens, intra-continental rifts, back-arc regions and at slow- and ultraslow-spreading mid-ocean-ridge systems (e.g., Coney, 1980; Verdel et al., 2007; Whitney et al., 2013). MCCs are products of normal-fault displacement, typically sufficient to exhume rocks from below the brittle-ductile transition, in which the exhumed footwall commonly adopts an arched or domed geometry (Platt et al., 2015). Continental MCCs typically consist of (1) a core of ductilely-deformed, mid- to lower-crustal metamorphic rocks in the footwall, (2) a gently dipping to subhorizontal detachment fault or low-angle normal fault (LANF) overlain by (3) hanging wall rocks that are either unmetamorphosed or significantly lower metamorphic grade than the footwall core (Platt et al., 2015). Although detachment faults have been studied extensively, the initial configuration and geometric evolution of these faults remain debated. LANFs slip at angles $<30^{\circ}$ and may accumulate tens of kilometres of displacement (Axen, 2004; Lister and Davis, 1989). However, standard Andersonian rock mechanics and the rarity of earthquake focal mechanisms attributable to normal faults of low dips (Collettini and Sibson, 2001; Jackson and White, 1989) seem incompatible with low-angle initiation and slip $\left(<30^{\circ}\right)$. The rolling hinge model is an attempt at reconciling these contrasting views accounting for the observed low-angle geometry of detachment faults at the surface, the rarity of moderate-to-large earthquakes associated with LANFs and the initiation at angles consistent with Andersonian rock mechanics (Axen and Bartley, 1997; Buck, 1988; Wernicke and Axen, 1988). In this model the majority of slip occurs within the seismogenic crust at moderate to high angles while the shallow part of the detachment fault may be abandoned for slipping at low angles (see Platt et al., 2015) and the deeper part of the detachment fault may sole into the middle crust (Cooper et al., 2017).

In oceanic core complexes, the question of the initial dip of detachment faults that are now shallowly dipping near the surface has been resolved in favour of an initially high dip angle (Whitney et al., 2013). There, paleomagnetic studies (Garcés and Gee, 2007; MacLeod 
et al., 2011; Morris et al., 2009) have revealed that footwall rotation on the order of $\sim 40-80^{\circ}$ occurred on a near-ocean-ridge-parallel axis. Although paleomagnetism has been applied to rocks of continental MCCs (e.g., Campbell-Stone et al., 2000; Holm et al., 1993; Livaccari and Geissman, 2001), these studies revealed minor back-tilting $\left(<15^{\circ}\right)$ of the footwall in the direction of slip (and hence do not require an initially steeply dipping fault), or structural complexities that preclude a unique interpretation of the paleomagnetic data (Axen and Bartley, 1997).

Low-temperature thermochronometry is a powerful tool to date the exhumational cooling of footwall rocks that accompany major normal fault slip in the crust during extension and to reconstruct the crustal thermal structure during progressive extension and exhumation (Stockli, 2005). The temperature sensitivity $\left(\sim 300-40^{\circ} \mathrm{C}\right)$ of fission-track and (U-Th[-Sm] $) / \mathrm{He}$ dating makes these low-temperature thermochronometers especially useful for the study of nearsurface to upper-crustal tectonic and erosional processes (Ehlers and Farley, 2003; Stockli, 2005). Low-temperature thermochronometry has been applied as a tool to constrain the original dip of LANFs in continental MCCs and to measure slip rates (e.g., Dokka, 1993; Foster et al., 1993; Holm et al., 1992; Lee, 1995; Pease et al., 1999). Such studies have provided variable evidence for both low and high initial fault dips. In the Basin-and-Range province of the southwestern USA, thermochronometric studies commonly resulted in the estimation of the original fault dips of $<30^{\circ}$ (Wernicke, 1995, and references therein). Such low initial dips are in apparent contradiction with the rolling hinge model. On the other hand, compelling thermochronometric evidence from the northern Snake Range in the Basin-andRange province (Lee, 1995) and the Central Menderes Massif in Turkey (Gessner et al., 2001) suggests patterns of footwall cooling compatible with a rolling hinge evolution of these MCCs.

The majority of thermochronometric studies of continental MCCs have focussed on examples in the Basin-and-Range province in the USA and the Aegean region in Greece. These extensional provinces were active in the Late Cretaceous-Miocene (e.g., Brichau et al., 2008; Carter et al., 2004, 2006; Dokka, 1993; Fitzgerald et al., 2009; Foster and John, 1999; Foster et al., 1991; Howard and Foster, 1996; John and Foster, 1993; McGrew and Snee, 1994; Miller et al., 1999; Pease et al., 1999; Richard et al., 1990; Seward et al., 2009; Thomson et al., 2009; Wells et al., 2000). Because of the long inactivity, erosion and deformation post-dating their initial tectonic exhumation introduces significant uncertainties in the interpretation of thermochronometric data from these ancient sites (Axen and Bartley, 1997; Fayon et al., 2000; Fitzgerald et al., 2009; Gans and Gentry, 2016; Holm et al., 1993).

Relatively few studies have targeted continental MCCs that are active or have recently ceased to be so, and such examples are globally rare (Spencer, 2010). Active examples include core 
complexes and gneiss domes in the central Himalayas (Kapp et al., 2008; McCallister et al., 2013; Murphy et al., 2002), Sulawesi (Advokaat et al., 2017; Hennig et al., 2017; Spencer, 2011), the D'Entrecasteaux Islands of Papua New Guinea (Baldwin et al., 1993; Little et al., 2011; Ollier and Pain, 1981); and the Suckling-Dayman metamorphic core complex (Daczko et al., 2011; Little et al., 2019; Mizera et al., 2019; Webber et al., 2018; Wallace et al., 2014). In active MCC settings, considerably less uncertainty exists with respect to geometry of the detachment faults and the geodynamic context. Additionally, uncertainties related to the overall thermal structure may be greatly reduced compared to ancient settings amid modernday heat flow data.

Largely due to its remoteness, the Suckling-Dayman metamorphic core complex (SDMCC) has received little attention even though it has been argued to represent the clearest and mostconvincing example of an active rolling-hinge style continental MCC on Earth (Spencer, 2010). Constraints on the present-day regional thermal structure of the Woodlark Rift (Goodliffe et al., 2000; Martinez et al., 2001; Taylor and Huchon, 2002; Tjhin, 1976) allow for a reasonable estimate of the regional pre-extensional geothermal gradient. In addition, recent geophysical and geodetic studies (Abers et al., 2016; Eilon et al., 2015; Ferris et al., 2006; Wallace et al., 2014) provide a well-constrained geodynamic framework of the active deformation field.

The focus of this study is to constrain the cooling and exhumation history of the footwall of the SDMCC using various methods of low-temperature thermochronometry. We determined the timing of the onset of extension, quantified the dip-slip rate of the Mai'iu Fault on a million-year timescale, and constrained its initial fault dip. Conceivably, the results will provide a further test of the rolling hinge model and verify the exceedingly high slip-rate of the fault. In addition to the application of low-temperature thermochronometry, we use Raman spectroscopy of carbonaceous material (RSCM) to aid the mapping of paleo-isotherms on the footwall of the SDMCC. Rare for thermochronometric studies on metamorphic core complexes, double-dating by $\mathrm{U}-\mathrm{Pb}$ geochronology was carried out to elucidate the crystallization history of zircons.

\subsection{Tectonic setting}

\subsubsection{The Woodlark Rift}

Most of the southeastern Papua New Guinea region, including the mountainous spine of the Papuan Peninsula and the thinned crust of the Woodlark Rift and Louisiade Archipelago (Figure 4.1), is composed of the Papuan Orogen that resulted from the collision of rifted 
Australian continental margin with the Cape Vogel Arc (CVA) in the Paleogene (Davies and Jaques, 1984; Davies and Smith, 1971; Davies and Warren, 1992; Webb et al., 2014). Following north-directed subduction of the leading oceanic lithosphere, the CVA and its basement, the Papuan Ultramafic Belt (PUB), were thrust southwestward over the now deformed and accreted rifted Australian margin (Davies and Jaques, 1984). This north-dipping megathrust is the Owen Stanley Fault (Figure 4.1, OSF; Davies, 1980). Southwestward obduction of the PUB over the rifted Australian margin crust had started by $58.3 \pm 0.4 \mathrm{Ma}$ as suggested by ${ }^{40} \mathrm{Ar} /{ }^{39} \mathrm{Ar}$ plateau ages of amphibole from its metamorphic sole (Lus et al., 2004). The Paleogene collision zone had become jammed and uplifted during the Peninsular Orogeny in the Late Eocene-Early Oligocene (van Ufford and Cloos, 2005) as evidenced by up to 10 $\mathrm{km}$ of clastic sediment eroded from this orogen being deposited in a foreland basin (the Aure Trough) to the west of the Papuan Orogen (Finlayson et al., 1977; Ott and Mann, 2015). An ${ }^{40} \mathrm{Ar} /{ }^{39} \mathrm{Ar}$ plateau age on metamorphic amphibole of $35.5 \pm 1.6 \mathrm{Ma}$ of oceanic crust (the Emo Metamorphics) caught up in this collision zone between the rifted Australian margin in the south and the PUB in the north has been interpreted to date the metamorphism accompanying this collisional event (Worthing and Crawford, 1996).

The Woodlark Rift in southeastern Papua New Guinea is an up to $\sim 100 \mathrm{~km}$-wide domain in a tectonically complex region typified by rapid rotation of several microplates (Figure 4.1; inset). Together, the microplates accommodate overall oblique convergence of the Australian and Pacific Plates at a rate of $\sim 110 \mathrm{~mm} / \mathrm{yr}$ (Wallace et al., 2004). Between the Australian and Pacific Plates, the continental Woodlark Rift transitions eastward into the oceanic Woodlark Basin at $151.8^{\circ} \mathrm{E}$ (Figure 4.1, Taylor et al., 1999). Extension in southeastern Papua New Guinea is achieved by anticlockwise rotation of the Trobriand Block and the Woodlark Plate (relative to the Australian Plate) about Euler poles located on and south of the Papuan Peninsula to the east (Figure 4.1, inset) (Wallace et al., 2004, 2014), respectively. Extension rates decrease gradually from the Woodlark Basin in the east $(20-40 \mathrm{~mm} / \mathrm{yr})$ to the Woodlark Rift (10-15 mm/yr) in the west (Wallace et al., 2014). In the latter, extension is accommodated by slip on NW to WNW-striking normal faults. These are segmented by NE to NNE-striking right-lateral strike-slip transfer faults. Near the field area for this study, extension is thought to be accommodated almost entirely by slip on a single structure, the Mai'iu Fault (Figure 4.1) (Fitz and Mann, 2013; Little et al., 2007, 2019; Wallace et al., 2014).

The D'Entrecasteaux Islands (Figure 4.1) host the world's youngest known ultra-high pressure (UHP) eclogitic rocks (Baldwin et al., 2008). Estimates for the timing of UHP metamorphism from zircon $\mathrm{U}-\mathrm{Pb}$, garnet Lu-Hf and phengite ${ }^{40} \mathrm{Ar} /{ }^{39} \mathrm{Ar}$ dating range from $\sim 8-5 \mathrm{Ma}$ (Baldwin and Das, 2015; DesOrmeau et al., 2017; Gordon et al., 2012; Monteleone, 2007; Zirakparvar et al., 2011) and 4.3 $\pm 0.4 \mathrm{Ma}$ (zircon $\mathrm{U}-\mathrm{Pb}$ ) for high pressure (HP) eclogitic rocks (Baldwin et al., 2004). Rapid cooling from $<500$ to $\sim 80-40^{\circ} \mathrm{C}$ between $\sim 4.0-0.4 \mathrm{Ma}$ 


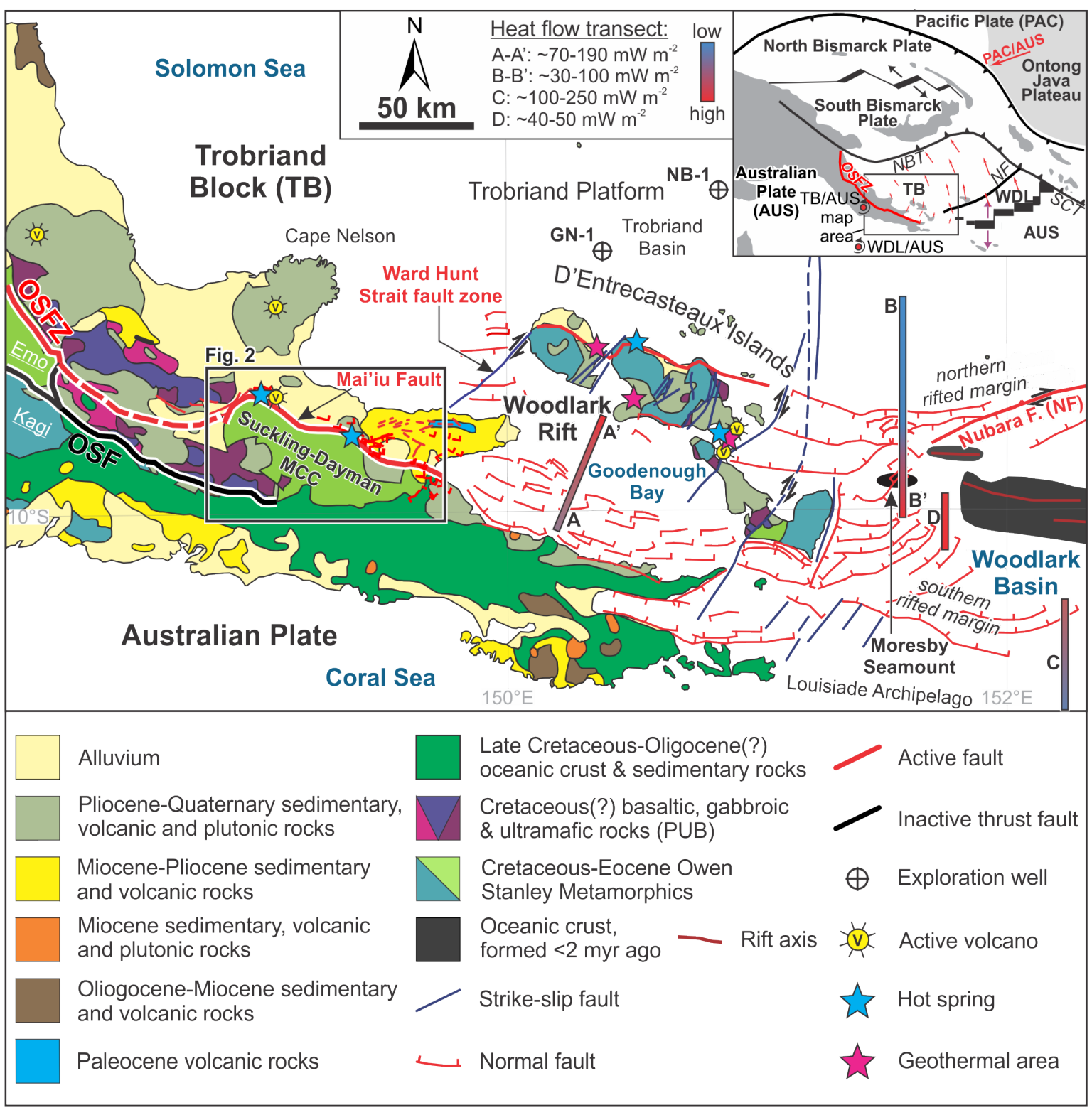

Figure 4.1: Tectonic setting of the Woodlark Rift. Basemap modified from D'Addario et al. (1976) after Little et al. (2019). Location of NB-1 (Nubiam No.1) and GN-1 (Goodenough No.1) wells from Tjhin (1976). Geothermal areas and hot springs are from Davies (1973) and Little et al. (2019). Heat flow transects are based on data from Martinez et al. (2001) and Goodliffe et al. (2000) and are qualitative only (red - high heat flow, purple - intermediate, blue - low heat flow). Abbreviations: Emo - Emo Metamorphics, Kagi - Kagi Metamorphics, OSF - Owen Stanley Fault, OSFZ - Owen Stanley Fault Zone. Inset: Contemporaneous tectonic map of Papua New Guinea with present-day TB/AUS and WDL/AUS poles of rotation derived from the inversion of campaign GPS data (Wallace et al., 2004, 2014). Abbreviations: NBT - New Britain Trench, OSFZ - Owen Stanley Fault Zone, SCT - San Cristobal Trench, TB - Trobriand Block, WDL - Woodlark Plate. Bold red arrow (PAC/AUS) is contemporary velocity of the Pacific Plate relative to the Australian Plate $(10-11 \mathrm{~cm} / \mathrm{yr})$. Bold purple arrows represent Woodlark-Australia spreading in the Woodlark Basin. 
is indicated by ${ }^{40} \mathrm{Ar} /{ }^{39} \mathrm{Ar}$, K-Ar, fission-track and (U-Th)/He thermochronometry on hornblende, biotite, white mica, K-feldspar and apatite of gneissic rocks from the core zone of the gneiss domes and the bounding shear zones (Baldwin et al., 1993; Fitzgerald et al., 2008). Subaerial exposure of the D'Entrecasteaux Islands started by $2.7 \pm 0.3 \mathrm{Ma}$ as evidenced by zircon $\mathrm{U}-\mathrm{Pb}$ ages from eroded gneiss clasts in offshore sediments recovered from an exploration well (GN-1) in the Trobriand Basin (Figure 4.1, Baldwin and Ireland, 1995).

The lithospheric structure of the Woodlark Rift is known from seismic (Abers et al., 2002, 2016; Eilon et al., 2014, 2015; Ferris et al., 2006; Jin et al., 2015; Zelt et al., 2001) and gravity (Geological Survey of Papua New Guinea and British Geological Survey, 2004) studies. These studies demonstrate: (1) continental crust-like seismic Moho depths of 30-40 km beneath the Papuan Peninsula (including the SDMCC) and 42-49 km beneath the Trobriand Platform (i.e., the rift shoulders), but values of only $25-30 \mathrm{~km}$, and locally as shallow as $17 \mathrm{~km}$, beneath the D'Entrecasteaux Islands (Figure 4.1); (2) continuously decreasing seismic Moho depths from 45-55 km below Cape Nelson to $15-20 \mathrm{~km}$ below the active Woodlark spreading centre (Figure 4.1); (3) a seismic velocity structure that is consistent with an intermediate-felsic crustal bulk composition of this continental rift $\left(\mathrm{V}_{p}=5.6-6.9 \mathrm{~km} / \mathrm{s}\right.$ at 10-25 km depth); (4) the SDMCC and the gneiss domes of the D'Entrecasteaux Islands are (partly) characterized by low Bouguer gravity anomalies; and (5) the crustal region between Cape Nelson and the active Woodlark spreading centre (Figure 4.1) is underlain by a $<100$-km-wide corridor of asthenospheric mantle $\left(\Delta \mathrm{V}_{p} / \mathrm{V}_{p} \leq-4 \%\right)$ requiring almost complete removal of the lithospheric mantle along the axis of the Woodlark Rift.

In terms of thermal structure, the Woodlark Rift exhibits heat flow that is relatively low outside of the axial corridor of removed lithospheric mantle. Near-bottom single temperature readings of $\sim 70$ and $\sim 66^{\circ} \mathrm{C}$, respectively, from 2.8 and $2.4 \mathrm{~km}$-deep exploration wells (GN-1 and NB-1) about 140-200 km to the northeast of the SDMCC (Figure 4.1) suggest presentday regional geothermal gradients of only $\sim 20^{\circ} \mathrm{C} / \mathrm{km}$ (Tjhin, 1976) assuming thermal equilibrium of the temperature measurements and a seafloor temperature of $20^{\circ} \mathrm{C}$ at $\sim 30 \mathrm{~m}$ water depth. In Goodenough Bay, some $\sim 120 \mathrm{~km}$ east of the SDMCC (Figure 4.1), topography and sediment-corrected heat flow values average $73 \mathrm{mWm}^{-2}$ (A-A'; Figure 4.1) (Martinez et al., 2001). From this heat flow value, a modern geothermal gradient of $\sim 23^{\circ} \mathrm{C} / \mathrm{km}$ can be modelled assuming a linear geotherm and a lithospheric conductivity of $3.2 \mathrm{~W} \mathrm{~m}^{-1 \circ} \mathrm{C}^{-1}$ (cf. Martinez et al., 2001). In the eastern parts of the Woodlark Rift, heat flow drops to values of $\sim 30$ and $\sim 40-50 \mathrm{mWm}^{-2}$ at the northern and southern rifted margins (B and C; Figure 4.1), respectively (Goodliffe et al., 2000; Taylor and Huchon, 2002). Heat flow is high only proximal to the propagating tip of the Woodlark spreading centre $\left(100-250 \mathrm{mWm}^{-2}\right)$ and adjacent to the nearby gneiss domes (average $190 \mathrm{mWm}^{-2}$ ) of the D'Entrecasteaux Islands (A', B', D; Figure 4.1) (Goodliffe et al., 2000; Martinez et al., 2001). Heat flow highs correlate 
with hot springs and calc-alkaline to transitional peralkaline Quaternary rhyolitic volcanism (Figure 4.1) (Catalano, 2012; Davies, 1973; Smith and Milsom, 1984).

\subsubsection{The Suckling-Dayman metamorphic core complex}

The Suckling-Dayman metamorphic core complex (SDMCC; Figure 4.2) is an E-W-trending structural dome with a maximum strike-parallel width of $\sim 60 \mathrm{~km}$. Its topography is dominated by three mountain peaks (Mts. Suckling, Dayman, and Masasoru) that decrease in elevation eastward from 3.7 to $2.3 \mathrm{~km}$ (Davies and Smith, 1974; Little et al., 2019; Mizera et al., 2019; Spencer, 2010). Coinciding with the eastwardly decrease in summit elevation, the exposed width of the exhumed Mai' iu Fault surface parallel to the slip direction decreases from $\sim 43 \mathrm{~km}$ at Mt. Suckling to $\sim 13 \mathrm{~km}$ at Mt. Masasoru. Structurally, the SDMCC is bounded to the north by the Mai' iu Fault, an active low-angle normal fault, emerging from Holocene river gravels near sea level at a dip of 20-22 (Little et al., 2019; Mizera et al., 2019). Fault kinematic indicators, including slickenlines (Little et al., 2019) and the orientation of large-scale fault plane corrugations (Daczko et al., 2011) indicate a NNE-trending fault slip direction $\left(012 \pm 008^{\circ}\right)$ on the Mai'iu Fault (Figure 4.2). This direction is parallel to present-day extension directions of the Trobriand Block relative to the Australian Plate as constrained by campaign GPS data from a regional network (Wallace et al., 2014). Up-dip of the modern fault trace, the exhumed Mai'iu Fault appears to form a single continuous surface that is expressed by the spectacularly smooth and corrugated topography of the domal footwall of the SDMCC. Smoothest and most planar at the present-day fault scarp, the convex-up arched abandoned Mai'iu Fault becomes more shallowly dipping in the up-dip direction (Mizera et al., 2019), and increasingly dissected by NNE draining streams. The exhumed fault becomes sub-horizontal and forms an $\sim \mathrm{E}-\mathrm{W}$-trending drainage divide near the topographic crest of the dome (Figure 4.2; Little et al., 2019). South of the main divide, erosional remnants of the back-tilted fault surface dip $10-15^{\circ}$ to the south (Mizera et al., 2019). Exhumed Mai'iu Fault surface remnants can be traced over $28 \pm 4$ km (Mizera et al., 2019).

The northward continuation of the Mai'iu Fault at depth appears to coincide with a gently dipping $\left(30-40^{\circ}\right)$ linear corridor of microseismicity at depths between $12-25 \mathrm{~km}$. This corridor projects upwards to the surface trace of the Mai'iu Fault and indicates continuing activity on the fault down-dip (Abers et al., 2016). In the eastern part of the MCC, the otherwise smooth and barren footwall of the SDMCC is overlain by a single rider block of south-tilted former hanging wall rocks (the Gwoira Conglomerate). These infill a scoop-like synformal depression between Mts. Dayman and Masasoru (Figure 4.2). There, a very lowangle segment of the Mai'iu Fault was abandoned in favour of a more steeply dipping (42 \pm $7^{\circ}$ ) hanging wall splay, called the Gwoira Fault (Figure 4.2) (Webber, 2017). North of Mt. Suckling, the Mai'iu Fault appears to be crosscut and offset by several high-angle normal 


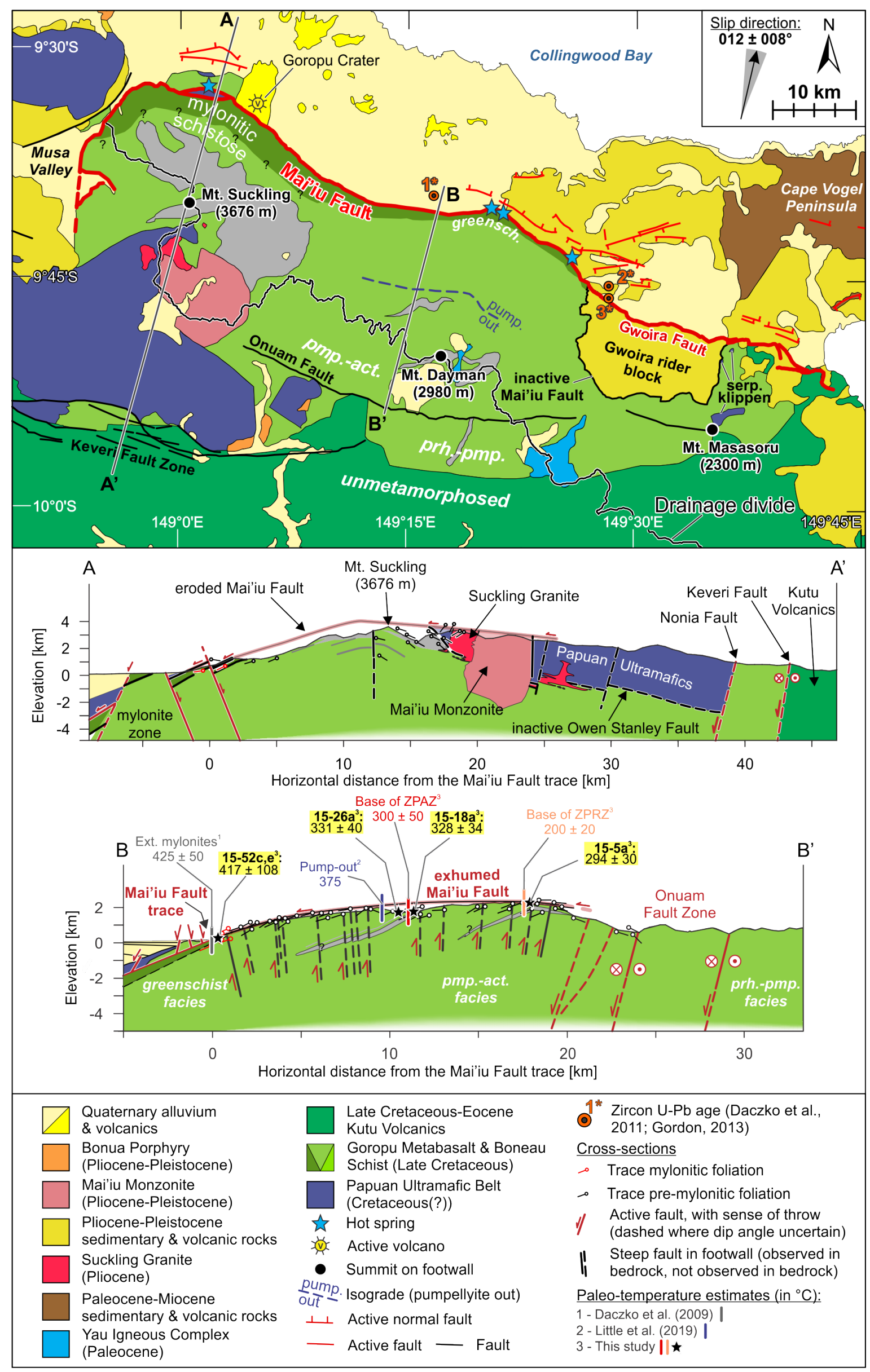


Figure 4.2: Geological map of the Suckling-Dayman metamorphic core complex. Modified from Davies and Smith (1974) and Little et al. (2019). Drainage divide from Mizera et al. (2019). Metamorphic facies after Davies (1980). Abbreviations: greensch. - greenschist facies, pmp.-act. - pumpellyite-actinolite facies, prh.-pmp. - prehnite-pumpellyite facies. Number labels $1 *-3 *$ refer to zircon U-Pb ages reported in Daczko et al. (2011) and Gordon (2013). Number labels in cross-section B-B' refer to paleo-temperature estimates based on published data (Daczko et al., 2009; Little et al., 2019) and data presented in this study.

faults (A-A'; Figure 4.2) and is inferred to be inactive there (Little et al., 2019).

The dominant lithology of the SDMCC, the Goropu Metabasalt, is mylonitic up to 1-2 km south of the Mai'iu Fault trace (Little et al., 2019). Farther south, mylonitic fabrics transition into non-mylonitic schistose ones. The Mai'iu Fault footwall consists of a 3-4-km-thick carapace (inferred thickness of the Kutu Volcanics south of the SDMCC; Davies, 1980) of metamorphosed basalt with MORB affinities (Smith, 2013), the Goropu Metabasalt, that is locally intruded by stocks of gabbroic-tonalitic rocks (Yau Igneous Complex) (Figure 4.2). Locally pillow structures are preserved in the metabasalt. Minor hyaloclastite, pelagic limestone, tuffaceous marl and calcareous-siliceous phyllite (the Bonenau Schist) are intercalated with the Goropu Metabasalt on Mt. Dayman and more abundantly on Mt. Suckling (Figure 4.2) (Smith and Davies, 1976). The age of the Goropu Metabasalt (Late Cretaceous, Maastrichtian) is constrained by planktonic foraminifera in limestone strata interbedded with the metabasalt in the footwall of the SDMCC (Smith and Davies, 1976) and by two detrital zircon U-Pb ages of the pelitic Bonenau Schist hosting these zircons that indicate maximum depositional ages of $\sim 103$ and $\sim 72 \mathrm{Ma}$ (Chapter 2). The Goropu Metabasalt grades southward into unmetamorphosed basalts that appear to be lithologically and compositionally equivalent, the Kutu Volcanics (Smith, 2013; Smith and Davies, 1976). Planktonic foraminifera in fossiliferous strata interbedded with the Kutu Volcanics indicate Late Cretaceous (Maastrichtian) and Eocene ages.

Pseudosection modelling of the mineral assemblages in the mylonitic metabasalt near the range front indicate pressure-temperature (P-T) conditions of 5.9-7.2 kbar and $425 \pm 50^{\circ} \mathrm{C}$, respectively (Daczko et al., 2009). Further south, Little et al. (2019) mapped a pumpellyiteout isograd on the northern flank of Mt. Dayman (Figure 4.2), suggesting that the rocks south of this isograd were subjected to maximum metamorphic temperatures of $\leq 375^{\circ} \mathrm{C}$ prior to their extensional exhumation. Overall, the metamorphic grade decreases southwards from greenschist facies at the present-day fault scarp; to pumpellyite-actinolite facies on the upper northern flank of the dome; to prehnite-pumpellyite facies south of the Onuam Fault (Figure 4.2; Daczko et al., 2009; Davies, 1980). 
The footwall of the SDMCC also exposes two suites of metamorphosed igneous intrusive rocks. Paleocene tholeiitic gabbroic and tonalitic rocks of the Yau Igneous Complex intrude the Goropu Metabasalt to the east and southeast of Mt. Dayman. Plio-Pleistocene calcalkaline (Suckling Granite) and high-K (Mai'iu Monzonite, Bonua Porphyry) granitoids intrude the Goropu Metabasalt and PUB near and to the south of Mt. Suckling (Figure 4.2) (Chapter 2). In addition, rare (Quaternary?) undeformed basaltic andesite dikes intrude the mylonitic Goropu Metabasalt near the range front (Daczko et al., 2011; Little et al., 2019). There, hydrothermal springs with water temperatures of $56-54^{\circ} \mathrm{C}$ and low sulphate contents $\left(<0.03 \% \mathrm{SO}_{4}^{2-}\right)$ suggest circulation of meteoric water heated by rapidly exhuming footwall rocks at depth (Latter, 1964; Little et al., 2019). Basaltic andesite lava erupted from Goropu crater due north of Mt. Suckling (Figure 4.2) between 1943 and 1944 (Baker, 1946). On the SDMCC, tectonized peridotite of the PUB in the vicinity of Mts. Suckling and Masasoru (Figure 4.2) occurs in the footwall of the Mai'iu Fault, suggesting that the Mai'iu Fault locally crosscut the older OSF rather than reactivating it perfectly (Figure 4.2, A-A'; Davies, 1980; Little et al., 2019).

With data and observations from previous studies, the following evolution of the SDMCC can be reconstructed: Seafloor spreading produced the protolith of the Goropu Metabasalt (the inferred correlatives of the Emo Metamorphics in the central Papuan Peninsula) in the Late Cretaceous (<103-66 Ma) (Chapter 2; Smith and Davies, 1976). In the Late CretaceousPaleogene, the OSF carried rocks of the Goropu Metabasalt to depth of 20-30 km beneath the nascent CVA in the upper plate to the north (Daczko et al., 2011; Davies and Jaques, 1984; Little et al., 2019). Subduction of the rifted Australian continental margin jammed the subduction zone and resulted in the onset of southwestward obduction of the PUB over a hyperextended part of the Australian continent at 58.3 \pm 0.4 Ma (Davies and Jaques, 1984; Lus et al., 2004). Obduction of the PUB was accompanied by continued arc magmatism of the CVA in Paleocene-Eocene times ( 59-47 Ma, and possibly until the Late Eocene; Davies and Smith, 1971; Jaques and Chappell, 1980; Rogerson et al., 1991; Walker and McDougall, 1982). Zircon U-Pb ages of the Yau Igneous Complex that range from $\sim 60.4$ to $\sim 56.6$ Ma suggest that it intruded into the down-going plate of the Goropu Metabasalt at that time (Chapter 2).

The timing of the termination of slip on the OSF (sole of the PUB) is not precisely constrained, but in the Miocene a structurally lower thrust emplaced the Goropu Metabasalt southward over rifted continental margin rocks of the Australian Plate (Kagi Metamorphics) (Davies and Jaques, 1984; Little et al., 2019). A fundamental shift to an extensional tectonic regime occurred in the latest Miocene. By $\sim 6$ Ma seafloor spreading in the Woodlark Basin had begun (Taylor et al., 1999). Debate exists as to whether extension in the Woodlark Rift had commenced before the initiation of seafloor spreading in the Woodlark Basin, between 
9.3-7.8 Ma (Taylor and Huchon, 2002), or if extension in the continental rift started at $\sim 4$ Ma (Petersen and Buck, 2015), thereby post-dating initial seafloor spreading.

Extensional re-activation of the Paleogene OSF as a normal fault by $3.8 \pm 0.2 \mathrm{Ma}$ is suggested by the intrusion of the Suckling Granite, Mai'iu Monzonite and Bonua Porphyry into the footwall of the Mai'iu Fault between $~ 3.8-2.0$ Ma (Chapter 2). These were cut by the Mai'iu Fault and exhumed in its footwall. Plio-Pleistocene ${ }^{40} \mathrm{Ar} /{ }^{39} \mathrm{Ar}$ dates (2.2-3.0 $\mathrm{Ma}$ ) from glassy pseudotachylyte in foliated cataclasite and ultracataclasite of the Goropu Metabasalt suggest mixed-mode seismic/aseismic slip behaviour of the Mai'iu Fault that formed near the brittle-ductile transition along a high-stress ramp at 10-12 km depth (Little et al., 2019). Holocene and modern slip rates for the Mai'iu Fault range from $11.7 \pm 7.0$ $\mathrm{mm} / \mathrm{yr}$ (Webber et al., 2018, with uncertainty recast to $2 \sigma$ ) over the past $\sim 5.5 \mathrm{kyr}$ to presentday rates of 7.5-9.6 mm/yr (Wallace et al., 2014, recast to a fault dip of $21^{\circ}$ ). The age of a tephra $(0.6 \pm 0.4 \mathrm{Ma})$ from the uppermost exposed section of the Gwoira Conglomerate suggests a Pleistocene depositional age of this unit (Chapter 3).

\subsection{Methods}

\subsubsection{Sampling strategy}

Twenty-one footwall samples of the Goropu Metabasalt and intercalated metasedimentary rocks (the Bonenau Schist), the pre-extensional Yau Igneous Complex and syn-extensional granitoids (Suckling Granite, Mai'iu Monzonite, Bonua Porphyry) were collected at different distances from the Mai' iu Fault trace along transects subparallel to the slip direction (Figures 4.2 and 4.3). The purpose of these samples was to determine the cooling and exhumation history of the footwall using fission track and $(\mathrm{U}-\mathrm{Th}[-\mathrm{Sm}]) / \mathrm{He}$ methods. In addition, we collected eight detrital clasts and three boulders of the Yau Igneous Complex in the Gwoira Conglomerate and modern streams in the footwall and hanging wall of the Mai'iu Fault, respectively. Also, five samples of sand from modern streams in the footwall and in the hanging wall at the range front were collected to expand the spatial coverage of the sampling and to date material that would otherwise be inaccessible due to the dense rainforest that covers large areas of the SDMCC. Standard mineral separation techniques, including crushing, grinding, heavy liquid and magnetic susceptibility techniques were employed to separate zircon and apatite. Details of the mineral separation techniques are provided in Supplementary material B.3. Finally, nine samples of the Bonenau Schist were collected from a range of structural levels of the footwall to target carbonaceous material suitable for analysis by Raman spectroscopy in order to derive estimates of peak metamorphic temperatures using the temperature calibrations of Beyssac et al. (2002) and Kouketsu et al. (2014). 


\subsubsection{Raman spectroscopy of carbonaceous material}

Raman spectra of detrital grains of carbonaceous material (CM) in samples of pelitic phyllites and calcareous schist (part of the Bonenau Schist) were measured on polished thin sections by an Alpha 300R+ confocal Raman microscope with a $532 \mathrm{~nm}$ laser located at the Department of Chemistry, University of Otago, New Zealand. For details of spectra acquisition, peak fitting procedures and choice of thermometer calibration the reader is referred to Appendix A.4 and Supplementary material B.3. Mean temperature estimates from Raman spectroscopy of carbonaceous material (RSCM) based on the calibrations of Beyssac et al. (2002) and Kouketsu et al. (2014) were assigned reported uncertainties of \pm 30 and $\pm 50^{\circ} \mathrm{C}$, respectively. Where the $2 \sigma$ uncertainty of the mean of the RSCM-derived temperatures exceeded the reported uncertainties, the $2 \sigma$ values were used instead. A summary of the RSCM data is presented in Table B.3.

\subsubsection{Zircon $\mathrm{U}-\mathrm{Pb}$ geochronology and trace element analysis}

$\mathrm{U}-\mathrm{Pb}$ analyses on zircons from the Goropu Metabasalt and Bonenau Schist were performed on polished (in-situ) and unpolished (depth profiling) zircons. Depth profiling was chosen over in-situ dating because of the convenience for zircon double-dating with (U-Th)/He. Depth-profile U-Pb and trace element analyses were performed at the UTChron Laboratories at the University of Texas at Austin, using a PhotonMachines Analyte G.2 $193 \mathrm{~nm}$ excimer laser. U-Pb isotopic and trace element data were collected from the same crystals by placing two spots next to each other on each zircon grain. Polished zircons that were previously analysed by fission-track methodology were analysed by laser ablation using a REsonetics RESOlution M-50A-LR system, with a COMPex 102193 nm excimer UV laser at the John de Laeter Centre, Curtin University in split-stream mode, in which half of the ablated material was sent to a Nu Plasma multi-collector-ICP-MS (MC-ICP-MS) for isotopic analysis and the other half of the material to an Agilent 7700s quadrupole ICP-MS for elemental analysis. No common lead $\left(\mathrm{Pb}_{c}\right)$ correction was employed, but single ${ }^{206} \mathrm{~Pb} /{ }^{238} \mathrm{U}$ dates were corrected for ${ }^{230} \mathrm{Th}$ disequilibrium assuming $\mathrm{Th} / \mathrm{U}_{\text {magma }}=3 .{ }^{230} \mathrm{Th}$-corrected single-grain ${ }^{206} \mathrm{~Pb} /{ }^{238} \mathrm{U}$ dates are reported at the 2SE (standard error) confidence level (Electronic appendices 1 and 7). For sample ages of the Goropu Metabasalt and the Bonenau Schist, the geometric mean and the $2 \sigma$ (standard deviation) uncertainty are given unless otherwise stated. For a detailed description of the instrumental and operational conditions of the zircon $\mathrm{U}-\mathrm{Pb}$ and trace element analysis, the reader is referred to Appendix A.2. 


\subsubsection{Low-temperature thermochronometry}

\section{Fission track}

Apatite and zircon crystals were analysed using the external detector method. Ages were calculated using the zeta approach (Hurford and Green, 1983) with zeta values of $131 \pm 12$ (2SE) for CN1/zircon (JO) and $343 \pm 15$ (2SE) for CN5/apatite (JO), respectively. Apatite and zircon were counted at magnifications of x1000 (dry) and x1000 (oil), respectively, with a Zeiss Axio Imager M1m at Victoria University of Wellington. Central ages (Galbraith and Laslett, 1993) are reported at the $2 \sigma$ level. For details of the etching conditions, age calculation and data representation the reader is referred to Appendix A.5. Fission-track ages and zeta calibration values are presented in Tables B.4 and B.5, respectively.

\section{(U-Th[-Sm])/He thermochronometry}

Zircon and apatite grains were screened for inclusions, clarity, morphology and size. Each crystal was photographed and morphometrically measured for alpha-ejection correction. Concentrations of ${ }^{4} \mathrm{He}, \mathrm{U}$, Th, and Sm were measured by isotope dilution using a quadrupole mass spectrometer (for ${ }^{4} \mathrm{He}$ ) and inductively coupled plasma mass spectrometer (for $\mathrm{U}$, Th, and $\mathrm{Sm}$ ) at the University of Texas at Austin. For details of the analytical technique, the reader is referred to Appendix A.6. Single-aliquot and mean zircon, apatite and magnetite $(\mathrm{U}-\mathrm{Th}[-\mathrm{Sm}]) / \mathrm{He}$ ages are reported at the $2 \sigma$ level. Zircon, apatite and magnetite(U-Th[$\mathrm{Sm}]) / \mathrm{He}$ data are presented in Tables B.6, B.7 and B.8, respectively. Results from zircon $(\mathrm{U}-\mathrm{Th}) /(\mathrm{Pb}-\mathrm{He})$ double-dating are summarized in Table B.9.

\section{Temperature sensitivity}

Zircon fission-track (ZFT), zircon (U-Th)/He (ZHe), apatite fission-track (AFT), and apatite $(\mathrm{U}-\mathrm{Th}-\mathrm{Sm}) / \mathrm{He}$ systems were assigned closure temperatures of $300^{\circ} \mathrm{C}$ (Tagami, 2005), $220^{\circ} \mathrm{C}$ (Guenthner et al., 2013), $110^{\circ} \mathrm{C}$ (Laslett et al., 1987) and $80^{\circ} \mathrm{C}$ (Wolf et al., 1998), respectively. Closure temperatures at the higher end of published values were chosen because of the inferred rapid cooling of the footwall rocks based on published constraints on the slip rate of the Mai'iu Fault. For the bases of the zircon partial annealing zone (PAZ) and the zircon partial retention zone (PRZ) values of $300 \pm 50^{\circ} \mathrm{C}$ (Rahn et al., 2004) and $200 \pm$ $20^{\circ} \mathrm{C}$ (Wolfe and Stockli, 2010) were adopted.

\subsection{5 ${ }^{26} \mathrm{Al} /{ }^{10} \mathrm{Be}$ cosmogenic nuclide dating}

Three quartz clasts (pebble-cobble size) were collected in the upper and lower stratigraphic sections of the Gwoira Conglomerate for ${ }^{26} \mathrm{Al} /{ }^{10} \mathrm{Be}$ cosmogenic nuclide burial dating. Standard mineral separation techniques were used to purify the crushed quartz separates at Victoria University of Wellington. ${ }^{26} \mathrm{Al} /{ }^{10} \mathrm{Be}$ burial ages are reported at the $2 \sigma$ level. For details 
of the sample preparation and age calculation the reader is referred to Appendix A.7. The ${ }^{26} \mathrm{Al} /{ }^{10} \mathrm{Be}$ burial age data are presented in Table B.10.

\subsection{Results and interpretation}

\subsubsection{Paleo-temperature estimates from graphite crystallinity}

The spectra of CM of samples from the Bonenau Schist (Figure B.12) on the footwall of the SDMCC, in the first order $\left(1000-1800 \mathrm{~cm}^{-1}\right)$ region, resemble those from low-grade to greenschist-facies metamorphic rocks (see Beyssac et al., 2002) generally with a broad peak in the D-band region (1000-1500 $\mathrm{cm}^{-1}$, Lünsdorf et al., 2017). This broad peak is sometimes decorated with shoulders on the low- and high-wavenumber sides (Figure B.12), suggesting the presence of multiple defect bands (e.g., D1, D3, D4). In the G-band region (1500-1700 $\mathrm{cm}^{-1}$, Lünsdorf et al., 2017), the $\mathrm{G}$ band may show a shoulder on the high-wavenumber side (e.g., Figures B.12a and h), which is typically associated with the D2 defect band.

Graphite crystallinity is thought to be largely dependent on the temperature to which the CM was subjected to (e.g., Beyssac et al., 2002). Knowing that there is a southward decrease in metamorphic grade away from the Mai'iu Fault trace (Figure 4.2), it is expected that graphite crystallinity decreases with increasing slip-parallel distance from the fault trace. For this reason, we plotted the position of the peak of the G band (Table B.3), an indicator of graphite crystallinity, against distance from the fault trace (Figure 4.4). The position of the $\mathrm{G}$ band in highly crystalline graphite is typically found at $\sim 1580 \mathrm{~cm}^{-1}$ and shifts to higher wavenumbers in less crystalline CM (Beyssac et al., 2002). For each sample on this transect, the distance from the Mai'iu Fault trace has been determined as circumferential distance along the warped surface of the Mai' iu Fault parallel to the reported mean slip direction $012^{\circ}$ (Little et al., 2019). For details of this reconstruction the reader is referred to the Supplementary material B.3.

On this transect parallel to the slip direction of the Mai'iu Fault on Mt. Dayman (Figure 4.4), the position of the peak of the $\mathrm{G}$ band increases relatively steadily from $1578.1 \pm 0.3 \mathrm{~cm}^{-1}$ (2SE) at the fault trace (PNG-15-52c and e) to $1593.1 \pm 0.9 \mathrm{~cm}^{-1}$ (2SE) near the summit of Mt. Dayman (PNG-15-5a) (Table B.3), suggesting overall lower graphite crystallinity to the south. Two samples from the same outcrop near the fault trace (PNG-15-52c and e) show similar $\mathrm{G}$ band positions (1578.1 $\pm 0.3 \mathrm{~cm}^{-1}$ vs. $1579.2 \pm 0.4 \mathrm{~cm}^{-1}$, Table B.3) but yielded a broad range of $\mathrm{R} 22_{\text {area }}$ ratios (0.15-0.65; Electronic appendix 6). For the discussion below, we treat them as one sample and refer to it as PNG-15-52c,e (Table B.3). Three samples (yellow circles in Figure 4.4) 20 km east of Mt. Dayman collected near an inactive segment 
of the Mai'iu Fault (Figure 4.3) appear to define a steeper trend in which the position of the $\mathrm{G}$ band shifts to higher wavenumbers $\left(\sim 1584.2-1592.2 \mathrm{~cm}^{-1}\right.$, Table B.3) within a shorter distance $(\sim 3 \mathrm{~km})$ from the fault trace compared to samples of the Bonenau Schist from the northern flank of Mt. Dayman (black circles in Figure 4.4).

Employing the FWHM-D1 temperature calibration of Kouketsu et al. (2014), relevant to samples in the prehnite-pumpellyite and pumpellyite-actinolite facies, and the R2 calibration of Beyssac et al. (2002) for greenschist-facies rocks (only PNG-15-52c,e), RSCM of eight samples of the Bonenau Schist in the footwall of the SDMCC yielded peak metamorphic temperatures ranging from $276 \pm 45$ to $423 \pm 112^{\circ} \mathrm{C}(2 \sigma)$ (Figure 4.3). These are broadly consistent with those inferred from the map distribution of prehnite-pumpellyite to greenschist-facies mineral assemblages (ca. $250-425^{\circ} \mathrm{C}$ ) as described in previous studies (Daczko et al., 2009; Davies, 1980). Importantly, the temperatures generally decrease southward away from the fault trace, as expected for an exhumed dip-slip fault surface (Figures 4.2 and 4.3). The only anomaly in this respect is sample PNG-16-16a which yielded a RSCM temperature of $276 \pm 45^{\circ} \mathrm{C}$ that is statistically lower than that of two other samples (PNG16-27a, PNG-14-15a) that yielded $366 \pm 30^{\circ} \mathrm{C}$ and $373 \pm 30^{\circ} \mathrm{C}$ (Figure 4.3), respectively, at about the same distance from the fault trace.

Because graphitization is generally regarded as an irreversible process (Beyssac et al., 2002), these RSCM-derived temperatures are interpreted as peak metamorphic temperatures. We infer that peak metamorphic temperatures were reached prior to extensional slip on the Mai'iu Fault. As these samples were generally collected within a few tens of meters of the fault plane, these can be used to map paleo-isotherms onto the exhumed Mai'iu Fault.

\subsubsection{Zircon U-Pb dating and trace elements}

Zircon U-Pb ages of 17 samples from the Suckling Granite, Mai'iu Monzonite, Bonua Porphyry, quartz-gabbros and tonalites of the Yau Igneous Complex and two metasedimentary samples of the Bonenau Schist are presented in Table 4.1. Rounded detrital zircons of the Bonenau Schist samples (PNG-15-18c, PNG-16-1153a) yielded U-Pb ages of $103.0 \pm 5.7$ and $71.6 \pm 3.3 \mathrm{Ma}$, respectively, that were interpreted as maximum depositional ages (MDAs). Weighted mean $\mathrm{U}-\mathrm{Pb}$ ages of zircon from the Yau Igneous Complex range between $60.4 \pm$ 2.5 and $56.6 \pm 2.3 \mathrm{Ma}$ and were suggested to date its intrusion into the Goropu Metabasalt. Lastly, the weighted mean ages of the syn-extensional Suckling Granite, Mai'iu Monzonite and Bonua Porphyry indicate that they intruded the Goropu Metabasalt between $3.8 \pm 0.2$ and $2.0 \pm 0.1 \mathrm{Ma}$. 


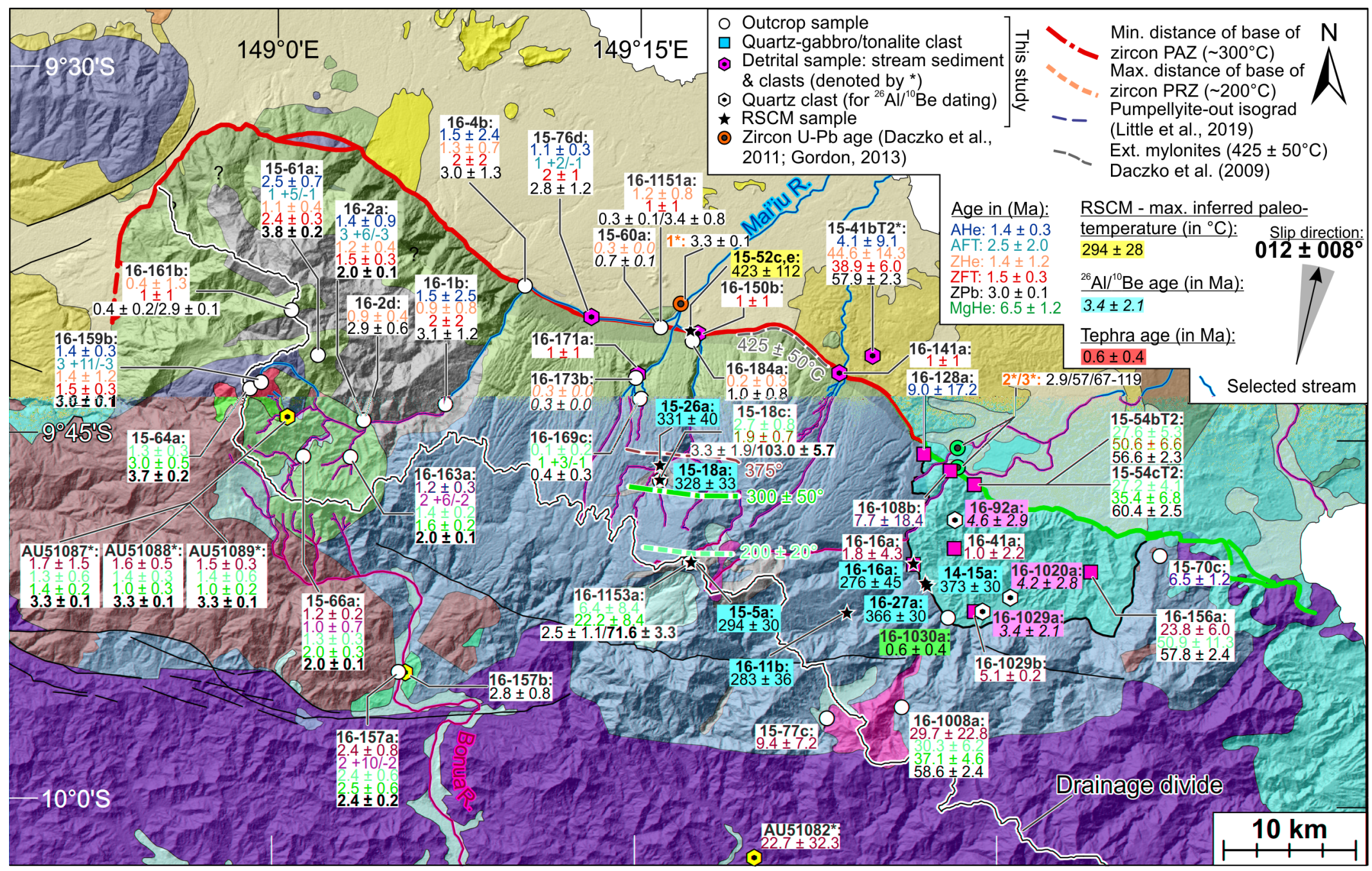

$\infty$ 
Figure 4.3: Geologic map of the Suckling-Dayman metamorphic core complex with sample location and results from U-Pb, fission track, $(\mathrm{U}-\mathrm{Th}[-\mathrm{Sm}]) / \mathrm{He},{ }^{26} \mathrm{Al} /{ }^{10} \mathrm{Be}$ analyses and Raman spectroscopy of carbonaceous material (RSCM). The map (identical to Figure 4.2) is underlain by a hillshade model (Shuttle Radar Topography Mission, $30 \mathrm{~m}$ ). Chronometer abbreviations: AHe - apatite (U-Th-Sm)/He, AFT - apatite fission track, ZHe - zircon (U$\mathrm{Th}) / \mathrm{He}, \mathrm{ZFT}$ - zircon fission track, ZPb - zircon U-Pb, MgHe - magnetite (U-Th-Sm)/He. Number labels: normal font - geometric mean age $\pm 2 \sigma$ uncertainty, bold font - weighted mean $\pm 2 \sigma$ uncertainty, italic font - single analysis \pm analytical uncertainty. Prefix 'PNG-' has been omitted from sample labels for convenience. $012 \pm 008^{\circ}$ and arrow represent slip direction of the Mai'iu Fault. Drainage divide from Mizera et al. (2019). Only a selection of streams relevant to the discussion are shown.

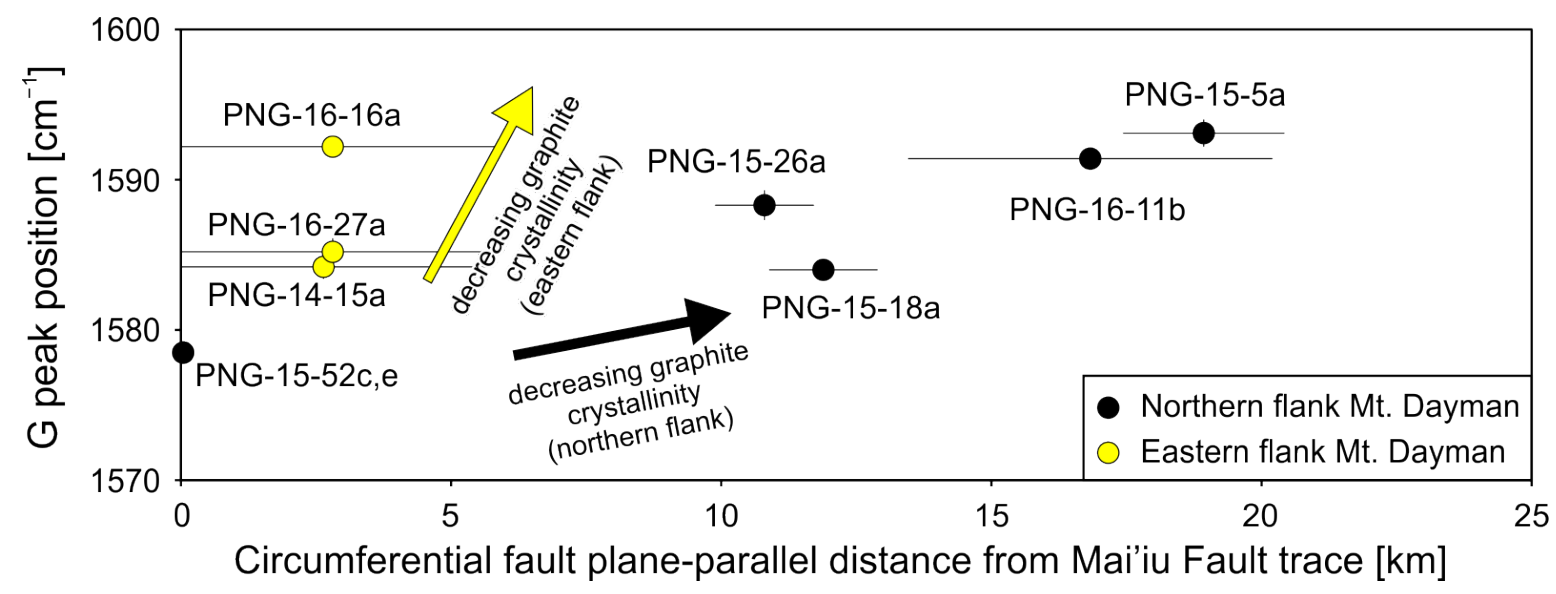

Figure 4.4: Position of the $\mathrm{G}$ band plotted against slip-parallel circumferential distance from the Mai'iu Fault trace. Graphite crystallinity is inferred from the Raman shift of the G peak position. Black and yellow circles represent samples collected on the northern and eastern flanks of Mt. Dayman, respectively. Error bars in the y-direction (position of the G peak) are 2SE (standard error). Errors in the x-direction (distance from the fault trace) are based on a reconstruction in Supplementary material B.3 (Figure B.13). Because of uncertainties with regard to the position of the Mai'iu Fault trace beneath the Gwoira Conglomerate, errors of $\pm 3 \mathrm{~km}$ were assigned to the samples from the eastern flank of Mt. Dayman. 
Table 4.1: Summary of U-Pb, fission-track and (U-Th[-Sm])/He data from the Suckling-Dayman metamorphic core complex.

\begin{tabular}{|c|c|c|c|c|c|c|c|c|c|c|c|c|c|}
\hline Unit & Sample & $\begin{array}{l}\text { Sample } \\
\text { type }\end{array}$ & $\begin{array}{c}\text { Longitude* } \\
{[\text { E] }}\end{array}$ & $\begin{array}{c}\text { Latitude* } \\
{[\text { [S] }}\end{array}$ & $\begin{array}{c}\text { Distance }^{a} \\
{[\mathbf{k m}]}\end{array}$ & Mineral & $\begin{array}{c}\text { U-Pb }{ }^{b} \text { age } \\
{[\mathrm{Ma}]}\end{array}$ & $\pm \mathbf{2} \sigma$ & $\begin{array}{c}\text { FT }^{c} \text { age } \\
{[\mathrm{Ma}]}\end{array}$ & $\pm \mathbf{2} \sigma$ & $\begin{array}{c}\mathbf{H e}^{d} \text { age } \\
{[\mathrm{Ma}]}\end{array}$ & $\pm \mathbf{2} \sigma$ & $\begin{array}{l}\text { Inferred age of } \\
\text { zircon growth }\end{array}$ \\
\hline Bas. and. dike & PNG-15-60a & outcrop & $149^{\circ} 16^{\prime} 7.11^{\prime \prime}$ & $9^{\circ} 40^{\prime} 38.91^{\prime \prime}$ & 0.19 & $\mathrm{Zrn}$ & 0.7 & $0.1^{1}$ & & & 0.3 & $0.02^{1}$ & syn \\
\hline \multirow[t]{7}{*}{ Bonenau Schist } & PNG-15-18c & outcrop & $149^{\circ} 15^{\prime} 57.29^{\prime \prime}$ & $9^{\circ} 46^{\prime} 49.30^{\prime \prime}$ & 11.89 & $\mathrm{Zrn}$ & 103.0 & $5.7^{2}$ & $1.9^{\dagger}$ & 0.7 & 2.7 & 0.8 & pre, $\downarrow$ ZPRZ/ZPAZ? \\
\hline & PNG-15-18c & outcrop & $149^{\circ} 15^{\prime} 57.29^{\prime \prime}$ & $9^{\circ} 46^{\prime} 49.30^{\prime \prime}$ & 11.89 & $\mathrm{Zrn}$ & 3.3 & 1.9 & & & & & syn \\
\hline & PNG-16-2d & outcrop & $149^{\circ} 3^{\prime} 43.05^{\prime \prime}$ & $9^{\circ} 44^{\prime} 28.65^{\prime \prime}$ & 19.97 & $\mathrm{Zrn}$ & 2.9 & 0.6 & & & 0.9 & 0.4 & syn \\
\hline & PNG-16-161b & outcrop & $149^{\circ} 00^{\prime} 39.21^{\prime \prime}$ & $9^{\circ} 39^{\prime} 58.37^{\prime \prime}$ & 13.27 & $\mathrm{Zrn}$ & 2.9 & 0.1 & $1^{\ddagger}$ & 1 & 0.4 & 1.3 & syn \\
\hline & PNG-16-161b & outcrop & $149^{\circ} 0{ }^{\prime} 39.21^{\prime \prime}$ & $9^{\circ} 39^{\prime} 58.37^{\prime \prime}$ & 13.27 & $\mathrm{Zrn}$ & 0.4 & 0.2 & & & & & syn \\
\hline & PNG-16-1153a & outcrop & $149^{\circ} 17^{\prime} 11.62^{\prime \prime}$ & $9^{\circ} 50^{\prime} 11.74 "$ & 18.93 & $\mathrm{Zrn}$ & 71.6 & $3.3^{2}$ & $22.2^{\dagger}$ & 8.4 & 6.4 & 8.4 & pre, in ZPRZ/ZPAZ? \\
\hline & PNG-16-1153a & outcrop & $149^{\circ} 17^{\prime} 11.62^{\prime \prime}$ & $9^{\circ} 50^{\prime} 11.74 "$ & 18.93 & $\mathrm{Zrn}$ & 2.5 & 1.1 & & & & & syn \\
\hline \multirow[t]{2}{*}{ Bonua Porphyry } & PNG-16-157a & outcrop & $149^{\circ} 5,17.41^{\prime \prime}$ & $9^{\circ} 54^{\prime} 45.84^{\prime \prime}$ & 32.82 & $\mathrm{Zrn}$ & 2.4 & $0.2^{2}$ & $2.5^{\dagger}$ & 0.6 & 2.4 & 0.6 & syn \\
\hline & PNG-16-157a & outcrop & $149^{\circ} 5,17.41^{\prime \prime}$ & $9^{\circ} 54^{\prime} 45.84^{\prime \prime}$ & 32.82 & $\mathrm{Ap}$ & & & $2^{\ddagger}$ & $+10 /-2$ & 2.4 & 0.8 & \\
\hline \multirow[t]{10}{*}{ Goropu Metabasalt } & PNG-16-1b & outcrop & $149^{\circ} 7^{\prime} 4.45^{\prime \prime}$ & $9^{\circ} 43^{\prime} 47.81^{\prime \prime}$ & 12.34 & $\mathrm{Zrn}$ & 3.1 & 1.2 & $2^{\ddagger}$ & 2 & 0.9 & 0.8 & syn \\
\hline & PNG-16-1b & outcrop & $149^{\circ} 7^{\prime} 4.45^{\prime \prime}$ & $9^{\circ} 43^{\prime} 47.81^{\prime \prime}$ & 12.34 & Ap & & & & & 1.5 & 2.5 & \\
\hline & PNG-16-4b & outcrop & $149^{\circ} 10^{\prime} 16.43^{\prime \prime}$ & $9^{\circ} 38^{\prime} 54.54^{\prime \prime}$ & 0.04 & $\mathrm{Zrn}$ & 3.0 & 1.3 & $2^{\ddagger}$ & 2 & 1.3 & 0.7 & syn, $\downarrow$ ZPRZ/ZPAZ? \\
\hline & PNG-16-4b & outcrop & $149^{\circ} 10^{\prime} 16.43^{\prime \prime}$ & $9^{\circ} 38^{\prime} 54.54 "$ & 0.04 & Ap & & & & & 1.5 & 2.4 & \\
\hline & PNG-16-169c & outcrop & $149^{\circ} 15^{\prime} 7.57^{\prime \prime}$ & $9^{\circ} 43^{\prime} 30.75^{\prime \prime}$ & 5.97 & $\mathrm{Zrn}$ & 0.4 & 0.3 & $1^{\ddagger}$ & $+3 /-1$ & 0.1 & 0.2 & syn \\
\hline & PNG-16-173b & outcrop & $149^{\circ} 14^{\prime} 53.66^{\prime \prime}$ & $9^{\circ} 42^{\prime} 40.33^{\prime \prime}$ & 4.44 & $\mathrm{Zrn}$ & 0.3 & $0.03^{1}$ & & & 0.3 & $0.02^{1}$ & syn \\
\hline & PNG-16-180b & outcrop & $149^{\circ} 15^{\prime} 55.65^{\prime \prime}$ & $9^{\circ} 41^{\prime} 22.71^{\prime \prime}$ & 1.68 & $\mathrm{Zrn}$ & 1.9 & 0.5 & & & & & syn \\
\hline & PNG-16-184a & outcrop & $149^{\circ} 16^{\prime} 3.97^{\prime \prime}$ & $9^{\circ} 40^{\prime} 51.41^{\prime \prime}$ & 0.76 & $\mathrm{Zrn}$ & 1.0 & 0.8 & & & 0.2 & 0.3 & syn \\
\hline & PNG-16-1151a & outcrop & $149^{\circ} 16^{\prime} 7.11^{\prime \prime}$ & $9^{\circ} 40^{\prime} 38.91^{\prime \prime}$ & 0.15 & $\mathrm{Zrn}$ & 3.4 & 0.8 & $1^{\ddagger}$ & 1 & 1.2 & 0.8 & syn, $\downarrow$ ZPRZ/ZPAZ? \\
\hline & PNG-16-1151a & outcrop & $149^{\circ} 16^{\prime} 7.11^{\prime \prime}$ & $9^{\circ} 40^{\prime} 38.91 "$ & 0.15 & $\mathrm{Zrn}$ & 0.3 & 0.1 & & & & & syn \\
\hline \multirow[t]{6}{*}{ Mai'iu Monzonite } & PNG-15-66a & outcrop & $149^{\circ} 1 ’ 14.32^{\prime \prime}$ & $9^{\circ} 45^{\prime} 58.16^{\prime \prime}$ & 25.52 & $\mathrm{Zrn}$ & 2.0 & $0.1^{2}$ & $2.0^{\dagger}$ & 0.3 & 1.3 & 0.3 & syn \\
\hline & PNG-15-66a & outcrop & $149^{\circ} 1$ ' 14.32" & $9^{\circ} 45^{\prime} 58.16^{\prime \prime}$ & 25.52 & Ap & & & $1.0^{\dagger}$ & 0.7 & 1.2 & 0.2 & \\
\hline & PNG-16-2a & outcrop & $149^{\circ} 3^{\prime} 43.05^{\prime \prime}$ & $9^{\circ} 44^{\prime} 28.65^{\prime \prime}$ & 19.97 & $\mathrm{Zrn}$ & 2.0 & $0.1^{2}$ & $1.5^{\dagger}$ & 0.3 & 1.2 & 0.4 & syn \\
\hline & PNG-16-2a & outcrop & $149^{\circ} 3^{\prime} 43.05^{\prime \prime}$ & $9^{\circ} 44^{\prime} 28.65^{\prime \prime}$ & 19.97 & Ap & & & $3^{\ddagger}$ & $+6 /-3$ & 1.4 & 0.9 & \\
\hline & PNG-16-159b & outcrop & $148^{\circ} 59^{\prime} 23.91^{\prime \prime}$ & $9^{\circ} 42^{\prime} 56.14^{\prime \prime}$ & 20.35 & $\mathrm{Zrn}$ & 3.0 & $0.1^{2}$ & $1.5^{\dagger}$ & 0.3 & 1.4 & 1.2 & syn \\
\hline & PNG-16-159b & outcrop & $148^{\circ} 59^{\prime} 23.91^{\prime \prime}$ & $9^{\circ} 42^{\prime} 56.14^{\prime \prime}$ & 20.35 & Ap & & & $3^{\ddagger}$ & $+11 /-3$ & 1.4 & 0.3 & \\
\hline
\end{tabular}


Table 4.1 - continued from previous page

\begin{tabular}{|c|c|c|c|c|c|c|c|c|c|c|c|c|c|}
\hline Unit & Sample & $\begin{array}{l}\text { Sample } \\
\text { type }\end{array}$ & $\begin{array}{l}\text { Longitude* } \\
{[\text { [E] }}\end{array}$ & $\begin{array}{l}\text { Latitude* }^{*} \\
{[\mathrm{~S}]}\end{array}$ & $\begin{array}{c}\text { Distance }^{a} \\
{[\mathbf{k m}]}\end{array}$ & Mineral & $\begin{array}{c}\mathbf{U}_{-} \mathbf{P} b^{b} \text { age } \\
{[\mathrm{Ma}]}\end{array}$ & $\pm \mathbf{2} \sigma$ & $\begin{array}{c}\text { FT }^{c} \text { age } \\
{[\mathrm{Ma}]}\end{array}$ & $\pm \mathbf{2} \sigma$ & $\begin{array}{c}\mathbf{H e}^{d} \text { age } \\
{[\mathrm{Ma}]}\end{array}$ & $\pm \mathbf{2} \sigma$ & $\begin{array}{l}\text { Inferred age of } \\
\text { zircon growth }\end{array}$ \\
\hline & PNG-16-163a & outcrop & $149^{\circ} 3^{\prime} 10.74^{\prime \prime}$ & $9^{\circ} 45^{\prime} 58.80^{\prime \prime}$ & 22.95 & $\mathrm{Zrn}$ & 2.0 & $0.1^{2}$ & $1.6^{\dagger}$ & 0.2 & 1.4 & 0.2 & syn \\
\hline & PNG-16-163a & outcrop & $149^{\circ} 3^{\prime} 10.74 "$ & $9^{\circ} 45^{\prime} 58.80^{\prime \prime}$ & 22.95 & Ap & & & $2^{\ddagger}$ & $+6 /-2$ & 1.2 & 0.3 & \\
\hline \multirow[t]{9}{*}{ Suckling Granite } & AU51087 & float & $149^{\circ} 0^{\prime} 5^{\prime \prime}$ & $9^{\circ} 44^{\prime} 10^{\prime \prime}$ & $N A$ & $\mathrm{Zrn}$ & 3.3 & $0.1^{2}$ & $1.4^{\dagger}$ & 0.2 & 1.3 & 0.6 & syn \\
\hline & AU51087 & float & $149^{\circ} 0^{\prime} 5^{\prime \prime}$ & $9^{\circ} 44^{\prime} 10^{\prime \prime}$ & $N A$ & Ap & & & & & 1.7 & 1.5 & \\
\hline & AU51088 & float & $149^{\circ} 0^{\prime} 5^{\prime \prime}$ & $9^{\circ} 44^{\prime} 10^{\prime \prime}$ & $N A$ & $\mathrm{Zrn}$ & 3.3 & $0.1^{2}$ & $1.0^{\dagger}$ & 0.3 & 1.4 & 0.3 & syn \\
\hline & AU51088 & float & $149^{\circ} 0^{\prime} 5^{\prime \prime}$ & $9^{\circ} 44^{\prime} 10^{\prime \prime}$ & $N A$ & Ap & & & & & 1.6 & 0.5 & \\
\hline & AU51089 & float & $149^{\circ} 0^{\prime} 5^{\prime \prime}$ & $9^{\circ} 44^{\prime} 10^{\prime \prime}$ & $N A$ & $\mathrm{Zrn}$ & 3.3 & $0.1^{2}$ & $1.0^{\dagger}$ & 0.2 & 1.4 & 0.6 & syn \\
\hline & AU51089 & float & $149^{\circ} 0^{\prime} 5^{\prime \prime}$ & $9^{\circ} 44^{\prime} 10^{\prime \prime}$ & $N A$ & Ap & & & & & 1.5 & 0.3 & \\
\hline & PNG-15-61a & outcrop & $149^{\circ} 1^{\prime} 39.11^{\prime \prime}$ & $9^{\circ} 41^{\prime} 45.63^{\prime \prime}$ & 17.75 & $\mathrm{Zrn}$ & 3.8 & $0.2^{2}$ & $2.4^{\dagger}$ & 0.3 & 1.1 & 0.4 & syn \\
\hline & PNG-15-61a & outcrop & $149^{\circ} 1$ ' 39.11" & $9^{\circ} 41^{\prime} 45.63^{\prime \prime}$ & 17.75 & Ap & & & $1^{\ddagger}$ & $+5 /-1$ & 2.5 & 0.7 & \\
\hline & PNG-15-64a & outcrop & $148^{\circ} 58^{\prime} 51.26^{\prime \prime}$ & $9^{\circ} 43^{\prime} 12.12^{\prime \prime}$ & 21.38 & $\mathrm{Zrn}$ & 3.7 & $0.2^{2}$ & $3.0^{\dagger}$ & 0.5 & 1.3 & 0.3 & syn \\
\hline Yau Igneous & AU51082 & float & $149^{\circ} 19^{\prime} 59^{\prime \prime}$ & $10^{\circ} 2^{\prime} 12.09^{\prime \prime}$ & $N A$ & Ap & & & & & 22.7 & 32.3 & \\
\hline \multirow{14}{*}{ Complex } & PNG-15-41bT2 & float & $149^{\circ} 24^{\prime} 37.94^{\prime \prime}$ & $9^{\circ} 41^{\prime} 49.39^{\prime \prime}$ & $N A$ & $\mathrm{Zrn}$ & 57.9 & $2.3^{2}$ & $38.9^{\dagger}$ & 6.0 & 44.6 & 14.3 & pre \\
\hline & PNG-15-41bT2 & float & $149^{\circ} 24^{\prime} 37.94^{\prime \prime}$ & $9^{\circ} 41^{\prime} 49.39^{\prime \prime}$ & $N A$ & Ap & & & & & 4.1 & 9.1 & \\
\hline & PNG-15-54bT2 & clast & $149^{\circ} 29^{\prime} 0.17^{\prime \prime}$ & $9^{\circ} 46^{\prime} 59.49^{\prime \prime}$ & $N A$ & $\mathrm{Zrn}$ & 56.6 & $2.3^{2}$ & $50.6^{\dagger}$ & 6.6 & 27.6 & 5.3 & pre \\
\hline & PNG-15-54cT2 & clast & $149^{\circ} 29^{\prime} 0.17^{\prime \prime}$ & $9^{\circ} 46^{\prime} 59.49^{\prime \prime}$ & $N A$ & $\mathrm{Zrn}$ & 60.4 & $2.5^{2}$ & $35.4^{\dagger}$ & 6.8 & 27.2 & 4.1 & pre \\
\hline & PNG-15-77c & float & $149^{\circ} 22^{\prime} 56.37^{\prime \prime}$ & $9^{\circ} 56^{\prime} 33.87^{\prime \prime}$ & $N A$ & Ap & & & & & 9.4 & 7.2 & \\
\hline & PNG-16-16a & clast & $149^{\circ} 26^{\prime} 29.28^{\prime \prime}$ & $9^{\circ} 50^{\prime} 12.88^{\prime \prime}$ & $N A$ & Ap & & & & & 1.8 & 4.3 & \\
\hline & PNG-16-41a & clast & $149^{\circ} 28^{\prime} 11.01^{\prime \prime}$ & $9^{\circ} 49^{\prime} 34.28^{\prime \prime}$ & $N A$ & Ap & & & & & 1.0 & 2.2 & \\
\hline & PNG-16-108b & clast & $149^{\circ} 27^{\prime} 58.11^{\prime \prime}$ & $9^{\circ} 46^{\prime} 22.77^{\prime \prime}$ & $N A$ & Ap & & & & & 7.7 & 18.4 & \\
\hline & PNG-16-128a & clast & $149^{\circ} 26^{\prime} 54.58^{\prime \prime}$ & $9^{\circ} 45^{\prime} 41.48^{\prime \prime}$ & $N A$ & Ap & & & & & 9.0 & 17.2 & \\
\hline & PNG-16-156a & clast & $149^{\circ} 33^{\prime} 48.91^{\prime \prime}$ & $9^{\circ} 50^{\prime} 28.98^{\prime \prime}$ & $N A$ & $\mathrm{Zrn}$ & 57.8 & $2.4^{2}$ & & & 50.9 & 11.3 & pre \\
\hline & PNG-16-156a & clast & $149^{\circ} 33^{\prime} 48.91^{\prime \prime}$ & $9^{\circ} 50^{\prime} 28.98 "$ & $N A$ & Ap & & & & & 23.8 & 6.0 & \\
\hline & PNG-16-1008a & outcrop & $149^{\circ} 26^{\prime} 2.10^{\prime \prime}$ & $9^{\circ} 56^{\prime} 5.27 "$ & 12.77 & $\mathrm{Zrn}$ & 58.6 & $2.4^{2}$ & $37.1^{\dagger}$ & 4.6 & 30.3 & 6.2 & pre \\
\hline & PNG-16-1008a & outcrop & $149^{\circ} 26^{\prime} 2.10^{\prime \prime}$ & $9^{\circ} 56^{\prime} 5.27^{\prime \prime}$ & 12.77 & Ap & & & & & 29.7 & 22.8 & \\
\hline & PNG-16-1029a & clast & $149^{\circ} 29^{\prime} 1.57^{\prime \prime}$ & $9^{\circ} 52^{\prime} 8.58^{\prime \prime}$ & $N A$ & Ap & & & & & 5.1 & 0.2 & \\
\hline PUB & PNG-15-70c & outcrop & $149^{\circ} 36^{\prime} 41.33^{\prime \prime}$ & $9^{\circ} 49^{\prime} 48.43^{\prime \prime}$ & 1.88 & Mag & & & & & 6.5 & 1.2 & \\
\hline
\end{tabular}


Table 4.1 - continued from previous page

\begin{tabular}{|c|c|c|c|c|c|c|c|c|c|c|c|c|c|}
\hline Unit & Sample & $\begin{array}{l}\text { Sample } \\
\text { type }\end{array}$ & $\begin{array}{c}\text { Longitude* } \\
{[E]}\end{array}$ & $\begin{array}{c}\text { Latitude* } \\
{[\mathrm{S}]}\end{array}$ & $\begin{array}{l}\text { Distance }^{a} \\
{[\mathbf{k m}]}\end{array}$ & Mineral & $\begin{array}{c}\text { U-Pb }{ }^{b} \text { age } \\
{[\text { Ma] }}\end{array}$ & $\pm \mathbf{2} \sigma$ & $\begin{array}{c}\text { FT }^{c} \text { age } \\
{[\mathrm{Ma}]}\end{array}$ & $\pm \mathbf{2} \sigma$ & $\begin{array}{c}\mathbf{H e}^{d} \text { age } \\
{[\mathrm{Ma}]}\end{array}$ & $\pm \mathbf{2} \sigma$ & $\begin{array}{l}\text { Inferred age of } \\
\text { zircon growth }\end{array}$ \\
\hline \multirow[t]{6}{*}{ Stream sediments } & PNG-15-76d & detrital & $149^{\circ} 13^{\prime} 2.76^{\prime \prime}$ & $9^{\circ} 40^{\prime} 10.11^{\prime \prime}$ & $N A$ & $\mathrm{Zrn}$ & 2.8 & 1.2 & $2^{\ddagger}$ & 1 & & & \\
\hline & PNG-15-76d & detrital & $149^{\circ} 13^{\prime} 2.76^{\prime \prime}$ & $9^{\circ} 40^{\prime} 10.11 "$ & $N A$ & Ap & & & $1^{\ddagger}$ & $+2 /-1$ & 1.1 & 0.3 & \\
\hline & PNG-16-141a & detrital & $149^{\circ} 23^{\prime} 21.39^{\prime \prime}$ & $9^{\circ} 42^{\prime} 20.09^{\prime \prime}$ & $N A$ & $\mathrm{Zrn}$ & & & $1^{\ddagger}$ & 1 & & & \\
\hline & PNG-16-150b & detrital & $149^{\circ} 17^{\prime} 38.83^{\prime \prime}$ & $9^{\circ} 40^{\prime} 52.12^{\prime \prime}$ & $N A$ & $\mathrm{Zrn}$ & & & $1^{\ddagger}$ & 1 & & & \\
\hline & PNG-16-157b & detrital & $149^{\circ} 5^{\prime} 17.41^{\prime \prime}$ & $9^{\circ} 54^{\prime} 45.84^{\prime \prime}$ & $N A$ & $\mathrm{Zrn}$ & 2.8 & 0.8 & & & & & \\
\hline & PNG-16-171a & detrital & $149^{\circ} 14^{\prime} 59.37^{\prime \prime}$ & $9^{\circ} 42^{\prime} 31.27^{\prime \prime}$ & $N A$ & $\mathrm{Zrn}$ & & & $1^{\ddagger}$ & 1 & & & \\
\hline
\end{tabular}

*: Reference datum AGD1966, AMG Zone 55.

${ }^{a}$ : Refers to circumferential distance from the Mai' iu Fault trace measured on transects parallel to the slip direction (see Supplementary material B. 3 for details).

${ }^{b}$ : Refers to geometric mean zircon U-Pb age. Italicized numbers refer to U-Pb age determined by in-situ dating.

${ }^{c}$ : Refers to fission track central age $\left(^{\dagger}\right)$ or maximum likelihood age $\left(^{\ddagger}\right)$. See Table B.4.

$d$ : Refers to geometric mean $(\mathrm{U}-\mathrm{Th}[-\mathrm{Sm}]) / \mathrm{He}$ age.

$e$ : Inferred time and regime of zircon growth (see text for discussion). ZPRZ - zircon partial retention zone, ZPAZ - zircon partial annealing zones; 'pre' and 'syn' refer to pre- and syn-extensional zircon growth, respectively. Downward pointing arrow signifies below, e.g., syn, $\downarrow$ ZPRZ/ZPAZ means syn-extensional zircon growth below the ZPRZ/ZPAZ

1: Denotes analytical uncertainty only (i.e., single-grain analysis).

2 : Weighted mean age including $2 \sigma$ uncertainty from Chapter 2 


\section{The Goropu Metabasalt and Bonenau Schist}

Zircons are relatively sparse in the Goropu Metabasalt and Bonenau Schist despite the mostly large ( $\sim 10-30 \mathrm{~kg}$ ) samples collected. Two samples of the Goropu Metabasalt (PNG-16-1b, PNG-16-4b) in the footwall of the Mai'iu Fault yielded about 100 zircon crystals each but for most other samples the return was much lower (mostly $<5-20$ grains). Zircons in the Goropu Metabasalt are generally euhedral, slightly pink but clear, range in size between approximately $60-400 \mu \mathrm{m}$, and have aspect ratios typically between 2:1 and 3:1. Zircons from the Bonenau Schist include both euhedral, and rounded zircon grains (PNG-15-18c, Figure 4.5). The euhedral zircons have slightly higher aspect ratios (2:1 and 3:1) and overall larger grain sizes $(>100-250 \mu \mathrm{m})$ than the rounded zircons that generally have smaller aspect ratios (1:1 to $2: 1)$ and overall smaller grain sizes (generally $<150 \mu \mathrm{m})$. Zircons of the latter group are regarded as detrital.

Most zircons have $U$ and Th contents that fall within a relatively narrow range of 100-400 ppm. Although we systematically scanned three thin sections of the two Goropu Metabasalt samples with the highest zircon concentrations (PNG-16-1b, PNG-16-4b) in backscatter electron mode using a microprobe, zircon was nowhere observed in situ. Thus the context of the zircon grains to the Goropu Metabasalt host remains presently unknown. Cathodoluminescence (CL) images of internal surfaces of zircons recovered from the Goropu Metabasalt (PNG-16-1b, PNG-16-4b, PNG-16-169c) and Bonenau Schist (PNG-15-18c, PNG-16-161b) show variable textures (Figure 4.5); these include stripy, oscillatory (faint), patchy and complex. While some crystals reveal core and rim domains (e.g., z-3, z-25, PNG-16-1b; Figure 4.5 ), in most cases such a zonation is not apparent.

Although the protolith age of the Bonenau Schist and the Goropu Metabasalt is known to be Late Cretaceous (Chapter 2; Smith and Davies, 1976), 135 out of $183{ }^{230}$ Th-corrected zircon ${ }^{206} \mathrm{~Pb} /{ }^{238} \mathrm{U}$ dates from the Goropu Metabasalt and the euhedral zircon fraction of the Bonenau Schist range between $\sim 4$ and $\sim 0.2 \mathrm{Ma}$ (Electronic appendix 1, Figure $4.6 \mathrm{a}$ ). Polished zircons dated by the in-situ method yielded ${ }^{230} \mathrm{Th}$-corrected ${ }^{206} \mathrm{~Pb} /{ }^{238} \mathrm{U}$ dates that are mostly $<4 \mathrm{Ma}$ (24 out of 41), both in rims and cores of grains (Figures 4.5 and 4.6b). We have applied a numeric $\mathrm{Pb}_{c}$ correction to the depth-profiled $\mathrm{U}-\mathrm{Pb}$ analyses after Andersen (2002) using Iolite software (Paton et al., 2011) to assess the degree to which the U-Pb analyses were affected by $\mathrm{Pb}_{c}$. The $\mathrm{Pb}_{c^{-}}$and ${ }^{230} \mathrm{Th}$-corrected ${ }^{206} \mathrm{~Pb} /{ }^{238} \mathrm{U}$ values are slightly younger than the $\mathrm{Pb}_{c}$-uncorrected but ${ }^{230} \mathrm{Th}$-corrected ${ }^{206} \mathrm{~Pb} /{ }^{238} \mathrm{U}$ dates and show less scatter (Figure B.14). In some cases, however, this correction resulted in negative $\mathrm{Pb}_{c^{-}}$and ${ }^{230} \mathrm{Th}$-corrected ${ }^{206} \mathrm{~Pb} /{ }^{238} \mathrm{U}$ dates. For the purpose of this study the $\mathrm{Pb}_{c}$-uncorrected values are used. We note, however, that the overall interpretations are not affected by choosing the $\mathrm{Pb}_{c}$ uncorrected values. 


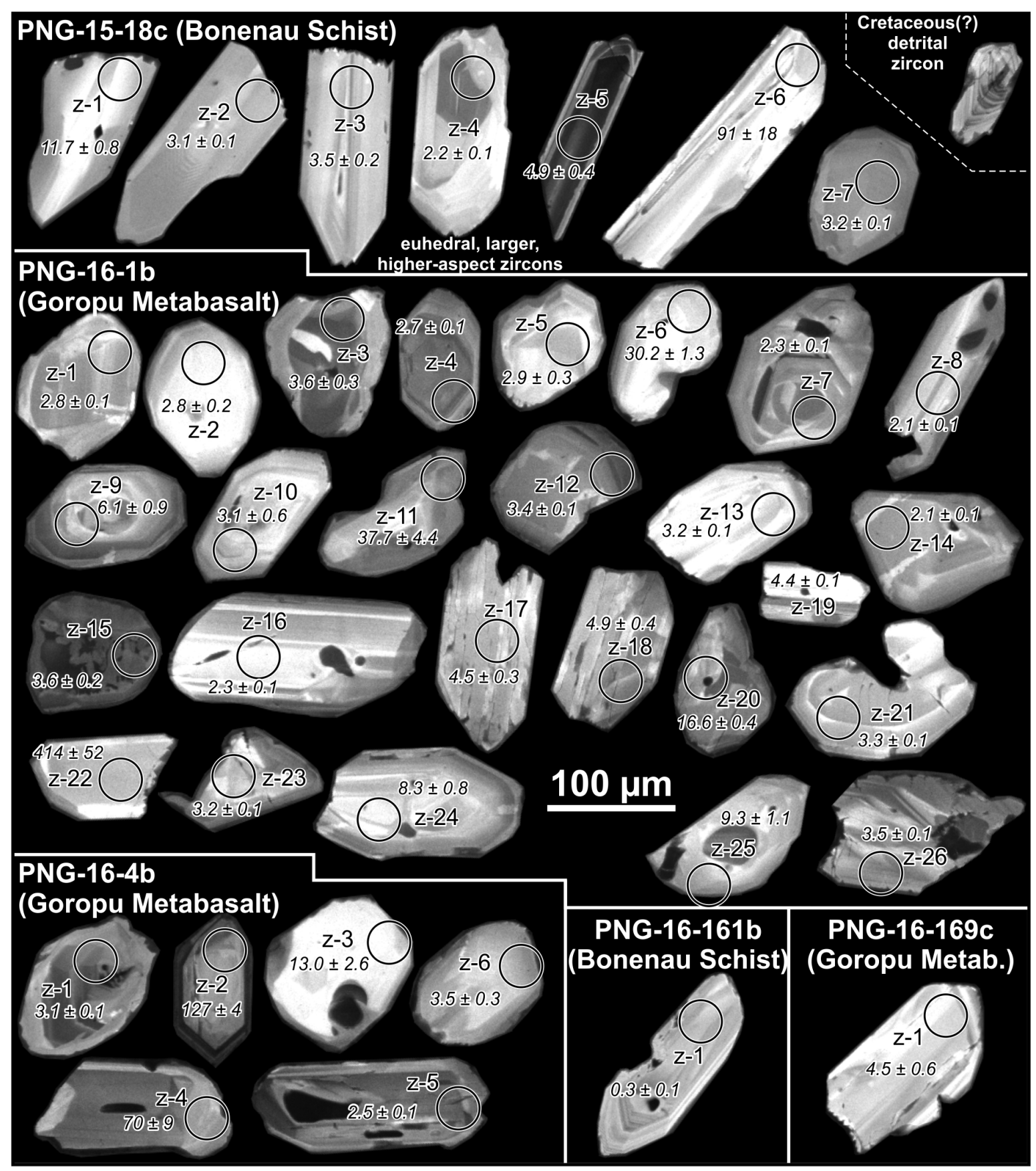

Figure 4.5: Cathodoluminescence (CL) images of zircons from the Bonenau Schist (PNG15-18c, PNG-16-161b) and Goropu Metabasalt (PNG-16-1b, PNG-16-4b, PNG-16-169c). Scale bar $(100 \mu \mathrm{m})$ applies to zircons of each sample. Circles and labels (only suffix z-1, etc.) represent position of laser spot analyses. Numbers represent corresponding ${ }^{206} \mathrm{~Pb} /{ }^{238} \mathrm{U}$ date and 2SE uncertainty. Please note, most $\mathrm{U}-\mathrm{Pb}$ analyses are highly discordant (Figures B.15c and d, Electronic appendix 7). 

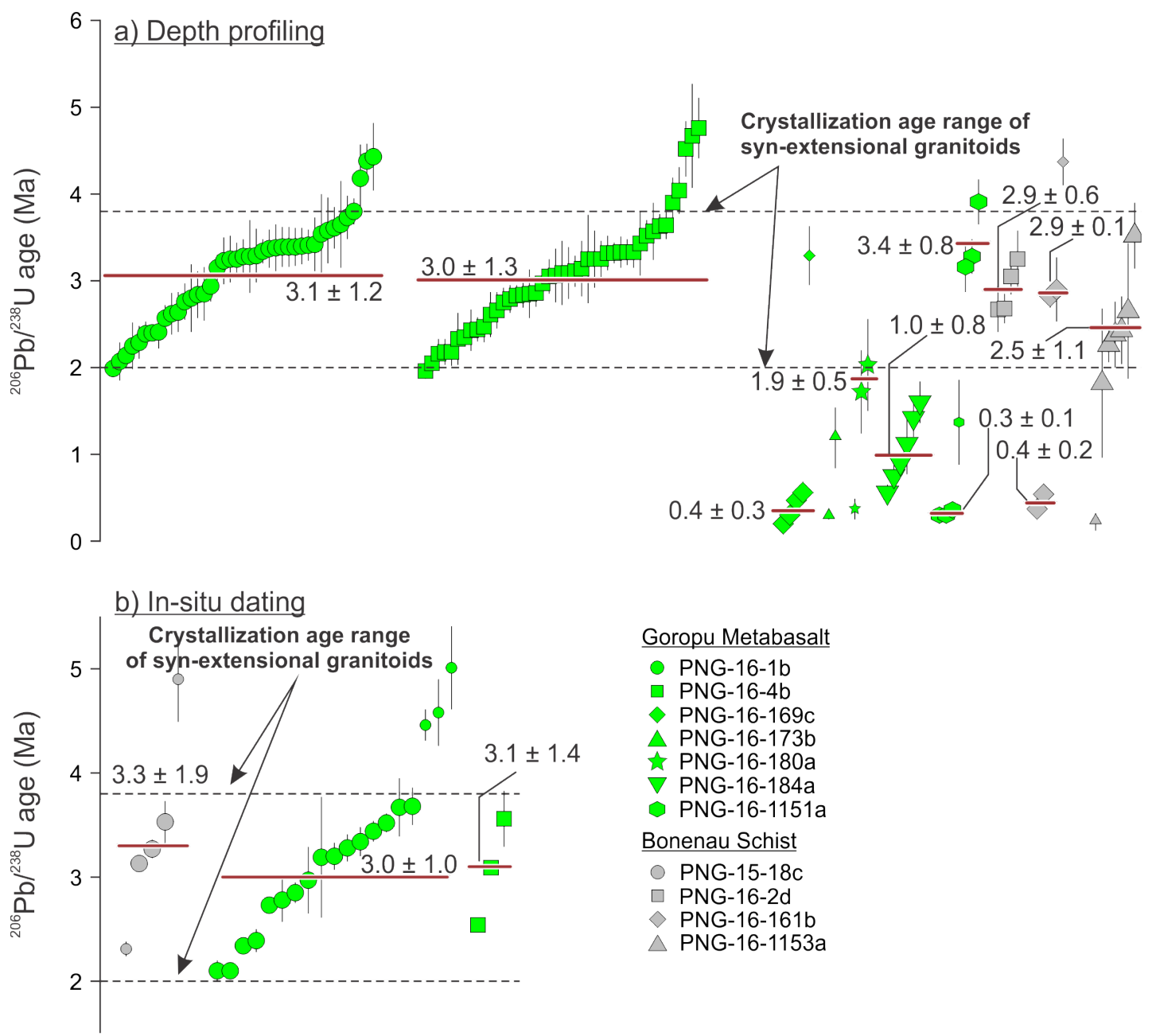

Figure 4.6: Rank-order plot of ${ }^{230} \mathrm{Th}$-corrected zircon ${ }^{206} \mathrm{~Pb} /{ }^{238} \mathrm{U}$ dates from samples of the Goropu Metabasalt and Bonenau Schist dated by (a) depth profiling and (b) the conventional in-situ approach. Error bars of individual analyses correspond to the 2SE confidence interval. Red bars and number labels refer to geometric mean ages $( \pm 2 \sigma)$. Note, two geometric mean ages have been calculated for PNG-16-161b and PNG-16-1151a. Smaller-size symbols in this figure indicate ${ }^{206} \mathrm{~Pb} /{ }^{238} \mathrm{U}$ dates that were excluded from the calculation of the geometric mean age of the respective samples. 
Both depth-profile and in-situ U-Pb analyses of zircons of the Goropu Metabasalt and Bonenau Schist are generally discordant and some appear to be as old as $1137 \pm 47 \mathrm{Ma}$ (Electronic appendices 1 and 7, Figure B.15). From samples where sufficient numbers of zircon U-Pb analyses are available to plot them in a Tera-Wasserburg diagram (PNG-16-1b and PNG$16-4 \mathrm{~b}$ of the Goropu Metabasalt), the upper intercepts of these intersect the Concordia at ${ }^{207} \mathrm{~Pb} /{ }^{206} \mathrm{~Pb} \sim 0.6-0.85$, possibly indicating a ternary $\mathrm{Pb}$ composition consisting of radiogenic, modern $\mathrm{Pb}_{c}$ and geologic $\mathrm{Pb}_{c}$ (Figure B.15). Although we do not attribute geologic significance to the upper-intercept ages, it is important to note that they are not Cretaceous (Figure B.15). Due to the relatively young $\mathrm{U}-\mathrm{Pb}$ dates of these zircons (typically $<4 \mathrm{Ma}$ ), it is possible that some of the discordance is an analytical artefact of low ${ }^{207} \mathrm{~Pb}$ counts. However, if that was the general case then the error ellipses would be expected to be systematically larger in the $\mathrm{y}-\left({ }^{207} \mathrm{~Pb} /{ }^{206} \mathrm{~Pb}\right)$-direction. Although this may apply to some individual analyses, overall the error ellipses do not show systematic elongation in the y-direction (Figure B.15).

$\mathrm{Th} / \mathrm{U}$ values range from 0.1 to 8.8 but most values are between $0.5-3.0$. Excluding ${ }^{230} \mathrm{Th}$ corrected ${ }^{206} \mathrm{~Pb} /{ }^{238} \mathrm{U}$ dates $>5 \mathrm{Ma}$ due to their significant discordance, depth profiling of zircons from two Goropu Metabasalt samples (PNG-16-1b and PNG-16-4b) yielded mean ages of $3.1 \pm 1.2$ and $3.0 \pm 1.3 \mathrm{Ma}$, respectively (Figure 4.6a). This is within error of the mean ages of $3.0 \pm 1.0$ and $3.1 \pm 1.4 \mathrm{Ma}$, respectively, obtained from in-situ dating of zircons from the same two samples (Figure 4.6b). The mean ages of the other Goropu Metabasalt and Bonenau Schist samples range from $3.4 \pm 0.8$ to $0.3 \pm 0.1 \mathrm{Ma}$ (Figure 4.6). Two age populations are apparent from zircons in PNG-16-161b and PNG-16-1151a but this may be a result of the low number of analyses (Figure 4.6a). We regard the ${ }^{230} \mathrm{Th}$-corrected ${ }^{206} \mathrm{~Pb} /{ }^{238} \mathrm{U}$ dates $<1 \mathrm{Ma}$ of zircons of the Goropu Metabasalt and Bonenau Schist as tentative because of their low ${ }^{206} \mathrm{~Pb} /{ }^{238} \mathrm{U}$ signal to noise (i.e., analytical background) ratios. However, confidence in some of the $<1 \mathrm{Ma}{ }^{230} \mathrm{Th}$-corrected ${ }^{206} \mathrm{~Pb} /{ }^{238} \mathrm{U}$ dates arises from the doubledating approach (see below).

For reference, the age range of the syn-extensional granitoids reported in Chapter 2 has been added in Figure 4.6. From these plots it is clear that the majority of ${ }^{230} \mathrm{Th}$-corrected ${ }^{206} \mathrm{~Pb} /{ }^{238} \mathrm{U}$ dates of euhedral zircon from samples of the Goropu Metabasalt and Bonenau Schist span the same age range $(\sim 3.8-2.0 \mathrm{Ma})$ as the dated suite of syn-extensional granitoids near Mt. Suckling (Figure 4.6). The inferred U-Pb MDAs of Bonenau Schist samples PNG-15-18c (103.0 $\pm 5.7 \mathrm{Ma})$ and PNG-16-1153a (71.6 $\pm 3.3 \mathrm{Ma})$ are older than those from the coarser, euhedral zircons in the same samples which yielded mean ages of $3.3 \pm$ 1.9 and $2.5 \pm 1.1 \mathrm{Ma}$, respectively.

Trace elements of zircons (Electronic appendices 5 and 7) from the Goropu Metabasalt, the 


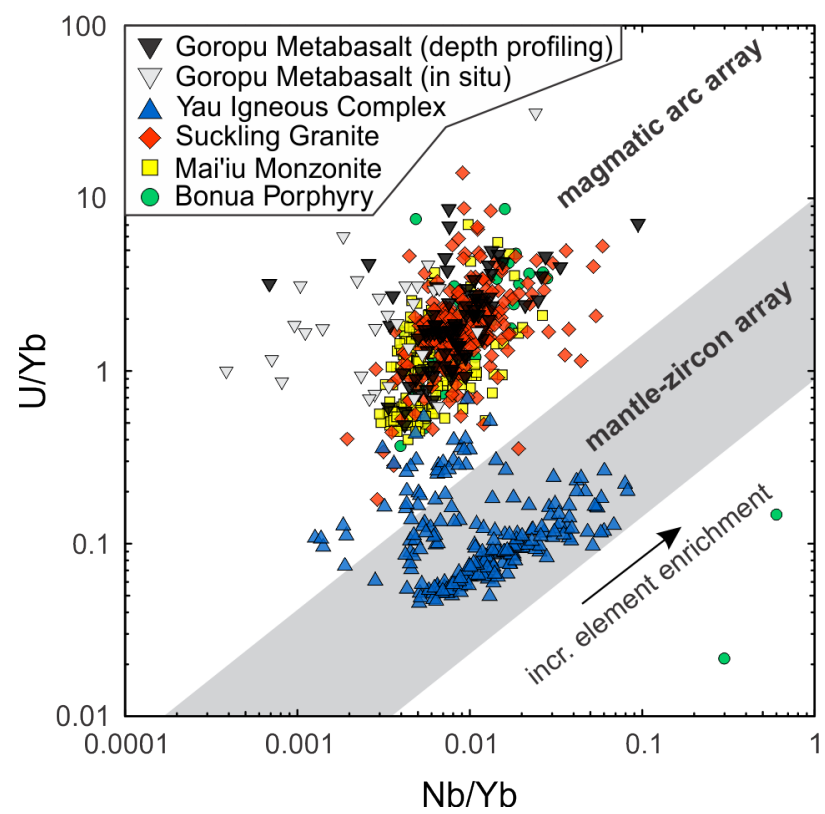

Figure 4.7: Tectono-magmatic discrimination diagram for zircon after Grimes et al. (2015). Note, trace elements of the Goropu Metabasalt (black inverted triangles), Yau Igneous Complex (blue upright triangles), Suckling Granite (red diamonds), Mai'iu Monzonite (yellow squares) and Bonua Porphyry (green circles) were determined by depth-profile analyses. Grey inverted triangles (also Goropu Metabasalt) were measured by laser-ablation splitstreaming (LASS)-ICP-MS analyses.

Yau Igneous Complex and the syn-extensional granitoids of the SDMCC are plotted in a $\mathrm{Nb} / \mathrm{Yb}$ vs. U/Yb diagram (Figure 4.7) after Grimes et al. (2015) to identify their tectonomagmatic affiliation. This diagram reveals that zircons from the Goropu Metabasalt (black and grey inverted triangles, Figure 4.7) have essentially identical $\mathrm{Nb} / \mathrm{Yb}$ and $\mathrm{U} / \mathrm{Yb}$ as the zircons of the Suckling Granite (red diamonds), Mai'iu Monzonite (yellow squares) and Bonua Porphyry (green circles). The $\mathrm{Nb} / \mathrm{Yb}$ and $\mathrm{U} / \mathrm{Yb}$ of the Goropu Metabasalt zircons are, however, distinct from those of the tholeiitic Yau Igneous Complex (blue upright triangles).

\section{U-Pb analysis of zircons from modern stream sediments}

Modern stream sediments were collected in the Mai'iu and Bonua Rivers. Both streams drain Mt. Suckling: the Mai'iu River (PNG-15-76d) to the north, and the Bonua River (PNG-16-157b) to the south (Figure 4.3). Zircons in these stream sediments are generally euhedral. ${ }^{230} \mathrm{Th}$-corrected ${ }^{206} \mathrm{~Pb} /{ }^{238} \mathrm{U}$ dates of detrital zircons from the Mai'iu River (PNG-15-76d) range from $701 \pm 23$ to $1.6 \pm 0.4 \mathrm{Ma}$ (Electronic appendix 1). The ${ }^{230} \mathrm{Th}$ corrected ${ }^{206} \mathrm{~Pb} /{ }^{238} \mathrm{U}$ age spectrum of the Mai'iu River sample is overwhelmingly dominated by the presence of 4-2-Ma-old zircons (Figure 4.8a). The mean age of the ${ }^{230} \mathrm{Th}$-corrected ${ }^{206} \mathrm{~Pb} /{ }^{238} \mathrm{U} \leq 5 \mathrm{Ma}$ is $2.8 \pm 1.2 \mathrm{Ma}$ (Figure 4.3). Only $\sim 7 \%$ of the analyses (20 out of 301) yielded dates $>10 \mathrm{Ma}$, most of which are discordant. One concordant analysis yielded a Cretaceous (114 $\pm 3 \mathrm{Ma}){ }^{206} \mathrm{~Pb} /{ }^{238} \mathrm{U}$ date (Electronic appendix 1). On a kernel density es- 
timation (KDE) diagram, ${ }^{230} \mathrm{Th}$-corrected ${ }^{206} \mathrm{~Pb} /{ }^{238} \mathrm{U}$ dates of PNG-15-76d $<10$ Ma reveal a main adaptive KDE peak at $\sim 3.1$ Ma with a shoulder on the younger side. The probability density function (PDF) of the same sample suggests, however, a bimodal spectrum (Figure 4.8a). In contrast to the KDE, the PDF takes into account the analytical uncertainties of the individual ${ }^{206} \mathrm{~Pb} /{ }^{238} \mathrm{U}$ dates (Vermeesch, 2012).

${ }^{230} \mathrm{Th}$-corrected ${ }^{206} \mathrm{~Pb} /{ }^{238} \mathrm{U}$ dates of zircons from the Bonua River sample PNG-16-157b range from $976 \pm 33$ to $0.2 \pm 0.1 \mathrm{Ma}$ (Electronic appendix 1), but most dates fall within a narrow range of 3-2 Ma (Figure 4.8b). A single discordant ${ }^{207} \mathrm{~Pb} /{ }^{206} \mathrm{~Pb}$ date is $4852 \pm 56$ $\mathrm{Ma}$ (Electronic appendix 1). The mean age of the ${ }^{230} \mathrm{Th}$-corrected ${ }^{206} \mathrm{~Pb} /{ }^{238} \mathrm{U} \leq 5 \mathrm{Ma}$ is 2.8 $\pm 0.8 \mathrm{Ma}$ (Figure 4.3). Only $\sim 5 \%$ of the analyses (12 out of 257 ) yielded ${ }^{230} \mathrm{Th}$-corrected ${ }^{206} \mathrm{~Pb} /{ }^{238} \mathrm{U}$ dates $>10 \mathrm{Ma}$, of which only one gave a near-concordant date; namely $976 \pm 33$ $\mathrm{Ma}$ (Electronic appendix 1). Plotting the ${ }^{230} \mathrm{Th}$-corrected ${ }^{206} \mathrm{~Pb} /{ }^{238} \mathrm{U}$ dates in a KDE diagram reveals that dates $<10$ Ma have a unimodal distribution with a single adaptive KDE and PDF peak at $\sim 2.8 \mathrm{Ma}$ (Figure $4.8 \mathrm{~b}$ ).

The zircon $\mathrm{U}-\mathrm{Pb}$ data sets from the Mai'iu and Bonua Rivers are an excellent example of the influence of the fertility of the source rocks with respect to the content of zircon in the derived sediment. More than $80 \%$ of ${ }^{230} \mathrm{Th}$-corrected ${ }^{206} \mathrm{~Pb} /{ }^{238} \mathrm{U}$ dates in the Mai'iu River (PNG-15-76d), and more than 90\% in the Bonua River (PNG-16-157b) lie in a narrow window of $\sim 4-2 \mathrm{Ma}$ (Figure 4.8) that is essentially indistinguishable from outcrop ages of the Suckling Granite ( 3.8-3.3 Ma) and Mai'iu Monzonite ( 3.0-2.0 Ma). Considering the spatial dominance of the mafic-ultramafic footwall rocks, the extremely high zircon fertility of the Mai'iu Monzonite and Suckling Granite compared to that of the zircon-poor units (Goropu Metabasalt, Bonenau Schist, PUB) is exemplified by the lack of zircon ${ }^{206} \mathrm{~Pb} /{ }^{238} \mathrm{U}$ dates attributable to the latter.

Further, the shape of the adaptive KDE and PDF age spectra (Figure 4.8) is probably a reflection of the drainage divide on the footwall of the SDMCC. For PNG-16-157b, both adaptive KDE and PDF indicate a dominant peak at $\sim 2.8$ Ma. For PNG-15-76d, the PDF shows a clear bimodal spectrum whereas this apparent bimodality is depressed in the adaptive KDE function. Using a slightly lower (constant) bandwidth of 0.30 instead of that suggested by the adaptive KDE (0.39), the bimodality suggested by the PDF is reproduced. While the Mai'iu River drains areas of the Mai'iu Monzonite and Suckling Granite, the Bonua River does not drain the area of the latter (Figure 4.3). The overall younger age of the adaptive KDE and PDF peaks of PNG-16-157b (Bonua River) and its unimodal shape (Figure 4.8b) may suggest that zircons in this sample were almost exclusively derived from erosion of the Mai'iu Monzonite whereas the bimodality of the PDF in PNG-15-76d (Mai'iu River, Figure 4.8a) likely reflects erosion of both the Suckling Granite and Mai'iu Monzonite. 

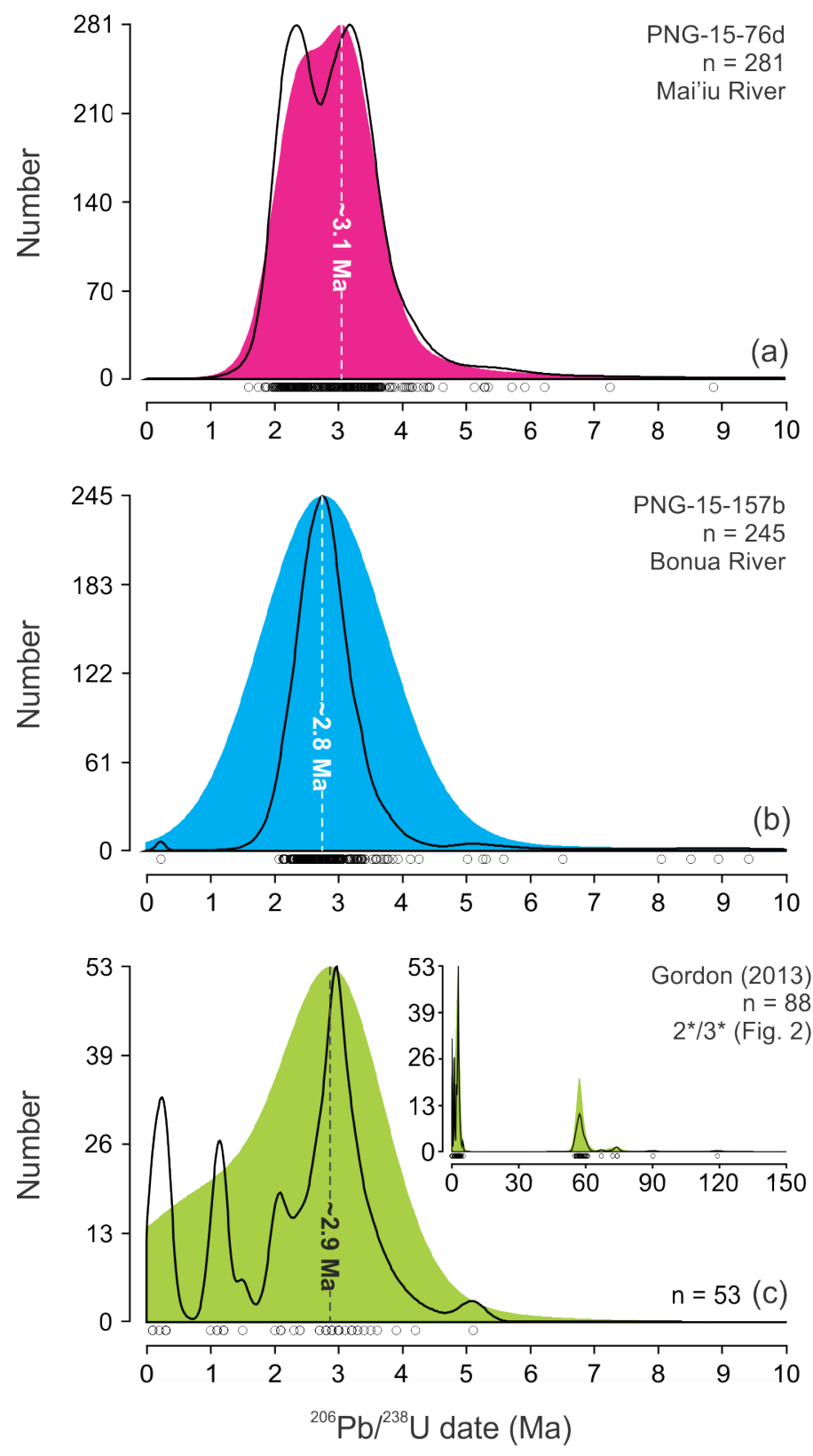

Figure 4.8: Detrital zircon ${ }^{206} \mathrm{~Pb} /{ }^{238} \mathrm{U}$ dates of streams draining the Suckling-Dayman metamorphic core complex for a 0-10 Ma time window. Sediments collected in the Mai'iu (a) and Bonua (b) Rivers are from this study. Detrital zircon from the Nauwandowan River and Dare Creek (c) are from Gordon (2013). Inset in (c) depicts age spectra from 0-150 Ma. Coloured peaks are displayed as adaptive kernel density estimation functions (KDE; Vermeesch, 2012). For reference, the black solid line represents the probability density function. Number labels represent KDE peak values. Black circles refer to individual ${ }^{206} \mathrm{~Pb} /{ }^{238} \mathrm{U}$ dates. 


\subsubsection{Fission-track thermochronometry}

Most zircon crystals from samples of the Goropu Metabasalt (PNG-16-4b, PNG-16-169c, PNG-16-1151a) and the sediments of streams that drain Mt. Dayman (PNG-16-141a, PNG16-150b, PNG-16-171a), and the majority of apatite crystals in samples of the syn-extensional granitoids, either had one or zero spontaneous tracks $\left(\mathrm{N}_{s}\right)$ leading to difficulties in accurate counting and to unreliable errors that are typically underestimated as the fundamental statistics of the central age method no longer apply (Galbraith, 2005). To mitigate this, the maximum likelihood approach presented by Warren-Smith et al. (2016) was employed. This approach allows to estimate $95 \%$ errors for the case $\mathrm{N}_{s}=0, \mathrm{~N}_{i}>1$ (Warren-Smith et al., 2016). Where calculated, the maximum likelihood (ML) ages are given in Table B.4. In all cases, the differences between the central age and the ML age is minimal $(<1$ myr). The uncertainties of the ML ages are, however, significantly larger (Table B.4). In the following, ML ages are used instead of the central ages where they are available. It should be noted, however, that the interpretation of the data is not significantly affected by the choice of the age (central vs. ML age). Radial plots of all samples are presented in Figure B.16.

ZFT and AFT ages from all samples studied here range from $50.6 \pm 6.6$ to $1.0 \pm 0.2 \mathrm{Ma}$ (Tables 4.1 and B.4). ZFT ages from all samples of the Yau Igneous Complex in the footwall of the Mai' iu Fault and clasts in the Gwoira Conglomerate and a modern stream on the hanging wall of the Mai'iu Fault, as well as one footwall sample of the Bonenau Schist (PNG-161153a), are older (50.6-22.2 Ma) than those from footwall samples of the syn-extensional granitoids (3.0-1.0 Ma), Goropu Metabasalt (2.0-1.0 Ma) and other samples of the Bonenau Schist on Mts. Suckling and Dayman (1.9-1.0 Ma) (Table 4.1, Figure 4.3). Apatite from the syn-extensional granitoids yielded AFT ages of $3+11 /-3$ to $1.0 \pm 0.7$ Ma that are essentially indistinguishable from the ZFT ages of the same samples (Table 4.1, Figure 4.3).

To visualize expected cooling trends, which broadly includes increasing FT and (U-Th[$\mathrm{Sm}]$ /He ages with southward circumferential distance from the fault trace, we projected samples of all units that were collected on Mts. Suckling and Dayman onto a single transect parallel to the known slip direction (Figure 4.9). For reference, the mean zircon U-Pb ages depicted in Figure 4.6 have been projected onto that same transect (Figure 4.9a). From this diagram it is evident that the mean zircon $\mathrm{U}-\mathrm{Pb}$ ages of samples from the Goropu Metabasalt and Bonenau Schist closer to the Mai' iu Fault trace are generally younger than those of the syn-extensional granitoids farther away from the fault trace. On this transect, zircon $\mathrm{U}-\mathrm{Pb}$ ages that are older than the 0-5-Ma range of Figure 4.9 are indicated by black arrows pointing upwards (PNG-15-18c, PNG-16-1153a). Similarly the ZFT ages from all units reveal a trend of increasing age southward from the fault trace (Figure 4.9b). A sample of the Bonenau Schist (PNG-16-1153a), with a ZFT age of 22.4 \pm 8.4 Ma (Figure 4.3), falls outside the $<5 \mathrm{Ma}$ age bound (Figure $4.9 \mathrm{~b}$ ). At the same distance from the fault trace, the ZFT ages 
from the syn-extensional granitoids ( $\sim 3-2 \mathrm{Ma}$ ) are much younger than the $\sim 22-\mathrm{Ma}$ ZFT age of PNG-16-1153a. No clear trend in AFT age with distance from the fault is evident (Figure $4.9 \mathrm{c}$ ), and is likely a reflection of the difficulties with accurate counting due to the low $\mathrm{N}_{s}$. No age-altitude relationships are evident in the ZFT and AFT data sets (Figures B.17a and c).

Zircon and apatite in a sediment sample (PNG-15-76d) of the Mai' iu River, which drains the granitoids near Mt. Suckling, yielded ZFT and AFT ages of $2 \pm 1$ and $1+2 /-1 \mathrm{Ma}$, respectively (Table 4.1, Figure 4.3). Zircon in sediments from streams draining the northern flank of Mt. Dayman (PNG-16-141a, PNG-16-150b, PNG-16-171a) all yielded ZFT ages of $1 \pm 1 \mathrm{Ma}$ (Table 4.1). In general, no statistically significant older age components than those described above are recorded in zircons and apatites from streams draining the northern flank of the SDMCC (Figure B.16). The reason for this lies probably in the high zircon fertility in streams draining the syn-extensional granitoids on Mt. Suckling (see above). For streams draining the northern flank of Mt. Dayman, on the other hand, where no syn-extensional granitoids are known to exist (Figure 4.3), resetting of the ZFT system is inferred. No apatite was present in the streams draining Mt. Dayman.

Clasts derived from the Yau Igneous Complex, in the Gwoira Conglomerate just south of the trace of the Gwoira Fault, and in a stream in the hanging wall of the Mai' iu Fault, yielded ZFT ages between $50.6 \pm 6.6$ and $35.4 \pm 6.8 \mathrm{Ma}$ (Table 4.1, Figure 4.3). Clasts of Suckling Granite in the headwaters of the Mai' iu River gave ZFT ages of $1.4 \pm 0.2$ to $1.0 \pm 0.2 \mathrm{Ma}$ (Table 4.1, Figure 4.3).

\subsection{4 (U-Th[-Sm])/He thermochronometry}

$\mathrm{ZHe}, \mathrm{AHe}$ and $\mathrm{MgHe}$ aliquot ages were screened for potential relationships with parameters such as effective uranium (eU), Th/U and grain size (effective spherical radius, ESR) (Tables B.6-B.8). No obvious systematic correlations with these intensive parameters were, however, identified.

$\mathrm{ZHe}$ ages from all samples studied here range from $50.9 \pm 11.3$ to $0.1 \pm 0.2 \mathrm{Ma}$ and $\mathrm{AHe}$ ages from $29.7 \pm 22.8$ to $1.0 \pm 2.2 \mathrm{Ma}$ (Table 4.1, Figure 4.3). The ZHe ages are typically younger than ZFT ages from the same samples. In cases where ZHe ages are older than the ZFT ages, they generally overlap within the stated uncertainties. ZHe ages of the Yau Igneous Complex in the footwall of the Mai'iu Fault, including clasts in the Gwoira Conglomerate, a modern stream on the hanging wall of the Mai'iu Fault, as well as one footwall sample of the Bonenau Schist (PNG-16-1153a) are older (50.9-6.4 Ma) than footwall samples from the syn-extensional granitoids (2.4-1.1 Ma), Goropu Metabasalt (1.3-0.1 Ma) and other samples of the Bonenau Schist on Mts. Suckling and Dayman (2.7-0.4 Ma) (Table 4.1, Figure 4.3). ZHe ages tend to increase with distance from the fault trace (Figure 4.9d). 


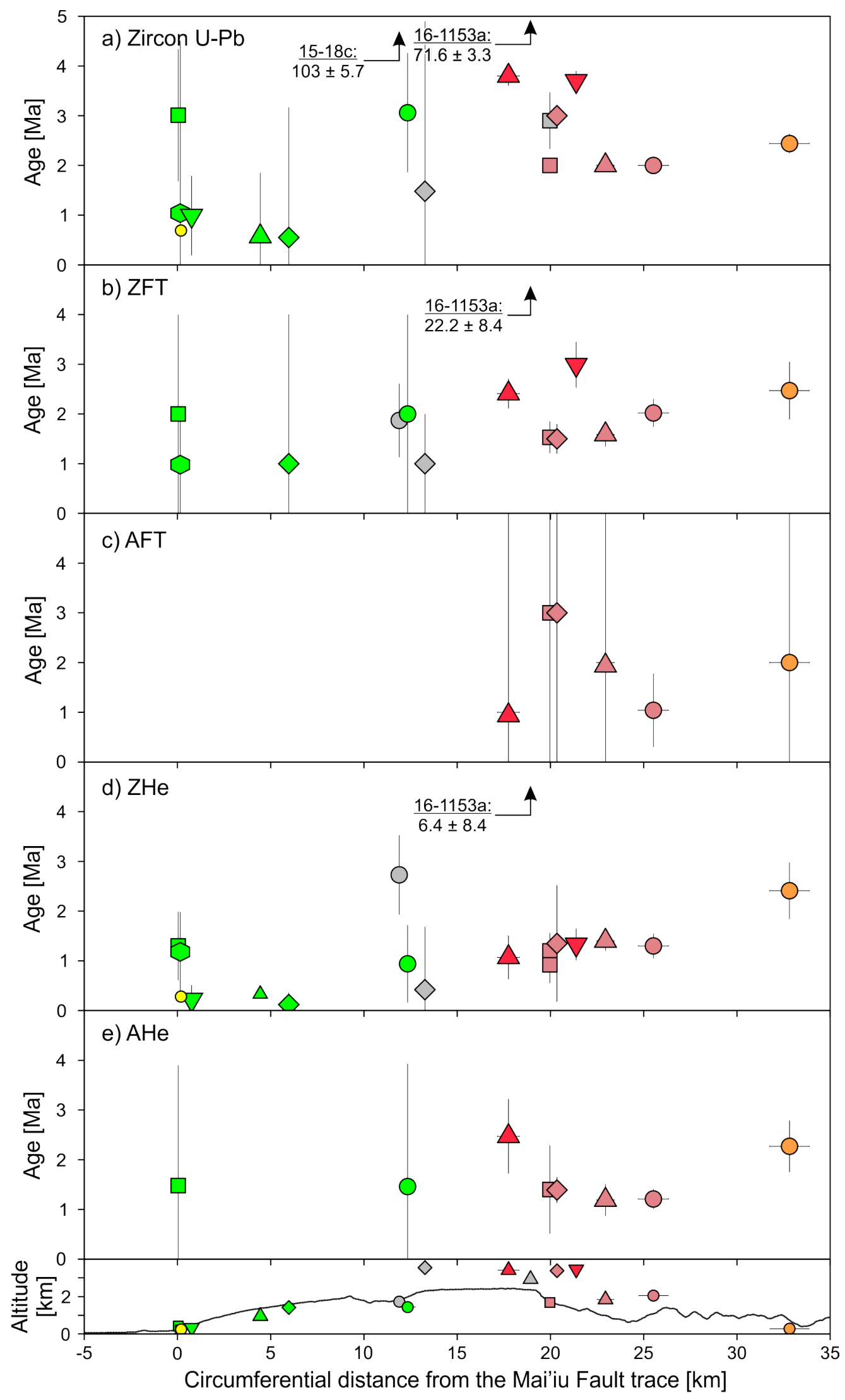

Goropu Metabasalt

- PNG-16-1b

- PNG-16-4b

PNG-16-169c

PNG-16-173b

PNG-16-184a

- PNG-16-1151a

Bonua Porphyry

- PNG-16-157a
Suckling Granite

$\triangle$ PNG-15-61a

$\checkmark$ PNG-15-64a

Mai'iu Monzonite

- PNG-15-66a

PNG-16-2a

PNG-16-159b

$\triangle$ PNG-16-163a
Bonenau Schist

- PNG-15-18c

$\square$ PNG-16-2d

> PNG-16-161e

$\triangle$ PNG-16-1153a

Basaltic andesite dike

- PNG-15-60a 
Figure 4.9: Thermochronometric ages plotted against slip-parallel distance from the Mai'iu Fault trace. Results from (a) zircon U-Pb, (b) ZFT, (c) ZHe, (d) AFT and (e) AHe analyses. Uncertainties are given at the $2 \sigma$ level (see Table 4.1). The panel at the bottom shows the sample locations and the topography of a transect parallel to the slip direction through Mt. Dayman (parallel to B-B' in Figure 4.2). No vertical exaggeration. Distance from the fault trace was constrained from the curved surface of a digital terrain model (Figure B.13).

The ZHe age of Bonenau Schist sample PNG-16-1153a (6.4 \pm 8.4 Ma, Figure 4.9d) falls off this trend, as do the mean zircon U-Pb ages and ZFT ages of this sample of pelitic phyllite (Figures 4.9a and b). A tonalite of the Yau Igneous Complex southeast of Mt. Dayman (PNG-16-1008a) yielded a ZHe age of $30.3 \pm 6.2 \mathrm{Ma}$ and an AHe age of $29.7 \pm 22.8 \mathrm{Ma}$, within error of the ZFT age (Table 4.1, Figure 4.3). No age-altitude relationships are evident in the $\mathrm{ZHe}$ and $\mathrm{AHe}$ data sets (Figures B.17b and d).

The AHe ages are typically younger than the AFT ages of the same samples or overlap within the stated uncertainties. Rare apatite grains separated from two samples of the Goropu Metabasalt (PNG-16-1b and PNG-16-4b) yield AHe ages of $1.5 \pm 2.5$ and $1.5 \pm 2.4 \mathrm{Ma}$ (Table 4.1), respectively. No systematic linear trend of increasing AHe age with distance from the fault trace is evident in Figure 4.9e.

Two multi-grain aliquots of magnetite from a sample of serpentinite (PNG-15-70c) of the PUB on the far eastern side of the SDMCC (Figure 4.3) north of Mt. Masasoru yielded a $\mathrm{MgHe}$ age of $6.5 \pm 1.2 \mathrm{Ma}$ (Table 4.1). The MgHe age is interpreted as marking the timing of magnetite growth (Cooperdock and Stockli, 2016).

Clasts of the Yau Igneous Complex in the Gwoira Conglomerate in the footwall of the Gwoira Fault, in active streams draining the hanging wall of the Mai'iu Fault and in active streams draining southward from the drainage divide yielded ZHe ages of $50.9 \pm 11.3$ to $27.2 \pm 4.1 \mathrm{Ma}$; and AHe ages of $23.8 \pm 6.0$ to $1.0 \pm 2.2 \mathrm{Ma}$ (Table 4.1, Figure 4.3). River clasts derived from erosion of the Suckling Granite in the headwaters of the Mai' iu River yielded ZHe ages of $1.4 \pm 0.6$ to $1.3 \pm 0.6 \mathrm{Ma}$ and AHe ages of $1.7 \pm 1.5$ to $1.5 \pm 0.3 \mathrm{Ma}$ (Table 4.1, Figure 4.3). Apatite in the Mai' iu River at the range front yielded an AHe age of $1.1 \pm 0.3 \mathrm{Ma}$ (Table 4.1, Figure 4.3), similar to AHe ages of the Mai'iu Monzonite on Mt. Suckling $(\sim 1.4-1.2 \mathrm{Ma})$.

Double dating of zircon reveals that most single-grain aliquots adhere to the expected age relationship whereby the (U-Th)/He ages are younger or within error of the ${ }^{230} \mathrm{Th}$-corrected ${ }^{206} \mathrm{~Pb} /{ }^{238} \mathrm{U}$ dates (Figure 4.10a, Table B.9). Those that plot in the "forbidden zone" (Figures $4.10 \mathrm{a}$ and $\mathrm{b}$ ), whereby (U-Th)/He $>\mathrm{U}-\mathrm{Pb}$, have been excluded from the calculation of the geometric mean ages of the respective samples. For reference, the crystallization age of 
Suckling Granite sample PNG-15-61a (Table 4.1), the oldest known syn-extensional granitoid from near the summit of Mt. Suckling, is also plotted in Figure 4.10b. The majority of $\mathrm{ZHe}$ ages from the syn-extensional granitoids, the subpopulation of euhedral zircons of the Goropu Metabasalt and some of the Bonenau Schist on Mts. Suckling and Dayman form a group at 3-1 Ma. The remainder of the zircons from samples of the Goropu Metabasalt, a basaltic andesite dike and one sample of the Bonenau Schist (PNG-16-161b) form a separate group with ZHe single-grain ages of $<0.4 \mathrm{Ma}$ (Figure 4.10c). Many zircons of this latter group of $\mathrm{ZHe}$ ages plot on or close to the $\mathrm{U}-\mathrm{Pb}-(\mathrm{U}-\mathrm{Th}) / \mathrm{He}$ equiline and this is taken as lending some confidence to the young $(<1 \mathrm{Ma}){ }^{230} \mathrm{Th}$-corrected ${ }^{206} \mathrm{~Pb} /{ }^{238} \mathrm{U}$ dates with low signal to noise ratio.

\subsection{5 ${ }^{26} \mathrm{Al} /{ }^{10} \mathrm{Be}$ burial ages}

Three quartz clasts collected in the Gwoira Conglomerate at increasing southward distances from the Gwoira Fault yielded ${ }^{26} \mathrm{Al} /{ }^{10} \mathrm{Be}$ ages between $4.6 \pm 2.9$ and $3.4 \pm 2.1 \mathrm{Ma}(2 \sigma)$ (Figure 4.3, Table B.10). Albeit with large uncertainties, the mean ${ }^{26} \mathrm{Al} /{ }^{10} \mathrm{Be}$ ages decrease southward, consistent with the southward tilt of the Gwoira Conglomerate which exposes older strata to the south.

\subsection{Discussion}

\subsubsection{Euhedral Plio-Pleistocene zircons in the Goropu Metabasalt}

Typically in low-temperature thermochronometric studies of MCCs, it is assumed that the minerals crystallized prior to their later cooling and exhumation as a result of extension and slip on the detachment fault. Here we show that this may not always be the case. Maastrichtian planktonic foraminifera (Smith and Davies, 1976) and inferred 103-72-Ma zircon $\mathrm{U}-\mathrm{Pb}$ depth-profile MDAs from detrital zircons in the Bonenau Schist (Chapter 2) provide strong evidence that the protolith of the Goropu Metabasalt is Late Cretaceous in age. In addition, the Paleocene age (based on weighted mean ages of $260.4-56.6 \mathrm{Ma}$ ) of the Yau Igneous Complex provides a minimum age for the Goropu Metabasalt (Chapter 2). A significant, but puzzling, finding of this study is that most zircons recovered from the Goropu Metabasalt, and the euhedral subpopulation of zircons of the Bonenau Schist yielded PlioPleistocene ${ }^{230} \mathrm{Th}$-corrected ${ }^{206} \mathrm{~Pb} /{ }^{238} \mathrm{U}$ dates, greatly post-dating the inferred Late Cretaceous age of the protolith.

The presence of Plio-Pleistocene zircons in the Goropu Metabasalt is puzzling inasmuch as such minerals would not be expected to occur in rocks with bulk MORB compositions and $\mathrm{Zr}$ 

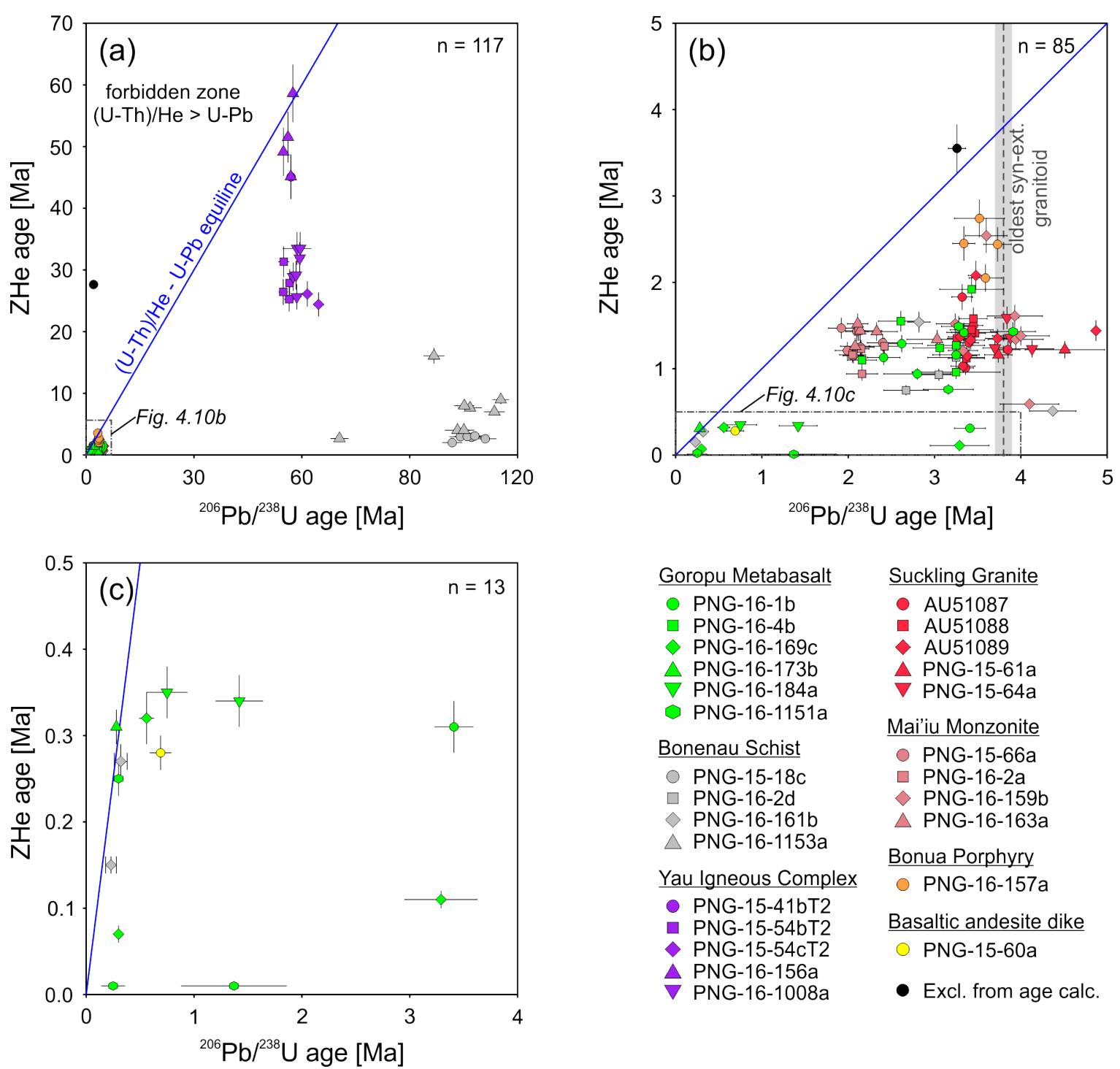

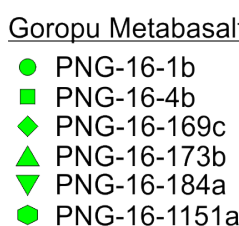

PNG-16-1151a

Bonenau Schist

- PNG-15-18c

$\square$ PNG-16-2d

PNG-16-161b

$\triangle$ PNG-16-1153a

Yau Igneous Complex

- PNG-15-41bT2

- PNG-15-54bT2

- PNG-15-54cT2

$\triangle$ PNG-16-156a

$\nabla$ PNG-16-1008a
Suckling Granite

- AU51087

- AU51088

AU51089

$\triangle$ PNG-15-61a

$\nabla$ PNG-15-64a

Mai'iu Monzonite

- PNG-15-66a

- PNG-16-2a

- PNG-16-159b

$\triangle$ PNG-16-163a

Bonua Porphyry

- PNG-16-157a

Basaltic andesite dike

- PNG-15-60a

- Excl. from age calc.

Figure 4.10: Results from zircon (U-Th) $/(\mathrm{Pb}-\mathrm{He})$ double-dating for increasingly younger time windows. Error bars represent $2 \sigma(\mathrm{ZHe})$ and $2 \mathrm{SE}\left({ }^{206} \mathrm{~Pb} /{ }^{238} \mathrm{U}\right)$ uncertainties. Where not visible, error bars are smaller than the size of the symbol. Blue solid line is the (U-Th)/He$\mathrm{U}-\mathrm{Pb}$ equiline. Black-filled symbols were rejected from the calculation of the geometric mean age because they violate the fundamental relationship of $\mathrm{U}-\mathrm{Pb} \geq \mathrm{ZHe}$. 
contents of $\sim 80-115$ ppm (Chapter 2; Smith, 2013) according to zircon saturation thermometry (Boehnke et al., 2013; Watson and Harrison, 1983). Although zircon may crystallize in evolved late-stage melts in MOR settings, this almost exclusively happens in coarse grained oxide-rich gabbros and tonalites (Schaltegger and Davies, 2017, and references therein); for example potentially in the quartz-gabbros and tonalites of the Yau Igneous Complex.

Alternatively, original zircons of Cretaceous age could have lost $\mathrm{Pb}$ and thus record the timing of metamorphism. Such a process has been shown to affect radiation-damaged zircons that are particularly susceptible to alteration, even at a low-metamorphic grade (Hay and Dempster, 2009). The rather low to moderate U and Th (generally 100-400 ppm) concentrations, the euhedral shape and clarity and the apparently magmatic zonation of zircons from the Goropu Metabasalt and the euhedral subpopulation of the Bonenau Schist (e.g., PNG16-1b: z-4, z-10, z12; Figure 4.5), as well as the absence of sieve-like textures typically associated with radiation damage (e.g., Chen and Zhou, 2017) are inconsistent with this interpretation. They do not support wholesale $\mathrm{Pb}$ loss by volume diffusion or dissolution and re-precipitation (Hay and Dempster, 2009). Thermal resetting of the U-Pb system in zircons by volume diffusion at greenschist-facies conditions relevant to the Goropu Metabasalt samples is unlikely (Möller et al., 2002; Villa and Hanchar, 2017). Furthermore, no Cretaceous upper intercepts were observed in Tera-Wasserburg diagrams from samples of the Goropu Metabasalt (PNG-16-1b, PNG-16-4b, Figures B.15a, b and d).

We argue, then, that the zircons in the Goropu Metabasalt were not derived from the basaltic protolith but were introduced via magmatic-hydrothermal fluids (sensu lato). This interpretation is supported by the zircons having trace element signatures that are identical to those of the Plio-Pleistocene syn-extensional granitoids (Figure 4.7) in the Mt. Suckling area; moreover, the signatures are distinct from those of the Paleocene tholeiitic Yau Igneous Complex that formed probably in a MORB setting. Finally, most zircons from the Goropu Metabasalt yielded ${ }^{230} \mathrm{Th}$-corrected ${ }^{206} \mathrm{~Pb} /{ }^{238} \mathrm{U}$ dates that overlap with the U-Pb crystallization ages ( 3.8-2.0 Ma) of the syn-extensional granitoids (Figure 4.6, Chapter 2).

Collectively, we interpret the above observations to indicate that the zircons in the Goropu Metabasalt grew as a result of the same magmatic pulse that produced the syn-extensional granitoids near Mt. Suckling. The exact origin and nature of the zircons in the Goropu Metabasalt, however, remains obscure, as they were nowhere observed petrographically in any of the samples of this unit and no dikes of granitic material were observed anywhere in the footwall. A possible host for the Plio-Pleistocene zircons in the Goropu Metabasalt may be veins (unrecrystallized quartz veins, quartz-actinolite veins, deformed albite-rich veins with subordinate quartz, calcite veins, post-mylonitic epidote and prehnite veins) that were observed by Little et al. (2019) in the mylonitic and non-mylonitic rocks of the metabasaltic 
footwall of the Mai'iu Fault. The same argument also applies to euhedral zircons separated from the Bonenau Schist with aspect ratios of 2:1 to 3:1 and Plio-Pleistocene ${ }^{230}$ Th-corrected ${ }^{206} \mathrm{~Pb} /{ }^{238} \mathrm{U}$ dates of $\leq 4 \mathrm{Ma}$ (Figure 4.6).

\subsubsection{Expanding the spatial coverage of the $\mathrm{U}-\mathrm{Pb}$ age record}

Because of the dense rainforest cover and inaccessibility of large parts of the footwall of the SDMCC, it is unknown whether igneous rocks with ages between those of the Paleocene Yau Igneous Complex ( 60.4-56.6 Ma) and the Plio-Pleistocene granitoids in the Mt. Suckling area ( 3.8-2.0 Ma) intruded the footwall of the SDMCC. Stream sediments allow us to further increase the spatial coverage of our sampling. Sediments from modern streams draining Mt. Suckling are dominated by ${ }^{230} \mathrm{Th}$-corrected zircon ${ }^{206} \mathrm{~Pb} /{ }^{238} \mathrm{U}$ dates between $\sim 4-2 \mathrm{Ma}$ (Figures 4.3 and 4.8) and lack evidence for older intrusions. Although we analysed in total about 500 zircons from the Mai'iu and Bonua Rivers, it is possible that we missed other intrusions if their zircon fertility was low compared to those of the Suckling Granite and Mai'iu Monzonite.

East of Mt. Dayman, $\mathrm{Pb}_{c}$-corrected zircon ${ }^{206} \mathrm{~Pb} /{ }^{238} \mathrm{U}$ dates reported in an unpublished thesis (Gordon, 2013) from the Dare Creek and Nauwandowan River draining Mt. Dayman and the Gwoira Conglomerate (2*, 3*; Figure 4.3) show a young population with an adaptive KDE mode at $\sim 2.9 \mathrm{Ma}$, slightly younger than the peak suggested by the PDF of the same sample (Figure 4.8c). Zircons from this population have been described as commonly stubby to rounded with evidence of late to post-magmatic poorly zoned rims (Gordon, 2013). We infer that zircons of this population are derived from erosion of the Goropu Metabasalt, having ages consistent with those that we determined for this unit. In contrast to zircons from the Mai'iu and Bonua Rivers, several older age components ( $\sim 57 \mathrm{Ma}, \sim 67-119 \mathrm{Ma}, \sim 288 \mathrm{Ma})$ are apparent in this dataset on a KDE diagram of $\mathrm{Pb}_{c}$-corrected zircon ${ }^{206} \mathrm{~Pb} /{ }^{238} \mathrm{U}$ dates from the Nauwandowan River and Dare Creek (Figure 4.8c).

Based on zircon $\mathrm{U}-\mathrm{Pb}$ ages (Chapter 2), we attribute the adaptive KDE mode at $\sim 57 \mathrm{Ma}$ to reflect erosion of the Yau Igneous Complex and the scattered Cretaceous ${ }^{206} \mathrm{~Pb} /{ }^{238} \mathrm{U}$ dates ( $\sim 67-119 \mathrm{Ma}$ ) to erosion of the Bonenau Schist. The Cretaceous zircons sampled by Gordon (2013) are relatively small $(30-50 \mu \mathrm{m})$ and reveal oscillatory zoning, similar to the detrital zircons that we observed from the Bonenau Schist (Figure 4.5, top right corner). As is the case for the Mai' iu and Bonua Rivers that drain Mt. Suckling, no zircon ${ }^{206} \mathrm{~Pb} /{ }^{238} \mathrm{U}$ dates between $\sim 5 \mathrm{Ma}$ and $\sim 55 \mathrm{Ma}$ have been identified in the study of Gordon (2013). Collectively, the detrital datasets of this study and that of Gordon (2013) lack evidence for Cenozoic thermotectonic events that post-date the formation of Goropu Metabasalt and the intrusion of the gabbros and tonalites of the Yau Igneous Complex in the Cretaceous-Paleocene, and pre-date the extensional reactivation of the OSF in the Pliocene. 


\subsubsection{Evidence for a preserved zircon PRZ and PAZ}

The positions of the bases of a fossil ZFT PAZ and a ZHe PRZ on the northern flank of the SDMCC may be indicated by the ages of two samples from the Bonenau Schist (PNG-1518c, PNG-16-1153a) at distances of $\sim 12-19 \mathrm{~km}$ from the modern fault trace (Figure 4.3). The ZFT and ZHe ages of sample PNG-16-1153a are $22.2 \pm 8.4$ and $6.4 \pm 8.4 \mathrm{Ma}$ (Figure 4.9, Table 4.1), respectively. These results suggest incomplete resetting of Cretaceous ( 115-70 Ma, Table B.9) ages prior to exhumation. The oldest single-grain ZHe age of PNG-16-1153a is $16.1 \pm 1.3 \mathrm{Ma}$, indicating almost complete resetting of this grain.

In apparent disagreement with the above inference, a RSCM-derived peak metamorphic temperature for sample PNG-15-5a near the summit of Mt. Dayman (Figure 4.3) is $294 \pm 30^{\circ} \mathrm{C}$, much higher than would be anticipated for partial resetting of the ZHe system. At this temperature, the ZHe ages would be expected to be fully reset (base of zircon PRZ at $200^{\circ} \mathrm{C}$; Wolfe and Stockli, 2010). It is, however, possible that the temperatures inferred from the crystallinity of CM may have been affected by deformation processes during exhumation of the Mai'iu Fault plane (e.g., Barzoi, 2015; Kirilova et al., 2018; Nakamura et al., 2015). Other than temperature, factors that may influence the crystallinity of CM are original chemical composition, the microtexture of the kerogen precursor and strain energy (Bustin et al., 1995). We therefore prefer a maximum pre-extensional temperature of $200 \pm 20^{\circ} \mathrm{C}$ for the summit area of Mt. Dayman, as suggested by the maximum position of the base of the zircon PRZ (Figure 4.3).

Some 7-8 km to the north of PNG-16-1153a, the ZHe (2.7 $\pm 0.8 \mathrm{Ma})$ age of Bonenau Schist PNG-15-18c appears to be fully reset (Figures 4.3 and 4.9). This is consistent with peak metamorphic temperatures of $328 \pm 33$ and $330 \pm 40^{\circ} \mathrm{C}$ derived from RSCM of two nearby samples of the Bonenau Schist. It is also consistent with the pumpellyite-out isograd of Little et al. (2019) (Figure 4.3). Zircons from the same sample yielded a ZFT age of $1.9 \pm$ $0.7 \mathrm{Ma}$ indicating that it may be fully reset. Ten zircons of Bonenau Schist sample PNG15-18c (Figure 4.3) were dated by FT analyses, seven of which were also dated by U-Pb. Like zircons from the Goropu Metabasalt, the in-situ U-Pb analyses suggest syn-extensional (re-)crystallization of the zircons at less than $\sim 4 \mathrm{Ma}$ (Figure 4.5 ). Those with higher ${ }^{230} \mathrm{Th}-$ corrected ${ }^{206} \mathrm{~Pb} /{ }^{238} \mathrm{U}$ dates are inferred to have incorporated excess $\mathrm{Pb}_{c}$ because the U-Pb analyses are highly discordant (only $\sim 5-9 \%$ concordance between ${ }^{207} \mathrm{~Pb} /{ }^{235} \mathrm{U}$ and ${ }^{206} \mathrm{~Pb} /{ }^{238} \mathrm{U}$ systems; Electronic appendix 7). Because of the Plio-Pleistocene ${ }^{230}$ Th-corrected ${ }^{206} \mathrm{~Pb} /{ }^{238} \mathrm{U}$ dates of PNG-15-18c, the ZFT age $(1.9 \pm 0.7 \mathrm{Ma})$ derived from the same crystals cannot be ascribed to complete resetting of a Cretaceous protolith age. The RSCM-derived temperature of $328 \pm 33^{\circ} \mathrm{C}$ (PNG-15-18a) from the same outcrop supports, however, the notion that sample PNG-15-18c is fully reset with respect to both the ZFT and ZHe systems. 
If our interpretation of these ZHe ages is correct, then PNG-15-18c is the only sample in our dataset in which zircons were fully reset and demonstrably cooled from temperatures above the closure isotherm of the ZHe system (i.e., from below the PRZ). Although with uncertainty, we infer that this also applies to the ZFT system. We suggest that the bases of the zircon PAZ and PRZ lie between the fully (PNG-15-18c) and the partially (PNG-161153a) reset samples (Figure 4.3). Closer sampling will be required to determine the bases of the zircon PAZ and PRZ more precisely.

\subsubsection{Evidence for pre-extensional cooling of the Yau Igneous Complex}

Southeast of Mt. Dayman, a tonalite of the Yau Igneous Complex (PNG-16-1008a) has ZFT and ZHe ages of $37.1 \pm 4.6$ and $30.3 \pm 6.2 \mathrm{Ma}$ (Figure 4.3), respectively, within the range of the ZFT and ZHe ages ( $\sim 50.9-27.2 \mathrm{Ma})$ of erosional products of the Yau Igneous Complex found in the Gwoira rider block and in a stream in the hanging wall of the Mai'iu Fault. These ages are interpreted as a cooling event pre-dating extensional slip on the Mai'iu Fault (see below), during which the samples cooled to temperatures of less than $\sim 130^{\circ} \mathrm{C}$ (the lower temperature limit of the zircon PRZ; Wolfe and Stockli, 2010). The AHe age of PNG-16-1008a is $29.7 \pm 22.8 \mathrm{Ma}$, suggesting that this rock has passed through temperatures of $<80^{\circ} \mathrm{C}$ prior to final exhumation by slip on the Mai'iu Fault. In contrast to the ZFT and $\mathrm{ZHe}$ ages of the same sample (PNG-16-1008a), the large $2 \sigma$ uncertainty of this AHe age may indicate residence in the apatite PRZ. Partial to near-complete resetting of the AHe system in rocks of the Yau Igneous Complex is also supported by AHe ages of the erosional products of this unit (clasts in the Gwoira rider block and streams in the footwall and hanging wall of the Mai' iu Fault) that range from $23.8 \pm 6.0$ to $1.0 \pm 2.2 \mathrm{Ma}$ (Figure 4.3).

The proximity of PNG-16-1008a to the unmetamorphosed rocks of the Kutu Volcanics $\sim 13$ $\mathrm{km}$ south of the inferred Mai'iu Fault trace below the Gwoira Conglomerate (Figure B.13) indicates lesser burial prior to extensional exhumation compared to rocks on the northern flank of Mt. Dayman. This is also consistent with the lower pre-extensional temperatures of $<80^{\circ} \mathrm{C}$ inferred from the incomplete resetting of the AHe system of the Yau Igneous Complex. Yet, at about $12 \mathrm{~km}$ from the Mai'iu Fault trace, the ZHe system in Bonenau Schist sample PNG-15-18c on Mt. Dayman is fully reset, implying pre-extensional temperatures in excess of $\sim 200^{\circ} \mathrm{C}$.

The ZFT and ZHe ages of the Yau Igneous Complex are clearly not related to the PlioceneRecent extensional phase. These Oligocene ZFT and ZHe ages do, however, overlap with the later stages of the Peninsular Orogeny (van Ufford and Cloos, 2005) and may hence record cooling related to the tectonic activity along the collision zone of the rifted Australian margin in the south with the CVA in the north. 


\subsubsection{Timing of the onset of extension}

ZFT, ZHe, AFT and AHe ages from samples of the Suckling Granite, Mai'iu Monzonite, Bonua Porphyry, Goropu Metabasalt and the euhedral subpopulation of the Bonenau Schist in the footwall of the Mai'iu Fault on Mts. Suckling and Dayman are essentially all $\leq 3$ Ma. These ages are interpreted to record extensional cooling of the footwall of the SDMCC by slip on the Mai'iu Fault and provide a minimum estimate for the timing of the onset of extension. Zircons from these samples crystallized syn-extensionally, however, and the implications on the calculation of a slip rate are further discussed below.

Based on the U-Pb age of the oldest known sample of the Suckling Granite $(3.8 \pm 0.2$ Ma, PNG-15-61a), it has been argued that extensional reactivation of the Mai'iu Fault had occurred by that time (Chapter 2). If any older syn-extensional granitoids exist on Mt. Suckling, we found no evidence for them in samples of detrital zircons from the present-day Mai'iu and Bonua Rivers where the vast majority of ${ }^{230} \mathrm{Th}$-corrected ${ }^{206} \mathrm{~Pb} /{ }^{238} \mathrm{U}$ dates fall within the 4-2 Ma zircon $\mathrm{U}-\mathrm{Pb}$ range (Figure 4.8). A minimum age for the onset of motion on the Mai'iu Fault can also be derived from the onset of subaerial exposure of the footwall rocks of the SDMCC. The ${ }^{26} \mathrm{Al} /{ }^{10} \mathrm{Be}$ burial ages of three quartz clasts from the Gwoira Conglomerate derived from the erosion of the footwall suggest that extension had begun by the age of the oldest and stratigraphically deepest sample; that is by $4.6 \pm 2.9 \mathrm{Ma}$. The large uncertainties of the ${ }^{26} \mathrm{Al} /{ }^{10} \mathrm{Be}$ burial ages (Table B.10) hinder any precise age determination. At face value, however, the mean ${ }^{26} \mathrm{Al} /{ }^{10} \mathrm{Be}$ burial ages suggest a Pliocene depositional age for the syn-tectonic Gwoira Conglomerate by extension and associated slip on the Mai'iu Fault (Figure 4.3).

An independent estimate for the timing of the onset of extension can be deduced from the finite slip magnitude of the Mai' iu Fault (30-45 km; Little et al., 2019; Mizera et al., 2019) and the Holocene dip-slip rate of Webber et al. (2018). Using their mean value of $11.7 \mathrm{~mm} / \mathrm{yr}$, this calculation yields an estimate for the age of the onset of extension of $\sim 3.8-2.6 \mathrm{Ma}$. The calculation assumes, however, a constant slip rate in time and relies on the knowledge of the finite slip magnitude.

Taken together, the age constraints from the crystallization ages of the syn-extensional granitoids, the extensional cooling recorded by low-temperature thermochronometry, the depositional age of the syn-tectonic Gwoira Conglomerate, and the backwards projection of the known Holocene slip rate, suggest that footwall exhumation had started by $\sim 4 \mathrm{Ma}$. Note that this inference for the onset of slip on the Mai' iu Fault post-dates the suggested 8.4 Ma age for the beginning of Woodlark extension (Taylor and Huchon, 2002), but is similar to the $4.1-0.4$ Ma timing of gneiss dome exhumation in the D'Entrecasteaux Islands (Baldwin et al., 1993; Baldwin and Ireland, 1995; DesOrmeau et al., 2014; Fitzgerald et al., 2008; 
Gordon et al., 2012) (Figure 4.1).

\subsubsection{Apparent dip-slip rate of the Mai'iu Fault}

Fault slip rates based on thermochronometry may be estimated from the inverse slope of the mineral age with distance on slip-parallel footwall traverses as long as (1) isotherms are stationary (2) cooling of footwall rocks is only attributable to vertical exhumation caused by fault slip and (3) the thermochronometers were completely reset and had zero age before extension (Foster and John, 1999; Ketcham, 1996; Stockli, 2005; Wells et al., 2000).

The first assumption is difficult to evaluate, but two-dimensional conductive thermal modelling by Ketcham (1996) suggests that isotherms (that are relevant to the ZFT and ZHe thermochronometers) approach dynamic steady-state after $\sim 1-2$ myr after the onset of extension. Above we inferred that extension by slip on the Mai'iu Fault had initiated by $\sim 4$ Ma and that the FT and (U-Th[-Sm])/He thermochronometers from the Mai'iu Fault footwall rocks yielded ages that are mostly $\leq 3 \mathrm{Ma}$, thus approaching dynamic steady state. Although shown to also influence the shape and spacing of isotherms at depth, the effects of topography and erosion (Ehlers and Farley, 2003; Mancktelow and Grasemann, 1997; Robinson et al., 2010; Stüwe et al., 1994) are likely to be negligible in the case of the SDMCC, especially for the ZFT and ZHe system due to their higher temperature sensitivities compared to those of the AFT and AHe thermochronometers that are more susceptible to near-surface processes. The smooth topography of the SDMCC (i.e., the preserved fault plane) implies that erosion was insignificant in the exhumation process.

The second assumption, i.e., cooling of footwall rocks is only attributable to vertical exhumation caused by fault slip, is probably not entirely true. This is because isostatic uplift and flexural unloading of the footwall of the SDMCC (Little et al., 2019; Mizera et al., 2019) would have contributed to cooling (Wells et al., 2000). The degree to which flexural unloading of the footwall of the SDMCC contributed to the overall cooling signal of the FT and $(\mathrm{U}-\mathrm{Th}[-\mathrm{Sm}]) / \mathrm{He}$ systems is, however, thought to be negligible compared to that caused by slip on the Mai'iu Fault.

The third assumption, a zero age prior to extension, is probably violated by most zircons in samples of the Suckling Granite, Mai'iu Monzonite, Bonua Porphyry, Goropu Metabasalt and two samples of the Bonenau Schist (PNG-16-2d, PNG-16-161b) on the footwall of the SDMCC (Figure 4.3) because they have syn-extensional U-Pb ages. Although they are inferred to record cooling of the SDMCC footwall, they are not cooling ages sensu Foster and John (1999) from which a slip rate can be deduced. This is elaborated in the following section. 
Based on data from Al-in-amphibole and -biotite barometry (Chapter 2), the Suckling Granite and Mai'iu Monzonite intruded the footwall syn-extensionally at $\sim 3.8-2.0 \mathrm{Ma}$ at depths of $\sim 2-15 \mathrm{~km}$. Although it is expected that the geothermal gradient increased since the onset of extension at $\sim 4 \mathrm{Ma}$, the syn-extensional geothermal gradient would have had to be on the order of $\sim 100-40$ and $\sim 60-25^{\circ} \mathrm{C} / \mathrm{km}$ by $\sim 2 \mathrm{Ma}$, respectively, for the ZFT and the ZHe ages of the Mai'iu Monzonite and Suckling Granite to record cooling through the closure isotherms (i.e., $\sim 300^{\circ} \mathrm{C}$ for ZFT and $\sim 200^{\circ} \mathrm{C}$ for ZHe system). Such high syn-extensional geothermal gradients far exceed the present-day regional geotherm in the Woodlark Rift (see below). Cooling rates of the syn-extensional granitoids, inferred from their zircon $\mathrm{U}-\mathrm{Pb} \mathrm{vs}$. ZFT ages and ZFT vs. ZHe ages, respectively, indicate rapid cooling from $\sim 650^{\circ} \mathrm{C}$ (approximate crystallization temperature of the granitoids) to temperatures of $\sim 300^{\circ} \mathrm{C}$ (ZFT system) at rates of $\sim 750-200^{\circ} \mathrm{C} / \mathrm{myr}$ and from $\sim 300$ to $\sim 200^{\circ} \mathrm{C}$ (ZHe system) at rates of $\sim 700$ $50^{\circ} \mathrm{C} / \mathrm{myr}$. We attribute these exceedingly high cooling rates recorded in the syn-extensional granitoids on Mt. Suckling to conductive cooling from their intrusion into a cooler part of the crust. Hence, the ZFT and ZHe ages of the syn-extensional granitoids cannot be solely ascribed to cooling of the footwall through exhumation but record an additional component of conductive cooling.

Lastly, although an overall trend of increasing age with distance from the fault is apparent for the ZFT and ZHe systems in Figure 4.9, this trend mimics that exhibited by the zircon mean $\mathrm{U}-\mathrm{Pb}$ ages. Calculating a regression line that takes into account uncertainties in both the age and the distance from the fault trace (after York, 1969), and that is based on all samples on this transect, would result in exceedingly high dip-slip rates of $160 \pm 1542$ and $23 \pm$ $8 \mathrm{~km} / \mathrm{myr}(2 \sigma)$ for the ZFT and ZHe systems, respectively. Assuming that slip on the Mai'iu Fault had initiated at $\sim 4 \mathrm{Ma}$ and that the slip rate was constant in time, the lower of these, the ZHe-based dip-slip rate of $23 \pm 8 \mathrm{~km} /$ myr would imply slip magnitudes of $\sim 60-120 \mathrm{~km}$ considering the $2 \sigma$ uncertainty of this rate; this is much higher than previous estimates (30$45 \mathrm{~km}$ ) from Little et al. (2019) and Mizera et al. (2019). Based on the arguments presented above, we suggest that the ZFT and ZHe ages of the syn-extensional granitoids cannot be used to calculate a slip rate.

While cooling ages would be expected from the structurally deepest portions of footwall (those closest to the Mai' iu Fault trace), the zircons possibly grew at a shallower crustal level than would be expected from their sample location; that is, a mismatch between the structural sample depth (as determined by the distance of the sample to the Mai'iu Fault trace) and the depth at which the zircons of the respective samples may have (re-)crystallized. Although the zircon crystallization depth is unknown, we can infer it using the dip-slip rate of Webber et al. (2018) and assuming a fault dip of $30^{\circ}$ and a constant slip rate through time. This calculation indicates that zircons from the Goropu Metabasalt on the northern flank of 
Mts. Suckling and Dayman may have (re-)crystallized at depths between about -1 to $20 \mathrm{~km}$. Cooling through the closure isotherms of the ZFT and ZHe systems is probable (see discussion below) for the zircons that may have crystallized at depths closer to the maximum of this range $(\sim 20 \mathrm{~km})$, those with $\mathrm{U}-\mathrm{Pb}$ mean ages $\geq 3 \mathrm{Ma}$, and those closest to the fault trace (i.e., PNG-16-4b and the older subpopulation of zircons of PNG-16-1151a).

For the other samples of the Goropu Metabasalt and the Bonenau Schist with mean U-Pb ages of $\sim 2.9-0.3 \mathrm{Ma}$ and farther south of the fault trace (PNG-16-2d, PNG-16-161b, PNG16-169c, PNG-16-173b, PNG-16-184, PNG-16-1151a), we infer that the zircons likely grew during exhumation of the footwall of the SDMCC and after the rocks passed through the closure isotherms of the ZFT and ZHe systems. If that were the case, then the ZFT and $\mathrm{ZHe}$ ages of these samples could not be used for the calculation of a slip rate because the crystallization depths may not equate to the structural depths of the samples. As for the synextensional granitoids on Mt. Suckling, high syn-extensional geothermal gradients would be required $\left(\sim 140-15^{\circ} \mathrm{C} / \mathrm{km}\right)$ to allow complete resetting of the ZFT and ZHe systems, respectively, and subsequent cooling through the closure isotherm.

In contrast, due to their low closure temperatures, the AFT $\left(\sim 120^{\circ} \mathrm{C}\right)$ and $\mathrm{AHe}\left(\sim 80^{\circ} \mathrm{C}\right)$ systems likely record cooling with the exhuming footwall. Unfortunately, the relatively large uncertainties in our AFT and AHe datasets make them unsuitable for the calculation of a slip rate. Based on the Cretaceous ${ }^{206} \mathrm{~Pb} /{ }^{238} \mathrm{U}$ dates $(\sim 108-102 \mathrm{Ma})$ of the same zircon grains that were double-dated by the $(\mathrm{U}-\mathrm{Th}) / \mathrm{He}$ method $(\sim 3.1-2.0 \mathrm{Ma})$, we infer that only zircons from PNG-15-18c (Figure 4.3) were completely reset and consequently cooled through the closure isotherms of the zircon PRZ. This also may apply to zircon from PNG-16-4b and the older zircon subpopulation of PNG-16-1151a (Figure 4.3) as discussed above. Thus, only zircons from these three samples may fulfil the pre-requisites (cf. Foster and John, 1999) for the calculation of an apparent slip rate.

The inverse of the slope on a plot of apparent ZHe age versus circumferential distance parallel to the slip direction of the Mai'iu Fault plane yields an apparent dip-slip rate of $8.1 \pm 1.3$ $\mathrm{km} / \mathrm{myr}(2 \sigma)$ (Figure 4.11). This dip-slip rate was estimated from linear least-squares fitting after York (1969) for uncorrelated errors that accounts for uncertainties in both the measured $\mathrm{ZHe}$ age and the measured distance. This rate is regarded as a minimum estimate due to the potential effects of the advection of isotherms (cf. Ketcham, 1996) after the onset of extension at $\sim 4 \mathrm{Ma}$. Furthermore, it has been argued that, at face value, the intrusion depths inferred from Al-in-amphibole and -biotite barometry of the Mai'iu Monzonite and Suckling Granite would require a dip-slip rate of $>12 \mathrm{~km} / \mathrm{myr}$ in order to exhume these granitoids from pre-extensional depths of $\sim 2-8 \mathrm{~km}$ to their present-day position $\sim 20-25 \mathrm{~km}$ south of the Mai'iu Fault trace and elevations of up to $\sim 3.4 \mathrm{~km}$ (Chapter 2). 


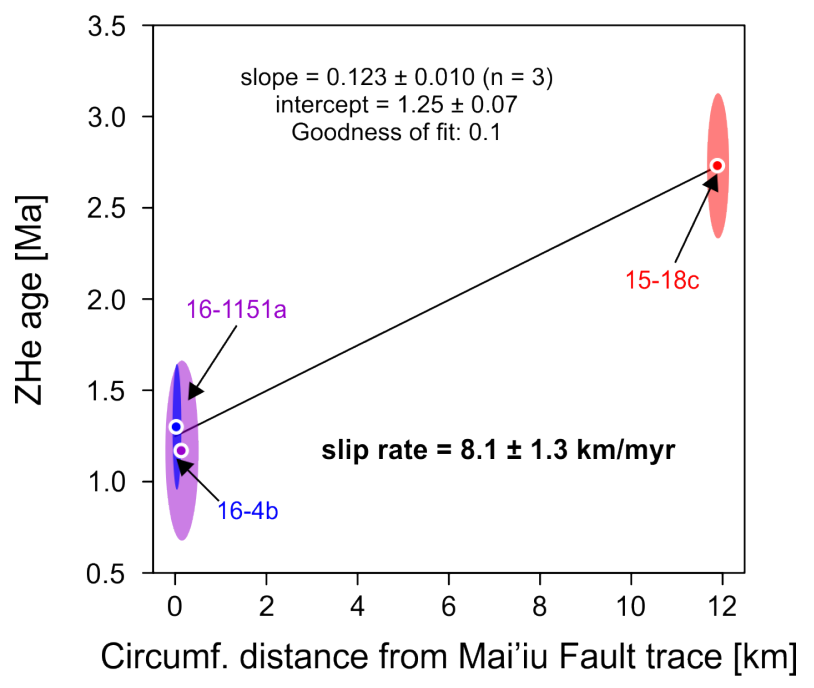

Figure 4.11: Zircon (U-Th)/He (ZHe) ages plotted against slip-parallel circumferential distance from the Mai'iu Fault trace. The calculation of the slope was carried out using linear least-squares fitting after York (1969) for uncorrelated errors (Cantrell, 2008) that accounts for uncertainties in both the measured $\mathrm{ZHe}$ age and the measured circumferential distance.

Our constraints on the long-term dip-slip rate of the Mai'iu Fault agree well with those determined by Wallace et al. (2014) and Webber et al. (2018). The agreement of these dipslip rates determined independently from four methods (campaign GPS, cosmogenic nuclide dating, thermochronometry, restoration of intrusion depths) over three different time scales (annual, millennial, million-year) suggests that the Mai'iu Fault was slipping at cm-per-year rates since $\sim 3 \mathrm{Ma}$.

\subsubsection{The initial dip of the Mai'iu Fault}

In order to successfully reconstruct the initial fault geometry, several inherent assumptions must be met: (1) the pre-extensional geothermal gradient is known or can be calculated, (2) the samples are on or close to the exhumed fault plane and have maintained their relative position during faulting, and (3) substantial lateral variations in the thermal gradient can be ruled out (Foster and John, 1999; Pease et al., 1999).

The modern-day regional geothermal gradient in the Woodlark Rift is about $20-23^{\circ} \mathrm{C} / \mathrm{km}$ (based on drill hole and heat flow data presented in Garside and Stoen, 1973; Martinez et al., 2001; Stoen and Garside, 1973). The near-bottom-hole temperatures from the Goodenough No.1 $\left(\sim 70^{\circ} \mathrm{C}\right)$ and Nubiam No.1 $\left(\sim 66^{\circ} \mathrm{C}\right)$ exploration wells were, however, not corrected for the possible cooling effect of the drilling mud used. From the mud log accompanying the well completion record of Goodenough No.1 (Garside and Stoen, 1973) it appears that drill mud temperatures were relatively constant $\left(\sim 46-49^{\circ} \mathrm{C}\right)$ at depths between $\sim 1524$ and $\sim 2347 \mathrm{~m}$, respectively. The temperature reading $\left(70^{\circ} \mathrm{C}\right)$ in Goodenough No.1 was taken on 
the last day of operation at $2649 \mathrm{~m}$ (not at the bottom of the hole at $2835 \mathrm{~m}$ ) at about the same depth where the temperature of the drilling mud was last measured (1-3 days earlier) at $\sim 57^{\circ} \mathrm{C}$, possibly indicating that the final temperature reading $\left(70^{\circ} \mathrm{C}\right)$ was influenced by the cooler temperatures of the drilling mud. Thus, it is likely that the modern geotherms inferred from the near-bottom-hole temperatures of the Goodenough No.1 and Nubiam No.1 wells are minimum values.

Because it is expected that since the onset of extension the geothermal gradient would have increased in the Woodlark Rift, however, these present-day constraints are probably maximum estimates of the pre-extensional geotherm. That is because the westward propagation of the Woodlark spreading centre (since $\sim 6 \mathrm{Ma}$; Taylor et al., 1999) and removal of the lithosphere coupled with adiabatic upwelling of asthenospheric mantle (Abers et al., 2016; Eilon et al., 2015) would have caused an increase in crustal temperatures over time. For the calculation of the initial dip, we assume pre-extensional geothermal gradients of $10-20^{\circ} \mathrm{C} / \mathrm{km}$.

With respect to the second assumption, although the footwall is cut by steep brittle cm-to-mscale strike-slip and normal faults striking approximately parallel to the Mai'iu Fault trace, that have up to several tens of meters of slip (Mizera et al., 2019), overall movement on the low-angle normal fault has not been disrupted by these low-offset faults (Little et al., 2019).

The third assumption is difficult to assess. We speculate that the diameters of the Suckling Granite and Mai'iu Monzonite on Mt. Suckling (Figure 4.3) are insufficiently voluminous to have significantly disturbed the geothermal gradient across the entire strike-parallel length of the SDMCC. Calk and Naeser (1973) showed that titanite FT (partial annealing zone at $\sim 265-310^{\circ} \mathrm{C}$; Coyle and Wagner, 1998) ages within $\sim 50 \mathrm{~m}$ from a basalt intrusion with a diameter of $\sim 100 \mathrm{~m}$ were fully-partially reset but approached background values at $75 \mathrm{~m}$ from the intrusion, a distance equating to less than twice the diameter of basaltic intrusion. Further evidence from two-dimensional modelling revealed that heat supplied from the intrusion of plutons will be confined to within a few half-widths of the magmatic body (Hanson and Barton, 1989; Jaeger, 1964).

Thus, it is unlikely that the paleo-temperature estimates (see below) along a slip-parallel transect on the northern flank of Mt. Dayman would have been affected by the syn-extensional intrusions near Mt. Suckling. East of Mt. Suckling no voluminous extension-related intrusions have been observed in the field (Davies and Smith, 1974). Recent, but volumetrically small, magmatic activity along the Mai'iu Fault trace is attested by four or five $<1$-m-scale basaltic andesite dikes of probably Quaternary age (Little et al., 2019; Daczko et al., 2011) and an historic eruption at the Goropu Crater (Baker, 1946) (Figure 4.2). 
In order to constrain the slip-parallel paleo-temperature gradient along the exhumed Mai'iu Fault plane, from which the initial dip of the Mai'iu Fault can be estimated assuming a pre-extensional geotherm (see below), we considered paleo-temperature constraints from low-temperature thermochronometry (the bases of the zircon PAZ and PRZ) and RSCM presented above, as well as published temperature constraints for the extensional shear zone mylonites (Daczko et al., 2009) (Figure 4.12). Because the exact positions of the exhumed bases of the zircon PAZ and PRZ in the case of the SDMCC are poorly known, we assigned uncertainties of $\pm 3.5 \mathrm{~km}$ to the position of each of the two paleo-isotherms in the $\mathrm{x}$-direction (Figure 4.12); $3.5 \mathrm{~km}$ is about half of the circumferential distance parallel to the slip-direction between PNG-15-18c (the minimum distance of the zircon PAZ from the fault trace) and PNG-16-1153a (the maximum distance of the zircon PRZ from the fault trace) (Figure 4.3). For reference, the pumpellyite-out isograd of Little et al. (2019) is shown but it is not included into the calculation because it has no formal uncertainty associated with it (it solely indicates a maximum temperature of $\sim 375^{\circ} \mathrm{C}$; Beiersdorfer and Day, 1995).

Also excluded from the calculation of the paleo-temperature gradient are two temperature estimates derived from RSCM (PNG-15-5a, PNG-16-16a). Sample PNG-15-5a has been discarded because the RSCM-derived temperature $\left(294 \pm 30^{\circ} \mathrm{C}\right)$ is significantly higher than would be expected from the temperature inferred from the base of the zircon PRZ $\left(\sim 200^{\circ} \mathrm{C}\right)$ near the summit area of Mt. Dayman (Figure 4.3). Also, the peak-metamorphic temperature of PNG-16-16a has been excluded from the calculation of the paleo-temperature gradient as it is anomalous in the context of the other RSCM data available (Figures 4.3 and 4.4).

In order to account for errors in both $\mathrm{x}$ - and y-variables, i.e., the circumferential fault planeparallel distance from the Mai' iu Fault and the paleo-temperature estimates, a weighted leastsquares regression analysis after York (1969) was performed. The calculated best-fit paleotemperature gradient, i.e., pre-unroofing down-dip thermal gradient of the exposed footwall (Wernicke, 1995), is $9.7 \pm 2.2^{\circ} \mathrm{C} / \mathrm{km}(2 \sigma$; brown solid line and semi-transparent error envelope in Figure 4.12) which intersects the y-axis (paleo-temperature) at $421 \pm 16^{\circ} \mathrm{C}$. Because we included two samples (PNG-14-15a, PNG-16-27a) from the eastern flank of Mt. Dayman where the pre-extensional temperatures might have been lower than those on a slip-parallel transect across the northern flank of Mt. Dayman, we regard this paleo-temperature gradient as a minimum estimate.

A mean annual paleo-surface temperature of $27 \pm 3^{\circ} \mathrm{C}$ was assumed, based on a continuous 12-myr-record (Zhang et al., 2014) at ODP site $806\left(0^{\circ} 19 .^{\prime} \mathrm{N}, 159^{\circ} 21.7^{\prime} \mathrm{E}\right)$ from the Ontong Java Plateau (Figure 4.1, inset) in the Pacific Ocean (Berger, 1993), the closest longterm record currently available for this region. This temperature is similar to, albeit slightly higher than, the mean annual temperatures of $22-26^{\circ} \mathrm{C}$ for the central-southeastern Papua 


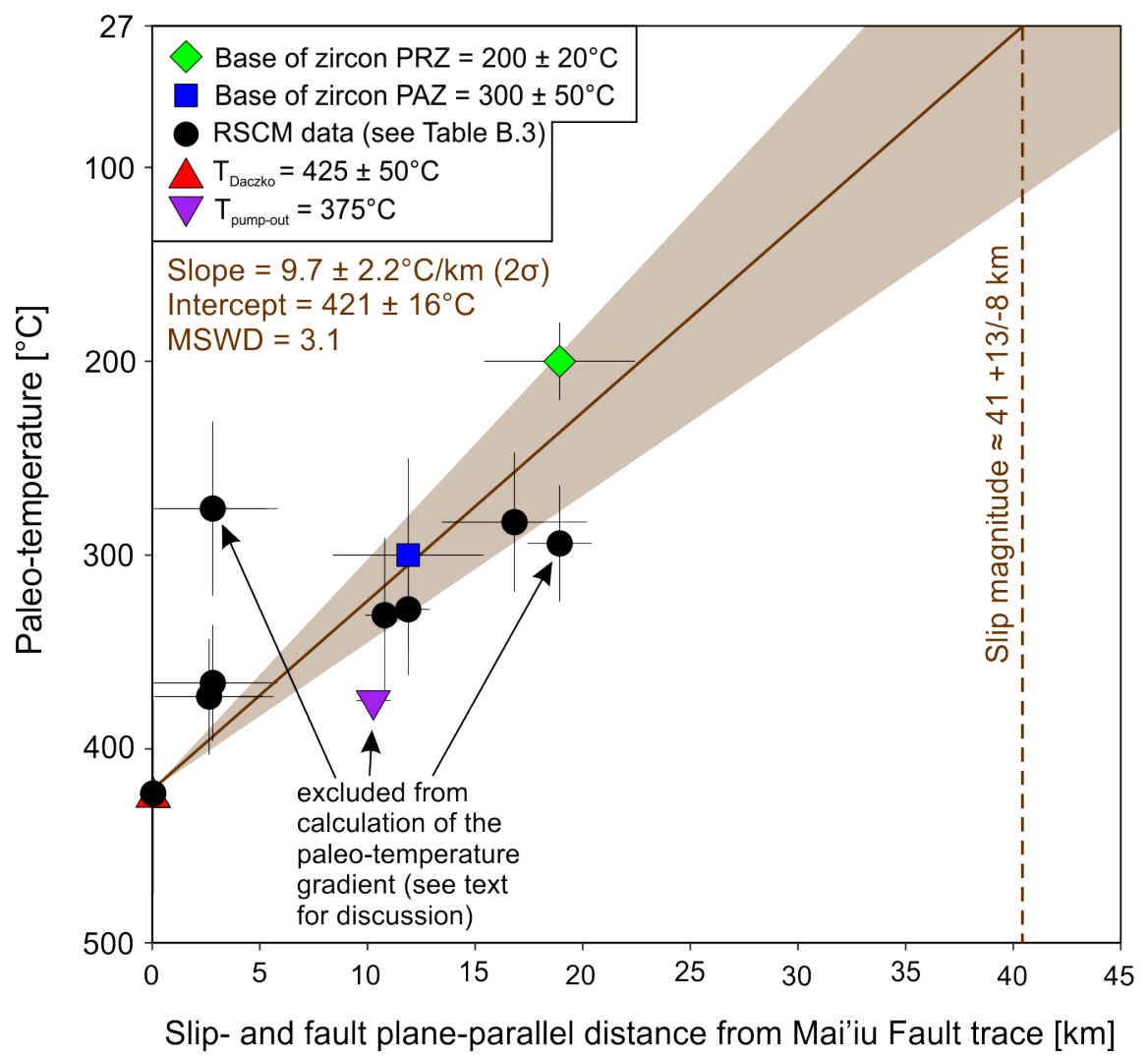

Figure 4.12: Reconstruction of the fault-plane parallel paleo-temperature gradient of the exhumed Mai'iu Fault surface. Paleo-temperature estimates are inferred from the bases of the zircon PAZ $\left(300 \pm 50^{\circ} \mathrm{C}\right)$ and PRZ $\left(200 \pm 20^{\circ} \mathrm{C}\right)$, data from RSCM (see Table B.3) and the published metamorphic temperature of $425 \pm 50^{\circ} \mathrm{C}$ from the extensional shear zone mylonites (Daczko et al., 2009). Because of the uncertainty in the positions of bases of the zircon PAZ and PRZ, the base of the PAZ has been estimated at the minimum (at PNG-1518c) circumferential distance from the Mai'iu Fault trace; and the base of the PRZ at the maximum (at PNG-16-1153a) circumferential distance. The surface temperature of $27^{\circ} \mathrm{C}$ was inferred from the 12-myr-record of Zhang et al. (2014) at ODP site 806. The brown solid line and semi-transparent polygon represent the mean paleo-temperature gradient and the $2 \sigma$ error envelope, respectively. The linear least-squares regression analysis of the best-fit line was carried out after York (1969) for uncorrelated errors using a MS Excel spreadsheet after Cantrell (2008) that accounts for uncertainties in both the paleo-temperature estimates and the measured circumferential distance from the Mai'iu Fault trace. For the calculation of the best-fit line, input errors in the paleo-temperature variable were \pm 30 and $\pm 50^{\circ} \mathrm{C}$ for the Kouketsu et al. (2014) and Beyssac et al. (2002) calibrations, respectively. Where the $1 \sigma$ uncertainty of the mean RSCM-derived temperatures exceeded the reported uncertainties, the $1 \sigma$ uncertainty was used instead. $1 \sigma$ output uncertainties of the y-axis intercept and the slope of the best-fit line were recast to $2 \sigma$ uncertainties. 
New Guinea region measured over the period 1961-1990 (National Center for Atmospheric Research Staff, 2019). The intercept of the paleo-temperature gradient with the paleo-surface temperature $\left(27^{\circ} \mathrm{C}\right)$ allows for an estimate of the slip magnitude of the Mai' iu Fault, which is $\sim 41+13 /-8 \mathrm{~km}$. This value is on the higher end of the range of 30-45 km inferred by Little et al. (2019). Because we suggest that the paleo-temperature gradient is a minimum, the total slip of $41+13 /-8 \mathrm{~km}$ is likely to be an overestimate.

For the estimation of the initial dip of the Mai'iu Fault we employed equation 1 outlined by Wernicke (1995):

$$
\theta=\sin ^{-1} \frac{d T / d w}{d T / d z}
$$

whereby $d T / d w$ and $d T / d z$ refer to the slip-parallel down-dip paleo-temperature gradient and the vertical pre-extensional geothermal gradient, respectively. Assuming pre-extensional geothermal gradients ranging from 10 to $20^{\circ} \mathrm{C} / \mathrm{km}$, this calculation yields an average of $44 \pm$ $28^{\circ}(2 \sigma)$, with an absolute minimum of $26^{\circ}$. Thus, the $2 \sigma$ uncertainty is misleading inasmuch it suggests dip angles as low as $16^{\circ}$. The relationship of the calculated paleo-temperature gradient and the assumed pre-extensional geothermal gradient is also shown in Figure 4.13. In this diagram, the average initial dip of the Mai'iu Fault (yellow circle) lies close to $\sim 45^{\circ}$ for the range of pre-extensional geothermal gradients considered here. The grey box depicts the range of possible values based on the $2 \sigma$ uncertainty of the mean of the slip-parallel paleo-temperature gradient $\left(9.7 \pm 2.2^{\circ} \mathrm{C} / \mathrm{km}\right)$ and the $10-20^{\circ} \mathrm{C} / \mathrm{km}$ range of pre-extensional geotherms.

For pre-extensional geothermal gradients ranging from $10-20^{\circ} \mathrm{C} / \mathrm{km}$, the paleo-temperature constraints in Figure 4.12 convert to paleo-depths of $\sim 10-43 \mathrm{~km}$. From the pumpellyiteactinolite facies mineral assemblages of the footwall of the SDMCC, that locally contain aragonite, lawsonite and blue amphibole (Davies, 1980), Daczko et al. (2009) inferred peak metamorphic pressures of 6-9.5 kbar and maximum burial depths of 20-30 km for the rocks in the footwall of the SDMCC. Thus, for the lowest pre-extensional geotherm regarded here $\left(10^{\circ} \mathrm{C} / \mathrm{km}\right)$ the conversion from paleo-temperatures to paleo-depths will exceed the maximum burial depths suggested by Daczko et al. (2009), possibly indicating that the preextensional geothermal gradient was $>10^{\circ} \mathrm{C} / \mathrm{km}$. The peak metamorphic pressures of 6-9.5 kbar have, however, not yet been confirmed by mineral compositional data (Daczko et al., 2009) and the pressure-to-depth conversion assumes a known crustal density. With regard to the crustal density, the upper plate of the Mai'iu Fault consist of the mafic-ultramafic rocks of the PUB (Davies and Jaques, 1984), suggesting average rock densities of about 3000-3200 $\mathrm{kg} / \mathrm{m}^{3}$. Its thickness north of the SDMCC on the coastal plain and the Cape Vogel Peninsula is, however, poorly known as it is covered there by up to $\sim 5 \mathrm{~km}$ of Miocene-Pleistocene sedimentary rocks (Smith and Davies, 1976) (Figure 4.2). 


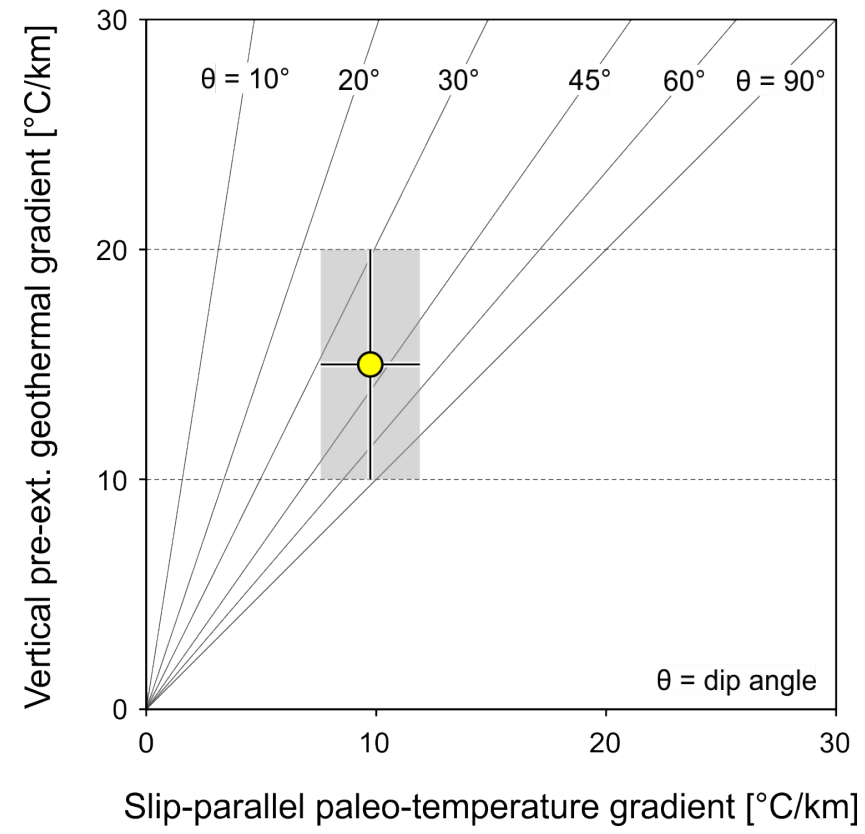

Figure 4.13: Plot of slip-parallel paleo-temperature gradient versus vertical pre-extensional geothermal gradient for the Mai'iu Fault after Wernicke (1995). The average initial dip of the Mai'iu Fault (yellow circle) and the error bars are based on the mean slip-parallel paleotemperature gradient $\left(9.7 \pm 2.2^{\circ} \mathrm{C} / \mathrm{km}\right)$ and the $2 \sigma$ uncertainty of the mean, and the assumed range of pre-extensional geothermal gradients of $10-20^{\circ} \mathrm{C} / \mathrm{km}$. The grey semi-transparent box displays the range of possible initial dip angles based on the values provided above. Grey dashed lines represent the upper and lower limit of the range of assumed pre-extensional geotherms. 
Presently dipping $20-22^{\circ}$ at the surface, our average estimate of the initial dip of the Mai'iu Fault of $\sim 44^{\circ}$ implies $>20^{\circ}$ of back-rotation of the Mai'iu Fault since the onset of extension. Only in the extreme case of a $20^{\circ} \mathrm{C} / \mathrm{km}$ pre-extensional geothermal gradient and the lower $2 \sigma$ bound (i.e., $7.5^{\circ} \mathrm{C} / \mathrm{km}$ ) of the slip-parallel paleo-temperature gradient is the initial $\operatorname{dip}<30^{\circ}$. This would, however, imply that the regional pre-extensional geotherm has not changed much in the last $\sim 4 \mathrm{Ma}$, a scenario that is unlikely given the active and rapidly evolving nature of the Woodlark Rift (Abers et al., 2016; Eilon et al., 2015; Smith and Milsom, 1984; Wallace et al., 2014; DesOrmeau et al., 2018). Our mean estimate of the initial dip is consistent with independent constraints from the restoration of bedding-fault cut-off angles of the lower strata of the Gwoira Conglomerate against the inactive Mai'iu Fault in the Gwoira rider block and a paleomagnetic study on the Goropu Metabasalt from the northern flank of Mt. Dayman that constrained the initial dip of the Mai'iu Fault at $\sim 44^{\circ}$ and 41-49 ${ }^{\circ}$, respectively (Little et al., 2019; Watson, 2019). Taken together, all three methods independently constrain the initial dip of the Mai'iu Fault between about $40-50^{\circ}$, consistent with a rolling hinge-style evolution (Buck, 1988; Wernicke, 1995) of this continental MCC.

\subsection{Conclusions}

This study provides the first attempt to document the cooling and exhumation history of the footwall of the Mai'iu Fault, one of only a few demonstrably-active low-angle normal faults (LANFs) globally. In this study we provide evidence for the onset of extension along the Mai'iu Fault, an apparent time-averaged dip-slip rate on a million-year time scale, the slipparallel paleo-temperature gradient of the exhumed Mai'iu Fault plane and the initial dip of the Mai'iu Fault. The major conclusions are listed below.

$\mathrm{U}-\mathrm{Pb}$ dating, $\mathrm{CL}$ images and trace element analyses of euhedral zircons from the Goropu Metabasalt and Bonenau Schist collectively suggest the zircons are not genetically related to the original protoliths of these units. Due to their Plio-Pleistocene age (mostly $<4 \mathrm{Ma}$ ), these zircons are considered to have grown during exhumation of the Mai'iu Fault footwall.

Detrital zircon and apatite in modern stream sediments confirm the young $\mathrm{U}-\mathrm{Pb}, \mathrm{FT}$ and (U$\mathrm{Th}[-\mathrm{Sm}]) / \mathrm{He}$ ages recorded in footwall rock samples from the northern flank of the SDMCC. A remarkable result is the virtual absence of age components $>4 \mathrm{Ma}$ in zircons from the Mai'iu and Bonua Rivers that drain Mt. Suckling. This is most likely a consequence of the high zircon fertility of the young granitoids compared to that of the more mafic rock units, despite the spatial dominance of the latter.

The observed age spectra ( 4-2 Ma) of detrital zircons in streams draining Mt. Suckling 
confirm the age range ( $\sim 3.8-2.0 \mathrm{Ma})$ of the syn-extensional granitoids. The absence of zircons with ${ }^{206} \mathrm{~Pb} /{ }^{238} \mathrm{U}$ dates that post-date the formation of the Goropu Metabasalt and the Yau Igneous Complex and pre-date the exhumation of the SDMCC may suggest that the subducted Goropu Metabasalt slab was relatively inert between $~ 55$ to 5 Ma.

A preserved zircon PRZ on the northern flank of Mt. Dayman is indicated by two samples of the Bonenau Schist that yielded fully and partially reset ZHe ages at $\sim 12$ and $\sim 19 \mathrm{~km}$ slip-parallel circumferential distance from the modern Mai'iu Fault trace, respectively. Similarly, a zircon PAZ is inferred on the northern flank of Mt. Dayman. The exact positions of the bases of the inferred zircon PRZ and PAZ are loosely constrained to between 12-19 km from the modern fault trace.

To the southeast of Mt. Dayman and proximal to the transition between the Goropu Metabasalt and the unmetamorphosed Kutu Volcanics, ZFT and ZHe ages of $37.1 \pm 4.6$ and $30.3 \pm 6.2$ $\mathrm{Ma}$, respectively, and an incompletely reset AHe age (29.7 $\pm 22.8 \mathrm{Ma})$ of a tonalite of the Yau Igneous Complex suggest an earlier cooling event that pre-dates extension and exhumation of the footwall of the SDMCC, possibly associated with uplift of the basement during the Peninsular Orogeny.

$\mathrm{U}-\mathrm{Pb}$ geochronology of the syn-extensional granitoids, zircon and apatite fission-track and (U-Th[-Sm])/He ages of $\leq 3$ Ma from the footwall of the Mai'iu Fault and constraints on the depositional age of the syn-tectonic Gwoira Conglomerate from ${ }^{26} \mathrm{Al} /{ }^{10} \mathrm{Be}$ burial age dating and a tephra deposit suggest that slip on the Mai'iu Fault had begun by $\sim 4$ Ma.

Based on $\mathrm{ZHe}$ ages of three samples that we infer to have recorded the entire cooling path from below the base of the zircon PRZ to their present positions on the northern flank of the SDMCC, a minimum apparent dip-slip rate of $8.1 \pm 1.3 \mathrm{~km} / \mathrm{myr}$ has been calculated. This is slightly lower than the dip-slip rate of $>12 \mathrm{~km} / \mathrm{myr}$ implied by the intrusion depths of the syn-extensional granitoids on Mt. Suckling. Collectively, these results suggest that the Mai'iu Fault slipped at cm-per-year rates and confirm a constant dip-slip rate of the Mai'iu Fault on annual to million-year time scales.

Combining paleo-temperature estimates derived from the bases of the zircon PRZ and PAZ, RSCM, and a published metamorphic temperature of the extensional shear zone mylonites yields a minimum paleo-temperature gradient of $9.7 \pm 2.2^{\circ} \mathrm{C} / \mathrm{km}$ that intersects the paleotemperature axis at $421 \pm 16^{\circ} \mathrm{C}$ for a slip-parallel transect on Mt. Dayman. The intersection of this minimum paleo-temperature gradient with the paleo-surface temperature suggests a maximum finite slip magnitude of $41+13 /-8 \mathrm{~km}$ for the Mai' iu Fault. 
Based on the paleo-temperature gradient, and assuming a range of potential pre-extensional geothermal gradients $\left(10-20^{\circ} \mathrm{C} / \mathrm{km}\right)$, the average initial dip of the Mai'iu Fault has been constrained at $\sim 44^{\circ}$, indicating $>20^{\circ}$ of back-rotation of the exhumed Mai'iu Fault surface. Thus, we concur with previous suggestions that the continental SDMCC evolved in a rollinghinge style fashion. 


\section{Synthesis}

This thesis presents three stand-alone research studies, each adding to and bringing together new constraints on the tectonic evolution of the Suckling-Dayman metamorphic core complex (SDMCC) and the southeastern Papua New Guinea region. Revisiting the objectives set out in the introduction, the key findings of this thesis are summarised below, concluding with thoughts on future research directions.

\section{Constrain the onset of extensional slip on the Mai'iu Fault}

Extensional re-activation of the former subduction thrust, the Owen Stanley Fault, and the timing of the onset of slip on the Mai'iu Fault is constrained by (1) the intrusion of the oldest known syn-extensional granitoid at $3.8 \pm 0.2 \mathrm{Ma}$; (2) zircon and apatite fissiontrack (FT) and (U-Th[-Sm])/He ages that document cooling of the footwall of the SDMCC since $\sim 3 \mathrm{Ma}$; (3) cosmogenic-nuclide-derived ${ }^{26} \mathrm{Al} /{ }^{10} \mathrm{Be}$ burial ages of quartz clasts from the syn-tectonic Gwoira Conglomerate ( 4.6-3.4 Ma), together with (U-Th[-Sm])/He ages of a tephra deposit in the uppermost exposed sequence of this conglomerate dated at $0.6 \pm$ $0.4 \mathrm{Ma}$; and (4) estimates of $3.8-2.6 \mathrm{Ma}$ based on the backwards projection of the known Holocene dip-slip rate of the Mai'iu Fault (Webber et al., 2018). Based on these results I conclude that slip on the Mai'iu Fault in the western Woodlark Rift commenced at $\sim 4$ Ma.

\section{Assess the dip-slip rate of the Mai'iu Fault on a million-year timescale}

In this thesis, a long-term dip-slip rate of $8.1 \pm 1.3 \mathrm{~km} / \mathrm{myr}(2 \sigma)$ has been estimated for the Mai'iu Fault using zircon (U-Th)/He (ZHe) low-temperature thermochronometry. This dip-slip rate is, however, regarded as a minimum estimate for two reasons. First, the regression analysis does not take into account the potential effects of the advection of isotherms (cf. Ketcham, 1996). Second, a dip-slip rate of $\geq 12 \mathrm{~km} / \mathrm{myr}$ is required to restore the intrusion depths (inferred from Al-in-amphibole and -biotite thermobarometry) of samples of the syn-extensional Mai'iu Monzonite and Suckling Granite on Mt. Suckling. Notwithstanding the uncertainties in the precise determination of the long-term dip-slip rate of the Mai'iu Fault, the constraints presented in this thesis are broadly consistent with those derived from cosmogenic nuclide dating of the lowermost Mai'iu Fault scarp $(11.7 \pm 7.0 \mathrm{~mm} / \mathrm{yr}, 2 \sigma$; Webber et al., 2018) and a regional campaign GPS network (7.5-9.6 mm/yr, data of Wallace et al., 2014, recast to a dip-slip rate using a dip of $21^{\circ}$ ). In conclusion, it is remarkable that constraints on the dip-slip rate of the Mai'iu Fault based on four independent methods (cam- 
paign GPS, cosmogenic nuclide dating, thermochronometry, restoration of intrusions depths) and over three different time scales (annual, millennial, million-year) yielded essentially the same results: a cm-per-year dip-slip rate of the Mai'iu Fault.

\section{Determine the original dip of the Mai'iu Fault}

Combining paleo-temperature estimates derived from the bases of a ZHe partial retention zone (PRZ) and a zircon FT (ZFT) partial annealing zone (PAZ), peak-metamorphic temperatures inferred from Raman spectroscopy of carbonaceous material (RSCM) thermometry, and a published peak metamorphic temperature constraint on the extensional shear zone mylonites near the surface trace of the Mai'iu Fault (Daczko et al., 2009), a minimum paleotemperature gradient of $9.7 \pm 2.2^{\circ} \mathrm{C} / \mathrm{km}(2 \sigma)$ with a y-axis (paleo-temperature) intercept at $421 \pm 16^{\circ} \mathrm{C}$ has been estimated. The intersection of this paleo-temperature gradient with the inferred paleo-surface temperature of $27 \pm 3^{\circ} \mathrm{C}$ (Zhang et al., 2014) suggests a maximum finite slip magnitude of $41+13 /-8 \mathrm{~km}$ for the Mai'iu Fault. For a range of potential pre-extensional geothermal gradients, in this thesis assumed to be between 10 and $20^{\circ} \mathrm{C} / \mathrm{km}$, the paleo-temperature gradient implies a mean original dip of the Mai' iu Fault of $\sim 44^{\circ}$, thus suggesting $>20^{\circ}$ of back-rotation of the exhumed Mai'iu Fault surface. Although an initial dip of $<30^{\circ}$ cannot be ruled out entirely based on the results presented in this thesis, I concur with previous studies (Little et al., 2019; Watson, 2019) that presented evidence for $\sim 20-30^{\circ}$ of back-rotation of the exhumed Mai'iu Fault surface. This is consistent with a rolling hingestyle evolution of this continental MCC (Buck, 1988; Wernicke and Axen, 1988). Because the Mai'iu Fault acts in isolation, a shallow fault dip resulting from rotation of a series of initially steeply dipping normal faults that merge to form a composite detachment fault (the "domino" fault model) can be ruled out.

\section{Place constraints on the pre-extensional history of the SDMCC}

This thesis provides important findings on the pre-extensional history ( $>4 \mathrm{Ma}$ ) of the SDMCC. One of the key results is that zircons from two samples of the Bonenau Schist, interbedded within the oceanic Goropu Metabasalt, yielded U-Pb ages of $103.0 \pm 5.7$ and $71.6 \pm 3.3 \mathrm{Ma}$ that are regarded as maximum depositional ages (MDAs). Previous paleogeographic reconstructions (Seton et al., 2016; Whattam, 2009) of the southwestern Pacific region included the Goropu Metabasalt and the Emo Metamorphics as part of a Cretaceous back-arc basin to the northeast of the Australian continent prior to the opening of the Coral Sea. The age of this back-arc basin presently rests on the temporally restricted timeframe provided by the Maastrichtian planktonic foraminifera identified by Smith and Davies (1976) in the Bonenau Schist. The new zircon $\mathrm{U}-\mathrm{Pb}$ ages presented in this thesis confirm a Late Cretaceous age of this back-arc basin. 
Major oxide and trace element compositions of the gabbroic-tonalitic rocks of the Yau Igneous Complex suggest that this unit formed in a MORB environment. Zircon U-Pb ages of quartz-gabbros and tonalites of the Yau Igneous Complex range from $\sim 60.4$ to $\sim 56.6 \mathrm{Ma}$ and post-date the formation of the Goropu Metabasalt in the Late Cretaceous. The age of the Yau Igneous Complex provides a minimum age for the oceanic protolith of the Goropu Metabasalt.

The documentation of zircon xenocrysts with a Cretaceous ( 120-90 Ma) age component in the granitoids of the SDMCC is an important finding. This age component is similar to those from metasedimentary units on the central Papuan Peninsula, the D'Entrecasteaux Islands and the Louisiade Archipelago and other inherited zircons noted in granitoids of the Woodlark Rift (Adshead and Appleby, 1996; DesOrmeau et al., 2014; Kopi et al., 2004; Zirakparvar et al., 2013). These data concur with previous suggestions (Davies and Smith, 1971) that the Kagi Metamorphics (and rocks of equivalent composition and age) form a single belt, from the Aure-Moresby Fold and Thrust Belt in the northwest of the Papuan Peninsula to the Louisiade Archipelago in the southeast, that underlies the mafic-ultramafic rocks of the SDMCC. In agreement with previous authors (Kopi et al., 2004; Zirakparvar et al., 2013), I suggest that the Kagi Metamorphics were derived from erosion of rocks belonging to the Whitsunday Volcanic Province in Queensland, Australia.

Although sparse, some evidence for Eocene-Miocene events in the basement underlying the SDMCC may exist in the inherited zircons of the granitoids. The U-Pb dates of these zircons overlap with the time of activity of the Paleocene-Eocene Cape Vogel Arc, the Peninsular Orogeny and the Maramuni Arc. Older inherited zircons ( $197-1752 \mathrm{Ma})$ indicate recycling of Jurassic-Paleoproterozoic material. Evidence for the Peninsular Orogeny may also come from ZFT and ZHe cooling ages of $\sim 51-27$ Ma recorded in the gabbroic-tonalitic rocks of the Yau Igneous Complex.

\section{Other conclusions}

Detrital zircon and apatite from modern sediments in streams draining Mts. Suckling and Dayman confirm the mostly Plio-Pleistocene U-Pb, FT and (U-Th[-Sm])/He ages recorded in outcrop samples from the northern flank of the SDMCC. In the Mai'iu and Bonua Rivers, both draining Mt. Suckling, the virtual absence of age components $>4 \mathrm{Ma}$ is likely a consequence of the erosion of source rocks with greatly contrasting zircon fertilities.

The observed age spectra ( 4-2 Ma) of detrital zircons in streams draining Mt. Suckling confirm the age range ( $\sim 3.8-2.0 \mathrm{Ma})$ of the syn-extensional granitoids. The absence of zircons with ${ }^{206} \mathrm{~Pb} /{ }^{238} \mathrm{U}$ dates that post-date the Late Cretaceous Goropu Metabasalt and Paleocene Yau Igneous Complex, and pre-date the extensional exhumation of the SDMCC may suggest 
that the subducted Goropu Metabasalt slab was relatively inert during that time (between $\sim 55$ to $\sim 5 \mathrm{Ma}$ ).

The age of a tephra $(0.6 \pm 0.4 \mathrm{Ma})$ from the upper exposed sections of the Gwoira Conglomerate provides a Pleistocene age for this part of the unit. The importance of this age is twofold. First, it provides the first radiometric age of the Gwoira Conglomerate and second, it constrains the time of abandonment of the now inactive part of the Mai'iu Fault in favour of the Gwoira Fault. Possible sources of the tephra are the Moresby and Dawson Strait Volcanics on the D'Entrecasteaux Islands.

\section{Broader contributions arising from this thesis}

The outcomes of this thesis provide contributions to the disciplines of structural geology, thermochronology, zirconology, detrital geochronology, and tephrochronology.

The reconstruction of the initial dip of the Mai'iu Fault provides supportive evidence for the rolling hinge model (Buck, 1988; Wernicke and Axen, 1988). Although this thesis cannot answer the question of whether or not normal faults can nucleate at low dips $\left(<30^{\circ}\right)$ in homogeneous, intact rock without any form of weakness (e.g., such as pre-existing faults), the results presented in Chapter 4 suggest that the Mai'iu Fault initially slipped at steeper dips before being back-rotated. The latter behaviour has been documented in oceanic MCCs where the rolling hinge model has been confirmed (e.g., Garcés and Gee, 2007). While compelling evidence in favour of the rolling hinge model has been presented elsewhere (Gessner et al., 2001; Lee, 1995), the Mai'iu Fault in Papua New Guinea is possibly the clearest example of a continental LANF that evolved through this process (Little et al., 2019; Mizera et al., 2019; Spencer, 2010).

A puzzling byproduct of this thesis is the recognition that zircons recovered from the Goropu Metabasalt and some in the Bonenau Schist are not related to the formation of their protoliths in the Cretaceous but instead (re-)crystallized syn-extensionally in the Plio-Pleistocene. The implications of this are twofold. First, although this might be unique to rocks of the SDMCC, the occurrence of Plio-Pleistocene zircons in the Goropu Metabasalt and Bonenau Schist challenges the general assumption that minerals targeted for dating by low-temperature thermochronometry are necessarily related to the protolith. This emphasizes the utility of U-Pb dating even in thermochronological studies where the protolith age is known. Second, the occurrence of zircons in low-grade metamorphic rocks that post-date the protolith age is also remarkable inasmuch as it suggests that zircons grew in-situ in the absence of melt or allochthonous prior to incorporation (by veins?) into the rock. I regard the latter as being more likely in the case of zircons from the Goropu Metabasalt as these generally exhibit magmatic cathodoluminescence (CL) textures (and generally lack metamorphic rims) and exhibit trace 
element characteristics indistinguishable from those of the zircons from the granitoids on Mt. Suckling. Thus, zircons in fine-grained metabasites should generally be treated with suspicion, this being in accordance with zircon saturation thermometry (Schaltegger and Davies, 2017; Watson and Harrison, 1983).

Detrital zircons in streams draining Mt. Suckling provide a remarkable example of the effects of variable zircon fertility in the drainage area. Despite the aerial prevalence of mafic rocks in the drainage area, the detrital age spectra of the Mai'iu and Bonua Rivers are virtually free of zircons that can be ascribed to the protolith ages of the Bonenau Schist and Goropu Metabasalt. Instead, the age spectra reflect the high zircon fertility of Suckling Granite and Mai'iu Monzonite (as well as minor contributions of Plio-Pleistocene zircons from the Goropu Metabasalt and Bonenau Schist). In recent years the role of zircon fertility in detrital zircon studies has attained increasing attention (e.g., Mason et al., 2019; Moecher and Samson, 2006; Spencer et al., 2018). This thesis further emphasizes the importance of knowing the bedrock zircon fertility in the drainage area.

Although not initially an objective of this thesis, the complexity of the age spectrum of a tephra required a thorough analysis of the various ways of loosing $\mathrm{He}$ or acquiring excess $\mathrm{He}$ in the $(\mathrm{U}-\mathrm{Th}[-\mathrm{Sm}]) / \mathrm{He}$ system, resulting in the creation of Chapter 3. This chapter provides possibly the first convincing geological example of the 'bad neighbor effect' (Gautheron et al., 2012; Spiegel et al., 2009) and highlights the importance of the air-abrasion treatment for magnetite grains to mitigate the problems associated with He implantation (Blackburn et al., 2007). Moreover, it challenges the assumption that $\mathrm{ZHe}$ ages of xenocrystic zircons should be fully reset due to the low closure temperature of the ZHe system (Blackburn et al., 2008). Lastly, the zircon (U-Th)/(Pb-He) double-dating approach is a viable tool to distinguish geological meaningful from geologically meaningless $\mathrm{ZHe}$ ages.

\section{Directions for future research}

This thesis provides a first temporal baseline for future geo- and thermochronometric studies to build on. Although samples have been collected widely across the footwall, large areas remain poorly dated. These include the largely unexplored southern parts of the footwall of the Mai'iu Fault (south Mt. Dayman), in which the presence of a fossil apatite PAZ and PRZ is suspected, and the hanging wall. Major challenges that remain for future geo- and thermochronometric studies are the poor outcrop exposure and the general infertility with respect to zircon and apatite from the Goropu Metabasalt that covers vast areas of the SDMCC.

The conclusions of this thesis largely rest on data from zircons. Apatite is generally rare but does occur in rocks of the Yau Igneous Complex, and locally in the Goropu Metabasalt. Apatite fission-track analysis would yield additional constraints on the cooling history and 
would permit inverse modelling, thereby extending the thermal histories to temperatures $<110^{\circ} \mathrm{C}$. Further, the recent advent of apatite $\mathrm{U}-\mathrm{Pb}$ dating and its temperature sensitivity $\left(550-375^{\circ} \mathrm{C}\right)$ to mid-lower crustal processes (Smye et al., 2018) makes it a potential thermochronometer to bridge the temperature gap between the zircon U-Pb and ZFT systems.

Similarly, ${ }^{40} \mathrm{Ar} /{ }^{39} \mathrm{Ar}$ dating may provide an avenue to explore events in the temperature range of approximately $600-300^{\circ} \mathrm{C}$. A number of samples have been submitted for ${ }^{40} \mathrm{Ar} /{ }^{39} \mathrm{Ar}$ analysis as part of this thesis but the results were not available at the time of writing. From the author's experience, suitable minerals for conventional ${ }^{40} \mathrm{Ar} /{ }^{39} \mathrm{Ar}$ dating are rare in the finegrained Goropu Metabasalt. However, coarse-grained hornblende, biotite, white mica and $\mathrm{K}$-feldspar are abundant in the granitoids and white mica is often found in the pelitic schists.

Zircon U-Pb LA-ICP-MS dating was primarily carried out by depth profiling due to the ease of double dating with the (U-Th)/He methodology. In order to explore the significance of the broad range of ${ }^{206} \mathrm{~Pb} /{ }^{238} \mathrm{U}$ dates recorded by zircons in the quartz-gabbros and tonalites of the Yau Igneous Complex, CL imaging and dating of zircon in thin sections is recommended. Similarly, the presence of zircon as inclusions in early and late crystallizing phases of the Mai'iu Monzonite may provide further insight into the rather broad range of zircon ${ }^{206} \mathrm{~Pb} /{ }^{238} \mathrm{U}$ dates in these rocks.

Further work will enable a more thorough understanding of the petrogenesis of the igneous rocks of the SDMCC. Whole-rock isotopic analyses ( $\mathrm{Sr}, \mathrm{Nd}, \mathrm{Pb}, \mathrm{Hf}$ ) will add additional insight into their petrogenesis. Sr isotopic analyses on syn-tectonic granodioritic rocks on the D'Entrecasteaux Islands have been carried out (Korchinski et al., 2014) but no such analyses are available for the syn-extensional granitoids on Mt. Suckling.

In-situ $\mathrm{O}$ and $\mathrm{Hf}$ isotopic analyses have been carried out by Stacia Gordon (University of Nevada) on zircons from the Suckling Granite and Mai'iu Monzonite. These analyses (not reported here) will be the basis for a future study. Similar analyses from the Yau Igneous Complex, in conjunction with whole-rock elemental and isotopic analyses, will help constrain the origin of these zircons and more thoroughly elucidate the tectonic context of the gabbroic-tonalitic rocks.

The pristine preservation of the abandoned Mai'iu Fault surface implies little erosion, despite the high-rainfall tropical environment. Quartz from stream sediments, soils and outcrop have been analyzed by cosmogenic ${ }^{10} \mathrm{Be}$-in-quartz to derive erosion rates. The results suggest very low erosion rates (mostly $\sim 30-100 \mathrm{~m} / \mathrm{myr}$ ), consistent with the smooth topography of the SDMCC. This is counter to the topical paradigm that tectonic setting is more important than climatic setting for erosion (von Blanckenburg et al., 2004). 
Appendix 


\section{A Analytical techniques}

This appendix outlines the analytical techniques used in this thesis. Modifications or additional details and/or corrections to the techniques described below can be found in Chapters 2-4 where relevant.

\section{A.1 Whole rock major oxide and trace element analysis}

Elemental concentrations were determined using a $1 \mathrm{KW}$ Bruker S8 Tiger wavelength dispersive X-ray fluorescence (WDS-XRF) analyser at the University of Waikato, New Zealand. Major element concentrations were determined on fused glass disks cast using a 10:1 flux ratio in lithium borate flux, while trace element concentrations were determined using pressed pellets. Samples were analysed under vacuum, with trace element results calibrated against a series of international XRF reference materials using the values of Govindaraju (1994). Trace element concentrations were measured on a Thermo-Scientific Element 2 sector-field ICP-MS housed at Victoria University Wellington, New Zealand. An in-house gravimetric multi-element synthetic mixture was employed to calibrate the unknowns and to monitor for drift. A secondary reference material (AGV-2) served to determine the accuracy of the unknowns. Accuracies are typically $<10 \%$ for most elements and the measured AGV-2 values generally overlap with those recommended by USGS at the $2 \sigma$ level. Accuracies of elements that did not overlap with the recommended values at $2 \sigma$ level are $\mathrm{Ba}(\sim 9 \%), \operatorname{Er}(\sim 18 \%), \mathrm{Ga}$ $(\sim 12 \%), \mathrm{Gd}(\sim 18 \%), \mathrm{La}(\sim 7 \%), \mathrm{Sr}(\sim 8 \%), \mathrm{Tb}(\sim 15 \%)$ and $\mathrm{Zr}(\sim 11 \%)$. Trace elements were considered below the detection limit if their concentrations were within error of the $3 \sigma$ limit of the procedural blank.

\section{A.2 U-Pb and trace LA-ICP-MS analysis}

\section{Depth profiling}

Depth profiling was chosen over conventional in-situ dating on polished zircon grains because of the convenience for zircon double-dating with (U-Th)/He. Zircon grains from the non-magnetic heavy fraction were sprinkled onto double-sided adhesive tape. In a few in- 
stances where zircon yields were low, hand-picking was required. Isotopic $\mathrm{U}-\mathrm{Pb}$ and trace element analyses were performed at the UTChron Laboratories at the University of Texas at Austin. Zircon grains were ablated with a $30-\mu \mathrm{m}$ spot size using a PhotonMachines Analyte G.2 $193 \mathrm{~nm}$ excimer laser for $30 \mathrm{sec}$ at $10 \mathrm{~Hz}$. Analyses were depth-profiled (time-resolved) in order to monitor multiple age domains, including inherited cores following procedures described in Marsh and Stockli (2015). A GJ1 zircon was used as an internal zircon standard $\left({ }^{206} \mathrm{~Pb} /{ }^{238} \mathrm{U}\right.$ age $=601.7 \pm 1.3 \mathrm{Ma}$; Jackson et al., 2004) and was interspersed with unknown zircons at a 4:1 ratio. Plešovice $\left({ }^{206} \mathrm{~Pb} /{ }^{238} \mathrm{U}\right.$ age $=337.13 \pm 0.37 \mathrm{Ma}$; Sláma et al., 2008) and in-house Pak1 zircons were used as secondary standards $\left({ }^{206} \mathrm{~Pb} /{ }^{238} \mathrm{U}\right.$ age $=43.03$ $\pm 0.01 \mathrm{Ma}$ ). Trace element analyses followed the same scheme with NIST-612 glass (Pearce et al., 1997) as a primary standard and GSE-1G glass (Jochum et al., 2005) and natural zircon AusZ5 (Kennedy et al., 2014) as secondary reference material. Where U-Pb isotopic and trace element data were collected from the same crystals, two spots were placed next to each other on each zircon grain, rather than to simultaneous split-stream, in order not to undermine $\mathrm{U}-\mathrm{Pb}$ precision.

\section{Conventional analyses of polished zircons}

Zircon U-Pb analyses were performed at the John de Laeter Centre, Curtin University, using a REsonetics RESOlution M-50A-LR system, with a COMPex 102193 nm excimer UV laser. For each analysis, the samples were ablated for $35 \mathrm{sec}$ at a $5 \mathrm{~Hz}$ repetition rate using a $33-\mu \mathrm{m}$ spot size and laser energy of $2.3 \mathrm{~J} / \mathrm{cm}^{2}$ after two cleaning pulses and a $40 \mathrm{sec}$ background analysis; an additional $40 \mathrm{sec}$ of baseline was collected after each analysis. The laser-ablation system was operated in split-stream mode, in which half of the ablated material was sent to a Nu Plasma multi-collector-ICP-MS (MC-ICP-MS) and the other half of the material to an Agilent 7700s quadrupole ICP-MS. Reference zircons $91500\left({ }^{206} \mathrm{~Pb} /{ }^{238} \mathrm{U}\right.$ age $=1062.4$ \pm 0.4 Ma; Wiedenbeck et al., 1995), GJ1 $\left({ }^{206} \mathrm{~Pb} /{ }^{238} \mathrm{U}\right.$ age $=601.7 \pm 1.3 \mathrm{Ma}$; Jackson et al., 2004), and Plešovice $\left({ }^{206} \mathrm{~Pb} /{ }^{238} \mathrm{U}\right.$ age $=337.13 \pm 0.37 \mathrm{Ma}$; Sláma et al., 2008) were analyzed throughout the run (standard block every 20 unknowns). Reference material 91500 was used as the primary standard for $\mathrm{U}-\mathrm{Pb}$ analyses and $\mathrm{GJ} 1$ for the trace element analyses (assuming $43.1 \% \mathrm{Zr}$ in unknowns and using ${ }^{91} \mathrm{Zr}$ as the reference isotope).

\section{Data reduction and age calculation}

Data reduction was performed using Iolite software with the IgorPro package (IgorPro; Paton et al., 2011) and VisualAge data reduction scheme (Petrus and Kamber, 2012). Ages were calculated using Excel add-in Isoplot v.4 (Ludwig, 2009) using decay constants as recommended by the IUGS Subcommission in Geochronology (Steiger and Jaeger, 1977) and adapting a ${ }^{238} U /{ }^{235} U$ value of 137.824 for GJ1 determined by Hiess et al. (2012). Propagation of systematic and random errors was performed in accord with a workflow proposed by 
Horstwood et al. (2016). All single-grain dates are ${ }^{206} \mathrm{~Pb} /{ }^{238} \mathrm{U}$ dates if not otherwise stated and reported at the 2SE (standard error) confidence level. Due to isobaric interferences in the measurement of ${ }^{204} \mathrm{~Pb}, \mathrm{a}{ }^{204} \mathrm{~Pb}$-based correction could not be applied. However, due to careful inspection of the isotopic signals in Iolite it was possible to identify zones of high common lead $\left(\mathrm{Pb}_{c}\right)$ and avoid them by shortening the integration window accordingly.

\section{A.3 Electron probe micro-analysis}

Major and minor elements were determined by electron probe micro-analysis (EPMA) using a JEOL JXA 8230 at Victoria University of Wellington, New Zealand. Qualitative and quantitative analyses of samples were achieved using energy dispersive spectrometry (EDS) and wavelength dispersive spectrometry (WDS) techniques, respectively. Operating condition were: $15 \mathrm{kV}$ accelerating voltage, $12 \mathrm{nA}$ beam current focused on a $1 \mu \mathrm{m}$ spot, $30 \mathrm{sec}$ counting time on peak position. In order to reduce the effects of different matrices on the accuracy of the measurements, calibration for quantitative analysis was undertaken using international standards of similar composition and structure to materials being analysed. A $\mathrm{ZAF}$ correction (where $\mathrm{Z}$ is atomic number, $\mathrm{A}$ is absorption and $\mathrm{F}$ is fluorescence) was used to calculate all elemental concentrations. Minor elements $(<1 \mathrm{wt} \%)$ were calibrated against synthetic oxides. Calibrated international standards were analysed as unknowns to monitor instrumental drift as well as the precision and accuracy of the analyses.

\section{A.4 Raman spectroscopy of carbonaceous material}

An Alpha 300R+ confocal Raman microscope (Witec GmbH, Ulm, Germany) was used for the Raman mapping. A 100x dry objective (Zeiss, Germany) and a $532 \mathrm{~nm}$ laser (Coherent, Santa Clara, California, USA) with a power of $5.0 \mathrm{~mW}$ were used. The 100x objective and the $532 \mathrm{~nm}$ laser wavelength resulted in a spatial resolution of $\sim 370 \mathrm{~nm}$. The spatial resolution of the microscope had previously been validated (Rooney et al., 2018). The microscope was calibrated and optimised with a silicon wafer before each map by verifying the position and intensity of the $\mathrm{Si}$ band at $520.6 \mathrm{~cm}^{-1}$. A medium-resolution grating of 600 grooves $\mathrm{mm}^{-1}$ was employed and centred at $2000 \mathrm{~cm}^{-1}$. The microscope was equipped with a mechanical stage and a piezoelectric stage. Individual Raman spectra were acquired in square grid patterns with a step size of $360 \mathrm{~nm}$ and an acquisition time of $2 \mathrm{sec}$ per point. The maps presented are $25 \times 25 \mu \mathrm{m}$ with the number of measurement points being 69 × $69(4,761 \mathrm{spec}-$ tra). The microscope lacked optical transmission functionality, so surface graphite grains were used as initial indicators of where sub-surface graphite grains were possibly located. 
Maps were obtained by focusing 1-2 $\mu \mathrm{m}$ below the surface to ensure only unadulterated graphite grains were measured. For each sample, 3-4 maps were measured. The raw Raman data were processed and analysed using the Witec Project Plus software. The Raman spectra were first corrected for cosmic spikes. Spectra were cropped to remove the spectral region below $800 \mathrm{~cm}^{-1}$. A linear baseline was fitted over 800-1200 and 1650-2000 $\mathrm{cm}^{-1}$, and subsequently subtracted. A sum spatial filter was applied to form an intensity map of the graphite grains. Several spectra were averaged over a single grain to improve signal to noise. Five Lorentzian functions were manually loosely fitted over the region 1000-1900 $\mathrm{cm}^{-1}$ before applying an automatic fit with 1000 iterations. If convergence was not reached, the functions were manually adjusted until the automatic fit reached convergence.

\section{A.5 Fission track analysis}

Apatite crystals were mounted in epoxy resin and zircon crystals in teflon rounds (Gleadow et al., 1976). Apatite mounts were etched in $5.5 \mathrm{~N} \mathrm{HNO}_{3}$ for $20.0 \pm 0.5 \mathrm{sec}$ at $21 \pm 1{ }^{\circ} \mathrm{C}$ (Carlson et al., 1999) and immediately rinsed with water. Zircon mounts were etched in a binary eutectic melt of $\mathrm{NaOH}-\mathrm{KOH}$ at temperatures of $\sim 210-215^{\circ} \mathrm{C}$ for times ranging from approximately 36 to $140 \mathrm{hrs}$. Thermal neutron irradiation was carried out at the TRIGA reactor at Oregon State University. Samples were analysed using the external detector method. Mica detectors were etched for $40 \mathrm{~min}$ in $40 \% \mathrm{HF}$ at room temperature. Ages were calculated using the zeta approach (Hurford and Green, 1983) - $131 \pm 12$ (2SE) for CN1/zircon (JO) and $343 \pm 15$ (2SE) for CN5/apatite (JO). Apatite and zircon were counted at magnifications of x1000 (dry) and x1000 (oil), respectively, with a Zeiss Axio Imager M1m at Victoria University of Wellington, New Zealand. Central ages (Galbraith and Laslett, 1993) are reported at the $2 \sigma$ level. Trackkey (Dunkl, 2002) and RadialPlotter (Vermeesch, 2009) were used for data processing, error calculation and graphical presentation.

\section{A.6 (U-Th[-Sm] $) /$ He analysis}

After LA-ICP-MS U-Pb analysis, zircon crystals were removed from the double-sided adhesive tape for $(\mathrm{U}-\mathrm{Th}[-\mathrm{Sm}]) / \mathrm{He}$ dating. Selected zircon and apatite crystals were screened for inclusions, clarity, morphology and size. Each crystal was photographed and morphometrically measured for alpha-ejection correction and subsequently placed in platinum (Pt) tubes $\left(<1 \mathrm{~mm}^{3}\right.$ ) for in-vacuo laser heating and degassing at $\sim 1300^{\circ} \mathrm{C}$ for $10 \mathrm{~min}$ and $\sim 1050{ }^{\circ} \mathrm{C}$ for $5 \mathrm{~min}$, respectively. Routinely, multiple heating cycles are necessary to ensure complete degassing $(>99 \%)$ of the individual zircon aliquots. In order to detect inclusions, one 
re-extraction step was added for apatite. Released gas $\left({ }^{4} \mathrm{He}\right)$ was spiked with a ${ }^{3} \mathrm{He}$ tracer, cryogenically purified, and measured by isotope dilution on a quadrupole noble gas mass spectrometer. Subsequent to complete degassing the Pt tubes were retrieved from the ultrahigh vacuum extraction line. Apatite aliquots were dissolved using ${ }^{230} \mathrm{Th}^{235}{ }^{23}{ }^{149} \mathrm{Sm}$-spiked $30 \% \mathrm{HNO}_{3}$ at $85^{\circ} \mathrm{C}$ for $90 \mathrm{~min}$. The zircon aliquots were unwrapped from Pt tubes and dissolved using pressure vessel double digestion procedures. This procedure includes (1) spiking with a ${ }^{230} \mathrm{Th}_{-}{ }^{235} \mathrm{U}-{ }^{149} \mathrm{Sm}$ tracer, (2) two digestion cycles in a $\mathrm{HF}_{-} \mathrm{HNO}_{3}$ mixture for $\sim 84 \mathrm{~h}$ and $\sim 60 \mathrm{~h}$ at $220^{\circ} \mathrm{C}$, respectively, and (3) insoluble fluoride conversion using $6 \mathrm{~N} \mathrm{HCl}$ for $\sim 10 \mathrm{~h}$ at $180^{\circ} \mathrm{C}$.

For magnetite $\mathrm{He}$ analysis, magnetite grains were picked using plastic tweezers from the hand-magnet fraction, cleaned, and scanned by high-resolution X-ray computed tomography $(\mu-\mathrm{CT})$ to exclude magnetite with inclusions and matrix intergrowth. Selected magnetite grains were then air abraded for 2-4 hours at 2-4 PSI to remove the outermost portion potentially susceptible to He implantation from $\mathrm{U}$, Th and $\mathrm{Sm}$ from the surrounding matrix. Given the small starting grain size $(\sim 80-200 \mu \mathrm{m})$, full abrasion to remove $\geq$ one stopping distance in magnetite ( $\sim 16 \mu \mathrm{m}$; Blackburn et al., 2007) could generally not be confirmed. Post-abrasion, grains were cleaned to remove the abraded magnetite-dust adhering to the crystal. Due to the small grain size and the low $U$ and $T h$ concentrations in magnetite (i.e., generally at 10-100 ppb level) multi-grain aliquots consisting of 6 to 25 grains were analysed. Each multi-grain aliquot was placed in separate Pt tubes $\left(\sim 12 \mathrm{~mm}^{3}\right)$ and subjected to He extraction procedures similar to those of zircon. Subsequent to He extraction, magnetite was unpacked from the platinum tubes into Savillex beakers and digested in a two-step HF$\mathrm{HNO}_{3}$ and $\mathrm{HCl}$ procedure similar to that of zircon, but using a hot plate at $180^{\circ} \mathrm{C}$.

$\mathrm{U}$, Th, and Sm concentrations of apatite, zircon and magnetite were determined by isotope dilution using a gravimetrically calibrated $\sim 1$ pbb U-Th-Sm standard solution mixed with a ${ }^{230} \mathrm{Th}_{-}{ }^{235} \mathrm{U}-{ }^{149} \mathrm{Sm}$ spike. Measurements were conducted on a ThermoFisher Element2 solution ICP-MS. Apatite and zircon (U-Th[-Sm])/He ages were calculated using in-house software Helios with standard $\mathrm{F}_{T}$ corrections (Farley et al., 1996). Single $\mathrm{F}_{T}$-corrected (U$\mathrm{Th}[-\mathrm{Sm}]$ )/He ages are reported with an estimated analytical uncertainty of $8 \%(2 \sigma)$ (Reiners, 2005). Magnetite (U-Th-Sm)/He ages were calculated by iteratively solving the He age equation using blank corrected He, U, Th and Sm concentrations. For sample ages, the geometric mean and the $2 \sigma$ uncertainties are reported unless otherwise stated. 


\section{A.7 $\quad{ }^{26} \mathbf{A l} /{ }^{10} \mathbf{B e}$ cosmogenic nuclide analysis}

Quartz clasts were taken from the Gwoira Conglomerate from recent stream cuttings (PNG16-92a, PNG-16-1020a) and from an exposure revealed by a recent landslip (PNG-16-1029a) (Figure B.18). It is suspected that samples PNG-16-92a and PNG-16-1020a would have been exposed within the last couple of thousand years. This inference is based on geomorphologic grounds (i.e., steep-sided, relatively narrow valleys near the angle of repose) and the erodibility of the Gwoira Conglomerate and the terraces that overly the Gwoira Conglomerate in the southern parts of the Gwoira depression (Figure B.18). The age of the terraces is unknown, but they are inferred to be late Quaternary. The youngest terrace is underlain by lacustrine sand and silt beds (at least $\sim 2 \mathrm{~m}$ thick, Figure B.19) of the Biman Sandstone that rest on the Gwoira Conglomerate (Webber, 2017). A wood sample from these beds returned an Accelerator Mass Spectrometry (AMS) ${ }^{14} \mathrm{C}$ age that was indistinguishable from the background, implying that it is $>60 \mathrm{ka}$ (Little et al., 2019). Based on stream profile modelling, Webber (2017) suggested uplift rates of $4.2 \pm 3.6 \mathrm{~mm} / \mathrm{yr}$ for the Gwoira Gonglomerate. These uplift rates would translate into incision rates of $\sim 1-8 \mathrm{~m} / \mathrm{kyr}$ assuming incision kept up with uplift. It is, however, possible that incision occurred at higher rates after the present river network was established and taking into account bedload abrasion (Stock et al., 2005). Similarly, scarp retreat and slope failure at site PNG-16-1029a are inferred to occur fast. The thickness of the overburden at each site is not precisely known but it is up to several tens of meters at sites PNG-16-92a and PNG-16-1020a (Figures B.20a and c), suggesting complete shielding from nucleonic cosmic rays prior to incision (Dunai, 2010). At site PNG-16-1020a, the amount of previous overburden is more difficult to determine, but the late Quaternary terraces that overly the Gwoira Conglomerate rise to $>20-30$ m adjacent to the Duap River (Figure B.20b). Because all three samples have experienced some post-burial exposure, the ${ }^{26} \mathrm{Al} /{ }^{10} \mathrm{Be}$ are regarded as minimum ages (Granger and Muzikar, 2001).

Burial ages were determined from ${ }^{26} \mathrm{Al} /{ }^{10} \mathrm{Be}$ following standard procedures (Granger, 2006; Granger and Muzikar, 2001). Aluminium (Al) and beryllium (Be) chemistry were conducted at the VUW Cosmogenic Nuclide Lab at Victoria University of Wellington, New Zealand. Following physical and chemical purification, the quartz was dissolved in concentrated HF and a ${ }^{9} \mathrm{Be}$ carrier was added (305 ppm VUW-PK2 from phenacite). The native Al content of the quartz measured on ICP-MS precluded the need for an $\mathrm{Al}$ carrier. $\mathrm{Al}$ and $\mathrm{Be}$ separation followed von Blanckenburg et al. (2004) and Norton et al. (2008), respectively. The native ${ }^{27} \mathrm{Al}$ content was measured on a Thermo Neptune ICP-MS with a Cs spike to correct for ionisation interferences. The ${ }^{10} \mathrm{Be} /{ }^{9} \mathrm{Be}$ and ${ }^{26} \mathrm{Al} /{ }^{27} \mathrm{Al}$ measurements were made by AMS at PRIME Lab. Burial ages were determined from the measured ${ }^{26} \mathrm{Al}$ and ${ }^{10} \mathrm{Be}$ concentrations 
following Granger and Muzikar (2001):

$$
t=\frac{\tau_{26} \tau_{27}}{\left(\tau_{10}-\tau_{10}\right)} \ln \left(\frac{N_{26}}{N_{10}} \frac{P_{10}}{P_{26}}\right)
$$

where $\mathrm{N}_{i}$ is the measured concentration of the nuclide, $\mathrm{P}_{i}$ is the production rate, $\tau_{i}$ is the mean-life, and $t$ is the burial age. The production ratio, $\frac{P_{26}}{P_{10}}$, is assumed to be 6.75 . The mean-life is defined as $\ln \frac{2}{t_{1 / 2}}$, where the half-life, $t_{1 / 2}$, for ${ }^{26} \mathrm{Al}$ is $0.705 \mathrm{Ma}$ (Nishiizumi et al., 2004) and 1.39 Ma for ${ }^{10} \mathrm{Be}$ (Chmeleff et al., 2010; Korschinek et al., 2010). Analytical uncertainties were propagated through to the final burial ages. Due to the large uncertainties on the ${ }^{26} \mathrm{Al} /{ }^{27} \mathrm{Al}$ measurements and low total $\mathrm{Al}$ counts, these burial ages are indicative only. 


\section{B Supplementary material}

\section{B.1 Supplementary material Chapter 2}

\section{Petrography}

\section{The Yau Igneous Complex}

The Yau Igneous Complex consists of dolerites, gabbros, quartz-gabbros and tonalites. The porphyritic dolerites are cataclastically deformed with signs of dynamic recrystallization of quartz. The gabbroic rocks are medium-coarse grained, subhedral-granular, appear to be undeformed and some samples have granophyre-like textures. The gabbroic-tonalitic rocks consist principally of plagioclase, clinopyroxene and opaques ( $\mathrm{Fe}-\mathrm{Ti}$ oxides, $\mathrm{Fe}-(\mathrm{Cu})$ sulfides). Other phases include amphibole, quartz, chlorite, pumpellyite, phrenite, titanite and apatite. Low-grade metamorphism is indicated by the presence of prehnite and pumpellyite. Clinopyroxene is often replaced by amphibole (hornblende, tremolite, actinolite; Smith and Davies, 1976). Clinopyroxenes are typically Fe-rich augite and Fe-rich pigeonite in the gabbroic samples and diopside and Fe-rich augite in the dolerites. In the dolerites, clinopyroxene occurs as porphyroclasts and clusters of subgrains with polygonal boundaries. Plagioclase is generally cloudy and near-completely albitized or altered to epidote and sericite(?). Both clinopyroxene and plagioclase (or their alteration products) are regularly euhedral, but in one sample (PNG-16-41a) pyroxene is subhedral-anhedral in the interstices of plagioclase. The dominance of plagioclase in this sample and the interstitial anhedral character of the clinopyxroxene suggest it is a cumulate rock. Fe-Ti oxides (ilmenite \pm magnetite) are typically skeletal. In places Fe-Ti oxides in association with chlorite and pumpellyite appear to replace titanite (or vice versa?). Fe-Ti oxides are present in all the gabbroic rocks but are virtually absent in the dolerites. In contrast, pyrite is typically euhedral and is common in the dolerites, and lesser so, in the gabbroic rocks. Epidote and calcite are locally present in veins. Accessory minerals are titanite, apatite and zircon.

\section{The Suckling Granite}

The Suckling Granite is a typically medium-grained, inequigranular rock ranging from granodiorite to quartz-monzodiorite that is generally undeformed. It consists principally of plagioclase, K-feldspar, quartz, biotite, hornblende, Fe-oxides, Ti-oxides and Fe-sulfides. However, the abundance of the mafic phases is variable. Some rocks (AU51087, AU51088, 
AU51089) contain both biotite and hornblende (typically magnesio-hornblende), others (PNG15-64a) contain only biotite, and still others (PNG-15-61a) contain neither biotite (but its alteration product chlorite) nor hornblende but include white mica. Accessory minerals include zircon, apatite (not in PNG-15-64a), allanite-(Ce) (only observed in PNG-15-64a) and titanite (in all samples, but rare in PNG-15-61a and PNG-15-64a). Zircons have been identified in plagioclase, K-feldspar, quartz and biotite. The outcrop samples (PNG-15-61a, PNG15-64a) are clearly more altered than the detrital clasts (AU51087, AU51088, AU51089). The replacement of biotite by chlorite attest to some degree of low-grade metamorphic alteration. In terms of deformation, one sample (PNG-15-61a) differs from the others by showing a progression from magmatic to ductile solid-state deformation. This sample has a porphyritic texture with relatively large, euhedral, zoned plagioclase often enclosed in a finer-grained groundmass that contains foliae of white mica (Figure B.5a). Larger white mica clots are frequently interspersed with oxide phases that are similarly aligned (Figure B.5a). Secondary white mica (or sericite(?)) is locally aligned parallel to cleavage planes (Figure B.5b) or fractures of the plagioclase phenocrysts. Solid-state deformation is indicated by the peripheral breakage and bending/kinking of plagioclase phenocrysts (Figure B.5a) and locally developed plagioclase-boudinage and bookshelf-like tilting (Figure B.5c). Late discordant quartz veins crosscut the ductile fabric (Figure B.5d), but the development of quartz subgrains in the veins suggests dislocation creep at temperatures $\geq 300{ }^{\circ} \mathrm{C}$ (Passchier and Trouw, 2005).

\section{The Mai'iu Monzonite}

The Mai'iu Monzonite is a medium-grained, inequigranular rock that varies from monzonite and monzodiorite to quartz-monzodiorite and is generally undeformed. One sample (PNG16-163a) is a hornblendite. Phases include plagioclase (oligoclase-andesine), K-feldspar, quartz, biotite, clinopyroxene, hornblende (mostly magnesio-hornblende \pm tschermakitic paragasite) and titanite. Key differences between the Suckling Granite and the Mai'iu Monzonite are the lower quartz and K-feldspar contents in samples of the Mai'iu Monzonite, the higher relative abundances of mafic phases (biotite, hornblende) and accessories (zircon, apatite, titanite). Titanite forms abundant, large (several hundred $\mu \mathrm{m}$ large) euhedral phenocrysts. Zircon has been identified as inclusions in hornblende, plagioclase, biotite, K-feldspar and quartz, as well as at grain boundaries. Similarly, apatite occurs commonly as small inclusions in hornblende, biotite and plagioclase. Some samples of the Mai'iu Monzonite contain poikilitic textures with K-feldspar oikocrysts enclosing quartz, biotite, hornblende, titanite and apatite, and plagioclase oikocrysts enclosing biotite, hornblende and apatite. Such poikilitic textures are not present in samples of the Suckling Granite. The relative abundance of mafic phases (hornblende, biotite) is variable but may be up to $80 \%$ (PNG-16-163a). The Mai'iu Monzonite is generally quartz-bearing but quartz is rare or absent in some samples (PNG-16-163a). Ilmenite has been identified as inclusions in biotite. In 
addition, tiny crystals $(\leq 15 \mu \mathrm{m})$ of chromium-rich spinel/magnetite $(\mathrm{Cr}=11-31 \mathrm{wt} \% ; \mathrm{Fe}=$ $62-83 \mathrm{wt} \%$ ) has been observed as inclusions in hornblende. Although the Mai'iu Monzonite is deeply weathered and susceptible to erosion, as is reflected by an accompanying topographic depression southeast of Mt. Suckling, feldspars appear relatively fresh. Low-grade metamorphic alteration is apparent in the local replacement of biotite by chlorite. In contrast to the medium grained plutonic rocks, a dike sampled in mapped area of Mai'iu Monzonite has a similar mineral assemblage but finer-grained texture. The plagioclase in this sample is euhedral and exhibits obvious zoning at the microscopic scale. The amphibole in the dike rock is magnesio-hastingsite, tschermakite and paragasite. A boulder of monzonite (PNG16-174a) recovered from a landslip deposit on the northern flank of Mt. Dayman is here grouped with the Mai'iu Monzonite. It shows an equigranular texture and consists chiefly of $\mathrm{K}$-feldspar and amphibole and minor quartz, Fe-Ti oxides, chlorite and apatite. Parts of the thin section contain plagioclase oikocrysts enclosing smaller amphibole.

\section{The Bonua Porphyry}

A sample of the Bonua Porphyry (PNG-16-157a) is a sparsely porphyritic monzonite and consists primarily of biotite, clinopyroxene, K-feldspar, plagioclase, calcite and rare amphibole. Accessories are zircon, apatite and pyrite. The Bonua Porphyry differs from the Mai'iu Monzonite by bearing clinopyroxene (diopside) as the dominant mafic phase (instead of amphibole) and K-feldspar instead of plagioclase as the prevailing feldspar. The K-feldspar phenocrysts enclose grains of clinopyroxene, biotite and apatite. The clinopyroxenes reveal oscillatory zoning. Some K-feldspar clusters are aligned in an apparent flow texture. Numerous calcite-filled vesicles are surrounded by corona-like structures with clinopyroxene, K-feldspar, and chlorite. The K-feldspar is commonly felty and the grain boundaries are difficult to identify. Zircon has been identified at the interface of biotite/K-feldspar and prehnite/K-feldspar. The Bonua Porphyry has been altered as evidenced by the replacement of biotite by chlorite. A dike (AU51095) collected some $\sim 10 \mathrm{~km}$ east of the sample location of PNG-16-157a is here grouped with the Bonua Porphyry due to its proximity and similar composition. This sample is a latite and has a trachytoidal texture with aligned biotite. The sample contains phenocrysts of orthopyroxene, clinopyroxene, biotite, opaques and serpentinized olivine phenocrysts in an optically non-resolvable fine-grained quartzo-feldspathic(?) groundmass.

\section{Basaltic andesite dikes}

Two basaltic andesite dikes crop out at the lowermost fault scarp at Biniguni Falls (PNG15-60a) and at the Gwariu Gorge (PNG-16-150c). Sample PNG-15-60a is a porphyritic dike consisting of clinopyroxene (diopside-augite) phenocrysts in a fine-grained groundmass of plagioclase, biotite, titanite, pumpellyite and chlorite. Epidote and muscovite were identified in this dike by Caffi (2008). The second dike (PNG-16-150c) contains phenocrysts 
of amphibole, clinopyroxene, quartz, chlorite, plagioclase (albite), calcite and pyrite. Relic clinopyroxene is only preserved in cores of some of the amphiboles. The dike margin to the adjacent wall rock is very fine grained and chilled.

\section{Thermobarometry}

\section{Thermobarometric calculations}

From the previously reported occurrence of andalusite (stable at $\leq 4$ kbar; Clarke et al., 2005) in the contact aureole of the Suckling Granite and Mai'iu Monzonite (Smith and Davies, 1976), low crystallization pressures were expected. A variety of published Al-in-amphibole thermobarometeric calibrations are available for low-variance mineral assemblages (Hammarstrom and Zen, 1986; Johnson and Rutherford, 1989; Schmidt, 1992). However, these were generally calibrated at pressures $\geq 2$ kbar. A recent calibration by Mutch et al. (2016) was employed that is applicable to amphiboles from granitoid bulk compositions at nearsolidus temperatures $\left(725 \pm 75^{\circ} \mathrm{C}\right)$ and pressures of $0.8-10 \mathrm{kbar}$. We used WinAmptb software (Yavuz and Döner, 2017) to estimate the structural formulae of calcic amphibole EPMA analyses, determine cation site allocations and calculate pressures, temperatures and oxygen fugacities. Amphibole compositions were determined using the $13 \mathrm{eCNK}$ (13 cations excluding $\mathrm{Ca}, \mathrm{Na}, \mathrm{K}$ ) normalization scheme and the ferric iron content was estimated on the basis of 23 oxygen anhydrous cations. Relative oxygen fugacity ( $\triangle \mathrm{NNO}$ ) values were calculated after Ridolfi et al. (2010). The results are presented in Electronic appendix 2.

For comparison, we determined pressures after Anderson and Smith (1995) in combination with the thermometer of Holland and Blundy (1994). This was done for three samples (PNG-15-66a, PNG-16-159b, PNG-16-163a) where both amphibole and plagioclase EPMA compositions were available using an MS Excel spreadsheet provided by Anderson (2008). The thermobarometeric calibration of Anderson and Smith (1995) accounts for the possible effects of emplacement temperature. Most of our amphiboles pass the compositional requirements for the application of this thermobarometer, i.e., $\mathrm{Fe}^{3+} /\left(\mathrm{Fe}^{3+}+\mathrm{Fe}^{2+}\right)>0.25$ 0.65 and $\mathrm{Fe}_{t o t} /\left(\mathrm{Fe}_{t o t}+\mathrm{Mg}\right) \sim 0.40-0.65$. Similarly, plagioclase compositions $\left(\sim \mathrm{An}_{21-27}\right)$ from the same samples are similar to the restricted values $\left(\sim \mathrm{An}_{25-35}\right)$ commonly applied to the calculation of pressures from Al-in-amphibole thermobarometry (Anderson and Smith, 1995, and references therein).

Independent pressure estimates were derived from the Al-in-biotite thermobarometer of Uchida et al. (2007). Although this barometer is less well studied, Mutch et al. (2016) confirmed a positive correlation of $\mathrm{Al}_{\text {tot }}$ in biotite with pressure in their experiments, supporting its general validity. Biotite is variably altered to chlorite in many samples of the syn-extensional 
granitoids and therefore unsuitable for Al-in-biotite barometry. Unaltered biotite from two samples of the Mai'iu Monzonite (PNG-15-66a, PNG-16-159b) were used for the calculation of pressures from Al-in-biotite barometry. Biotite formula calculations were carried out using an MS Excel spreadsheet of Tindle (2001) on the basis of 22 oxygens (without Li). The results are presented in Electronic appendix 3.

To compensate for the topographic relief over which the outcrop samples were collected, the pressure estimates were normalized to 3400 m.a.s.l., an altitude that approximates the exhumed Mai'iu Fault plane on Mt. Suckling, assuming a lithostatic pressure gradient of $0.29 \mathrm{kbar} / \mathrm{km}$.

\section{Amphibole textures and compositions}

Outcrop samples of the Mai'iu Monzonite and stream boulders of the Suckling Granite contain abundant euhedral amphibole grains characterized by a green pleochroism. No obvious reaction rims have been identified. Backscatter electron (BSE) images reveal that most amphiboles have a diffuse patchy texture with brighter cores and darker rims (Figure B.6). No oscillatory zonation was observed. Patchy zoning may indicate partial dissolutionrecrystallization or diffusive re-equilibration (Streck, 2008). Patchy zoning from dissolutionrecrystallization typically involves discrete compositional changes across different patches with sharp boundaries (Streck, 2008). This was generally not observed. The generally diffuse boundaries of the bright patches seen in BSE images (Figure B.6) may indicate that diffusive re-equilibration has acted to produce the observed zoning. However, it has been suggested that $\mathrm{Al}$ diffusion is very slow and magmatic $\mathrm{Al}$ contents are expected to be retained even in large and slow-cooling plutons (Hammarstrom and Zen, 1986).

All amphiboles analysed in this study classify as calcic amphiboles (Electronic appendix 2). The majority of amphiboles in the Mai'iu Monzonite (PNG-15-66a, PNG-16-159b, PNG16-163a) and Suckling Granite (AU51087, AU51088) are magnesio-hornblendes with minor tschermakite, edenite and pargasite (Electronic appendix 2). Conversely, amphiboles of the Mai'iu Monzonite dike (PNG-16-2a) are mostly magnesio-hastingsite with subordinate tschermarkite and pargasite components (Electronic appendix 2). However, amphibole rim compositions in the Mai'iu Monzonite and Suckling Granite samples are almost exclusively magnesio-hornblende (Figure B.7a) and magnesio-hastingsite in the dike sample (Figure B.7b). Amphiboles show significant inter-crystalline (3.2-11.0 wt \%) and less significant intra-crystalline (4.6-9.0 wt\%) variations in $\mathrm{Al}_{2} \mathrm{O}_{3}$. Bright core regions are generally enriched in $\mathrm{Ti}, \mathrm{Al}, \mathrm{Fe}, \mathrm{Na}$ and $\mathrm{K}$ while darker rims usually have higher $\mathrm{Mg}$ and $\mathrm{Si}$ contents. $\mathrm{Ca}, \mathrm{Cr}, \mathrm{Mn}, \mathrm{Fl}$ and $\mathrm{Cl}$ contents are mostly invariant and do not seem to follow the zoning patterns. A substitution analysis is given below (Figure B.8). 
For samples of the Mai'iu Monzonite (i.e., polished thin sections) we analysed amphiboleplagioclase pairs. Although we analysed core and rim regions of amphibole, only analyses from homogenous BSE-dark rim domains were used for the calculation of the crystallization pressures. All samples contain the mineral assemblage (plagioclase, hornblende, biotite, K-feldspar, quartz, titanite, magnetite/ilmenite, apatite) required to buffer the major oxide components in a calc-alkaline system (Hammarstrom and Zen, 1986; Hollister et al., 1987; Mutch et al., 2016). On this basis, all our samples are suitable for the application of a lowthermodynamical variance thermobarometer.

\section{Substitution analysis}

The amphibole composition is a function of a series of substitutions that are sensitive to temperature, pressure and oxygen fugacity $\left(f \mathrm{O}_{2}\right)$. The influence of these intensive parameters on the amphibole composition can be investigated by a substitution analysis. In Figure B.8 we plotted tetrahedrally coordinated aluminium $\left({ }^{[I V]} \mathrm{Al}\right.$ ) against (a) octahedrally coordinated aluminium $\left({ }^{[V I]} \mathrm{Al}\right)$, (b) A-site occupancy or ${ }^{[A]}(\mathrm{Na}+\mathrm{K})$, (c) Ti content and (d) a combination of (a), (b) and (c) plus $\mathrm{Fe}^{3+}$. The black arrows show the direction of the exchange vectors and the label at the arrowheads indicate the name of the substitution vector. The yellow circles represent the end-member composition of the calcic amphiboles: tremolite (TR), edenite (ED), hornblende (HB), tschermakite (TK), pargasite (PG) and glaucophane (GL).

${ }^{[I V]} \mathrm{Al}$ vs. ${ }^{[V I]} \mathrm{Al}$ : Amphibole rim compositions suggest that there is an overall positive correlation between ${ }^{[I V]} \mathrm{Al}$ and ${ }^{[V I]} \mathrm{Al}$ (Figure B.8a). Both edenite and tschermakite substitutions appear to influenced the amphibole compositions.

${ }^{[I V]} \mathrm{Al}$ vs. ${ }^{[A]}(\mathrm{Na}+\mathrm{K})$ : Amphibole rim analyses define a positive correlation between ${ }^{\left[{ }^{[V]}\right.} \mathrm{Al}$ and A-site occupancy (Figure B.8b). The trend is subparallel to the paragasite exchange vector.

${ }^{[I V]} \mathrm{Al}$ vs. Ti: A positive correlation of Ti content and ${ }^{[I V]} \mathrm{Al}$ is apparent from Figure B.8c, but the intra-sample variability is sub-parallel to the Ti-tschermakite vector at best.

${ }^{[I V]} \mathrm{Al}$ vs. ${ }^{[V I]} \mathrm{Al}+\mathrm{Fe}^{3+}+2 \mathrm{Ti}+{ }^{[A]}(\mathrm{Na}+\mathrm{K})$ : Virtually all amphibole rim compositions plot on the 1:1 line, suggesting no charge deficiencies (Figure B.8d). Figure B.8d also suggests that the other vectors (e.g., plagioclase, glaucophane) had little impact on the amphibole compositions.

The substitution analysis suggests that the pressure-sensitive tschermakite and the temperaturesensitive edenite substitution influenced the final compositions of the amphibole rims (Figure B.8a). The influence of substitutions by Ti is likely to be minimal. This is because the Ti 
concentrations are relatively low $(\sim 0.14$ a.p.f.u $)$ and the intra- and inter-sample variabilities are relatively minor (Electronic appendix 2). It also appears that ${ }^{[A]}(\mathrm{Na}+\mathrm{K})$ is dominated by a pargasitic, rather than an edenitic coupled substitution.

\section{Comparison with Anderson and Smith (1995) calibration}

For outcrop samples where plagioclase compositions were available, the thermobarometer of Anderson and Smith (1995) yielded average pressures of $0.7 \pm 0.4$ kbar (PNG-15-66a), $2.5 \pm$ $1.0 \mathrm{kbar}$ (PNG-16-159b) and $1.7 \pm 1.1 \mathrm{kbar}$ (PNG-16-163a) at the $2 \sigma$ level. In comparison, the calibration of Mutch et al. (2016) gave pressures of $1.3 \pm 0.3 \mathrm{kbar}$ (PNG-15-66a), $2.3 \pm$ $0.7 \mathrm{kbar}$ (PNG-16-159b) and $1.8 \pm 0.6 \mathrm{kbar}$ (PNG-16-163a) at the $2 \sigma$ level, similar to those of the Anderson and Smith (1995) calibration. 
Table B.1: Feldspar ${ }^{207} \mathrm{~Pb} /{ }^{206} \mathrm{~Pb}$ LA-ICP-MS data

\begin{tabular}{|c|c|c|c|c|c|c|c|c|}
\hline Identifier & ${ }^{207} \mathrm{~Pb} /{ }^{206} \mathrm{~Pb}$ & $\pm 2 \sigma$ & Identifier & ${ }^{207} \mathrm{~Pb} /{ }^{206} \mathrm{~Pb}$ & $\pm 2 \sigma$ & Identifier & ${ }^{207} \mathrm{~Pb} /{ }^{206} \mathrm{~Pb}$ & $\pm 2 \sigma$ \\
\hline PNG-15-61a-2 & 0.8140 & 0.04589 & PNG-15-64a-1 & 0.8263 & 0.01787 & PNG-15-66a-2 & 0.8327 & 0.01718 \\
\hline PNG-15-61a-4 & 0.8351 & 0.03389 & PNG-15-64a-4 & 0.8303 & 0.04472 & PNG-15-66a-3 & 0.8309 & 0.02236 \\
\hline PNG-15-61a-6 & 0.8346 & 0.03470 & PNG-15-64a-5 & 0.8293 & 0.03998 & PNG-15-66a-6 & 0.8346 & 0.03988 \\
\hline PNG-15-61a-7 & 0.8175 & 0.04787 & PNG-15-64a-8 & 0.8281 & 0.07183 & PNG-15-66a-8 & 0.8391 & 0.01728 \\
\hline PNG-15-61a-11 & 0.8701 & 0.12367 & PNG-15-64a-10 & 0.8533 & 0.02778 & PNG-15-66a-10 & 0.8318 & 0.02368 \\
\hline PNG-15-61a-13 & 0.8140 & 0.02876 & PNG-15-64a-12 & 0.8585 & 0.02331 & PNG-15-66a-12 & 0.8185 & 0.03504 \\
\hline PNG-15-61a-15 & 0.8656 & 0.03904 & PNG-15-64a-14 & 0.8251 & 0.02560 & PNG-15-66a-13 & 0.8484 & 0.02387 \\
\hline PNG-15-61a-17 & 0.8399 & 0.05290 & PNG-15-64a-16 & 0.8359 & 0.02009 & PNG-15-66a-15 & 0.8532 & 0.01530 \\
\hline PNG-15-61a-20 & 0.8462 & 0.04548 & PNG-15-64a-18 & 0.8375 & 0.09659 & PNG-15-66a-18 & 0.8309 & 0.01856 \\
\hline PNG-15-61a-22 & 0.8452 & 0.03461 & PNG-15-64a-20 & 0.8349 & 0.02219 & PNG-15-66a-19 & 0.8451 & 0.01608 \\
\hline PNG-15-61a-24 & 0.8002 & 0.05077 & PNG-15-64a-23 & 0.8254 & 0.02458 & PNG-15-66a-22 & 0.8403 & 0.01313 \\
\hline PNG-15-61a-26 & 0.8268 & 0.02909 & PNG-15-64a-25 & 0.8485 & 0.01945 & PNG-15-66a-24 & 0.8342 & 0.02612 \\
\hline PNG-15-61a-28 & 0.8285 & 0.06793 & PNG-15-64a-26 & 0.8254 & 0.09651 & PNG-15-66a-25 & 0.8383 & 0.02140 \\
\hline PNG-15-61a-30 & 0.8310 & 0.04588 & PNG-15-64a-28 & 0.8244 & 0.05330 & PNG-15-66a-27 & 0.8293 & 0.01847 \\
\hline PNG-15-61a-32 & 0.8286 & 0.05374 & PNG-15-64a-30 & 0.8366 & 0.02176 & PNG-15-66a-29 & 0.8300 & 0.01610 \\
\hline PNG-15-61a-34 & 0.8304 & 0.03368 & PNG-15-64a-31 & 0.8331 & 0.01639 & PNG-15-66a-32 & 0.8168 & 0.01766 \\
\hline PNG-15-61a-35 & 0.8248 & 0.04220 & PNG-15-64a-33 & 0.8411 & 0.01415 & PNG-15-66a-34 & 0.8489 & 0.02385 \\
\hline PNG-15-61a-38 & 0.8495 & 0.04498 & PNG-15-64a-35 & 0.8076 & 0.02211 & PNG-15-66a-36 & 0.8327 & 0.01614 \\
\hline PNG-15-61a-39 & 0.8118 & 0.03832 & PNG-15-64a-38 & 0.8410 & 0.01266 & PNG-15-66a-38 & 0.8255 & 0.16614 \\
\hline PNG-15-61a-42 & 0.8140 & 0.04589 & PNG-15-64a-39 & 0.8359 & 0.02552 & PNG-15-66a-40 & 0.8407 & 0.01556 \\
\hline PNG-15-61a-44 & 0.8107 & 0.08263 & PNG-15-64a-42 & 0.8398 & 0.01963 & PNG-15-66a-42 & 0.8208 & 0.02113 \\
\hline PNG-15-61a-45 & 0.8390 & 0.02825 & PNG-15-64a-43 & 0.8731 & 0.04555 & PNG-15-66a-44 & 0.8414 & 0.01835 \\
\hline PNG-15-61a-47 & 0.8459 & 0.03376 & PNG-15-64a-45 & 0.8427 & 0.07506 & PNG-15-66a-47 & 0.8423 & 0.01919 \\
\hline PNG-15-61a-49 & 0.8220 & 0.04200 & PNG-15-64a-47 & 0.8422 & 0.07506 & PNG-15-66a-48 & 0.8453 & 0.04523 \\
\hline PNG-15-61a-51 & 0.8654 & 0.03712 & PNG-15-64a-50 & 0.8263 & 0.03793 & PNG-15-66a-50 & 0.8233 & 0.02135 \\
\hline Average $\pm \mathbf{2} \sigma$ & 0.8324 & 0.00808 & Average $\pm \mathbf{2} \sigma$ & 0.8361 & 0.01025 & Average $\pm \mathbf{2} \sigma$ & 0.8350 & 0.01196 \\
\hline
\end{tabular}




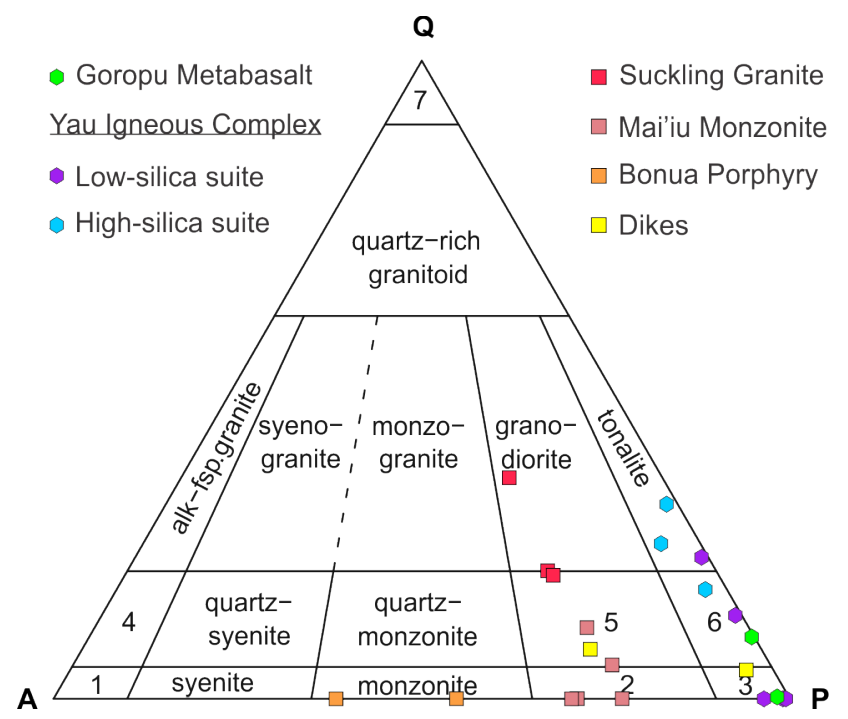

Figure B.1: QAP rock classification diagram after Streckeisen (1974). For convenience volcanic and plutonic rocks are depicted on the same diagram. 1 - alkali-feldspar syenite, 2 - monzodiorite, monzogabbro, 3 - diorite, gabbro, 4 - quartz-alkali-feldspar syenite, 5 - quartz-monzodiorite, quartz-monzogabbro, 6 - quartz-diorite, quartz-gabbro, quartzanorthosite, 7 - quartzolite.

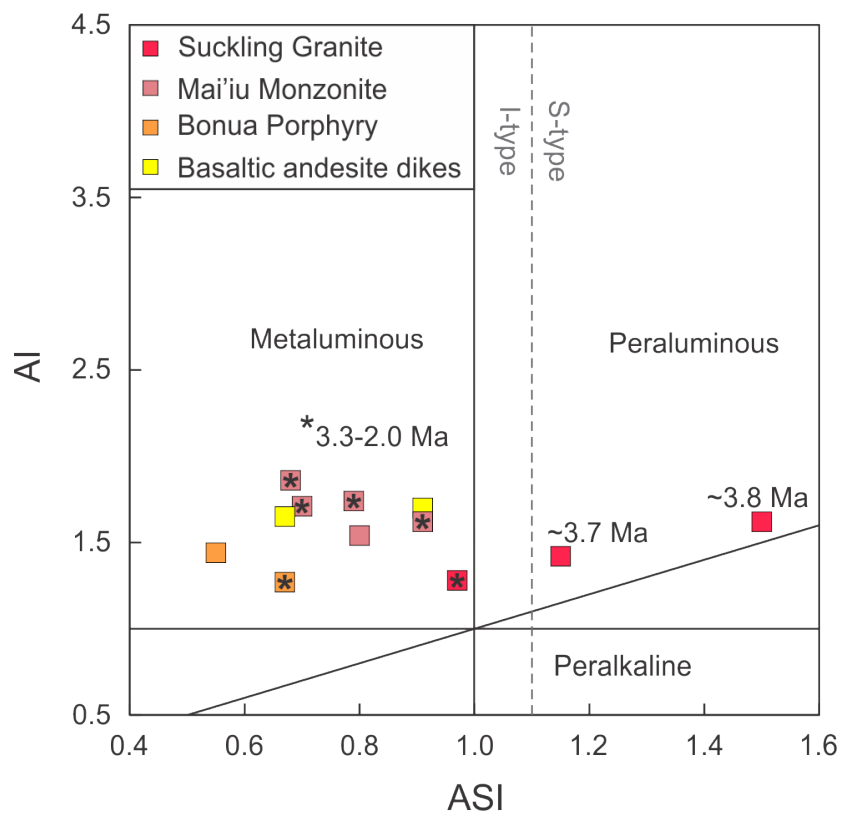

Figure B.2: Classification of calc-alkaline and high-K igneous rocks after Shand (1947). ASI $=\mathrm{Al} /(\mathrm{Ca}+\mathrm{Na}+\mathrm{K}) ; \mathrm{AI}=\mathrm{Al}-(\mathrm{K}+\mathrm{Na})$. Abbreviations: ASI - aluminium saturation index, AI - alkalinity index. I-type-S-type boundary after Chappell and White (1974). Number labels refer to $\mathrm{U}-\mathrm{Pb}$ ages from the the various units (Table 2.3). 

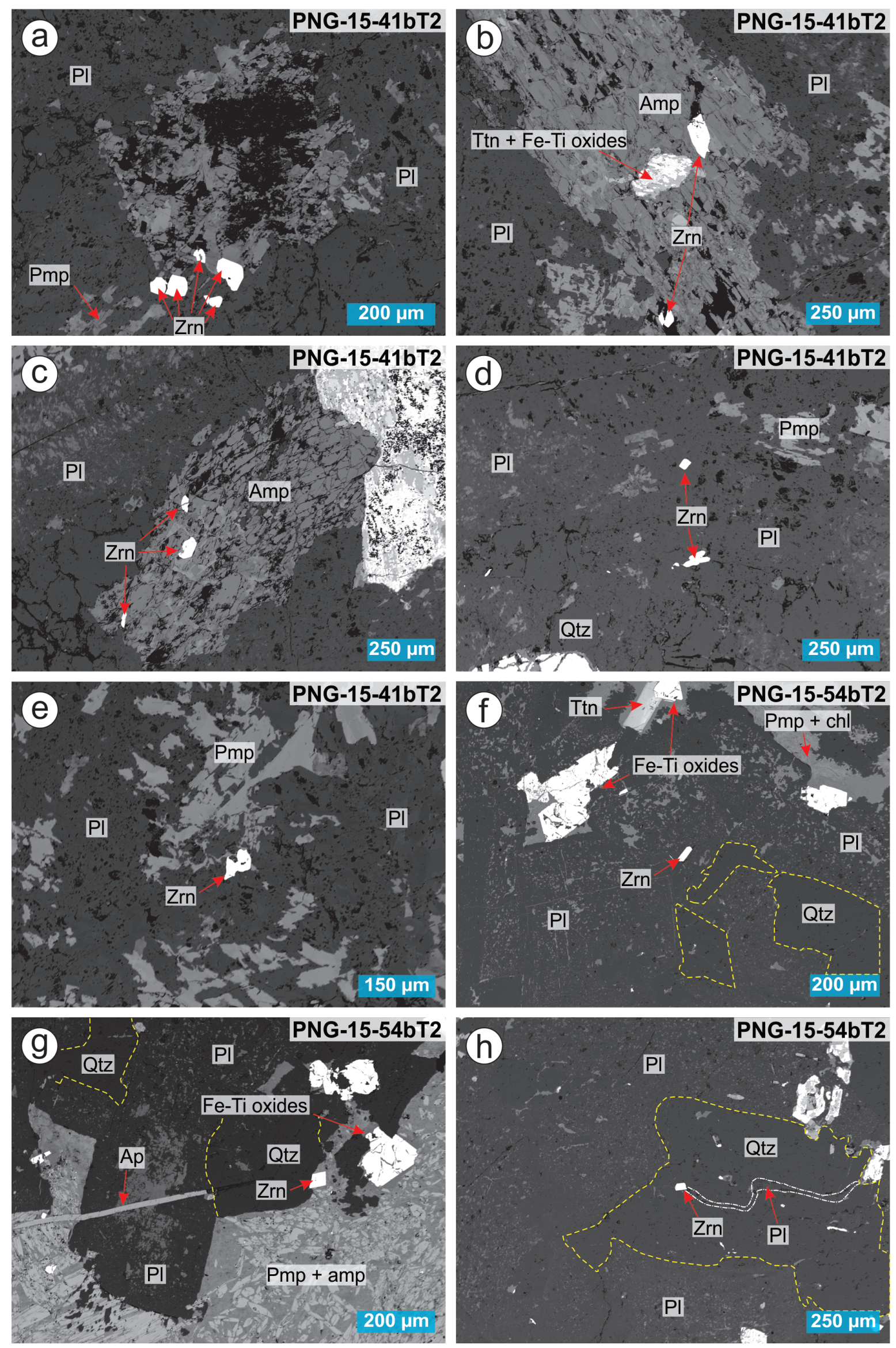


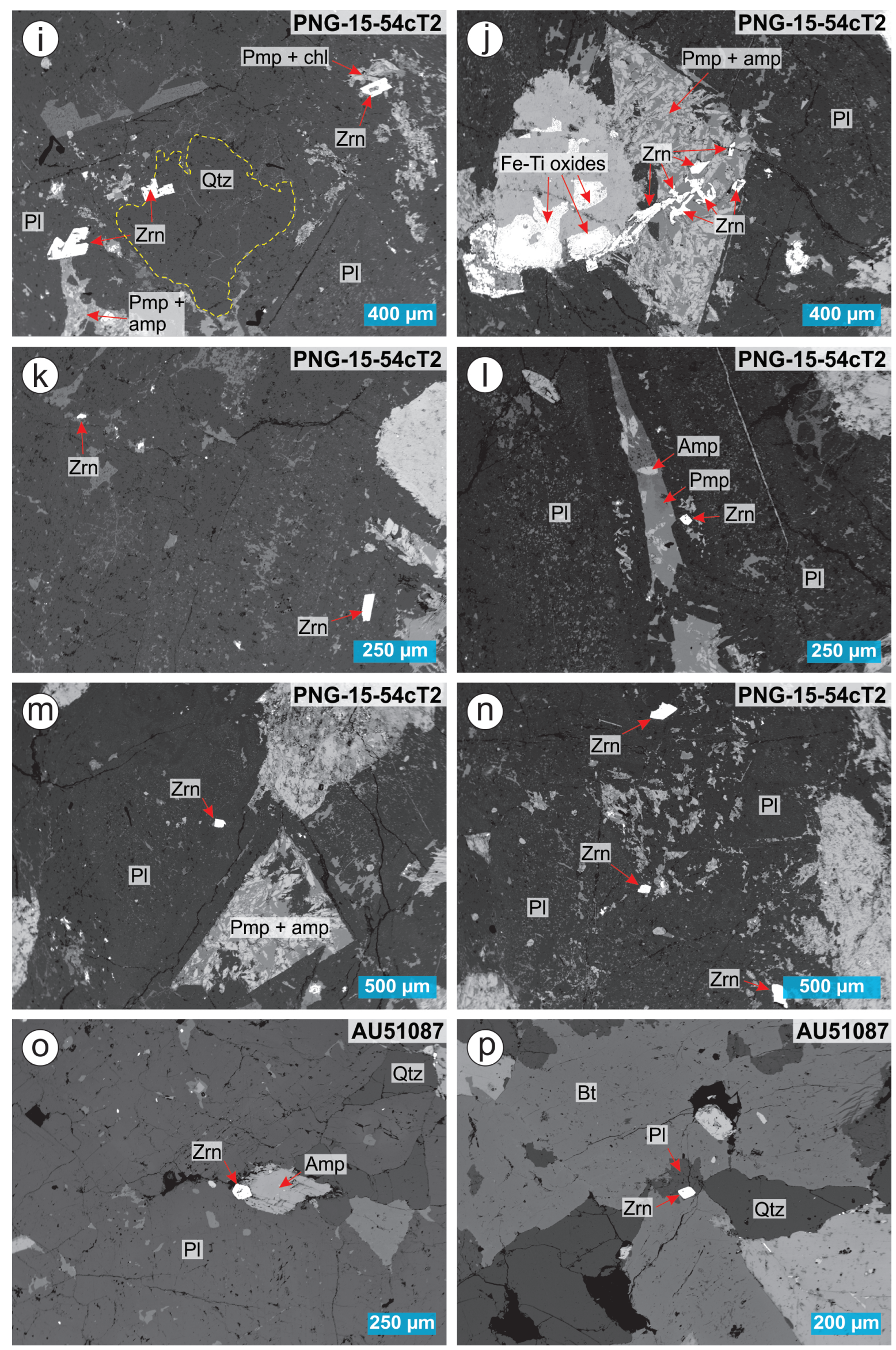



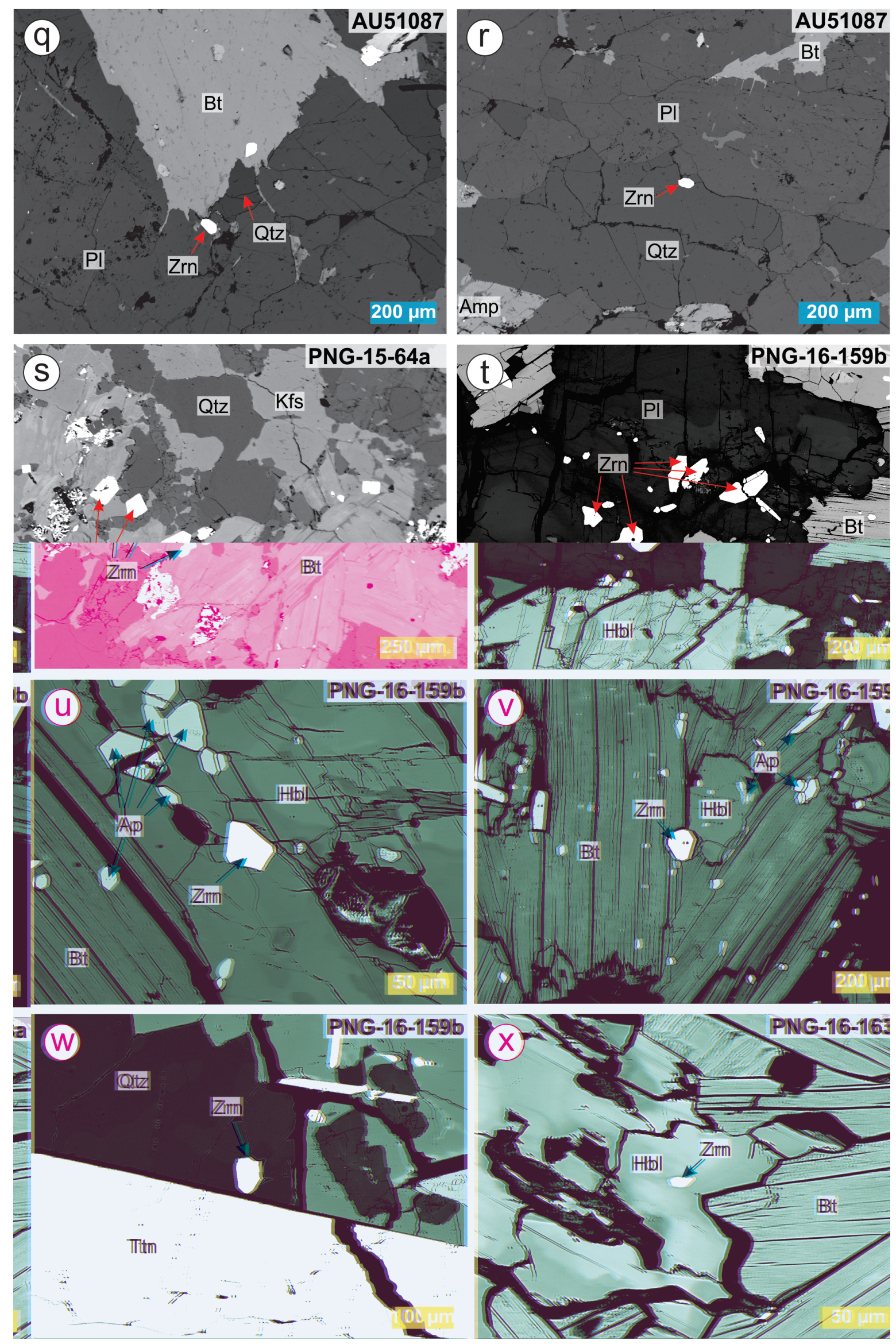
Figure B.3: EPMA back-scatter electron images showing the in-situ occurrence of zircon in samples of the Yau Igneous Complex (a-n), the Suckling Granite (o-s), and the Mai'iu Monzonite (t-x). (a) Euhedral and anhedral zircon grains at the interface of amphibole and plagioclase. (b) Euhedral zircon and titanite/Fe-Ti oxides in amphibole. (c) Euhedral zircon in amphibole. Note, zircon appear to be aligned to cleavage direction of amphibole. (d) Euhedral and anhedral zircon in plagioclase. (e) Anhedral zircon in plagioclase. (f) Euhedral zircon in plagioclase. Note the dark grey 'matrix' enclosing zircon has an albitic composition. Tiny medium-grey blebs are relic anorthite-rich domains. (g) Euhedral zircon fragment in a mesostasis consisting essentially of amphibole (light grey) and pumpellyite (medium grey). (h) Euhedral zircon at the tip of a sealed fracture (outlined by white stippled line) with an albitic composition in a quartz grain (outlined by yellow dashed line). (i) Zircon at the interface between quartz and plagioclase and at the interface between plagioclase and pumpellyite/chlorite. (j) Network of zircon in mesostasis consisting of amphibole and pumpellyite. Note porous appearance of Fe-Ti oxides. (k) Euhedral and anhedral zircon in plagioclase. (l) Euhedral zircon in plagioclase adjacent to amphibole-pumpellyite mesostasis. (m) Zircon in plagioclase. (n) Euhedral and subhedral zircon in plagioclase. (o) Euhedral zircon at interface between amphibole and plagioclase. (p) Euhedral zircon at interface between plagioclase and biotite. (q) Euhedral zircon in plagioclase. (r) Subhedral zircon in quartz. (s) Euhedral zircon at the interfaces between biotite, quartz and plagioclase. (t) Euhedral zircon in plagioclase. (u) Euhedral zircon in amphibole. (v) Euhedral zircon at interface between amphibole and biotite. (w) Euhedral zircon enclosed in quartz at the interface to titanite. (x) Subhedral zircon in amphibole. Mineral abbreviations after Siivola and Schmid (2007). 

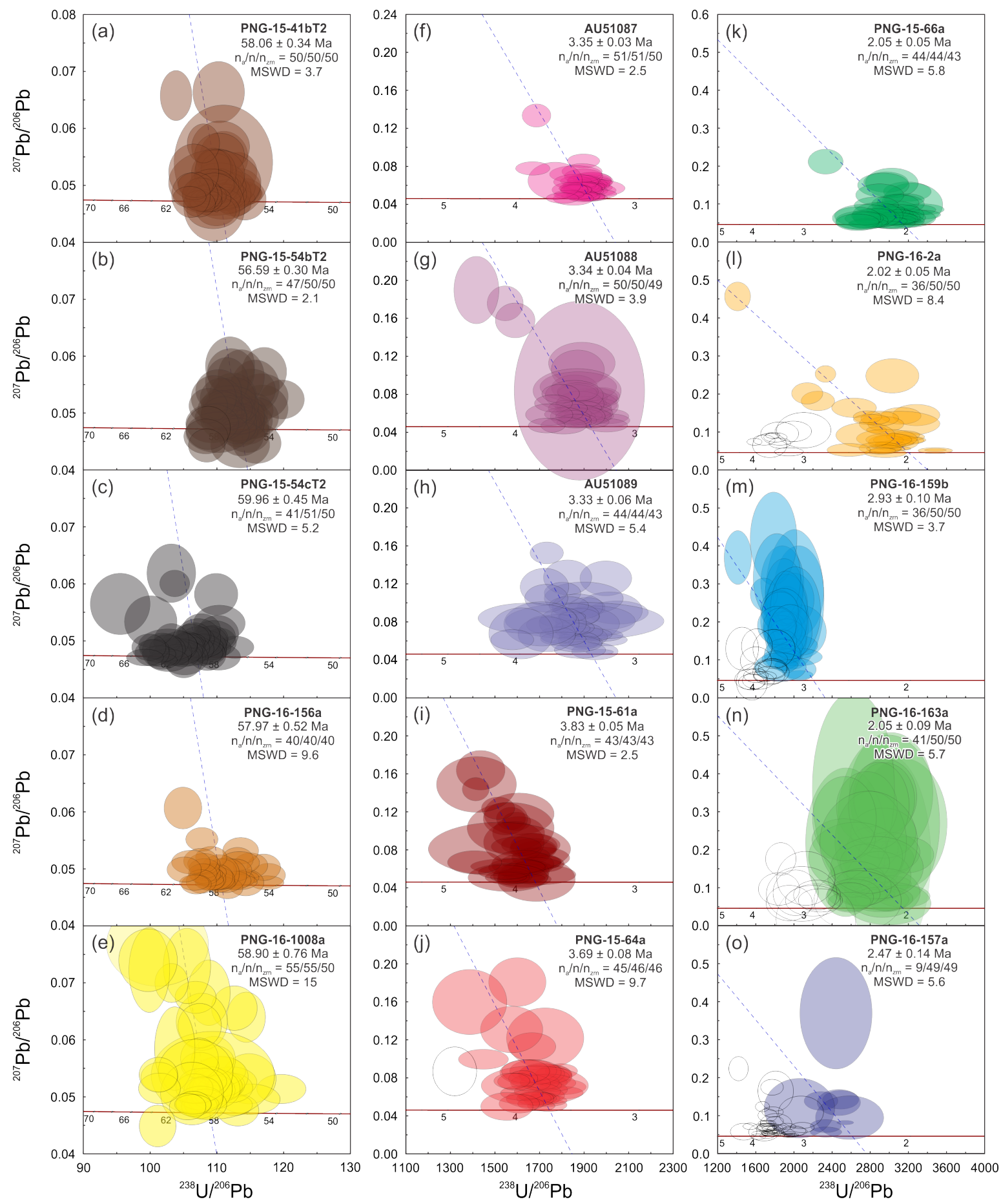

Figure B.4: Zircon U-Pb Tera-Wasserburg diagrams of the Yau Igneous Complex (a-e), Suckling Granite (f-j), Mai'iu Monzonite (k-n), and Bonua Porphyry (o). The upper intercepts were anchored at ${ }^{207} \mathrm{~Pb} /{ }^{206} \mathrm{~Pb}=0.83 . \mathrm{n}_{a}$ - number of analyses constituting the age; $\mathrm{n}$ - number of analyses; $\mathrm{n}_{z r n}$ - number of zircons analysed. Error ellipses are 2SE. Empty ellipses have been excluded from the calculation of the lower-intercept age. 

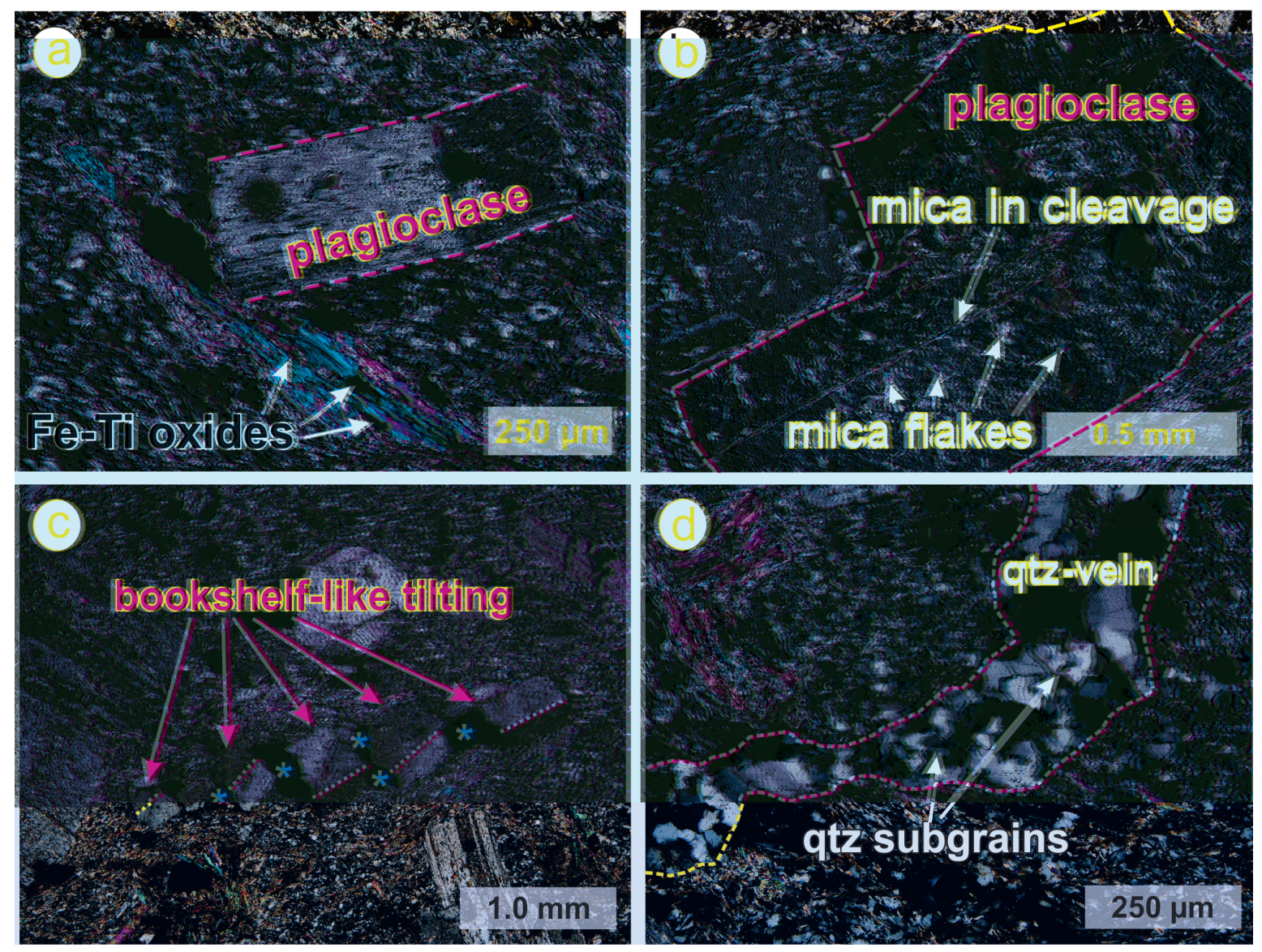

Figure B.5: Cross-polarized micro-photographs of deformed granite PNG-15-61a. (a) Bending (note difference in extinction) and peripheral breakage of plagioclase phenocryst. Fe-Ti oxides appear to be aligned in the larger white mica clots. (b) Secondary white mica in cleavage planes and interspersed in plagioclase phenocryst. (c) Bookshelf-like tilting of fragments of a single plagioclase phenocryst. Asterisks mark locations where material has been removed during the thin-section preparation. Yellow stippled line marks the boundary between the areas of the plagioclase fragments that are extinct and those that are not. (d) Discordant quartz vein showing subgrains indicative of dynamic recrystallization. 

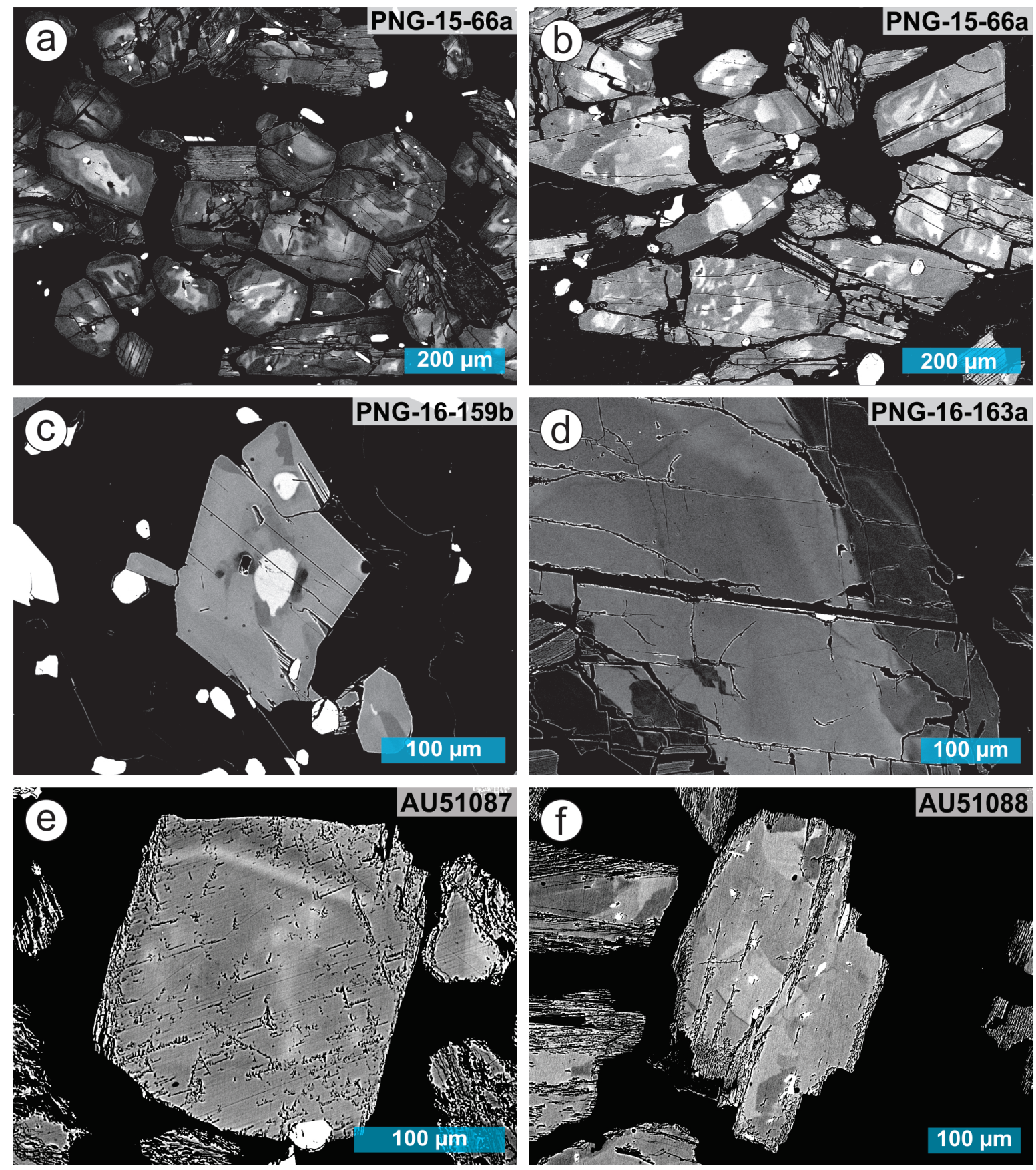

Figure B.6: EPMA back-scatter electron images showing zoning in amphibole in samples of the Mai'iu Monzonite (a-d) and Suckling Granite (e-f). Patchy zoning of amphibole in (a-c) predominantly in the central parts of the amphibole grains. (d) Rare simple core-rim zoning. (e-f) Diffuse to slightly patchy zoning in amphiboles of the Suckling Granite samples AU51087 and AU51088. 

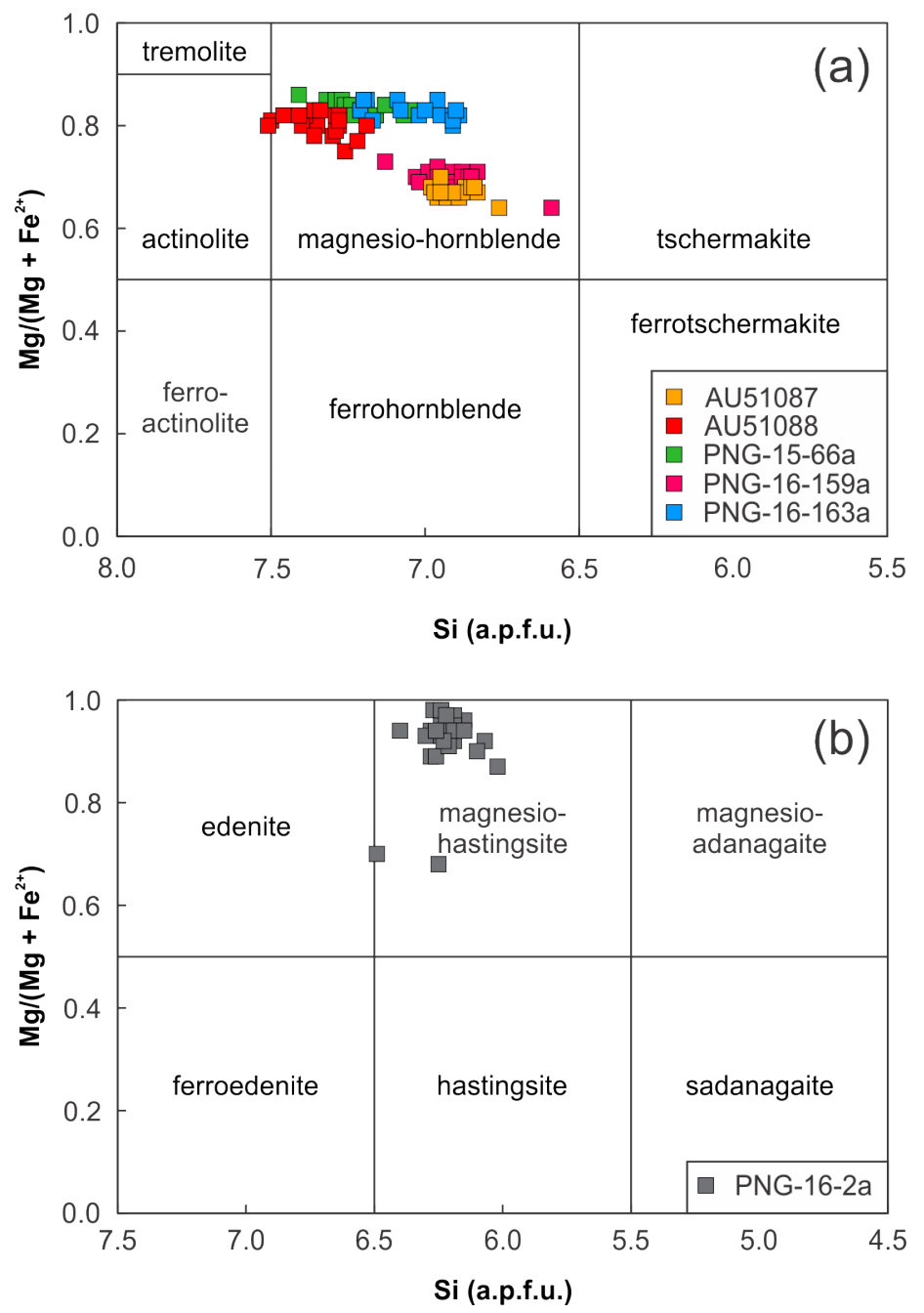

Figure B.7: Amphibole compositions of samples of the Suckling Granite and Mai' iu Monzonite after Leake et al. (1997). (a) Suckling Granite (AU51087, AU51088) and plutonic Mai'iu Monzonite (PNG-15-66a, PNG-16-159b, PNG-16-163a) samples. (b) Mai'iu Monzonite dike (PNG-16-2a). Abbreviation: a.p.f.u. - atoms per formula unit. 

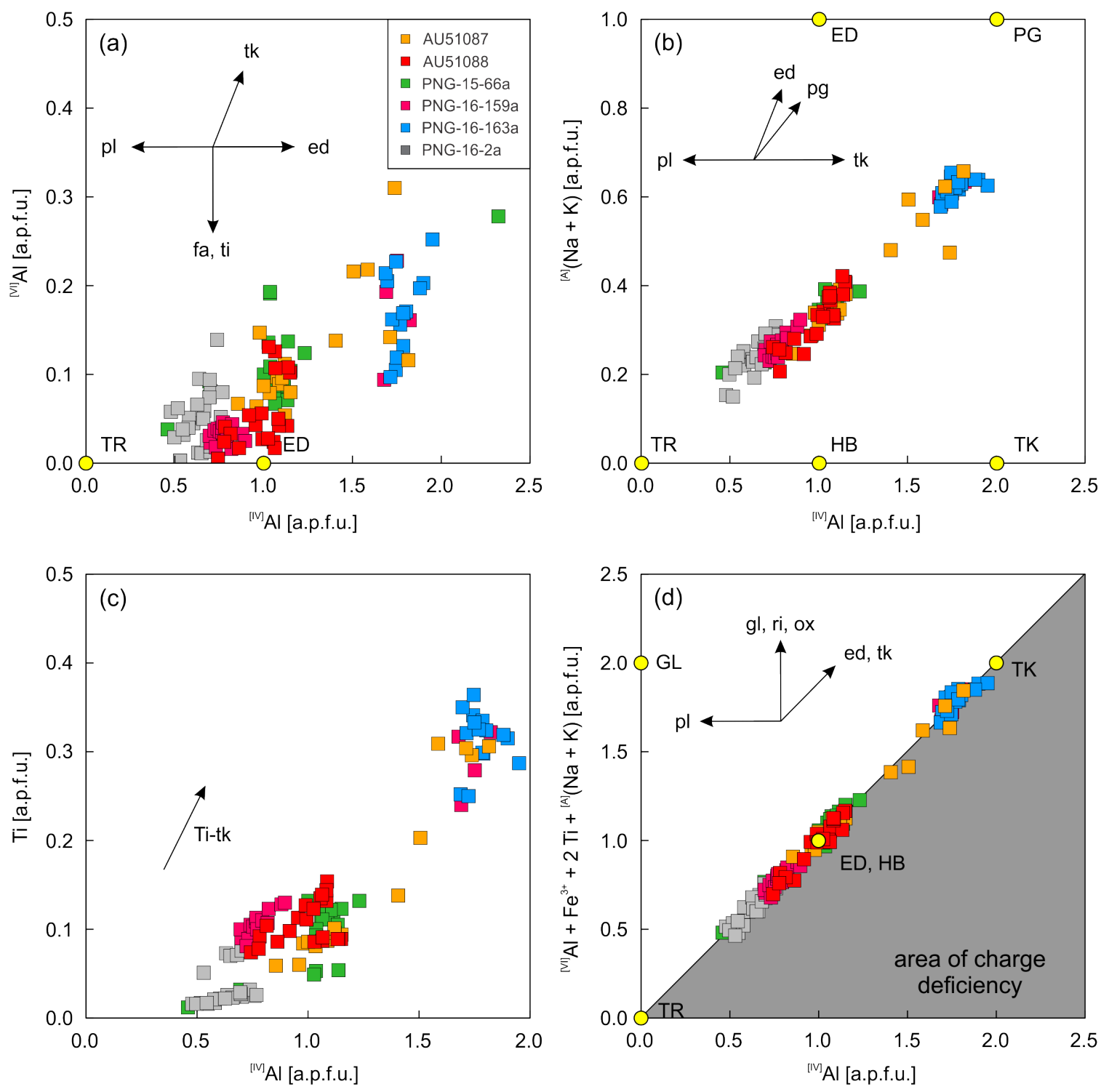

Figure B.8: Substitution analysis of amphibole compositions after Blundy and Holland (1990) and Poli and Schmidt (1992). Tetrahedrally-coordinated ${ }^{[I V]} \mathrm{Al}$ plotted against (a) octahedrally-coordinated ${ }^{[V I]} \mathrm{Al}$, (b) A-site occupancy ${ }^{[A]}(\mathrm{Na}+\mathrm{K})$, (c) Ti content, and (d) ${ }^{[V I]} \mathrm{Al}+\mathrm{Fe}^{3+}+2 \mathrm{Ti}+{ }^{[A]}(\mathrm{Na}+\mathrm{K})$. Abbreviations: $e d / \mathrm{ED}-$ edenite, $h b / \mathrm{HB}$ - hornblende, $f a$ - fayalite, $g l / \mathrm{GL}$ - glaucophane, $p g / \mathrm{PG}$ - pargasite, $p l$ - plagioclase, $r i$ - richterite, $o x$ oxyhornblende, Ti-tk - Ti-tschermakite, $t k / \mathrm{TK}$ - tschermakite, $t r / \mathrm{TR}$ - tremolite. Lowercase abbreviations refer to exchange vectors and capitalized abbreviations refer to end members. All units in a.p.f.u. - atoms per formula unit. 


\section{B.2 Supplementary material Chapter 3}

\section{Secular disequilibrium in zircon from the tephra}

Because zircon tends to fractionate Th relative to $U$ during crystal growth, this may result in excess ${ }^{230} \mathrm{Th}$ (half-life $=\sim 75.7 \mathrm{ka}$ ) and a secular equilibrium age that underestimates the 'true' eruption age by a few tens of \% (Farley et al., 2002). The severity of this inaccuracy decreases with increasing eruption age and increasing magma residence time (Farley et al., 2002). Therefore, ZHe ages $<\sim 1$ Ma should be corrected for intermediate daughter nuclide disequilibrium. We employed $\mathrm{MCHeCalc}$, a Monte Carlo computational routine that calculates probability density functions for disequilibrium-corrected (U-Th)/He ages based on the uncorrected (U-Th)/He ages, the crystallization ages, and the $\mathrm{D}_{230}$ (Schmitt et al., 2010). $\mathrm{D}_{230}$ is the initial ${ }^{232} \mathrm{Th} /{ }^{238} \mathrm{U}$ activity ratio when the crystals grows and relates to the ${ }^{232} \mathrm{Th} /{ }^{238} \mathrm{U}$ of the crystal and the magma, provided that the magma remains in secular equilibrium (Farley et al., 2002).

No glass shards were found in the tephra, probably because they were devitrified in the tropical climate, nor do we know its whole-rock composition. Therefore, in order to apply a disequilibrium correction, the ${ }^{232} \mathrm{Th} /{ }^{238} \mathrm{U}$ of the magma was inferred. Assuming the Dawson Strait Volcanics on the D'Entrecasteaux Islands are the source region of the tephra, the average $\mathrm{Th} / \mathrm{U}$ of volcanic rocks $\left(\mathrm{SiO}_{2}=\sim 67-71 \mathrm{wt} \%\right)$ from Dobu, Fergusson, Sanaroa and Oiau Islands reported in Catalano (2012) and Smith and Johnson (1981) is $\sim 5.5$. Similarly, the $\mathrm{Th} / \mathrm{U}$ of volcanic rocks from the Moresby Strait Volcanics $\left(\mathrm{SiO}_{2}=\sim 69-74 \mathrm{wt} \%\right)$ reported by Smith and Johnson (1981) is $\sim 4.5$. Because no bulk composition of the tephra is available and volcanic activity of the Moresby Strait Volcanics and the Dawson Strait Volcanics overlap in time, either are equally likely. Thus we assumed $\mathrm{Th} / \mathrm{U}_{\text {magma }}=5$.

The calculation of disequilibrium-corrected $\mathrm{ZHe}$ ages also requires the deficit of ${ }^{231} \mathrm{~Pa}$ to be known or estimated. Like ${ }^{230} \mathrm{Th},{ }^{231} \mathrm{~Pa}$ may be fractionated from $\mathrm{U}$, but due to its shorter half-life ( $\sim 32.8 \mathrm{ka}$ ) the effects on the ZHe ages are typically assumed to be negligible unless for zircons with very young crystallization ages (Schmitt et al., 2010, and reference therein). For the calculation, we assumed full equilibrium, i.e. ${ }^{231} \mathrm{~Pa}=1$. For the crystallization age, the weighted mean ${ }^{230} \mathrm{Th}$-corrected zircon ${ }^{206} \mathrm{~Pb} /{ }^{238} \mathrm{U}$ age (also assuming $\mathrm{Th} / \mathrm{U}_{\text {magma }}=5$ ) of $1.1 \pm 0.2(2 \sigma)$ was used instead of the respective ${ }^{206} \mathrm{~Pb} /{ }^{238} \mathrm{U}$ dates of the individual aliquots (although no significant difference was observed if the corresponding ${ }^{206} \mathrm{~Pb} /{ }^{238} \mathrm{U}$ dates were used instead). Monte Carlo calculations with low (100,000 trails) and high (1,000,000 trails) resolution yielded essentially the same results. The results from the high resolution calculation are reported in Table B.2. Note, the two oldest ZHe aliquots were not corrected for ${ }^{230} \mathrm{Th}$ disequilibrium as they pre-date the zircon $\mathrm{U}-\mathrm{Pb}$ age. 
The output file 'Erupages' indicated that there was no overlap between individual $t_{\text {erp }}$ (age of eruption) distributions, nor was the data compatible to define an eruption time. Therefore, the calculated eruption ages were restricted to the 'Monte Carlo-corrected He age' ( $0.47 \pm$ $0.28 \mathrm{Ma}, 2 \sigma)$ and 'Minimum Dispersion He age' $(0.71 \pm 0.14 \mathrm{Ma}, 2 \sigma)$ modes. Although both ages overlap with the uncorrected $\mathrm{ZHe}$ geometric mean age $(0.7 \pm 0.4 \mathrm{Ma}, 2 \sigma)$, 'Minimum Dispersion He age' is essentially identical to the uncorrected $\mathrm{ZHe}$ mean age. Because the inaccuracy introduced by ${ }^{230} \mathrm{Th}$ disequilibrium for most zircons is expected to be on the order of $\sim 10 \%$ (similar to the reported analytical uncertainty of the ZHe ages, i.e., $\sim 8 \%$ ) for eruption ages of $\sim 0.5 \mathrm{Ma}$ (Farley et al., 2002), the error introduced by ignoring ${ }^{230} \mathrm{Th}$ disequilibrium is relatively minor in our case. For this reason and the fact that for the calculation of the disequilibrium corrected $\mathrm{ZHe}$ ages a series of assumptions had to be made (see above), the uncorrected $\mathrm{ZHe}$ ages are preferred.

Table B.2: Correction for secular ${ }^{230} \mathrm{Th}$ disequilibrium of single-grain $\mathrm{ZHe}$ ages.

\begin{tabular}{lcccccc}
\hline & \multicolumn{2}{c}{ Diseq. uncorrected } & & \multicolumn{3}{c}{ Diseq. corrected } \\
\cline { 2 - 3 } Aliquot & (U-Th)/He age & $\pm 2 \sigma$ & $D_{230}$ & & (U-Th)/He age & $\pm 2 \sigma$ \\
\hline zPNG-16-1030a-1 & 0.76 & 0.06 & 0.18 & 0.77 & 0.07 \\
zPNG-16-1030a-2 & 1.01 & 0.08 & 0.07 & 1.03 & 0.09 \\
zPNG-16-1030a-3-DS & 0.92 & 0.07 & 0.11 & 0.94 & 0.08 \\
zPNG-16-1030a-4-DS & 1.66 & 0.13 & & & \\
zPNG-16-1030a-6 & 0.47 & 0.04 & 0.10 & 0.47 & 0.04 \\
zPNG-16-1030a-7 & 1.64 & 0.13 & & & \\
zPNG-16-1030a-10-DS & 0.65 & 0.05 & 0.13 & 0.66 & 0.06 \\
zPNG-16-1030a-11-DS & 0.91 & 0.07 & 0.12 & 0.93 & 0.08 \\
zPNG-16-1030a-16 & 0.64 & 0.05 & 0.19 & 0.65 & 0.06 \\
\hline
\end{tabular}

Suffix -DS denotes aliquots analysed by Rudra Chatterjee/Daniel Stockli. Italic font: Aliquots not corrected for secular disequilibrium. See text for discussion. For the disequilibrium correction, a crystallization age of $1.1 \pm 0.2 \mathrm{Ma}(2 \sigma)$ and a $\mathrm{Th} / \mathrm{U}_{\text {magma }}=5$ were assumed. See text for discussion. 


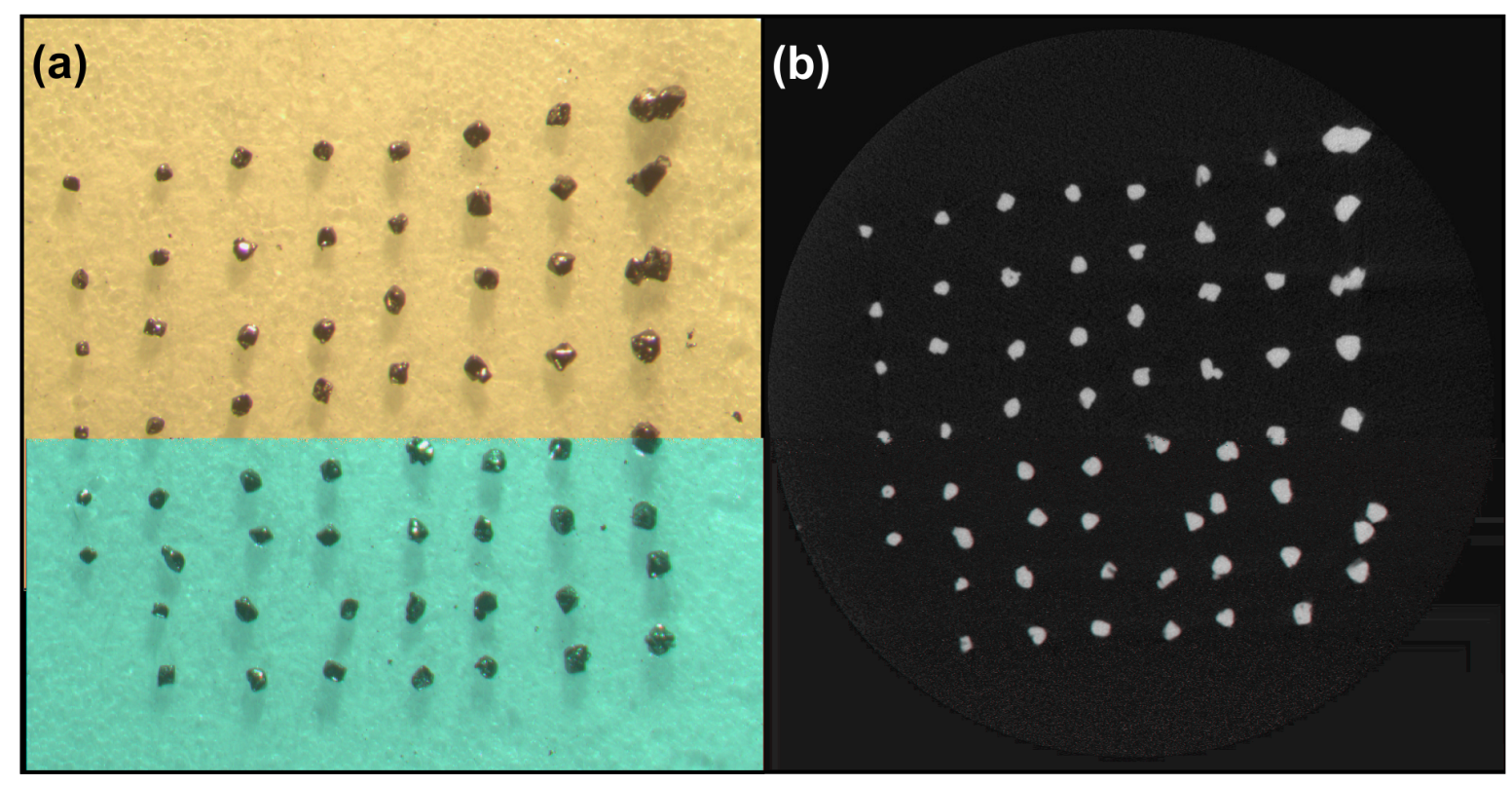

Figure B.9: Example of CT data. (a) Magnetite mounts prepared for CT scans. Field of view is $\sim 3 \mathrm{~mm}$ across. (b) Volume rendering of magnetite grains to detect inclusions that have a different density (darker if lower density, brighter if higher density) from the magnetite. The grains with these inclusions were avoided for analysis. Field of view is $\sim 4-5 \mathrm{~mm}$ across.

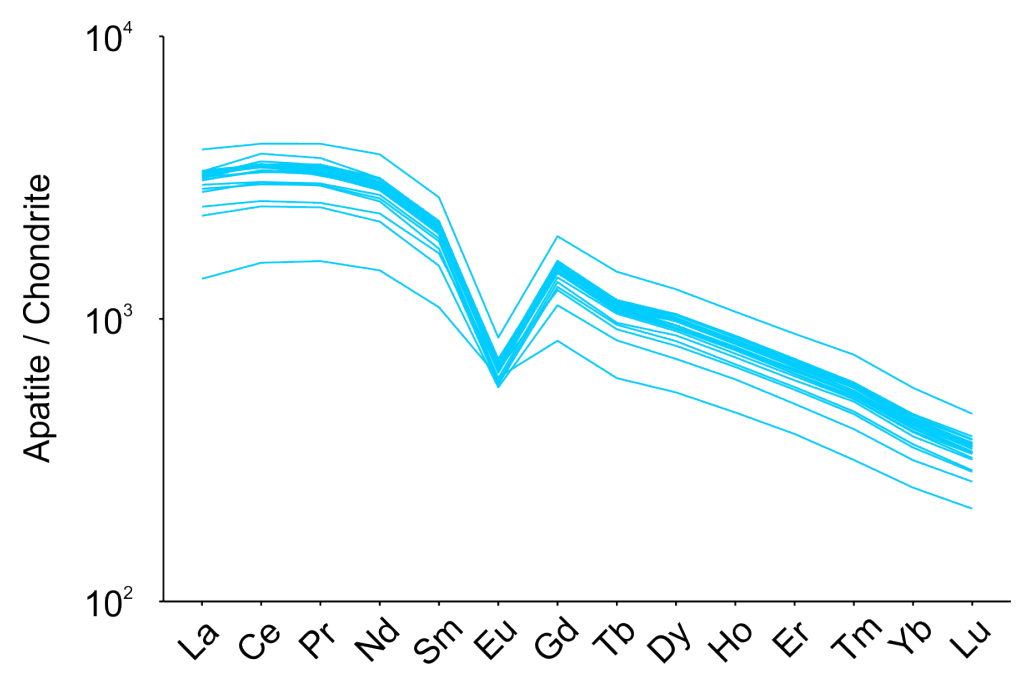

Figure B.10: Chondrite-normalized apatite rare earth element plot. Chondrite normalization values from Taylor and McLennan (1985). No zoning was apparent from depth profiling over the penetration depth of $\sim 10-15 \mu \mathrm{m}$. 

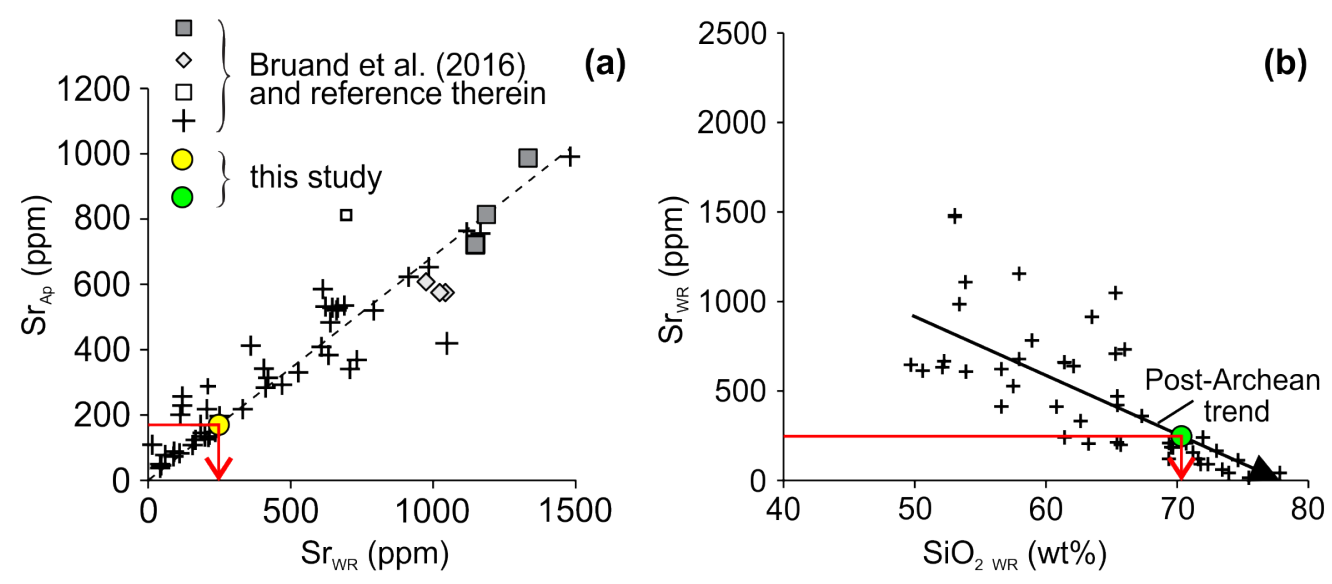

Figure B.11: $\mathrm{SiO}_{2}$ content of whole rock inferred from $\mathrm{Sr}$ in apatite. (a) $\mathrm{Sr}$ content in apatite $\left(\mathrm{Sr}_{A p}\right)$ vs. Sr content in whole-rock $\left(\mathrm{Sr}_{W R}\right)$. Yellow circle represents the mean $\mathrm{Sr}_{A p}=172$ ppm of 25 apatite crystals measured by LA-ICP-MS. The resulting $\mathrm{Sr}_{W R}=247 \mathrm{ppm}$. (b) $\mathrm{Sr}_{W R}$ vs. $\mathrm{SiO}_{2}$ content in whole-rock $\left(\mathrm{SiO}_{2 W R}\right)$. Symbols as in (a). For samples with $\mathrm{Sr}_{W R}<650 \mathrm{ppm}$ the "Post-Archean trend" of Bruand et al. (2016) was used. Green circle represents the mean $\mathrm{Sr}_{W R}=247$ ppm from which a $\mathrm{SiO}_{2 W R}$ of $\sim 70 \mathrm{wt} \%$ is deduced. 


\section{B.3 Supplementary material Chapter 4}

\section{Mineral separation}

Mineral separations were carried out at Victoria University of Wellington, New Zealand, employing standard techniques. Because of expected low yields of minerals suitable for fissiontrack (FT) and (U-Th[-Sm])/He analyses, special care was taken and the conventional work flow was slightly adapted to reduce the chance of contamination. Rocks were crushed in a Boyd crusher and further disintegrated using a disk mill. Instead of using conventional sieves, a custom made sieve apparatus was used in which a new nylon mesh cloth $(60,125$ and $250 \mu \mathrm{m}$ ) was used for each sample to avoid contamination. The target grain size fraction (60-250 $\mu \mathrm{m})$ was washed on a Wilfley wet shaking table. For samples with expected low zircon yields (those from the Goropu Metabasalt and the Bonenau Schist) the target grain size fraction was washed in beakers instead. Subsequent steps involved standard magnetic (Frantz Isodynamic Magnetic Separator) and density separation techniques using methylene iodide.

\section{Circumferential distance from the Mai'iu Fault trace}

In order to determine the distance of a sample from the fault trace, we approximated the distance from the fault trace by constructing transects parallel to the mean slip direction of the Mai'iu Fault (Figure B.13). Estimates of the slip direction are based on measurements of wear striae and fine corrugations on the fault pavement $\left(012 \pm 3^{\circ}, 95 \%\right.$ C. I. $)$ and the ductile extension lineation (008 $\pm 4^{\circ}, 95 \%$ C. I.) of the mylonites at the range front (Little et al., 2019), fault surface remnants on interfluves (017 $\pm 4^{\circ}, 95 \%$ C. I.; Mizera et al., 2019) and the NNE trending megacorrugations of the SDMCC (Daczko et al., 2011). Together, these data suggest a slip direction between $004^{\circ}$ and $021^{\circ}$ with an average of approximately $012^{\circ}$. Therefore, the distance from the fault trace was measured on transects parallel to $004^{\circ}, 012^{\circ}$ and $021^{\circ}$. The differences in the distance between the transects parallel to $004^{\circ}$ and $021^{\circ}$ compared to that of the mean value $\left(012^{\circ}\right)$ translate into uncertainties of $\sim 0.6-9.5 \%$.

Because of the convex-up shape of the footwall of the SDMCC, measuring the horizontal distance between the Ma'iu Fault trace and the samples instead of the curved surface would lead to an underestimate of the 'true' distance. We note however, that the horizontal distance underestimates the calculate surface distances by no more than $14 \%$. The angular change over the entire exposed footwall is on average $\sim 1^{\circ} \mathrm{km}^{-1}$. For the determination of the 'true' length, we used a $30 \mathrm{~m}$ digital terrain model (DTM) in ArcGIS by using the 'Add Surface Information' tool in the '3D Analyst Tools' toolbox. The calculated surface lengths are likely a good approximation on the smooth surface of Mt. Dayman. The distances calculated for the 
samples on Mt. Suckling and south of the main divide likely overestimate the 'true' distance because of the more rugged topography there.

Estimation of the distance from the fault trace is straight-forward for samples on Mt. Suckling and Mt. Dayman. Further east, however, the Mai'iu Fault was abandoned in favour of a forward-stepping hanging splay fault, the Gwoira Fault. There, rocks of equivalent metamorphic grade as those further west north of Mt. Dayman are overlain by the Gwoira Conglomerate. We used the modelled fault surface of the Goropu Metabasalt below the Gwoira depression (see Webber, 2017) to infer the position of the Mai' iu Fault trace below the Gwoira Conglomerate at sea level. This inferred fault trace is depicted in Figure B.13. For samples PNG-14-15a, PNG-16-16b, PNG-16-27a and PNG-16-1008a, the distance from the fault trace was measured with respect to this inferred fault trace (Figure B.13). Note, because of the uncertainties associated with this approach, uncertainties of $\pm 3 \mathrm{~km}$ were assigned to the above mentioned samples.

\section{Choice of RSCM temperature calibration}

For the calculation of peak metamorphic temperatures based on graphite crystallinity, several thermometer calibrations are available (Aoya et al., 2010; Beyssac et al., 2002; Kouketsu et al., 2014; Lahfid et al., 2010; Rahl et al., 2005). Because of the higher temperatures over which they were calibrated (approximately $650-330^{\circ} \mathrm{C}$ ), those of Beyssac et al. (2002) and Aoya et al. (2010) are only suitable for the greenschist-facies rocks at the range front of the SDMCC. A calibration that spans the temperature range of $700-100^{\circ} \mathrm{C}$ has been proposed by Rahl et al. (2005). In addition to the $\mathrm{R} 2$ area ratio (derived from the area of the defect bands D1 and D2 relative to the ordered graphite band G) used in the calibrations of Beyssac et al. (2002) and Aoya et al. (2010), the calibration of Rahl et al. (2005) includes the R1 intensity ratio which relates the amplitude of the defect band D1 to that of the G band. Although attractive because of its broad temperature range, we found that the determination of the amplitudes of D1 and G of the carbonaceous material studied here is associated with larger errors.

Calibrations that are suitable for low-grade metamorphic rocks are those of Lahfid et al. (2010) and Kouketsu et al. (2014). Because its general applicability is presently unclear and due to the restricted temperature range for which it was calibrated $\left(\sim 320-200^{\circ} \mathrm{C}\right)$, the calibration of Lahfid et al. (2010) was avoided. Two calibrations have been proposed by Kouketsu et al. (2014) who observed an inverse correlation between metamorphic temperature and the full width at half maximum (FWHM) of the D1 and D2 defect bands. The two calibrations (for D1 and D2) are applicable over a temperature range of $\sim 400-150^{\circ} \mathrm{C}$ and therefore ideally suited for the prehnite-pumpellyite and pumpellyite-actinolite facies rocks 
of the SDMCC. We used their FMHW-D1 calibration to avoid uncertainties associated with the fitting of the $\mathrm{G}$ and D2 bands in poorly crystalline (or amorphous) carbonaceous material (see Kouketsu et al., 2014). Because their calibrations start to fail at $\sim 400{ }^{\circ} \mathrm{C}$ (i.e., they will underestimate the 'true' temperature), we employed the calibration of Beyssac et al. (2002) for samples in the greenschist-facies part of the SDMCC. 
Table B.3: Raman spectroscopy data

\begin{tabular}{|c|c|c|c|c|c|c|c|c|c|c|c|c|c|c|c|c|c|c|}
\hline \multirow[b]{2}{*}{ Sample } & \multirow{2}{*}{$\begin{array}{c}\text { Latitude* } \\
\text { [S] }\end{array}$} & \multirow{2}{*}{$\begin{array}{l}\text { Longitude* } \\
\text { [E] }\end{array}$} & \multicolumn{2}{|c|}{ D1 position } & \multicolumn{2}{|c|}{ D1 FWHM } & \multicolumn{2}{|l|}{ G position } & \multicolumn{2}{|c|}{ G FWHM } & \multicolumn{2}{|c|}{ D2 position } & \multicolumn{2}{|c|}{ D2 FWHM } & \multicolumn{2}{|l|}{$\mathrm{R} 2_{\text {area }}$} & \multirow{2}{*}{$\begin{array}{l}\mathrm{T}_{D 1} \\
{\left[{ }^{\circ} \mathrm{C}\right]}\end{array}$} & \multirow{2}{*}{$\begin{array}{l}\mathrm{T}_{R 2} \\
{\left[{ }^{\circ} \mathrm{C}\right]}\end{array}$} \\
\hline & & & Mean & $2 \mathrm{SE}$ & Mean & $2 \mathrm{SE}$ & Mean & $2 \mathrm{SE}$ & Mean & $2 \mathrm{SE}$ & Mean & 2SE & Mean & $2 \mathrm{SE}$ & Mean & $2 \mathrm{SE}$ & & \\
\hline PNG-14-15a & $9^{\circ} 51^{\prime} 0.4^{\prime \prime}$ & $149^{\circ} 26^{\prime} 58.1^{\prime \prime}$ & 1344.0 & 0.6 & 48.9 & 0.8 & 1584.2 & 0.8 & 45.3 & 0.7 & 1611.6 & 0.7 & 25.2 & 0.5 & 0.7 & 0.00 & $373 \pm 14 / 30$ & \\
\hline PNG-15-5a & $9^{\circ} 50^{\prime} 14.5^{\prime \prime}$ & $149^{\circ} 17^{\prime} 16.1^{\prime \prime}$ & 1341.7 & 0.5 & 85.5 & 2.3 & 1593.1 & 0.9 & 40.1 & 0.8 & 1611.8 & 0.7 & 25.4 & 0.6 & 0.7 & 0.00 & $294 \pm 29 / 30$ & \\
\hline PNG-15-18a & $9^{\circ} 46^{\prime} 49.3^{\prime \prime}$ & $149^{\circ} 15^{\prime} 57.3^{\prime \prime}$ & 1340.7 & 0.2 & 69.6 & 1.8 & 1584.0 & 0.7 & 46.9 & 1.4 & 1608.3 & 0.2 & 24.8 & 0.6 & 0.7 & 0.00 & $328 \pm 33 / 30$ & \\
\hline PNG-15-26a & $9^{\circ} 46^{\prime} 15.9^{\prime \prime}$ & $149^{\circ} 15^{\prime} 58.0^{\prime \prime}$ & 1343.7 & 0.6 & 68.5 & 2.2 & 1588.3 & 1.0 & 44.4 & 1.1 & 1611.0 & 0.6 & 25.9 & 0.5 & 0.7 & 0.00 & $331 \pm 40 / 30$ & \\
\hline PNG-15-52c & $9^{\circ} 40^{\prime} 47.3^{\prime \prime}$ & $149^{\circ} 17^{\prime} 21.5^{\prime \prime}$ & 1347.4 & 0.4 & 38.3 & 0.9 & 1578.1 & 0.3 & 25.8 & 0.6 & 1614.5 & 0.7 & 18.8 & 1.4 & 0.4 & 0.02 & & $469 \pm 95 / 50$ \\
\hline PNG-15-52e & $9^{\circ} 40^{\prime} 47.3^{\prime \prime}$ & $149^{\circ} 17^{\prime} 21.5^{\prime \prime}$ & 1342.9 & 0.3 & 47.0 & 0.5 & 1579.2 & 0.4 & 35.5 & 0.7 & 1609.4 & 0.4 & 21.3 & 0.7 & 0.6 & 0.01 & & $375 \pm 37 / 50$ \\
\hline PNG-15-52c,e & $9^{\circ} 40^{\prime} 47.3^{\prime \prime}$ & $149^{\circ} 17^{\prime} 21.5^{\prime \prime}$ & 1345.4 & 0.4 & 42.0 & 0.8 & 1578.6 & 0.2 & 30.0 & 0.9 & 1612.3 & 0.6 & 19.9 & 0.9 & 0.5 & 0.02 & & $423 \pm 112 / 50$ \\
\hline PNG-16-11b & $9^{\circ} 52^{\prime} 17.1^{\prime \prime}$ & $149^{\circ} 23^{\prime} 48.6^{\prime \prime}$ & 1338.9 & 0.4 & 90.5 & 1.9 & 1591.4 & 0.6 & 38.6 & 0.7 & 1609.9 & 0.3 & 24.7 & 0.4 & 0.7 & 0.00 & $283 \pm 36 / 30$ & \\
\hline PNG-16-16a & $9^{\circ} 50^{\prime} 12.9^{\prime \prime}$ & $149^{\circ} 26^{\prime} 29.3^{\prime \prime}$ & 1341.8 & 0.5 & 94.0 & 2.4 & 1592.2 & 0.7 & 40.8 & 0.8 & 1611.6 & 0.4 & 26.2 & 0.5 & 0.7 & 0.00 & $276 \pm 45 / 30$ & \\
\hline PNG-16-27a & $9^{\circ} 51^{\prime} 6.3^{\prime \prime}$ & $149^{\circ} 27^{\prime} 1.5^{\prime \prime}$ & 1345.4 & 0.5 & 52.0 & 1.0 & 1585.2 & 0.9 & 44.7 & 0.5 & 1612.3 & 0.6 & 26.1 & 0.4 & 0.7 & 0.01 & $366 \pm 17 / 30$ & \\
\hline
\end{tabular}

*: Reference datum AGD1966, AMG Zone 55 .

Units of peak positions and full width at half maximum (FWHM) are in $\mathrm{cm}^{-1}$. Uncertainties are represented by two standard errors (2SE) which were determined by dividing the two standard deviations of the measurements by the square root of the number of measurements. Uncertainties of the FWHM-D1 (Kouketsu et al., 2014) and R2 (Beyssac et al., 2002) calibrations are \pm 30 and $\pm 50^{\circ} \mathrm{C}$, respectively.

Where the $2 \sigma$ uncertainty exceeds the uncertainties reported by Kouketsu et al. (2014) and Beyssac et al. (2002), the $2 \sigma$ uncertainty is reported instead. 
Table B.4: Fission track data

\begin{tabular}{|c|c|c|c|c|c|c|c|c|c|}
\hline Sample & Mineral & $\mathrm{N}$ & $\begin{array}{l}\rho_{d} \times 10^{5} \\
(\text { counted) }\end{array}$ & $\begin{array}{l}\rho_{s} \times 10^{5} \\
\text { (counted) }\end{array}$ & $\begin{array}{l}\rho_{i} \times 10^{5} \\
\text { (counted) }\end{array}$ & $\begin{array}{c}\mathrm{U} \\
(\mathrm{ppm})\end{array}$ & $\begin{array}{l}\mathrm{P}\left(\chi^{2}\right) \\
\operatorname{Var} \%\end{array}$ & $\begin{array}{l}\operatorname{Age}^{a} \pm 2 \sigma \\
(\mathrm{Ma})\end{array}$ & $\begin{array}{c}\text { M.L. }{ }^{b} \text { age } \pm 2 \sigma \\
\text { (Ma) }\end{array}$ \\
\hline \multicolumn{10}{|l|}{ Suckling Granite: } \\
\hline 2576/AU51087 & Zircon & 20 & $3.82(3802)$ & $0.63(217)$ & $11.04(3810)$ & 940 & $0.28(13)$ & $1.42 \pm 0.22$ & \\
\hline 2577/AU51088 & Zircon & 22 & $3.78(3802)$ & $0.21(74)$ & $4.81(1706)$ & 419 & $0.16(24)$ & $1.04 \pm 0.28$ & \\
\hline 2578/AU51089 & Zircon & 20 & 3.74 (3802) & $0.24(124)$ & $6.39(3286)$ & 561 & $0.2(22)$ & $0.97 \pm 0.21$ & \\
\hline PNG-15-61a & Zircon & 22 & $4.04(3802)$ & $0.44(287)$ & $4.86(3154)$ & 392 & $0.43(0)$ & $2.41 \pm 0.30$ & \\
\hline PNG-15-61a & Apatite & 29 & $12.86(9726)$ & $0.01(14)$ & $1.8(2495)$ & 19.45 & $0.96(0)$ & $1.24 \pm 0.66$ & $1(+5 /-1)$ \\
\hline PNG-15-64a & Zircon & 26 & $3.99(3802)$ & $0.69(574)$ & $6.18(5160)$ & 507 & $0(27)$ & $2.99 \pm 0.46$ & \\
\hline \multicolumn{10}{|c|}{ Mai’iu Monzonite: } \\
\hline PNG-15-66a & Zircon & 20 & $3.95(3802)$ & $0.24(270)$ & $3.11(3481)$ & 259 & $0.18(11)$ & $2.02 \pm 0.28$ & \\
\hline PNG-15-66a & Apatite & 20 & $12.26(12664)$ & $0.014(8)$ & $2.73(1613)$ & 26.88 & $0.98(0)$ & $1.04 \pm 0.74$ & \\
\hline PNG-16-2a & Zircon & 23 & 4.07 (4232) & $0.38(246)$ & $7.25(4721)$ & 676 & $0(34)$ & $1.53 \pm 0.32$ & \\
\hline PNG-16-2a & Apatite & 20 & $14.46(14000)$ & $0.071(17)$ & $4.25(1547)$ & 17.59 & $0.92(0)$ & $2.72 \pm 1.32$ & $3(+6 /-3)$ \\
\hline PNG-16-159b & Zircon & 20 & $4.31(4232)$ & $0.1(160)$ & $1.96(3035)$ & 152 & $0.08(23)$ & $1.50 \pm 0.30$ & \\
\hline PNG-16-159b & Apatite & 20 & $13.38(12664)$ & $0.011(6)$ & $1.02(548)$ & 9.44 & $0.87(0)$ & $2.50 \pm 2.00$ & $3(+11 /-3)$ \\
\hline PNG-16-163a & Zircon & 20 & $4.49(4232)$ & $0.11(194)$ & $2.1(3569)$ & 145 & $0.47(0)$ & $1.60 \pm 0.24$ & \\
\hline PNG-16-163a & Apatite & 20 & $13.06(12664)$ & $0.017(14)$ & $2.29(1505)$ & 16.37 & $0.95(0)$ & $2.08 \pm 1.12$ & $2(+6 /-2)$ \\
\hline \multicolumn{10}{|l|}{ Bonua Porphyry: } \\
\hline PNG-16-157a & Zircon & 10 & $4.46(4232)$ & $0.53(179)$ & 5.85 (1989) & 519 & $0.07(23)$ & $2.47 \pm 0.58$ & \\
\hline PNG-16-157a & Apatite & 20 & $12.58(12664)$ & $0.025(7)$ & $1.02(652)$ & 5.55 & $0.99(53)$ & $1.98 \pm 1.78$ & $2(+10 /-2)$ \\
\hline \multicolumn{10}{|l|}{ Bonenau Schist: } \\
\hline PNG-15-18c & Zircon & 10 & $4.34(4232)$ & $0.22(61)$ & 4.29 (1196) & 428 & $0(45)$ & $1.87 \pm 0.74$ & \\
\hline PNG-16-161b & Zircon & 6 & 4.37 (4232) & $0.05(5)$ & $3.56(392)$ & 251 & 0 (109) & $0.49 \pm 0.64$ & $1(+1 /-1)$ \\
\hline PNG-16-1153a & Zircon & 17 & $4.52(4378)$ & $3.07(362)$ & $3.52(415)$ & 244 & $0(70)$ & $22.2 \pm 8.4$ & \\
\hline \multicolumn{10}{|c|}{ Goropu Metabasalt: } \\
\hline PNG-16-1b & Zircon & 28 & $4.25(4232)$ & $0.19(97)$ & $3.06(1574)$ & 271 & $0.93(0)$ & $1.72 \pm 0.36$ & $2(+2 /-2)$ \\
\hline PNG-16-4b & Zircon & 25 & $4.4(4232)$ & $0.23(62)$ & 3.57 (949) & 263 & $0(48)$ & $2.33 \pm 0.82$ & $2(+2 /-2)$ \\
\hline PNG-16-169c & Zircon & 8 & $4.28(4232)$ & $0.14(16)$ & $3.06(349)$ & 210 & $0.17(39)$ & $1.36 \pm 0.84$ & $1(+3 /-1)$ \\
\hline PNG-16-1151a & Zircon & 6 & $4.36(4378)$ & $3.43(182)$ & $8.06(427)$ & 688 & $0(128)$ & $0.98 \pm 1.42$ & $1(+1 /-1)$ \\
\hline \multicolumn{10}{|c|}{ Yau Igneous Complex: } \\
\hline PNG-15-41bT2 & Zircon & 20 & $4.1(4232)$ & $3.69(410)$ & $2.54(282)$ & 212 & $0.99(0)$ & $38.9 \pm 6.0$ & \\
\hline PNG-15-54bT2 & Zircon & 20 & $4.22(4232)$ & $2.65(775)$ & $1.46(425)$ & 111 & $0.39(12)$ & $50.6 \pm 6.6$ & \\
\hline PNG-15-54cT2 & Zircon & 19 & $3.97(4232)$ & $4.17(983)$ & $2.81(662)$ & 268 & $0(32)$ & $35.4 \pm 6.8$ & \\
\hline PNG-16-1008a & Zircon & 13 & $4.42(4378)$ & $6.82(593)$ & $5.31(462)$ & 375 & $0.53(0)$ & $37.1 \pm 4.6$ & \\
\hline \multicolumn{10}{|l|}{ Stream sediment: } \\
\hline PNG-15-76d & Zircon & 83 & $3.86(3802)$ & $0.24(802)$ & $3.23(10837)$ & 300 & $0(39)$ & $1.88 \pm 0.22$ & $2(+1 /-1)$ \\
\hline PNG-15-76d & Apatite & 37 & $12.49(9726)$ & $0.01(29)$ & $2.36(6685)$ & 20.47 & $0(83)$ & $1.04 \pm 0.46$ & $1(+2 /-1)$ \\
\hline PNG-16-141a & Zircon & 41 & $4.36(4378)$ & 0.03 (19) & $4.66(3125)$ & 398 & 0 (379) & $0.31 \pm 0.38$ & $1(+1 /-1)$ \\
\hline PNG-16-150b & Zircon & 9 & $4.6(4378)$ & $0.11(33)$ & $5.5(1618)$ & 428 & $0(135)$ & $0.62 \pm 0.62$ & $1(+1 /-1)$ \\
\hline PNG-16-171a & Zircon & 150 & 4.19 (4169) & 0.04 (107) & $3.92(9938)$ & 323 & 0 (112) & $0.32 \pm 0.09$ & $1(+1 /-1)$ \\
\hline
\end{tabular}

$\mathrm{N}$ is the number of crystals counted. $\rho_{d}$ refers to the density of induced tracks in the dosimeter glass. $\rho_{s}$ and $\rho_{i}$ refer to spontaneous and induced track densities, respectively. $\mathrm{P}\left(\chi^{2}\right)$ is the probability of $\chi^{2}$ for $\nu$ degrees of freedom where $\nu=\mathrm{N}-1$. $a$ : Central age calculated after Galbraith and Laslett (1993).

${ }^{b}$ : M.L. age is maximum likelihood age calculated using the method detailed in Warren-Smith et al. (2016). 
Table B.5: Zeta calibration factors

\begin{tabular}{|c|c|c|c|c|c|c|c|c|c|c|c|}
\hline Irradiation & Standard & Dosimeter & $\mathrm{N}$ & $\rho_{d} \times 10^{5}$ & $\mathrm{~N}_{d}$ & $\rho_{s} \times 10^{5}$ & $\mathrm{~N}_{s}$ & $\rho_{i} \times 10^{5}$ & $\mathrm{~N}_{i}$ & Zeta & $\pm 2 \sigma$ \\
\hline VUW09-17 & Apatite, Durango & CN5 & 20 & 12.17 & 13048 & 0.17 & 330 & 1.08 & 2163 & 345 & 183 \\
\hline VUW29-23 & Apatite, Durango & CN5 & 20 & 9.15 & 9726 & 0.16 & 321 & 0.83 & 1665 & 362 & 198 \\
\hline VUW29-22 & Apatite, Fish Canyon Tuff & CN5 & 20 & 9.27 & 9726 & 0.19 & 85 & 1.09 & 477 & 318 & 333 \\
\hline VUW44-07 & Apatite, Durango & CN5 & 20 & 13.23 & 14000 & 0.15 & 299 & 1.15 & 2290 & 366 & 201 \\
\hline VUW13-02 & Apatite, Durango & CN5 & 20 & 15.68 & 14225 & 0.17 & 341 & 1.45 & 2897 & 335 & 172 \\
\hline \multirow[t]{2}{*}{ VUW13-23 } & Apatite, Fish Canyon Tuff & CN5 & 20 & 12.51 & 11612 & 0.20 & 46 & 1.54 & 361 & 344 & 482 \\
\hline & & & & & & & \multicolumn{3}{|c|}{ Weighted mean $\pm 2 \mathrm{SE}$} & 343 & 15 \\
\hline VUW30-18 & Zircon, Fish Canyon Tuff & $\mathrm{CN} 1$ & 20 & 3.69 & 3802 & 5.45 & 1880 & 5.25 & 1810 & 149 & 44 \\
\hline VUW32-26 & Zircon, Fish Canyon Tuff & $\mathrm{CN} 1$ & 20 & 3.58 & 3676 & 5.72 & 1442 & 5.42 & 1367 & 146 & 50 \\
\hline VUW39-10 & Zircon, Fish Canyon Tuff & $\mathrm{CN} 1$ & 20 & 4.44 & 4378 & 6.06 & 763 & 6.49 & 818 & 117 & 53 \\
\hline VUW16-24 & Zircon, Fish Canyon Tuff & $\mathrm{CN} 1$ & 20 & 3.82 & 4072 & 5.61 & 1145 & 5.38 & 1097 & 138 & 53 \\
\hline VUW43-09 & Zircon, Fish Canyon Tuff & $\mathrm{CN} 1$ & 20 & 4.20 & 4169 & 5.88 & 1008 & 5.73 & 903 & 122 & 47 \\
\hline \multirow[t]{2}{*}{ VUW43-18 } & Zircon, Fish Canyon Tuff & $\mathrm{CN} 1$ & 20 & 4.14 & 4169 & 6.59 & 1111 & 5.90 & 1083 & 117 & 48 \\
\hline & & & & & & & \multicolumn{3}{|c|}{ Weighted mean $\pm 2 \mathrm{SE}$} & 131 & 12 \\
\hline
\end{tabular}

$\mathrm{N}$ is the number of crystals counted. $\rho_{d}$ refers to density of induced tracks in dosimeter glass. $\rho_{s}$ and $\rho_{i}$ refer to spontaneous and induced track densities, respectively. Note: $2 \mathrm{SE}$ refers to two standard error. 
Table B.6: Zircon (U-Th)/He age data.

\begin{tabular}{|c|c|c|c|c|c|c|c|c|c|c|c|c|}
\hline Unit & $\begin{array}{l}\text { Sample \& } \\
\text { Aliquot }\end{array}$ & $\begin{array}{l}\text { Age } \\
(\mathrm{Ma})\end{array}$ & $\begin{array}{l} \pm 2 \sigma \\
\text { (Ma) }\end{array}$ & $\begin{array}{c}\mathrm{U} \\
(\mathrm{ppm})\end{array}$ & $\begin{array}{l}\text { Th } \\
(\mathrm{ppm})\end{array}$ & $\begin{array}{l}\text { Sm } \\
(\mathrm{ppm})\end{array}$ & $\begin{array}{l}\mathrm{eU}^{*} \\
(\mathrm{ppm})\end{array}$ & $\mathrm{Th} / \mathrm{U}$ & $\begin{array}{c}\mathrm{He} \\
(\mathrm{nmol} / \mathrm{g})\end{array}$ & $\begin{array}{l}\text { mass } \\
(\mu \mathrm{g})\end{array}$ & $\mathrm{F}_{T}$ & ESR \\
\hline Bas. and. dike & zPNG-15-60a-1 & 0.28 & 0.02 & 116 & 101 & 0 & 139 & 0.87 & 0.14 & 1.91 & 0.67 & 34.87 \\
\hline Bonenau & zPNG-15-18c-1 & 2.99 & 0.24 & 185 & 61 & 0 & 199 & 0.33 & 2.22 & 1.93 & 0.69 & 36.92 \\
\hline \multirow{20}{*}{ Schist } & zPNG-15-18c-5 & 2.87 & 0.23 & 93 & 31 & 0 & 100 & 0.33 & 0.77 & 0.36 & 0.50 & 20.74 \\
\hline & zPNG-15-18c-6 & 2.96 & 0.24 & 374 & 293 & 348 & 443 & 0.79 & 3.73 & 0.46 & 0.52 & 22.58 \\
\hline & zPNG-15-18c-9 & 2.00 & 0.16 & 128 & 79 & 0 & 146 & 0.62 & 0.98 & 0.92 & 0.62 & 29.10 \\
\hline & zPNG-15-18c-10 & 3.08 & 0.25 & 166 & 69 & 0 & 182 & 0.42 & 1.68 & 0.59 & 0.56 & 24.10 \\
\hline & zPNG-15-18c-11 & 2.62 & 0.21 & 58 & 20 & 0 & 62 & 0.35 & 0.53 & 0.81 & 0.60 & 27.26 \\
\hline & zPNG-16-2d-1 & 0.75 & 0.06 & 27 & 50 & 6 & 39 & 1.84 & 0.11 & 1.83 & 0.67 & 35.51 \\
\hline & zPNG-16-2d-3 & 1.13 & 0.09 & 33 & 37 & 2 & 42 & 1.10 & 0.18 & 3.21 & 0.71 & 40.15 \\
\hline & zPNG-16-2d-5 & 0.93 & 0.07 & 133 & 80 & 1 & 151 & 0.60 & 0.58 & 5.10 & 0.76 & 50.06 \\
\hline & zPNG-16-161b-1 & 0.51 & 0.04 & 148 & 135 & 104 & 179 & 0.91 & 0.40 & 8.61 & 0.80 & 61.36 \\
\hline & zPNG-16-161b-4 & 1.54 & 0.12 & 53 & 77 & 1 & 71 & 1.45 & 0.48 & 9.08 & 0.80 & 62.23 \\
\hline & zPNG-16-161e-1 & 0.27 & 0.02 & 75 & 57 & 0 & 88 & 0.75 & 0.09 & 2.43 & 0.70 & 39.34 \\
\hline & zPNG-16-161e-3 & 0.15 & 0.01 & 143 & 92 & 0 & 165 & 0.64 & 0.09 & 1.94 & 0.68 & 35.45 \\
\hline & zPNG-16-1153a-3 & 7.63 & 0.61 & 87 & 121 & 1 & 115 & 1.40 & 3.42 & 3.00 & 0.72 & 42.41 \\
\hline & zPNG-16-1153a-5 & 7.99 & 0.64 & 189 & 86 & 3 & 209 & 0.45 & 6.14 & 1.82 & 0.68 & 35.56 \\
\hline & zPNG-16-1153a-6 & 7.00 & 0.56 & 65 & 77 & 1 & 82 & 1.19 & 2.31 & 3.75 & 0.74 & 46.06 \\
\hline & zPNG-16-1153a-8 & 4.01 & 0.32 & 58 & 75 & 1 & 76 & 1.28 & 1.08 & 1.50 & 0.65 & 33.48 \\
\hline & zPNG-16-1153a-10 & 4.02 & 0.32 & 218 & 85 & 1 & 237 & 0.39 & 3.59 & 2.12 & 0.70 & 37.54 \\
\hline & zPNG-16-1153a-12 & 8.96 & 0.72 & 284 & 174 & 0 & 324 & 0.61 & 10.12 & 1.31 & 0.64 & 31.61 \\
\hline & zPNG-16-1153a-25 & 2.67 & 0.21 & 87 & 104 & 3 & 111 & 1.19 & 1.19 & 3.66 & 0.74 & 46.10 \\
\hline & zPNG-16-1153a-32 & 16.07 & 1.29 & 78 & 62 & 0 & 92 & 0.79 & 5.39 & 1.93 & 0.67 & 34.88 \\
\hline Bonua & zPNG-16-157a-1 & 2.45 & 0.20 & 129 & 247 & 8 & 185 & 1.92 & 1.87 & 6.20 & 0.76 & 49.92 \\
\hline \multirow[t]{5}{*}{ Porphyry } & zPNG-16-157a-8 & 2.05 & 0.16 & 86 & 83 & 2 & 105 & 0.96 & 0.84 & 3.20 & 0.72 & 42.53 \\
\hline & zPNG-16-157a-9 & 2.74 & 0.22 & 149 & 276 & 23 & 212 & 1.86 & 2.50 & 9.07 & 0.79 & 57.85 \\
\hline & zPNG-16-157a-19 & 4.09 & 0.33 & 256 & 360 & 5 & 339 & 1.41 & 6.09 & 16.77 & 0.81 & 64.51 \\
\hline & zPNG-16-157a-34 & 2.44 & 0.20 & 277 & 193 & 4 & 321 & 0.70 & 2.98 & 3.09 & 0.70 & 38.89 \\
\hline & zPNG-16-157a-51 & 3.55 & 0.28 & 440 & 611 & 9 & 580 & 1.39 & 8.57 & 9.90 & 0.77 & 51.93 \\
\hline Goropu & zPNG-16-1151a-1 & 1.49 & 0.12 & 96 & 121 & 6 & 124 & 1.27 & 0.76 & 6.80 & 0.77 & 51.86 \\
\hline \multirow[t]{15}{*}{ Metabasalt } & zPNG-16-1151a-2 & 0.25 & 0.02 & 126 & 107 & 2 & 151 & 0.84 & 0.13 & 1.23 & 0.63 & 30.96 \\
\hline & zPNG-16-1151a-4 & 1.43 & 0.11 & 116 & 77 & 4 & 134 & 0.66 & 0.67 & 1.56 & 0.65 & 31.99 \\
\hline & zPNG-16-1151b-1 & 0.76 & 0.06 & 95 & 82 & 35 & 114 & 0.86 & 0.34 & 3.66 & 0.72 & 42.11 \\
\hline & zPNG-16-1151b-2 & 0.01 & 0.00 & 277 & 323 & 74 & 352 & 1.16 & 0.02 & 3.34 & 0.73 & 43.30 \\
\hline & zPNG-16-1151b-3 & 0.01 & 0.00 & 177 & 320 & 55 & 251 & 1.81 & 0.01 & 4.54 & 0.74 & 46.76 \\
\hline & zPNG-16-1b-9 & 0.94 & 0.07 & 168 & 88 & 0 & 188 & 0.52 & 0.73 & 5.15 & 0.77 & 50.57 \\
\hline & zPNG-16-1b-18 & 0.31 & 0.03 & 451 & 315 & 4 & 524 & 0.70 & 0.64 & 3.95 & 0.72 & 41.90 \\
\hline & zPNG-16-1b-19 & 1.42 & 0.11 & 254 & 148 & 2 & 288 & 0.58 & 1.65 & 4.26 & 0.74 & 45.78 \\
\hline & zPNG-16-1b-24 & 1.29 & 0.10 & 42 & 29 & 0 & 48 & 0.70 & 0.28 & 11.95 & 0.82 & 66.78 \\
\hline & zPNG-16-1b-26 & 1.16 & 0.09 & 127 & 85 & 1 & 146 & 0.67 & 0.75 & 13.02 & 0.82 & 67.79 \\
\hline & zPNG-16-1b-28 & 1.13 & 0.09 & 69 & 58 & 0 & 83 & 0.84 & 0.42 & 13.07 & 0.83 & 69.78 \\
\hline & zPNG-16-4b-35 & 1.10 & 0.09 & 87 & 89 & 1 & 107 & 1.02 & 0.47 & 3.57 & 0.73 & 43.16 \\
\hline & zPNG-16-4b-36 & 1.92 & 0.15 & 136 & 159 & 3 & 172 & 1.17 & 1.38 & 8.46 & 0.77 & 51.57 \\
\hline & zPNG-16-4b-37 & 1.55 & 0.12 & 78 & 95 & 1 & 100 & 1.23 & 0.63 & 5.51 & 0.75 & 48.93 \\
\hline & zPNG-16-4b-39 & 0.96 & 0.08 & 50 & 38 & 1 & 59 & 0.75 & 0.24 & 8.22 & 0.80 & 59.16 \\
\hline
\end{tabular}


Table B.6 - continued from previous page

\begin{tabular}{|c|c|c|c|c|c|c|c|c|c|c|c|c|}
\hline Unit & $\begin{array}{l}\text { Sample \& } \\
\text { Aliquot }\end{array}$ & $\begin{array}{l}\text { Age } \\
\text { (Ma) }\end{array}$ & $\begin{array}{l} \pm 2 \sigma \\
\text { (Ma) }\end{array}$ & $\begin{array}{c}\mathrm{U} \\
(\mathrm{ppm})\end{array}$ & $\begin{array}{l}\text { Th } \\
(\mathrm{ppm})\end{array}$ & $\begin{array}{l}\mathrm{Sm} \\
(\mathrm{ppm})\end{array}$ & $\begin{array}{l}\mathrm{eU}^{*} \\
(\mathrm{ppm})\end{array}$ & $\mathrm{Th} / \mathrm{U}$ & $\begin{array}{c}\mathrm{He} \\
(\mathrm{nmol} / \mathrm{g})\end{array}$ & $\begin{array}{l}\text { mass } \\
(\mu \mathrm{g})\end{array}$ & $\mathrm{F}_{T}$ & ESR \\
\hline & zPNG-16-4b-41 & 1.24 & 0.10 & 39 & 64 & 4 & 54 & 1.64 & 0.28 & 7.68 & 0.78 & 56.26 \\
\hline & zPNG-16-4b-42 & 1.27 & 0.10 & 183 & 131 & 0 & 213 & 0.71 & 1.12 & 5.11 & 0.76 & 49.83 \\
\hline & zPNG-16-169c-1 & 0.11 & 0.01 & 183 & 119 & 2 & 210 & 0.65 & 0.08 & 1.49 & 0.65 & 31.90 \\
\hline & zPNG-16-169c-3 & 0.07 & 0.01 & 195 & 167 & 2 & 234 & 0.86 & 0.06 & 1.94 & 0.67 & 35.31 \\
\hline & zPNG-16-169c-6 & 0.32 & 0.03 & 101 & 68 & 11 & 117 & 0.67 & 0.13 & 1.45 & 0.65 & 32.40 \\
\hline & zPNG-16-169c-99 & 0.09 & 0.01 & 72 & 68 & 1 & 88 & 0.95 & 0.03 & 2.01 & 0.68 & 36.63 \\
\hline & zPNG-16-173b-2 & 0.31 & 0.02 & 113 & 44 & 0 & 123 & 0.39 & 0.14 & 1.69 & 0.68 & 35.69 \\
\hline & zPNG-16-184a-1 & 0.35 & 0.03 & 76 & 69 & 2 & 92 & 0.92 & 0.12 & 3.02 & 0.70 & 39.02 \\
\hline & zPNG-16-184a-5 & 0.34 & 0.03 & 92 & 136 & 4 & 124 & 1.47 & 0.16 & 3.46 & 0.71 & 40.71 \\
\hline & zPNG-16-184a-99 & 0.10 & 0.01 & 156 & 244 & 4 & 212 & 1.57 & 0.08 & 3.44 & 0.73 & 43.68 \\
\hline Mai'iu & zPNG-15-66a-13 & 1.21 & 0.10 & 181 & 137 & 2 & 212 & 0.76 & 1.06 & 5.59 & 0.77 & 51.23 \\
\hline \multirow[t]{22}{*}{ Monzonite } & zPNG-15-66a-20 & 1.47 & 0.12 & 206 & 323 & 4 & 280 & 1.57 & 1.68 & 6.52 & 0.75 & 48.28 \\
\hline & zPNG-15-66a-35 & 1.25 & 0.10 & 199 & 185 & 2 & 242 & 0.93 & 1.19 & 5.57 & 0.73 & 43.53 \\
\hline & zPNG-15-66a-40 & 1.15 & 0.09 & 105 & 110 & 1 & 131 & 1.05 & 0.71 & 36.05 & 0.87 & 98.90 \\
\hline & zPNG-15-66a-46 & 1.30 & 0.10 & 150 & 155 & 2 & 185 & 1.03 & 0.99 & 6.92 & 0.76 & 49.69 \\
\hline & zPNG-15-66a-49 & 1.43 & 0.11 & 114 & 177 & 1 & 155 & 1.55 & 1.08 & 87.89 & 0.90 & 132.45 \\
\hline & zPNG-16-2a-12 & 1.44 & 0.12 & 351 & 329 & 4 & 427 & 0.94 & 2.34 & 3.09 & 0.70 & 39.08 \\
\hline & zPNG-16-2a-2 & 1.16 & 0.09 & 118 & 104 & 2 & 142 & 0.88 & 0.68 & 6.85 & 0.76 & 50.06 \\
\hline & zPNG-16-2a-46 & 0.94 & 0.08 & 705 & 455 & 4 & 810 & 0.65 & 2.89 & 2.51 & 0.70 & 38.43 \\
\hline & zPNG-16-2a-47 & 1.23 & 0.10 & 490 & 959 & 8 & 711 & 1.95 & 3.67 & 6.40 & 0.77 & 53.69 \\
\hline & zPNG-16-2a-9 & 1.26 & 0.10 & 581 & 1282 & 18 & 876 & 2.21 & 4.61 & 6.63 & 0.77 & 52.99 \\
\hline & zPNG-16-159b-7 & 1.61 & 0.13 & 89 & 106 & 6 & 113 & 1.20 & 0.77 & 12.60 & 0.78 & 54.74 \\
\hline & zPNG-16-159b-13 & 1.34 & 0.11 & 141 & 115 & 5 & 167 & 0.82 & 0.99 & 18.01 & 0.81 & 64.73 \\
\hline & zPNG-16-159b-21 & 1.21 & 0.10 & 68 & 70 & 4 & 84 & 1.03 & 0.40 & 4.20 & 0.72 & 41.97 \\
\hline & zPNG-16-159b-22 & 1.52 & 0.12 & 66 & 64 & 3 & 81 & 0.97 & 0.47 & 3.45 & 0.71 & 40.63 \\
\hline & zPNG-16-159b-27 & 2.54 & 0.20 & 60 & 59 & 3 & 73 & 1.00 & 0.81 & 13.72 & 0.81 & 62.68 \\
\hline & zPNG-16-159b-43 & 0.59 & 0.05 & 115 & 135 & 6 & 146 & 1.17 & 0.33 & 4.36 & 0.71 & 39.96 \\
\hline & zPNG-16-159b-46 & 1.38 & 0.11 & 85 & 58 & 3 & 98 & 0.69 & 0.55 & 6.76 & 0.75 & 47.38 \\
\hline & zPNG-16-163a-1 & 1.34 & 0.11 & 40 & 48 & 2 & 51 & 1.22 & 0.30 & 18.87 & 0.83 & 70.23 \\
\hline & zPNG-16-163a-3 & 1.26 & 0.10 & 73 & 82 & 3 & 91 & 1.13 & 0.49 & 7.98 & 0.78 & 55.30 \\
\hline & zPNG-16-163a-5 & 1.43 & 0.11 & 99 & 92 & 1 & 120 & 0.93 & 0.80 & 28.46 & 0.86 & 90.30 \\
\hline & zPNG-16-163a-7 & 1.52 & 0.12 & 81 & 64 & 1 & 96 & 0.79 & 0.65 & 14.99 & 0.83 & 72.48 \\
\hline & zPNG-16-163a-28 & 1.44 & 0.12 & 96 & 127 & 6 & 125 & 1.32 & 0.76 & 7.40 & 0.78 & 53.89 \\
\hline Suckling & zAU51087-13 & 1.30 & 0.10 & 1308 & 709 & 2 & 1471 & 0.54 & 7.16 & 2.54 & 0.69 & 37.02 \\
\hline \multirow[t]{11}{*}{ Granite } & zAU51087-14 & 1.83 & 0.15 & 558 & 566 & 2 & 688 & 1.01 & 4.71 & 2.48 & 0.69 & 37.55 \\
\hline & zAU51087-17 & 1.22 & 0.10 & 1081 & 1395 & 1 & 1402 & 1.29 & 6.85 & 4.40 & 0.74 & 46.08 \\
\hline & zAU51087-35 & 1.01 & 0.08 & 990 & 515 & 1 & 1109 & 0.52 & 4.39 & 2.92 & 0.72 & 41.72 \\
\hline & zAU51087-41 & 1.50 & 0.12 & 1045 & 1556 & 4 & 1403 & 1.49 & 8.24 & 3.36 & 0.72 & 42.83 \\
\hline & zAU51087-42 & 1.03 & 0.08 & 418 & 179 & 1 & 460 & 0.43 & 1.93 & 6.16 & 0.75 & 46.76 \\
\hline & zAU51088-24 & 1.45 & 0.12 & 501 & 457 & 3 & 606 & 0.91 & 3.42 & 3.57 & 0.72 & 41.52 \\
\hline & zAU51088-26 & 1.35 & 0.11 & 514 & 535 & 3 & 638 & 1.04 & 3.31 & 3.07 & 0.71 & 40.30 \\
\hline & zAU51088-38 & 1.41 & 0.11 & 515 & 516 & 3 & 634 & 1.00 & 3.70 & 5.77 & 0.76 & 50.24 \\
\hline & zAU51088-44 & 1.58 & 0.13 & 393 & 351 & 2 & 474 & 0.89 & 3.15 & 7.27 & 0.78 & 54.06 \\
\hline & zAU51088-48 & 1.42 & 0.11 & 279 & 264 & 2 & 339 & 0.95 & 1.98 & 5.61 & 0.76 & 49.47 \\
\hline & zAU51088-5 & 1.12 & 0.09 & 107 & 104 & 1 & 131 & 0.97 & 0.66 & 15.39 & 0.83 & 74.02 \\
\hline
\end{tabular}


Table B.6 - continued from previous page

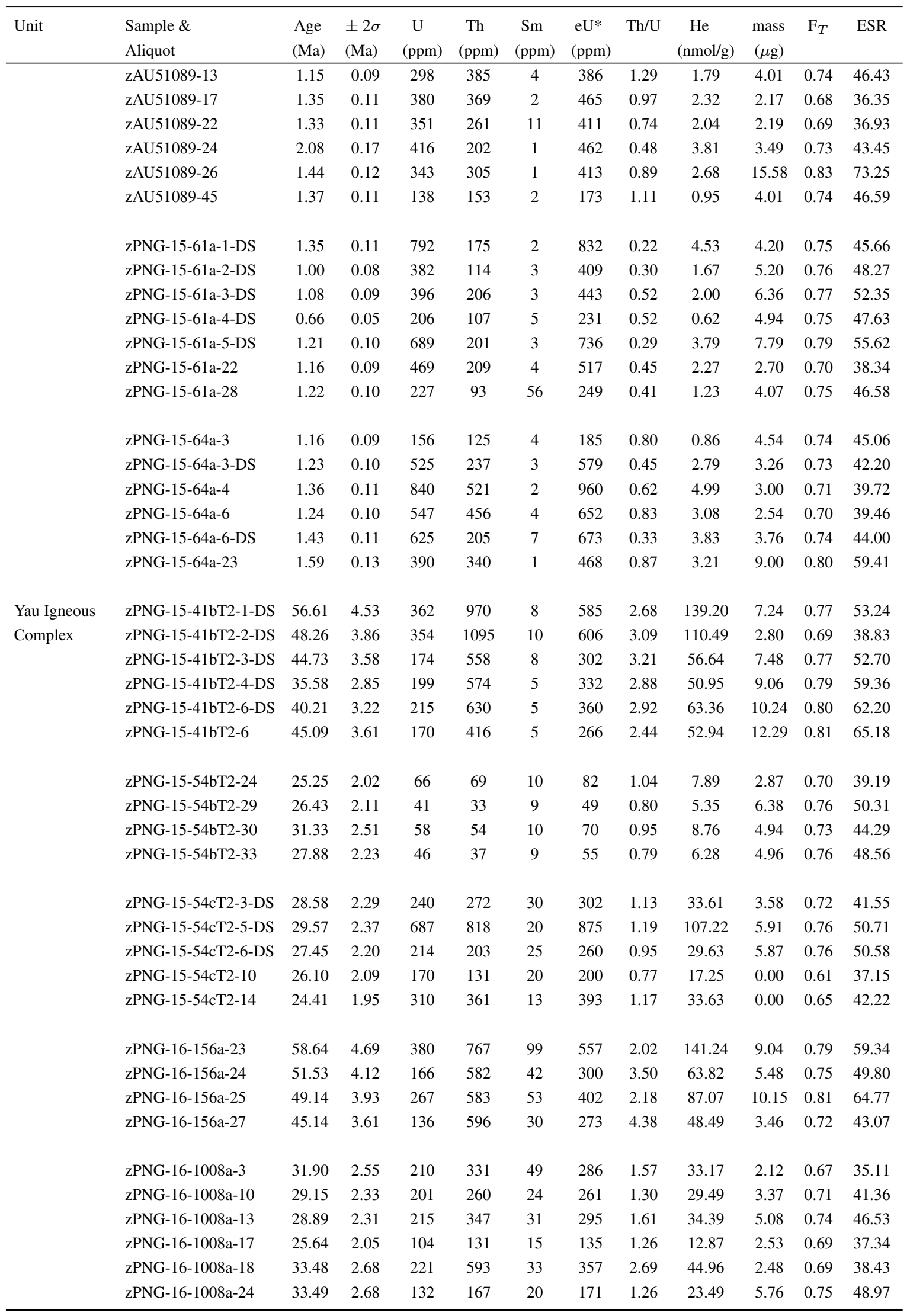

$*$ : eU = effective uranium $(\mathrm{U}+0.235 \mathrm{Th})$.

Suffix -DS denotes aliquots analysed by Rudra Chatterjee/Daniel Stockli. 
Table B.7: Apatite (U-Th-Sm)/He age data.

\begin{tabular}{|c|c|c|c|c|c|c|c|c|c|c|c|c|}
\hline Unit & $\begin{array}{l}\text { Sample \& } \\
\text { Aliquot }\end{array}$ & $\begin{array}{l}\text { Age } \\
\text { (Ma) }\end{array}$ & $\begin{array}{l} \pm 2 \sigma \\
(\mathrm{Ma})\end{array}$ & $\begin{array}{c}\mathrm{U} \\
(\mathrm{ppm})\end{array}$ & $\begin{array}{l}\text { Th } \\
\text { (ppm) }\end{array}$ & $\begin{array}{l}\text { Sm } \\
(\mathrm{ppm})\end{array}$ & $\begin{array}{l}\mathrm{eU}^{*} \\
(\mathrm{ppm})\end{array}$ & $\mathrm{Th} / \mathrm{U}$ & $\begin{array}{c}\mathrm{He} \\
(\mathrm{nmol} / \mathrm{g})\end{array}$ & $\begin{array}{l}\text { mass } \\
(\mu \mathrm{g})\end{array}$ & $\mathrm{F}_{T}$ & ESR \\
\hline Bonua & PNG-16-157a-1 & 2.1 & 0.2 & 5 & 9 & 45 & 7 & 1.92 & 0.06 & 4.41 & 0.72 & 54.66 \\
\hline \multirow[t]{4}{*}{ Porphyry } & PNG-16-157a-2 & 2.7 & 0.2 & 3 & 8 & 46 & 5 & 2.43 & 0.06 & 7.53 & 0.76 & 67.49 \\
\hline & PNG-16-157a-3 & 2.9 & 0.2 & 5 & 11 & 63 & 8 & 2.24 & 0.10 & 7.68 & 0.76 & 65.85 \\
\hline & PNG-16-157a-5 & 2.2 & 0.2 & 3 & 8 & 44 & 5 & 2.66 & 0.04 & 1.71 & 0.63 & 41.52 \\
\hline & PNG-16-157a-6 & 2.1 & 0.2 & 8 & 13 & 57 & 11 & 1.61 & 0.09 & 3.05 & 0.69 & 50.23 \\
\hline Goropu & PNG-16-1b-1 & 0.8 & 0.1 & 19 & 52 & 32 & 32 & 2.69 & 0.06 & 0.39 & 0.42 & 24.08 \\
\hline \multirow[t]{7}{*}{ Metabasalt } & PNG-16-1b-5 & 8.2 & 0.7 & 10 & 31 & 36 & 17 & 3.19 & 0.47 & 1.33 & 0.61 & 38.86 \\
\hline & PNG-16-1b-10 & 2.6 & 0.2 & 19 & 38 & 55 & 28 & 2.06 & 0.27 & 3.16 & 0.70 & 51.68 \\
\hline & PNG-16-4b-94 & 0.8 & 0.1 & 7 & 24 & 42 & 12 & 3.58 & 0.04 & 2.81 & 0.69 & 50.03 \\
\hline & PNG-16-4b-96 & 2.7 & 0.2 & 15 & 39 & 56 & 24 & 2.62 & 0.22 & 1.29 & 0.60 & 37.64 \\
\hline & PNG-16-4b-97 & 1.1 & 0.1 & 19 & 65 & 64 & 34 & 3.48 & 0.12 & 2.25 & 0.63 & 41.49 \\
\hline & PNG-16-4b-98 & 3.4 & 0.3 & 23 & 93 & 82 & 45 & 4.13 & 0.50 & 1.52 & 0.60 & 38.25 \\
\hline & PNG-16-4b-99 & 0.9 & 0.1 & 13 & 43 & 23 & 23 & 3.41 & 0.06 & 1.21 & 0.57 & 34.99 \\
\hline Mai'iu & PNG-15-66a-1-DS & 1.2 & 0.1 & 26 & 64 & 39 & 41 & 2.47 & 0.18 & 2.81 & 0.68 & 48.92 \\
\hline \multirow[t]{17}{*}{ Monzonite } & PNG-15-66a-2-DS & 1.2 & 0.1 & 28 & 52 & 33 & 40 & 1.85 & 0.20 & 6.31 & 0.75 & 63.10 \\
\hline & PNG-15-66a-3-DS & 1.2 & 0.1 & 31 & 69 & 49 & 47 & 2.21 & 0.20 & 2.95 & 0.67 & 47.36 \\
\hline & PNG-15-66a-4-DS & 1.2 & 0.1 & 26 & 65 & 46 & 41 & 2.52 & 0.18 & 2.43 & 0.66 & 45.30 \\
\hline & PNG-15-66a-5-DS & 1.1 & 0.1 & 27 & 62 & 40 & 42 & 2.27 & 0.17 & 3.08 & 0.69 & 49.77 \\
\hline & PNG-15-66a-6-DS & 1.4 & 0.1 & 36 & 84 & 53 & 56 & 2.33 & 0.26 & 1.99 & 0.62 & 39.93 \\
\hline & PNG-16-2a-1 & 1.1 & 0.1 & 15 & 14 & 85 & 19 & 0.89 & 0.08 & 1.90 & 0.66 & 43.30 \\
\hline & PNG-16-2a-3 & 2.0 & 0.2 & 4 & 13 & 49 & 7 & 3.54 & 0.06 & 6.62 & 0.74 & 61.56 \\
\hline & PNG-16-2a-4 & 1.6 & 0.1 & 16 & 17 & 83 & 20 & 1.11 & 0.13 & 4.36 & 0.73 & 57.36 \\
\hline & PNG-16-2a-5 & 1.1 & 0.1 & 103 & 27 & 146 & 110 & 0.26 & 0.45 & 2.97 & 0.70 & 48.70 \\
\hline & PNG-16-159b-1 & 1.5 & 0.1 & 6 & 17 & 39 & 10 & 2.69 & 0.05 & 1.43 & 0.60 & 37.28 \\
\hline & PNG-16-159b-4 & 1.3 & 0.1 & 4 & 11 & 44 & 7 & 2.83 & 0.03 & 1.81 & 0.61 & 38.34 \\
\hline & PNG-16-159b-6 & 1.4 & 0.1 & 8 & 21 & 52 & 13 & 2.60 & 0.06 & 1.70 & 0.61 & 38.96 \\
\hline & PNG-16-163a-1 & 1.3 & 0.1 & 9 & 29 & 33 & 16 & 3.04 & 0.09 & 13.46 & 0.81 & 83.61 \\
\hline & PNG-16-163a-2 & 1.4 & 0.1 & 14 & 52 & 36 & 26 & 3.81 & 0.13 & 3.14 & 0.67 & 47.93 \\
\hline & PNG-16-163a-3 & 0.9 & 0.1 & 13 & 43 & 31 & 23 & 3.35 & 0.08 & 2.60 & 0.65 & 44.77 \\
\hline & PNG-16-163a-5 & 1.3 & 0.1 & 10 & 34 & 31 & 18 & 3.56 & 0.08 & 1.97 & 0.64 & 42.71 \\
\hline & PNG-16-163a-6 & 1.2 & 0.1 & 13 & 32 & 34 & 20 & 2.53 & 0.09 & 2.61 & 0.68 & 47.84 \\
\hline \multirow{5}{*}{$\begin{array}{l}\text { Stream } \\
\text { sediment }\end{array}$} & PNG-15-76d-1-DS & 1.3 & 0.1 & 23 & 50 & 63 & 35 & 2.17 & 0.19 & 5.85 & 0.75 & 62.45 \\
\hline & PNG-15-76d-2-DS & 1.0 & 0.1 & 14 & 21 & 20 & 19 & 1.52 & 0.08 & 5.40 & 0.75 & 61.57 \\
\hline & PNG-15-76d-3-DS & 1.1 & 0.1 & 11 & 37 & 50 & 19 & 3.54 & 0.09 & 4.02 & 0.71 & 54.65 \\
\hline & PNG-15-76d-4-DS & 1.0 & 0.1 & 17 & 52 & 51 & 30 & 3.01 & 0.12 & 5.28 & 0.73 & 59.65 \\
\hline & PNG-15-76d-5-DS & 1.0 & 0.1 & 15 & 34 & 60 & 23 & 2.29 & 0.10 & 9.09 & 0.78 & 72.45 \\
\hline Suckling & 2576-1-DS & 1.2 & 0.1 & 10 & 21 & 73 & 15 & 2.03 & 0.07 & 4.04 & 0.72 & 56.15 \\
\hline \multirow[t]{7}{*}{ Granite } & 2576-2-DS & 1.7 & 0.1 & 15 & 28 & 90 & 22 & 1.90 & 0.13 & 1.92 & 0.64 & 42.16 \\
\hline & AU51087-3-DS & 2.1 & 0.1 & 10 & 20 & 72 & 15 & 1.95 & 0.14 & 8.69 & 0.78 & 73.27 \\
\hline & AU51087-4-DS & 3.0 & 0.2 & 10 & 25 & 110 & 16 & 2.49 & 0.21 & 7.81 & 0.77 & 68.39 \\
\hline & AU51087-5-DS & 5.6 & 0.3 & 12 & 26 & 88 & 19 & 2.08 & 0.44 & 7.61 & 0.77 & 69.11 \\
\hline & AU51087-6-DS & 1.2 & 0.1 & 14 & 29 & 101 & 21 & 2.01 & 0.11 & 7.50 & 0.76 & 66.87 \\
\hline & AU51088-1 & 1.5 & 0.1 & 11 & 31 & 93 & 18 & 2.98 & 0.09 & 1.84 & 0.62 & 40.18 \\
\hline & AU51088-2 & 1.4 & 0.1 & 12 & 16 & 74 & 16 & 1.30 & 0.09 & 4.42 & 0.71 & 53.88 \\
\hline
\end{tabular}


Table B.7 - continued from previous page

\begin{tabular}{|c|c|c|c|c|c|c|c|c|c|c|c|c|}
\hline Unit & $\begin{array}{l}\text { Sample \& } \\
\text { Aliquot }\end{array}$ & $\begin{array}{l}\text { Age } \\
\text { (Ma) }\end{array}$ & $\begin{array}{l} \pm 2 \sigma \\
(\mathrm{Ma})\end{array}$ & $\begin{array}{c}\mathrm{U} \\
(\mathrm{ppm})\end{array}$ & $\begin{array}{l}\text { Th } \\
(\mathrm{ppm})\end{array}$ & $\begin{array}{l}\mathrm{Sm} \\
(\mathrm{ppm})\end{array}$ & $\begin{array}{l}\mathrm{eU}^{*} \\
(\mathrm{ppm})\end{array}$ & $\mathrm{Th} / \mathrm{U}$ & $\begin{array}{c}\mathrm{He} \\
(\mathrm{nmol} / \mathrm{g})\end{array}$ & $\begin{array}{l}\text { mass } \\
(\mu \mathrm{g})\end{array}$ & $\mathrm{F}_{T}$ & ESR \\
\hline & AU51088-3 & 1.5 & 0.1 & 7 & 22 & 78 & 13 & 2.94 & 0.08 & 8.81 & 0.78 & 72.01 \\
\hline & AU51088-4 & 1.7 & 0.1 & 10 & 33 & 102 & 18 & 3.18 & 0.12 & 5.18 & 0.73 & 59.31 \\
\hline & AU51088-5 & 2.0 & 0.2 & 8 & 30 & 100 & 15 & 3.72 & 0.13 & 6.67 & 0.76 & 65.68 \\
\hline & AU51088-6 & 1.5 & 0.1 & 12 & 16 & 55 & 16 & 1.29 & 0.08 & 1.03 & 0.58 & 34.50 \\
\hline & AU51089-1 & 1.5 & 0.1 & 13 & 39 & 41 & 22 & 2.94 & 0.11 & 1.71 & 0.60 & 38.31 \\
\hline & AU51089-2 & 1.5 & 0.1 & 7 & 11 & 55 & 10 & 1.68 & 0.05 & 2.45 & 0.65 & 42.86 \\
\hline & AU51089-3 & 1.4 & 0.1 & 14 & 35 & 87 & 23 & 2.48 & 0.12 & 4.16 & 0.71 & 54.76 \\
\hline & AU51089-4 & 1.7 & 0.1 & 8 & 29 & 76 & 15 & 3.44 & 0.10 & 2.95 & 0.67 & 47.28 \\
\hline & AU51089-5 & 1.6 & 0.1 & 8 & 22 & 53 & 13 & 2.89 & 0.08 & 2.38 & 0.67 & 46.39 \\
\hline & AU51089-6 & 1.4 & 0.1 & 13 & 30 & 33 & 20 & 2.32 & 0.09 & 1.54 & 0.60 & 37.20 \\
\hline & PNG-15-61a-1-DS & 2.1 & 0.2 & 6 & 15 & 49 & 10 & 2.55 & 0.08 & 3.96 & 0.70 & 51.39 \\
\hline & PNG-15-61a-2-DS & 2.3 & 0.2 & 7 & 13 & 106 & 11 & 1.86 & 0.10 & 3.37 & 0.71 & 53.17 \\
\hline & PNG-15-61a-3-DS & 3.0 & 0.2 & 5 & 7 & 53 & 7 & 1.52 & 0.08 & 3.99 & 0.71 & 53.82 \\
\hline & PNG-15-61a-4-DS & 2.6 & 0.2 & 6 & 14 & 84 & 10 & 2.19 & 0.10 & 2.74 & 0.69 & 49.28 \\
\hline & PNG-15-61a-5-DS & 6.2 & 0.5 & 4 & 7 & 43 & 6 & 1.72 & 0.14 & 2.13 & 0.67 & 46.09 \\
\hline & PNG-15-61a-6-DS & 5.1 & 0.4 & 3 & 8 & 74 & 5 & 2.53 & 0.10 & 3.10 & 0.69 & 50.26 \\
\hline Yau Igneous & AU51082-1 & 4.6 & 0.3 & 1 & 3 & 127 & 3 & 2.41 & 0.04 & 1.38 & 0.58 & 35.31 \\
\hline \multirow[t]{29}{*}{ Complex } & AU51082-2 & 17.0 & 1.0 & 1 & 2 & 140 & 2 & 2.57 & 0.14 & 2.23 & 0.66 & 44.64 \\
\hline & AU51082-4 & 13.9 & 0.8 & 1 & 2 & 157 & 2 & 2.72 & 0.11 & 1.35 & 0.58 & 35.30 \\
\hline & AU51082-5 & 22.8 & 1.4 & 1 & 2 & 148 & 2 & 2.37 & 0.20 & 3.85 & 0.69 & 50.00 \\
\hline & AU51082-6 & 49.3 & 3.0 & 1 & 1 & 130 & 2 & 2.00 & 0.37 & 2.53 & 0.66 & 45.66 \\
\hline & PNG-15-41bT2-31 & 5.8 & 0.3 & 2 & 26 & 197 & 9 & 11.76 & 0.25 & 16.03 & 0.80 & 84.23 \\
\hline & PNG-15-41bT2-42 & 10.0 & 0.6 & 2 & 21 & 248 & 8 & 9.14 & 0.41 & 21.62 & 0.80 & 83.29 \\
\hline & PNG-15-41bT2-50 & 1.6 & 0.1 & 2 & 20 & 245 & 8 & 8.55 & 0.06 & 15.32 & 0.79 & 80.19 \\
\hline & PNG-15-41bT2-97 & 12.3 & 0.7 & 2 & 14 & 150 & 6 & 8.70 & 0.30 & 6.09 & 0.74 & 62.21 \\
\hline & PNG-15-41bT2-98 & 1.4 & 0.1 & 2 & 15 & 218 & 6 & 7.62 & 0.04 & 13.24 & 0.80 & 83.73 \\
\hline & PNG-15-41bT2-99 & 3.2 & 0.2 & 1 & 12 & 149 & 5 & 9.98 & 0.07 & 26.66 & 0.84 & 102.40 \\
\hline & PNG-15-77c-1-DS & 10.4 & 0.8 & 1 & 2 & 194 & 2 & 2.58 & 0.11 & 2.58 & 0.66 & 45.89 \\
\hline & PNG-15-77c-2-DS & 3.4 & 0.2 & 1 & 3 & 164 & 3 & 2.27 & 0.04 & 2.31 & 0.67 & 46.30 \\
\hline & PNG-15-77c-3-DS & 9.8 & 0.6 & 1 & 2 & 142 & 2 & 2.83 & 0.07 & 1.40 & 0.62 & 39.62 \\
\hline & PNG-15-77c-4-DS & 12.3 & 0.7 & 0 & 2 & 250 & 2 & 6.09 & 0.10 & 0.77 & 0.53 & 31.66 \\
\hline & PNG-15-77c-5-DS & 6.1 & 0.4 & 1 & 3 & 314 & 3 & 3.37 & 0.08 & 1.49 & 0.59 & 36.42 \\
\hline & PNG-15-77c-6-DS & 13.2 & 0.8 & 1 & 2 & 198 & 2 & 3.01 & 0.11 & 1.59 & 0.62 & 40.64 \\
\hline & PNG-16-16a-16 & 6.1 & 0.5 & 0 & 1 & 77 & 1 & 2.82 & 0.04 & 14.76 & 0.80 & 82.41 \\
\hline & PNG-16-16a-96 & 1.8 & 0.1 & 1 & 1 & 93 & 1 & 2.44 & 0.01 & 1.73 & 0.63 & 40.92 \\
\hline & PNG-16-16a-97 & 1.3 & 0.1 & 1 & 1 & 85 & 2 & 1.23 & 0.01 & 1.38 & 0.62 & 38.66 \\
\hline & PNG-16-16a-98 & 2.3 & 0.2 & 1 & 2 & 111 & 2 & 3.30 & 0.02 & 1.68 & 0.63 & 41.99 \\
\hline & PNG-16-16a-99 & 0.6 & 0.1 & 0 & 1 & 82 & 1 & 3.30 & 0.00 & 4.74 & 0.71 & 55.00 \\
\hline & PNG-16-41a-94 & 0.5 & 0.0 & 1 & 5 & 85 & 3 & 3.94 & 0.01 & 2.35 & 0.67 & 47.65 \\
\hline & PNG-16-41a-97 & 2.0 & 0.2 & 1 & 5 & 101 & 3 & 3.92 & 0.03 & 3.26 & 0.70 & 52.90 \\
\hline & PNG-16-108b-96 & 1.6 & 0.1 & 1 & 4 & 107 & 2 & 5.36 & 0.02 & 4.66 & 0.73 & 59.69 \\
\hline & PNG-16-108b-97 & 19.5 & 1.6 & 1 & 11 & 202 & 4 & 13.62 & 0.30 & 1.11 & 0.57 & 35.59 \\
\hline & PNG-16-108b-98 & 14.2 & 1.1 & 1 & 1 & 105 & 1 & 2.13 & 0.09 & 2.06 & 0.66 & 44.85 \\
\hline & PNG-16-128a-20 & 24.7 & 1.5 & 1 & 1 & 81 & 2 & 1.31 & 0.18 & 6.42 & 0.76 & 65.86 \\
\hline & PNG-16-128a-95 & 10.4 & 0.6 & 1 & 5 & 259 & 4 & 3.74 & 0.16 & 1.73 & 0.62 & 39.86 \\
\hline & PNG-16-128a-96 & 4.5 & 0.3 & 2 & 4 & 109 & 4 & 2.12 & 0.06 & 2.19 & 0.66 & 44.79 \\
\hline
\end{tabular}


Table B.7 - continued from previous page

\begin{tabular}{|c|c|c|c|c|c|c|c|c|c|c|c|c|}
\hline Unit & $\begin{array}{l}\text { Sample \& } \\
\text { Aliquot }\end{array}$ & $\begin{array}{l}\text { Age } \\
\text { (Ma) }\end{array}$ & $\begin{array}{l} \pm 2 \sigma \\
(\mathrm{Ma})\end{array}$ & $\begin{array}{c}\mathrm{U} \\
(\mathrm{ppm})\end{array}$ & $\begin{array}{l}\text { Th } \\
\text { (ppm) }\end{array}$ & $\begin{array}{l}\mathrm{Sm} \\
(\mathrm{ppm})\end{array}$ & $\begin{array}{l}\mathrm{eU}^{*} \\
(\mathrm{ppm})\end{array}$ & $\mathrm{Th} / \mathrm{U}$ & $\begin{array}{c}\mathrm{He} \\
(\mathrm{nmol} / \mathrm{g})\end{array}$ & $\begin{array}{l}\text { mass } \\
(\mu \mathrm{g})\end{array}$ & $\mathrm{F}_{T}$ & ESR \\
\hline & PNG-16-128a-97 & 18.3 & 1.1 & 1 & 5 & 269 & 4 & 3.51 & 0.31 & 4.18 & 0.68 & 48.18 \\
\hline & PNG-16-128a-98 & 1.8 & 0.1 & 0 & 1 & 97 & 1 & 2.09 & 0.01 & 35.28 & 0.85 & 109.62 \\
\hline & PNG-16-128a-99 & 13.9 & 0.8 & 1 & 2 & 155 & 2 & 2.06 & 0.11 & 1.18 & 0.60 & 37.00 \\
\hline & PNG-16-156a-1 & 19.9 & 1.6 & 1 & 2 & 147 & 2 & 3.05 & 0.16 & 1.29 & 0.57 & 35.15 \\
\hline & PNG-16-156a-2 & 27.8 & 2.2 & 2 & 7 & 391 & 6 & 3.90 & 0.68 & 2.94 & 0.66 & 45.20 \\
\hline & PNG-16-156a-3 & 23.7 & 1.9 & 1 & 3 & 226 & 3 & 3.36 & 0.28 & 1.93 & 0.60 & 38.42 \\
\hline & PNG-16-156a-5 & 25.5 & 2.0 & 1 & 3 & 186 & 3 & 2.76 & 0.26 & 1.23 & 0.58 & 35.34 \\
\hline & PNG-16-156a-6 & 22.7 & 1.8 & 1 & 7 & 220 & 4 & 8.35 & 0.31 & 1.36 & 0.58 & 36.09 \\
\hline & PNG-16-1008a-2 & 18.5 & 1.1 & 1 & 2 & 177 & 2 & 2.57 & 0.17 & 1.17 & 0.59 & 37.02 \\
\hline & PNG-16-1008a-3 & 27.4 & 1.6 & 1 & 2 & 132 & 2 & 2.45 & 0.23 & 4.28 & 0.73 & 57.58 \\
\hline & PNG-16-1008a-4 & 41.7 & 2.5 & 1 & 3 & 229 & 3 & 2.22 & 0.58 & 1.81 & 0.65 & 42.95 \\
\hline & PNG-16-1008a-5 & 24.2 & 1.5 & 1 & 5 & 289 & 4 & 4.68 & 0.40 & 2.06 & 0.64 & 43.54 \\
\hline & PNG-16-1008a-6 & 44.8 & 2.7 & 2 & 3 & 237 & 4 & 1.64 & 0.70 & 1.25 & 0.61 & 38.60 \\
\hline & PNG-16-1029a-5 & 5.0 & 0.4 & 3 & 2 & 131 & 4 & 0.76 & 0.08 & 1.07 & 0.58 & 34.30 \\
\hline & PNG-16-1029a-6 & 5.2 & 0.4 & 1 & 3 & 126 & 2 & 2.84 & 0.04 & 0.86 & 0.51 & 29.96 \\
\hline
\end{tabular}

*: eU = effective uranium $(\mathrm{U}+0.235 \mathrm{Th})$.

Suffix -DS denotes aliquots analysed by Rudra Chatterjee/Daniel Stockli.

Table B.8: Magnetite (U-Th-Sm)/He age data.

\begin{tabular}{lcccccccccc}
\hline Sample/Aliquot & $\begin{array}{c}\text { Age } \\
(\mathrm{Ma})\end{array}$ & $\begin{array}{c} \pm 2 \sigma \\
(\mathrm{Ma})\end{array}$ & $\begin{array}{c}\mathrm{U} \\
(\mathrm{ppm})\end{array}$ & $\begin{array}{c}\mathrm{Th} \\
(\mathrm{ppm})\end{array}$ & $\begin{array}{c}\mathrm{Sm} \\
(\mathrm{ppm})\end{array}$ & $\begin{array}{c}\mathrm{eU} * \\
(\mathrm{ppm})\end{array}$ & $\mathrm{Th} / \mathrm{U}$ & $\begin{array}{c}\mathrm{He} \\
(\mathrm{nmol} / \mathrm{g})\end{array}$ & $\begin{array}{c}\text { mass } \\
(\mu \mathrm{g})\end{array}$ & \# of grains \\
\hline mgPNG-15-70c-1 & 6.9 & 2.8 & 148 & 178 & 108 & 190 & 1.20 & 0.01 & 26 & 23 \\
mgPNG-15-70c-2 & 6.2 & 1.0 & 480 & 138 & 300 & 513 & 0.29 & 0.02 & 28 & 12 \\
\hline
\end{tabular}

*: eU = effective uranium $(\mathrm{U}+0.235 \mathrm{Th})$. 
Table B.9: Zircon (U-Th)/(Pb-He) age data

\begin{tabular}{|c|c|c|c|c|c|}
\hline Unit & Aliquot & $\mathrm{ZHe}$ age & $\pm 2 \sigma$ & ${ }^{206} \mathrm{~Pb} /{ }^{238} \mathrm{U}$ date & $\pm 2 \mathrm{SE}$ \\
\hline Suckling & zAU51087-13 & 1.3 & 0.1 & 3.4 & 0.1 \\
\hline \multirow[t]{23}{*}{ Granite } & zAU51087-14 & 1.8 & 0.1 & 3.3 & 0.1 \\
\hline & zAU51087-17 & 1.2 & 0.1 & 3.8 & 0.1 \\
\hline & zAU51087-35 & 1.0 & 0.1 & 3.4 & 0.1 \\
\hline & zAU51087-41 & 1.5 & 0.1 & 3.5 & 0.1 \\
\hline & zAU51087-42 & 1.0 & 0.1 & 3.3 & 0.1 \\
\hline & zAU51088-5 & 1.1 & 0.1 & 3.4 & 0.2 \\
\hline & zAU51088-24 & 1.5 & 0.1 & 3.4 & 0.3 \\
\hline & zAU51088-26 & 1.4 & 0.1 & 3.3 & 0.1 \\
\hline & zAU51088-38 & 1.4 & 0.1 & 3.5 & 0.1 \\
\hline & zAU51088-44 & 1.6 & 0.1 & 3.5 & 0.2 \\
\hline & zAU51088-48 & 1.4 & 0.1 & 3.4 & 0.3 \\
\hline & zAU51089-13 & 1.1 & 0.1 & 3.4 & 0.1 \\
\hline & zAU51089-17 & 1.4 & 0.1 & 3.7 & 0.1 \\
\hline & zAU51089-22 & 1.3 & 0.1 & 3.4 & 0.2 \\
\hline & zAU51089-24 & 2.1 & 0.2 & 3.5 & 0.1 \\
\hline & zAU51089-26 & 1.4 & 0.1 & 4.9 & 0.6 \\
\hline & zAU51089-45 & 1.4 & 0.1 & 3.3 & 0.1 \\
\hline & zPNG-15-61a-22 & 1.2 & 0.1 & 3.7 & 0.2 \\
\hline & zPNG-15-61a-28 & 1.2 & 0.1 & 4.5 & 0.5 \\
\hline & zPNG-15-64a-3 & 1.2 & 0.1 & 4.1 & 0.3 \\
\hline & zPNG-15-64a-4 & 1.4 & 0.1 & 3.9 & 0.1 \\
\hline & zPNG-15-64a-6 & 1.2 & 0.1 & 3.7 & 0.1 \\
\hline & zPNG-15-64a-23 & 1.6 & 0.1 & 3.8 & 0.1 \\
\hline Yau Igneous & zPNG-15-41bT2-6 & 45.1 & 3.6 & 57.0 & 1.0 \\
\hline \multicolumn{6}{|l|}{ Complex } \\
\hline & zPNG-15-54bT2-24 & 25.2 & 2.0 & 56.5 & 1.4 \\
\hline & zPNG-15-54bT2-29 & 26.4 & 2.1 & 54.8 & 1.3 \\
\hline & zPNG-15-54bT2-30 & 31.3 & 2.5 & 55.0 & 1.5 \\
\hline & zPNG-15-54bT2-33 & 27.9 & 2.2 & 56.6 & 1.2 \\
\hline & zPNG-15-54cT2-10 & 26.1 & 2.1 & 61.5 & 1.3 \\
\hline & zPNG-15-54cT2-14 & 24.4 & 2.0 & 64.6 & 1.5 \\
\hline & zPNG-16-156a-23 & 58.6 & 4.7 & 57.5 & 1.0 \\
\hline & zPNG-16-156a-24 & 51.5 & 4.1 & 56.2 & 1.1 \\
\hline & zPNG-16-156a-25 & 49.1 & 3.9 & 54.9 & 1.0 \\
\hline & zPNG-16-156a-27 & 45.1 & 3.6 & 56.9 & 1.0 \\
\hline & zPNG-16-1008a-3 & 31.9 & 2.6 & 59.4 & 1.2 \\
\hline & zPNG-16-1008a-10 & 29.1 & 2.3 & 58.4 & 1.2 \\
\hline & zPNG-16-1008a-13 & 28.9 & 2.3 & 57.6 & 1.1 \\
\hline & zPNG-16-1008a-17 & 25.6 & 2.1 & 58.6 & 1.4 \\
\hline & zPNG-16-1008a-18 & 33.5 & 2.7 & 58.7 & 4.0 \\
\hline & zPNG-16-1008a-24 & 33.5 & 2.7 & 59.5 & 1.2 \\
\hline Bas. and. dike & zPNG-15-60a-1 & 0.3 & 0.0 & 0.7 & 0.1 \\
\hline \multirow[t]{2}{*}{ Mai’iu } & zPNG-15-66a-13 & 1.2 & 0.1 & 2.0 & 0.1 \\
\hline & & & & \multicolumn{2}{|c|}{ Continued on next page } \\
\hline
\end{tabular}


Table B.9 - continued from previous page

\begin{tabular}{|c|c|c|c|c|c|}
\hline Unit & Aliquot & ZHe age & $\pm 2 \sigma$ & ${ }^{206} \mathrm{~Pb} /{ }^{238} \mathrm{U}$ date & $\pm 2 \mathrm{SE}$ \\
\hline \multirow[t]{22}{*}{ Monzonite } & zPNG-15-66a-20 & 1.5 & 0.1 & 1.9 & 0.2 \\
\hline & zPNG-15-66a-35 & 1.2 & 0.1 & 2.1 & 0.2 \\
\hline & zPNG-15-66a-40 & 1.1 & 0.1 & 2.1 & 0.1 \\
\hline & zPNG-15-66a-46 & 1.3 & 0.1 & 2.4 & 0.2 \\
\hline & zPNG-15-66a-49 & 1.4 & 0.1 & 2.1 & 0.1 \\
\hline & zPNG-16-2a-2 & 1.2 & 0.1 & 2.1 & 0.2 \\
\hline & zPNG-16-2a-9 & 1.3 & 0.1 & 2.4 & 0.2 \\
\hline & zPNG-16-2a-12 & 1.4 & 0.1 & 2.1 & 0.1 \\
\hline & zPNG-16-2a-46 & 0.9 & 0.1 & 2.2 & 0.2 \\
\hline & zPNG-16-2a-47 & 1.2 & 0.1 & 2.1 & 0.1 \\
\hline & zPNG-16-159b-7 & 1.6 & 0.1 & 3.9 & 0.3 \\
\hline & zPNG-16-159b-13 & 1.3 & 0.1 & 3.9 & 0.3 \\
\hline & zPNG-16-159b-21 & 1.2 & 0.1 & 3.3 & 0.2 \\
\hline & zPNG-16-159b-22 & 1.5 & 0.1 & 3.2 & 0.2 \\
\hline & zPNG-16-159b-27 & 2.5 & 0.2 & 3.6 & 0.2 \\
\hline & zPNG-16-159b-43 & 0.6 & 0.0 & 4.1 & 0.3 \\
\hline & zPNG-16-159b-46 & 1.4 & 0.1 & 4.0 & 0.3 \\
\hline & zPNG-16-163a-1 & 1.3 & 0.1 & 3.0 & 0.4 \\
\hline & zPNG-16-163a-3 & 1.3 & 0.1 & 2.1 & 0.2 \\
\hline & zPNG-16-163a-5 & 1.4 & 0.1 & 2.3 & 0.2 \\
\hline & zPNG-16-163a-7 & 1.5 & 0.1 & 2.1 & 0.1 \\
\hline & zPNG-16-163a-28 & 1.4 & 0.1 & 2.1 & 0.3 \\
\hline Bonua & zPNG-16-157a-1 & 2.4 & 0.2 & 3.3 & 0.1 \\
\hline \multirow[t]{4}{*}{ Porphyr } & zPNG-16-157a-8 & 2.0 & 0.2 & 3.6 & 0.2 \\
\hline & zPNG-16-157a-9 & 2.7 & 0.2 & 3.5 & 0.3 \\
\hline & zPNG-16-157a-34 & 2.4 & 0.2 & 3.7 & 0.2 \\
\hline & zPNG-16-157a-51 & 3.5 & 0.3 & 3.3 & 0.1 \\
\hline Goropu & zPNG-16-1b-9 & 0.9 & 0.1 & 2.8 & 0.4 \\
\hline \multirow[t]{18}{*}{ Metabasalt } & zPNG-16-1b-18 & 0.3 & 0.0 & 3.4 & 0.2 \\
\hline & zPNG-16-1b-19 & 1.4 & 0.1 & 3.3 & 0.1 \\
\hline & zPNG-16-1b-20 & 27.6 & 2.2 & 2.1 & 0.2 \\
\hline & zPNG-16-1b-24 & 1.3 & 0.1 & 2.6 & 0.2 \\
\hline & zPNG-16-1b-26 & 1.2 & 0.1 & 3.3 & 0.3 \\
\hline & zPNG-16-1b-28 & 1.1 & 0.1 & 2.4 & 0.2 \\
\hline & zPNG-16-4b-35 & 1.1 & 0.1 & 2.2 & 0.2 \\
\hline & zPNG-16-4b-36 & 1.9 & 0.2 & 3.4 & 0.4 \\
\hline & zPNG-16-4b-37 & 1.5 & 0.1 & 2.6 & 0.3 \\
\hline & zPNG-16-4b-39 & 1.0 & 0.1 & 3.3 & 0.5 \\
\hline & zPNG-16-4b-41 & 1.2 & 0.1 & 3.1 & 0.3 \\
\hline & zPNG-16-4b-42 & 1.3 & 0.1 & 3.3 & 0.3 \\
\hline & zPNG-16-169c-1 & 0.1 & 0.0 & 3.3 & 0.3 \\
\hline & zPNG-16-169c-3 & 0.1 & 0.0 & 0.3 & 0.1 \\
\hline & zPNG-16-169c-6 & 0.3 & 0.0 & 0.6 & 0.1 \\
\hline & zPNG-16-173b-2 & 0.3 & 0.0 & 0.3 & 0.0 \\
\hline & zPNG-16-184a-1 & 0.3 & 0.0 & 0.7 & 0.2 \\
\hline & zPNG-16-184a-5 & 0.3 & 0.0 & 1.4 & 0.2 \\
\hline
\end{tabular}


Table B.9 - continued from previous page

\begin{tabular}{|c|c|c|c|c|c|}
\hline Unit & Aliquot & ZHe age & $\pm 2 \sigma$ & ${ }^{206} \mathrm{~Pb} /{ }^{238} \mathrm{U}$ date & $\pm 2 \mathrm{SE}$ \\
\hline & zPNG-16-1151b-1 & 0.8 & 0.1 & 3.2 & 0.3 \\
\hline & zPNG-16-1151b-2 & 0.01 & 0.00 & 1.4 & 0.5 \\
\hline & zPNG-16-1151b-3 & 0.01 & 0.00 & 0.2 & 0.1 \\
\hline & zPNG-16-1151b-5 & 90.9 & 7.3 & 873.0 & 61.0 \\
\hline & zPNG-16-1151a-1 & 1.5 & 0.1 & 3.3 & 0.2 \\
\hline & zPNG-16-1151a-2 & 0.2 & 0.0 & 0.3 & 0.0 \\
\hline & zPNG-16-1151a-4 & 1.4 & 0.1 & 3.9 & 0.3 \\
\hline Bonenau & zPNG-15-18c-1 & 3.0 & 0.2 & 106.0 & 3.6 \\
\hline \multirow[t]{20}{*}{ Schist } & zPNG-15-18c-5 & 2.9 & 0.2 & 107.2 & 3.7 \\
\hline & zPNG-15-18c-6 & 3.0 & 0.2 & 104.1 & 3.1 \\
\hline & zPNG-15-18c-9 & 2.0 & 0.2 & 101.8 & 2.8 \\
\hline & zPNG-15-18c-10 & 3.1 & 0.2 & 108.1 & 2.2 \\
\hline & zPNG-15-18c-11 & 2.6 & 0.2 & 111.0 & 3.1 \\
\hline & zPNG-16-2d-1 & 0.8 & 0.1 & 2.7 & 0.3 \\
\hline & zPNG-16-2d-3 & 1.1 & 0.1 & 3.2 & 0.3 \\
\hline & zPNG-16-2d-5 & 0.9 & 0.1 & 3.1 & 0.2 \\
\hline & zPNG-16-161b-1 & 0.5 & 0.0 & 4.4 & 0.3 \\
\hline & zPNG-16-161b-4 & 1.5 & 0.1 & 2.8 & 0.1 \\
\hline & zPNG-16-161e-1 & 0.3 & 0.0 & 0.3 & 0.1 \\
\hline & zPNG-16-161e-3 & 0.1 & 0.0 & 0.2 & 0.1 \\
\hline & zPNG-16-1153a-3 & 7.6 & 0.6 & 106.8 & 3.3 \\
\hline & zPNG-16-1153a-5 & 8.0 & 0.6 & 105.2 & 2.8 \\
\hline & zPNG-16-1153a-6 & 7.0 & 0.6 & 113.6 & 2.9 \\
\hline & zPNG-16-1153a-8 & 4.0 & 0.3 & 103.3 & 3.5 \\
\hline & zPNG-16-1153a-10 & 4.0 & 0.3 & 105.1 & 2.9 \\
\hline & zPNG-16-1153a-12 & 9.0 & 0.7 & 115.3 & 2.3 \\
\hline & zPNG-16-1153a-25 & 2.7 & 0.2 & 70.5 & 2.5 \\
\hline & zPNG-16-1153a-32 & 16.1 & 1.3 & 96.7 & 2.9 \\
\hline
\end{tabular}

Suffix -DS denotes aliquots analysed by Rudra Chatterjee/Daniel Stockli.

${ }^{206} \mathrm{~Pb} /{ }^{238} \mathrm{U}$ date corrected for ${ }^{230} \mathrm{Th}$ disequilibrium assuming $\mathrm{Th} / \mathrm{U}_{\text {mamga }}=3$.

See Table B.6 and Electronic appendix 1 for raw data. 


\begin{tabular}{|c|c|c|c|c|c|c|c|c|c|c|}
\hline Sample & $\begin{array}{l}\text { Latitude* } \\
\quad[\mathrm{S}]\end{array}$ & $\begin{array}{l}\text { Longitude* } \\
{[E]}\end{array}$ & $\begin{array}{c}\text { Elevation } \\
{[\mathrm{m}]}\end{array}$ & $\begin{array}{l}\text { Quartz } \\
{[\mathrm{g}]}\end{array}$ & $\begin{array}{c}{ }^{9} \text { Be carrier added } \\
{[\mathrm{mg}]}\end{array}$ & $\begin{array}{c}{ }^{10} \mathbf{B e}^{\#, a} \\
{\left[\mathbf{1 0}^{3} \text { atoms } \mathbf{g}^{-1}\right]}\end{array}$ & $\begin{array}{l}{ }^{27} \mathbf{A l} \\
{[\mathbf{m g}]}\end{array}$ & $\begin{array}{c}{ }^{26} \mathbf{A l}^{b} \\
{\left[\mathbf{1 0}^{3} \text { atoms g }^{-1}\right]}\end{array}$ & ${ }^{26} \mathbf{A} \mathbf{l} /{ }^{10} \mathbf{B e}^{c}$ & $\begin{array}{c}\text { Burial age }^{d} \\
{[\mathrm{Ma}]}\end{array}$ \\
\hline PNG 16-92a & $9^{\circ} 48^{\prime} 24.5^{\prime \prime}$ & $149^{\circ} 28^{\prime} 11.1^{\prime \prime}$ & 360 & 64.4787 & 0.30091 & $27.38 \pm 0.90$ & 1.2896 & $20.08 \pm 11.77$ & $0.73 \pm 0.43$ & $4.59 \pm 2.92$ \\
\hline PNG 16-1020a & $9^{\circ} 51^{\prime} 33.8^{\prime \prime}$ & $149^{\circ} 30^{\prime} 30.9^{\prime \prime}$ & 357 & 65.6315 & 0.30161 & $24.11 \pm 1.15$ & 1.3126 & $20.98 \pm 11.79$ & $0.87 \pm 0.49$ & $4.24 \pm 2.78$ \\
\hline PNG 16-1029a & $9^{\circ} 52^{\prime} 8.6^{\prime \prime}$ & $149^{\circ} 29^{\prime} 1.6^{\prime \prime}$ & 455 & 50.6051 & 0.30131 & $28.68 \pm 1.20$ & 2.9351 & $38.00 \pm 16.26$ & $1.33 \pm 0.57$ & $3.37 \pm 2.14$ \\
\hline Procedural blank & & & & & 0.29988 & & & & & \\
\hline
\end{tabular}

*: Reference datum AGD1966, AMG Zone 55

\#: Full ${ }^{10} \mathrm{Be}$ procedural blanks were less than $1.9 \%$ of the ${ }^{10} \mathrm{Be} /{ }^{9} \mathrm{Be}$ values measured in any sample and were used to correct for background.

$a, b, c$. Uncertainties are reported at the $1 \sigma$ level.

$d$ : Uncertainties are reported at the $2 \sigma$ level. 


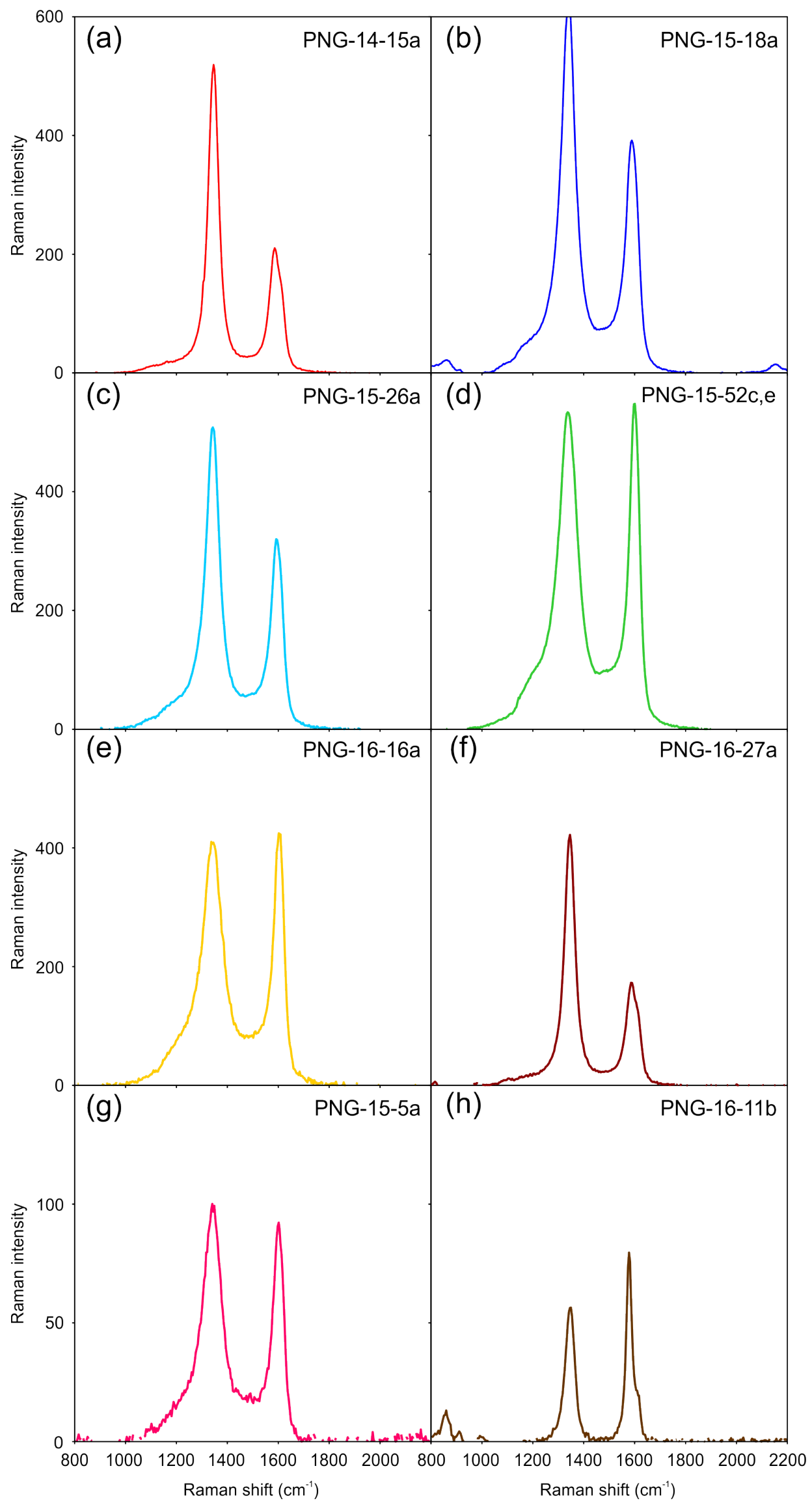

Figure B.12: Representative Raman spectra of carbonaceous material from eight Bonenau Schist samples in the region $800-2200 \mathrm{~cm}^{-1}$. 


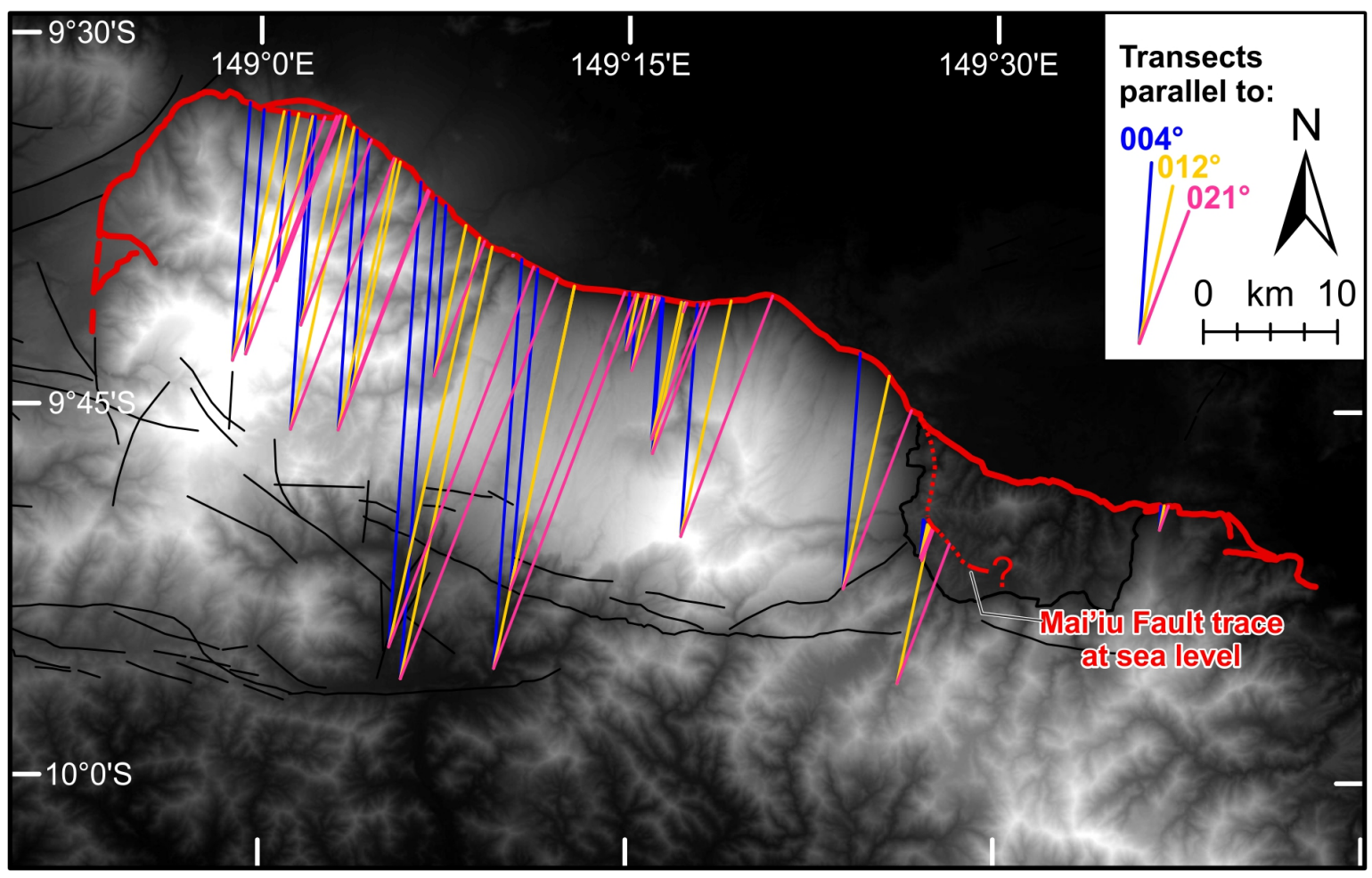

Figure B.13: Determination of the distances of samples from the Mai'iu Fault trace on the curved surface (Shuttle Radar Topography Mission, $30 \mathrm{~m}$ ) of the Suckling-Dayman metamorphic core complex. Blue, yellow and magenta lines were computed for each sample parallel to $004^{\circ}, 012^{\circ}$ and $021^{\circ}$, respectively. The Mai'iu Fault trace at sea level (stippled red line) was approximated from cross-sections presented by Webber (2017). 

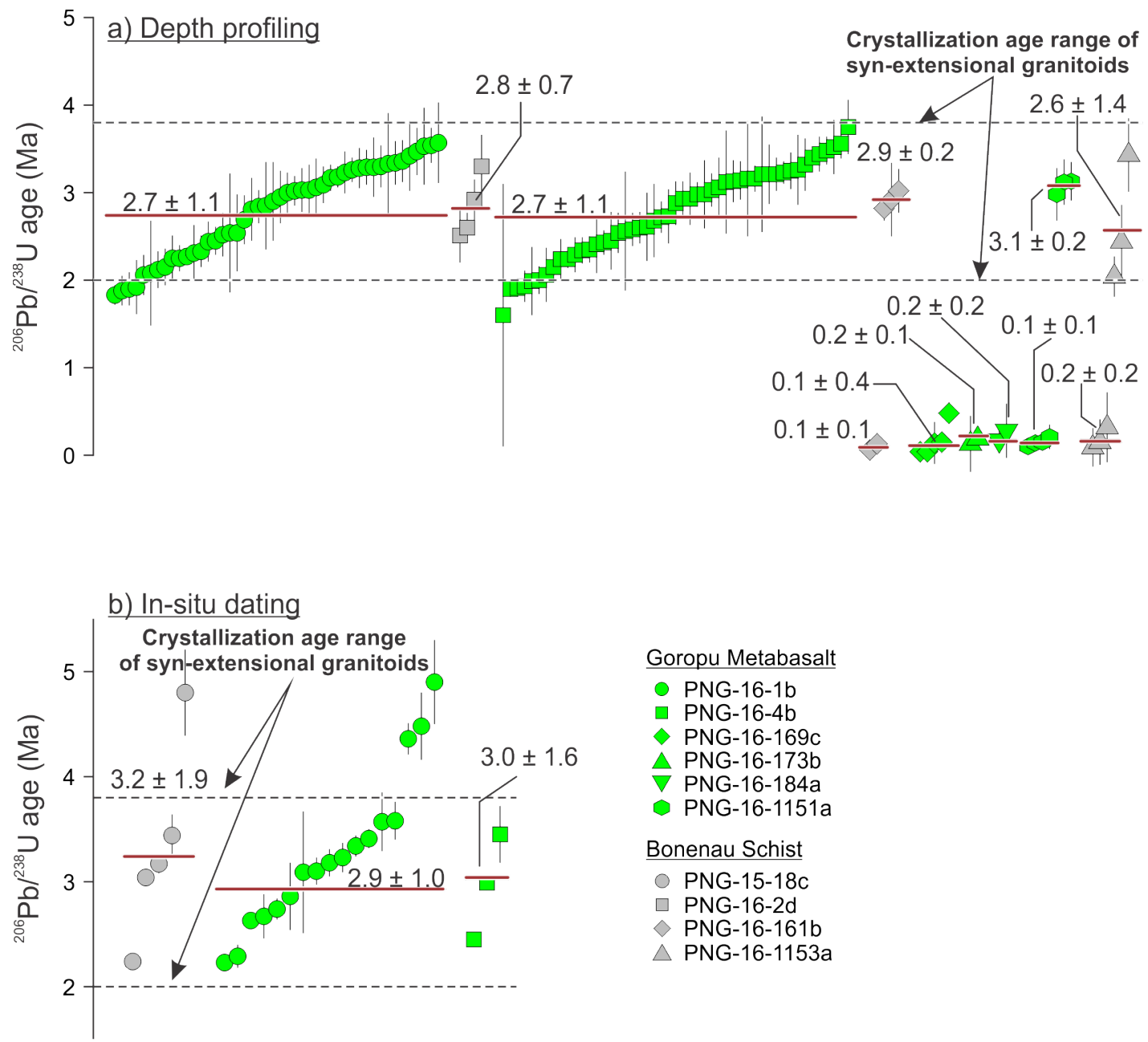

Figure B.14: Rank-order plot of $\mathrm{Pb}_{c^{-}}$and ${ }^{230} \mathrm{Th}$-corrected zircon ${ }^{206} \mathrm{~Pb} /{ }^{238} \mathrm{U}$ dates from samples of the Goropu Metabasalt and Bonenau Schist. Red bars and number labels refer to geometric mean ages $( \pm 2 \sigma)$. 


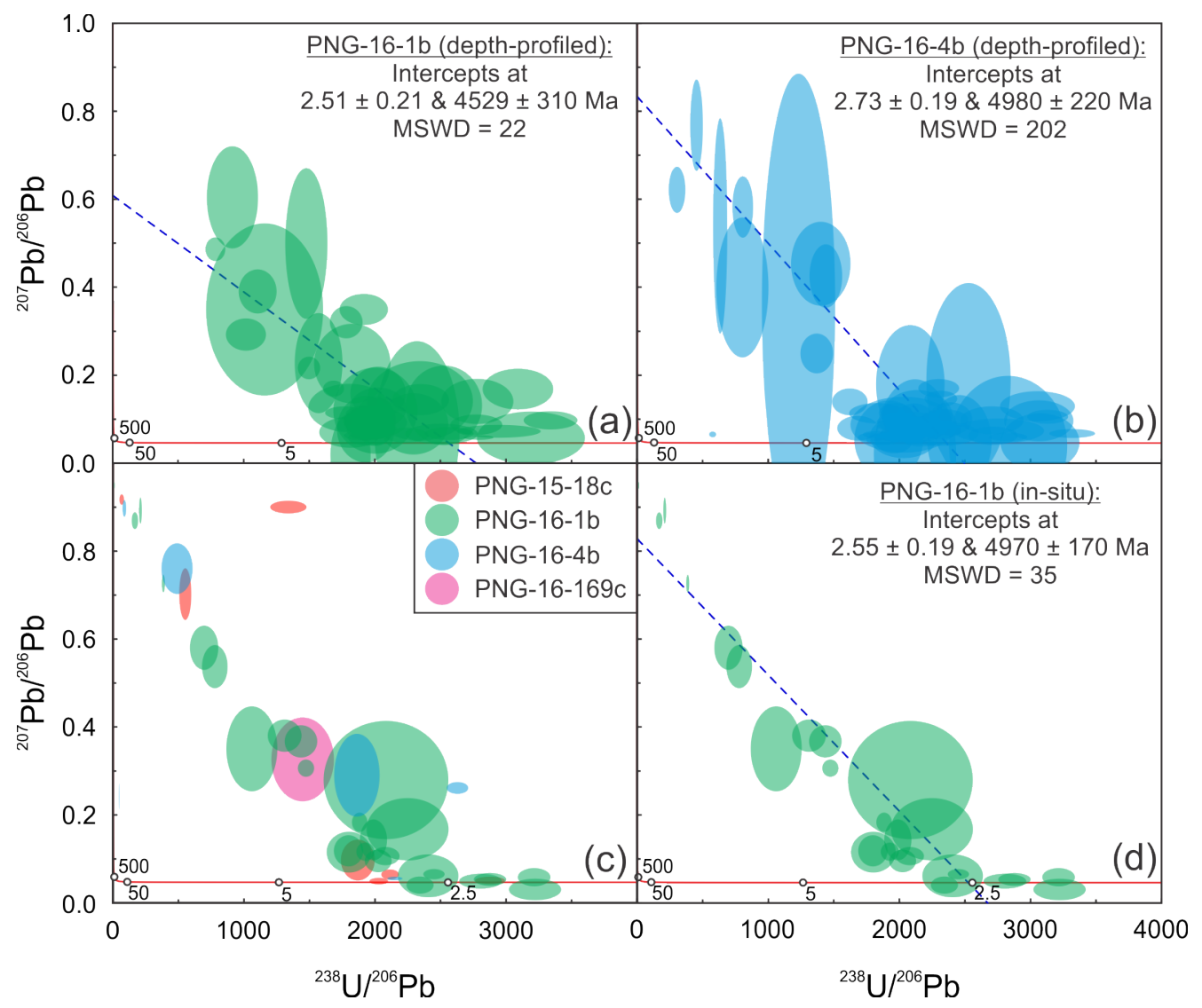

Figure B.15: Tera-Wasserburg diagrams of zircon $\mathrm{U}-\mathrm{Pb}$ analyses from depth profiling and conventional in-situ dating on polished internal surfaces. (a) U-Pb analyses of PNG-16$1 \mathrm{~b}$ from depth profiling. (b) U-Pb analyses of PNG-16-4b from depth profiling. (c) U-Pb analyses from PNG-15-18c, PNG-16-1b, PNG-16-4b and PNG-16-169c plotted in a single diagram. (d) U-Pb analyses of PNG-16-1b from in-situ dating. Note, although no relevance is given to the upper intercepts, it is important to note that they did not yield Cretaceous ages. Rather, the model-2 solutions in Isoplot (model-1 could not be calculated) suggest ${ }^{207} \mathrm{~Pb} /{ }^{206} \mathrm{~Pb}$ values between $\sim 0.85-0.60$. For comparison, the $\mathrm{Pb}_{c}$ composition of the Suckling Granite and Mai' iu Monzonite is ${ }^{207} \mathrm{~Pb} /{ }^{206} \mathrm{~Pb} \sim 0.83$ (see Table B.1). 
Suckling Granite - PNG-15-61a $(\mathrm{n}=30)$

Central age $=1.24 \pm 0.66 \mathrm{Ma}(2 \sigma)$

Dispersion $=0 \%$

$\mathrm{P}\left(\mathrm{X}^{2}\right)=0.96$

Apatite

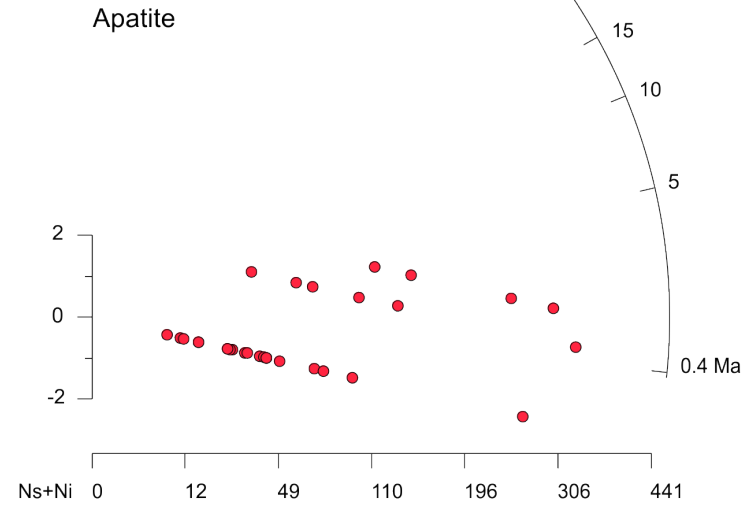

Mai'iu Monzonite - PNG-16-2a $(\mathrm{n}=20)$

Central age $=2.72 \pm 1.32 \mathrm{Ma}(2 \sigma)$

Dispersion $=0 \%$

$\mathrm{P}\left(\mathrm{X}^{2}\right)=0.92$

Apatite

Central age $=2.08 \pm 1.12 \mathrm{Ma}(2 \sigma)$

Dispersion $=0 \%$

$\mathrm{P}\left(\mathrm{X}^{2}\right)=0.95$

Apatite

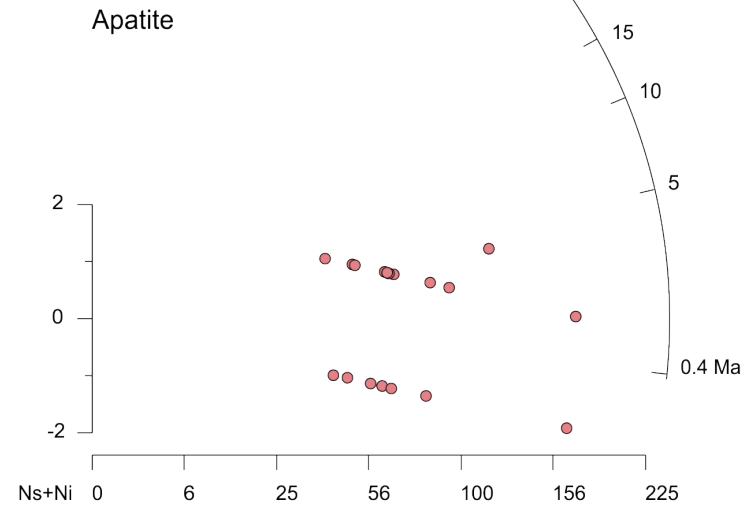

Mai'iu Monzonite - PNG-15-66a $(n=20)$

Central age $=1.04 \pm 0.74 \mathrm{Ma}(2 \sigma)$

Dispersion $=0 \%$

$\mathrm{P}\left(\mathrm{X}^{2}\right)=0.98$

Apatite

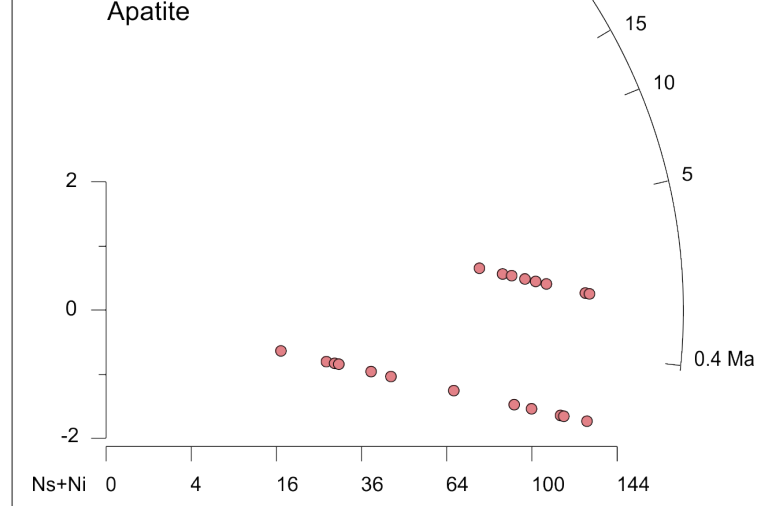

Mai'iu Monzonite - PNG-16-159b $(\mathrm{n}=20)$

Central age $=2.50 \pm 2.00 \mathrm{Ma}(2 \sigma)$

Dispersion $=0 \%$

$\mathrm{P}\left(\mathrm{X}^{2}\right)=0.87$

Apatite

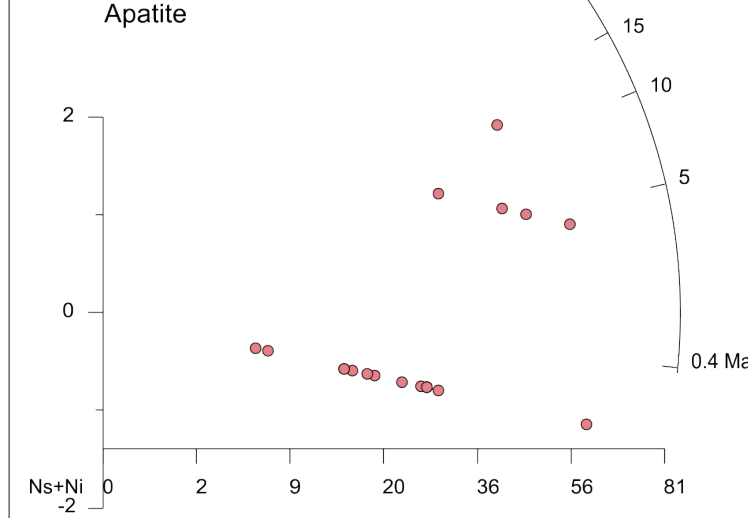

Bonua Porphyry - PNG-16-157a $(n=20)$

Central age $=1.98 \pm 1.78 \mathrm{Ma}(2 \sigma)$

Dispersion $=53 \%$

$\mathrm{P}\left(\mathrm{X}^{2}\right)=0.99$

Apatite

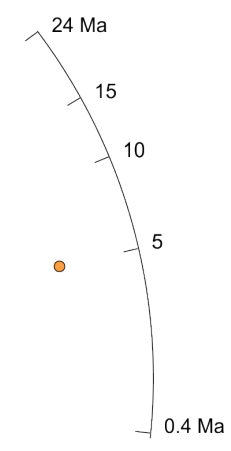

$\begin{array}{lllllllll} & & & & & & & \\ N \text { Ns+Ni } & 0 & 6 & 25 & 56 & 100 & 156 & 225\end{array}$ 
Suckling Granite - AU51087 $(n=20)$

Central age $=1.42 \pm 0.22 \mathrm{Ma}(2 \sigma)$

Dispersion $=13 \%$

$P\left(X^{2}\right)=0.28$

Zircon
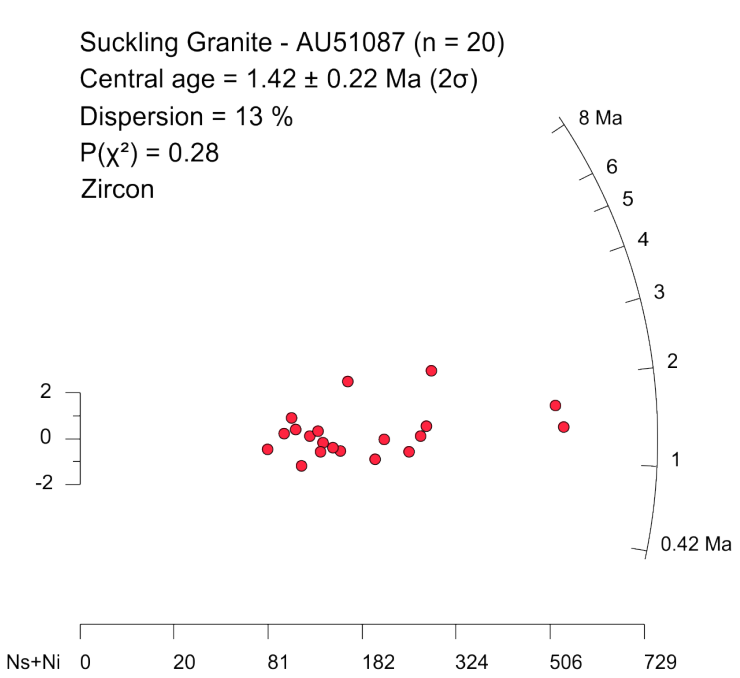

Suckling Granite - AU51089 $(\mathrm{n}=20)$

Central age $=0.97 \pm 0.21 \mathrm{Ma}(2 \sigma)$

Dispersion $=22 \%$

$\mathrm{P}\left(\mathrm{X}^{2}\right)=0.20$

Zircon
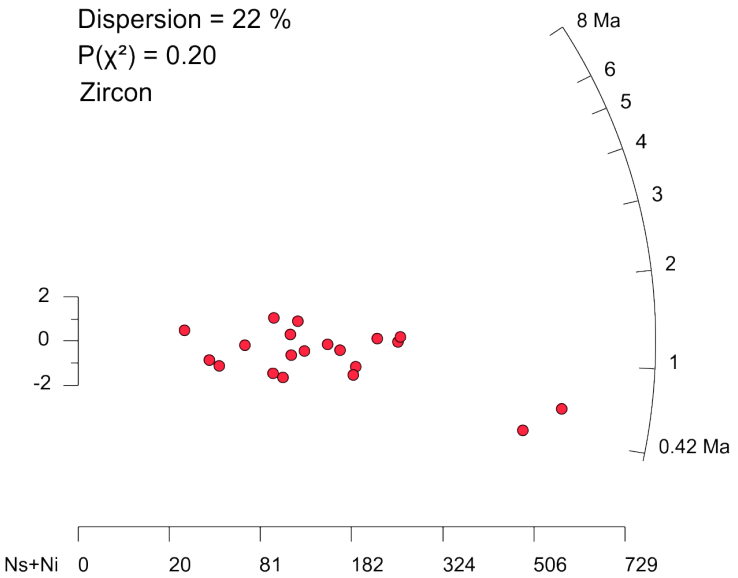

Suckling Granite - PNG-15-64a $(\mathrm{n}=26)$

Central age $=2.99 \pm 0.46 \mathrm{Ma}(2 \sigma)$

Dispersion $=27 \%$

$\mathrm{P}\left(\mathrm{X}^{2}\right)=0.00$

Zircon
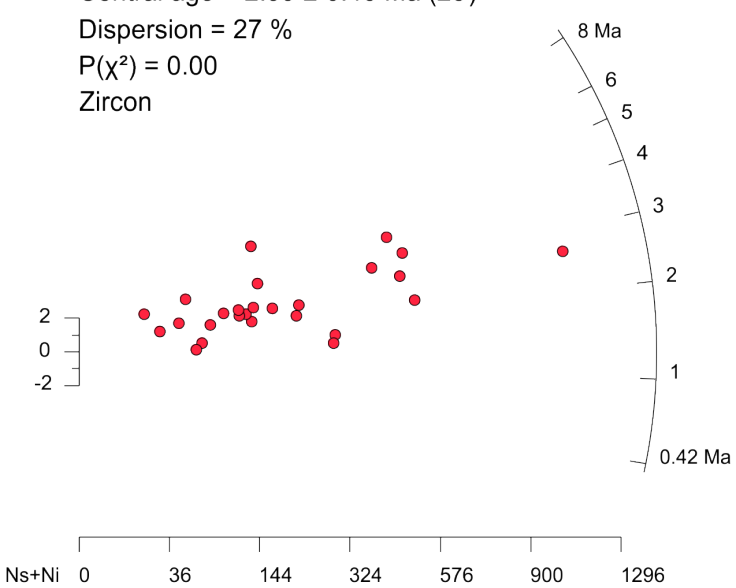

Suckling Granite - AU51088 ( $\mathrm{n}=21)$

Central age $=1.04 \pm 0.28 \mathrm{Ma}(2 \sigma)$

Dispersion $=24 \%$

$\mathrm{P}\left(\mathrm{X}^{2}\right)=0.16$

Zircon

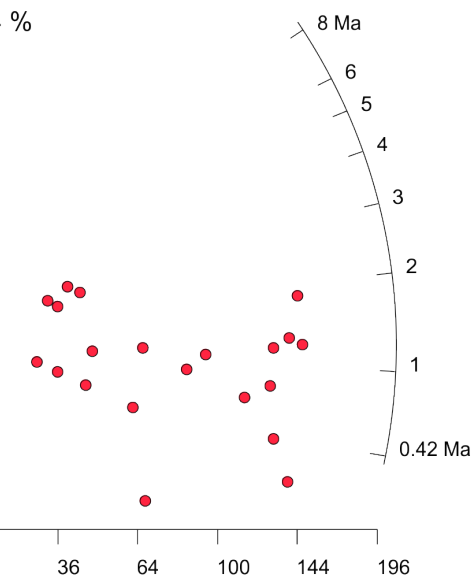

Suckling Granite - PNG-15-61a $(n=22)$

Central age $=2.41 \pm 0.30 \mathrm{Ma}(2 \sigma)$

Dispersion $=0 \%$

$\mathrm{P}\left(\mathrm{X}^{2}\right)=0.43$

Zircon

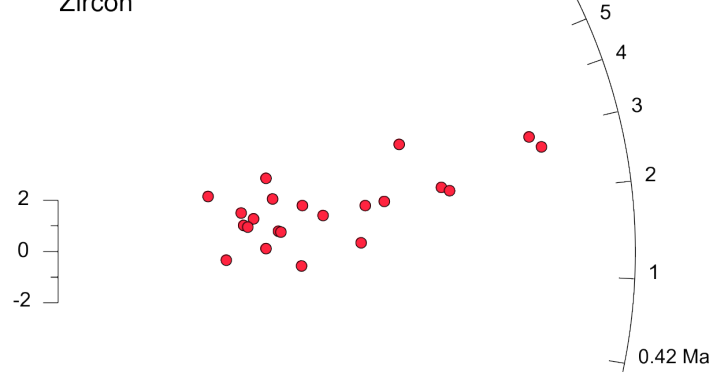

$\begin{array}{lllllllll}\text { Ns+Ni } & 0 & 16 & 64 & 144 & 256 & 400 & 576\end{array}$

Mai'iu Monzonite - PNG-15-66a $(n=20)$

Central age $=2.02 \pm 0.28 \mathrm{Ma}(2 \sigma)$

Dispersion $=11 \%$

$P\left(X^{2}\right)=0.18$

Zircon

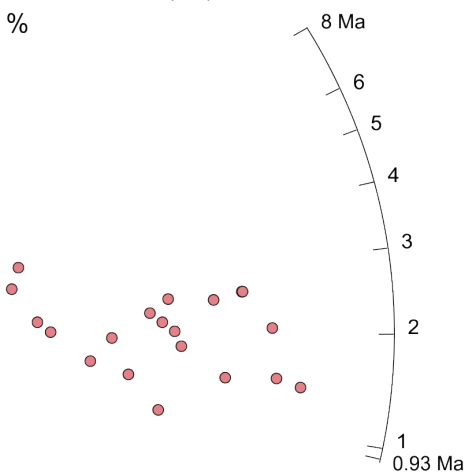

$\left.\begin{array}{l}2 \\ 0 \\ -2\end{array}\right]$

$0.93 \mathrm{Ma}$

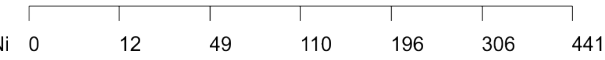


Mai'iu Monzonite - PNG-16-2a $(\mathrm{n}=23)$

Central age $=1.53 \pm 0.32 \mathrm{Ma}(2 \sigma)$

Dispersion $=34 \%$

$\mathrm{P}\left(\mathrm{X}^{2}\right)=0.00$

Zircon

Central age $=1.60 \pm 0.24 \mathrm{Ma}(2 \sigma)$

Dispersion $=0 \%$

$\mathrm{P}\left(\mathrm{X}^{2}\right)=0.47$

Zircon

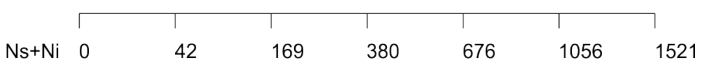

Mai'iu Monzonite - PNG-16-159b $(n=20)$

Central age $=1.50 \pm 0.30 \mathrm{Ma}(2 \sigma)$

Dispersion $=23 \%$

$\mathrm{P}\left(\mathrm{X}^{2}\right)=0.08$

Zircon

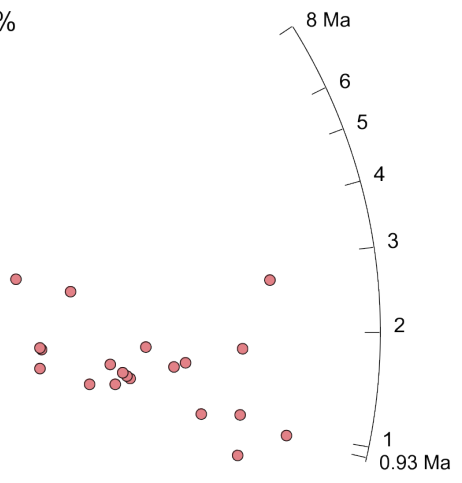

Bonua Porphyry - PNG-16-157a $(\mathrm{n}=10)$

Central age $=2.47 \pm 0.58 \mathrm{Ma}(2 \sigma)$

Dispersion $=23 \%$

$P\left(X^{2}\right)=0.07$

Zircon
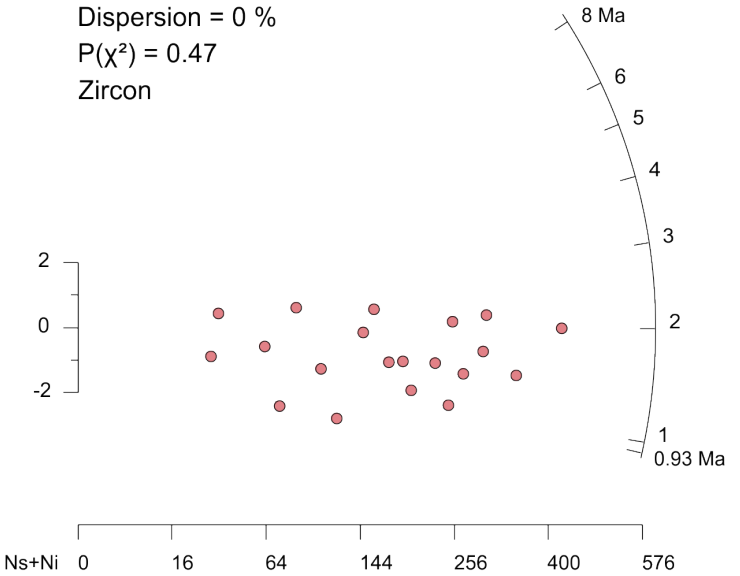

Goropu Metabasalt - PNG-16-1b $(n=28)$

Central age $=1.72 \pm 0.36 \mathrm{Ma}(2 \sigma)$

Dispersion $=0 \%$

$\mathrm{P}\left(\mathrm{X}^{2}\right)=0.93$

Zircon

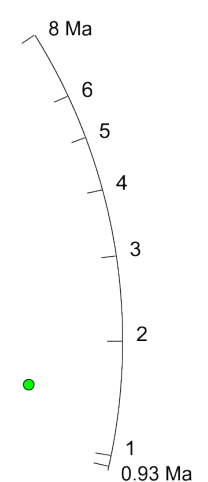

Goropu Metabasalt - PNG-16-4b $(n=25)$

Central age $=2.33 \pm 0.82 \mathrm{Ma}(2 \sigma)$

Dispersion $=48 \%$

$\mathrm{P}\left(\mathrm{X}^{2}\right)=0.00$

Zircon
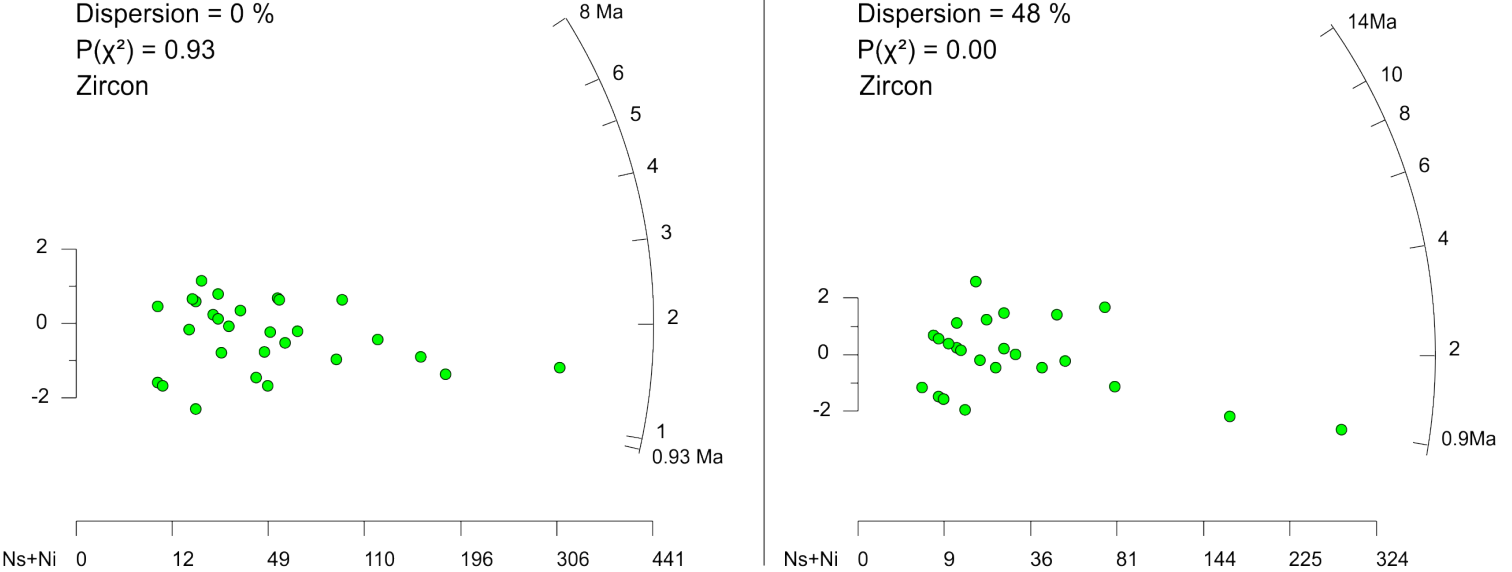
Goropu Metabasalt - PNG-16-169c $(n=8)$

Central age $=1.36 \pm 0.84 \mathrm{Ma}(2 \sigma)$

Dispersion $=39 \%$

$\mathrm{P}\left(\mathrm{X}^{2}\right)=0.17$

Zircon
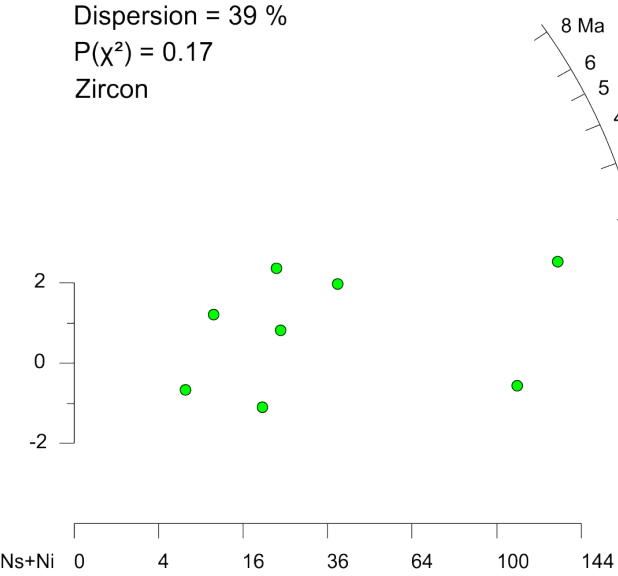

Bonenau Schist - PNG-15-18c $(n=10)$ Central age $=1.87 \pm 0.74 \mathrm{Ma}(2 \sigma)$

Dispersion $=45 \%$

$\mathrm{P}\left(\mathrm{X}^{2}\right)=0.00$

Zircon
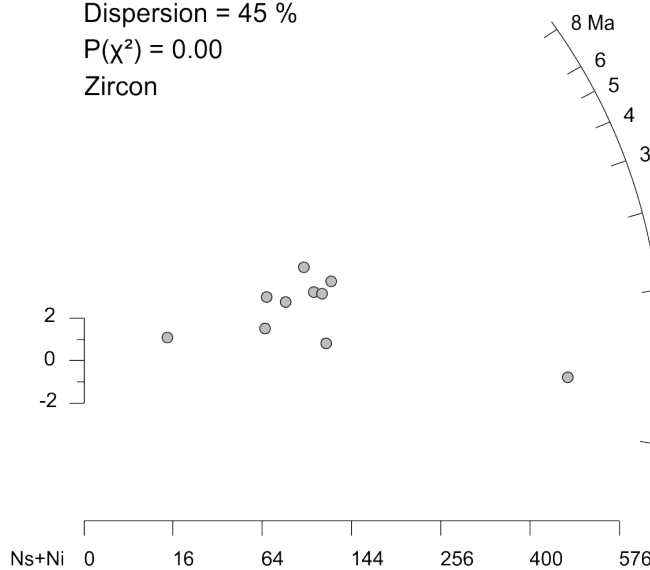

Bonenau Schist - PNG-16-1153a $(\mathrm{n}=17)$

Central age $=22.2 \pm 8.4 \mathrm{Ma}(2 \sigma)$

Dispersion $=70 \%$

$P\left(X^{2}\right)=0.00$

Zircon

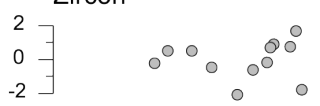
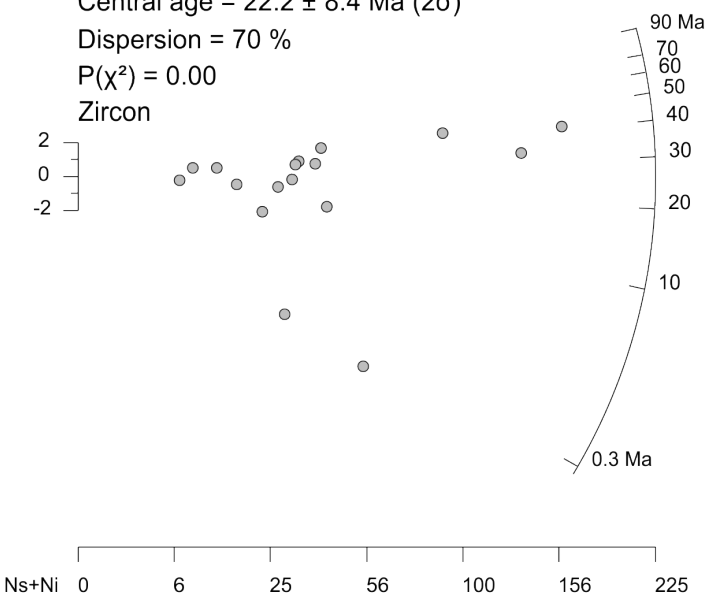

Goropu Metabasalt - PNG-16-1151a ( $\mathrm{n}=4)$

Central age $=0.98 \pm 1.42 \mathrm{Ma}(2 \sigma)$

Dispersion $=128 \%$

$P\left(X^{2}\right)=0.00$

Zircon
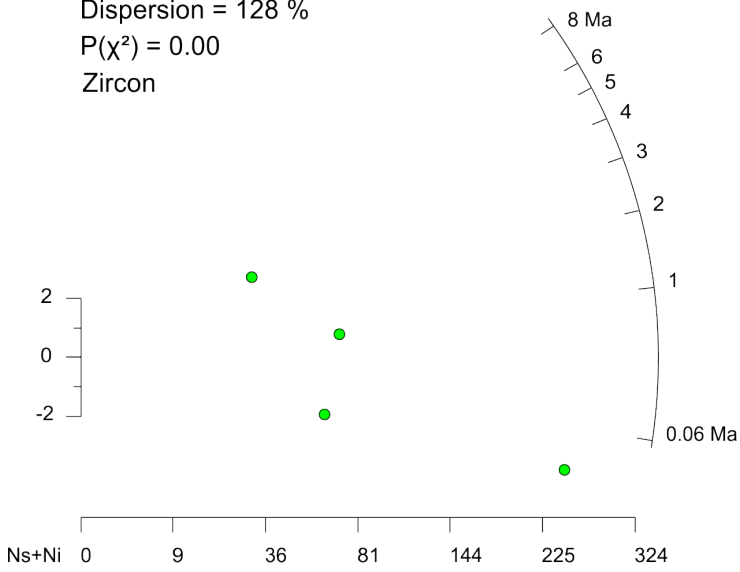

Bonenau Schist - PNG-16-161b ( $\mathrm{n}=6)$

Central age $=0.49 \pm 0.64 \mathrm{Ma}(2 \sigma)$

Dispersion $=109 \%$

$P\left(X^{2}\right)=0.00$

Zircon

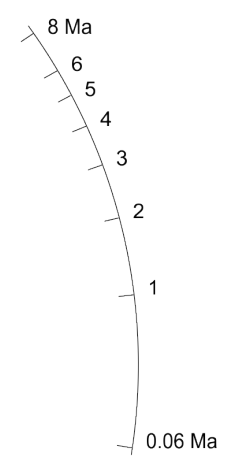

$\begin{array}{llllllllll}\mathrm{Ns}+\mathrm{Ni} & 0 & 4 & 16 & 36 & 64 & 100 & 144 & 196\end{array}$

Yau Igneous Complex - PNG-15-41bT2 $(n=20)$

Central age $=38.9 \pm 6.0 \mathrm{Ma}(2 \sigma)$

Dispersion $=0 \%$

$P\left(X^{2}\right)=0.99$

Zircon

$\left.\begin{array}{c}2 \\ 0 \\ -2\end{array}\right]$

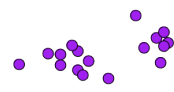

$+90 \mathrm{Ma}$

70
70
50
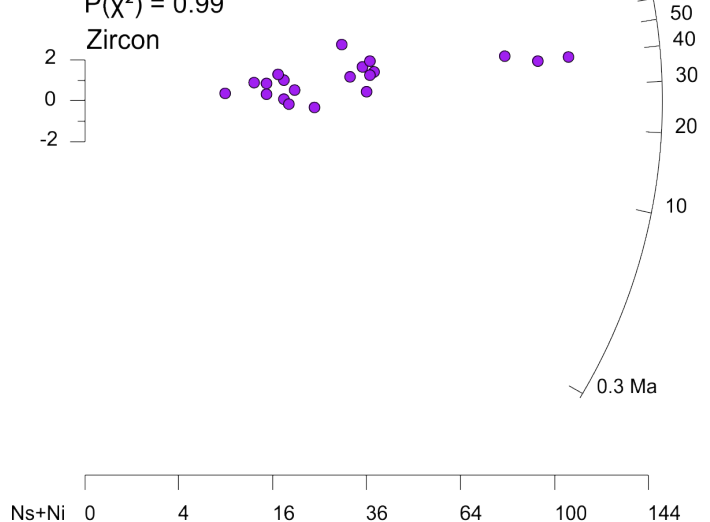
Yau Igneous Complex - PNG-15-54bT2 $(\mathrm{n}=20)$

Central age $=50.6 \pm 6.6 \mathrm{Ma}(2 \sigma)$

Dispersion $=12 \%$

$\mathrm{P}\left(\mathrm{X}^{2}\right)=0.39$

$\left.{ }_{2}^{2}\right]_{-7}^{\text {Zircon }}$

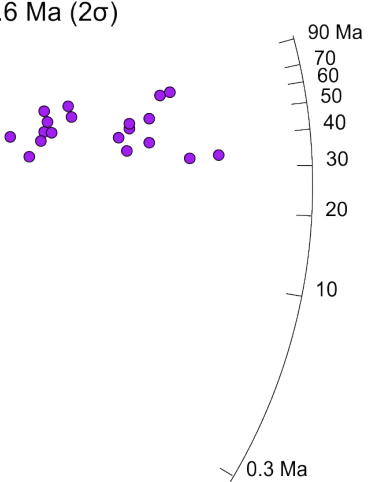

Yau Igneous Complex - PNG-15-54cT2 $(n=19)$

Central age $=35.4 \pm 6.8 \mathrm{Ma}(2 \sigma)$

Dispersion $=32 \%$

$\mathrm{P}\left(\mathrm{X}^{2}\right)=0.00$

Zircon

$\begin{array}{r}2 \\ 0 \\ -2\end{array}-$

$\circ$
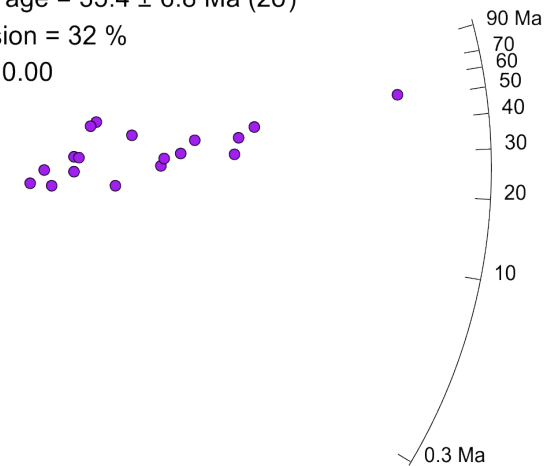

$\begin{array}{lllllllll} & & \mid & & & & & \\ N \text { Ns+Ni } & 0 & 12 & 49 & 110 & 196 & 306 & 441\end{array}$

Stream sediment - PNG-15-76d $(n=43)$

Central age $=1.04 \pm 0.46 \mathrm{Ma}(2 \sigma)$

$\left.\begin{array}{r}2 \\ 0 \\ -2\end{array}\right] \quad \div \quad \circ 8$

Zircon

$-\quad-\begin{gathered}50 \\ 40\end{gathered}$

$-$

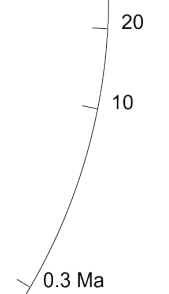

\begin{tabular}{|l|l|l|l|l|}
\hline & & & & \\
0 & 25 & 56 & 100 & 150
\end{tabular}

$\begin{array}{llllllll}\mathrm{Ns}+\mathrm{Ni} & 0 & 6 & 25 & 56 & 100 & 156 & 225\end{array}$

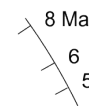

Dispersion $=83 \%$

$\mathrm{P}\left(\mathrm{X}^{2}\right)=0.00$

Apatite

Stream sediment - PNG-16-141a $(n=41)$

Central age $=0.31 \pm 0.38 \mathrm{Ma}(2 \sigma)$

Dispersion $=379 \%$

$P\left(X^{2}\right)=0.00$

Zircon

5

3

$-2$
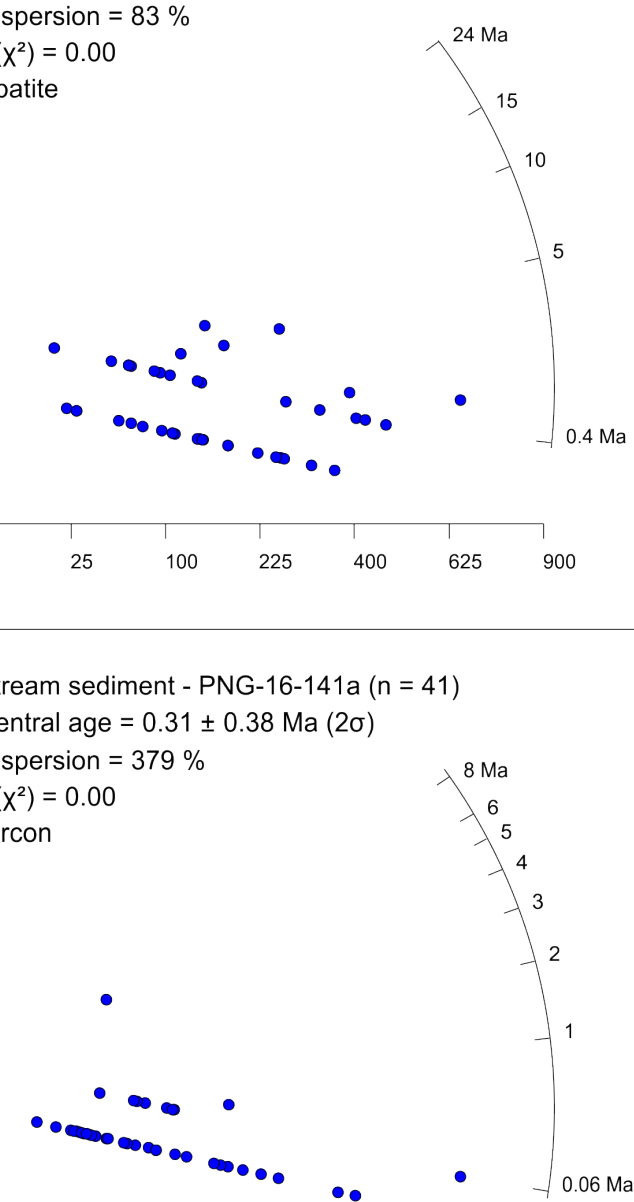

25900
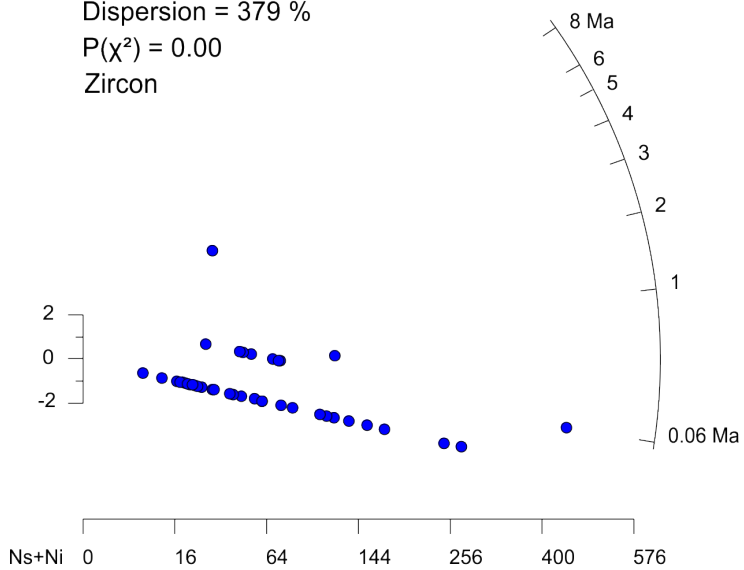

Stream sediment - PNG-15-76d $(n=83)$

Central age $=1.88 \pm 0.22 \mathrm{Ma}(2 \sigma)$

Dispersion $=39 \%$

$P\left(X^{2}\right)=0.00$

Zircon

$\begin{array}{r}2 \\ 0 \\ -2\end{array}-$
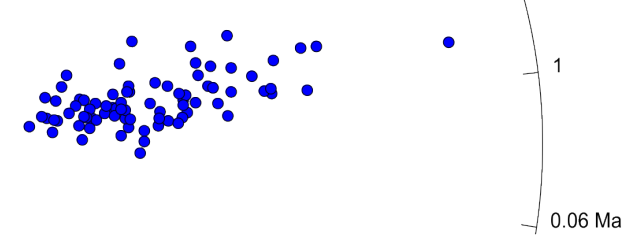

$0.06 \mathrm{Ma}$

$\begin{array}{lllllllll}\text { Ns+Ni } & 0 & 30 & 121 & 272 & 484 & 756 & 1089\end{array}$ 

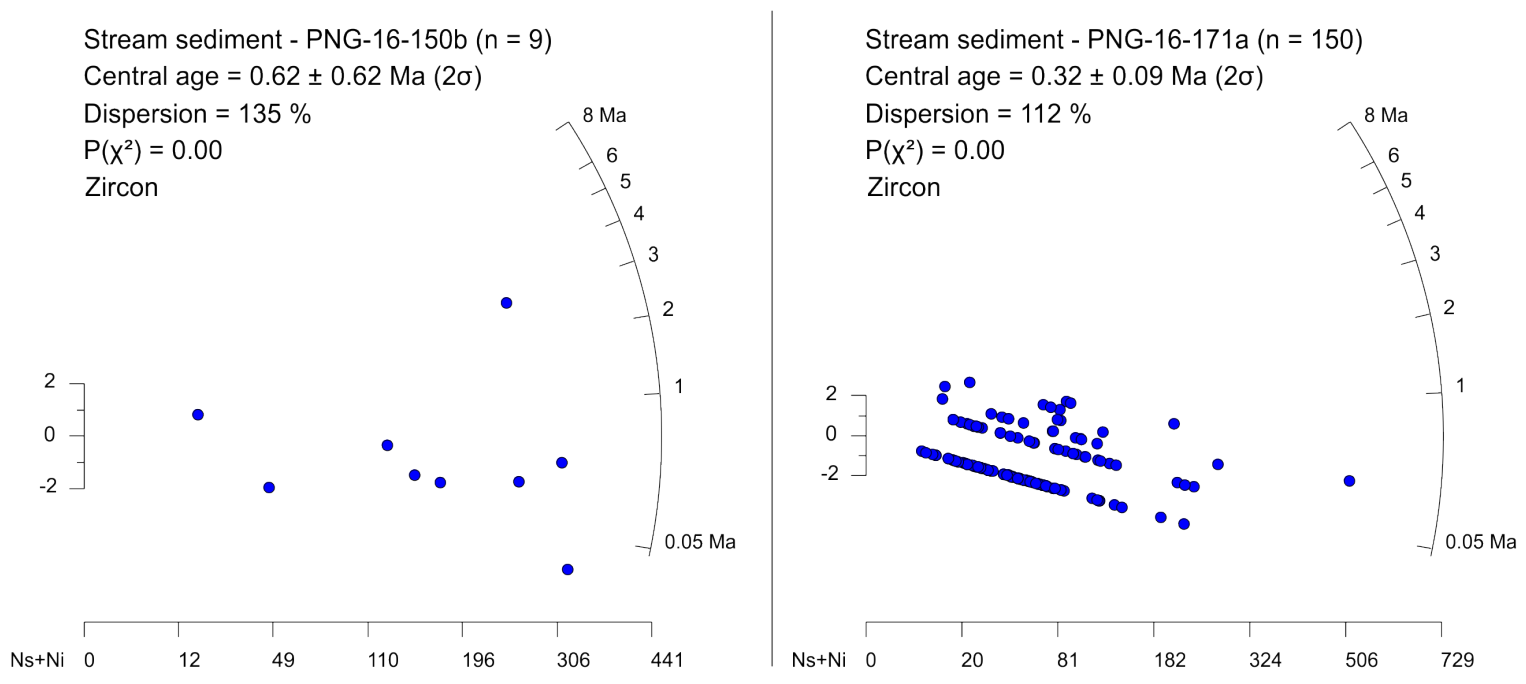

Figure B.16: Radial plots of apatite and zircon fission-track data. $\mathrm{N}_{s}$ and $\mathrm{N}_{i}$ refer to the number of spontaneous and induced tracks, respectively. Note, parallel arrays arise from multiple grains with identical $\mathrm{N}_{s}$ (typically 0 or 1 ). 

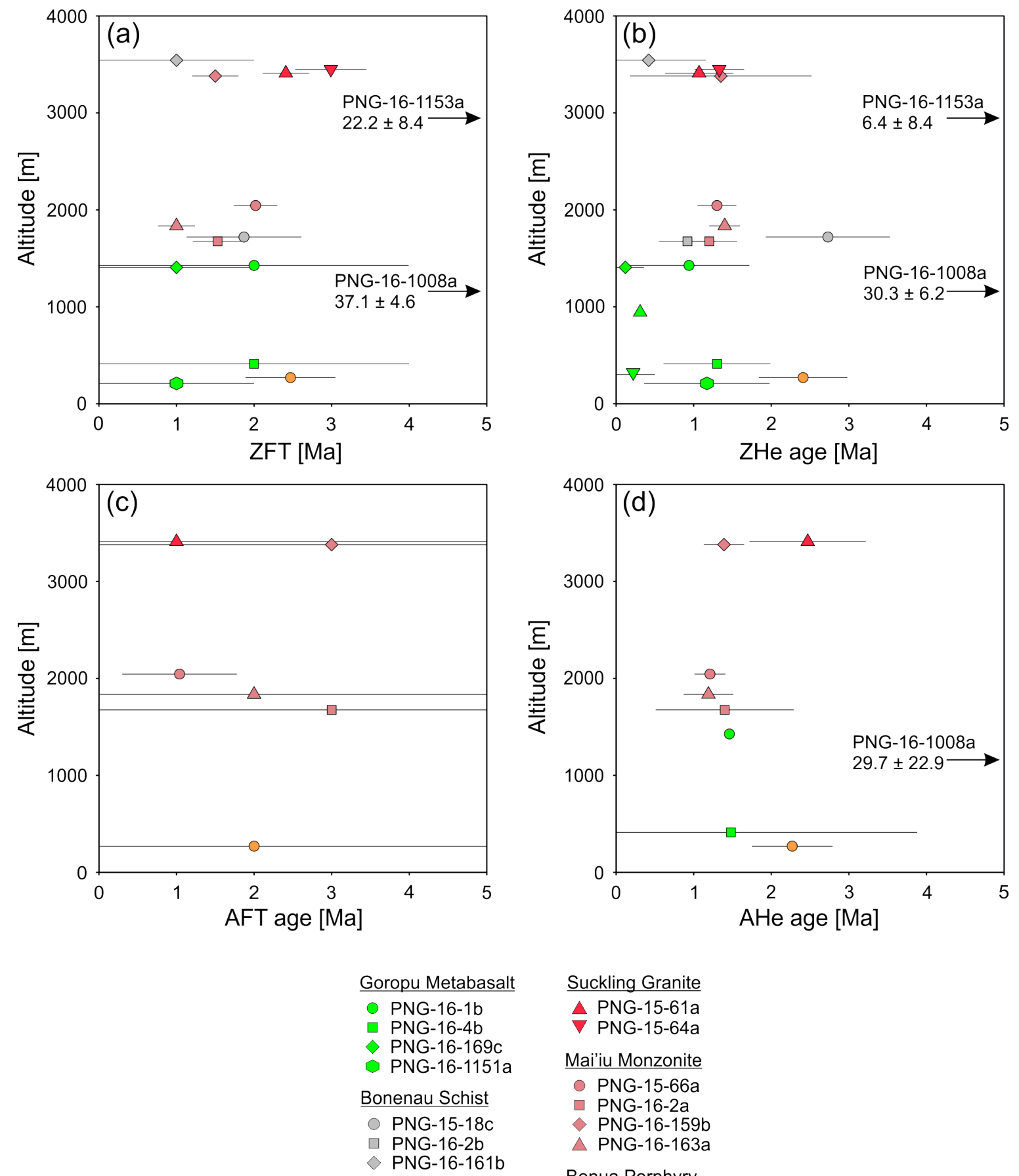

$$
\begin{gathered}
\underline{\text { Suckling Granite }} \\
\Delta \text { PNG-15-61a } \\
\text { PNG-15-64a } \\
\text { Mai'iu Monzonite } \\
\hline \text { PNG-15-66a } \\
\text { PNG-16-2a } \\
\text { PNG-16-159b } \\
\triangle \text { PNG-16-163a } \\
\text { Bonua Porphyry } \\
\text { PNG-16-157a }
\end{gathered}
$$

Figure B.17: Age-altitude plots for the ZFT, ZHe, AFT, and AHe systems. Error bars are $2 \sigma$. ZFT and AFT ages are central ages and, where available, maximum likelihood ages (see Table B.4). 

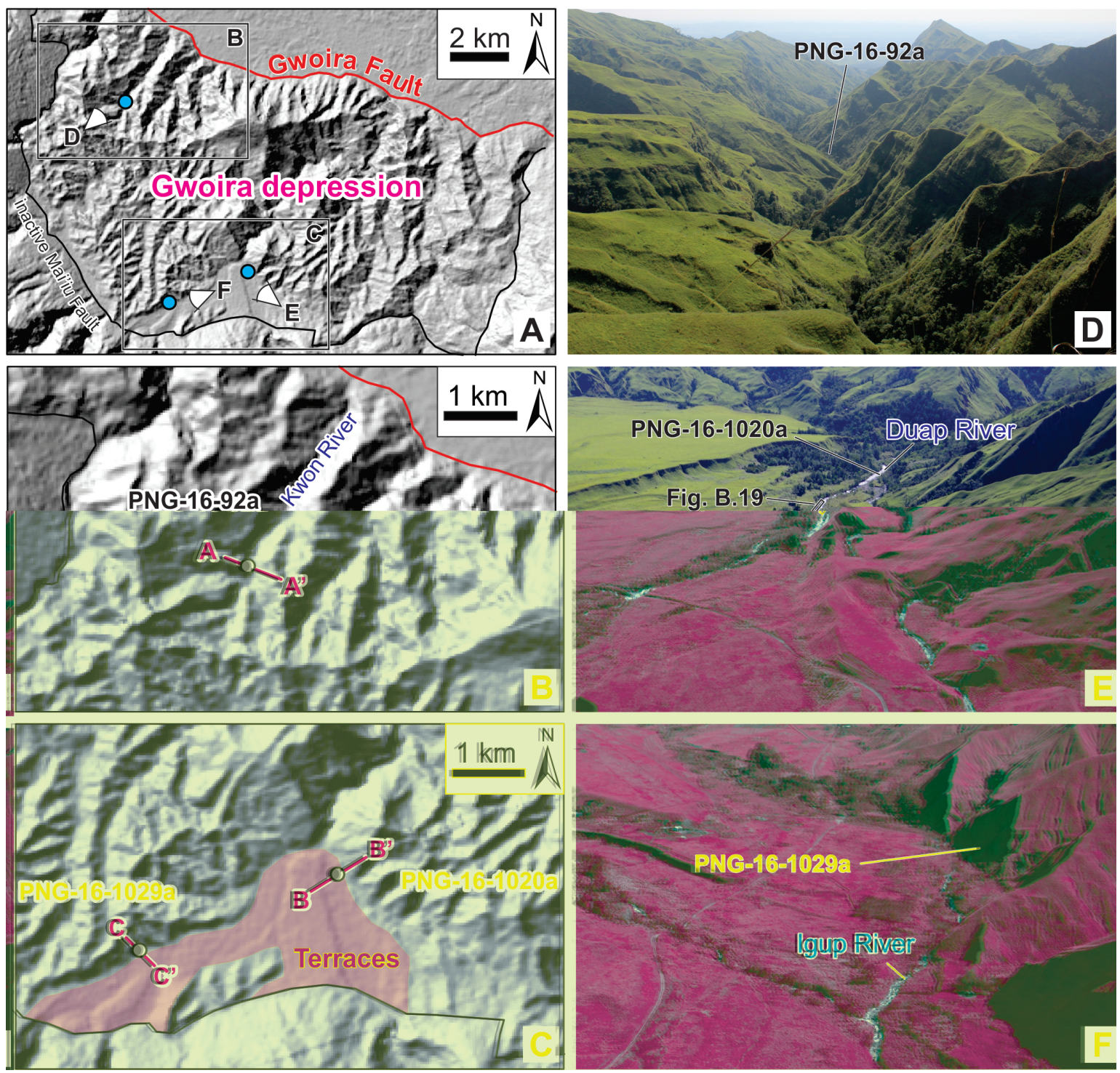

Figure B.18: Location and setting of quartz samples (blue circles) collected for ${ }^{26} \mathrm{Al} /{ }^{10} \mathrm{Be}$ burial age dating from the Gwoira Conglomerate. A-C are snapshots of a hillshade model (Shuttle Radar Topography Mission, $30 \mathrm{~m}$ ) of the Gwoira depression. A-A', B-B' and CC' mark the traces of cross-sections (Figure B.20) illustrating the topography on either side of the samples collected for burial age dating. D-F are field photographs that show the approximate locations of the samples and that provide a more detailed picture of the local topography. Photo credits: Daniel Stockli and Marcel Mizera. 


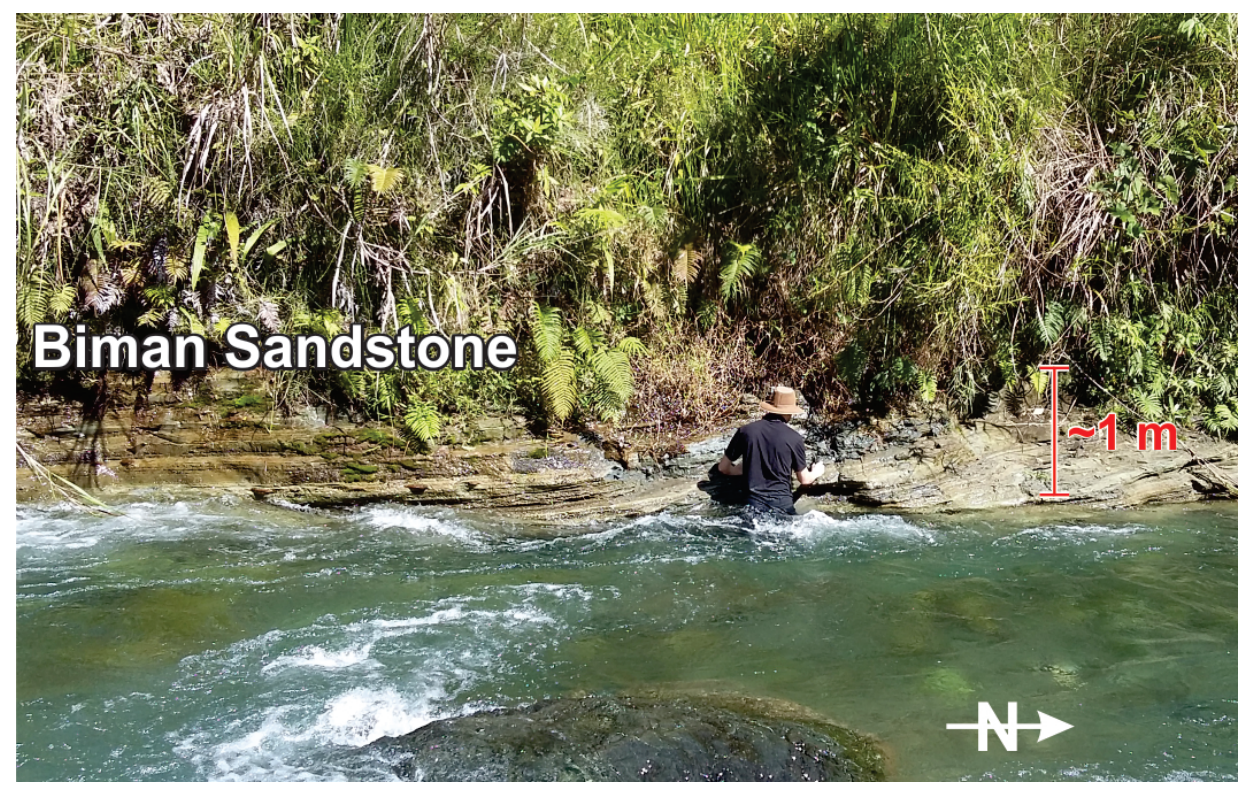

Figure B.19: Photograph of the Biman Sandstone. Sand and silt beds of this unit dip southward at up to $7^{\circ}$. Photo credit: Sam Webber. 

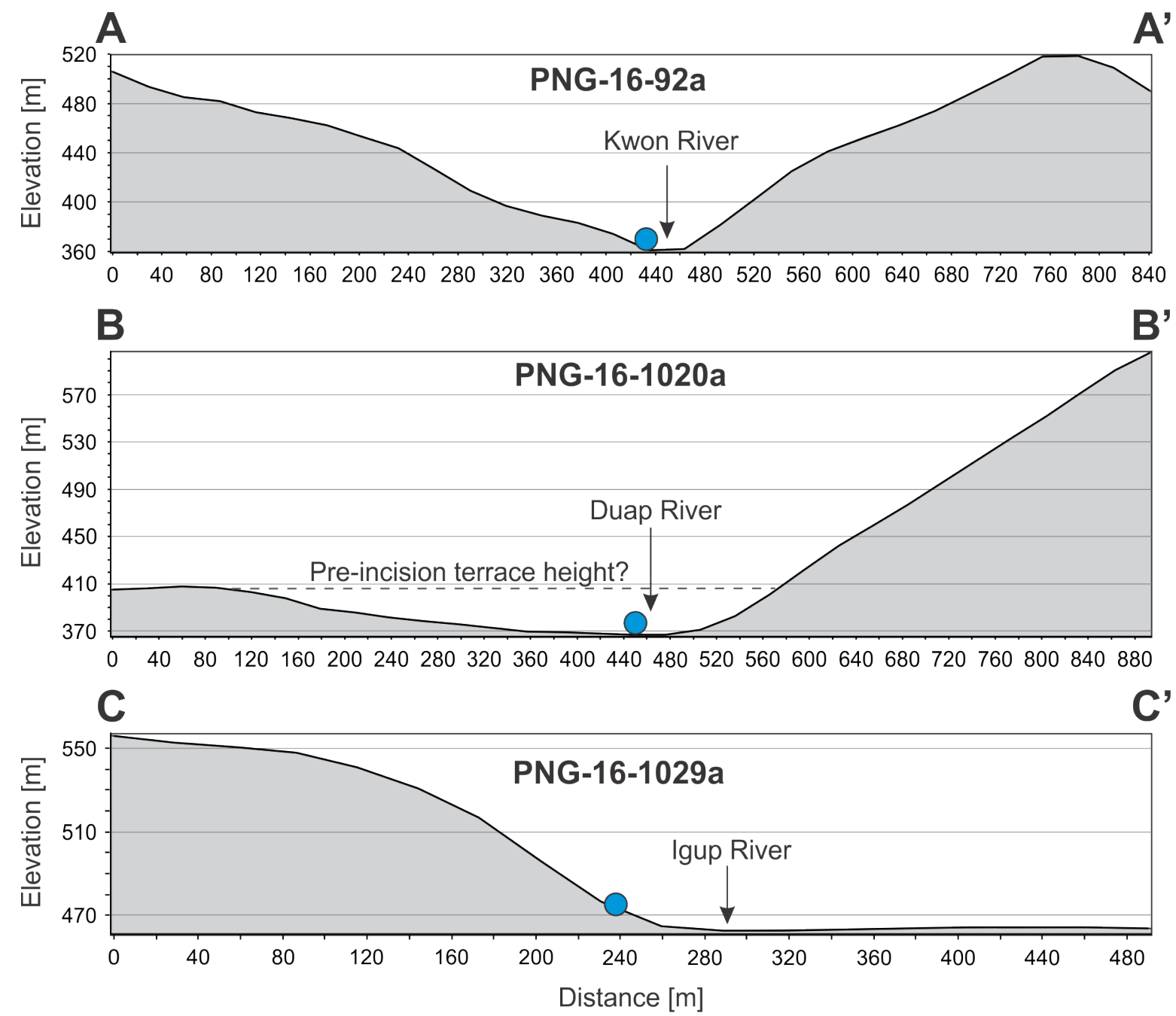

Figure B.20: Cross-sections through the Gwoira Conglomerate illustrating topography on either side of the samples collected for ${ }^{26} \mathrm{Al} /{ }^{10} \mathrm{Be}$ burial age dating. No vertical exaggeration. 


\section{Electronic appendices}

Electronic appendix 1: Full zircon $\mathrm{U}-\mathrm{Pb}$ depth-profile data.

Electronic appendix 2: Full Al-in-amphibole dataset.

Electronic appendix 3: Full Al-in-biotite dataset.

Electronic appendix 4: Full apatite trace element dataset.

Electronic appendix 5: Full zircon trace element dataset.

Electronic appendix 6: Full Raman spectroscopic dataset.

Electronic appendix 7: Full zircon $\mathrm{U}-\mathrm{Pb}$ and trace element split-stream dataset.

Please see attached CD-ROM for electronic appendices or refer to:

http://researcharchive.vuw.ac.nz/handle/10063/8241. 


\section{Bibliography}

Abers, G. A., Eilon, Z., Gaherty, J. B., Jin, G., Kim, Y., Obrebski, M., and Dieck, C. (2016). Southeast Papuan crustal tectonics: Imaging extension and buoyancy of an active rift. Journal of Geophysical Research: Solid Earth, 121(2):951-971.

Abers, G. A., Ferris, A., Craig, M., Davies, H. L., Lerner-Lam, A. L., Mutter, J. C., and Taylor, B. (2002). Mantle compensation of active metamorphic core complexes at Woodlark rift in Papua New Guinea. Nature, 418:862-865.

Abers, G. A. and Roecker, S. W. (1991). Deep structure of an arc-continent collision: Earthquake relocation and inversion for upper mantle $\mathrm{P}$ and $\mathrm{S}$ wave velocities beneath Papua New Guinea. Journal of Geophysical Research: Solid Earth, 96(B4):6379-6401.

Aciego, S., Kennedy, B. M., DePaolo, D. J., Christensen, J. N., and Hutcheon, I. (2003). $\mathrm{U}-\mathrm{Th} / \mathrm{He}$ age of phenocrystic garnet from the $79 \mathrm{AD}$ eruption of Mt. Vesuvius. Earth and Planetary Science Letters, 216(1):209-219.

Adshead, N. and Appleby, A.-K. (1996). The Umuna Au-Ag deposit, Misima Island, Papua New Guinea: Spatially but not genetically associated with porphyry. Technical report, Australian Mineral Foundation, Glenside, Australia.

Advokaat, E. L., Hall, R., White, L. T., Watkinson, I. M., Rudyawan, A., and BouDagherFadel, M. K. (2017). Miocene to recent extension in NW Sulawesi, Indonesia. Journal of Asian Earth Sciences, 147:378-401.

Andersen, T. (2002). Correction of common lead in $\mathrm{U}-\mathrm{Pb}$ analyses that do not report ${ }^{204} \mathrm{~Pb}$. Chemical Geology, 192(1):59-79.

Anderson, E. M. (1951). The Dynamics of Faulting, Etc. Oliver and Boyd, revised edition.

Anderson, J. L. (2008). Plagioclase-hornblende thermobarometry (RiMG069_ch04_hbld_plag_thermo-jla.xls).

Anderson, J. L. and Smith, D. R. (1995). The effects of temperature and $\mathrm{fO}_{2}$ on the Al-inhornblende barometer. American Mineralogist, 80(5-6):549-559.

Aoya, M., Kouketsu, Y., Endo, S., Shimizu, H., Mizukami, T., Nakamura, D., and Wallis, S. (2010). Extending the applicability of the Raman carbonaceous-material geothermometer 
using data from contact metamorphic rocks. Journal of Metamorphic Geology, 28(9):895914.

Arevalo, R. and McDonough, W. F. (2010). Chemical variations and regional diversity observed in MORB. Chemical Geology, 271(1):70-85.

Axen, G. J. (2004). Mechanics of low-angle normal faults. In Karner, G., Taylor, B., Driscoll, N., and Kohlstedt, D. L., editors, Rheology and deformation in the lithosphere at continental margins, pages 46-91. Columbia Univ. Press, New York, USA.

Axen, G. J. and Bartley, J. M. (1997). Field tests of rolling hinges: Existence, mechanical types, and implications for extensional tectonics. Journal of Geophysical Research: Solid Earth, 102(B9):20515-20537.

Baker, G. (1946). Preliminary note on volcanic eruptions in the Goropu Mountains, Southeastern Papua, during the period December, 1943, to August, 1944. The Journal of Geology, 54(1):19-31.

Baldwin, S. L. and Das, J. P. (2015). Atmospheric Ar and Ne returned from mantle depths to the Earth's surface by forearc recycling. Proceedings of the National Academy of Sciences, 112(46):14174.

Baldwin, S. L., Fitzgerald, P. G., and Webb, L. E. (2012). Tectonics of the New Guinea Region. Annual Review of Earth and Planetary Sciences, 40(1):495-520.

Baldwin, S. L. and Ireland, T. R. (1995). A tale of two eras: Pliocene-Pleistocene unroofing of Cenozoic and late Archean zircons from active metamorphic core complexes, Solomon Sea, Papua New Guinea. Geology, 23(11):1023-1026.

Baldwin, S. L., Lister, G. S., Hill, E. J., Foster, D. A., and McDougall, I. (1993). Thermochronologic constraints on the tectonic evolution of active metamorphic core complexes, D’Entrecasteaux Islands, Papua New Guinea. Tectonics, 12(3):611-628.

Baldwin, S. L., Monteleone, B. D., Webb, L. E., Fitzgerald, P. G., Grove, M., and Hill, J. E. (2004). Pliocene eclogite exhumation at plate tectonic rates in eastern Papua New Guinea. Nature, 431:263-267.

Baldwin, S. L., Webb, L. E., and Monteleone, B. D. (2008). Late Miocene coesite-eclogite exhumed in the Woodlark Rift. Geology, 36(9):735-738.

Barzoi, S. C. (2015). Shear stress in the graphitization of carbonaceous matter during the low-grade metamorphism from the northern Parang Mountains (South Carpathians) - Implications to graphite geothermometry. International Journal of Coal Geology, 146:179187. 
Beiersdorfer, R. E. and Day, H. W. (1995). Mineral paragenesis of pumpellyite in low-grade mafic rocks. In Schiffman, P. and Day, H. W., editors, Low Grade Metamorphism of Mafic Rocks, volume 296 of Geological Society of America Special Paper, pages 5-27.

Bergen, K. J., Shaw, J. H., Leon, L. A., Dolan, J. F., Pratt, T. L., Ponti, D. J., Morrow, E., Barrera, W., Rhodes, E. J., Murari, M. K., and Owen, L. A. (2017). Accelerating slip rates on the Puente Hills blind thrust fault system beneath metropolitan Los Angeles, California, USA. Geology, 45(3):227-230.

Berger, W. H. (1993). Quaternary oxygen isotope record of pelagic foraminifers; Site 806, Ontong Java Plateau. Proceedings of the Ocean Drilling Program, Scientific Results, $130: 381$.

Beyssac, O., Goffé, B., Chopin, C., and Rouzaud, J. N. (2002). Raman spectra of carbonaceous material in metasediments: a new geothermometer. Journal of Metamorphic Geology, 20(9):859-871.

Blackburn, T. J., Stockli, D. F., Carlson, R. W., and Berendsen, P. (2008). (U-Th)/He dating of kimberlites-A case study from north-eastern Kansas. Earth and Planetary Science Letters, 275(1):111-120.

Blackburn, T. J., Stockli, D. F., and Walker, J. D. (2007). Magnetite (U-Th)/He dating and its application to the geochronology of intermediate to mafic volcanic rocks. Earth and Planetary Science Letters, 259(3):360-371.

Blewett, R. S., Black, L. P., Sun, S.-s., Knutson, J., Hutton, L. J., and Bain, J. H. C. (1998). $\mathrm{U}-\mathrm{Pb}$ zircon and Sm-Nd geochronology of the Mesoproterozoic of North Queensland: implications for a Rodinian connection with the Belt supergroup of North America. Precambrian Research, 89(3):101-127.

Blondes, M. S., Reiners, P. W., Edwards, B. R., and Biscontini, A. (2007). Dating young basalt eruptions by (U-Th)/He on xenolithic zircon. Geology, 35(1):17-20.

Blundy, J. D. and Holland, T. J. B. (1990). Calcic amphibole equilibria and a new amphiboleplagioclase geothermometer. Contributions to Mineralogy and Petrology, 104(2):208224.

Bodorkos, S., Sheppard, S., Saroa, D., Tsiperau, C. U., and Sircombe, K. N. (2013). New SHRIMP U-Pb zircon ages from the Wau-Bulolo region, Papua New Guinea. Technical report, Geoscience Australia.

Boehnke, P., Watson, E. B., Trail, D., Harrison, T. M., and Schmitt, A. K. (2013). Zircon saturation re-revisited. Chemical Geology, 351:324-334. 
Brichau, S., Ring, U., Carter, A., Bolhar, R., Monié, P., Stockli, D., and Brunel, M. (2008). Timing, slip rate, displacement and cooling history of the Mykonos detachment footwall, Cyclades, Greece, and implications for the opening of the Aegean Sea basin. Journal of the Geological Society, 165(1):263-277.

Brown, C. M. (1977). Yule - Papua New Guinea, Sheet SC/55-2 International Index.

Bruand, E., Storey, C., and Fowler, M. (2016). An apatite for progress: Inclusions in zircon and titanite constrain petrogenesis and provenance. Geology, 44(2):91-94.

Bryan, S. E., Constantine, A. E., Stephens, C. J., Ewart, A., Schön, R. W., and Parianos, J. (1997). Early Cretaceous volcano-sedimentary successions along the eastern Australian continental margin: Implications for the break-up of eastern Gondwana. Earth and Planetary Science Letters, 153(1):85-102.

Bryan, S. E., Cook, A., Allen, C. M., Siégel, C., Purdy, D., Greentree, J., and Uysal, T. (2012). Early-mid Cretaceous tectonic evolution of eastern Gondwana: from silicic LIP magmatism to continental rupture. Episodes, 35(1):142-152.

Buck, W. R. (1988). Flexural rotation of normal faults. Tectonics, 7(5):959-973.

Bulois, C., Pubellier, M., Chamot-Rooke, N., and Delescluse, M. (2017). Successive rifting events in marginal basins: the example of the Coral Sea region (Papua New Guinea). Tectonics, 37(1):3-29.

Burkett (2017). The geological evolution of the Kulumadau epithermal gold deposit, Woodlark Island, Papua New Guinea. PhD thesis, University of New South Wales.

Bustin, R. M., Ross, J. V., and Rouzaud, J. N. (1995). Mechanisms of graphite formation from kerogen: experimental evidence. International Journal of Coal Geology, 28(1):1-36.

Caffi, P. (2008). Evolution of an active metamorphic core complex, Suckling-Dayman Massif, eastern Papua New Guinea. BSc Honor's thesis, Macquarie University, Sydney, Australia.

Calk, L. C. and Naeser, C. W. (1973). The Thermal Effect of a Basalt Intrusion on Fission Tracks in Quartz Monzonite. The Journal of Geology, 81(2):189-198.

Cameron, M. L. (2014). Rifting and subduction in the Papuan Peninsula, Papua New Guinea: The significance of the Trobriand Trough, the Nubara strike-slip fault, and the Woodlark Rift to the present configuration of Papua New Guinea. PhD thesis, The University of Alabama, Tuscaloosa, Alabama. 
Campbell-Stone, E., John, B. E., Foster, D. A., Geissman, J. W., and Livaccari, R. F. (2000). Mechanisms for accommodation of Miocene extension: Low-angle normal faulting, magmatism, and secondary breakaway faulting in the southern Sacramento Mountains, southeastern California. Tectonics, 19(3):566-587.

Cantrell, C. A. (2008). Technical Note: review of methods for linear least-squares fitting of data and application to atmospheric chemistry problems. Atmos. Chem. Phys., 8:54775487.

Carlson, W. D., Donelick, R. A., and Ketcham, R. A. (1999). Variability of apatite fissiontrack annealing kinetics: I. Experimental results. American Mineralogist, 84(9):12131223.

Carter, T. J., Kohn, B. P., Foster, D. A., and Gleadow, A. J. (2004). How the Harcuvar Mountains metamorphic core complex became cool: Evidence from apatite (U-Th)/He thermochronometry. Geology, 32(11):985-988.

Carter, T. J., Kohn, B. P., Foster, D. A., Gleadow, A. J., and Woodhead, J. D. (2006). Latestage evolution of the Chemehuevi and Sacramento detachment faults from apatite (UTh)/He thermochronometry-Evidence for mid-Miocene accelerated slip. GSA Bulletin, 118(5-6):689-709.

Catalano, J. P. (2012). Geochemical and ${ }^{40} \mathrm{Ar} /{ }^{39} \mathrm{Ar}$ constraints on the evolution of volcanism in the Woodlark Rift, Papua New Guinea. Master's thesis, Syracuse University.

Chappell, B. W. and White, A. J. R. (1974). Two contrasting granite types. Pacific Geology, 8:173-174.

Chaproniere, G. C. H. (2009). Foraminiferal Biostratigraphy of Samples from the Adau Limestone, Ada'u River area, Mt Suckling, Papua New Guinea. Technical report.

Chen, W. T. and Zhou, M.-F. (2017). Hydrothermal alteration of magmatic zircon related to $\mathrm{NaCl}$-rich brines: Diffusion-reaction and dissolution-reprecipitation processes. American Journal of Science, 317:177-215.

Chmeleff, J., von Blanckenburg, F., Kossert, K., and Jakob, D. (2010). Determination of the ${ }^{10} \mathrm{Be}$ half-life by multicollector ICP-MS and liquid scintillation counting. Nuclear Instruments and Methods in Physics Research Section B: Beam Interactions with Materials and Atoms, 268(2):192-199.

Clarke, D. B., Dorais, M., Barbarin, B., Barker, D., Cesare, B., Clarke, G., El Baghdadi, M., Erdmann, S., Förster, H.-J., Gaeta, M., Gottesmann, B., Jamieson, R. A., Kontak, D. J., Koller, F., Leal Gomes, C., London, D., Morgan, VI, G. B., Neves, L. J. P. F., Pattison, D. R. M., Pereira, A. J. S. C., Pichavant, M., Rapela, C. W., Renno, A. D., Richards, S., 
Roberts, M., Rottura, A., Saavedra, J., Sial, A. N., Toselli, A. J., Ugidos, J. M., Uher, P., Villaseca, C., Visonà, D., Whitney, D. L., Williamson, B., and Woodard, H. H. (2005). Occurrence and Origin of Andalusite in Peraluminous Felsic Igneous Rocks. Journal of Petrology, 46(3):441-472.

Cloos, M., Sapiie, B., Quarles van Ufford, A., Weiland, R. J., Warren, P. Q., and McMahon, T. P. (2005). Collisional delamination in New Guinea: The geotectonics of subducting slab breakoff. In Cloos, M., Sapiie, B., Quarles van Ufford, A., Weiland, R. J., Warren, P. Q., and McMahon, T. P., editors, Collisional Delamination in New Guinea: The Geotectonics of Subducting Slab Breakoff, number 400 in Geological Society of America Special Paper, pages 1-51. Geological Society of America.

Cluzel, D., Aitchison, J. C., and Picard, C. (2001). Tectonic accretion and underplating of mafic terranes in the Late Eocene intraoceanic fore-arc of New Caledonia (Southwest Pacific): geodynamic implications. Tectonophysics, 340(1):23-59.

Coble, M. A., Burgess, S. D., and Klemetti, E. W. (2017). New zircon (U-Th)/He and $\mathrm{U} / \mathrm{Pb}$ eruption age for the Rockland tephra, western USA. Quaternary Science Reviews, 172:109-117.

Cohen, K. M., Finney, S. C., Gibbard, P. L., and Fan, J. (2013). The ICS International Chronostratigraphic Chart. Episodes, 36:199-204.

Collettini, C. (2011). The mechanical paradox of low-angle normal faults: Current understanding and open questions. Tectonophysics, 510(3):253-268.

Collettini, C. and Sibson, R. H. (2001). Normal faults, normal friction? Geology, 29(10):927-930.

Collins, W. J., Huang, H.-Q., and Jiang, X. (2016). Water-fluxed crustal melting produces Cordilleran batholiths. Geology, 44(2):143-146.

Coney, P. J. (1980). Cordilleran metamorphic core complexes: An overview. In Crittenden, Jr., M. D., Coney, P. J., and Davis, G. H., editors, Cordilleran Metamorphic Core Complexes, volume 153, pages 7-31. Geological Society of America.

Cooper, F. J., Platt, J. P., and Behr, W. M. (2017). Rheological transitions in the middle crust: insights from Cordilleran metamorphic core complexes. Solid Earth, 8:199-215.

Cooper, P. and Taylor, B. (1987). Seismotectonics of New Guinea: A model for arc reversal following arc-continent collision. Tectonics, 6(1):53-67.

Cooperdock, E. H. and Stockli, D. F. (2016). Unraveling alteration histories in serpentinites and associated ultramafic rocks with magnetite (U-Th)/He geochronology. Geology, 44(11):967-970. 
Corfu, F., Hanchar, J. M., Hoskin, P. W. O., and Kinny, P. (2003). Atlas of Zircon Textures. Reviews in Mineralogy and Geochemistry, 53(1):469-500.

Coyle, D. A. and Wagner, G. A. (1998). Positioning the titanite fission-track partial annealing zone. Chemical Geology, 149(1):117-125.

Crawford, A. J., Meffre, S., and Symonds, P. A. (2003). 120 to 0 Ma tectonic evolution of the southwest Pacific and analogous geological evolution of the 600 to 220 Ma Tasman Fold Belt System. In Evolution and dynamics of the Australian Plate, volume The Geological Society of America Special Paper of Geological Society of Australia Special Publication, pages 377-397.

Daczko, N. R., Caffi, P., Halpin, J. A., and Mann, P. (2009). Exhumation of the Dayman dome metamorphic core complex, eastern Papua New Guinea. Journal of Metamorphic Geology, 27(6):405-422.

Daczko, N. R., Caffi, P., and Mann, P. (2011). Structural evolution of the Dayman dome metamorphic core complex, eastern Papua New Guinea. GSA Bulletin, 123(11-12):23352351.

D'Addario, G. W., Dow, D. B., and Swoboda, R. (1976). Geology of Papua New Guinea, 1:2,500,000. Bureau of Mineral Resources, Geology and Geophysics.

Danišík, M., Schmitt, A. K., Stockli, D. F., Lovera, O. M., Dunkl, I., and Evans, N. J. (2017). Application of combined U-Th-disequilibrium/U-Pb and (U-Th)/He zircon dating to tephrochronology. Quaternary Geochronology, 40:23-32.

Davidson, J., Hassanzadeh, J., Berzins, R., Stockli, D. F., Bashukooh, B., Turrin, B., and Pandamouz, A. (2004). The geology of Damavand volcano, Alborz Mountains, northern Iran. GSA Bulletin, 116(1):16-29.

Davies, H. L. (1973). Fergusson Island - Papua New Guinea, Sheet SC/56-5 International Index.

Davies, H. L. (1980). Folded thrust fault and associated metamorphism in the SucklingDayman massif, Papua New Guinea. American Journal of Science, 280-A:171-191.

Davies, H. L. (2012). The geology of New Guinea-the cordilleran margin of the Australian continent. Episodes, 35:87-102.

Davies, H. L. and Jaques, A. L. (1984). Emplacement of ophiolite in Papua New Guinea. Geological Society, London, Special Publications, 13(1):341-349. 
Davies, H. L., Perembo, R. C. B., Winn, R. D., and KenGemar, P. (1997). Terranes of the New Guinea Orogen. In Hancock, G., editor, Proceedings of the PNG Geology, Exploration and Mining Conference, pages 61-66, Madang, Papua New Guinea. Australasian Institute of Mining and Metallurgy.

Davies, H. L. and Smith, I. E. M. (1971). Geology of Eastern Papua. GSA Bulletin, 82(12):3299-3312.

Davies, H. L. and Smith, I. E. M. (1974). Tufi-Cape Nelson - Papua New Guinea, Sheet SC/55-8,4 International Series.

Davies, H. L., Symonds, P. A., and Ripper, I. D. (1984). Structure and evolution of the southern Solomon Sea region. BMR Journal of Australian Geology \& Geophysics, 9:49_ 68 .

Davies, H. L. and Warren, R. G. (1988). Origin of eclogite-bearing, domed, layered metamorphic complexes (“core complexes") in the D'Entrecasteaux Islands, Papua New Guinea. Tectonics, 7(1):1-21.

Davies, H. L. and Warren, R. G. (1992). Eclogites of the D'Entrecasteaux Islands. Contributions to Mineralogy and Petrology, 112(4):463-474.

Davies, H. L. and Williamson, A. N. (1998). Buna - Papua New Guinea, Sheet SC/55-3 International Index.

DesOrmeau, J. W., Gordon, S. M., Little, T. A., and Bowring, S. A. (2014). Tracking the exhumation of a Pliocene (U)HP terrane: $\mathrm{U}-\mathrm{Pb}$ and trace-element constraints from zircon, D'Entrecasteaux Islands, Papua New Guinea. Geochemistry, Geophysics, Geosystems, 15(10):3945-3964.

DesOrmeau, J. W., Gordon, S. M., Little, T. A., Bowring, S. A., and Chatterjee, N. (2017). Rapid time scale of Earth's youngest known ultrahigh-pressure metamorphic event, Papua New Guinea. Geology, 45(9):795-798.

DesOrmeau, J. W., Gordon, S. M., Little, T. A., Bowring, S. A., Schoene, B., Samperton, K. M., and Kylander-Clark, A. R. C. (2018). Using eclogite retrogression to track the rapid exhumation of the Pliocene Papua New Guinea UHP terrane. Journal of Petrology, 59(10):2017-2042.

Dokka, R. K. (1993). Original dip and subsequent modification of a Cordilleran detachment fault, Mojave extensional belt, California. Geology, 21(8):711-714.

Dow, D. B. (1977). A geological synthesis of Papua New Guinea. Bur. Miner. Resour. Aust. Bull., 201:1-41. 
Dow, D. B., Smit, J. A. J., Bain, J. H. C., and Ryburn, R. J. (1972). Geology of the South Sepik Region, New Guinea. Technical Report 1972/133, Bureau of Mineral Resources, Geology and Geophysics, Canberra, Australia.

Dow, D. B., Smit, J. A. J., and Page, R. W. (1974). Wau - Papua New Guinea, Sheet SB/55-14 International Index.

Drummond, B. J., Collins, C. D. N., and Gibson, G. (1979). The crustal structure of the Gulf of Papua and northwest Coral Sea. BMR Journal of Australian Geology \& Geophysics, $4: 341-351$.

Dunai, T. J. (2010). Cosmogenic Nuclides: Principles, Concepts and Applications in the Earth Surface Sciences. Cambridge University Press, Cambridge.

Dunkl, I. (2002). Trackkey: a Windows program for calculation and graphical presentation of fission track data. Computers \& Geosciences, 28(1):3-12.

Ehlers, T. A. and Farley, K. A. (2003). Apatite (U-Th)/He thermochronometry: methods and applications to problems in tectonic and surface processes. Earth and Planetary Science Letters, 206(1):1-14.

Eilon, Z., Abers, G. A., Gaherty, J., and Jin, G. (2015). Imaging continental breakup using teleseismic body waves: The Woodlark Rift, Papua New Guinea. Geochemistry, Geophysics, Geosystems, 16(8):2529-2548.

Eilon, Z., Abers, G. A., Jin, G., and Gaherty, J. B. (2014). Anisotropy beneath a highly extended continental rift. Geochemistry, Geophysics, Geosystems, 15(3):545-564.

Ewart, A., Schon, R. W., and Chappell, B. W. (1992). The Cretaceous volcanicplutonic province of the central Queensland (Australia) coast—a rift related 'calc-alkaline' province. Earth and Environmental Science Transactions of the Royal Society of Edinburgh, 83(1-2):327-345.

Falvey, D. A. and Pritchard, T. (1982). Preliminary palaeomagnetic results from northern Papua New Guinea: evidence for large microplate rotations. In Transactions Third Circum-Pacific Energy and Mineral Resources Conference, pages 593-599, Hawaii.

Farley, K. A. (2002). (U-Th)/He Dating: Techniques, Calibrations, and Applications. Reviews in Mineralogy and Geochemistry, 47(1):819-844.

Farley, K. A., Kohn, B. P., and Pillans, B. (2002). The effects of secular disequilibrium on (U-Th)/He systematics and dating of Quaternary volcanic zircon and apatite. Earth and Planetary Science Letters, 201(1):117-125. 
Farley, K. A., Wolf, R. A., and Silver, L. T. (1996). The effects of long alpha-stopping distances on (U-Th)/He ages. Geochimica et Cosmochimica Acta, 60(21):4223-4229.

Fayon, A. K., Peacock, S. M., Stump, E., and Reynolds, S. J. (2000). Fission track analysis of the footwall of the Catalina detachment fault, Arizona: Tectonic denudation, magmatism, and erosion. Journal of Geophysical Research: Solid Earth, 105(B5):11047-11062.

Ferris, A., Abers, G. A., Zelt, B., Taylor, B., and Roecker, S. (2006). Crustal structure across the transition from rifting to spreading: the Woodlark rift system of Papua New Guinea. Geophysical Journal International, 166(2):622-634.

Finlayson, D. M., Drummond, B. J., Collins, C. D. M., and Connelly, J. B. (1977). Crustal structures in the region of the Papuan Ultramafic Belt. Physics of the Earth and Planetary Interiors, 14:13-29.

Finlayson, D. M., Muirhead, K. J., Webb, J. P., Gibson, G., Furumoto, A. S., Cooke, R. J. S., and Russell, A. J. (1976). Seismic Investigation of the Papuan Ultramafic Belt. Geophysical Journal International, 44(1):45-59.

Fitz, G. and Mann, P. (2013). Tectonic uplift mechanism of the Goodenough and Fergusson Island gneiss domes, eastern Papua New Guinea: Constraints from seismic reflection and well data. Geochemistry, Geophysics, Geosystems, 14(10):3969-3995.

Fitzgerald, P. G., Baldwin, S. L., Miller, S. R., Perry, S. E., Webb, L. E., and Little, T. A. (2008). Low-temperature constraints on the evolution of metamorphic core complexes of the Woodlark Rift system, southeastern Papua New Guinea. AGU Fall Meeting 2008, San Francisco, USA, Abstract T11B-1865.

Fitzgerald, P. G., Duebendorfer, E. M., Faulds, J. E., and O'Sullivan, P. (2009). South Virgin-White Hills detachment fault system of SE Nevada and NW Arizona: Applying apatite fission track thermochronology to constrain the tectonic evolution of a major continental detachment fault. Tectonics, 28(2):1-31.

Foster, D. A., Gleadow, A. J. W., Reynolds, S. J., and Fitzgerald, P. G. (1993). Denudation of metamorphic core complexes and the reconstruction of the transition zone, West central Arizona: Constraints from apatite fission track thermochronology. Journal of Geophysical Research: Solid Earth, 98(B2):2167-2185.

Foster, D. A. and John, B. E. (1999). Quantifying tectonic exhumation in an extensional orogen with thermochronology: examples from the southern Basin and Range Province. Geological Society, London, Special Publications, 154(1):343-364.

Foster, D. A., Miller, D. S., and Miller, C. F. (1991). Tertiary extension in the Old Woman Mountains Area, California: Evidence from apatite fission track analysis. Tectonics, 10(5):875-886. 
Francis, G. (1985). Stratigraphy of the Cape Vogel Basin. Technical Report 1985/4, Geological Survey of Papua New Guinea, Port Moresby.

Francis, G., Lock, J., and Okuda, Y. (1987). Seismic stratigraphy and structure of the area to the southeast of the Trobriand Platform. Geo-Marine Letters, 7(3):121-128.

Gaina, C. and Müller, D. (2007). Cenozoic tectonic and depth/age evolution of the Indonesian gateway and associated back-arc basins. Earth-Science Reviews, 83(3):177-203.

Gaina, C., Müller, D. R., Royer, J., and Symonds, P. (1999). Evolution of the Louisiade triple junction. Journal of Geophysical Research: Solid Earth, 104(B6):12927-12939.

Galbraith, R. F. (2005). Chapter 3: Track counts and densities: fission-track dating. In Statistics for fission-track analysis, page 240. Chapman and Hall/CRC, New York, USA, 1 edition.

Galbraith, R. F. and Laslett, G. M. (1993). Statistical models for mixed fission track ages. Nuclear Tracks and Radiation Measurements, 21(4):459-470.

Gans, P. B. and Gentry, B. J. (2016). Dike emplacement, footwall rotation, and the transition from magmatic to tectonic extension in the Whipple Mountains metamorphic core complex, southeastern California. Tectonics, 35(11):2564-2608.

Garcés, M. and Gee, J. S. (2007). Paleomagnetic evidence of large footwall rotations associated with low-angle faults at the Mid-Atlantic Ridge. Geology, 35(3):279-282.

Gardner, P. M. (1972). Hollow apatites in a layered basic intrusion, Norway. Geological Magazine, 109(5):385-392.

Garside, I. E. and Stoen, J. D. (1973). Goodenough No. 1 well completion report. Technical report, Amoco Australia Exploration Company, Sydney, Australia.

Gautheron, C., Tassan-Got, L., Ketcham, R. A., and Dobson, K. J. (2012). Accounting for long alpha-particle stopping distances in (U-Th-Sm)/He geochronology: 3D modeling of diffusion, zoning, implantation, and abrasion. Geochimica et Cosmochimica Acta, 96:4456.

Geological Survey of Papua New Guinea and British Geological Survey (2004). Gravity map of Papua New Guinea. Geological Survey of Papua New Guinea.

Gessner, K., Ring, U., Johnson, C., Hetzel, R., Passchier, C. W., and Güngör, T. (2001). An active bivergent rolling-hinge detachment system: Central Menderes metamorphic core complex in western Turkey. Geology, 29(7):611-614. 
Gill, J. B., Morris, J. D., and Johnson, R. W. (1993). Timescale for producing the geochemical signature of island arc magmas: U-Th-Po and Be-B systematics in recent Papua New Guinea lavas. Geochimica et Cosmochimica Acta, 57(17):4269-4283.

Glaessner, M. F. (1949). Mesozoic fossils from the Snake River, Central New Guinea. Queensland Mus. Mem., 12(4):165-180.

Gleadow, A. J. W., Hurford, A. J., and Quaife, R. D. (1976). Fission track dating of zircon: Improved etching techniques. Earth and Planetary Science Letters, 33(2):273-276.

Glen, R. A. and Meffre, S. (2009). Styles of Cenozoic collisions in the western and southwestern Pacific and their applications to Palaeozoic collisions in the Tasmanides of eastern Australia. Tectonophysics, 479(1):130-149.

Goodliffe, A. M., Martinez, F., Taylor, B., Lewis, T. J., Taylor, A. E., and Screaton, E. J. (2000). The geothermal signature of continental breakup: results from the Woodlark Basin. In Transactions of the American Geophysical Union, volume 81, page F1114.

Gordon, K. (2013). Detrital zircon provenance study, Mount Dayman, Papua New Guinea. Coursework for partial completion of Honours in Geology, Macquarie University, Sydney, Australia.

Gordon, S. M., Little, T. A., Hacker, B. R., Bowring, S. A., Korchinski, M., Baldwin, S. L., and Kylander-Clark, A. R. C. (2012). Multi-stage exhumation of young UHP-HP rocks: Timescales of melt crystallization in the D'Entrecasteaux Islands, southeastern Papua New Guinea. Earth and Planetary Science Letters, 351-352:237-246.

Govindaraju, K. (1994). 1994 compilation of working values and sample description for 383 geostandards. Geostandards Newsletter, 18:1-158.

Graham, I. T. (2009). Report for Kula Gold - unpublished report.

Granger, D. E. (2006). A review of burial dating methods using ${ }^{26} \mathrm{Al}$ and ${ }^{10} \mathrm{Be}$. In AlonsoZarza, A. M. and Tanner, L. H., editors, In Situ-Produced Cosmogenic Nuclides and Quantification of Geological Processes. Geological Society of America.

Granger, D. E. and Muzikar, P. F. (2001). Dating sediment burial with in situ-produced cosmogenic nuclides: theory, techniques, and limitations. Earth and Planetary Science Letters, 188(1):269-281.

Grimes, C. B., Wooden, J. L., Cheadle, M. J., and John, B. E. (2015). "Fingerprinting" tectono-magmatic provenance using trace elements in igneous zircon. Contributions to Mineralogy and Petrology, 170(5):46. 
Guenthner, W. R., Reiners, P. W., Ketcham, R. A., Nasdala, L., and Giester, G. (2013). Helium diffusion in natural zircon: Radiation damage, anisotropy, and the interpretation of zircon (U-Th)/He thermochronology. American Journal of Science, 313(3):145-198.

Hammarstrom, J. and Zen, E. (1986). Aluminum in hornblende: an empirical igneous geobarometer. American Mineralogist, 71(11-12):1297-1313.

Hanson, R. B. and Barton, M. D. (1989). Thermal development of low-pressure metamorphic belts: Results from two-dimensional numerical models. Journal of Geophysical Research: Solid Earth, 94(B8):10363-10377.

Hart, N. R., Stockli, D. F., and Hayman, N. W. (2016). Provenance evolution during progressive rifting and hyperextension using bedrock and detrital zircon U-Pb geochronology, Mauléon Basin, western Pyrenees. Geosphere, 12(4):1166-1186.

Hastie, A. R., Kerr, A. C., Pearce, J. A., and Mitchell, S. F. (2007). Classification of altered volcanic island arc rocks using immobile trace elements: development of the Th-Co discrimination diagram. Journal of Petrology, 48(12):2341-2357.

Hay, D. C. and Dempster, T. J. (2009). Zircon behaviour during low-temperature metamorphism. Journal of Petrology, 50(4):571-589.

Head, M. J., Aubry, M.-P., Walker, M., Miller, K. G., and Pratt, B. R. (2017). A case for formalizing subseries (subepochs) of the Cenozoic Era. Episodes, 40(1):22-27.

Hennig, J., Hall, R., Forster, M. A., Kohn, B. P., and Lister, G. S. (2017). Rapid cooling and exhumation as a consequence of extension and crustal thinning: Inferences from the Late Miocene to Pliocene Palu Metamorphic Complex, Sulawesi, Indonesia. Tectonophysics, 712-713:600-622.

Hiess, J., Condon, D. J., McLean, N., and Noble, S. R. (2012). ${ }^{238} \mathrm{U}^{235} \mathrm{U}$ systematics in terrestrial uranium-bearing minerals. Science, 335(6076):1610-1614.

Hill, K. C. and Gleadow, A. J. W. (1990). Apatite fission track analysis of the Papuan Basin. In Carman, G. J. and Carman, Z., editors, Petroleum Exploration and Development in Papua New Guinea: Proceedings of the First PNG Petroleum Convention, pages 119-136, Port Moresby, Papua New Guinea.

Hill, K. C. and Hall, R. (2003). Mesozoic-Cenozoic evolution of Australia's New Guinea margin in a west Pacific context. In Hillis, R. R. and Müller, R. D., editors, Evolution and dynamics of the Australian Plate, volume Geological Society of America Special Paper of Geological Society of Australia Special Publication, pages 265-290. 
Holland, T. and Blundy, J. (1994). Non-ideal interactions in calcic amphiboles and their bearing on amphibole-plagioclase thermometry. Contributions to Mineralogy and Petrology, 116(4):433-447.

Hollister, L. S., Grissom, G. C., Peters, E. K., Stowell, H. H., and Sisson, V. B. (1987). Confirmation of the empirical correlation of $\mathrm{Al}$ in hornblende with pressure of solidification of calc-alkaline pluton. American Mineralogist, 72:231-239.

Holm, D. K., Geissman, J. W., and Wernicke, B. (1993). Tilt and rotation of the footwall of a major normal fault system: Paleomagnetism of the Black Mountains, Death Valley extended terrane, California. GSA Bulletin, 105(10):1373-1387.

Holm, D. K., Snow, J. K., and Lux, D. R. (1992). Thermal and barometric constraints on the intrusive and unroofing history of the Black Mountains: Implications for timing, initial dip, and kinematics of detachment faulting in the Death Valley Region, California. Tectonics, 11(3):507-522.

Holm, R. J. and Poke, B. (2018). Petrology and crustal inheritance of the Cloudy Bay Volcanics as derived from a fluvial conglomerate, Papuan Peninsula (Papua New Guinea): An example of geological inquiry in the absence of in situ outcrop. Cogent Geoscience, 4(1):1450198.

Holm, R. J., Rosenbaum, G., and Richards, S. W. (2016). Post 8 Ma reconstruction of Papua New Guinea and Solomon Islands: Microplate tectonics in a convergent plate boundary setting. Earth-Science Reviews, 156:66-81.

Holm, R. J., Spandler, C., and Richards, S. W. (2013). Melanesian arc far-field response to collision of the Ontong Java Plateau: Geochronology and petrogenesis of the Simuku Igneous Complex, New Britain, Papua New Guinea. Tectonophysics, 603:189-212.

Holm, R. J., Spandler, C., and Richards, S. W. (2015). Continental collision, orogenesis and arc magmatism of the Miocene Maramuni arc, Papua New Guinea. Gondwana Research, 28(3):1117-1136.

Holm, R. J., Tapster, S., Jelsma, H. A., Rosenbaum, G., and Mark, D. F. (2019). Tectonic evolution and copper-gold metallogenesis of the Papua New Guinea and Solomon Islands region. Ore Geology Reviews, 104:208-226.

Hopkins, J. L. and Seward, D. (2019). Towards robust tephra correlations in early and pre-Quaternary sediments: A case study from North Island, New Zealand. Quaternary Geochronology, 50:91-108.

Horstwood, M. S. A., Košler, J., Gehrels, G., Jackson, S. E., McLean, N. M., Paton, C., Pearson, N. J., Sircombe, K., Sylvester, P., Vermeesch, P., Bowring, J. F., Condon, 
D. J., and Schoene, B. (2016). Community-derived standards for LA-ICP-MS U-(Th-)Pb geochronology - uncertainty propagation, age interpretation and data reporting. Geostandards and Geoanalytical Research, 40(3):311-332.

Hourigan, J. K., Reiners, P. W., and Brandon, M. T. (2005). U-Th zonation-dependent alphaejection in (U-Th)/He chronometry. Geochimica et Cosmochimica Acta, 69(13):3349_ 3365 .

House, M. A., Wernicke, B. P., and Farley, K. A. (1998). Dating topography of the Sierra Nevada, California, using apatite (U-Th)/He ages. Nature, 396(6706):66-69.

Howard, K. A. and Foster, D. A. (1996). Thermal and unroofing history of a thick, tilted Basin-and-Range crustal section in the Tortilla Mountains, Arizona. Journal of Geophysical Research: Solid Earth, 101(B1):511-522.

Hu, Z., Zhang, W., Liu, Y., Chen, H., Gaschnig, R. M., Zong, K., Li, M., Gao, S., and Hu, S. (2013). Rapid bulk rock decomposition by ammonium fluoride $\left(\mathrm{NH}_{4} \mathrm{~F}\right)$ in open vessels at an elevated digestion temperature. Chemical Geology, 355:144-152.

Hurford, A. J. and Green, P. F. (1983). The zeta age calibration of fission-track dating. Chemical Geology, 41:285-317.

Ito, H., Nanayama, F., and Nakazato, H. (2017a). Zircon U-Pb dating using LA-ICP-MS: Quaternary tephras in Boso Peninsula, Japan. Quaternary Geochronology, 40:12-22.

Ito, H., Spencer, C. J., Danišík, M., and Hoiland, C. W. (2017b). Magmatic tempo of Earth's youngest exposed plutons as revealed by detrital zircon U-Pb geochronology. Scientific Reports, 7(1):12457.

Jackson, J. A. and White, N. J. (1989). Normal faulting in the upper continental crust: observations from regions of active extension. Journal of Structural Geology, 11(1):1536.

Jackson, S. E., Pearson, N. J., Griffin, W. L., and Belousova, E. A. (2004). The application of laser ablation-inductively coupled plasma-mass spectrometry to in situ $\mathrm{U}-\mathrm{Pb}$ zircon geochronology. Chemical Geology, 211(1):47-69.

Jaeger, J. C. (1964). Thermal effects of intrusions. Reviews of Geophysics, 2(3):443-466.

Jaffey, A. H., Flynn, K. F., Glendenin, L. E., Bentley, W. C., and Essling, A. M. (1971). Precision measurement of half-lives and specific activities of ${ }^{235} \mathrm{U}$ and ${ }^{238} \mathrm{U}$. Physical Review C, 4(5):1889-1906.

Jakeš, P. and Gill, J. (1970). Rare earth elements and the island arc tholeiitic series. Earth and Planetary Science Letters, 9(1):17-28. 
Jaques, A. L. and Chappell, B. W. (1980). Petrology and trace element geochemistry of the Papuan Ultramafic Belt. Contributions to Mineralogy and Petrology, 75(1):55-70.

Jin, G., Gaherty, J. B., Abers, G. A., Kim, Y., Eilon, Z., and Buck, R. W. (2015). Crust and upper mantle structure associated with extension in the Woodlark Rift, Papua New Guinea from Rayleigh-wave tomography. Geochemistry, Geophysics, Geosystems, 16(11):38083824.

Jochum, K. P., Nohl, U., Herwig, K., Lammel, E., Stoll, B., and Hofmann, A. W. (2005). GeoReM: A New Geochemical Database for Reference Materials and Isotopic Standards. Geostandards and Geoanalytical Research, 29(3):333-338.

John, B. E. and Foster, D. A. (1993). Structural and thermal constraints on the initiation angle of detachment faulting in the southern Basin and Range: The Chemehuevi Mountains case study. GSA Bulletin, 105(8):1091-1108.

Johnson, M. C. and Rutherford, M. J. (1989). Experimental calibration of the aluminumin-hornblende geobarometer with application to Long Valley caldera (California) volcanic rocks. Geology, 17(9):837-841.

Johnson, R. W., Mackenzie, D. E., and Smith, I. E. M. (1978). Delayed partial melting of subduction-modified mantle in Papua New Guinea. Tectonophysics, 46(1):197-216.

Jones, M. T., Augland, L. E., Shephard, G. E., Burgess, S. D., Eliassen, G. T., Jochmann, M. M., Friis, B., Jerram, D. A., Planke, S., and Svensen, H. H. (2017). Constraining shifts in North Atlantic plate motions during the Palaeocene by U-Pb dating of Svalbard tephra layers. Scientific Reports, 7(1):6822.

Joseph, L. E. and Finlayson, E. J. (1991). A revised stratigraphy of Muyua (Woodlark Island). Technical Report 1991/3, Geological Survey of Papua New Guinea, Port Moresby, Papua New Guinea.

Joshima, M. and Honza, E. (1986). Age estimation of the Solomon Sea based on heat flow data. Geo-Marine Letters, 6(4):211-217.

Joshima, M., Okuda, Y., Murakami, F., Kishimoto, K., and Honza, E. (1986). Age of the Solomon Sea Basin from magnetic lineations. Geo-Marine Letters, 6(4):229-234.

Kapp, P., Stockli, D., Taylor, M., and Ding, L. (2008). Development of active low-angle normal fault systems during orogenic collapse: Insight from Tibet. Geology, 36(1):7-10.

Kennedy, A. K., Wotzlaw, J.-F., Schaltegger, U., Crowley, J. L., and Schmitz, M. (2014). Eocene zircon reference material for microanalysis of $\mathrm{U}-\mathrm{Th}-\mathrm{Pb}$ isotopes and trace elements. The Canadian Mineralogist, 52(3):409-421. 
Ketcham, R. A. (1996). Thermal models of core-complex evolution in Arizona and New Guinea: Implications for ancient cooling paths and present-day heat flow. Tectonics, 15(5):933-951.

Kirilova, M., Toy, V., Rooney, J., Giorgetti, C., Gordon, K., Collettini, C., and Takeshita, T. (2018). Structural disorder of graphite and implications for graphite thermometry. Solid Earth, 9(1):223-231.

Knesel, K. M., Cohen, B. E., Vasconcelos, P. M., and Thiede, D. S. (2008). Rapid change in drift of the Australian plate records collision with Ontong Java plateau. Nature, 454(454):754-757.

Kopi, G., Findlay, R. H., and Williams, I. (2004). Age and provenance of the Owen Stanley Metamorphic Complex, East Papuan Composite Terrane, Papua New Guinea. Technical report, Geological Survey of Papua New Guinea (unpublished report), Port Moresby, Papua New Guinea.

Korchinski, M. S., Vry, J., Little, T. A., Millet, M.-A., Bicknell, R., Smith, E., and Handt, A. (2014). Timing of UHP exhumation and rock fabric development in gneiss domes containing the world's youngest eclogite facies rocks, southeastern Papua New Guinea. Journal of Metamorphic Geology, 32(9):1019-1039.

Korschinek, G., Bergmaier, A., Faestermann, T., Gerstmann, U. C., Knie, K., Rugel, G., Wallner, A., Dillmann, I., Dollinger, G., von Gostomski, C. L., Kossert, K., Maiti, M., Poutivtsev, M., and Remmert, A. (2010). A new value for the half-life of ${ }^{10}$ Be by HeavyIon Elastic Recoil Detection and liquid scintillation counting. Nuclear Instruments and Methods in Physics Research Section B: Beam Interactions with Materials and Atoms, 268(2):187-191.

Kouketsu, Y., Mizukami, T., Mori, H., Endo, S., Aoya, M., Hara, H., Nakamura, D., and Wallis, S. (2014). A new approach to develop the Raman carbonaceous material geothermometer for low-grade metamorphism using peak width. Island Arc, 23(1):33-50.

Lackschewitz, K., Bogaard, P., and Mertz, D. (2001). ${ }^{40} \mathrm{Ar} /{ }^{39} \mathrm{Ar}$ ages of fallout tephra layers and volcaniclastic deposits in the sedimentary succession of the western Woodlark Basin, Papua New Guinea: the marine record of Miocene-Pleistocene volcanism. Geological Society, London, Special Publications, 187(1):373.

Lackschewitz, K., Mertz, D., Devey, C., and Garbe-Schönberg, C.-D. (2003). Late Cenozoic volcanism in the western Woodlark Basin area, SW Pacific: the sources of marine volcanic ash layers based on their elemental and $\mathrm{Sr}-\mathrm{Nd}$ isotope compositions. Bulletin of Volcanology, 65(2):182-200. 
Lahfid, A., Beyssac, O., Deville, E., Negro, F., Chopin, C., and Goffé, B. (2010). Evolution of the Raman spectrum of carbonaceous material in low-grade metasediments of the Glarus Alps (Switzerland). Terra Nova, 22(5):354-360.

Lancaster, P. J., Strachan, R. A., Bullen, D., Fowler, M., Jaramillo, M., and Saldarriaga, A. M. (2017). U-Pb zircon geochronology and geodynamic significance of 'Newer Granite' plutons in Shetland, northernmost Scottish Caledonides. Journal of the Geological Society, 174(3):486-497.

Laslett, G. M., Green, P. F., Duddy, I. R., and Gleadow, A. J. W. (1987). Thermal annealing of fission tracks in apatite 2. A quantitative analysis. Chemical Geology: Isotope Geoscience section, 65(1):1-13.

Latter, J. H. (1964). Explanatory notes to accompany a geological sketch map of part of the Western Daga Ranges, Papua. Technical Report 113, Bureau of Mineral Resources, Geology and Geophysics, Canberra, Australia.

Le Maitre, R. W., Streckeisen, A., Zanettin, B., Le Bas, M. J., Bonin, B., and Bateman, P., editors (2002). Igneous Rocks: A Classification and Glossary of Terms: Recommendations of the International Union of Geological Sciences Subcommission on the Systematics of Igneous Rocks. Cambridge University Press, Cambridge, 2 edition.

Leake, B., Woolley, A., Arps, C. E. S., Birch, W. D., Gilbert, M. C., Grice, J. D., Hawthorne, F. C., Kato, A., Kisch, H. J., Krivovichev, V. G., Linthout, K., Laird, J., and Mandarino, J. (1997). Nomenclature of Amphiboles: Report of the Subcommittee on Amphiboles of the International Mineralogical Association Commission on New Minerals and Mineral Names. Mineralogical Magazine, 61(2):295-321.

Lee, J. (1995). Rapid uplift and rotation of mylonitic rocks from beneath a detachment fault: Insights from potassium feldspar ${ }^{40} \mathrm{Ar} /{ }^{39} \mathrm{Ar}$ thermochronology, northern Snake Range, Nevada. Tectonics, 14(1):54-77.

Lindley, I. D. (2014). Suckling Dome and the Australian-Woodlark plate boundary in eastern Papua: the geology of the Keveri and Ada'u Valleys. Australian Journal of Earth Sciences, 61(8):1125-1147.

Lissenberg, C. J., Rioux, M., Shimizu, N., Bowring, S. A., and Mével, C. (2009). Zircon dating of oceanic crustal accretion. Science, 323(5917):1048-1050.

Lister, G. S. and Davis, G. A. (1989). The origin of metamorphic core complexes and detachment faults formed during Tertiary continental extension in the northern Colorado River region, U.S.A. Journal of Structural Geology, 11(1):65-94. 
Little, T. A., Baldwin, S. L., Fitzgerald, P. G., and Monteleone, B. D. (2007). Continental rifting and metamorphic core complex formation ahead of the Woodlark spreading ridge, D’Entrecasteaux Islands, Papua New Guinea. Tectonics, 26(1):1-26.

Little, T. A., Hacker, B. R., Gordon, S. M., Baldwin, S. L., Fitzgerald, P. G., Ellis, S., and Korchinski, M. (2011). Diapiric exhumation of Earth's youngest (UHP) eclogites in the gneiss domes of the D'Entrecasteaux Islands, Papua New Guinea. Tectonophysics, 510(1):39-68.

Little, T. A., Webber, S., Mizera, M., Boulton, C., Oesterle, J., Ellis, S., Boles, A., van der Pluijm, B., Norton, K., Seward, D., Biemiller, J., and Wallace, L. M. (2019). Evolution of a rapidly slipping, active low-angle normal fault, Suckling-Dayman Metamorphic Core Complex, SE Papua New Guinea. GSA Bulletin.

Livaccari, R. F. and Geissman, J. W. (2001). Large-magnitude extension along metamorphic core complexes of western Arizona and southeastern California: Evaluation with paleomagnetism. Tectonics, 20(5):625-648.

Lünsdorf, N. K., Dunkl, I., Schmidt, B. C., Rantitsch, G., and von Eynatten, H. (2017). Towards a Higher Comparability of Geothermometric Data Obtained by Raman Spectroscopy of Carbonaceous Material. Part 2: A Revised Geothermometer. Geostandards and Geoanalytical Research, 41(4):593-612.

Ludwig, K. R. (2009). Isoplot v. 4 for Excel 2007.

Lus, W. Y., McDougall, I., and Davies, H. L. (2004). Age of the metamorphic sole of the Papuan Ultramafic Belt ophiolite, Papua New Guinea. Tectonophysics, 392(1):85-101.

MacLeod, C. J., Carlut, J., Escartín, J., Horen, H., and Morris, A. (2011). Quantitative constraint on footwall rotations at the $15^{\circ} 45^{\prime} \mathrm{N}$ oceanic core complex, Mid-Atlantic Ridge: Implications for oceanic detachment fault processes. Geochemistry, Geophysics, Geosystems, 12(5):1-29.

Macnab, R. P. (1969). Geology of the Aroa - upper Dilava - Auga - Middle Angabunga Rivers area, Papua. Technical Report 69/126, Bureau of Mineral Resources, Geology and Geophysics, Canberra, Australia.

Mancktelow, N. S. and Grasemann, B. (1997). Time-dependent effects of heat advection and topography on cooling histories during erosion. Tectonophysics, 270(3):167-195.

Marsh, J. H. and Stockli, D. F. (2015). Zircon U-Pb and trace element zoning characteristics in an anatectic granulite domain: Insights from LASS-ICP-MS depth profiling. Lithos, 239:170-185. 
Martinez, F., Goodliffe, A. M., and Taylor, B. (2001). Metamorphic core complex formation by density inversion and lower-crust extrusion. Nature, 411:930-934.

Mason, C. C., Romans, B. W., Stockli, D. F., Mapes, R. W., and Fildani, A. (2019). Detrital zircons reveal sea-level and hydroclimate controls on Amazon River to deep-sea fan sediment transfer. Geology, 47(6):563-567.

Matthews, N. E., Vazquez, J. A., and Calvert, A. T. (2015). Age of the Lava Creek supereruption and magma chamber assembly at Yellowstone based on ${ }^{40} \mathrm{Ar} /{ }^{39} \mathrm{Ar}$ and $\mathrm{U}-\mathrm{Pb}$ dating of sanidine and zircon crystals. Geochemistry, Geophysics, Geosystems, 16(8):2508-2528.

McCallister, A. T., Taylor, M. H., Murphy, M. A., Styron, R. H., and Stockli, D. F. (2013). Thermochronologic constraints on the late Cenozoic exhumation history of the Gurla Mandhata metamorphic core complex, Southwestern Tibet. Tectonics, 33(2):27-52.

McDougall, I. and Harrison, T. M. (1999). Geochronology and Thermochronology by the ${ }^{40} \mathrm{Ar}{ }^{\beta 9} \mathrm{Ar}$ method. Oxford University Press, New York, USA.

McGrew, A. J. and Snee, L. W. (1994). ${ }^{40} \mathrm{Ar} /{ }^{39} \mathrm{Ar}$ thermochronologic constraints on the tectonothermal evolution of the Northern East Humboldt range metamorphic core complex, Nevada. Tectonophysics, 238(1):425-450.

Meier, K., Spiegel, C., Monien, P., Klügel, A., and Kolb, V. (2018). Deformation-induced solution-precipitation as a potential non-thermal process affecting the apatite (U-Th)/He system. In Conference Abstracts, page 139, Quedlinburg, Germany.

Miller, E. L., Dumitru, T. A., Brown, R. W., and Gans, P. B. (1999). Rapid Miocene slip on the Snake Range-Deep Creek Range fault system, east-central Nevada. GSA Bulletin, 111(6):886-905.

Miller, J. S., Matzel, J. E. P., Miller, C. F., Burgess, S. D., and Miller, R. B. (2007). Zircon growth and recycling during the assembly of large, composite arc plutons. Journal of Volcanology and Geothermal Research, 167(1):282-299.

Milsom, J. (1973). The gravity field of the Papuan Peninsula. Geologie en Mijnbouw, 52(1):13-20.

Min, K., Renne, P. R., and Huff, W. D. (2001). ${ }^{40} \mathrm{Ar} /{ }^{39} \mathrm{Ar}$ dating of Ordovician K-bentonites in Laurentia and Baltoscandia. Earth and Planetary Science Letters, 185(1):121-134.

Mizera, M., Little, T. A., Biemiller, J., Ellis, S., Webber, S., and Norton, K. (2019). Structural and gemorphic evidence for rolling-hinge style deformation of an active continental lowangle normal fault, SE Papua New Guinea. Tectonics, 38. 
Möller, A., O’Brien, P. J., Kennedy, A., and Kröner, A. (2002). Polyphase zircon in ultrahightemperature granulites (Rogaland, SW Norway): constraints for $\mathrm{Pb}$ diffusion in zircon. Journal of Metamorphic Geology, 20(8):727-740.

Moecher, D. P. and Samson, S. D. (2006). Differential zircon fertility of source terranes and natural bias in the detrital zircon record: Implications for sedimentary provenance analysis. Earth and Planetary Science Letters, 247(3):252-266.

Monteleone, B. (2007). Timing and conditions of formation of the D'Entrecasteaux Islands, southeastern Papua New Guinea. PhD thesis, Syracuse University.

Monteleone, B., Baldwin, S. L., Ireland, R., T., and Fitzgerald, P. G. (2001). Thermochronological constraints for the tectonic evolution of the Moresby Seamount, Woodlark Basin, Papua New Guinea. In Huchon, P., Taylor, B., and Klaus, A., editors, Proceedings of the Ocean Drilling Program, volume 180 of Scientific Results, pages 1-35. US Govermint Printing Office, Washington DC.

Morgan, L. E. and Renne, P. R. (2008). Diachronous dawn of Africa's Middle Stone age: New ${ }^{40} \mathrm{Ar} /{ }^{39} \mathrm{Ar}$ ages from the Ethiopian Rift. Geology, 36(12):967-970.

Morris, A., Gee, J. S., Pressling, N., John, B. E., MacLeod, C. J., Grimes, C. B., and Searle, R. C. (2009). Footwall rotation in an oceanic core complex quantified using reoriented Integrated Ocean Drilling Program core samples. Earth and Planetary Science Letters, 287(1):217-228.

Morrison, G. W. (1980). Characteristics and tectonic setting of the shoshonite rock association. Lithos, 13(1):97-108.

Mucek, A. E., Danišík, M., de Silva, S. L., Schmitt, A. K., Pratomo, I., and Coble, M. A. (2017). Post-supereruption recovery at Toba Caldera. Nature Communications, 8:15248.

Murphy, M., Yin, A., Kapp, P., Harrison, T., Manning, C., Ryerson, F., Lin, D., and Jinghui, G. (2002). Structural evolution of the Gurla Mandhata detachment system, southwest Tibet: Implications for the eastward extent of the Karakoram fault system. GSA Bulletin, 114(4):428-447.

Murray, K. E., Orme, D. A., and Reiners, P. W. (2014). Effects of U-Th-rich grain boundary phases on apatite helium ages. Chemical Geology, 390:135-151.

Mutch, E. J. F., Blundy, J. D., Tattitch, B. C., Cooper, F. J., and Brooker, R. A. (2016). An experimental study of amphibole stability in low-pressure granitic magmas and a revised Al-in-hornblende geobarometer. Contributions to Mineralogy and Petrology, 171(10):85. 
Nakamura, Y., Oohashi, K., Toyoshima, T., Satish-Kumar, M., and Akai, J. (2015). Strain-induced amorphization of graphite in fault zones of the Hidaka metamorphic belt, Hokkaido, Japan. Journal of Structural Geology, 72:142-161.

National Center for Atmospheric Research Staff (2019). The climate data guide: Global surface temperature data: HadCRUT4 and CRUTEM4. https://climatedataguide.ucar.edu/climate-data/global-surface-temperature-data-hadcrut4and-crutem4. Last accessed: 11.03.2019.

Nion, S. T. S., Rogerson, R., Griffin, T. J., and Arnold, G. O. (1987). Introduction to the geology of the Uyaknji Complex, Papua New Guinea. Technical Report 87/20, Geological Survey of Papua New Guinea.

Nishiizumi, K., Hillegonds, D. J., McHargue, L. R., and Jull, A. J. T. (2004). Exposure and terrestrial histories of new lunar and martian meteorites. In Proceedings of the 35th Lunar and Planetary Science Conference, Houston, USA.

Norton, K. P., von Blanckenburg, F., Schlunegger, F., Schwab, M., and Kubik, P. W. (2008). Cosmogenic nuclide-based investigation of spatial erosion and hillslope channel coupling in the transient foreland of the Swiss Alps. Geomorphology, 95(3):474-486.

Ollier, C. D. and Pain, C. F. (1981). Active gneiss domes in Papua New Guinea: New tectonic landforms. Zeitschrift für Geomorphologie, 25(2):133-145.

Ott, B. and Mann, P. (2015). Late Miocene to Recent formation of the Aure-Moresby foldthrust belt and foreland basin as a consequence of Woodlark microplate rotation, Papua New Guinea. Geochemistry, Geophysics, Geosystems, 16(6):1988-2004.

Page, R. W. (1976). Geochronology of igneous and metamorphic rocks in the New Guinea Highlands. Bull. Aust. Bur. Mineral Resour., 162:125.

Passchier, C. W. and Trouw, R. A. (2005). Microstructures. Springer Berlin Heidelberg, 2 edition.

Paton, C., Hellstrom, J., Paul, B., Woodhead, J., and Hergt, J. (2011). Iolite: Freeware for the visualisation and processing of mass spectrometric data. J. Anal. At. Spectrom., 26:2508-2518.

Pearce, J. A. (2008). Geochemical fingerprinting of oceanic basalts with applications to ophiolite classification and the search for Archean oceanic crust. Lithos, 100(1):14-48.

Pearce, J. A., Harris, N. B. W., and Tindle, A. G. (1984). Trace element discrimination diagrams for the tectonic interpretation of granitic rocks. Journal of Petrology, 25(4):956983. 
Pearce, J. A. and Parkinson, I. J. (1993). Trace element models for mantle melting: application to volcanic arc petrogenesis. Geological Society, London, Special Publications, 76(1):373.

Pearce, N. J., Perkins, W. T., Westgate, J. A., Gorton, M. P., Jackson, S. E., Neal, C. R., and Chenery, S. P. (1997). A compilation of new and published major and trace element data for NIST SRM 610 and NIST SRM 612 glass reference materials. Geostandards Newsletter, 21(1):115-144.

Pearson, P. N., Wade, B. S., Backman, J., Raffi, I., and Monechi, S. (2017). Sub-series and sub-epochs are informal units and should continue to be omitted from the International Chronostratigraphic Chart. Episodes, 40(1):5-7.

Pease, V., Foster, D., Wooden, J., O’Sullivan, P., Argent, J., and Fanning, C. (1999). The Northern Sacramento Mountains, southwest United States. Part II: Exhumation history and detachment faulting. Geological Society, London, Special Publications, 164(1):199_ 238.

Peccerillo, A. and Taylor, S. R. (1976). Geochemistry of eocene calc-alkaline volcanic rocks from the Kastamonu area, Northern Turkey. Contributions to Mineralogy and Petrology, 58(1):63-81.

Peters, K. J. (2007). Tectonic evolution of a metamorphic core complex on Misima Island and implications for the history of continental extension in the Woodlark Rift, southeastern Papua New Guinea. Master of Science, Victoria University of Wellington, Wellington, New Zealand.

Petersen, K. D. and Buck, R. W. (2015). Eduction, extension, and exhumation of ultrahighpressure rocks in metamorphic core complexes due to subduction initiation. Geochemistry, Geophysics, Geosystems, 16(8):2564-2581.

Petrus, J. A. and Kamber, B. S. (2012). VizualAge: A novel approach to laser ablation ICP-MS U-Pb geochronology data reduction. Geostandards and Geoanalytical Research, 36(3):247-270.

Pieters, P. E. (1978). Port Moresby-Kalo-Aroa - Papua New Guinea, Sheets SC/55-6, 7 and 11 International Index.

Platt, J. P., Behr, W. M., and Cooper, F. J. (2015). Metamorphic core complexes: windows into the mechanics and rheology of the crust. Journal of the Geological Society, 172(1):927. 
Poli, S. and Schmidt, M. W. (1992). A comment on "Calcic amphibole equilibria and a new amphibole - plagioclase geothermometer" by J.D. Blundy and T.J.B. Holland (Contrib Mineral Petrol (1990) 104: 208-224). Contributions to Mineralogy and Petrology, 111(2):273-278.

Prior, M. G., Stockli, D. F., and Singleton, J. S. (2016). Miocene slip history of the Eagle Eye detachment fault, Harquahala Mountains metamorphic core complex, west-central Arizona. Tectonics, 35(8):1913-1934.

Rahl, J. M., Anderson, K. M., Brandon, M. T., and Fassoulas, C. (2005). Raman spectroscopic carbonaceous material thermometry of low-grade metamorphic rocks: Calibration and application to tectonic exhumation in Crete, Greece. Earth and Planetary Science Letters, 240(2):339-354.

Rahn, M. K., Brandon, M. T., Batt, G. E., and Garver, J. I. (2004). A zero-damage model for fission-track annealing in zircon. American Mineralogist, 89(4):473-484.

Reiners, P. W. (2005). Zircon (U-Th)/He Thermochronometry. Reviews in Mineralogy and Geochemistry, 58(1):151-179.

Richard, S. M., Fryxell, J. E., and Sutter, J. F. (1990). Tertiary structure and thermal history of the Harquahala and Buckskin Mountains, west central Arizona: Implications for denudation by a major detachment fault system. Journal of Geophysical Research: Solid Earth, 95(B12):19973-19987.

Ridolfi, F., Renzulli, A., and Puerini, M. (2010). Stability and chemical equilibrium of amphibole in calc-alkaline magmas: an overview, new thermobarometric formulations and application to subduction-related volcanoes. Contributions to Mineralogy and Petrology, 160(1):45-66.

Rioux, M., Johan Lissenberg, C., McLean, N. M., Bowring, S. A., MacLeod, C. J., Hellebrand, E., and Shimizu, N. (2012). Protracted timescales of lower crustal growth at the fast-spreading East Pacific Rise. Nature Geoscience, 5:275-278.

Robinson, A. C., Yin, A., and Lovera, O. M. (2010). The role of footwall deformation and denudation in controlling cooling age patterns of detachment systems: An application to the Kongur Shan extensional system in the Eastern Pamir, China. Tectonophysics, 496(1):28-43.

Rogerson, R., Queen, L., and Francis, G. (1993). The Papuan Ultramafic Belt Arc Complex. In Wheller, G., editor, Islands and basins: correlation and comparison of onshore and offshore geology, pages 28-29. CCOP/SOPAC Miscellaneous Report. 
Rogerson, R., Williamson, A., and Francis, G. (1986). Recent advances in the knowledge of geology, energy resources and metallogenesis of Papua New Guinea since 1981. In GEOSEA V Proceedings Vol . II, Geol. Soc. Malaysia Bulletin, volume 20, pages 23-37.

Rogerson, R. J. and Hilyard, D. B. (1989). Scrapland: A suspect composite Terrane in Papua New Guinea. Technical Report 1989/11, Geological Survey of Papua New Guinea.

Rogerson, R. J., Queen, L., Joseph, L., Lloyd, A., Webb, A., and Booth, G. (1991). New stratigraphic and whole-rock geochemical data from the Waria river area, northern Papuan Peninsula. Technical Report 1991/7, Geological Survey of Papua New Guinea.

Rooney, J. S., Tarling, M. S., Smith, S. A., and Gordon, K. C. (2018). Submicron raman spectroscopy mapping of serpentinite fault rocks. Journal of Raman Spectroscopy, 49(2):279_ 286.

Rubatto, D., Gebauer, D., and Fanning, M. (1998). Jurassic formation and Eocene subduction of the Zermatt-Saas-Fee ophiolites: implications for the geodynamic evolution of the Central and Western Alps. Contributions to Mineralogy and Petrology, 132(3):269-287.

Ruprecht, P., Plank, T. A., Jin, G., and Abers, G. A. (2013). Rifting and UHP exhumation in Eastern Papua New Guinea: Temperature and pressure constraints from primitive magmas. AGU Fall Meeting 2013, San Francisco, USA, Abstract T21B-2559R.

Ruxton, B. P. (1966). Correlation and stratigraphy of dacitic ash-fall layers in northeastern Papua. Journal of the Geological Society of Australia, 13(1):41-67.

Ruxton, B. P. (1999). The Managalase volcanic field and associated mineral occurrences, Papua New Guinea. In Pacific Rim Congress 99, pages 335-340.

Ruxton, B. P. and McDougall, I. (1967). Denudation rates in northeast Papua from potassium-argon dating of lavas. American Journal of Science, 265(7):545-561.

Sambridge, M. S. and Compston, W. (1994). Mixture modeling of multi-component data sets with application to ion-probe zircon ages. Earth and Planetary Science Letters, 128(3):373-390.

Sano, Y., Tsutsumi, Y., Terada, K., and Kaneoka, I. (2002). Ion microprobe U-Pb dating of Quaternary zircon: implication for magma cooling and residence time. Journal of Volcanology and Geothermal Research, 117(3):285-296.

Schaltegger, U. and Davies, J. H. F. L. (2017). Petrochronology of zircon and baddeleyite in igneous rocks: Reconstructing magmatic processes at high temporal resolution. Reviews in Mineralogy and Geochemistry, 83(1):297-328. 
Schellart, W. P., Lister, G. S., and Toy, V. G. (2006). A Late Cretaceous and Cenozoic reconstruction of the Southwest Pacific region: Tectonics controlled by subduction and slab rollback processes. Earth-Science Reviews, 76(3):191-233.

Schmidt, M. W. (1992). Amphibole composition in tonalite as a function of pressure: an experimental calibration of the Al-in-hornblende barometer. Contributions to Mineralogy and Petrology, 110(2):304-310.

Schmitt, A. K., Stockli, D. F., Niedermann, S., Lovera, O. M., and Hausback, B. P. (2010). Eruption ages of Las Tres Vírgenes volcano (Baja California): A tale of two helium isotopes. Quaternary Geochronology, 5(5):503-511.

Schoene, B. (2014). 4.10 - U-Th-Pb Geochronology. In Holland, H. D. and Turekian, K. K., editors, Treatise on Geochemistry (Second Edition), pages 341-378. Elsevier, Oxford.

Schärer, U. (1984). The effect of initial ${ }^{230} \mathrm{Th}$ disequilibrium on young U-Pb ages: the Makalu case, Himalaya. Earth and Planetary Science Letters, 67(2):191-204.

Seton, M., Mortimer, N., Williams, S., Quilty, P., Gans, P., Meffre, S., Micklethwaite, S., Zahirovic, S., Moore, J., and Matthews, K. J. (2016). Melanesian back-arc basin and arc development: Constraints from the eastern Coral Sea. Gondwana Research, 39:77-95.

Seward, D., Vanderhaeghe, O., Siebenaller, L., Thomson, S., Hibsch, C., Zingg, A., Holzner, P., Ring, U., and Duchêne, S. (2009). Cenozoic tectonic evolution of Naxos Island through a multi-faceted approach of fission-track analysis. Geological Society, London, Special Publications, 321(1):179-196.

Shand, S. J. (1947). The eruptive rocks. John Wiley \& Sons, New York, USA, 3rd edition.

Sharp, W. D. and Clague, D. A. (2006). 50-Ma Initiation of Hawaiian-Emperor Bend Records Major Change in Pacific Plate Motion. Science, 313(5791):1281.

Shuster, D. L., Flowers, R. M., and Farley, K. A. (2006). The influence of natural radiation damage on helium diffusion kinetics in apatite. Earth and Planetary Science Letters, 249(3):148-161.

Siivola, J. and Schmid, R. (2007). Recommendations by the IUGS Subcommission on the Systematics of Metamorphic Rocks: List of mineral abbreviations. Web version 01.02.07.

Sisson, T. W., Schmitt, A. K., Danišík, M., Calvert, A. T., Pempena, N., Huang, C.-Y., and Shen, C.-C. (2019). Age of the dacite of Sunset Amphitheater, a voluminous Pleistocene tephra from Mount Rainier (USA), and implications for Cascade glacial stratigraphy. Journal of Volcanology and Geothermal Research. 
Sláma, J., Košler, J., Condon, D. J., Crowley, J. L., Gerdes, A., Hanchar, J. M., Horstwood, M. S. A., Morris, G. A., Nasdala, L., Norberg, N., Schaltegger, U., Schoene, B., Tubrett, M. N., and Whitehouse, M. J. (2008). Plešovice zircon - A new natural reference material for U-Pb and Hf isotopic microanalysis. Chemical Geology, 249(1):1-35.

Smith, I. E. M. (1972). High-potassium intrusives from southeastern Papua. Contributions to Mineralogy and Petrology, 34(2):167-176.

Smith, I. E. M. (1973). Late Cainozoic volcanism in the southeast Papuan Islands. Technical Report 1973/67, Bureau of Mineral Resources, Geology and Geophysics.

Smith, I. E. M. (1976). Peralkaline rhyolites from the D'Entrecasteaux Islands, Papua New Guinea. In Johnson, R. W., editor, Volcanism in Australasia, pages 275-286. Elsevier, Amsterdam.

Smith, I. E. M. (1981). Young volcanoes in eastern Papua. Geological Survey of Papua New Guinea Memoir, 10:257-265.

Smith, I. E. M. (1982). Volcanic evolution in eastern Papua. Tectonophysics, 87(1):315-333.

Smith, I. E. M. (2013). The chemical characterization and tectonic significance of ophiolite terrains in southeastern Papua New Guinea. Tectonics, 32(2):159-170.

Smith, I. E. M., Chappell, B. W., Ward, G. K., and Freeman, R. S. (1977). Peralkaline rhyolites associated with andesitic arcs of the southwest Pacific. Earth and Planetary Science Letters, 37(2):230-236.

Smith, I. E. M. and Compston, W. (1982). Strontium isotopes in Cenozoic volcanic rocks from southeastern Papua New Guinea. Lithos, 15(3):199-206.

Smith, I. E. M. and Davies, H. L. (1973a). Abau - Papua New Guinea, Sheet SC/55-12 International Index.

Smith, I. E. M. and Davies, H. L. (1973b). Samarai - Papua New Guinea, Sheet SC/56-9 International Index.

Smith, I. E. M. and Davies, H. L. (1976). Geology of the southeast Papuan mainland. Australian Bureau of Mineral Resources Geology and Geophysics bulletin 165.

Smith, I. E. M. and Johnson, R. W. (1981). Contrasting rhyolite suites in the Late Cenozoic of Papua New Guinea. Journal of Geophysical Research: Solid Earth, 86(B11):1025710272.

Smith, I. E. M. and Milsom, J. S. (1984). Late Cenozoic volcanism and extension in Eastern Papua. Geological Society, London, Special Publications, 16(1):163-171. 
Smye, A. J., Marsh, J. H., Vermeesch, P., Garber, J. M., and Stockli, D. F. (2018). Applications and limitations of $\mathrm{U}-\mathrm{Pb}$ thermochronology to middle and lower crustal thermal histories. Chemical Geology, 494:1-18.

Spencer, C. J., Kirkland, C. L., and Roberts, N. M. W. (2018). Implications of erosion and bedrock composition on zircon fertility: Examples from South America and Western Australia. Terra Nova, 30(4):289-295.

Spencer, J. E. (2010). Structural analysis of three extensional detachment faults with data from the 2000 Space-Shuttle Radar Topography Mission. GSA Today, 20(8):4-10.

Spencer, J. E. (2011). Gently dipping normal faults identified with Space Shuttle radar topography data in central Sulawesi, Indonesia, and some implications for fault mechanics. Earth and Planetary Science Letters, 308(3):267-276.

Spiegel, C., Kohn, B., Belton, D., Berner, Z., and Gleadow, A. (2009). Apatite (U-Th-Sm)/He thermochronology of rapidly cooled samples: The effect of He implantation. Earth and Planetary Science Letters, 285(1):105-114.

Steiger, R. H. and Jaeger, E. (1977). Subcommission of geochronology: convention on the use of decay constants in geo-and cosmochronology. Earth and Planetary Science Letters, 36:359-362.

Stock, J. D., Montgomery, D. R., Collins, B. D., Dietrich, W. E., and Sklar, L. (2005). Field measurements of incision rates following bedrock exposure: Implications for process controls on the long profiles of valleys cut by rivers and debris flows. GSA Bulletin, 117(1-2):174-194.

Stockli, D. F. (2005). Application of low-temperature thermochronometry to extensional tectonic settings. Reviews in Mineralogy and Geochemistry, 58(1):411-448.

Stockli, D. F., Farley, K. A., and Dumitru, T. A. (2000). Calibration of the apatite (U-Th)/He thermochronometer on an exhumed fault block, White Mountains, California. Geology, 28(11):983-986.

Stoen, J. D. and Garside, I. E. (1973). Nubiam No. 1 well completion report. Technical report, Amoco Australia Exploration Company, Sydney, Australia.

Streck, M. J. (2008). Mineral Textures and Zoning as Evidence for Open System Processes. Reviews in Mineralogy and Geochemistry, 69(1):595-622.

Streckeisen, A. (1974). Classification and nomenclature of plutonic rocks recommendations of the IUGS subcommission on the systematics of Igneous Rocks. Geologische Rundschau, 63(2):773-786. 
Stüwe, K., White, L., and Brown, R. (1994). The influence of eroding topography on steadystate isotherms. Application to fission track analysis. Earth and Planetary Science Letters, 124(1):63-74.

Suganuma, Y., Okada, M., Horie, K., Kaiden, H., Takehara, M., Senda, R., Kimura, J.-I., Kawamura, K., Haneda, Y., Kazaoka, O., and Head, M. J. (2015). Age of MatuyamaBrunhes boundary constrained by U-Pb zircon dating of a widespread tephra. Geology, 43(6):491-494.

Svensen, H. H., Hammer, Ø., and Corfu, F. (2015). Astronomically forced cyclicity in the Upper Ordovician and $\mathrm{U}-\mathrm{Pb}$ ages of interlayered tephra, Oslo Region, Norway. Palaeogeography, Palaeoclimatology, Palaeoecology, 418:150-159.

Symonds, P. A., Fritsch, J., and Schuler, H. U. (1984). Continental margin around the Western Coral Sea Basin: structural elements, seismic sequences and petroleum geological aspect. In Watson, S. T., editor, Transactions Third Circum-Pacific Energy and Mineral Resources Conference, pages 143-152, Honolulu.

Tagami, T. (2005). Zircon Fission-Track Thermochronology and Applications to Fault Studies. Reviews in Mineralogy and Geochemistry, 58(1):95-122.

Tapster, S., Roberts, N., Petterson, M., Saunders, A., and Naden, J. (2014). From continent to intra-oceanic arc: Zircon xenocrysts record the crustal evolution of the Solomon island arc. Geology, 42(12):1087-1090.

Taylor, B., Goodliffe, A. M., and Martinez, F. (1999). How continents break up: Insights from Papua New Guinea. Journal of Geophysical Research: Solid Earth, 104(B4):74977512.

Taylor, B. and Huchon, P. (2002). Active continental extension in the western Woodlark Basin: A synthesis of Leg 180 results. In Huchon, P., Taylor, B., and Klaus, A., editors, Proceedings of the Ocean Drilling Program, Scientific Results, volume 180, pages 1-36.

Taylor, S. and McLennan, S. (1985). The continental crust: Its composition and evolution. Blackwell Scientific Publications, Palo Alto, CA, United States.

Thomson, S. N., Ring, U., Brichau, S., Glodny, J., and Will, T. M. (2009). Timing and nature of formation of the Ios metamorphic core complex, southern Cyclades, Greece. Geological Society, London, Special Publications, 321(1):139-167.

Tindle, A. G. (2001). Biotite etc. formula unit calculations. http://www.open.ac.uk/earthresearch/tindle/AGTWebData/Mica-bio.xls. Last accessed: 05.14.18.

Tjhin, K. T. (1976). Trobriand Basin exploration, Papua New Guinea. The APEA Journal, pages $81-90$. 
Tulloch, A., Ramezan, J., Faure, K., and Allibone, A. (2010). Early Cretaceous magmatism in New Zealand and Queensland: intra-plate or intra-arc origin? In Buckman, S. and Blevin, P. L., editors, New England Orogen 2010 Conference Proceedings, pages 332335, University of New England, Armidale.

Uchida, E., Endo, S., and Makino, M. (2007). Relationship Between Solidification Depth of Granitic Rocks and Formation of Hydrothermal Ore Deposits. Resource Geology, 57(1):47-56.

van Ufford, A. Q. and Cloos, M. (2005). Cenozoic tectonics of New Guinea. AAPG Bulletin, 89(1):119-140.

Van Wyck, N. and Williams, I. S. (2002). Age and provenance of basement metasediments from the Kubor and Bena Bena Blocks, central Highlands, Papua New Guinea: constraints on the tectonic evolution of the northern Australian cratonic margin. Australian Journal of Earth Sciences, 49(3):565-577.

Verdel, C., Wernicke, B. P., Ramezani, J., Hassanzadeh, J., Renne, P. R., and Spell, T. L. (2007). Geology and thermochronology of Tertiary Cordilleran-style metamorphic core complexes in the Saghand region of central Iran. GSA Bulletin, 119(7-8):961-977.

Vermeesch, P. (2009). Radialplotter: a java application for fission track, luminescence and other radial plots. Radiation Measurements, 44(4):409-410.

Vermeesch, P. (2012). On the visualisation of detrital age distributions. Chemical Geology, 312-313:190-194.

Villa, I. M. and Hanchar, J. M. (2017). Age discordance and mineralogy. American Mineralogist, 102(12):2422-2439.

von Blanckenburg, F., Hewawasam, T., and Kubik, P. W. (2004). Cosmogenic nuclide evidence for low weathering and denudation in the wet, tropical highlands of Sri Lanka. Journal of Geophysical Research: Earth Surface, 109(F3).

Wai, K. M., Abbott, M. J., and Grady, A. E. (1994). The Sadowa Igneous Complex, Eastern Papua New Guinea: Ophiolite or not? In Goldschmidt Conference, pages 949-950, Edinburgh.

Walker, D. A. and McDougall, I. (1982). ${ }^{40} \mathrm{Ar} /{ }^{39} \mathrm{Ar}$ and K-Ar dating of altered glassy volcanic rocks: the Dabi Volcanics, P.N.G. Geochimica et Cosmochimica Acta, 46(11):2181-2190.

Wallace, L. M., Ellis, S., Little, T., Tregoning, P., Palmer, N., Rosa, R., Stanaway, R., Oa, J., Nidkombu, E., and Kwazi, J. (2014). Continental breakup and UHP rock exhuma- 
tion in action: GPS results from the Woodlark Rift, Papua New Guinea. Geochemistry, Geophysics, Geosystems, 15(11):4267-4290.

Wallace, L. M., Stevens, C., Silver, E., McCaffrey, R., Loratung, W., Hasiata, S., Stanaway, R., Curley, R., Rosa, R., and Taugaloidi, J. (2004). GPS and seismological constraints on active tectonics and arc-continent collision in Papua New Guinea: Implications for mechanics of microplate rotations in a plate boundary zone. Journal of Geophysical Research: Solid Earth, 109(B5):1-16.

Warren-Smith, E., Lamb, S., Seward, D., Smith, E., Herman, F., and Stern, T. (2016). Thermochronological evidence of a low-angle, mid-crustal detachment plane beneath the central South Island, New Zealand. Geochemistry, Geophysics, Geosystems, 17(10):42124235 .

Watson, E. B. and Harrison, T. M. (1983). Zircon saturation revisited: temperature and composition effects in a variety of crustal magma types. Earth and Planetary Science Letters, 64(2):295-304.

Watson, E. J. (2019). Using paleomagnetism to test rolling hinge behaviour of an active low angle normal fault, Papua New Guinea. MSc thesis, Victoria University of Wellington.

Webb, L., Baldwin, S., Little, T., and Fitzgerald, P. (2008). Can microplate rotation drive subduction inversion? Geology, 36(10):823-826.

Webb, L. E., Baldwin, S. L., and Fitzgerald, P. G. (2014). The Early-Middle Miocene subduction complex of the Louisiade Archipelago, southern margin of the Woodlark Rift. Geochemistry, Geophysics, Geosystems, 15(10):4024-4046.

Webber, S. (2017). Using structural geology and cosmogenic nuclide dating to infer the slip rate and frictional strength of the active Mai'iu Low-Angle Normal Fault, Eastern Papua New Guinea. Master's thesis, Victoria University of Wellington, Wellington, New Zealand.

Webber, S., Norton, K., Little, T., Wallace, L., and Ellis, S. (2018). How fast can low-angle normal faults slip? Insights from cosmogenic exposure dating of the active Mai'iu fault, Papua New Guinea. Geology, 46(3):227-230.

Webster, J. D. and Piccoli, P. M. (2015). Magmatic Apatite: A Powerful, Yet Deceptive, Mineral. Elements, 11(3):177-182.

Wells, M. L., Snee, L. W., and Blythe, A. E. (2000). Dating of major normal fault systems using thermochronology: An example from the Raft River detachment, Basin and Range, western United States. Journal of Geophysical Research: Solid Earth, 105(B7):1630316327. 
Wernicke, B. (1995). Low-angle normal faults and seismicity: A review. Journal of Geophysical Research: Solid Earth, 100(B10):20159-20174.

Wernicke, B. and Axen, G. J. (1988). On the role of isostasy in the evolution of normal fault systems. Geology, 16(9):848-851.

Whattam, S. A. (2009). Arc-continent collisional orogenesis in the SW Pacific and the nature, source and correlation of emplaced ophiolitic nappe components. Lithos, 113(1):88114.

Whitney, D. L. and Evans, B. W. (2010). Abbreviations for names of rock-forming minerals. American Mineralogist, 95(1):185-187.

Whitney, D. L., Teyssier, C., Rey, P., and Buck, W. R. (2013). Continental and oceanic core complexes. GSA Bulletin, 125(3-4):273-298.

Wiedenbeck, M., Allé, P., Corfu, F., Griffin, W. L., Meier, M., Oberli, F., Von Quadt, A., Roddick, J. C., and Spiegel, W. (1995). Three natural zircon standards for U-Th-Pb, LuHf, trace element and REE analyses. Geostandards Newsletter, 19(1):1-23.

Williams, I. S. and Claesson, S. (1987). Isotopic evidence for the Precambrian provenance and Caledonian metamorphism of high grade paragneisses from the Seve Nappes, Scandinavian Caledonides. Contributions to Mineralogy and Petrology, 97(2):205-217.

Wolf, R. A., Farley, K. A., and Kass, D. M. (1998). Modeling of the temperature sensitivity of the apatite (U-Th)/He thermochronometer. Chemical Geology, 148(1):105-114.

Wolfe, M. R. and Stockli, D. F. (2010). Zircon (U-Th)/He thermochronometry in the KTB drill hole, Germany, and its implications for bulk He diffusion kinetics in zircon. Earth and Planetary Science Letters, 295(1):69-82.

Worthing, M. A. and Crawford, A. J. (1996). The igneous geochemistry and tectonic setting of metabasites from the emo metamorphics, Papua New Guinea; A record of the evolution and destruction of a backarc basin. Mineralogy and Petrology, 58(1):79-100.

Wotzlaw, J.-F., Hüsing, S. K., Hilgen, F. J., and Schaltegger, U. (2014). High-precision zircon $\mathrm{U}-\mathrm{Pb}$ geochronology of astronomically dated volcanic ash beds from the Mediterranean Miocene. Earth and Planetary Science Letters, 407:19-34.

Yavuz, F. and Döner, Z. (2017). WinAmptb: A Windows program for calcic amphibole thermobarometry. Periodico di Mineralogia, 86:135-167.

York, D. (1969). Least squares fitting of a straight line with correlated errors. Earth and Planetary Science Letters, 5:320-324. 
Zelt, B. C., Taylor, B., and Goodliffe, A. M. (2001). 3-D crustal velocity structure at the rift tip in the Western Woodlark Basin. Geophysical Research Letters, 28(15):3015-3018.

Zhang, Y. G., Pagani, M., and Liu, Z. (2014). A 12-million-year temperature history of the tropical Pacific Ocean. Science, 344(6179):84-87.

Zirakparvar, N. A., Baldwin, S. L., and Vervoort, J. D. (2011). Lu-Hf garnet geochronology applied to plate boundary zones: Insights from the (U)HP terrane exhumed within the Woodlark Rift. Earth and Planetary Science Letters, 309(1):56-66.

Zirakparvar, N. A., Baldwin, S. L., and Vervoort, J. D. (2013). The origin and geochemical evolution of the Woodlark Rift of Papua New Guinea. Gondwana Research, 23(3):931943. 